Pathologe 2019 · 40 (Suppl 2):S41-S217 https://doi.org/10.1007/s00292-019-0616-1 Online publiziert: 7. Juni 2019

(c) Springer Medizin Verlag GmbH, ein Teil von Springer Nature 2019

\section{Jahrestagung der Deutschen Gesellschaft für Pathologie e.V.}

\author{
Frankfurt am Main, 13. bis 15. Juni 2019
}

\section{Keynotes}

\section{Neuroendokrine Neoplasien: Zwei Familien mit Gemeinsamkeiten und Unterschieden}

\section{KN01 \\ Neuroendocrine neoplasms. Two tumor groups with distinct features unified in one classification \\ G. Klöppel* \\ Institut für Allgemeine Pathologie und Pathologische Anatomie der Technischen Universität München, Munich, Germany}

All neuroendocrine neoplasms (NENs) are characterized by the expression of synaptophysin and chromogranin A (or B). Yet, they are not a homogeneous group of tumors. Paradigmatic for these tumors are the NENs of the gastroenteropancreatic (GEP) system. Two NEN families can be distinguished: predominantly well differentiated and lowproliferative NENs, called neuroendocrine tumors (NET), and poorly differentiated and high-proliferative NENs, called neuroendocrine carcinomas (NECs). Based on their proliferative activity, GEP NETs are further classified into G1, G2, and G3 tumors. NECs are per definition G3 carcinomas. The morphological NEN dichotomy is supported by differences in epidemiology, genetics, clinics, and prognosis, and potentially has its cause originating from different progenitor cells. Genetically, NECs are distinguished by TP53 and RB1 alterations, which are lacking in NETs and are helpful in the distinction of NETs from NECs. Comparison of the GEP NEN WHO classification with extragastroenteropancreatic NEN classifications commonly reveal differences in terminology and categorization. In addition, they lack a grading system. However, common to all NEN classifications is the recognition of two tumor families differing in histological differentiation and prognosis. This allows the construction of a uniform classification frame for all NENs.

\section{Stem cell-based organoids in human disease}

\section{KN02}

\section{Stem cell-based organoids in human disease}

H. Clevers*

University Medical Center Utrecht and Utrecht University, Hubrecht Institute for Developmental Biology and Stern Cell Research, Utrecht, Netherlands

Stem cells are the foundation of all mammalian life. Stem cells build and maintain our bodies throughout life. Every organ in our body is believed to harbor its own dedicated stem cells. These adult stem cells replace tissue that is lost due to wear and tear, trauma and disease. Adult stem cells

The supplement these abstracts are part of is not sponsered bei industry. Bei den mit * gekennzeichneten Autoren handelt es sich um die präsentierenden Autoren. are highly specialized and can only produce the tissue in which they reside; they ae 'multipotent'. Examples are bone marrow stem cells that make all blood cells, skin stem cells and gut stem cells. Even the brain is now known to harbor its specialized stem cells. The adult stem cells allow us to live 80-90 years, but this comes at a cost: they are the cells that most easily transform into cancer cells.

We have identified a gene (lgr5) that marks a series of known and novel adult stem cells, in organs such as the gut, the liver, the lung and the pancreas. We have learned to grow these stem cells in a dish into mini-versions of the human organs from which they derive. This so called organoid technology opens a range of avenues for the study of development, physiology and disease, and for personalized medicine. In the long run, cultured mini-organs may replace transplant organs from donors and hold promise in gene therapy.

\section{DGP-Hauptprogramm}

\section{Precision oncology-International perspectives}

\section{DGP01.01}

\section{Liquid biopsies-a disappointing promise in thoracic oncology?}

\section{P. Hofman*}

University Côte d'Azur, Nice, France

Liquid biopsy (LB) plays a major role in thoracic oncology. A number of recent reviews within this domain testify to the increasing importance of LB. The development of LBs provides a better understanding of the molecular and cellular mechanisms, the progression of lung cancer, and the treatment of patients. Among these studies, research into mutations in EGFR using plasma circulating free DNA (cf-DNA) have led to the use of LB in daily practice routine for patients with advanced stage or metastatic non-small cell lung carcinoma (NSCLC). This approach is now used in a large number of hospitals. The number of detectable biological targets in an LB that are potentially accessible to treatment has increased, and different biomarkers can be characterized in cf-DNA using next generation sequencing approach. The complexity of molecules for detection in the blood of patients with lung cancer has increased with advances in our understanding of the biology of the different components circulating in the blood. These components include free or complexed nucleic acids, microparticles including exosomes, circulating "non-hematological" cells including circulating tumor cells (CTCs), and proteins of serum and plasma The addition to these analyses of different circulating hematological normal cells (neutrophils, lymphocytes, monocytes, platelets), constituting a "liquid microenvironment", has progressively been envisaged. While taking into account the increasing complexity, a number of biomarkers have been developed for use, particularly in the clinic, for the interests of patients with advanced or metastatic lung cancer. However the absence of robust approaches for the detection of some of these blood components for their use in routine clinical practice probably explain the decline in interest for some biomarkers. We will review the major advantages and the limitations of using LB in thoracic oncology. 
DGP01.02

\section{Precision medicine in endometrial carcinoma}

\section{Matias-Guiu*}

Hospital U Arnau de Vilanova and Hospital U de Bellvitge Hospital Arnau de Vilanova, University of Lleida, and Hospital U de Bellvitge, Departments of Pathology, Barcelona, Spain

Endometrial carcinoma (EC) is frequent in western countries. There is low mortality in relative terms but high mortality in absolute terms. Managing patients with metastatic EC is a real challenge in clinical practice. There is need for individualizing diagnosis and treatment for EC patients. The most established prognostic criteria are based on traditional pathological features, such as histological type and grade and stage. However, new biomarkers and molecular approaches may be helpful in identifying patients at higher risk of recurrence.

There are different histological types of EC. The two most frequent types are endometrioid carcinoma (EEC), accounting for $80 \%$ of cases, and Serous carcinoma (SC) representing $15 \%$. Assessing appropriately histological type is very important to take treatment decisions, but there is a group of high grade tumors in which distinction between EEC and SC is subjected to inter-obverser variability. Immunohistochemistry and molecular techniques, including next generation sequencing may be good tools for tumors in the grey zone between EEC and SC.

TCGA performed an integrated genomic characterization of EEC and SC TCGA proposed a molecular classification of EC, somewhat independent of histological typing, in four groups: 1) Ultramutated, with POLE mutations and very good prognosis; 2) EEC with microsatellite instability, and 3) EEC with Low copy number alterations, both with intermediate prognosis; 4) EC with high copy number alterations, and frequent p53 mutations, with adverse prognosis. Several groups are trying to establish surrogates to bring TCGA approach to clinical practice.

Combining Histological typing and TCGA-based surrogate is good strategy, but both have a number of limitations. Moreover, there are some biomarkers that can have additional value (L1CAM, CTNNB1 mutations). Molecular tools can be applied to staging. Sentinel node biopsy has emerged as an interesting strategy to detect stage III EC that would be interpreted as stage I tumors. New strategies, like ultrastaging or OSNA technology, improves the precision of staging procedures.

Finally, liquid biopsy represents a good opportunity to identify patients with tendency to release cells into human body fluids. Identification of the specific exosome-related miRNA profile or specific mutational combinations in ctDNA, in plasma or in peritoneal washings before surgery, are promising tools to identify patients at higher risk of recurrence.

\section{DGP01.03}

\section{Molecular alterations and precision therapy in sarcomas}

\section{S. Ramon y Cajal* $^{*}$}

Hospital Clinic University Valle de Hebron, Barcelona, Spain

Sarcomas represent $1 \%$ of malignant tumors and show a great inter and intratumoral heterogeneity. The molecular study is crucial for making the diagnosis At the genomic level, the sarcomas can exhibit low genetic complexity, that include mutations, translocations (Ewing sarcoma, rhabdomyosarcoma, synovial sarcoma) or high genomic complexity, with multiple chromosomal alterations, such as dedifferentiated liposarcomas, osteosarcoma, leiomyosarcoma, pleomorphic liposarcoma, myxofibrosarcoma, undifferentiated sarcoma. Alterations in the epigenetic regulation, signaling pathways and cellular metabolism are also described in many sarcomas.

With this molecular background, the therapeutic perspectives focus on the identification of genetic drivers which are druggable, in the identification of central factors in the cell signaling and metabolic pathways as well as in the epigenetic regulation. Best examples are the KIT/PDGFR-A in the GISTs, mdm2/CDK4 in the dedifferentiated liposarcomas. ALK in myofibroblastic sarcomas, NTRK, Inhibitors of methylation (5-azathidine) for epigenetic regulation and others.
Immunotherapy with antiPDL1 antibodies is being applied in sarcomas with discrete results in pleomorphic sarcomas. Other immunological therapies, such as antimacrophage and CART lymphocytes are in development. In summary, the number of therapeutic targets is increasing in various types of sarcomas. The combination of specific therapies with inhibitors of cell signaling pathways plus immunotherapy and chemotherapy may change the current paradigms.

\section{DGP01.04}

Understanding the metastatic process by deep proteomic analysis of primary colon cancers and matched liver metastases using clinical FFPE tissues

M. H. A. Roehrl*

Memorial Sloan Kettering Cancer Center, New York, United States

Aim. Understanding the biology of the metastatic process will be key for advancing effective therapies for common cancers that are frequently diagnosed after metastasizing, such as colonic adenocarcinoma. Availability of matched normal-primary-metastasis triples is often rate limiting in research, and thus unlocking archival FFPE samples by ultra-high resolution Fourier-transform mass spectrometry for deep proteome profiling will open unmatched resources in biomarker discovery. We developed a robust deep proteome profiling method for FFPE and applied it to proteomic biomarker discovery in primary and matched metastatic colonic adenocarcinomas.

Methods. We selected 58 matched tumor and normal FFPE tissue samples from surgical resections of patients with colonic adenocarcinoma and synchronously resected liver metastases. We optimized the new S-Trap digestion and purification method for powerful ionic sodium dodecyl sulfate detergent solubilization and compared it to prior extraction protocols. We analyzed all samples by unbiased deep Fourier transform liquid chromatography Orbitrap mass spectrometry. Label-free data was analyzed by MaxQuant and clustering was performed in R.

Results. We developed new methods for extracting total proteomes from FFPE samples and verified extract quality and integrity by BCA assays and SDS-PAGE. We compared three trypsin-Lys C digestion methods (conventional in solution digestion, conventional in gel digestion, and the new suspension trap S-Trap method) and showed that the S-Trap had by far the highest peptide recovery ( $>93 \%$ ), while also efficiently removing SDS prior to MS injection. Each FFPE sample yielded $>5500$ unique robust protein identifications based on label-free MaxQuant searches. Cluster analysis provided a subset of proteins that are upregulated in metastases but not primary tumors or normal mucosa.

Conclusion. We developed a highly efficient proteome recovery method for FFPE tissue that allows strong ionic detergent solubilization and deep proteome coverage by Fourier transform LC-MS analysis. Applying our method to synchronous sets of primary and liver-metastatic colon cancer uncovered metastasis-specific groups of novel protein biomarkers that serve as novel targets for therapies that specifically attack the metastatic process. 


\section{Geschichte der Pathologie - Pathologie in der NS-Zeit}

\section{DGP03.01 \\ Die verwehrte Wiedergutmachung: Zum Verhältnis jüdischer und deutscher Pathologen nach 1945 am Beispiel von Paul Kimmelstiel und Carl Krauspe}

D. Groß*, M. Schmidt, H. Uhlendahl

Institut für Geschichte, Theorie und Ethik der RWTH Aachen, Aachen, Deutschland

Der Hamburger Pathologe Paul Kimmelstiel (1900-1970) ist als Namensgeber der diabetischen Glomerulosklerose (Kimmelstiel-Wilson-Syndrom) in die Medizingeschichte eingegangen. Als deutscher Jude wurde er nach der Machtübernahme Hitlers 1933 entlassen und zur Emigration genötigt. Ab 1961 kämpfte er im Nachkriegsdeutschland um Wiedergutmachung. Dabei war es ausgerechnet sein deutscher Kollege Carl Krauspe, der ihm durch ein kritisches Gutachten die beantragte Rechtsstellung eines ordentlichen Professors verwehrte.

Der Beitrag dokumentiert die zweifache Repression Kimmelstiels in Deutschland - vor und nach 1945; dies wird umso deutlicher, wenn man berücksichtigt, dass das ehemalige NS-Opfer Kimmelstiel in der beschriebenen Situation von dem ehemaligen NSDAP-Mitglied (und späteren DGP-Präsidenten) Krauspe begutachtet wurde.

Der skizzierte Fall Kimmelstiel/Krauspe steht so zugleich prototypisch für die Akzeptanzbarrieren, die emigrierten jüdische Hochschullehrern an deutschen Hochschullehrern in der Nachkriegszeit zu überwinden hatten.

\section{DGP03.03}

\section{Der Pathologe Friedrich Feyrter im Nationalsozialismus}

\section{T. Baumann*}

Universität Düsseldorf, Medizinische Fakultät, Institut für Geschichte, Theorie und Ethik der Medizin, Düsseldorf, Deutschland

Ziel. Der Pathologe Friedrich Feyrter (2. Juni 1895 bis 2. Dezember 1973) gilt heute als Mitbegründer der Neuroendokrinologie. Über seine Zeit im Nationalsozialismus ist bisher aber wenig bekannt. Die Universität Wien ernannte ihn 1935 zum Privatdozenten und nach Zwischenstationen in Breslau und Danzig wurde er 1941 Direktor des Pathologisch-Anatomischen Instituts an der Universität Graz. Dort wurde er nach Kriegsende entlassen. Ziel des Vortrags ist, Licht in das Wirken Feyrters während der Zeit des Nationalsozialismus zu bringen.

Methoden. Untersucht werden soll dies durch eine historisch-kritische Auswertung von Quellenmaterial, also insbesondere von Akten in verschiedenen Archiven.

Ergebnisse. Nach seinen eigenen Angaben in einem Fragebogen des „Military Government of Germany" war Friedrich Feryter 1927 bis 1931 Mitglied der Österreichischen Sozialdemokratischen Arbeiterpartei gewesen. 1937 trat er in den NS-Altherrenbund ein, 1939 in den NS-Dozentenbund (NSDoB) sowie den NS-Ärztebund und die Nationalsozialistische Volkswohlfahrt (NSV), 1940 in den Reichsbund Deutscher Beamter sowie 1942 in die NSDAP, hatte aber in keiner dieser Organisationen ein Amt ausgeübt. Anlässlich des Berufungsverfahrens in Göttingen wurde 1950 festgehalten, dass Feyrter im Februar 1946 in Graz entlassen worden sei, weil er der in Österreich für Prosektoren geltenden Anzeigepflicht für ein „,ärztliches Verschulden" nicht nachgekommen wäre. Die Entlassung erfolgte also nicht unmittelbar nach Kriegsende, was als Hinweis gewertet wurde, dass Feyrter nicht schwer belastet sei. Das Verfahren wurde bald eingestellt. Mittlerweile arbeitete Feyrter als Prosektor in einem Wiener Krankenhaus. Das niedersächsische Kultusministerium blockierte seine Berufung nicht und er übernahm den Lehrstuhl für Allgemeine Pathologie in Göttingen 1951 zunächst vertretungsweise.

Fazit. Friedrich Feyrter hatte sich offenkundig nicht bemüht, in möglichst wenig nationalsozialistischen Organisationen mitzuwirken, sondern das getan, was zu seiner Karriere nötig war. Umgekehrt war er aber auch nicht Mitglied besonders vieler NS-Organisationen gewesen, und er trat die- sen auch nicht besonders frühzeitig bei. Seine Forschungen in Graz, die sich etwa auf Alters- und Geschlechter-Differenzierungen bei Magen- und Darmkrebs bezogen, bieten bisher keinen Anhaltspunkt für verwerfliches ärztliches Handeln während der NS-Zeit.

\section{DGP03.04}

\section{Pathologie im Zeitalter der Gewalt - Mainz 1916 bis 1946}

L. Prüll*

Institut für Funktionelle und Klinische Anatomie, Mainz, Deutschland

Forschungen zur nationalsozialistischen Medizin fragen nach wie vor intensiv nach Tätern, Opfern und nach den Folgen für den Fachbetrieb. Das gilt auch für die Pathologie. Dieser Vortrag fragt auf der Basis eigener langjähriger Beschäftigung mit der Geschichte der Disziplin nach dem Kontext, in dem das Fach im „Dritten Reich“ arbeitete. Erkenntnisleitend ist dabei der Topos des „Zeitalters der Gewalt“, der in der historischen Forschung heuristischen Wert erlangte. Er soll aufgegriffen werden, um am Beispiel neuer Forschungen zum Fachbetrieb in Mainz zu zeigen, wie die Zeit der Weltkriege gerade in den Grenzlanden zum „feindlichen“ Ausland eine Atmosphäre der Verrohung kreierte, die eine Mitwirkung von Fachvertretern der Pathologie an der Gestaltung der nationalsozialistischen Gesundheitspolitik erheblich begünstigte.

\section{DGP03.06}

Pathologie und Pathologen im Nationalsozialismus: Rücktritt Herxheimers als Vorsitzender der Deutschen Pathologischen Gesellschaft 1933 in neuem Licht

\section{N.M. Franke ${ }^{1 *}$, K.-F. Bürrig ${ }^{2}$}

'Universität Leipzig, Institut für Kulturwissenschaften, Leipzig, Deutschland, ${ }^{2}$ St. Bernward Krankenhaus Hildesheim, Institut für Pathologie, Hildesheim, Deutschland

Gotthold Herxheimer (1872-1936) trat kurz nach der nationalsozialistischen Machtergreifung 1933 als Vorsitzender der Deutschen Pathologischen Gesellschaft (DPG) zurück. Dieser Vorgang spiegelt komplexe historische Zusammenhänge wider, die eine genaue Betrachtung und Darstellung verdienen.

Die Entscheidung zum „freiwilligen“ Rücktritt fiel auf einer Vorstandsitzung im April 1933 in Wiesbaden, deren Protokoll die intensive Einflussnahme des Schriftführers der DPG, Georg Benno Gruber, auf diesen Vorgang nicht erkennen lässt. Sein Schriftwechsel mit anderen Vorstandsmitgliedern der DPG und mit zu Rate gezogenen Pathologen ausserhalb dieses Gremiums im unmittelbaren Vorfeld der Vorstandssitzung zeigt dies deutlich auf.

Aus Rücksicht auf die neuen Machthaber kam es in Folge zur Absage der für das Frühjahr geplanten Rostocker Tagung der DPG. Dies auch weil einer der Hauptreferenten, Siegfried Oberndorfer aus München, wegen seiner jüdischen Herkunft dort nicht auftreten sollte.

Herxheimer war zum Protestantismus konvertierter Jude. Trotz seiner aktiven Teilnahme als Soldat am Ersten Weltkrieg wurde er aus seiner Stellung als Prosektor in Wiesbaden durch den Vollzug des Gesetzes zur Wiederherstellung des Berufsbeamtentums kurz nach seinem Rücktritt als Vorsitzender des DPG gedrängt.

Aus seinem Schriftwechsel mit Gruber ergibt sich eine eindeutig deutschnationale Haltung Herxheimers. Er wäre gern selbst Teil des neuen „nationalen Aufbruchs" gewesen und wandte sich zudem scharf gegen das „internationale Judentum“. Damit zeigte er eine Haltung, die in der deutschen Erinnerungspolitik erst noch breiter diskutiert werden muss: Die Sympathie von Menschen jüdischer Herkunft mit Zielen des Nationalsozialismus.

Mit dem Rücktritt Herxheimers begann der Weg der DPG zu einer „gleichgeschalteten“ medizinischen Fachvertretung im Nationalsozialismus. Dieser Prozess traf kaum auf Widerstand, sondern wurde von Teilen des Vorstands aktiv gefördert und kann als Selbstgleichschaltung bezeichnet werden, wie sie parallel auch in anderen wissenschaftlichen Gesell- 
schaften zu diesem frühen Zeitpunkt der nationalsozialistischen Diktatur stattfand. Aus einer bewusst „unpolitischen Haltung" der DPG im vorangegangenen Jahrzehnt wuchs über eine Begeisterung für die „Neue Zeit“ Antisemitismus und Zustimmung zur nationalsozialistischen Herrschaft auch unter den Vorstandsmitgliedern der DGP.

\section{DGP03.07}

\section{Tätigkeitsfelder und Forschungslandschaft der Pathologie in den 20er bis 40er Jahren}

\section{T. Braunschweig ${ }^{1 *}$, K. Schierle}

${ }^{1}$ RWTH Uniklinik Aachen, Institut für Pathologie, Aachen, Deutschland, 2Universitätsklinikum Leipzig, Institut für Pathologie, Leipzig, Deutschland

Das Ideal eines pathologischen Instituts bestand, insbesondere unter Virchow, aus dem Sektionsbereich und einer breiten Präparatesammlung für die Ausbildung von Studenten und klinisch tätigen Ärzten. Hauptpfeiler der Ausbildung bildete die Pathologie für das Verständnis des Krankheitsbegriffs und der Krankheitsentstehung. In diesem Zusammenhang wurde jedoch meist der Endzustand einer Erkrankung im Rahmen der Sektion dargestellt. Der Sonderverdienst Rudolf Virchows war die zusätzliche Betrachtung der zellulären Ebene unter Hinzuziehung mikroskopischer Präparate. Zusätzliche Abteilungen waren ein chemisches Labor, ein bakteriologisches Labor, und experimentelle Labore für Biologie, Immunologie, Zellforschung undTierställe. Im Gegensatz dazu wurden in England und Amerika in den Instituten neben den Sektionen klinisch relevante Arbeiten durchgeführt. Neben der histomorphologischen Diagnostik von Präparaten von Patienten wurden immunologische Behandlungen entwickelt und auch innerhalb von den Instituten durchgeführt. Hierzu hatten die Institute mitunter eigene Stationen mit Patientenbetten. Die Forschungsgebiete waren dementsprechend unterschiedlich. Anhand von Publikationen konnte gefunden werden, dass in Deutschen Zeitschriften überwiegend Erkrankungen großer Bandbreite beschrieben und auch häufig erstbeschrieben wurden. Die großen Sammlungen waren dafür meist die Grundlage und zogen dabei auch internationale Gäste an. In der englischen Zeitschrift für Pathologie wurden vor allem infektiologische Themen inklusive von Tierexperimenten veröffentlicht. In der amerikanischen Zeitschrift war ein sehr breites Spektrum abgebildet, im Gegensatz zu den anderen einige zu klinischen relevanten labor-histologischen Techniken.

\section{Endokrine Pathologie I}

\section{DGP04.01}

\section{Familiäre neuroendokrine Tumoren - mehr als nur MEN}

P. Komminoth*

Stadtspital Triemli, Institut für Pathologie, Zürich, Schweiz

Je nach Tumortyp sind 10 bis $40 \%$ der (neuro-)endokrinen Tumoren mit genetischen Syndromen assoziiert, darunter die klassischen multiplen endokrinen Neoplasie-Syndrome (MEN1 und MEN2), SDH-assoziierte familiäre Paragangliom-Pheochromozytom-Syndrome, von Hippel-Lindau-Syndrom (VHL), Neurofibromatose Typ 1 (NF1), Hyperparathyreose-Kieferzysten-Tumor-Syndrom, Carney-Komplex, McCuneAlbright-Syndrom, Li-Fraumeni Syndrom und familiäre nicht-medulläre Schilddrüsenkarzinome sowie neuere Entitäten wie MEN4, DICER1-Syndrom, Glucagonzell-Hyperplasie und Neoplasie-Syndrom.

Hereditären (neuro-)endokrine Tumorsyndrome zeigen phänotypisch erhebliche Überlappungen und neigen dazu, sich klinisch komplex und heterogen zu präsentieren, was durch eine $\mathrm{z}$. T. hohe Rate von sog. de-novoMutationen noch verstärkt wird.

Im Zeitalter der Präzisionsmedizin spielen Pathologen eine zentrale Rolle in der Diagnostik von familiären Krebssyndromen, indem sie durch die Identifizierung typischer morphologischer und immunhistochemischer Tumormanifestationen sowie Verteilmuster auf die Möglichkeit einer an- geborenen genetischen Störung hinweisen können und so das weitere Behandlungsmanagement, einschließlich Gentests, Beratung und gezielter Therapie, beeinflussen.

In diesem Übersichtsreferat wird auf die häufigsten hereditären (neuro-)endokrinen Tumorsyndrome eingegangen und die wichtigen Genotyp-Phänotyp-Korrelationen, die es zu erkennen gilt, beleuchtet.

\section{DGP04.02}

\section{Primärer Hyperaldosteronismus - Genetik und Pathologie}

\section{U. Scholl*}

Charité - Universitätsmedizin, Berlin, Deutschland

Der primäre Hyperaldosteronismus ist durch eine Überproduktion des Blutdruckhormons Aldosteron gekennzeichnet und stellt die häufigste Ursache einer sekundären Hypertonie dar. In etwa einem Drittel der Fälle liegen (typischerweise unilaterale) Aldosteron-produzierende Adenome vor, in etwa zwei Drittel der Fälle ein (bilateraler) idiopathischer Hyperaldosteronismus. Andere Ursachen, wie die unilaterale Hyperplasie, sind seltener. In den vergangenen 8 Jahren konnten somatische Mutationen in Ionenkanälen und -transportern als Ursache von Aldosteron-produzierenden Adenomen identifiziert werden. Dazu gehören der Kaliumkanal KCNJ5, der Calciumkanal CACNA1D sowie die ATPasen ATP1A1 und ATP2B3. Mutationen im Gen KCNJ5 kommen am häufigsten vor und sind mit größeren Tumoren, dem weiblichen Geschlecht sowie spezifischen histologischen Charakteristika assoziiert. Mutationen in KCNJ5 und ATPasen führen zu einer veränderten Ionenpermeabilität und Depolarisation sowie Aktivierung spannungsgesteuerter Calciumkanäle. Mutationen in Calciumkanälen führen direkt zu einem vermehrten Calciumeinstrom und zur Aktivierung von Signalwegen für die Aldosteronproduktion und Zellproliferation. Selten werden auch Mutationen in CTNNB1 (beta-Catenin) gefunden.

Es gibt erste Hinweise, dass auch der idiopathische Hyperaldosteronismus auf somatische Mutationen in sog. Aldosteron-produzierenden Zellclustern zurückzuführen sein könnte. Diese Strukturen treten auch in normalen Nebennieren mit zunehmendem Alter auf und weisen aus Aldosteron-produzierenden Adenomen bekannte somatische Mutationen auf. Selten liegen dem primären Hyperaldosteronismus Keimbahnmutationen zugrunde (sog. familiärer Hyperaldosteronismus). Ursächlich sind Mutationen in der Aldosteronsynthase CYP11B2, dem Chloridkanal CLCN2, dem Kaliumkanal KCNJ5 oder dem Calciumkanal CACNA1H. Keimbahnmutationen im Gen CACNA1D führen zu einem Syndrom aus primärem Hyperaldosteronismus, Epilepsie und neurologischen Auffälligkeiten.

\section{DGP04.03}

\section{Molekulare Klassifikation neuroendokriner Tumoren des Thymus}

H. Dinter', H. Bohnenberger', C.-A. Weis', A. Marx², J. Beck', E. Schütz', L. Brcic', H. Popper', G. Pelosi', S. Küffer ${ }^{1}$, P. Ströbel ${ }^{1 *}$

'Universitätsmedizin Göttingen, Institut für Pathologie, Göttingen, Deutschland, ${ }^{2}$ Universitätsmedizin Mannheim, Institut für Pathologie, Mannheim, Deutschland, ${ }^{3}$ Chronix Biomedical, Göttingen, Deutschland, ${ }^{4}$ Medizinische Universität Graz, Diagnostik und Forschungsinstitut für Pathologie, Graz, Österreich, ${ }^{5}$ University of Milan and Inter-Hospital Pathology Division, Department of Oncology and Hemato-Oncology, Mailand, Italien

Ziel. Die Klassifikation der Weltgesundheitsorganisation (WHO) für neuroendokrine Tumoren der Lunge (PNET) wird aus primär historischen Gründen auch für neuroendokrine Tumoren des Thymus (TNET) verwendet und unterscheidet hier typische und atypische Karzinoide (TC und AC), großzellige neuroendokrine Karzinome (LCNEC) und kleinzellige Karzinome (SCC), obwohl nicht untersucht wurde, ob alternative Klassifikationen besser für das Patientenmanagement geeignet sind. 


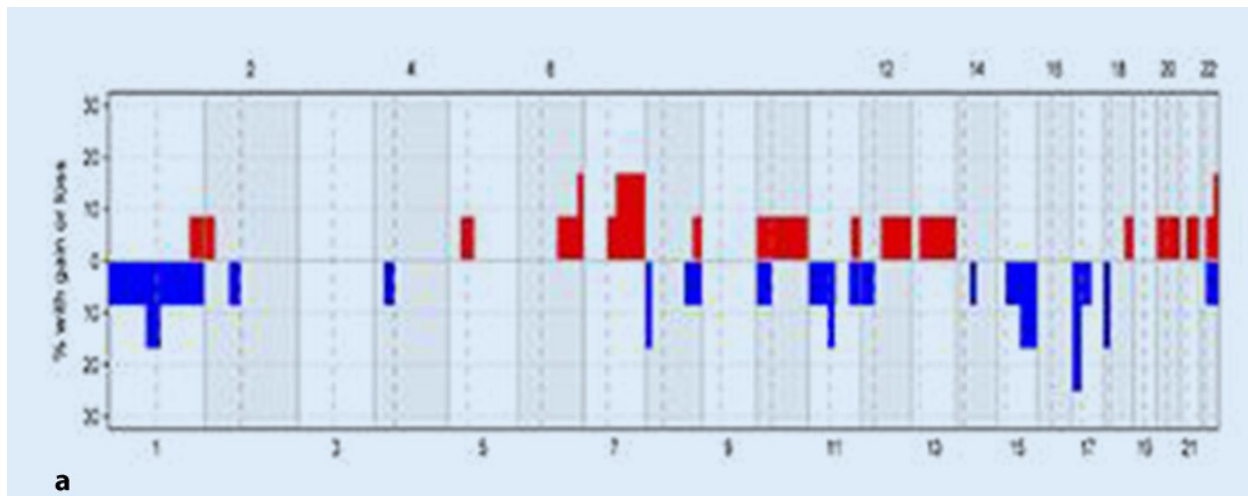

a

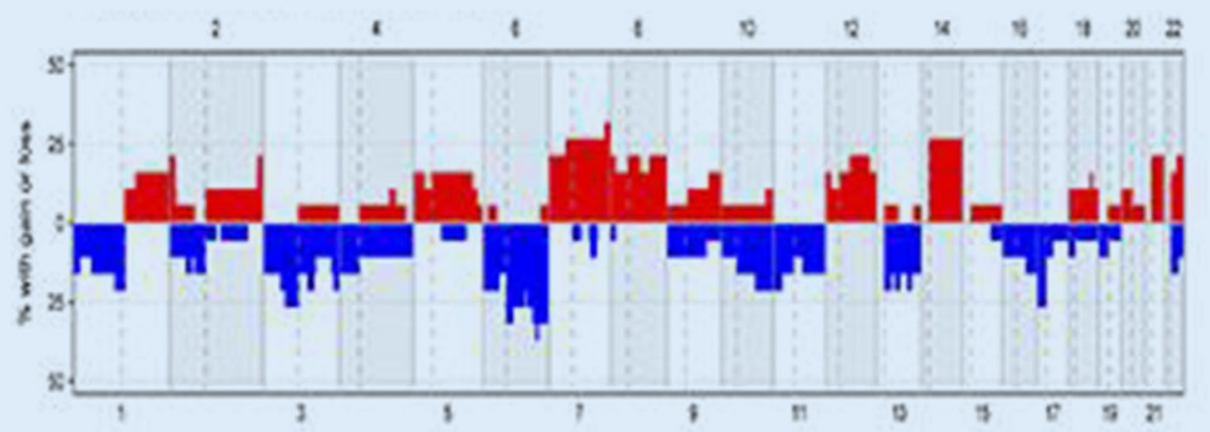

b

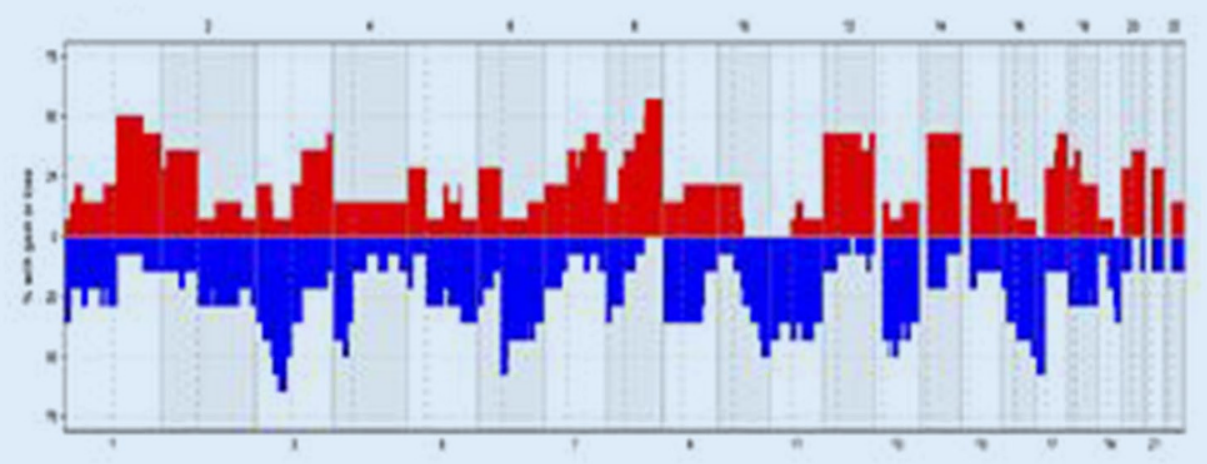

c

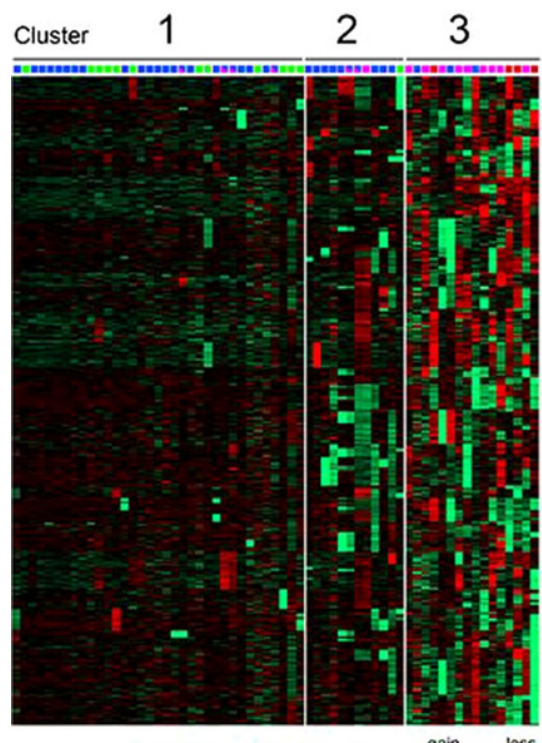

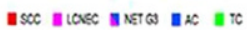

Abb. 2 |DGP04.03 4 WGS Daten ergaben 3 molekulare Cluster
Methoden. 107 TNET (22 TC, 51 AC, 28 LCNEC, 6 SCC) von 103 Patienten wurden jeweils nach WHO, ENETS, und einem grading-basierten Schema klassifiziert. Low coverage whole genome sequencing (WGS) wurde in 63 Fällen durchgeführt. Ein copy number instability (CNI) score wurde errechnet, um Tumoren zu vergleichen. 11 LCNEC wurden außerdem mittels targeted next generation sequencing untersucht. Die morphologischen Klassifikationen wurden mit den molekularen Merkmalen abgeglichen.

Ergebnisse. Die WGS Daten ergaben 3 Cluster $\left(\mathrm{CNI}_{\text {low }}, \mathrm{CNI}_{\text {int }}\right.$ and $\left.\mathrm{CNI}_{\text {high }}\right)$ (- Abb. 1 | DGP04.03 und Abb. 2 | DGP04.03). Cluster $\mathrm{CNI}_{\text {low }}$ and $\mathrm{CNI}_{\text {int }}$ enthielten nicht nur TC und AC, sondern auch 6 LCNEC. Cluster $\mathrm{CNI}_{\text {high }}$ enthielt alle SCC und 9 LCNEC, aber auch 3 AC. Keine morphologische Klassifikation konnte den molekularen Cluster zuverlässig vorhersehen (- Abb. 3 |DGP04.03). Fälle, in denen sowohl Primärtumoren als auch Metastasen des gleichen Patienten vorhanden waren, zeigten morphologische Progression von low grade zu high grade. Eine Analyse von LCNEC zeigte eine Subgruppe von intermediären NET G3 Tumoren, die sich von LCNEC durch ihre Karzinoid-Morphology, die Expression von Chromogranin, und Negativität für EZH2 unterschieden.

Fazit. TNET fallen in 3 molekulare Subgruppen, die nicht durch die gegenwärtig gültige WHO Klassifikation abgebildet werden. Wir schlagen 


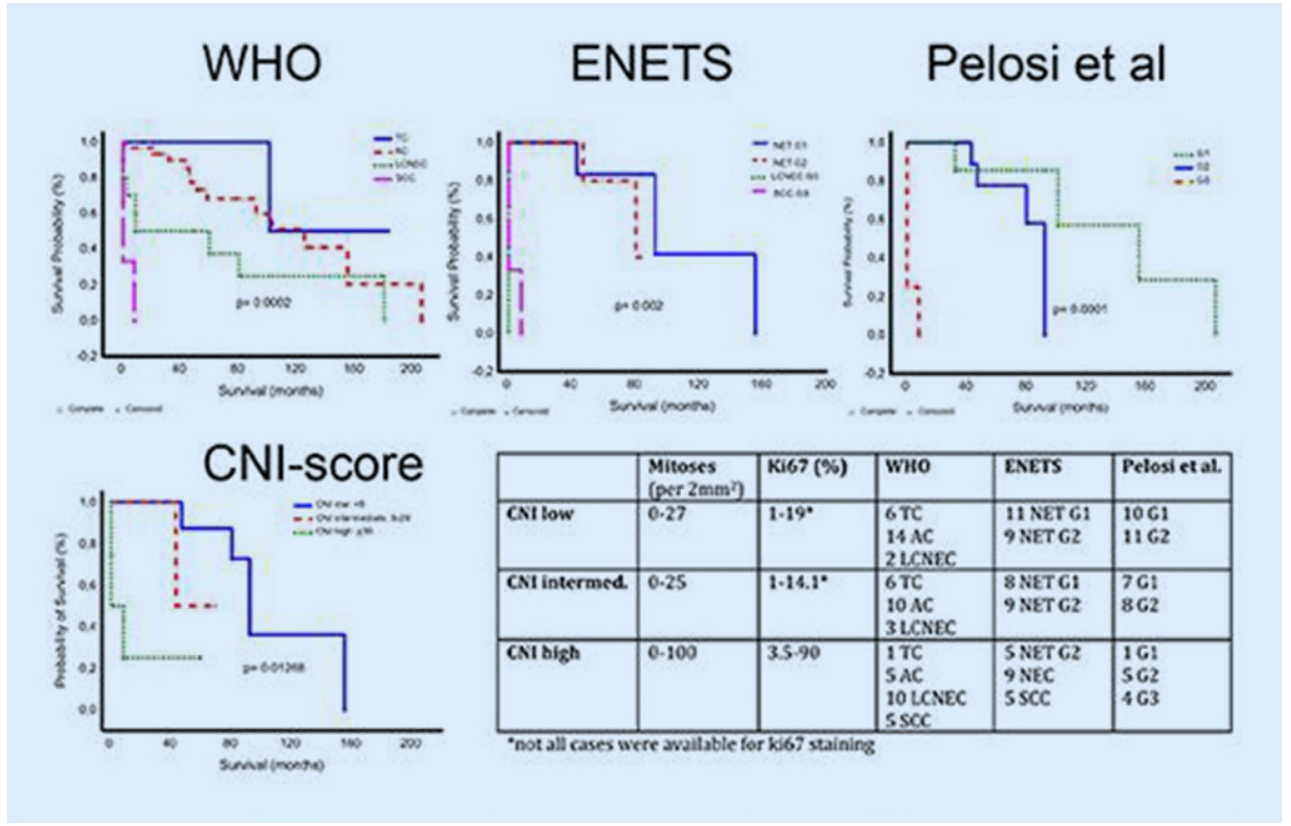

Abb. 3 | DGP04.03 $\varangle$ Vergleich morphologischer und molekularer Cluster in Bezug auf Prognose daher ein alternatives morpho-molekulares Gradingschema (Thy-NET G1-G3) für eine bessere Stratifizierung und Prognostizierung dieser seltenen Tumoren vor.

\section{DGP04.04}

\section{Immune checkpoint markers in gastroenteropancreatic neuroendocrine neoplasia}

F. Bösch' , K. Brüwer' ${ }^{1}$ A. Altendorf-Hofmann ${ }^{2}$, C. Auernhammer ${ }^{3}$, C. Spitzweg ${ }^{3}$, B. Westphalen ${ }^{3}$, S. Böck ${ }^{3}$, G. Schubert-Fritschle, , J. Werner', V. Heinemann ${ }^{3}$, M. Angele ${ }^{1}$, T. Kirchner ${ }^{5}$, T. Knösel ${ }^{5 *}$

${ }^{1}$ Klinik für Allgemein-, Viszeral- und Transplantationschirurgie am Klinikum der Universität München, Munich, Germany, ${ }^{2}$ Universitätsklinikum Jena, Tumorzentrum, Jena, Germany, ${ }^{3}$ Medizinische Klinik IV, Ludwig-Maximilians Universität, Munich, Germany, ${ }^{4}$ Tumorzentrum München, CCC, Munich, Germany, ${ }^{5}$ Pathologisches Institut der LMU, München, Germany

Aim. Cancer immunotherapy has evolved major breakthroughs in the last years. The cell surface receptor programmed death-1 (PD-1) and its ligand, programmed death ligand-1 (PD-L1) have been detected in various cancer types. However the analysis in gastroenteropancreatic neoplasia (GEP-NENs) is limited. Therefore, the aim of this study was to characterize GEP-NENs with regard to PD-1/PD-L1 pathway and tumor infiltrating lymphocytes (TILs).

Methods. On protein level we examined TILs, PD-1 and PD-L1 expression in tumor tissue of 244 GEP-NENs using immunohistochemistry. Expression levels were correlated with clinicopathological parameters including long-term survival in an observational study. In total 244 patients could be included.

Results. Most of the patients had a NEN of the small intestine (52.5\%) or the pancreas $(29.5 \%)$. All tumors could be graded by their morphology and Ki67 index, with 57.8\% G1, 34\% G2 and 8.2\% G3 tumors. High TILs (19.6\%) and high PD-1 (16.1\%) expression showed a significant correlation with shorter patient survival $(p<0.05)$ and with a higher grading. Furthermore, expression of PD-L1 (8.7\%) showed a trend to shorter patient survival.

Conclusions. High TILs and PD-1 expression are significantly associated with shorter patient survival and higher grading in GEP-NENs. PD-L1 expression showed a trend to shorter patient survival. Immunotherapy might be a promising therapeutic approach in GEP-NENs especially in tumors with high TILs.

Endocrine-Related Cancer, accepted January 2019, Impact 5,3
DGP04.05

DAXX immunohistochemistry for the in-situ detection of DAXX mutations in pancreatic neuroendocrine tumors

A. Jungbluth ${ }^{*}$, D. Klimstra', G. Nanjangud ${ }^{2}$, D. Frosina', J. Shia', J. Hechtman ${ }^{\text {' }}$ ${ }^{\prime}$ Memorial Sloan Kettering Cancer Center, Department of Pathology, New York, United States, ${ }^{2}$ Memorial Sloan Kettering Cancer Center, Sloan Kettering Institute, New York, United States

Aim. Death domain associated protein $(D A X X)$ gene encodes a nuclear protein that is involved in the assembly of telomeric chromatin. DAXX function is paramount to various nuclear functions such as transcription, cell cycle regulation and apoptosis. Recently, it has been shown that over $40 \%$ of PanNETs harbor mutations in either DAXX or ATRX (a-Thalassemia/x linked mental retardation (ATRX) gene). These mutations correspond with the presence of alternative lengthening of telomeres (ALT). IHC to DAXX is often used as a surrogate for sequencing wihere loss of DAXX immunostaining corresponds to the presence of DAXX gene alterations. Here, we aimed to elucidate the sensitivity of IHC for the detection of DAXX mutations.

Methods. Pancreatic neuroendocrine tumors (PanNETs) with DAXX mutations detected by sequencing and a subset of DAXX wild type PanNETs were analyzed for DAXX expression by IHC employing monoclonal antibody (mAb) E94 (sAbcam, ab32140).

Results. Of 154 molecularly tested PanNETs, 36 (30\%) harbored DAXX mutations. DAXX mutations tended to be mutually exclusive with ATRX mutations. 27 DAXX mutant PanNETs were available for IHC analysis, $23 / 27$ were negative by DAXX in-situ protein expression analysis (85.2\%). 4/27 DAXX mutants with retained in-situ protein expression harbored DAXX mutations within the last exon. Telomere-specific fluorescence in situ hybridization demonstrated alternative lengthening of telomeres (ALT) in all 4 cases which were positive for DAXX by IHC. Of 20 PanNETs with wild type DAXX, 19 retained were positive by DAXX in-situ analysis (95\%).

Conclusion. In-situ protein expression by IHC is a reliable way to detect DAXX mutations in PaNETs present in exons 1-3. Preserved DAXX protein expression does not exclude mutations in exon 4 , which are associated with alternative lengthening of telomeres. Sensitivity of immunohistochemical analysis for the detection of DAXX mutations, depends on the site of mutation. Lack of DAXX immunostaining is a reliable surrogate for the presence of DAXX mutations. However, preserved DAXX immunostaining does not exclude mutations of the last exon. 


\section{Endokrine Pathologie II}

\section{DGP05.01 Morphology and etiology of pheochromocytoma}

H.P.H. Neumann ${ }^{1 *}$, K. W. Schmid ${ }^{2}$, C. Eng ${ }^{3}$

${ }^{1}$ Albert-Ludwigs-University, Freiburg, Germany, ${ }^{2}$ Institute of Pathology, University of Duisburg and Essen, Germany, ${ }^{3}$ Cleveland Clinic, Cleveland, Ohio, USA

Pheochromocytoma, a potentially life-threatening tumor, has been histologically first described by Max Schottelius in 1886. He used Müller's chromate-containing solution which macroscopically transforms the surface of the tumor to dark-brown. Until today, these tumors are classified as chromaffin. The term pheochromocytoma goes back to Ludwig Pick in 1912. Modern skills for clinical diagnosis and treatment have contributed to tremendous improvements in the outcome of the patients. Still the major step is to consider this tumor in patients with unexplained symptoms, such as proxysms of tachycardia, headaches and episodes of profuse sweating. While endocrinologists prefer the biochemical pathway, radiological imaging is equally important for diagnosis. Plasma normetanephrine and abdominal magnetic resonance imaging are the key diagnostic methods. Nuclear medicine imaging is essential in detection of multiple and metastatic pheochromocytoma, today mainly performed with 68-Gallium-DOTATOC-PET-CT. Minimally invasive surgery is the current standard for treatment and the method of choice. Histopathologically, the tumor typically shows a "zellballen" pattern with chief cells and sustentacular cells. Chief cells are stained by chromogranin and synaptophysin; sustentacular cells with S-100. Histological and cytological scoring systems (the so-called PASS and GAPP scores) have been suggested, but these are not generally accepted for prediction of malignant pheochromocytoma. Undoubtedly, only lymph node or distant metastases provide the proof, and the 2019 WHO Classification of Endocrine Tumours has replaced the term malignant with metastatic pheochromocytoma. Patients who are $<30$ years, with multiple tumors, extraadrenal tumors and/or malignant tumors must be evaluated as carriers of germline mutations of one of the genes RET, VHL, NF1, SDHA, SDHB, SDHC, SDHD, SDHAF2, MAX or TMEM127 and must be considered thus to have manifestation of multiple endocrine ne- oplasia type 2, von Hippel-Lindau disease, neurofibromatosis type 1, paraganglioma syndromes type 1-5 or other familial pheochromocytoma syndromes, respectively. Immunohistochemistry has been extended towards staining of the normal protein components, for example by anti-SDHB. Patients with negative staining are likely to carry germline mutations in the respective susceptibility gene. Such patients should be advised to have genetic counseling followed by molecular genetic mutation screening.

\section{DGP05.03}

\section{Der Transkriptionsfaktor ChREBP erhöht die Proliferation und verringert die Glykogenspeicherung in pankreatischen $\beta$-Zellen bei diabetischen Mäusen}

\section{E. Knuth*, F. Dombrowski, S. Ribback}

Universitätsmedizin Greifswald, Institut für Pathologie, Greifswald, Deutschland

Ziel. In vitro stimuliert Glukose die Proliferationsaktivität pankreatischer $\beta$-Zellen, die womöglich durch den Transkriptionsfaktor carbohydrate responsive element binding protein (ChREBP) vermittelt wird, verbunden mit einer Aktivierung von Glykolyse, Lipogenese und alterierter Genexpression. Seine mögliche Rolle innerhalb der Pankreasinseln im Rahmen eines manifesten Diabetes mellitus mit gestörtem Glukose-Metabolismus wurden in vivo bei diabetischen Mäusen überprüft.

Methoden. Streptozotozin-diabetische Wildtyp-(WT) und ChREBPknockout (ChREBP-KO)-Mäuse erhielten eine intraportale Pankreasinseltransplantation in die Leber. Kontrolltiere blieben nicht diabetisch und erhielten keine Transplantation (Acht Gruppen, $n=20$, Dauer drei Monate). Vor der Perfusion erhielten sie den Proliferationsmarker 5-bromo2-desoxyuridin (BrdU). Es erfolgten histologische, immunhistologische und elektronenmikroskopische Analysen der präexistenten Pankreasinseln im Pankreasparenchym.

Ergebnisse. Der Anteil der Insulin-positiven $\beta$-Zellen in den Pankreasinseln war bei den diabetischen Mäusen beider Genotypen geringer als bei den nicht-diabetischen (diabetisch vs. nicht diabetisch: $28 \% \pm 3 \%$ vs. $80 \% \pm 1 \%, p<0,05)$.

Die $\beta$-Zell-Proliferationsrate der nicht diabetischen WT-Mäuse war im Vergleich zu den ChREBP-KO-Mäusen signifikant höher (WT vs. KO

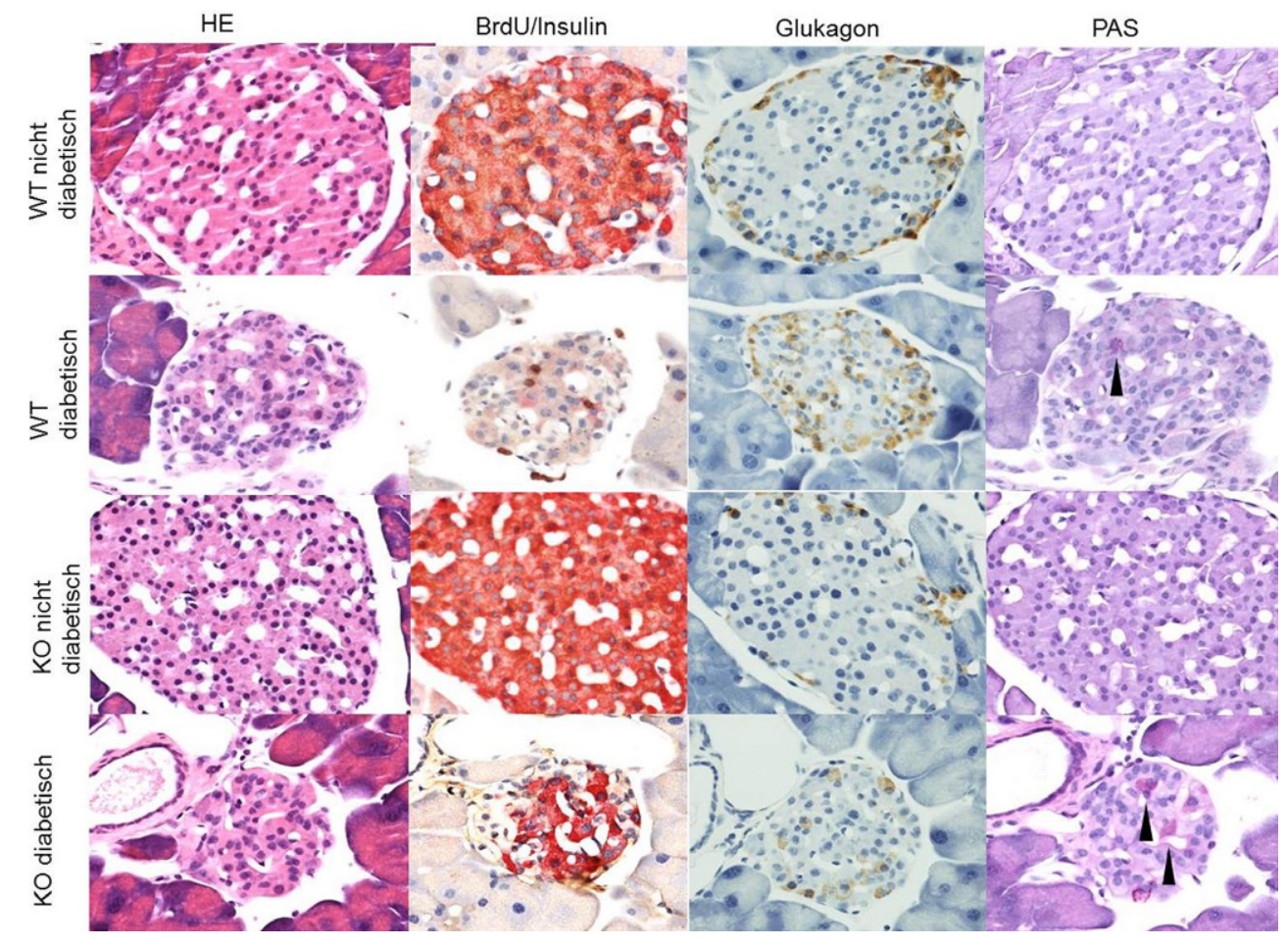

Abb. 1 | DGP05.03 $<$ Morphologie und Proliferationsaktivität von Pankreasinseln in Streptozotozindiabetischen und nicht diabetischen WT- und ChREBP-KO-Mäusen: Nachweis verkleinerter, zellärmerer Pankreasinseln (HE) aufgrund stark verminderter Insulin-positiver $\beta$-Zellen aber leicht erhöhter Proliferationsaktivität (erhöhte Zahl BrdU-positiver Zellkerne), veränderte Verteilung Glukagon-positiver a-Zellen und Nachweis PAS-positiver Zellen (PAS, Pfeilspitzen) bei den diabetischen Mäusen 


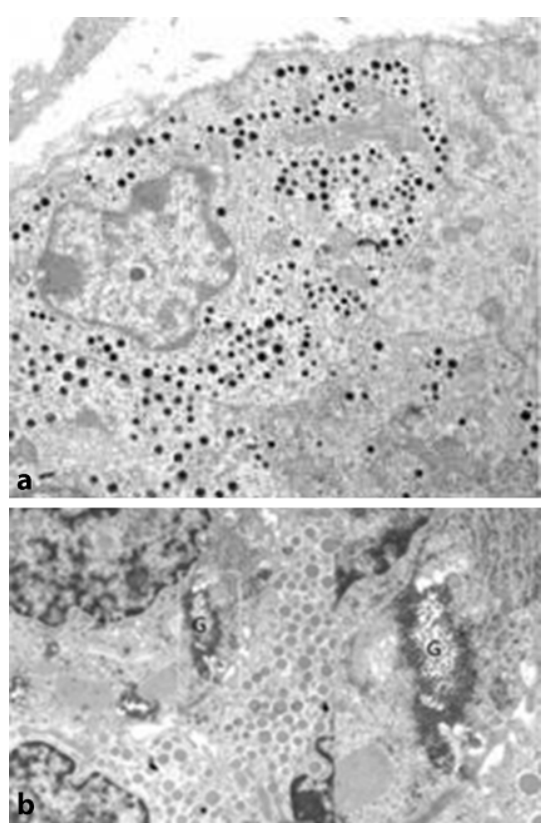

Abb. 2 | DGP05.03 $\triangle$ Elektronenmikroskopische Analyse. a Normale $\beta$-Zelle einer nicht diabetischen WTMaus mit regelhaften Granula-gefüllten Vesikeln ohne Nachweis einer Glykogenspeicherung. $\mathbf{b} \beta$-Zelle mit pathologischer Glykogenspeicherung $(G)$ in Form von a-Partiklen im Zytoplasma einer diabetischen ChREBPKO-Maus

$0,46 \% \pm 0,09 \%$ vs. $0,26 \% \pm 0,05 \%, p<0,05)$. Eine ähnliche Tendenz ergab sich bei den diabetischen WT-Tieren im Vergleich zu den KO-Tieren (n.s.) (• Abb. $1 \mid$ DGP05.03).

Bei den diabetischen Mäusen beider Genotypen ließen sich häufig PAS-positive Inselzellen nachweisen, was elektronenmikroskopisch a-Glykogenpartikeln entspricht (• Abb. 2 |DGP05.03).

Dabei war der Anteil von ChREBP-KO-Mäusen mit PAS-positiven Inselzellen signifikant höher als bei den WT-Mäusen (KO vs. WT diabetisch $57,5 \%$ vs. $12 \%, p<0,05)$.

Fazit. Auch in vivo stimuliert ChREBP im Rahmen eines Diabetes mellitus die glukose-vermittelte Proliferationsaktivität der $\beta$-Zellen und ist mit einer verringerten Glykogenspeicherung assoziiert. chREBP-abhängige Signalwege beeinflussen womöglich auch die Insulinsynthese und -sekretion und damit die Glukosetoleranz der pankreatischen $\beta$-Zellen.

\section{DGP05.04}

\section{EndoPath WHO: a custom-designed AmpliSeq panel for comprehensive endocrine tumor diagnostics including rare hereditary syndromes}

N. Valtcheva ${ }^{1 *}$, S. Kreutzer', M. Rechsteiner', N. Rupp', L. M. Roose', F. Beuschlein', C. Röösli3, O. Tschopp², A. Weber ${ }^{1}$

'University Hospital Zurich, Department of Pathology and Molecular Pathology, Zurich, Switzerland, ${ }^{2}$ University Hospital Zurich, Clinic for Endocrinology, Diabetology and Clinical Nutrition, Zurich, Switzerland, ${ }^{3}$ University Hospital Zurich, Department of Otorhinolaryngology, Zurich, Switzerland

Aim. A substantial proportion of (neuro)-endocrine tumors develop on the background of a hereditary tumor syndrome. In particular, paraganglioma/pheochromocytoma are associated in $>40 \%$ of cases with germline mutations in a variety of genes inculding those encoding subunits of the succinate dehydogenase (SDH) complex. With increasing knowledge gained throughout the last decade of cancer genome sequencing, the list of genes linked to endocrine tumor syndromes was expanded, which has been acknowledged in the 4th edition of the WHO classification of tumors of endocrine organs.

Methods. In order to include screening of also those genes recently linked to the inherited endocrine tumor syndromes in the routine diagnostics, we established and validated a custom-designed, 27 genes containing NGS panel (EndoPath WHO) using the Ion Torrent platform.
Results. Following validation on archival cases with known mutationals status, genetic testing of 32 patients routinely submitted to us due to clinically suspected hereditary syndromes was performed with the EndoPath WHO panel. Besides mutations in commonly affected genes (such as MEN1, RET, SDHA, SDHB, SDHC, SDHD), we also detected rare mutations in two young patients which would have been missed before: A 24year old patient with a pheochromocytoma had previously been tested negative for germline alterations in the genes $S D H A, S D H B, S D H C$ and $S D H D, V H L$ und RET. Applying the EndoPath WHO panel, a mutation in the gene $M A X$ was detected (p.Arg75Ter).

A 15-year old male patient developed bilateral head\&neck paragangliomas with loss of SDHB expression. Whereas the EndoPath WHO panel testing revealed a wild type status for the $S D H B$ gene, a mutation in the SDH assembly factor 2 (SDHAF2) gene (p.Gly78Arg) was detected. Mutations in the SDHAF2 gene, inherited in a autosomal dominant manner with maternal imprinting, cause the hereditary paraglioma syndrome 2 (PGL2). SDHAF2 is a highly conserved co-factor involved in the flavination of the SDH-A subunit and stability of the SDH complex, which explains the loss of SDHB immuno reactivity observed in this case.

Conclusion. Given the far-reaching implications for patients and theirs families, our findings emphasize the need for testing a broad range of genes in order to discover also rare germline mutations. Also patients with a negative family history should be tested, especially if their tumors present at young age and/or in multiple locations.

\section{DGP05.05}

\section{Gehören Karzinoide und kleinzelligen Karzinome der Lunge mit spindelzelligem Muster einer eigenen Tumorentität an?}

A. Kasajima ${ }^{1 * 2,2}$ B. Konukiewitz', N. Oka ${ }^{3}$, H. Suzuki ${ }^{4}$, T. Kameya ${ }^{5}$, A. Sakurada ${ }^{6}$, Y. Okada ${ }^{6}$, Y. Ishikawa ${ }^{7}$, H. Sasano ${ }^{3}$, W. Weichert', G. Klöppel ${ }^{7}$

${ }^{1}$ Institut für Allgemeine Pathologie und Pathologische Anatomie der Technischen Universität München, München, Deutschland, ${ }^{2}$ Deutsches Krebsforschungszentrum (DKFZ), Heidelberg, Deutschland, ${ }^{3}$ Tohoku University Graduate School of Medicine, Department of Pathology, Sendai, Japan, ${ }^{4}$ National Hospital Organization, Sendai Medical Center, Sendai, Japan, ${ }^{5}$ Shizuoka Cancer Center Hospital and Research Institute, Division of Pathology, Sizuoka, Japan, ${ }^{6}$ Tohoku University Graduate School of Medicine, Institute of Development, Aging and Cancer, Department of Thoracic Surgery, Sendai, Japan, ${ }^{7}$ The Cancer Institute Hospital of JFCR, Department of Pathology, Tokyo, Japan

Ziel. Bronchopulmonale neuroendokrine Neoplasien (BP-NEN), Karzinoide wie auch Karzinome, können eine spindelzellige Histologie zeigen. Ziel dieser Studie ist es, Inzidenz, biologische und klinisch-pathologische Eigenschaften der spindelzelligen Karzinoide und der spindelzelligen neuroendokrinen Karzinomen miteinander zu vergleichen, um die Hypothese zu überprüfen, ob beide Tumorgruppen einer Entität angehören.

Methoden. Die Studie wurde an Resektaten von 244 BP-NENs aus Japan mit bekanntem klinisch-pathologischem Profil durchgeführt. Die BPNEN wurden histologisch in spindelzellige und nicht-spindelzellige Tumore unterteilt.

Ergebnisse. Elf von 59 (19\%) Karzinoiden und 36 von 127 (28 \%) kleinzelligen Karzinome (SCLC) zeigten ein spindelzelliges Muster. Unter den großzelligen Karzinomen gab es keine spindelzelligen Tumoren. Frauen waren sowohl beim spindelzelligen Karzinoid (91 \% vs. 50 \%, beim nichtspindelzelligem Karzinoid, $p<0,001$ ) als auch beim spindelzelligen SCLC ( $35 \%$ vs. $6 \%$ beim nicht-spindelzelligen SCLC, $p<0,001$ ) häufiger betroffen als Männer. Starkes Zigarettenrauchen war sowohl bei den Karzinoidpatienten $(p=0,07)$ als auch bei den SCLC-Patienten $(p=0,03)$ nicht mit einem Spindelzelltyp assoziiert. Spindelzellige Karzinoide waren außerdem häufiger peripher lokalisiert als nicht-spindelzellige Karzinoide (55 \% vs. $27 \%, p=0,08)$. Immunohistochemisch zeigten spindelzellige SCLC eine stärkere Expression von neuroendokrinen Markern (CgA $p<0,01, \mathrm{CD} 56$ $p<0,001)$ sowie TTF-1 $(p<0,001)$ als nicht-spindelzellige SCLC. Das postoperative krankheitsfreie Überleben der Patienten mit spindelzelli- 
gem SCLC scheint besser zu sein als das der nicht-spindelzelligen SCLC Patienten $(p=0,3)$.

Fazit. Ein spindelzelliges Muster ist sowohl beim Karzinoid als auch beim SCLC signifikant mit dem weiblichem Geschlecht, geringem Zigarettenrauchen und peripherer Tumorlokalisation assoziiert. Diese Befunde könnten auf eine biologische Zusammengehörigkeit aller spindelzelligen BP-NEN hinweisen. Darüberhinaus könnten die spindelzelligen BP-NEN einer eigenen Tumorgruppe innerhalb der BP-NEN angehören. Immunohistochemische Untersuchungen zur Expression der Genprodukte p53, rb1 DAXX und ATRX sollen zur Klärung dieser Frage beitragen.

\section{Endokrine Pathologie - Schilddrüse I}

\section{DGP06.01 \\ The pathologists influence on psychological wellbeing of patients with carcinoma of the thyroid}

M. Teufel*

Universität Duisburg-Essen, Psychosomatische Medizin und Psychotherapie, Essen, Germany

Patients with carcinoma of the thyroid significantly suffer from psycho-oncological distress as well as of symptoms of depression and anxiety. Compared to other tumor entities, mental comorbidity is highest in thyroid cancer. Reasons for this high prevalence of psycho-oncological distress are various. Despite endocrinological alterations, an often unclear significance of the pathology diagnosis as "carcinoma" can be discussed as individually burdening challenges. Especially, in thyroid cancer it is hard to draw diagnostical determination, due to unclear clinical relevance of questionable pathology findings. A precipitous designation as "carcinoma" without verified certainty of potential consequences (invasiveness, prognosis, treatment necessity) might reassure the pathologist, but worry or even alarm the patient. Pathologists should be aware of their responsibility for patients' mental health, when describing thyroid tissue probes as carcinoma. An ongoing discussion process in pathology societies on how to name findings with unclear clinical significance is needed.

\section{DGP06.02}

\section{NIFTP-a subtle diagnosis in order to avoid patient's overtreatment and psychosomatic burden}

\section{S. Theurer* \\ Institut für Pathologie Universitätsklinikum Essen, Universität Duisburg Essen, Essen, Germany}

The major goals of the introduction of the non-invasive follicular neoplasia with papillary-like nuclear features (NIFTP) are to spare patients with a biologically indolent subgroup of the follicular variant of papillary carcinoma (FV-PTC) both overtreatment and the psychologically burden of a cancer/carcinoma diagnosis. Strict histological and molecular pathological criteria have been introduced for the diagnosis of NIFTP as a differential diagnosis of PTC. Histologically, an encapsulated/clearly demarcated lesion with $(>70 \%)$ follicular structure and the nuclear characteristics of PTC must be present as a prerequisite; invasion of capsule/vessels must be excluded as well as significant proportions (>30\%) showing a solid/trabecular/insular growth pattern, psammoma bodies, tumor necrosis, an increased mitotic rate $(>3 / 10 \mathrm{HPF})$ and/or a BRAF V600E mutation. The establishment of the NIFTP necessitated a redefinition of the diagnostic criteria of PTC and has implications on the evaluation of fine needle biopsy (FNB) of the thyroid gland. Although a prediction is difficult, the correct diagnosis of NIFTP could lead to a $10-20 \%$ reduction in thyroid carcinoma incidence.

\section{DGP06.03}

\section{Subtypisierung des follikulären Schilddrüsenkarzinoms (WHO} 2017) - sind alle Subtypen biologisch maligne?

\section{A. Schad*}

Universitätsmedizin Mainz, Institut für Pathologie, Mainz, Deutschland

Das follikuläre Schilddrüsenkarzinom (FTC) wird gegenüber dem follikulären Adenom (FA) durch den Nachweis einer Kapsel- und/oder Angioinvasion definiert. Die aktuelle WHO-Klassifikation unterscheidet dabei zwischen grob- und minimal-invasiven FTCs sowie bei den minimal-invasiven FTCs weiter zwischen minimal-invasiven FTCs mit Kapselpenetration ohne Angioinvasion und solchen mit Angioinvasion unterschiedlicher Ausprägung.

Diese Einteilung korrespondiert mit einem weiten Spektrum biologischen Verhaltens der unterschiedlichen Neoplasien, mit häufiger hämatogener Metastasierung bei grob-invasiven und angioinvasiven FTCs auf der einen Seite und einem weitgehend indolenten Verhalten mit exzellenter Langzeitprognose der nicht-angioinvasiven, minimal-invasiven FTCs auf der anderen Seite.

Analog zur Entwicklung beim Papillären Schilddrüsenkarzinom (PTC), bei dem durch die Einführung des NIFTP Tumore mit besonders günstiger Prognose nicht länger als Karzinom bezeichnet werden müssen, stellt sich auch beim FTC die Frage, ob nicht auch bei minimal-invasiven, nichtangioinvasiven FTCs oder aber auch bei follikulären Mikrokarzinomen aufgrund ihrer guten Prognose in Zukunft auf die Bezeichnung „Karzinom“ zugunsten einer Bezeichnung wie z. B. „follikuläre Neoplasie mit geringem malignen Potential" verzichtet werden könnte, mit dem Ziel einer abgestuften, das biologische Verhalten der verschiedenen follikulären Neoplasien besser reflektierenden und damit für die Patienten weniger belastenden Tumordiagnose und -nachsorge.

\section{Endokrine Pathologie - Schilddrüse II}

\section{DGP07.02 \\ Poorly differentiated thyroid carcinoma-an underdiagnosed entity}

M. Dettmer ${ }^{1 *}$, A. Schmitt ${ }^{1}$, P. Komminoth ${ }^{2}$, A. Perren ${ }^{1}$

'University of Bern, Institute of Pathology, Bern, Switzerland, ${ }^{2}$ Triemlispital

Zurich, Zurich, Switzerland

Poorly differentiated thyroid carcinomas (PDTC) are a rare subtype of thyroid carcinomas which are biologically situated between well differentiated papillary/follicular thyroid carcinomas and anaplastic thyroid carcinomas (ATC).

The diagnosis of conventional as well as oncocytic poorly differentiated is difficult and often missed in daily routine. The current WHO criteria to allow the diagnosis of PDTC are based on the results of a consensus meeting which was held in Turin 2006. The criteria are based on the identification of a malignant neoplasm, often with angioinvasion and/or wide invasion and the presence of a solid/trabecular/insular growth pattern, lack of nuclear features of papillary carcinoma, and one of the following additional features: (1) convoluted nuclei, (2) tumor necrosis, (3) 3 or more mitoses per 10 high-power fields. Even a minor poorly differentiated component of only $10 \%$ of a given carcinoma significantly affects patient prognosis and the oncocytic subtype may even have a worse outcome. Immunohistochemistry is not of much help and is mostly used to exclude a medullary thyroid carcinoma with calcitonin and to establish a follicular cell of origin via thyroglobulin staining. Due to the concept of stepwise dedifferentiation, there is a vast overlap of different molecular alterations like $B R A F, R A S, C T N N B 1, T P 53$ and others between different thyroid carcinoma subtypes. A distinctive molecular tumor profile is therefore currently not available.

MiR-23b and miR-150 affect patient prognosis and PDTC have a unique miRNA signature, which separates them from other thyroid carcinomas. 
The average relapse free survival is less than one year and about $50 \%$ of patients die of the disease. This requires a more aggressive therapy than a well differentiated thyroid carcinoma and encompasses radioiodine treatment plus the possibility of external beam radiation. Modern tyrosine kinase inhibitors offer in conjunction with powerful molecular diagnostic new chances in these difficult to treat carcinomas.

\section{DGP07.04}

MiRNAs are involved in tall cell morphology in papillary thyroid carcinoma and predict tumor prognosis

\section{Boos', A. Schmitt', H. Moch'², P. Komminoth ${ }^{3}$, C. Simillion', Y. Nikiforov',} M. Nikiforova ${ }^{4}$, A. Perren ${ }^{1}$, M. Dettmer ${ }^{1 *}$

'Universität Bern, Bern, Switzerland, ${ }^{2}$ University Hospital Zürich, Department of Pathology and Molecular Pathology, Zürich, Switzerland, ${ }^{3}$ Triemlispital Zurich, Zurich, Switzerland, ${ }^{4}$ University of Pittsburgh Medical Center, Pittsburgh, United States

Background. 5\% of papillary thyroid carcinomas (PTC) show an adverse clinical outcome (ACO). The tall cell variant of papillary thyroid carcinomas (TCV) is a good predictor of an ACO, however, the identification of tall-cells is subjective. MiRNA expression in PTC could be a powerful, more objective predictor of prognosis.

Methods. Forty-four PTC underwent miRNA profiling, twenty-four of them were TCV. The miRNA dataset was validated by analysis of expression of known target proteins (VEGF and PTEN) in 125 patients including $48 \mathrm{TCV}$ and 57 with an ACO.

Results. 149 miRNAs were significantly associated with an ACO, seventy-one of them with TC-morphology. Twenty-two miRNAs were identified as targets for VEGF and thirty-two as targets for PTEN. In univariate and multivariable analysis, reduced expression of PTEN and an increased expression of VEGF retained significance regarding a shorter relapse free survival. A classifier including TC-morphology, pT-stage, VEGF and PTEN renders an accuracy to predict patient relapse of $80 \%$.

Conclusions. MiRNAs predict outcome in PTC and are involved in TC-morphology in PTC. These miRs may serve as more objective indicators of an ACO than tall cell morphology. PTEN and VEGF protein expression are prognostically relevant and are at least partially regulated by miRNAs.

\section{DGP07.05}

\section{Cervical CUP-syndrome by a papillary thyroid carcinoma with transition into an undifferentiated carcinoma}

I. Petersen ${ }^{1 *}$, A. Müller ${ }^{2}$

'SRH Waldklinikum Gera, Institut für Pathologie, Gera, Germany, ${ }^{2}$ SRH Waldklinikum Gera, Klinik für Hals-Nasen-Ohrenheilkunde, Gera, Germany

Aim. Carcinoma of unknown primary site (CUP) still represents an important challenge for pathologists and clinicans despite the tremendous progress and possibilities of molecular tumor analysis. This is due to the fact that the optimal treatment usually requires the exact tumor classification and thus the identification of the organ and cellular origin of the cancer. We present a CUP case which presented as a cervical lymph node metastasis in which the tumor could not be characterized by the initial biopsy. However, the resection specimen resolved the case. Still, it highlights some issues and limitations in the molecular analysis of such samples.

Methods. The case report is based on the clinical history and pathological evaluation of a 81 year old female patient.

Results. She presented with a cervical lymph node metastasis without any signs of a prrimary tumor. The biospy specimen yielded the diagnosis of an undifferentiated carcinoma with solid tumor growth. Immunohistochemistry showed evidence for a squamous differentiation by the identification of a $\mathrm{p} 63$ and CK5/6 positivity together with a pan-cytokeratin expression (MNF116). There was no p16 positivity. In the resection specimen, a tumor of $50 \mathrm{~mm}$ was removed with partial cystic growth. Within the cyst, a papillary nodule was identified that showed typical morphological and immunohistochemical features of a papillary carcinoma, i. e. nuclear TTF1 and cytoplasmic thyreoglobulin expression. The nodule was partially seperated from the adjacent predominant undiffferentiated tumor component by a fibrous capsule. The undifferentiated carcinoma was TTF1 and thyreoglobulin negative and instead showed positivity for the above mentioned markers of the biopsy. There was a strict histomorphological and molecular switch between both compartments. Still, the undifferentiated carcinoma most probably evolved from the papillary cancer. Interestingly, there was an additional small lymph node that harboured the micrometastasis of the papillary thyroid carcinoma.

Conclusion. The case highlights the fact that some carcinomas may totally loose defining features of the primary tumor. It will be interesting to analyze both tumor components by molecular genetics to determine if mutation or methylome analysis is able to decipher the relationship of both tumor components and to better pinpoint the primary site of a CUP case than standard histopathology and immunohistochemistry.

\section{Präzisionsonkologie - freie Vorträge II}

\section{DGP08.01}

\section{$91 \%$ Spezifität und $100 \%$ Sensitivität bei der} Differenzialdiagnose zwischen benigne und maligne - eine Analyse von 485 Lungenproben

R. F. H. Walter ${ }^{1,2}$, P. Rozynek ${ }^{3}$, S. Casjens ${ }^{3}$, F.D. Mairinger', E. J. M. Speel', A. Zur Hausen ${ }^{4}$, S. Meier ${ }^{3}$, J. Wohlschlaeger', D. Theegarten', T. Behrens ${ }^{3}$, K.W. Schmid', T. Brüning ${ }^{3}$, G. Johnen ${ }^{3}$

'Institut für Pathologie, Universitätsklinikum Essen, Universität DuisburgEssen, Essen, Deutschland, ${ }^{2}$ Ruhrlandklinik, Westdeutsches Lungenzentrum am Universitätsklinikum Essen gGmbH, Essen, Deutschland, ${ }^{3}$ Institute for Prevention and Occupational Medicine of the German Social Accident Insurance, Institute of the Ruhr-University Bochum (IPA), Bochum, Deutschland, ${ }^{4}$ Department of Pathology, GROWSchool for Oncology \& Developmental Biology, Maastricht University Medical Center, Maastricht, Niederlande

Ziel. Lungenkrebs verursacht die meisten Krebstoten weltweit. Histologische Differenzialdiagnose kann erschwert sein, gerade wenn kleine Proben und Biopsien untersucht werden. Epigenetische Veränderungen sind gewebespezifische, frühzeitige Ereignisse während der Tumorgenese. Daher könnten diese als Biomarker für die Differenzialdiagnose zwischen benigne und maligne dienen.

Methoden. 138 FFPE Proben (116 Lungenkrebsfälle, 22 benigne Kontrollen) wurden mittels Pyrosequenzierung auf die Methylierung von $10 \mathrm{Li}$ teratur-basierten Methylierungsmarkern untersucht (APC, CDH2, CDKN2A, EFEMP1, FHIT, L1RE1, MGMT, PTEN, RARB und RASSF1). Die bioinformatische Auswertung wurde mittels „Classification and Regression Tree Algorithm“ (CART) und „Conditional Interference Trees“ (ctree) und „Receiver Operating Characteristic“ (ROC) durchgeführt. Eine Validierung erfolgte an 27 Lungenkrebsfällen, 38 benignen Kontrollen und 282 Lungenkrebsfällen aus der TCGA Datenbank („The Cancer Genome Atlas").

Ergebnisse. CART und ctree identifizierten jeweils die Kombination von L1RE1 und RARB als auch L1RE1 und RASSF1 als Methylierungsmarker mit hoher driskriminativer Stärke für die Differenzialdiagnose zwischen benigne und maligne (91 \% Spezifität, $100 \%$ Sensitivität, Fehlerrate 1,4 \%, $p<0,0001$ ).

Fazit. Gerade bei Biopsien und Proben limitierter Größe erweisen sich Methylierungsmarker als wertvoll für die Differenzialdiagnose. Die genutzte Methode kann in jedem Labor etabliert werden und ist einfach anzuwenden. Die simple Auswertung mittels eines Entscheidungsbaums ermöglicht eine sichere und schnelle Diagnose. 


\section{DGP08.02 \\ Comparison of PD-L1 expression between paired cytologic and histologic non-small cell lung cancer specimens}

C. Kümpers ${ }^{1 *}$, L. van der Linde ${ }^{2}$, M. Reisch' ${ }^{3}$, W. Vogel', L. Welker', S. Perner 'University Hospital Schleswig-Holstein, Campus Luebeck and Research Center Borstel, Leibniz Lung Center, Luebeck and Borstel, Pathology, Luebeck, Germany, ${ }^{2}$ LungenClinic, Großhansdorf, Germany, ${ }^{3}$ Institute for Applied Computer Science, Institute of Technology, Karlsruhe, Germany

Background and aims. Immunotherapy with immune checkpoint inhibitors has already shown promising results for therapy of NSCLC patients. Expression of PD-L1 measured by immunhistochemistry (IHC) on histologic samples seems to be suitable for identifying patients with a higher chance for a clinical benefit from immunotherapy, and PD-L1 expression assessed by IHC is in the context of companion diagnostic even mandatory for this therapy. Indeed, a huge portion of patients, estimated with 30 to $50 \%$, is diagnosed solely with cytologic specimens. So far, PD-L1 assays are not approved for immunocytochemistry. The aims of this study were to find out if assessment of PD-L1 expression on paired histologic and cytologic tumor specimens show matchable results and to investigate the interobserver variability between 3 independent investigators.

Methods. The study included 247 paired samples of NSCLC (153 adenocarcinoms and 94 squamous cell carcinomas). Samples were stained with PD-L1 clone 22C3pharm Dx. Membranous PD-L1 expression was evaluated and positive tumor cells were reported as percentage. Samples were categorized with tumor proportion scores as negative $(<1 \%)$, intermediate positive $(\geq 1$ to $<50 \%)$ and highly positive $(\geq 50 \%)$ and also compared with sheer values of PD-L1 expression. Concordance was defined if values of paired samples lay both within a delta of 10 . Interobserver variability was assessed with standard deviation from the mean.

Results. Defining values of PD-L1 expression between histologic and cytologic samples within a delta of 10 as concordant, concordance rate was $82 \%$. Overall agreement, based on identical values between the paired samples, was seen in approximately $53 \%$ of cases. With categorization of PDL1 expression based on tumor proportions scores, category was the same in $74.1 \%$. Most of these samples were scored as negative (91.8\%) due to a general low expression of PD-L1 in the cohort $(82.6 \%$ assessed on histologic samples, $77 \%$ assessed on cytologic samples). Interobserver variability was significantly pronounced for evaluation of cytologic specimens. Conclusion. Evaluation of PD-L1 expression in paired histologic and cytologic tumor specimens shows comparable results if a delta of 10 between the values is tolerated. Interpretation of PD-L1 expression is much more challenging for cytologic samples than for histologic samples which is reflected in a greater interobserver variability for cytologic samples in the current study.

\section{DGP08.03}

\section{Ln-situ protein detection of isocitrate dehydrogenase (IDH) mutations}

A. Jungbluth ${ }^{1 *}$, D. Frosina', M. Fayad', T. Basili de Oliveira', B. Alemar', M. Rosenblum' ', L. Tang', M. Hameed' ', B. Xu', R. Ghossein', D. Chute', B. Weigelt', S. Dogan'

'Memorial Sloan Kettering Cancer Center, Department of Pathology, New York, United States, ${ }^{2}$ Cleveland Clinic Foundation, Department of Pathology, Cleveland, United States

Aim. IDH is a mitochondrial enzyme, which is involved in the oxidative decarboxylation of isocitrate. Biologically active mutations of IDH2/IDH1 genes are present in various types of tumors and some mutations are associated with certain tumor types. Clinical trials selectively inhibiting mutated IDH2 proteins are on-going. Consequently, knowledge of the IDH mutation status has important therapeutic and diagnostic implications. Immunohistochemical analysis of IDH1 R132H has been well established in the diagnosis of glioma. Here we are studying a novel monoclonal antibody $(\mathrm{mAb})$ clone $11 \mathrm{C} 8 \mathrm{~B} 1$, which was generated to the IDH2(R172S) mutation.
Methods. MAb 11C8B1 was obtained commercially (Neweast Biosciences, Malvern, PA). A cell pellet of chondosarcoma cell line SW1353 harboring the IDH2(R172S) mutation was used as a positive control. Standard archival paraffin blocks were used.

Archival paraffin blocks with molecularly confirmed presence of IDH1/2 mutations could be retrieved. A total of 61 cases with molecularly pre-typed tumors harboring IDH1 or IDH2 mutations could be retrieved. A series of $25 \mathrm{IDH} 1 / 2$ wild-type tumors was also analyzed.

Results. Tumors with the following mutations and (n) cases were identified: IDH2:R172S (15); R172T (3); R172K (8); R172G (6); R172 W (4); R172M (4); IDH1: R132S (6); R132G (5); R132C (4); R132H (3); R132L (3). MAB 11C8B1 was immunopositive in all 15 IDH2(R172S) and 3/3 IDH2(R172T) mutated case. There was also staining in 2/6 IDH1(R132S) cases. No other mutated or any wild-type tumor was immunopositive with $\mathrm{mAb} 11 \mathrm{C} 8 \mathrm{~B} 1$.

Conclusion. Exact knowledge of IDH1/2 mutation status has important diagnostic and therapeutic implications. As new serological reagents become available, exact knowledge of their specificity is mandatory. Here we tested a novel $\mathrm{mAb} 11 \mathrm{C} 8 \mathrm{~B} 1$, which was generated to the IDH2(R172S) mutation. 11C8B1 reliably detects IDH2(R172S) mutations but also reacts with IDH2(R172T) and approximately one third of IDH1(R132S) mutations. This is not surprising, since these mutations differ only by single amino acids of the epitope. Most importantly, mAb 11C8B1 is negative in all wild-type cases.

In conclusion, taking into account its reactivity spectrum, mAb 11C8B1 is a useful diagnostic marker for the detection of IDH mutations and may serve as a rapid and inexpensive reagent for mutant protein detection.

\section{DGP08.04}

Performance comparison of the nanostring platform and targeted RNA-sequencing for I0-gene expression profiling in renal cell carcinomas

S. B. Talla ${ }^{1 *}$, E. Rempel', V. Endris', F. Stögbauer', A.-L. Volckmar', O. Neumann', S. Duensing ${ }^{1}$, J. Budczies', A. Stenzinger', M. Kirchner ${ }^{1}$

'University Hospital, Heidelberg, Germany

Aim. Gene signatures derived from focused gene expression profiling on formalin-fixed and paraffin-embedded (FFPE) tissue samples are currently being investigated as biomarkers in immunooncology. Here we compared two technologically different methods and their related assays for focused transcriptome profiling of FFPE clear cell renal cell carcinomas (ccRCC). Methods. Twenty seven tumor samples were extracted from $14 \mathrm{ccRCC}$ patients. RNA was extracted from FFPE preserved tumors using Maxwell system (Promega) and quantified by qubit (Thermofisher Scientific, USA). Approximately $100 \mathrm{ng}$ of RNA per sample was used for quantifying 730 target and 40 housekeeping genes included in the Human Pan Cancer Immune Profiling Panel on the nCounter system (NanoString Technologies, USA). Raw read counts were normalized by NanoStringDiff. For Ion Torrent $^{\text {th }}$ based RNA-sequencing, 10 ng cDNA per sample was used to amplify 395 target genes included in the Oncomine ${ }^{\mathrm{mat}}$ Immune Response Research Assay (Thermo Fisher Scientific, USA). Barcoded libraries were sequenced on the IonS5XL platform. Raw reads were normalized by DESeq2. SYBR green based qRT-PCR was used to validate core findings. R and Graphpad Prism7 were used for all statistical analyses.

Results. In general, both methods showed high technical reproducibility (Pearson correlation $(r) \geq 0.96$ ) and precision. We identified a common set of 248 genes shared by both assays, whose expression demonstrated a comparable bi-modal distribution and dynamic range. Comparison of normalized expression levels of 248 common genes, detected in the same samples on both platforms, showed a moderate level of linear correlation. However, when analyzing the fold change, estimated as ratio between male and female group, for each of the 248 genes, a high correlation (Spearman corr .73) between the two platforms was observed. Moreover, we noted lower re-test variability and a better resolution particularly for genes with low expression levels for the RNASeq assay compared to the nanostring test. Finally, using RT-PCR as an orthogonal method, we found varying 
degrees of correlation for a set of target genes measured by the nCounter and RNASeq assay.

Conclusion. Our data suggest that both platforms yield comparable results despite their intrinsic technical discrepancies when looking at a set of genes; may be employed interchangeably for this purpose. RNASeq provides a better signal-to-noise ratio when genes with low level expression are investigated.

\section{DGP08.05}

\section{Differentialdiagnostischer Nutzen des Nachweises von Isocitratdehydrogenase (IDH)-Mutationen bei der Untersuchung chondrogener Tumoren}

V. Schoeder ${ }^{1 *}$, S. Franke ${ }^{1}$, A. Roessner ${ }^{1}$, J. Haybäck ${ }^{1,2,3}$, D. Jechorek ${ }^{1}$

${ }^{1}$ Medizinische Fakultät, Otto-von-Guericke-Universität, Institut für Pathologie, Magdeburg, Deutschland, ${ }^{2}$ Medizinische Universität, Institut für Pathologie, Neuropathologie und Molekularpathologie, Innsbruck, Österreich, ${ }^{3}$ Medizinische Universität, Medizinische Universität Abteilung für Neuropathologie, Diagnostik- \& Forschungszentrum für Molekulare Biomedizin, Institut für Pathologie, Graz, Österreich

Ziel. Die Differentialdiagnostik von Chondrosarkomen ist anspruchsvoll Dies gilt zum einen, weil kleine Biopsien nicht immer repräsentative Tumoranteile erfassen und zum anderen, weil konventionelle Chondrosarkome und chondroblastische Osteosarkome einerseits sowie dedifferenzierte Chondrosarkome und undifferenzierte pleomorphe Sarkome des Knochens andererseits jeweils ein ähnliches histologisches Bild zeigen. Das führt zu Fehlinterpretationen und macht die korrekte Zuordnung zum Teil unmöglich. Daten aus der Literatur belegen, dass in etwa der Hälfte aller Enchondrome, konventionellen und dedifferenzierten Chondrosarkome Alterationen in den humanen Isocitratdehydrogenase (IDH)-Genen 1 und 2 charakteristisch sind. Dahingegen weisen die übrigen chondrogenen Malignome, wie auch andere Knochensarkome, keine IDH-Mutationen auf. Das Ziel dieser Arbeit ist, den Nutzen eines Nachweises von IDH-Mutationen in der Differentialdiagnose chondrogener Tumoren $\mathrm{zu}$ verifizieren.

Methoden. In der vorliegenden Arbeit wurden 70 konventionelle, 20 dedifferenzierte, 10 mesenchymale, 10 myxoide und 10 klarzellige Chondrosarkome, 30 Enchondrome und 20 chondroblastische Osteosarkome auf das Vorliegen von IDH-Mutationen geprüft. Als Vergleichsgruppe standen 30 undifferenzierte pleomorphe Sarkome zur Verfügung. Die gDNA wurde aus FFPE-Gewebe präpariert. Anschließend erfolgte die PCR und die Sequenzierung. Hierbei wurde nach Punktmutationen von IDH1 R132, IDH2 R172 und IDH2 R140 gesucht.

Ergebnisse. In den bisher untersuchten Proben der Enchondrome, der konventionellen und dedifferenzierten Chondrosarkome fanden sich IDH1 R132C-, IDH1 R132H, IDH2 R172G- und IDH2 R172S-Mutationen. Ähnliche Daten wurden bereits in der Literatur beschrieben. In den mesenchymalen, myxoiden und klarzelligen Chondrosarkomen, den chondroblastischen Osteosarkomen und pleomorphen Sarkomen wurden bisher keine Mutationen in IDH1- und IDH2-Genen gefunden.

Fazit. Unsere Daten weisen darauf hin, dass IDH-Mutationen bei der Unterscheidung von konventionellen Chondrosarkomen und chondroblastischen Osteosarkomen von Bedeutung sind. Weiterhin spielt die Anwesenheit von IDH-Mutationen bei dedifferenzierten Chondrosarkomen im Vergleich zu pleomorphen Sarkomen eine Rolle. Unsere Ergebnisse zeigen, dass der Nachweis von IDH-Mutationen bei unterschiedlichen diagnostischen Problemen von Knochentumoren hilfreich sein kann und erhebliche Relevanz für die Therapie beinhaltet.

\section{DGP08.06 \\ Detection of DNA damage repair deficiency through mutational signature analysis}

S. Burdak-Rothkamm ${ }^{\text {* }}$, M. Alawi', C. Droste', C. Petersen', K. Rothkamm ${ }^{1}$

'Universitätsklinikum Hamburg-Eppendorf, Hamburg, Germany

Aim. DNA damage repair (DDR) deficiencies are a frequent event in human cancer and influence treatment response. Mutational signatures are a novel molecular tool for the detection of DDR defects based on somatic base substitutions within their flanking sequence context, thus generating 96 different mutated trinucleotides. 30 validated distinct mutational signatures are now recognized in human cancers, and for many of them an aetiology has been proposed, including endogenous mutational processes, genotoxic agents and DDR deficiencies. The aim of this study is to establish signature-based algorithms which detect DDR defects in human tumours. Methods. 202 whole genome sequencing (WGS) data sets of prostate cancers were obtained from the EGA and ICGC data repositories with approval for the project from the Data Access Compliance Office (DACO). Mutational signatures based on the trinucleotide context of somatic variants were extracted as described by Alexandrov et al. (2013) and allocated to the 30 consensus mutational signatures from COSMIC (https://cancer. sanger.ac.uk/cosmic/signatures).

Results. Analysis of the data for mutational signatures revealed a high percentage of signature 1 und 5 that can be found ubiquitously in many cancers, but also evidence of signature 3 in $65 \%$ of tumours which is associated with homologous recombination (HR) deficiency, and $9 \%$ of tumours harbour signature 6,15 or 26 which reflect mismatch repair (MMR) deficiency. Signatures attributed to exogenous mutagenic agents were rare in this prostate cancer cohort with absence of signature 7 (UV exposure), signature 22 (aristolochic acid) and signature 11 (alkylating agents), whereas signature 4 (smoking carcinogens) was present in $1.5 \%$ of tumours. Signatures 2 and 13 which are attributed to endogenous DNA damage due to APOBEC-related activity were also absent in these data sets. However, for a number of mutational signatures that were found in this data set an underlying process has not yet been identified and further research is required. Conclusion. Mutational signatures for HR and MMR deficiency can be detected in prostate cancer. Further analysis for tumour mutational burden, novel rearrangement signatures and specific gene mutations will accomplish this study and feed into a comprehensive algorithm for the detection of DDR deficiencies in human cancer.

\section{DGP08.07}

Determining tumor mutational burden in patients with metastatic urothelial carcinoma by targeted gene panel sequencing

M. Eckstein', A. Hartmann', R. Stöhr', F. Haller', L. Tögel ${ }^{1 *}$, M. Evgeny'

'University of Erlangen-Nuremberg, Institute of Pathology, Erlangen, Germany

Aim. Immune checkpoint inhibitor therapy represents an emerging treatment modality with impressive clinical responses for a subset of cancer patients. Tumor mutational burden (TMB) is a novel biomarker with the potential to predict beneficial response to immune checkpoint inhibitors in different types of cancers, including metastasized urothelial carcinoma (mUC). Evaluation of reliable methods to accurately determine the TMB value is a prerequisite for the successful application of Immune checkpoint blockade therapies.

Methods. Genomic DNA was purified from 39 muscle-invasive urothelial bladder carcinomas and TMB values were assessed by whole genome sequencing (WGS; GPS Cancer, NantHealth) and panel sequencing (TruSight Oncology 500, Illumina Panel). Cell populations in immune infiltrates were determined by CD3, CD8 (cytotoxic T-Cells), CD56 (NKCells), and CD68 (macrophages) immunohistochemistry. PD-L1 status was evaluated using the SP263 assay (Ventana). TMB and immune cell infiltrates were correlated with follow-up data.

Results. Inter-method correlation revealed high concordance of TMB value prediction between TSO500 and WGS $\left(\mathrm{r}^{2}=0.72, p<0.0001\right)$. Prolonged 
disease specific survival was significantly associated with high TMB values (>10 mut/Mb). Likewise, elevated immune cell infiltrates provided similar prognostic value, indicating a positive correlation between TMB and the presence of tumor-associated Immune cells. However, no significant correlation between TMB value and the density of immune cell infiltrates or PD-L1 status of the tumor was observed.

Conclusion. This study provides insight into the utility and reliability of a novel NGS panel for the prediction of tumor mutational burden values in urothelial cancer specimens. Furthermore, our data indicate that TMB value assessment may serve independently to the PD-L1 status of the tumor as biomarker for patients with mUC who are likely to respond to immune checkpoint inhibitors.

\section{Aktuelle Habilitationen I}

\section{DGP09.01}

\section{Chromophobes Nierenzellkarzinom - Diagnostik und Prognostik}

F. Erlmeier*

Technische Universität München, Institut für Allgemeine Pathologie und Pathologische Anatomie, München, Deutschland

Das chromophobe Nierenzellkarzinom gehört zur Gruppe der nicht-klarzelligen Nierenzellkarzinome und tritt mit einer Inzidenz von 4-6 \% auf. Mit einer 5-Jahres-Überlebensrate von 78-100 \% zeigt der Tumor eine gute Prognose. Die Therapie besteht in erster Linie aus einer kompletten chirurgischen Resektion. Aufgrund seiner morphologischen Varianz bereitet das chromophobe Nierenzellkarzinom in der klinisch-pathologischen Routinediagnostik häufig Probleme. Der Tumor zeigt histologische Gemeinsamkeiten mit anderen Nierentumorsubtypen. Bis dato existiert kein eindeutiger diagnostischer Marker für das chromophobe Nierenzellkarzinom. Des Weiteren hat sich bis heute noch kein pathologisches Schema zur Abschätzung der Prognose bei dieser Entität durchgesetzt. In unserer Arbeit konnten wir zeigen, dass die Morphometrie ein hilfreiches Werkzeug bei der Unterscheidung der drei sich ähnelnden Tumorentitäten ist. Dies könnte ein erster Schritt in Richtung computergestützte Diagnostik sein. Hierbei könnte der Pathologe die Morphometrie als Hilfestellung bei der Diagnosefindung nutzen. Bezüglich der Bedeutung von prognostisch relevanten Biomarkern unterscheidet sich das chromophobe Nierenzellkarzinom als Mitglied der nicht-klarzelligen Nierenzellkarzinome von der Gruppe der klarzelligen Nierenzellkarzinome. In unserer Studie spielten beispielsweise PD-1 und PD-L1 beim chromophoben Nierenzellkarzinom keine prognostische Rolle. Die PD-L2 Expression scheint beim chromophoben Nierenzellkarzinom jedoch durchaus von prognostischer Relevanz zu sein. Generell liegt die Schwäche der Studien bezüglich des chromophoben Nierenzellkarzinoms eindeutig in der häufig niedrigen Fallzahl, die der geringen Inzidenz des Tumors geschuldet ist. Bis dato werden die chromophoben Nierenzellkarzinome bei Therapiestudien lediglich als kleine Subgruppe mituntersucht. Eine statistische Signifikanz lässt sich jedoch allein aufgrund der geringen Fallzahl nicht erkennen. Abschließend lässt sich festhalten, dass das chromophobe Nierenzellkarzinom eine Entität mit vielen bis dato ungeklärten Facetten ist und daher auch in Zukunft intensiv beforscht werden sollte.

\section{DGP09.02}

\section{Oversalted immunity: a story of Mr. Hyde}

Z. Popovic ${ }^{1 * 2}$, F. Chessa ${ }^{2}$, M. Embgenbroich ${ }^{3}$, V. Nordström², M. Bonrouhi ${ }^{2}$, S. Burgdorf ${ }^{3}$ H.-J. Gröne ${ }^{2}$

${ }^{1}$ Medizinische Fakultät Mannheim der Universität Heidelberg, Pathologisches Institut, Mannheim, Germany, ${ }^{2}$ Zelluläre und Molekulare Pathologie, Deutsches Krebsforschungszentrum, Heidelberg, Germany, ${ }^{3}$ Universität Bonn, LIMES Institut, Bonn, Germany

Aim. The aim of the habilitation work was to investigate the role of selected endogenous signals dominant in the pathogen-free microenvironment of solid organs on activation of the mononuclear phagocyte system during tissue damage. Here we set our focus on the effect of hyperosmolar micromilieu on dendritic cell function in vivo and in vitro.

Methods. Cell culture (ex-vivo generation of bone marrow derived macrophages and dendritic cells; antigen phagocytosis, processing and cross-priming assays); flow cytometry; murine kidney transplantation models; light microscopy, morphometry, confocal laser scanning microscopy, STED microscopy and ultrastructural imaging; RNA isolation, cDNA synthesis and Real-Time qRT-PCR; Proximity ligation assay; gene expression profiling.

Results. Our experiments on the effect of tissue hyperosmolarity on mononuclear phagocyte system have shown that homeostatic and post-transplant medullary dendritic cells demonstrate a switch towards a macrophage-like phenotype in comparison to cortical DCs. In line, bone marrow-derived dendritic cells developed ex vivo in sodium chloride-enriched medium gained an 'anti-inflammatory' M2-like signature. Microarray analysis of allotransplant dendritic cells displayed a medullary downregulation of genes mainly involved in alloantigen recognition. Thereby we have proposed that the medullary environment inhibits an alloimmune response by modulating phenotype and function of dendritic cells. Consecutively, we examined how a hyperosmolar microenvironment within a range 340-450 mOsm affects the capacity of dendritic cells to activate $\mathrm{CD}^{+} \mathrm{T}$ cells. Exposure of dendritic cells to NaCl-hypertonic microenvironment blunted the cross-priming (independent of NFAT5-signaling) and induced a reduction of dendritic cell-T cell contact time. A significant inhibition of cross-priming has been achieved by the non-ionic osmolyte mannitol as well. We have identified TRIF as a key mediator of this phenomenon. Moreover, we have detected a hypertonicity-triggered, TRIF-dependent clustering of MHC class I-SIINFEKL complexes, but not of single MHCI molecules.

Conclusion. We provided thus evidence for a novel mechanism of inhibition of antigen-specific $\mathrm{CD}^{+} \mathrm{T}$ cell response in hyperosmolar microenvironments and have pointed to the relevance of biophysical factors in immunologic reactions.

\section{DGP09.03 \\ Morphomolekulare Charakterisierung gastrointestinaler Karzinome}

\section{Jesinghaus*}

Technische Universität München, Institut für Pathologie, München, Deutschland

Das Aufgabenspektrum der klinisch-diagnostischen Pathologie sieht sich in den vergangenen Jahren einem immer stärkeren Wandel ausgesetzt. Neben der primär histologiebasierten Tumordiagnostik, welche noch immer die Basis aller weitergehenden Untersuchungsmethoden darstellt, rücken molekularpathologische Verfahren zunehmend in den Mittelpunkt. Hierbei werden bestimmte, morphologisch beobachtete Charakteristika mit spezifischen molekularen Veränderungen assoziiert, welche als Angriffspunkte zielgerichteter Therapien oder als zusätzlicher Faktor für eine zu untermauernde, primär histologisch gestellte Diagnose fungieren können. Im Sinne dieser sowohl morphologischen als auch molekularen, also morphomolekularen Klassifikationsleistungen, welche von der modernen Pathologie in massiv zunehmendem Maße erwartet werden, wurde im Rahmen der hier vorgestellten Forschungsarbeiten den spezifischen molekularen Charakteristika gastrointestinaler Karzinome sowie ihrer Beziehung zu bestimmten morphologischen und klinisch-prognostischen Charakteristika nachgegangen.

Den thematischen Schwerpunkt dieser Habilitation stellen mehrere Studien von Jesinghaus et al. dar, welche sich mit den genetischen Grundlagen kolorektaler Neoplasien und deren klinischen Implikationen befassten, wobei in jeder der hier aufgeführten Arbeiten den jeweiligen Tumorentitäten eine Breitspektrumsgenotypisierung mittels moderner Next Generation Sequencing Technologien zu Teil wurde. Hierbei wurden Wertigkeit und klinische Implikationen moderner Next Generation Sequencing Verfahren in der molekularpathologischen Routinediagnostik untersucht 
und zahlreiche potentiell therapierelevante genetische Alterationen und Resistenzmutationen identifiziert. Ferner konnten wir eine ausgeprägte inter- und intratumorale genetische Heterogenität synchroner Kolonkarzinome sowie eine räumlich-zeitliche Stabilität der Treibermutationen des kolorektalen Karzinoms bei multimetastasiertem Krankheitsverlauf nachweisen. Des Weiteren untersuchten wir die genetische Beziehung sowohl von gemischten adenoneuroendokrinen Karzinomen des Kolorektums als auch von Becherzellkarzinoiden der Appendix zum konventionellen kolorektalen Karzinom. Hierbei konnten wir zum einen eine enge genetische Verwandtschaft der gemischten adenoneuroendokrinen Karzinome zum klassischen Kolonkarzinom aufzeigen und zum anderen ein distinktes genetisches Profil der Becherzellkarzinoide der Appendix identifizieren.

\section{DGP09.04}

\section{Functional role and diagnostic value of aberrant cancer-related} DNA methylation patterns and long non-coding RNA expression

\section{E. Moskalev*}

Universitätsklinikum Erlangen, Institut für Pathologie, Erlangen, Germany

Aberrant onset of DNA methylation marks in oncogenesis, their functionality, abundance and reversibility imply an enormous potential both from a mechanistic perspective and as an extensive source of tumour markers and therapeutic targets. That is particularly relevant for tumour entities with only incompletely characterised epigenomes. This study aimed at establishment of novel abnormally methylated loci that play a role and exhibit high diagnostic value in selected tumour entities with an emphasis on gastrointestinal stromal tumours (GIST) and a rare condition of Carney triad (CT). Investigation of factors that are responsible for locus specificity of DNA methylation and elucidate the origin of tumour-associated epigenetic aberrations was yet another key focus of this work. Apart from these biological objectives, approaches had to be developed to accurately quantify DNA methylation percentages.

Our key findings include epigenetic silencing of succinate dehydrogenase subunit $\mathrm{C}(S D H C)$ by the gene's hypermethylation in tumours of CT. This is a likely tumourigenic event that additionally differentiates sporadic CT from phenotypically similar hereditary conditions. We show functional relevance and high diagnostic value of CD34, SPP1, and CD133 DNA methylation in GIST. Hypermethylation of growth hormone secretagogue receptor (GHSR) is an early epigenetic alteration of high diagnostic relevance in a broad spectrum of cancers. A concurrent epigenetic silencing of 10 antagonists of oncogenic Wnt/ $\beta$-catenin pathway in B cell chronic lymphocytic leukaemia may reflect the tumour epigenome reprogramming orchestrated by Polycomb-group repressive complexes. Finally, we demonstrate that long non-coding RNA HOTAIR enables locus specificity of DNA methylation in GIST and is capable of dual (hypo- or hypermethylation) epigenetic regulation. These findings suggest the feasibility of manipulating DNA methylation in tumour cells in a targeted manner. More transcripts of this class may contribute to development of malignant character of GIST

Summing up, we show a novel putative epigenetic mechanism of development of CT, propose candidatures for new epigenetic biomarkers in several tumour entities, demonstrate a novel role of HOTAIR as a factor of gene-specific DNA methylation in GIST and report a potential involvement of other lncRNAs in development of its malignant properties. These findings are of interest for epigenetic-based diagnostics and potentially for therapy of cancer.

\section{Personalisierte Medizin I. Zwischen Versprechen und Wirklichkeit - die vielen Gesichter der personalisierten Medizin}

\section{DGP12.01}

\section{Translation initiation factors and cancer-Current knowledge}

J. Haybaeck ${ }^{1 * 2,3}$

'Otto von Guericke Universität Magdeburg, Institut für Pathologie, Magdeburg, Germany, ${ }^{2}$ Medizinische Universität Innsbruck, Institut für Pathologie, Neuropathologie und Molekularpathologie, Innsbruck, Austria, ${ }^{3}$ Medizinische Universität Graz, Institut für Pathologie, Graz, Austria

The process of protein synthesis by eukaryotic ribosomes can be subdivided into four different stages: translation initiation, elongation, termination and ribosome recycling. Importantly, most of its regulation occurs at the first stage, the initiation phase, where the ribosome is assembled onto the mRNA. Realization of this initiation phase is supported by at least 12 different protein factors, so called eukaryotic initiation factors (eIFs). These factors therefore play a very important role in regular cell metabolism. Already nearly 30 years ago, it has been reported for the first time that overexpression of eIF4E led to the tumorigenic transformation of cell lines. The oncogenic nature of eIF4E was later confirmed by a plethora of studies. However, not only eIF4E but also many other eIFs have been associated with cancer initiation and progression (eIF4A, eIF4G, eIF2 $\alpha$...). Thereby, eIFs have been shown to be overexpressed in various tumor entities (breast cancer, lung cancer, colon cancer, ...) and to be also linked with worse patient survival. Furthermore, also genetic mutations affecting eIFs have been shown to be associated with cancer.

In the last years, our group has considerably contributed to cancer research in the eIF field. As such, we could show that eIF1, eIF5 and eIF6 play a major role in translational control of colon and rectum cancer. Similarly, we could also show that eIF6 is overexpressed in non-small cell lung cancer and plays a crucial role in its pathology as demonstrated by functional cell culture studies. Furthermore, we investigated the contribution of eIFs to diffuse large B-cell lymphoma. We could demonstrate that eIF1A, eIF3d and eIF2B5 are higher expressed in this neoplastic entity and that especially eIF2B5 possesses an important prognostic potential in this disease subtype.

Our results as well as the results of many other research groups worldwide underline thus the importance of eIFs in cancer and indicate that eIFs could be used as novel prognostic markers or therapeutic targets to help affected patients. Therefore, future research in this field is definitely needed.

\section{DGP12.04}

\section{Flotilline als Regulatoren der endosomalen Sortierung und des MAP-Kinase-Signalwegs}

\section{R. Tikkanen*}

Universität Giessen, Institut für Biochemistry, Giessen, Deutschland

Flotillin-1 und flotillin-2 sind hochkonservierte Protein, die ubiquitär exprimiert werden und in den Cholesterin-reichen Lipidmikrodomänen (Rafts) vorkommen. Die exakte molekulare Funktion der Flotilline ist bisher noch nicht im Detail geklärt worden, aber sie spielen eine Rolle bei der Signaltransduktion durch Membranrezeptoren, Zelladhäsion, Zellmigration und bei dem zellulären Vesikelverkehr. Flotilline sind zudem bei vielen Krebsarten überexprimiert, und ihr Expressionsgrad korreliert mit der Metastasierung und einer schlechten Prognose bei den Patienten. Wir haben gezeigt, dass Flotilline die Signaltransduktion durch den EGF-Rezeptor regulieren und Flotillin-Depletierung die Signale durch die Mitogen-aktivierten Proteinkinasen (MAPK), vor allem ERK, inhibiert. Flotillin-1 funktioniert als Scaffolding-Protein bei der MAPK-Kaskade, zudem reguliert es das Clustering und die Phosphorylierung des EGF-Rezeptors auf der Zelloberfläche nach EGF-Stimulierung. Vor kurzem haben wir gezeigt, dass Flotillin-1 mit einigen Untereinheiten des ESCRT-Komple- 
xes (Endosomal Sorting Complex Required for Transport) interagiert und dadurch die lysosomale Degradation von ubiquitinierten Membranproteinen wie EGF-Rezeptor reguliert. Zudem spielt Flotillin-1 eine Rolle bei derm Zusammenbau von HI-Viruspartikeln, die ebenfalls ESCRT-abhängig erfolgt. In diesem Vortrag werden die wichtigsten funktionellen Aspekte der Flotilline bei der Signaltransduktion in Krebszellen und bei der Metastasierung diskutiert.

\section{Personalisierte Medizin II. Zwischen Versprechen und Wirklichkeit - die vielen Gesichter der personalisierten Medizin}

\section{DGP13.01 \\ Interpretation von und Schlussfolgerungen aus RAS Mutationen in der molekularen Tumorkonferenz}

\section{R. Schäfer ${ }^{1 * 2,3}$}

${ }^{1}$ Charité - Universitätsmedizin Berlin, Comprehensive Cancer Center, Berlin, Deutschland, ${ }^{2}$ Deutsches Krebsforschungszentrum (DKFZ), Heidelberg, Deutschland, ${ }^{3}$ Deutsches Konsortium für Translationale Krebsforschung, Berlin, Deutschland

Mutationen RAS Genen gehören zu den häufigsten onkogenen Alterationen in primären Tumoren. Zahlreiche neuere Befunde legen nahe, dass RAS-Mutationen verstärkt in Therapie-resistenten Malignomen vorliegen. Die Mutationshäufigkeiten der RAS Isoformen KRAS, HRAS und NRAS schwanken stark je nach Tumortyp. Allgemein gilt, dass im Falle der RAS Mutationen Therapien, welche auf die Hemmung von RezeptorTyrosinkinasen abzielen, nicht wirksam sind. Trotz der Entdeckung der RAS Onkogene schon in den frühen 1980er Jahren sind die Fortschritte bei der Entwicklung therapeutischer Ansätze eher gering, obwohl in jüngster Zeit, insbesondere durch die NIH RAS Initiative in den USA, vermehrte Anstrengungen und erste Erfolge in der Präklinik zu verzeichnen sind. Die aktuell verfolgten Ant-RAS Strategien beruhen auf der direkten Inhibition der kleinen GTP-bindenden Proteine, der Blockade ihrer Biosynthese und funktionell wichtigen translationalen Modifikation (Membranbindung) sowie auf der Hemmung von nachgeschalteten Wegen der intrazellulären Kommunikation. Eine direkte Inhibition der RAS-Aktivität wurde bereits im Falle der KRAS G12C Mutation nachgewiesen, welche beispielsweise beim Lungenkarzinom im niedrigen Prozentbereich der $\mathrm{Pa}$ tienten vorkommt. Fortschritte sind auch bei der kombinierten Inhibition von Signalwegen erzielt worden, welche durch RAS Moleküle als zentrale molekulare Schalter aktiviert werden. Entsprechende klinische Studien wurden initiiert. Insgesamt stellen RAS Mutationen, welche im Rahmen von Hochdurchsatz-Sequenzierungen oder Amplikon-Sequenzierungen des klinischen Materials identifiziert und in molekularen Tumorkonferenzen besprochen werden, weiterhin eine große Herausforderung bei der Therapieempfehlung dar.

\section{DGP13.02}

\section{From Cohorts to intra-tumor heterogeneity: The many promises of organoid cultures}

\section{Regenbrecht ${ }^{1,2}$ \\ ${ }^{1} \mathrm{cpo} \mathrm{GmbH}$, Berlin, ${ }^{2}$ Universitätsklinikum Magdeburg, Magdeburg, Deutschland}

Organoids closely resemble the original tissue. They are self-organizing structures of correct cell types and perform certain tissue functions. As they faithfully recapitulate the essentials of tissue architecture and functionex vivo, they open up great possibilities for identifying novel therapeutic strategies in personali zed human disease models such as cancer. The recent progress inorganoid research has fueled great expectations on their use as patients' avatars, but whetherorganoids can truly live up to this challenge is, for some, still an open question. One of the greatest poten- tial applications of organoid models in cancer research is in the analysis of molecular mechanisms and interplay within the tumor, starting with the possibility for using organoids to establish living biobanks, for predicting therapeutic response, and furthermore,combining organoids with tools such as CRISPR opens up the possibility of establishing syngenic sibling cultures to study the effects of specific gene mutations on drug sensitivity. Cohorts of organoids can be used in the preclinical setting for the identification of potentially novel biomarkers and cohort stratification while at the same time serving as patient-specific models for individualized drug screening studies in the translational context. Both approaches lay the groundwork for the promises of personalized medicine.

Here, we will provide an overview from findings in the field of basic research in large data sets like the "Oncotrack" collection of models, where we have established a semi-automated pipeline for single-drug and multi-drug screening of organoids, showing the stability, reproducibility of cultivating $>80$ organoid models from patients with colorectal cancer (CRC) and subsequent drug testing. Building on this knowledge, we have performed drug screenings on peritoneal metastases of CRC, showing the broad range of resistance in this entity and in the best sense of translational medicine, eventually providing guidance for treatment in the future. Last not least, we have started to unravel how intra-tumor heterogeneity hampers first line targeted therapies in an individual patient by combining data from sequencing, drug screening and targeted proteomics.

Overall, we can start to envisage a future scenario in which patient-derived organoids could guide clinicians to identify more effective treatments while the patient is still in the hospital bed, basically in the same fashion that antibiogram tests, which are commonly used in the clinic to determine antibiotic susceptibilities.

\section{DGP13.04}

\section{Patient-derived sarcoma models - first results from the SarQma study}

M. Regenbrecht

Helios-Klinikum Berlin-Buch, Onkologie und Palliativmedizin, Berlin, Germany

Over the past decade, the development of new targeted therapeutics directed against specific molecular pathways involved in tumor cell proliferation and survival has allowed an essential improvement in carcinoma treatment. Unfortunately, the scenario is different for sarcomas for which the main therapeutic approach still consists in the combination of surgery, chemo-, and radiation therapy. The lack of innovative approaches in sarcoma treatment stems from the high degree of heterogeneity of this tumor type, with more that 70 different histopathological subtypes, and the limited knowledge of the molecular drivers of tumor development and progression.

Here we show that patient-derived 3D (PD3D) cell culture models allow for an in vitro system to systematically test single compounds and combinations thereof in a semi-automated manner, generating a pre-clinical dataset that in combination with clinical data, genomic and proteomics profiles may help to better understand the biology and ultimately identify more potent treatment regimen in the future.

Fresh surgical specimen are transferred into the lab, where they undergo several steps of mechanical and chemical dissociation. Cell aggregates are then seeded into 24 well plates in matrix-like scaffolds and allowed to grow until they reach $>100 \mu \mathrm{m}$. Organoids are then harvested and semi-automatically transferred to 384 -well plates and treated with a set of compounds that resemble the standard-of-care treatment as well as novel compounds of interest. Finally, viability is calculated as previously published by us. In parallel, protein extracts of the PD3D models are used for DigiWest, a multiplexed westernblot allowing to interrogate up to 200 (phospho)-proteins. We recruited so far 50 patients of which in 49 cases a biopsy was conducted. In 23 of these cases to little material was available, or the macroscopic consistency did not fit for sarcoma diagnosis. Of these 23 samples 5 were reported as sarcoma tissue afterwards, while 5 of the taken 26 samples were not sarcomas according to the final histopathology 
reports. Two third of the patients were male, while the median age was 55 and the mean age was 56.19 . Of all sarcoma samples $90.48 \%$ (19/21) were taken from tumors localized at the extremities, while the rest was located at the trunk. $52.38 \%(11 / 21)$ were growing in short term cell culture and were split at least to passage 1 (p1). $28.57 \%(6 / 21)$ were growing for long term analyses. Two of these six are myxoid liposarcomas, two are undifferentiated pleomorphic sarcomas or classified as not otherwise specified (UPS/ NOS), one was a myxoid liposarcoma and one a biphasic synovial sarcoma. Despite relatively low cell culture take-rates, we here show that it is feasible to generate organoids from sarcoma tissues using them for extensive characterization in order to better understand their biology and mechanisms of treatment. High-throughput drug-screening allows for an extensive characterization of pharmacokinetic properties of individual sarcomas. Using the same source of material for additional (phospho)-proteomics provides multiple layers of understanding.

At present, the structure of clinical trials is not amenable to $\mathrm{N}$ of 1 studies, so applying the information garnered from this platform, particularly combination therapy drug screens, remains a significant hurdle. The major technical limitation to the successful establishment of organoid cultures was insufficient amounts of fresh tissue with viable tumor cells. Increasing the tumor tissue available for organoid production would allow for culture media optimization and lead to a greater success rate. More viable tumor tissue could be made available through the acquisition of larger samples through surgical biopsies or resections.

Nevertheless, by their recapitulation of the donor tissue architecture, they provide an interesting and important tool to study the enormous variety of soft-tissue tumors.

\section{Precision Oncology-Uropathology}

\section{DGP14.03}

\section{Bladder cancer and therapy-from an immunologist's perspective}

\section{Ingersoll*}

Institute Pasteur, Paris, France

Research in our laboratory focuses on how immunity arises in the context of bladder diseases, including the response to immunotherapy for bladder cancer. Importantly, we are first and foremost immunologists, and as such, must keep in mind that our training and this perspective biases how we approach studies of the bladder and its associated diseases. This bias likely helps and hurts our work, in that we are focused on understanding the minutiae of the immune response. However, we may miss critical nonimmune parameters of disease progression or response that inform future therapeutic approaches. This presentation will detail our findings in preclinical models for bladder cancer and immunotherapy, highlighting our immunological biases and potential for integration of additional parameters of study to better understand this disease.

\section{DGP14.04}

\section{Predictive biomarkers in bladder cancer}

H. Reis*

Universitätsmedizin Essen, Institut für Pathologie, Essen, Germany

Embedded in a session on precision oncology on bladder cancer, this talk will give an overview on current, emerging and potential future therapy associated biomarkers in bladder cancer from the pathologist's perspective. Topics that will be covered include biomarkers of chemotherapy response, immune oncology (including PD-L1), and targeted therapy strategies.

\section{Uropathology meets Digital}

\section{DGP15.01}

Automated Gleason grading of prostate cancer tissue microarrays via deep learning

E. Arvaniti ${ }^{1,2}$, K. S. Fricker ${ }^{3}$, K. Smith ${ }^{4 *}$, M. Moret ${ }^{1}$, N. J. Rupp ${ }^{3}$, T. Hermanns ${ }^{5}$, C. Fankhauser ${ }^{5}$, N. Wey ${ }^{3}$, P. J. Wild', J. H. Rueschoff , M. Claassen ${ }^{1,2}$

'ETH Zurich, Institute for Molecular Systems Biology, Zurich, Switzerland, ${ }^{2}$ Swiss Institute for Bioinformatics, Lausanne, Switzerland, ${ }^{3}$ University of Zurich, Department of Pathology and Molecular Pathology, Zurich, Switzerland, ${ }^{4}$ Universitätsklinikum Frankfurt, Dr. Senckenbergisches Institut für Pathologie, Frankfurt am Main, Germany, ${ }^{5}$ University of Zurich, Department of Urology, Zurich, Switzerland

Aim. The Gleason grading system remains the most powerful prognostic predictor for patients with prostate cancer since the 1960's. Its application requires highly-trained pathologists, is tedious and yet suffers from limited inter-pathologist reproducibility, especially for the intermediate Gleason score 7 . Automated annotation procedures constitute a viable solution to remedy these limitations.

Methods. In this study, we present a deep learning approach for automated Gleason grading of prostate cancer tissue microarrays with Hematoxylin and Eosin (H\&E) staining. Our system was trained using detailed Gleason annotations on a discovery cohort of 641 patients and was then evaluated on an independent test cohort of 245 patients annotated by two pathologists.

Results. On the test cohort, the inter-annotator agreements between the model and each pathologist, quantified via Cohen's quadratic kappa statistic, were 0.75 and 0.71 respectively, comparable with the inter-pathologist agreement $(\mathrm{kappa}=0.71)$. Furthermore, the model's Gleason score assignments achieved pathology expert-level stratification of patients into prognostically distinct groups, on the basis of disease-specific survival data available for the test cohort.

Conclusion. Overall, our study shows promising results regarding the applicability of deep learning-based solutions towards more objective and reproducible prostate cancer grading, especially for cases with heterogeneous Gleason patterns.

\section{DGP15.02}

Deep learning-based segmentation and classification of prostate glands with minimal manual annotation in low- and intermediate risk prostate cancer

N. Harder ${ }^{*}$, A. Kapil', N. Brieu', M. Athelogou', H. Hessel', A. Buchner', C. Stief ${ }^{2}$, T. Kirchner ${ }^{3}$, R. Huss' ${ }^{1}$, G. Schmidt ${ }^{1}$

'Definiens AG, München, Germany, ${ }^{2}$ Ludwig-Maximilians-University/ Department of Urology, München, Germany, ${ }^{3}$ Ludwig-MaximiliansUniversity/Institute of Pathology, München, Germany

Accurate segmentation and quantification of glandular structures in prostate cancer (PCa) tissue sections is required to automatize established scoring methods and to discover novel prognostic and predictive biomarkers in precision medicine, e. g., characterizing the immune contexture of cancerous glands. We developed a gland segmentation approach for $\mathrm{H} \& \mathrm{E}$ which is challenging as epithelial and basal cells are not specifically stained and algorithms need to exploit the spatial organization of cells.

H\&E and CK18/p63 stained images from 121 PCa patients (Gleason scores 6 to $7 \mathrm{~b}$ ) were acquired from consecutive histopathological sections of FFPE radical prostatectomy resections. We trained a convolutional neural network (CNN) for semantic segmentation of H\&E images using automatically generated ground truth data from 100 patients. Ground truth was obtained by gland segmentation in the CK18/p63 section by basic image processing using brown dye (DAB) detection, and by transfer of the resulting segmentation masks to $\mathrm{H} \& \mathrm{E}$ with a hierarchical patch-based image co-registration. We extracted $20 \mathrm{k}$ H\&E image patches $(225 \times 225 \mu \mathrm{m})$ for $\mathrm{CNN}$ training from regions with the best co-registration quality w.r.t. 
Table 1 | DGP15.02 Quantitative evaluation of the segmentation quality for regions of interest from 9 patients reserved for testing. Mean $=0.95$, standard dev $=0.02$

\begin{tabular}{llllllllll} 
Patient ID & $\mathbf{1}$ & $\mathbf{2}$ & $\mathbf{3}$ & $\mathbf{4}$ & $\mathbf{5}$ & $\mathbf{6}$ & $\mathbf{7}$ & $\mathbf{8}$ & $\mathbf{9}$ \\
\hline $\begin{array}{l}\text { Number } \\
\text { glands }\end{array}$ & 13 & 31 & 32 & 240 & 33 & 4 & 165 & 47 & 27 \\
$\begin{array}{l}\text { Dice score } \\
\text { 0.937 }\end{array}$ & 0.962 & 0.923 & 0.949 & 0.963 & 0.983 & 0.953 & 0.921 & 0.978
\end{tabular}

Table 2 | DGP15.02 Confusion matrix for classification of

$5.12 \times 5.12 \mu \mathrm{m}$ image patches extracted from normal and non-nor-

mal (without associated $\mathrm{p} 63$ positive cells) glands

\begin{tabular}{llll} 
True class & Predicted class & Sum \\
& Normal & Non-normal & \\
\hline Normal & 3174 & 134 & 3308 \\
Non-normal & 47 & 553 & 600 \\
Sum & 3221 & 687 & 3908
\end{tabular}

normalized cross-correlation. We trained a CNN with UNet architecture and performed a second training using the predicted segmentation as new ground truth for boosting the accuracy. For gland splitting we used weight maps assigning high learning weights to pixels at gland separation borders. Those borders were manually annotated by drawing separation lines in the segmentation masks for $108 \mathrm{H} \& \mathrm{E}$ patches and used for refinement of the trained CNN.

We applied the CNN to H\&E WSIs of 21 patients reserved for testing and randomly extracted and manually annotated 9 regions including 592 gland objects for evaluation. Note that for applying the CNN the CK18/ p63 section is not required. Our approach yielded a mean Dice score of 0.95 (• Table 1 | DGP15.02, - Fig. 1 | DGP15.02). First experiments on CNN-based gland classification yielded promising results (95\% accuracy, - Table 2 | DGP15.02.

Our approach allows accurate segmentation of individual glands in $\mathrm{H} \& \mathrm{E}$ stained tissues without epithelial staining and with minimal manual annotation effort. This enables high precision analysis of the gland landscape, providing context for the spatial analysis of immune cell related biomarkers in further studies, aiming at the immune profiling of cancer patients to identify the most appropriate treatment options.
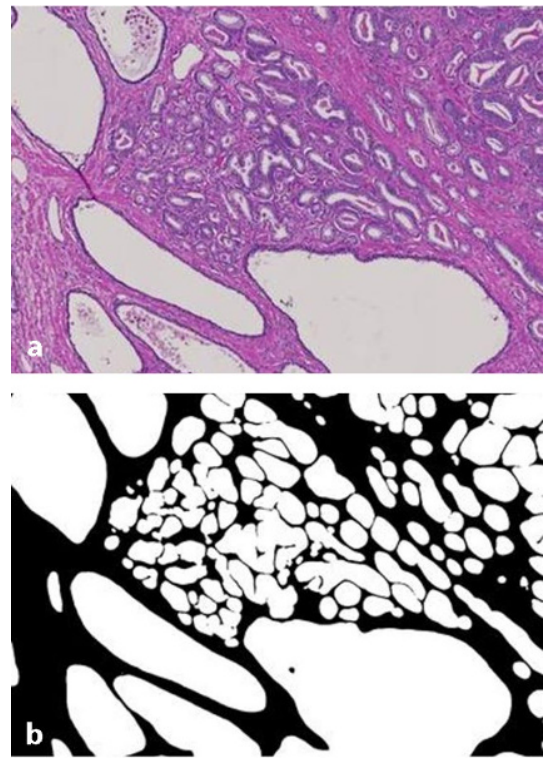

Fig. 1 | DGP15.02 Example segmentation result (a) H\&E image, gland segmentation result yielded by CNN (b)

\section{DGP15.03}

\section{Morphologisches 3D Modell der Drüsenarchitektur der menschlichen Prostata}

T. Bisson ${ }^{1 *}$, S. Lohmann ${ }^{1,2}$, I. Klempert ${ }^{2}$, M. Mandrela ${ }^{2}$, P. Hufnagl ${ }^{1,2}$ 'HTW Berlin, Berlin, Deutschland, ${ }^{2}$ Charité Universitätsmedizin Berlin/ Institut für Pathologie, Berlin, Deutschland

Ziel. Mit einem 2D Modell zur Generierung von Drüsenstrukturen in virtuellen Schnitten (WSI) kann man die Trainingsdaten für Deep Learning in geeigneter Weise ergänzen, um bessere Klassifikationsergebnisse zu erzielen [1]. Ein derartiges Modell eignet sich allerdings nicht zur räumlichen Interpretation von bildanalytischen Messergebnissen. Auch die histologische 3D Rekonstruktion unter Nutzung von MRT Aufnahmen ist ohne Modell schwer interpretierbar [2]. Wir stellen ein 3D Modell der Drüsenarchitektur der Prostata vor, welches sich mit dem Modell von Mandrela et al. verbinden lässt und eine räumliche Interpretation von Messdaten ermöglichen soll.

Methoden. Angesichts des Fehlens eines dreidimensionalen Modells des Drüsenepithels der Prostata wurden zunächst anhand von Literaturangaben und bildlichen Darstellungen Eigenschaften eines 3D Modells der Architektur der Drüsen bestimmt. Um diese zu modellieren wurde der Space Colonization Algorithmus verwendet, mit dem baumartige Strukturen generiert werden können, ohne dass dabei Kollisionen entstehen. Um die

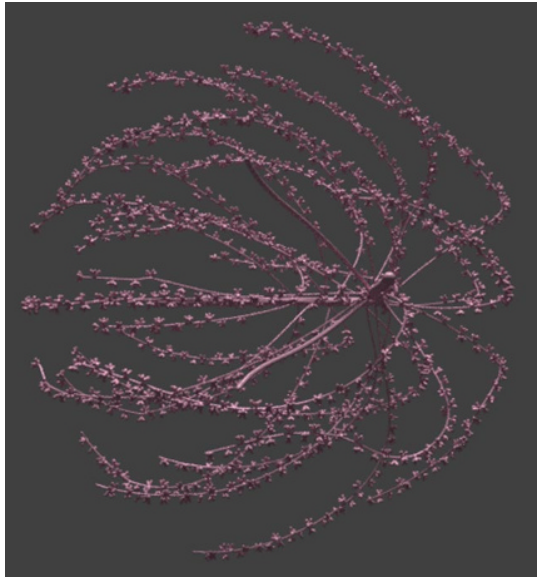

Abb. 1 | DGP15.03 4 Generiertes 3D Modell der prostatischen Drüsen

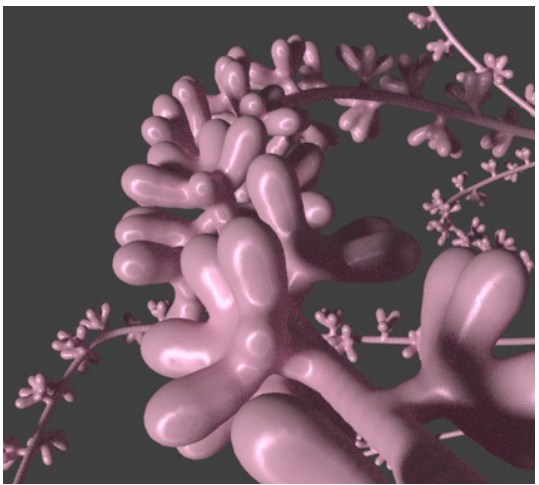

Abb. 2 |DGP15.03

4 Nahaufnahme der kollisionsfrei generierten Drüsen 
Struktur der Prostata zu erzeugen wurde der Algorithmus derart modifiziert, dass die Drüsenschläuche das typische flügelartige Wachstum zeigen und anstelle von Abzweigungen die Drüsenendstücke modelliert werden. Ergebnisse. Unter Verwendung des Space Colonization Algorithmus lässt sich kollisionsfrei die anatomische Struktur der prostatischen Drüsen sowie der Harnröhre und den Samenleitern modellieren. Das generierte Modell in $\bullet$ Abb. 1 |DGP15.03 zeigt das flügelartige Wachstum der Drüsenschläuche. Die - Abb. 2 |DGP15.03 zeigt einen vergrößerten Ausschnitt der Drüsenendstücke die nur wachsen, wenn sie sich dabei gegenseitig nicht ,treffen“.

Fazit. Mit den genannten Modellierungstechniken konnte ein 3D-Modell generiert werden, dass den anatomischen Vorstellungen nahe kommt. Um Aussagen über die Korrektheit des Modells machen zu können werden 2D-Schnitte durch das 3D-Modell gelegt, die mit realen histologischen Schnitten verglichen werden müssen. Eine weitere Möglichkeit der Evaluation besteht in dem Vergleich mit 3D-Rekonstruktionen auf der Basis histologischer Schnitte.

\section{Literatur}

1. Mandrela M, Lohmann S, Klempert I, Hufnagl P (2017) A model for simulation of glands on virtual slides. Virchows Archiv 471:207-207

2. Gibson E, Gaed M, Gómez JA, Moussa M, Romagnoli C, Pautler S, Ward AD (2013) 3D prostate histology reconstruction: An evaluation of image-based and fiducialbased algorithms. Medical physics:40(9)

\section{DGP15.04}

Semantische Pixelklassifikation zur Epithelsegmentierung in Mamma und Prostata mit neuronalen Netzen und Immunhistologie-gestützter Annotation

\section{A. Turzynski ${ }^{1 * 2,2}$ N. Weiss ${ }^{3}$, A. Napiwotzki', A. Lebeau', S. Heldmann ${ }^{3}$,} U. Jacobs' ${ }^{1}$, J. Lotz

${ }^{1}$ Gemeinschaftspraxis für Pathologie, Lübeck, Deutschland, ${ }^{2}$ PathoPlan GbR, Lübeck, Deutschland, ${ }^{3}$ Fraunhofer-Institut für Digitale Medizin MEVIS, Lübeck, Deutschland

Ziel. Im Rahmen einer computergestützten Diagnostik anhand von gescannten histologischen Schnitten (whole slide images, WSI) müssen anatomische Strukturen als semantische Objekte im Bild lokalisiert, klassifiziert und segmentiert werden. Neuronale Netze (NN) sind zur semantischen Pixelklassifikationen geeignet und können entsprechend trainiert werden. Die dazu notwendigen Annotationsarbeiten sind sehr arbeitsaufwändig. Es soll ein Immunhistologie-gestütztes Verfahren zur vereinfachten, nicht-manuellen Annotation entwickelt und an einem NN zur Pixelklassifikation überprüft werden.

Methoden. HE-Schnitte von Mamma und Prostata wurden als WSI gescannt (Pannoramic MIDI, Fa. Sysmex) und anschließend immunhistologisch für Panzytokeratin (AE1/AE3/CK8/18) umgefärbt. Die umgefärbten Schnitte wurden ebenfalls gescannt und durch Gigapixel-Bildregistrierung mit den Scans der HE-Färbung zur Deckung gebracht. Aus den Scans wurden kongruente Bildkacheln mit einer Kantenlänge von 512 Pixeln geschnitten. Die immunhistologischen Kacheln wurden dann in binäre Masken (Epithel und Nicht-Epithel) überführt. Die HE-Kacheln und die generierten Masken (3721 Paare) wurden zum Training eines modifizierten NN (Keras-Implementierung von U-Net, https://github.com/yihuihe/u-net) verwendet.

Ergebnisse. Mit diesem Ansatz lassen sich hochwertige Masken generieren, die die Grundwahrheit (ground truth) objektiv widerspiegeln. Sowohl die Bildregistrierung als auch die Aufbereitung der Masken sind verfahrenskritische Schritte. Die trainierten neuronalen Netze für Mamma und Prostata erreichen eine visuell sehr gute Segmentierung des Epithels bereits nach 50 Epochen. Die generierten Prädiktionen sind bereits als Graustufenausgabe im Trainings- und im Testdatensatz scharfkantig und passgenau. Insbesondere bei der Prostata werden dabei schmale Bindegewebssepten zwischen Drüsen erkannt, wenn diese auch für den Pathologen am HE-Bild erkennbar sind.
Fazit. Mit dem vorgestellten Verfahren können aufwändige manuelle Annotationen für die Erstellung von Trainingsmasken vermieden werden. Mithilfe von Immunhistologie, Bildregistrierung und Filterung kann eine hohe Anzahl an Masken generiert werden, die die ground truth schnell, objektiv und vollflächig wiedergeben. Darauf basierende erfolgreich trainierte NN zur semantischen Pixelklassifikation an HE-Schnitten schaffen eine wichtige Voraussetzung zur computergestützten Diagnostik.

\section{Uropathologie trifft Nuklearmedizin}

\section{DGP16.01}

\section{Theranostics in prostate cancer: current status and future perspectives}

K. Rahbar*

Universitätsklinikum Münster, Klinik für Nuklearmedizin, Münster, Germany

Prostate cancer is the most common cancer and the second most frequent cause of cancer related death in men. Since introduction of prostate specific membrane antigen (PSMA) small molecule ligands the management of prostate cancer patients has changed significantly. PSMA, also known as folate hydrolase I or glutamate carboxypeptidase II, is a type II transmembrane protein which is expressed on prostate epithelial cells, but overexpressed on prostate cancer cells and its metastases. Several retrospectives and recently also prospective studies using 68-Ga-PSMA-11 have shown the great potential and abilities in patients with biochemical recurrence and primary staging and in patients referred for radiation therapy changing therapy strategies.

Furthermore, PSMA targeted radioligand therapy using 177-Lutetium and 225-Actinium labeled ligands, has shown respectable response rates with a low toxicity profile in patients with heavily pretreated metastatic castration resistant prostate cancer. Current phase III trial using 177-Lu-PSMA-617 might bring this promising therapy option to approval, making it available for a greater number of patients in the future. PSMA represents an attractive molecular target for theranostics in prostate cancer.

\section{DGP16.02}

Expression of prostate-specific membrane antigen (PSMA) on biopsies as an independent risk stratifier of prostate cancer at time of initial diagnosis

A. Offermann ${ }^{1 *}$, M. C. Hupe ${ }^{2}$, C. Philippi', D. Roth', C. Kümpers' ${ }^{1}$ J. Ribbat-Idel', F. Becker', V. Joerg', A. S. Merseburger', J. Kirfel', V. Sailer', S. Perner ${ }^{1}$

'Universitätsklinikum Schleswig-Holstein, Campus Lübeck und Forschungszentrum Borstel, Leibniz Lungenzentrum, Institut für Pathologie, Lübeck, Germany, ${ }^{2}$ Universitätsklinikum Schleswig-Holstein, Campus Lübeck, Abteilung für Urologie, Lübeck, Germany

Objectives. Stratifying PCa patients into risk groups at time of initial diagnosis enabling a risk-adapted disease management is still a major clinical challenge. Existing studies evaluating the prognostic potential of PSMA for PCa were performed on radical prostatectomy specimens (RPE), i.e. decision making for disease management was already completed at time of sample analysis. Aim of our study was to assess the prognostic value of PSMA (prostate-specific membrane antigen) expression for prostate cancer (PCa) patients on biopsies at time of initial diagnosis.

Materials and methods. PSMA expression was assessed by immunohistochemistry on 294 prostate biopsies with corresponding RPE, 621 primary tumor foci from $242 \mathrm{RPE}, 43$ locally advanced or recurrent tumors, 34 lymph node metastases, 78 distant metastases and 52 benign prostatic samples. PSMA expression was correlated with clinico-pathologic features. Primary endpoint was recurrence free survival. Other clinicopathologic features included WHO/ISUP grade groups, PSA serum level, TNM-stage, and R-status. Chi-square test, ANOVA-analyses, Cox-regression and logrank tests were performed for statistical analyses. 
Results. High PSMA expression on both biopsy and RPE significantly associates with a higher risk of disease recurrence following curative surgery. The 5-year-recurrence free survival rates were $88.2 \%, 74.2 \%, 67.7 \%$ and $26.8 \%$ for patients exhibiting no, low, medium or high PSMA expression on biopsy, respectively. High PSMA expression on biopsy was significant in multivariate analysis predicting a 4 -fold increased risk of disease recurrence independently from established prognostic markers. PSMA significantly increases during PCa progression.

Conclusion. PSMA is an independent prognostic marker on biopsies at time of initial diagnosis and can predict disease recurrence following curative therapy for PCa. Our study proposes the application of the routinely used IHC marker PSMA for outcome prediction and decision making in risk-adapted PCa management on biopsies at time of initial diagnosis.

\section{DGP16.03}

\section{Erste klinisch-pathologische Hinweise für einen PSMA- unabhängigen Aufnahmemechanismus von ${ }^{68} \mathrm{Ga}-\mathrm{PSMA}-11 \mathrm{im}$ Speicheldrüsengewebe}

N.J. Rupp ${ }^{1 *}$, C. A. Umbricht ${ }^{2}$, D. A. Pizzuto ${ }^{3}$, D. Lenggenhager ${ }^{1}$, A. Töpfer ${ }^{1}$, J. Müller ${ }^{3}$, U.J. Mühlematter ${ }^{3}$, D. A. Ferraro ${ }^{3}$, M. Messerli3 , G. B. Morand ${ }^{4}$, G. F. Huber ${ }^{5}$, D. Eberli', R. Schibli' , C. Müller ${ }^{2}$, I. A. Burger ${ }^{3}$

'Universitätsspital, Institut für Pathologie und Molekularpathologie, Zürich, Schweiz, ${ }^{2}$ Zentrum für Radiopharmazeutische Wissenschaft ETH-PSI-USZ, Paul Scherrer Institut, Villingen-PSI, Schweiz, ${ }^{3}$ Universitätsspital, Klinik für Nuklearmedizin, Zürich, Schweiz, ${ }^{4}$ Universitätsspital, Klinik für Ohren-, Nasen-, Hals- und Gesichtschirurgie, Zürich, Schweiz, ${ }^{5}$ Kantonsspital,

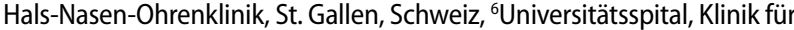
Urologie, Zürich, Schweiz

Ziel. Die auffallend starke Anreicherung von PSMA-Radioliganden in den Speicheldrüsen, welche für theranostische Zwecke im Prostatakarzinom verwendet werden, ist noch immer wenig verstanden. Insbesondere für PSMA-gekoppelte Radionuklidtherapie-Verfahren ist dies von grosser Relevanz, da die Anreicherung zur Bestrahlung der Speicheldrüsen und somit zu Dosis-limitierender Toxizität und ernsthaften Nebenwirkungen führen kann. Eine Aufklärung des Aufnahmemechanismus ist daher essenziell, um entsprechende Strategien zur Reduktion zu entwickeln Ziel dieser Studie war es zu untersuchen, ob die Akkumulation in den Glandulae submandibulares (SMG) durch PSMA-Expression (untersucht durch die zwei Methoden Immunhistochemie (IHC) und Autoradiographie (ARG)), erklärbar ist.

Methoden. Repräsentatives Gewebe von 9 Glandulae submandibulares, 9 Prostaten (mit Adenokarzinom) und 4 Pankreata wurden mittels PSMAImmunhistochemie (Immunoreaktivitäts-Score) sowie Autoradiographie mit ${ }^{177} \mathrm{Lu}$-PSMA-617 (relative Intensität gegenüber einem PSMA-positiven Standard) analysiert. Zusätzlich wurde der SUV ${ }_{\max }$ von den gleichen Organen in 60 Prostatakarzinompatienten im Rahmen eines Restaging mittels ${ }^{68} \mathrm{Ga}$-PSMA-11 PET untersucht.

Ergebnisse. Das Prostatakarzinomgewebe zeigte eine grosse Bandbreite von Färbungsintensitäten in der PSMA-IHC (Immunoreaktivitäts-Score 70-300) sowie in der ARG (1,33-21,98\%). Im ${ }^{68} \mathrm{Ga}$-PSMA-11 PET zeigte sich ebenfalls eine grosse Variabilität $\left(\mathrm{SUV}_{\max } 4,4-16\right)$, mit einer signifikanten Korrelation zwischen ARG und $\mathrm{SUV}_{\text {max }}\left(p<0,001, \mathrm{R}^{2}=0,897\right)$. Das Pankreasgewebe zeigte immunhistochemisch, in der ARG und im ${ }^{68} \mathrm{Ga}$-PSMA-11 PET keine Positivität $\left(\mathrm{IRS}=0, \mathrm{ARG}=0,1 \pm 0,05 \%, \mathrm{SUV}_{\max }\right.$ $3,1 \pm 1,1)$. Das Gewebe der Glandulae submandibulares zeigte nur fokale immunhistochemische Expression von PSMA, praktisch ausschliesslich in den Schaltstücken (,intercalated ducts“, IRS 10-15) sowie ein schwaches Signal in der ARG (1,3 $\pm 0,9 \%)$. Im ${ }^{68} \mathrm{Ga}$-PSMA-11 PET zeigte sich hingegen eine sehr starke Anreicherung in den SMG $\left(\mathrm{SUV}_{\max } 23,5 \pm 5,2\right)$. Fazit. Unsere Resultate deuten darauf hin, dass die starke in vivo Anreicherung von PSMA Radioliganden in den Speicheldrüsen nicht mit einer hohen Expression von PSMA im Gewebe korreliert (untersucht mittels Immunhistochemie und Autoradiographie). Die signifikante Radioaktivitätsanreicherung scheint in erster Linie durch einen PSMA-unabhängigen, bisher unbekannten Mechanismus abzulaufen.

\section{DGP16.04}

\section{Pro-metastatic effects of the mediator complex subunits CDK8 and CDK19 are mediated by altered cell-matrix interaction}

\section{Jörg ${ }^{1 *}$, A. Offermann' ', F. Becker', M. C. Hupe ${ }^{2}$, A. S. Merseburger ${ }^{2}$, V. Sailer',} J. Kirfel', J. Brägelmann ${ }^{3}$, S. Perner ${ }^{1}$

'Pathologie des Universitätsklinikums Schleswig Holstein, Lübeck, Germany, ${ }^{2}$ Klinik für Urologie, Universitätsklinikums Schleswig Holstein, Lübeck, Germany, ${ }^{3}$ Institut für Pathologie Universität zu Köln, Molekularpathologie, Cologne, Germany

Aim. Recently, we identified mediator complex subunit CDK19 overexpression in metastatic castration-resistant prostate cancer (mCRPC). Based on our in-vitro results showing that CDK19 inhibition substantially reduces cell migration and invasion of PCa cells, the aim of this study was to further investigate the role of CDK19 during metastatic spread of prostate cancer $(\mathrm{PCa})$ and during development of castration-resistance. Methods. Nuclear CDK19 expression was assessed by immunohistochemistry (IHC) on prostate needle biopsies of patients with localized $(n=172)$ or initially metastatic disease $(n=28)$. Cells were treated with various small molecule CDK19 inhibitors alone or in combination with flutamide or bicalutamide. Adhesion assays were performed by crystal violet staining of cells attaching on collagen I coated plates. Invasion was measured by using collagen coated cell inserts. Downstream targets were screened by the R\&D phospho-kinase array and semi-quantified by western blot. Proliferation was quantified by MTT cell viability assay.

Results. CDK19 is significantly higher expressed in PCa from patients with initially metastatic PCa compared to tumors from patients with localized disease. Inhibition of CDK19 significantly increases collagen I-dependent cell adhesion and promotes cell aggregation. In addition, CDK19 affects Wnt $/ \beta$-Catenin signaling by modulating the phosphorylation level of GSK3 $\beta$ which leads to altered activity of the $\beta$-Catenin destruction complex. Further, CDK19 inhibition sensitizes PCa cells to androgen receptor blockade by flutamide or bicalutamide.

Conclusion. In conclusion, our results give insight into the molecular mechanisms which might explain the pro-metastatic role of CDK19 in $\mathrm{PCa}$. The Wnt/ $\beta$-Catenin pathway as an essential regulator of cell-cell and cell-matrix interaction has been identified as a potential mechanism of CDK19-mediated migration. Our study contributes to unravel the molecular mechanisms driving aggressive $\mathrm{PCa}$ and supports CDK19 as a potential therapeutic target in advanced $\mathrm{PCa}$.

\section{DGP16.05}

\section{Mechanisms of osteoclast NFATc1 regulation during prostate} cancer bone metastases

\section{T. Mayr ${ }^{1 *}$, N. S. Polavaram², S. Dutta ${ }^{3}$, K. Datta ${ }^{3}$, M. Muders ${ }^{1}$}

${ }^{1}$ Institut für Pathologie, Universitaetsklinikum Bonn, Rudolf-Becker-Labor am Biomedizinischen Zentrum, Bonn, Germany, ${ }^{2}$ Department of Pathology, University of Nebraska Medical Center, Omaha, United States, ${ }^{3}$ Department of Biochemistry and Molecular Biology, University of Nebraska Medical Center, Omaha, United States

Aim. During bone metastases, communication between prostate cancer cells and the bone microenvironment is essential. Molecular mediators like neuropilin-2 play important roles in this process. Our study aims at elucidating molecular mechanisms of neuropilin-2 mediated inhibition of osteoclast function during prostate cancer bone metastases formation. Methods. Mouse bone marrow derived osteoclasts were isolated from 6-10 weeks old C57BL/6 mice and transgenic mice from a conditional NRP2 knock out in the myeloid lineage model system (CSF1R-Cre; NRP2 floxP/ floxP). Osteoclastic precursors were differentiated into mature osteoclasts by adding M-CSF and RANKL or conditioned media from the bone metastatic prostate cancer cell lines LNCaP C4-2B or PC3. Immuneflourescence staining was executed to study NFATc1 intracellular location. Flou-4 AM staining was used to detect intracellular calcium levels.

Results. NFATc1 is central to osteoclastogenesis induced by metastatic prostate cancer. NRP2 inhibits osteoclast differentiation and function 
by repressing NFATc1 via blocking the calcineurin pathway. Active calcineurin induces the dephosphorylation of NFATc1 that is important for its translocation to the nucleus. Because of its function as a transcription factor only nuclear NFATc1 is functional. The calcineurin pathway is controlled by intracellular $\mathrm{Ca}$ levels. Intracellular Ca levels are significantly increased in LNCaP C4-2 B conditioned media treated osteoclasts after depletion of NRP2.

Conclusion. Regulation of osteoclastogenesis is important for prostate cancer bone metastases. Osteoclast derived NRP2 inhibits osteoclast differentiation and function by blocking NFATc1. Blocking NRP2 on osteoclasts results in increased intracellular Calcium levels which, in turn, activate the calcineurin pathway that is responsible for nuclear translocation of NFATc1.

\section{Standardisierter Workflow in der Pathologie - Präanalytik, digitalisierte Pathologie, KI}

\section{DGP17.02}

\section{Bedeutung standardisierter Schnittstellen für die Digitale Pathologie}

\section{R. Zwönitzer*}

imassense Deutschland GmbH, Berlin, Deutschland

Schnittstellen zwischen Computersystemen sind von entscheidender Bedeutung für deren Integration in das Umfeld einer Klinik oder einer Praxis. Patienten- und Auftragsverwaltung sowie Befundkommunikation und Abrechnung werden vorwiegend durch den HL7 Standard V2.X kommuniziert. Für Meldungen an öffentliche Register werden zunehmend ADT Datensätze gefordert. Für höhere Informationsdichten im wissenschaftlichen Umfeld sind Ergebnisse in strukturierter Form notwendig (z. B. HL7 CDA/FIHR). Diese strukturierten Befunde stellen jedoch hohe Anforderungen an die Datenerfassung mittels kodierter Werte und ihre Repräsentation im jeweiligen Kontext (Templates).

In der medizinischen Bildverarbeitung dagegen ist DICOM als servicebasierter Standard weltweit etabliert. Durch Anpassungen an die Anforderungen der virtuellen Mikroskopie wird dieser Standard attraktiv für die Pathologie. Die aktuellen Bemühungen des Standardkomitees streben ein heterogenes Gesamtsystem aus den unabhängigen Komponenten Slidescanner, Viewer, Bildanalyse und Archiv an, mit dem Ziel einzelner herstellerunabhängiger Systemteile, ähnlich dem Status Quo der Radiologie.

\section{DGP17.04}

\section{Anforderungsanalyse eines digitalen Workflows zur Hochdurchsatz-Diagnostik in der klinischen Pathologie}

J. Dieckmann ${ }^{1 * 2,}$, R. Lieberz ${ }^{3}$, C. Tank ${ }^{2}$, C. Döring ${ }^{3}$, P.J. Wild ${ }^{3}$

${ }^{1}$ Nordakademie, University of Applied Sciences, Fachbereich Business Informatics, Elmshorn, Deutschland, ${ }^{2}$ Philips GmbH, Digital and Computational Pathology, Hamburg, Deutschland, ${ }^{3}$ Universitätsklinikum Frankfurt, Dr. Senckenbergisches Institut für Pathologie, Frankfurt am Main, Deutschland

Ziel. Während die Digitalisierung des Gesundheitswesens nur langsam voranschreitet, bietet die Verwendung von virtuellen Mikroskopen innerhalb der Pathologie große Chancen, histologische Schnitte innerhalb eines Netzwerkes zu teilen und teilautomatisiert zu analysieren. Die nachhaltige Implementierung einer solchen Technologie kann aber erst gelingen, wenn die Voraussetzungen und Anforderungen eines vollständig digitalen Workflows erarbeitet und umgesetzt werden.

Methoden. Innerhalb dieser Arbeit wurde zunächst der Ist-Zustand des Workflows am Dr. Senckenbergischen Institut für Pathologie in Frankfurt/ Main in Form einer Feldbeobachtung dokumentiert und auf Schwachstellen hin untersucht. Aufbauend darauf wurde mittels Befragungen und Prozessanalysen ein möglicher Soll-Entwurf erarbeitet, aus welchem die grundlegenden Anforderungen an einen digitalen Workflow in der Pathologie hervorgehen.

Ergebnisse. Die Arbeit hat gezeigt, dass die Einführung eines digitalen $\mathrm{Pa}-$ thologiesystems vor allem durch den Einsatz eines digitalen Order-EntrySystems, der konsequenten Codierung von Arbeitsmaterialien und der Organisation eines digitalen Verteilerplatzes umgesetzt werden kann. Dabei stellt der Funktionsumfang des eingesetzten Laborinformationssystems die zentrale Rolle innerhalb der Systemlandschaft dar.

Fazit. Schlussendlich kann erst die lückenlose Interaktion zwischen dem Laborinformationssystem, der Betrachtungssoftware des virtuellen Mikroskops und den verwendeten Peripheriegeräten im Labor dazu führen, dass die digitale Transformation in der Pathologie gelingt.

\section{DGP17.05}

Ergebnisse der automatischen Erfassung von Patienteneinwilligungen am Comprehensive Cancer Center Freiburg

H. Fischer ${ }^{1,2}$, S. Schmid ${ }^{2}$, M. Boeker ${ }^{2,3}$, S. Auer ', M. Werner ${ }^{1,2,3}$, D. Kassahn ${ }^{1,2}$, P. Bronsert ${ }^{1,2,3}$

'Universitätsklinikum Freiburg, Institut für Klinische Pathologie, Freiburg, Deutschland, ${ }^{2}$ DKFZ, German Cancer Consortium (DKTK), Heidelberg, Deutschland, ${ }^{3}$ Universitätsklinikum Freiburg, Comprehensive Cancer Center Freiburg, Freiburg, Deutschland

Biobanken sind zentrale Instrumente der Krebsforschung. Die Rechtsgrundlage für die Erfassung von Biomaterialien und Patientendaten wird durch das Patienteneinwilligung (PI) dargestellt. Ohne PI sind Erfassung und Verknüpfung von Gewebeproben und zugehörigen Daten innerhalb einer Biobank nicht möglich. Um die Verfügbarkeit einer aktuellen PI zum Zeitpunkt der Biomaterialsammlung zu gewährleisten, ist ein schneller und automatisierter Prozess erforderlich. Wir präsentieren unserer Erfahrungen zur automatisierten PI Erfassung am Comprehensive Cancer Center Freiburg (CCCF) und vergleichen diese mit der konventionellen Erhebung.

Die PI steht zentral allen Abteilungen zur Verfügung. Sobald der Patient informiert und die PI unterschrieben hat, wird diese für den Patienten digitalisiert. Während der Digitalisierung wird a) eine Kopie der PI für den Patienten erstellt und gleichzeitig b) die PI zentral auf einem Klinikserver gespeichert. Die elektronische PI wird automatisch ausgewertet, auf Richtigkeit überprüft, in der CCCF Biobank-Datenbank gespeichert und anschließend an die jeweiligen Krankenhausinformationssysteme weitergeleitet. So stehen allen Abteilungen die Information zum Status der Patienteneinwilligung (vereinbart, abgelehnt/widersprochen, unangepasst) zur Verfügung.

Verglichen mit der herkömmlichen manuellen Verarbeitung hat die automatisierte Auswertung der PI eine schnellere Übertragungsrate. Die automatisierte Verarbeitung von zehn Zustimmungsformularen ist im Vergleich zur Verarbeitung von Hand erheblich schneller (Zeitersparnis bei zehn PIs 33 \%). Durch die automatisierte Auswertung von Einwilligungserklärungen treten Übertragungsfehler, die bei der manuellen Verarbeitung anfallen können, nicht auf $(p<0,001)$

Das händische Einholen und Auswerten der PI ist ein zeitintensiver Prozess. Die automatisierte Verarbeitung ermöglicht eine genaue und zeiteffiziente Übertragung aller erforderlichen Informationen nach Zustimmung des Patienten.

Die automatisierte Erfassung und Verarbeitung der PI ist ein wichtiges Instrument für longitudinal ausgerichtetes Biobanking und aufgrund der geltenden europäischen Datenschutzverordnung perspektivisch nahezu unvermeidlich. Das beschriebene Konzept ist nahtlos in die interdisziplinäre digitale Gesundheitsversorgung integriert, erleichtert die Bereitstellung von Patientendaten und zugehörigen Proben in standortübergreifenden Biobank-Netzwerken und Forschungsplattformen und ist unseres Wissens in Deutschland einzigartig. 


\section{Transplantationspathologie I}

\section{DGP18.02 \\ Lungentransplantation: Histomorphologische Diagnostik und klinische Aspekte

\author{
D. Jonigk* \\ Medizinische Hochschule Hannover, Institut für Pathologie, Hannover, \\ Deutschland
}

Die Funktion der transplantierten Lunge wird regelmäßig durch Alloimmunreaktionen mit sehr variablen klinischen Verläufen, verschiedenen beteiligten Effektorzellen- und molekülen sowie betroffenen Kompartimenten beeinträchtigt. Die akute zelluläre Abstoßung (ACR) nach Lungentransplantation (LuTx) trägt nicht nur zu einer akuten Transplantatdysfunktion mit erhöhter Mortalität bei, sondern ist neben anderen Faktoren wesentlich an der Entwicklung der chronischen Transplantatdysfunktion (chronic lung allograft dysfunction; CLAD) beteiligt, welche die Hauptursache für das limitierte Langzeitüberleben nach LuTx darstellt. Die CLAD ist dabei ein Überbegriff für zahlreiche immunologische und nicht-immunologische Schädigungen des Transplantates und wird wiederum in verschiedene phänotypische Untergruppen unterteilt. Wichtige prädisponierende Faktoren für die Entwicklung eines CLAD sind neben rekurrenten Episoden akuter Abstoßung auch nicht-immunologische Faktoren wie virale, bakterielle und mykotische Infektionen, gastroösophagelaler Reflux, eine prolongierte Ischämiezeit vor LuTx sowie ein Ischämie-Reperfusionschaden. Im Vordergrund stehen hier das bereits länger bekannte und vergleichbar gut beleuchtete, funktionell obstruktive CLAD (oCLAD, synonym BOS = Bronchiolitis obliterans Syndrom) und das erst in der letzten Zeit identifizierte und funktionell restriktive CLAD (rCLAD, synonym RAS = restriktives Allograft Syndrom).

Neben der ACR wurde analog zur Transplantation anderer solider Organe inzwischen auch bei der LuTx die Bedeutung der antikörpervermittelten (humoralen) Abstoßung (AMR) erkannt. Dabei sind aktuell in der Routinediagnostik weder für die ACR noch die AMR spezifische laborchemische, radiologische oder klinische Nachweisverfahren etabliert. Erst durch die synoptische Betrachtung aus morphologischen Verfahren mit histopathologischer Beurteilung einer Lungenbiopsie und mikrobiologischen, virologischen, serologischen sowie funktionellen Befunden wird eine ausreichende Sensitivität und Spezifität in der Abstoßungsdiagnostik erzielt. Im Vortrag werden die derzeit etablierten Kriterien für die morphologische Abstoßungsdiagnostik nach Lungentransplantation unter Berücksichtigung der wichtigsten Differentialdiagnosen dargestellt.

\section{DGP18.03 \\ Heterogeneity of acute GvHD throughout the upper and lower intestine in patients after allogenic hematopoietic stem cell transplantation}

\section{A. Kreft ${ }^{1 *}$, H. Neumann ${ }^{2}$, M. Schindeldecker ${ }^{3}$, E.M. Wagner-Drouet ${ }^{4}$ \\ 'Universitätsmedizin Mainz, Pathologie, Mainz, Germany, \\ ${ }^{2}$ Universitätsmedizin Mainz, Endoskopie, Mainz, Germany, \\ ${ }^{3}$ Universitätsmedizin Mainz, Pathologie/Tissue Biobank, Mainz, Germany, \\ ${ }^{4}$ Universitätsmedizin Mainz, Hämatologie, Mainz, Germany}

Aim. Intestinal graft-versus-host disease (GvHD) is a potentially life-threatening condition after allogenic hematological stem cell transplantation (alloHSCT). The diagnostic utility of endoscopic biopsies is impaired by the heterogeneity of GvHD manifestations throughout the intestine. On the basis of single biopsies or incomplete biopsy series from different patients, some investigators have advocated the upper and some the lower intestine for diagnosis and grading, whereas others have not found significant differences between biopsies from upper and lower intestines. Here we present a systematic evaluation of all anatomical regions accessible to endoscopic biopsies.

Methods. We investigated 22 complete biopsy series, each comprising biopsies from 10 different sites of the upper and lower intestine from 21 pa-

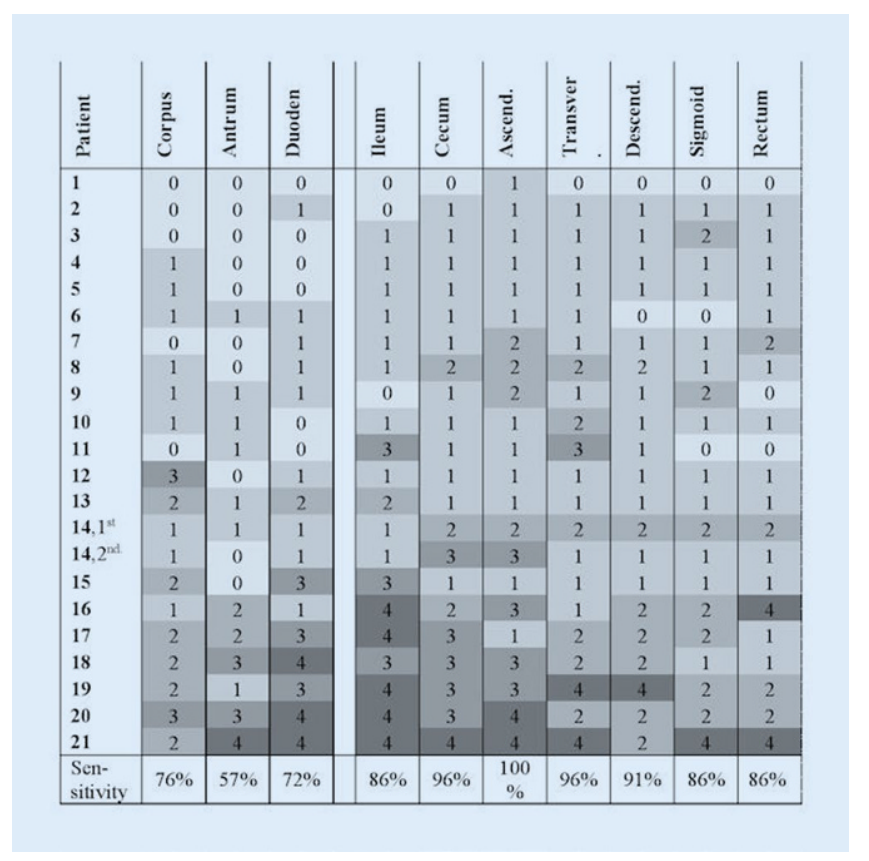

Fig. 1 | DGP18.03 $\Delta$ Distribution of different grades of acute graft-versushost disease

tients after alloHSCT. Each series included biopsies from corpus, antrum, duodenum, terminal ileum, cecum, ascending, transverse, and descending colon, sigmoid and rectum. All biopsies were re-evaluated by one of the authors (AK). For each of the investigated sites, a series of eight steps of hematoxylin and eosin staining, and an additional two steps of periodic acid Schiff staining from biopsies of the stomach and duodenum, were available as a standard. Histological scoring was performed by applying the Lerner score (no signs of $\mathrm{GvHD}=0$, crypt or gland cell apoptosis $=1$, destruction of crypts or glands $=2$, focal mucosa denudation $=3$, diffuse mucosa denudation $=4$ ).

Results. The majority of biopsies investigated revealed histological signs of acute GvHD. In the lower intestine, all biopsy sites revealed a sensitivity of at least $80 \%$, although higher sensitivity and more advanced grades of GvHD were found within the right colon and terminal ileum. In the upper intestine, biopsies from the duodenum were found to be the most sensitive and revealed the most advanced grades of GvHD (• Fig. 1 |DGP18.03).

Conclusion. Our results indicate that the most informative biopsies for GvHD diagnosis were those from the right colon and terminal ileum, and from the duodenum for the upper intestine, whereas biopsies from the left colon or stomach were less instructive.

\section{DGP18.04}

\section{Two decades of vascularized composite allograft transplantation}

T. Hautz ${ }^{*}$, B. G. Zelger', B. Zelger ${ }^{3}$, F. Messner', A. Weissenbacher', S. Schneeberger

'University Hospital for Visceral, Transplant and Thoracic Surgery, Medical University of Innsbruck, Innsbruck, Austria, ${ }^{2}$ Medical University of Innsbruck, Dept. of Pathology, Innsbruck, Austria, ${ }^{3}$ University Hospital for Dermatology, Venerology and Allergology, Medical University of Innsbruck, Innsbruck, Austria

Aim. Hand/forearm allotransplantation has become a therapeutic option for a carefully selected group of patients suffering from traumatic upper extremity amputation. The development of donor-specific alloantibodies (DSA) and chronic rejection remains a major threat in solid organ transplantation and is associated with inferior graft function and a higher rate of graft loss. An increasing number of antibody-mediated (ABMR) and chronic rejection has been reported for hand allograft recipients in the 
past years. We herein report long-term experience with a mean follow-up of 12 years.

Methods. Between 2000 and 2014 five patients received a bilateral hand $(n=3)$, bilateral forearm $(n=1)$ or unilateral hand $(n=1)$ transplant at Innsbruck University Hospital. Suspicious rejection was confirmed by histopathologic examination of a skin biopsy specimen and the cellular infiltrate was characterized by immunohistochemical stains. ABMR was diagnosed by presence of serum DSAs using Luminex $200^{\circ \mathrm{m}}$.

Results. Out of 38 rejection episodes observed in 5 patients during a 5-18 years follow-up, 25 were T-cell mediated rejections (65.89\%), 11 were classified as ABMR (28.85\%), one as a B-cell mediated rejection without DSAs (2.63\%), and one as a chronic rejection (2.63\%). ABMR manifested both early and late after transplantation. Histopathologic appearance of ABMR was heterogenous. In general, a higher number of CD20+ B-cells were recorded during ABMR compared to cellular rejection. While cellular rejections start with a perivascular CD3+ T-cell infiltrate in the superficial dermis, which migrates towards the epidermis, B-cell aggregates in ABMR were most often located in the deep dermis. ABMR was successfully treated with anti-CD25 and immunoadsorption in the majority of cases. However, the hand allograft of the unilateral hand transplant recipient had to be amputated at 7 years after multiple ABMRs with significant levels of serum DSAs, eventually resulting in chronic rejection with severe intimal hyperplasia and luminal narrowing. An association between complicated immunological courses including multiple rejection episodes and difficulties in adjustment of immunosuppression, and the development of DSAs and ABMR, was observed.

Conclusion. ABMR and chronic rejection in vascularized composite allograft recipients may be hard to diagnose and challenging to manage. An update of the current Banff classification including both types of rejection is urgently warranted.

\section{DGP18.05}

\section{Seltener Fall einer tumorverdächtigen lympho-nodalen Bazillären} Angiomatose in einem organtransplantierten Patienten

\section{K. Utpatel " ${ }^{*}$, Z. Provaznik ${ }^{2}$, C. Brochhausen', M. Evert ${ }^{1}$}

'Universität Regensburg, Institut für Pathologie, Regensburg, Deutschland 2Universitätsklinikum Regensburg, Herz-Thorax-Chirurgie, Regensburg, Deutschland

Ziel. Die Bazilläre Angiomatose ist eine infektiöse, pseudoneoplastische Gefäßreaktion, verursacht meist durch Bartonella henselae, getriggert durch eine Immundefizienz. Katzen sind der Hauptwirt von Bartonella henselae, weshalb die retikulohistiozytär-abszedierende Lymphadenitis des Immunkompetenten auch „Katzenkratzkrankheit“ genannt wird. Kutaner Befall und Ausbreitungsmuster ähneln dem Kaposi-Sarkom.

Methoden. Fallbericht einer Bazillären Angiomatose in einem Lymphknoten mit klinischem Verlauf und Darstellung der histologischen, elektronenmikroskopischen und molekularen Befunde.

Ergebnisse. Ein 60-jähriger herztransplanierter Patient stellte sich mit seit mehreren Tagen bestehendem Fieber und einem Gewichtsverlust von $5 \mathrm{~kg}$ in 10 Tagen in der Klinik vor. 4 Wochen zuvor lag bei ihm eine Handverletzung vor, ausgelöst durch einen Katzenbiss. In den Blutkulturen wurde kein Keimnachweis erzielt. Im CT zeigte sich eine axilläre Lymphknotenschwellung. Im Lymphknotenexstirpat fand sich ein fast den gesamten Lymphknoten einnehmendes tumorförmiges teilweise spindelzelliges $\mathrm{Ge}$ fäßproliferat. Gelegentliche Mikrothromben und fibrinoide Gefäßwandnekrosen sowie perikapilläre neutrophile Granulozyten, Makrophagen und Debris ergaben einen Vaskulitis-artigen Aspekt. Subendothelial zeigen sich basophile granuläre Ablagerungen, welche sich in der WarthinStarry Versilberung als büschelförmig angeordnete Stäbchenbakterien, in diesem Kontext verdächtig auf Bartonellen, identifizieren ließen. Sie konnten elektronenmikroskopisch überwiegend extrazellulär lokalisiert mit einer Länge bis $1,5 \mu \mathrm{m}$ und Breite bis $0,5 \mu \mathrm{m}$ verifiziert werden, passend $\mathrm{zu}$ Bartonellen. Schließlich konnte durch Amplifikation Bartonella-spezifischer DNA mittels PCR sowie anschließender Sequenzierung der direkte Erregernachweis von Bartonella henselae geführt werden. Eine Bazilläre
Angiomatose im Lymphknoten wurde diagnostiziert. Der Patient wurde erfolgreich mit Doxycyclin antibiotisch behandelt.

Fazit. Der Immunstatus ist entscheidend für den Verlauf einer Bartonellen Infektion. Beim immunsupprimiertem Patienten kann sich eine Bazilläre Angiomatose entwickeln, eine potentiell systemische Erkrankung. Die Kenntnis dieser Krankheit und die Abgrenzung vom Kaposi-Sarkom ist für die Therapie und Prognose des Patienten entscheidend, da sie als bakterielle Infektion mit Antibiotika geheilt werden kann.

\section{Präzisionsonkologie - freie Vorträge I}

\section{DGP19.01}

\section{Roof plate-specific spondin 2 (RSPO2)-Rearrangement - alternativer Weg zur WNT/ $\beta$-Catenin Aktivierung in hepatozellulären Tumoren mit Therapiepotential}

T. Longerich ${ }^{1 * 2,}$, V. Endris' ${ }^{1}$ O. Neumann ${ }^{1}$, E. Rempel', M. Kirchner', Z. Abadi', S. Uhrig', M. Kriegsmann ', K. H. Weiss ${ }^{2,4}$, A. Mehrabi, ${ }^{2,5}$, T. F. Weber ${ }^{2,6}$, B. K. Straub ${ }^{7}$, A. Rosenwald ${ }^{8}$, F. Schulze ${ }^{9}$, S. Fröhling ${ }^{10}$, R. Pellegrino', J. Budczies' ${ }^{1}$ P. Schirmacher ${ }^{1,2}$, A. Stenzinger ${ }^{1}$

'Pathologisches Institut, Uniklinikum, Heidelberg, Deutschland, ${ }^{2}$ Liver Cancer Center, Heidelberg, Deutschland, ${ }^{3}$ Angewandte Bioinformatik, Deutsches Krebsforschungszentrum, Heidelberg, Deutschland, ${ }^{4}$ Medizinische Klinik IV, Uniklinikum, Heidelberg, Deutschland, ${ }^{5}$ Chirurgische Klinik, Uniklinikum, Heidelberg, Deutschland, ${ }^{6}$ Diagnostische und Interventionelle Radiologie, Uniklinikum, Heidelberg, Deutschland, ${ }^{7}$ Institut für Pathologie, Universitätsmedizin Mainz, Mainz, Deutschland, ${ }^{8}$ Universität Würzburg und Comprehensive Cancer Center Mainfranken, Institut für Pathologie, Würzburg, Deutschland, ${ }^{9}$ Uniklinikum Frankfurt, Senckenbergisches Institut für Pathologie, Frankfurt, Deutschland, ${ }^{10}$ Nationales Centrum für Tumorerkrankungen und Deutsches Krebsforschungszentrum, Abteilung Translationale Medizinische Onkologie, Heidelberg, Deutschland

Wir haben in der Vergangenheit wiederholt $\beta$-Catenin-aktivierte hepatozelluläre Tumore diagnostiziert, bei denen die Sequenzanalyse des CTNNB1-Gens eine wildtypische Sequenz zeigte. Ziel der vorliegenden Studie war die Identifikation genetischer Alterationen, die funktionell die Rolle einer CTNNB1-Mutation in $\beta$-Catenin-aktivierten hepatozellulären Adenomen (HCA) und hepatozellulären Karzinomen (HCC) übernehmen können.

Hierzu wurden große HCA- ( $n=185)$ und HCC-Kohorten $(n=468)$ mittels Immunhistologien für CTNNB1 und Glutaminsynthetase, einem Zielgen des WNT/ $\beta$-Catenin-Signalwegs, untersucht und klassifiziert. Der Mutationsstatus des CTNNB1-Gens wurde in allen $\beta$-Catenin-aktivierten HCA und in allen HCC mit mindestens mäßiger nukleärer CTNNB1-Akkumulation (IRS $\geq 6$ ) bestimmt. Alle $\beta$-Catenin-aktivierten, CTNNB1-wildtypischen Tumore wurden mittels Ultradeep-Sequencing (Oncomine Comprehensive Assay v3) analysiert und die gefundenen Rearrangements mittels Anchored Multiplex PCR (AMP)-basierter Translokationsdetektion (Archer ${ }^{\circledR}$ FusionPlex ${ }^{\circledR}$ Solid Tumor Assay) validiert. Zudem wurde eine auf onkogene Signalwege fokussierte Expressionsanalyse in HCA durchgeführt.

In $1,6 \%$ aller HCA bzw. $18 \%$ der $\beta$-Catenin-aktivierten HCA sowie in $0,6 \%$ der untersuchten HCC wurde ein rekurrentes Roof plate-specific spondin 2 (RSPO2) Rearrangement detektiert, welches Folge einer 46,4 kb Mikrodeletion auf Chromosom 8q23.1 war. RSPO2-rearrangierte HCA zeigten eine Überexpression des RSPO2-Proteins, eine diffuse nukleäre CTNNB1-Akkumulation und eine Aktivierung des WNT-Signalwegs, die zu einer malignen Transformation prädisponiert. Im Gegensatz zu CTNNB1-mutierten HCA scheint eine zusätzliche aktivierende Mutation des TERT-Promoters für RSPO2-rearrangierte hepatozelluläre Tumore entbehrlich. Wenngleich $R S P O 2$-rearrangierte Tumore immunhistologisch eine Überexpression des RSPO2-Proteins aufwiesen, zeigten auch 
alle CTNNB1-mutierten HCA und einzelne HCA anderer Subtypen dieses Expressionsverhalten.

Somit stellt ein RSPO2-Rearrangement einen neuen molekularen Driver der Hepatokarzinogenese dar. Die tumorigene Wirkung wird durch eine starke Aktivierung des WNT/ß-Catenin-Signalwegs vermittelt. Das histologische Kennzeichen RSPO2-rearrangierter HCA ist die diffuse nukleäre CTNNB1-Akkumulation, wohingegen die RSPO2-Immunhistologie keinen geeigneten Biomarker darstellt. Präklinische Daten suggerieren, dass ein $\mathrm{RSPO} 2$-Rearrangement ein lohnendes Target für eine zielgerichtete Therapie sein könnte.

\section{DGP19.02}

\section{Nuclear NR4A3 immunostaining is a specific and sensitive novel marker for acinic cell carcinoma of the salivary glands}

F. Haller ${ }^{1 *}$, A. Skálová', S. Ihrler', B. Märkl', M. Bieg 5 , E. A. Moskalev', R. Erber', M. Baněčková', S. Wiemann', S. Müller', J. Zenk', R. Eilts', H. Iro', A. Hartmann', A. Agaimy'

${ }^{1}$ Friedrich-Alexander University Erlangen-Nürnberg, Institute of Pathology, Erlangen, Germany, ${ }^{2}$ Charles University, Faculty of Medicine in Plzen, Department of Pathology, Plzen, Czech Republic, ${ }^{3}$ Dermpath Munich, Munich, Germany, ${ }^{4}$ University Hospital Augsburg, Institute of Pathology, Augsburg, Germany, ${ }^{5}$ Berlin Institute of Health and Charité - Universitätsmedizin Berlin, Center for Digital Health, Berlin, Germany, ${ }^{6}$ German Cancer Research Center (DKFZ), Division of Molecular Genome Analysis, Heidelberg, Germany, ${ }^{7}$ University Hospital Erlangen, Friedrich-Alexander University Erlangen-Nuremberg, Department of Otorhinolaryngology, Head \& Neck Surgery, Erlangen, Germany, ${ }^{8}$ University Hospital Augsburg, Department of Otorhinolaryngology, Head and Neck Surgery, Augsburg, Germany

Aims. Employing comprehensive genomic and epigenomic profiling, we recently reported on recurrent translocations $[\mathrm{t}(4 ; 9)(\mathrm{q} 13 ; \mathrm{q} 31)]$ in Acinar Cell Carcinoma (AciCC) of the salivary glands. These translocations enable upregulation of the transcription factor Nuclear Receptor Subfamily 4 Group A Member 3 (NR4A3) at 9q31 through enhancer hijacking of active regulatory chromatin elements located within the secretory Ca-binding phosphoprotein (SCPP) gene cluster at 4q13. For the current study, we aimed at evaluating the diagnostic utility of NR4A3 immunostaining in the differential diagnosis of AciCC of the salivary glands.

Methods. Tissue slides of 64 AciCC samples (primary tumors, recurrences and metastases) and of 29 secretory (Mammary-analogue) carcinomas (MASCs), as well as a Tissue Microarray containing 70 other salivary gland carcinomas were analyzed by NR4A3 immunohistochemistry. The AciCCs samples were also evaluated by Fluorescence in-Situ hybridization employing a NR4A3 break-apart probe, and a subset of 15 AciCCs had been recently analyzed for genomic translocation events by NGS.

Results. 63 of 64 (98\%) AciCC samples showed nuclear expression of NR4A3 with varying intensity, whereas none of the MASCs or other salivary gland carcinomas showed any nuclear NR4A3 staining. Out of $58 \mathrm{Ac}-$ iCCs that could be successfully analyzed by FISH, 49 (84\%) showed aberrant signals including $44(76 \%)$ cases with break apart signals and $5(9 \%)$ with a single red split signal. In contrast, $9(16 \%)$ samples showed normal fusion signals. Of the AciCCs with normal NR4A3 FISH signals, two cases had been characterized by NGS previously and harbored a translocation upstream of the NR4A3 break-apart FISH probes.

Discussion. NR4A3 immunostaining is a novel and highly specific diagnostic marker for AciCC of the salivary glands. This is especially valuable in the differential diagnosis of high-grade transformed AciCCs and those with unusual histological pattern as well as their distinction from MASCs. In comparison to the NR4A3 FISH, NR4A3 immunostaining is a more sensitive marker, correctly identifying $98 \%$ vs. $84 \%$ of all AciCCs. The $9 \mathrm{q} 31$ genomic breakpoint can occur up to several hundred kbps upstream of the NR4A3 gene locus (not fully covered in the used FISH probe), explaining the discrepancy between normal NR4A3 FISH signals and positive NR4A3 immunostaining seen in $14 \%$ of cases.

\section{DGP19.03}

Etablierung und Evaluation primärer Organoid-Kulturen als translationale, prädiktive Testplattform für die Chemosensitivät von Tumoren

\section{M.-S. Bösherz*, S. Hakroush, J. Kitz, S. Küffer, P. Ströbel}

Universitätsmedizin Göttingen, Institut für Pathologie, Göttingen, Deutschland

Ziel. Im Zuge des Projekts werden In-vitro-Kulturen von Organoiden, d.h. dreidimensional und organotypisch wachsende Primärzellen, verschiedener Tumorentitäten etabliert und bezüglich ihres Nutzens zur molekularen Stratefizierung und Vorhersage des Ansprechens auf Chemotherapeutika evaluiert.

Methoden. Primäre Zellen wurden aus Resektatmaterial durch enzymatischen Verdau sowie mehrere Aufreinigungsschritte gewonnen und in Matrigel dreidimensional über mehrere Passagen kultiviert sowie ggf. kryoasserviert und wieder aufgetaut. Die kultvierten Organoide wurden in Paraffin eingebettet und (immun-)histochemisch mit dem jeweiligen Ursprungsgewebe verglichen sowie mittels Viabilitätsassays auf ihr Proliferationsverhalten und ihre Chemosensitivität hin untersucht.

Ergebnisse. Organoid-Kulturen wurden aus Resektaten von Pankreaskarzinomen, urologischen Tumoren und Thymomen hergestellt. Die primäre Anwachsrate der Pankreaskarzinom-Zellen bei bislang 20 Isolations-

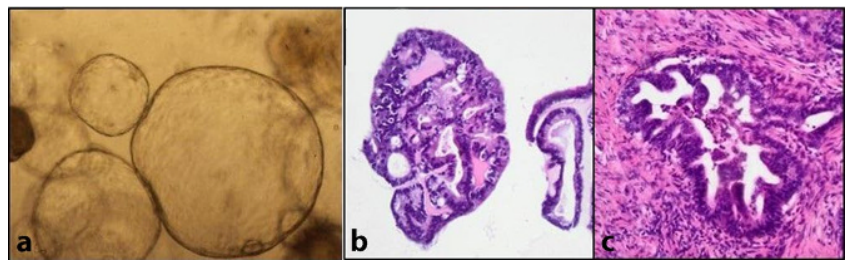

Abb. 1 | DGP19.03 $\triangle$ Pankreaskarzinom-Organoide (a invertiertes Mikroskop, b HE-Paraffinschnitt, c Ursprungsgewebe)

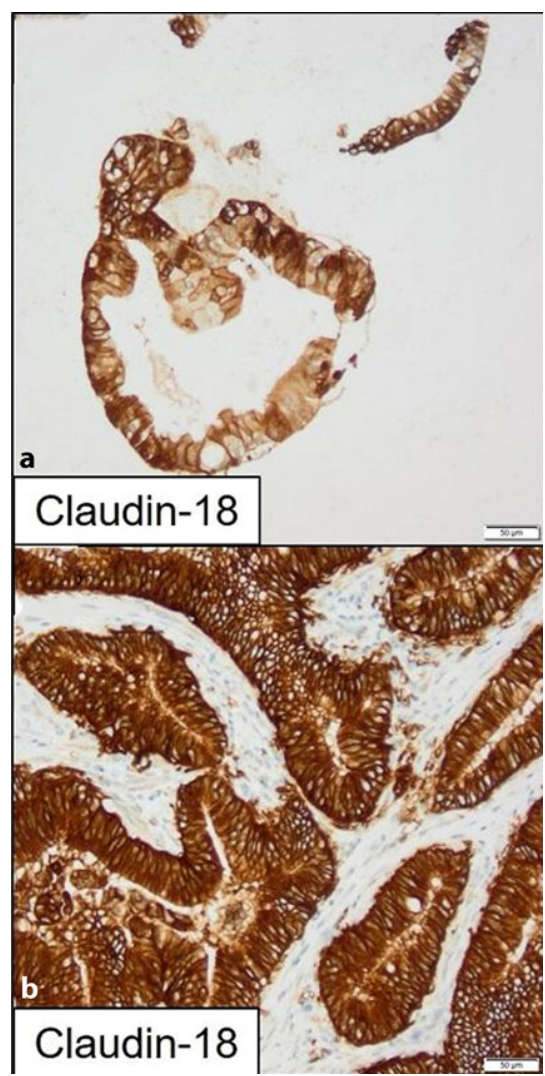

Abb. 2 | DGP19.03 Immunhistochemie an PankreaskarzinomOrganoiden (a) im Vergleich zum Ursprungsgewebe (b) 


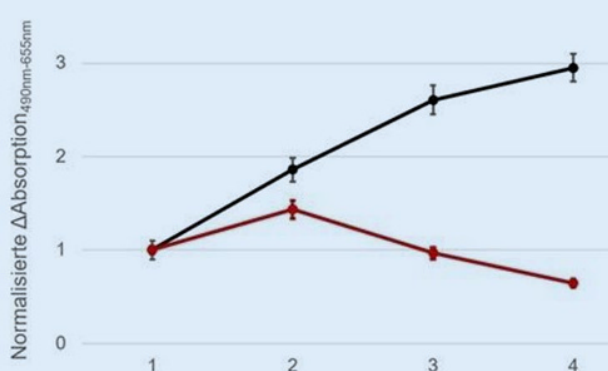

Tage

$\rightarrow$ Unbehandelt
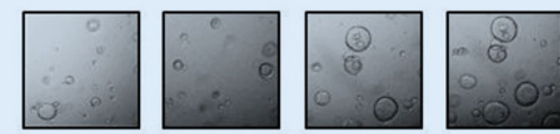

- Gemcitabin $(0,25 \mu \mathrm{M})$
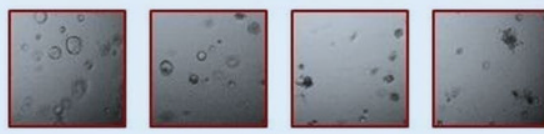

Abb. 3 | DGP19.03 $\Delta$ Proliferationsverhalten und Chemosensitivität von Pankreaskarzinom-Organoiden im MTS-Assay

versuchen lag bei $85 \%$. Die übliche Zeit bis zur Passage dieser Organoide beträgt 7-14 Tage; die am längsten kultivierte Linie ist aktuell in der 13. Passage. Während Pankreaskarzinom-Organoide stets als zystische Gebilde wachsen, zeigen Thymom-Organoide ein Spektrum von Zysten über Zellstränge bis hin zu soliden Sphären. Die kultivierten Organoide zeigen zum Ursprungsgewebe vergleichbare (immun-)histochemische Charakteristika (- Abb. 1 | DGP19.03 und $\bullet$ Abb. 2 |DGP19.03). Erste Versuche im 96-Well-Format zeigen, dass die Chemosenstivität der Organoide mittels herkömmlicher Viabilitätsassays (MTS) überprüft werden kann (• Abb. 3 |DGP19.03).

Fazit. Primärzell-Organoide stellen ein praktikables In-vitro-Modell zum Screening der Effektivität verschiedener Therapeutika dar, wobei die Rekapitulation der In-vivo-Histoarchitektur eine bessere Vergleichbarkeit mit dem Ursprungsgewebe als bei herkömmlichen zweidimensionalen In-vitro-Modellen suggeriert. Der Arbeitsaufwand und die Kosten müssen jedoch im Verhältnis zur Aussagekraft stehen. In kommenden Versuchen sollen die etablierten Organoid-Linien daher auf Genom- und Proteinexpressionsebene mit dem Ursprungsgewebe verglichen und ihr molekularbiologisches Profil in Beziehung zur Chemosensitivität gesetzt werden, um ihren Wert als künftiges präzisionsonkologisches Werkzeug abschätzen zu können.

\section{DGP19.04}

\section{Molekularpathologische Diagnostik primärer Lungenkarzinome mit sarkomatoider Differenzierung - Eröffnung neuer Therapiekonzepte}

\section{S. Stephan-Falkenau' ${ }^{1 *}$, J. Kollmeier ${ }^{2}$, A. Streubel', T.-G. Blum², T. Bauer², T. Mairinger ${ }^{1}$}

'Institut für Gewebediagnostik/MVZ Helios Klinikum Emil von Behring, Berlin, Deutschland, ${ }^{2}$ Lungenklinik Heckeshorn/Helios Klinikum Emil von Behring, Pneumologie, Berlin, Deutschland

Ziel. Nicht-kleinzellige Lungenkarzinome mit sarkomatoider Differenzierung (SC) stellen eine heterogene Gruppe von epithelialen Neoplasien mit aggressivem biologischem Verhalten, rascher Progredienz und schlechter Prognose dar. Viele Patienten sprechen nur schlecht auf eine Chemotherapie an. Auf der Suche nach therapeutischen Alternativen wurden in jüngster Zeit prädiktive Biomarker immunonkologischer und zielgerichteter Therapien wie Checkpoint- und Tyrosinkinase-Inhibition beschrieben. Mit dem Ziel einer molekularpathologischen Charakterisierung sarkoma- toider Lungenkarzinome wurden retrospektiv Patientendaten ausgewertet und archiviertes Tumorgewebe reanalysiert.

Methoden. Mittels Datenbankanalyse wurden Patienten der Lungenklinik Heckeshorn Berlin mit SC identifiziert, die histologische Diagnose überprüft und die Tumoren ggf. nach der jetzt gültigen WHO-Klassifikation (4. Aufl.) reklassifiziert. FFPE Material wurde immunhistochemisch mit AK gegen PD-L1 (Quartett GmbH, Berlin) und molekularpathologisch DNA- und RNA-basiert mittels Next Generation Sequencing (Ion Torrent, S5XL, ThermoFisher Scientific, Waltham, USA) untersucht.

Ergebnisse. 116 Tumore (monozentrisch) mit SC (71\% pleomorphe Karzinome, 16 \% Spindelzellkarzinome, 11 \% Riesenzellkarzinome, $2 \%$ Karzinosarkome, 0 Pulmoblastome) wurden identifiziert, ca. 1,7 \% aller seit 2008 diagnostizierten NSCLC. 90/116 (78 \%) Patienten zeigten einen positiven PD-L1-Status (Score 1-100). In 57/116 (49 \%)Tumoren ließ sich ein PD-L1 high score von $\geq 50$ nachweisen, positiv prädiktiv für eine Erstlinien-Therapie mit Checkpoint-Inhibitoren. Aus dem Tumorgewebe von 83/116 (72 \%) Patienten konnte DNA, von 93/116 (80 \%) Patienten RNA in ausreichender Qualität gewonnen und mittels NGS weiter untersucht werden. Am häufigsten fanden sich Mutationen im KRAS-Gen (36 \%), gefolgt von NRAS- (4\%) und BRAF-Mutationen (5\%, 2 V600E, 2 nonV600E). 2/83 Tumoren (2,4 \%) wiesen eine, unter TKI-Therapie als Resistenz-vermittelnd geltende MET-Amplifikation auf. Met Exon14 Skipping Events, ein potentielles Target für Crizotinib, ließ sich in 13/93 Fällen (14\%) nachweisen. In einem Fall fand sich eine seltene KIF5B-RET Fusion.

Fazit. SC weisen ein abweichendes tumorbiologisches Profil mit hohem Anteil PD-L1 exprimierender Tumoren und vermehrtem Nachweis eines MET Exon 14 Skipping Events auf. Eine standardisierte molekularpathologische Diagnostik eröffnet neue Möglichkeiten einer zielgerichteten oder immunonkologischen Therapie.

\section{DGP19.05}

\section{Classification of $\mathbf{1 0}$ cancer types using imaging mass spectrometry}

R. Casadonte', M. Kriegsmann ${ }^{2}$, S. Deininger ${ }^{3}$, D. Trede ${ }^{4}$, J. H. Kobarg ${ }^{4}$, T. Boskamp ${ }^{4}$, K. Kriegsmann $n^{5}$, W. Weichert ${ }^{6}$, K. Schwamborn ${ }^{6}$, C. Bollwein ${ }^{6}$, A. Perren ${ }^{7}$, J. Kriegsmann ${ }^{1 *, 8}$

'Proteopath GmbH, Trier, Germany, ${ }^{2}$ Institute of Pathology/University of Heidelberg, Heidelberg, Germany, ${ }^{3}$ Bruker Daltonik, Bremen, Germany, ${ }^{4} \mathrm{SCiLS}$, Bremen, Germany, ${ }^{5}$ Department of Hematology, Oncology and Rheumatology/University of Heidelberg, Heidelberg, Germany, ${ }^{6}$ Institute of Pathology/Technical University of Munich, Munich, Germany, ${ }^{7}$ Institute of Pathology/University of Bern, Bern, Switzerland, ${ }^{8}$ Center for Histology, Cytology and Molecular Diagnostic Trier, Trier, Germany

Aim. Typing of cancer subtypes requires histological, immunohistological and in some cases molecular pathological analyses. To support the pathologist in decision-making we have developed a mass spectrometry-based tumor typer using imaging mass spectrometry (IMS). Ten tumor types were included in the model including adenocarcinomas of the breast, liver, pancreas, colon and lung, squamous-cell carcinoma of the lung, urothelial carcinoma, lymphoma as well as pancreatic and gastrointestinal neuroendocrine tumors.

Methods. Formalin-fixed paraffin-embedded (FFPE) tissue microarray sections $(5 \mu \mathrm{m})$ were subjected to deparaffination, heat-induced epitope retrieval, in-situ trypsin digestion and deposition of a matrix solution for IMS analysis. MS data were acquired at a spatial resolution of $100 \mu \mathrm{m}$ using an Autoflex Speed TOF/TOF system. Tissue sections were stained by Hematoxylin and Eosin after IMS and cancer regions were annotated. Spectra of datasets each including a specific tumor were used to train three different classification models using R statistical software. An independent subset of spectra was used to validate all algorithms. Immunohistochemistry was performed for validation of results.

Results. Linear Discriminant Analysis (LDA), Support Vector Machine (SVM) and Random Forest (RF) were used for the classification analysis. The cohort was separated into a training set $(n=217)$ and a validation set $(n=105)$. The models ranked the contribution of each tumor profiling 
towards the optimal separation of spectra derived from different tissues with an overall accuracy of $96 \%$. In the validation set, tumors were correctly classified with an accuracy of $98 \%$ (LDA), $94 \%$ (SVM), and $93 \%$ (RF). The specificity in the recognition of the various tumor types was between 90 and $100 \%$.

Conclusion. For the first time IMS was applied to classify a large set of malignancies on FFPE tissue. The advantages of high accuracy, speed, saving materials and cost for consumables compared to IHC, make this method a great potential for routine diagnostics for supporting tumor classification.

\section{DGP19.06}

\section{Panelbasierte Bestimmung der Tumormutationslast (TMB) und} räumliche Heterogenität: Bedeutung für die klinische Diagnostik

M. Allgäuer 1* , D. Kazdal', J. Budczies', M. Kriegsmann', A. Harms', J. Leichsenring', A.-L. Volckmar', M. Kirchner', O. Neumann', R. Brandt', E. Rempel', C. Plöger', M. von Winterfeld', K. Kriegsmann ${ }^{2}$, P. Christopoulos ${ }^{3,4}$, H. Bischoff ${ }^{3}$, R. Penzel', H. Winter, ${ }^{4,5}$, M. Thomas ${ }^{3,4}$, P. Schirmacher ${ }^{1,6}$, V. Endris', A. Stenzinger ${ }^{1,4,6}$

'Pathologisches Institut, Uniklinikum Heidelberg, Abt. Allgemeine Pathologie und path. Anatomie, Heidelberg, Deutschland, ${ }^{2}$ Uniklinikum Heidelberg, Innere Medizin V: Hämatologie, Onkologie und Rheumatologie, Heidelberg, Deutschland, ${ }^{3}$ Uniklinikum Heidelberg, Innere MedizinOnkologie, Thoraxklinik, Heidelberg, Deutschland, ${ }^{4}$ Translational Lung Research Center (TLRC), Heidelberg, Deutschland, ${ }^{5}$ Uniklinikum Heidelberg, Thoraxchirurgie, Thoraxklinik, Heidelberg, Deutschland, ${ }^{6}$ Deutsches Konsortium für Translationale Krebsforschung, Partnerstandort Heidelberg, Heidelberg, Deutschland

Ziel. Die Tumormutationslast (engl.: tumor mutational burden, TMB) ist ein neuartiger Biomarker zur prospektiven Identifizierung von Patienten mit einer höheren Ansprechwahrscheinlichkeit auf immunonkologische Therapien. Neben verschiedenen technischen Aspekten der TMB-Bestimmung mit Hilfe von Genpanels in der Routinediagnostik könnte auch die Tumorbiologie an sich für eine Varianz der TMB verantwortlich sein. Ziel unserer Arbeit ist es, zu untersuchen ob aufgrund von intratumoraler $\mathrm{He}$ terogenität (ITH), wie sie z. B. in Adenokarzinomen der Lunge (ADC) auftritt, die TMB bei unterschiedlicher Entnahmelokalisation signifikant unterschiedlich ausfallen könnte.

Methoden. Bislang wurden 3-4 räumlich getrennte Tumorproben von 14 EGFR-negativen ADC mit dem TruSight ${ }^{\mathrm{TM}}$ Oncology 500 Assay auf einem NextSeq 500 Sequenzer (beide Illumina Inc.) analysiert. Zusätzlich wurde das Verhältnis von cytotoxischen CD8+ tumorinfiltrierenden Zellen zu CD45+ Gesamtlymphozyten computergestützt (QuPath) ermittelt sowie der PD-L1 Expressionsstatus konventionell bestimmt.

Ergebnisse. Im Durchschnitt wurde eine kodierende Genomregion von 1,27 Mbp mit einer mittleren Lesetiefe von $608 \times$ erfasst. Der Mittelwert der Mutationslast lag bei 6,84 Mutationen (mut) pro Mbp (Spannweite 0-17,3). Beim Vergleich unterschiedlicher Regionen eines Tumors zeigte sich in einem Drittel der Fälle (5/14) eine erhebliche Varianz ( \pm 5 mut/ Mbp) mit mittleren absoluten Abweichungen von 2,43 bis zu 4,17 mut/ Mbp und einer maximalen Abweichung von 11,76 mut/Mbp. Vorläufige Analysen zeigen in einem Teil der Fälle einen geringen Tumorzellgehalt in Verbindung mit geringer Lesetiefe und nicht angepasster automatisierter Variantenanalyse als mögliche Ursache auf. In den übrigen Fällen zeigte sich jedoch eine reale, biologisch bedingte Varianz der TMB Werte, in 2 von 14 Fällen sogar klinisch bedeutsam mit Werten beidseits der oft als Cutoff postulierten 10 mut/Mbp. Es zeigte sich keine Korrelation zwischen gemessener TMB und dem histologischen Wachstumsmuster, den CD8+ T-Zellinfiltraten oder der Expression von PD-L1.

Fazit. Wir konnten eine klinisch relevante, räumliche Heterogenität der TMB Messung in einem Teil der analysierten ADC feststellen. Um eine auf biologischen Grundlagen bestehende räumliche Heterogenität der TMBMessung von technisch bedingter Pseudoheterogenität zu unterscheiden, müssen zahlreiche Faktoren berücksichtig werden.

\section{DGP19.07}

\section{Cancer of unknown primary: Identifikation klonaler} Zusammenhänge in der klinischen Praxis

J. Leichsenring ${ }^{1 *}$, T. Bochtler2,3, V. Endris', A. Reiling ${ }^{2,3}$, O. Neumann', A.-L. Volckmar', M. Kirchner', M. Allgäuer', P. Schirmacher', A. Krämer ${ }^{2,3}$, A. Stenzinger ${ }^{?}$

'Pathologisches Institut, Universitätsklinikum Heidelberg, Heidelberg, Deutschland, ${ }^{2}$ German Cancer Research Center (DKFZ), Clinical Cooperation Unit Molecular Hematology/Oncology, Heidelberg, Deutschland, ${ }^{3}$ Universitätsklinikum Heidelberg, Innere Medizin V, Heidelberg, Deutschland

Ziel. Cancer of unknown primary (CUP) beschreibt Krebsfälle, in denen Metastasen histologisch gesichert wurden, ein Primärtumor jedoch nicht bekannt ist. Erschwerend kommen in vielen Fällen die Abgrenzung gegenüber vorhergehenden Tumorerkrankungen sowie z. B. nicht eindeutige histologische und immunhistochemische Ergebnisse hinzu. Wir haben im Rahmen einer speziellen CUP-Ambulanz die klonalen Zusammenhänge innerhalb dieser CUP-Fälle untersucht.

Methoden. Gezieltes Next Generation Sequencing mittels OCAv3 (NGS, Ion Torrent) wurde in 174 konsekutiven CUP-Fällen unserer Ambulanz an Paraffin-fixiertem Material durchgeführt.

Ergebnisse. 43/174 (24,7\%) Patienten hatten vorhergehende Krebserkrankungen, wobei paarweise genetische Daten von der vorhergehenden Krebserkrankung und dem CUP für 11 Patienten und paarweise genetische Daten von verschiedenen CUP Metastasen für 7 Patienten ausgewertet wurden. Wir fanden klonale Zusammenhänge in 16/18 Patienten. Innerhalb der Patientengruppe mit vorhergehenden Krebserkrankungen fanden sich 4 klonal unabhängige CUP-Tumore, welche Keimbahnmutationen in BRCA/BAP1 und ATM aufwiesen. 7 Fälle waren klonal mit der vorhergehenden Krebserkrankung verwandt, was zur Revision der Diagnose CUP führte. In den 7 Fällen ohne vorhergegangene Krebserkrankung zeigte sich eine klonale Verwandtschaft zwischen den Metastasen in 5 Fällen. In 2 Fällen konnte ein klonaler Zusammenhang nicht belegt werden.

Fazit. In gut selektierten CUP-Kohorten ist NGS ein hilfreiches Werkzeug zur Identifikation klonaler Zusammenhänge der zugrundeliegenden Krebserkrankungen. Bei klonaler Unabhängigkeit sollte eine prädisponierende Keimbahnmutation in Betracht gezogen werden.

\section{Transplantationspathologie II}

\section{DGP20.01}

\section{Moderne Konzepte zur dynamischen Konservierung von Leber} und Nieren im Rahmen einer Transplantation

T. Minor*

Uniklinik Essen, Chirurgische Forschung, Essen, Deutschland

Der steigende Organmangel führte zu einem Wandel in der experimentellen Erforschung von Organkonservierung-Strategien in der Transplantationsmedizin. Die einfache kalte Lagerung der Transplantate als Standard-Konservierungsverfahren bietet für Spenderorgane mit erweiterten Kriterien nicht immer optimale Bedingungen. Als klassische, dynamische Konservierungsmethode gilt die hypotherme, oxygenierte Maschinenperfusion (HMP). Durch die HMP wird das Gewebe mit Sauerstoff und Nährstoffen versorgt und eine metabolische Erholung des Transplantats vor Implantation ermöglicht. Ein moderneres Konzept ist die normotherme Maschinenperfusion (NMP), die durch Simulation physiologischer Konditionen eine Evaluation und Behandlung des Organs vor Transplantation ermöglicht. Studien zur NMP zeigten allerdings, dass eine vorgeschaltete Periode kalter Lagerung den funktionellen Vorteil der NMP abschwächt. Das kontrolliert oxygenierte Wiedererwärmen (COR) ist eine Strategie diesen Nachteil ausgleichen, indem das kalt gelagerte Transplantat langsam und schrittweise auf sub-normotherme oder normotherme Temperaturen erwärmt wird. So kann eine schonende Adaption des Energie-Stoffwechsels stattfinden und dem Wiedererwärmungsschaden vorgebeugt werden. 
DGP20.03

Algorithmus-basierte automatisierte Auswertung der Fibrose in der Gallengangatresie als objektiver Prädiktor einer Leberfrühtransplantation

J. Andruszkow ${ }^{1 *}$, B. Hartleben ${ }^{2}$, T. Ritz ${ }^{3}$, R. Knüchel', C. Petersen ${ }^{4}$, O. MadadiSanjani ${ }^{4}$

'Institut für Pathologie, Uniklinik der RWTH, Aachen, Deutschland, ${ }^{2}$ Institut für Pathologie, Medizinische Hochschule, Hannover, Deutschland, ${ }^{3}$ Institut für Pathologie/Universitätskrankenhaus Heidelberg, Heidelberg, Deutschland, ${ }^{4}$ Zentrum für Kinderchirurgie, Medizinische Hochschule, Hannover, Deutschland

Ziel. Die Gallengangatresie (GA) ist eine seltene Erkrankung des Neugeborenen, die über eine obliterative Cholangiopathie zur Leberzirrhose führt Wir konnten zeigen, dass eine bei Diagnosestellung fortgeschrittene Fibrose der Leber (Ishak-Score $\geq 4$ ) zu einer Frühtransplantation (FTx) innerhalb von 12 Monaten nach Hepatoportoenterostomie (HPE) führt. Da das Scoring der Fibrose jedoch einer Interobserver-Variabilität unterliegt $(K=0,68)$, ist das Ziel unserer Studie, eine Untersucher-unabhängige automatisierte Auswertung der Fibrose vorzunehmen, um eine verlässliche Aussage zum Risiko einer FTx angeben zu können.

Methoden. An insgesamt 34 Leberbiopsien zum Zeitpunkt der HPE wurde neben dem konventionellen Staging der Fibrose nach Ishak eine Algorithmus-basierte automatisierte Auswertung vorgenommen. In einem ersten Schritt wurde der prozentuale Flächenanteil der Fibrose in Bezug zur gesamten erfassten Leberbiopsie ermittelt. Danach wurde die maximale Dicke der Fibrosesepten sowie die Anzahl der Portalfelder bestimmt. Darüber hinaus wurde der Grad der portalen Entzündungsinfiltration ausgewertet. Die Ergebnisse wurden auf ihre Prädiktion hinsichtlich einer erforderlichen FTx untersucht.

Ergebnisse. Wie bereits gezeigt, korreliert eine reine Flächenmessung der Fibrose zwar mit dem Ishak-Score, kann im Gegensatz zum histologischen Staging jedoch keine Voraussage hinsichtlich der Entscheidung zu einer FTx geben. Die Messung der Septendicke zeigt zwar eine enge Korrelation mit dem Ishak-Score, kann jedoch ebenfalls als alleiniger Wert keine Aussage zur Prädiktion liefern. Eine Bestimmung der Portalfelder war bei ausgeprägten Gallengangsproliferaten in der fortgeschrittenen Fibrose schwierig und ließ sich nicht verlässlich reproduzieren. Hinsichtlich des Entzündungszellinfiltrates zeigten $>90 \%$ der Proben eine mäßige bis schwere portale Inflammation, so dass das Merkmal zur Unterscheidung der Fibrose nicht geeignet war.

Fazit. Bislang bietet der Ishak-Score die beste Prädiktion zur Risikobeurteilung einer Lebertransplantation innerhalb von 12 Monaten nach Diagnosestellung der GA. Die automatisierte Auswertung der Fibrose korreliert mit dem Score, bietet aber auch unter Zuhilfenahme weiterer Parameter keine signifikante Prädiktion hinsichtlich einer Leberfrühtransplantation. Aktuell erfolgt daher die Auswertung eines größeren Kollektivs, um ein automatisiertes Scoring-System mit prädiktivem Wert zu entwickeln.

\section{DGP20.04}

\section{Die Makrophagendichte in Nierentransplantatbiopsien ist prädiktiv für die Langzeitfunktion und korreliert mit Abstoßung, Fibrose und Infektion}

J. Schmitz ${ }^{1 *}$, A. Khalifa', I. Scheffner', W. Dai' , H. H. Kreipe', H. Haller', S. von Vietinghoff', W. Gwinner', J.H. Bräsen'

${ }^{1}$ Medizinische Hochschule Hannover (MHH), Institut für Pathologie, Hannover, Deutschland, ${ }^{2}$ Medizinische Hochschule Hannover $(\mathrm{MHH})$, Zentrum Innere Medizin, Klinik für Klinik für Nieren- und Hochdruckerkrankungen, Hannover, Deutschland

Ziel. Quantitative und qualitative Methoden zur Beurteilung und Lokalisation von Immunzellen könnten die diagnostische Genauigkeit in Nierenbiopsien erhöhen. Geringe Entzündungsinfiltrate im Gewebe sind nur schwer per Augenmaß quantifizierbar.

Methoden. Wir haben deshalb die Makrophagendichte in Nierentransplantatbiopsien mit digitaler Bildanalyse präzisiert ermittelt. Gewebe transplan- tierter Nieren von Protokoll- (36\%) und klinisch indizierten (64\%) Biopsien $(n=350)$ wurde mit dem Pan-Makrophagenmarker CD68 (Klon PG-M1), ein Subkollektiv aus 6-Wochen-Protokoll-Biopsien auch mit dem M1-Marker HLA-DR für inflammatorische Makrophagen und dem M2Marker CD206 für anti-inflammatorische Makrophagen, automatisiert gefärbt (Ventana), dann gescannt (Leica) und die positiv gefärbten Bereiche mit einem pixel-basierten Ansatz digital quantifiziert (Definiens Tissue Studio). Kortex, Medulla und extrarenales Gewebe wurden separat analysiert. Ergebnisse. Humorale und kombinierte Abstoßung waren mit erhöhter kortikaler Makrophageninfiltration assoziiert (keine Rejektion: 2,6 \%; Borderline: 1,9 \%; zelluläre Rejektion: 2,5 \%; humorale Rejektion: 4,4 \%; kombinierte Rejektion: 6,2 \%; $p<0,05)$. Die Makrophagendichte korrelierte mit der Zeit nach Transplantation: die höchsten Werte wurden gemessen, wenn die Zeit nach Transplantation ein Jahr überschritten hatte (5,8 \% verglichen mit $<1$ Jahr und $>90$ Tage $(4,1 \%),<90$ Tage und $>8$ Tage $(1,3 \%),<8$ Tage $(1,5 \%) ; p<0,05)$. Bei IF/TA (Banff) zeigte sich eine erhöhte Makrophageninfiltration parallel zum Grad der Fibrose (ci0: 1,5 \%, cil-3: 4.,\%; $p<0,001$ ). In 6-Wochen-Kontrollbiopsien war die Makrophagendichte prädiktiv für eine eGFR $<30 \mathrm{ml} / \mathrm{min} 4$ Jahre nach Nierentransplantation $(p<0,01)$. Die Einnahme von Diuretika korrelierte in 6-Wochen-Kontrollbiopsien dosisabhängig mit dem erhöhten Auftreten von Harnwegsinfekten, einem verringerten medullären $\mathrm{M} 1 / \mathrm{M} 2$-Verhältnis und geringerer Expression des Makrophagen-Infiltration-regulierenden Zytokins MCP1 (CCL2).

Fazit. Unsere Ergebnisse zeigen, dass Makrophagen eine wichtige Rolle bei aktiver Abstoßung, chronischer Transplantatdysfunktion, Fibrose und Infektion spielen und als prognostischer Marker in Transplantatnierenbiopsien genutzt werden können.

\section{Precision Oncology-Modern Diagnostics}

\section{DGP21.02}

\section{Supra-carcinoids: a new molecular entity of lung neuroendocrine} tumours

N. Alcala', N. Leblay', A. Gabriel', D. Hervas', J. Derks', A. Ghantous', C. Caux', J. Sandoval ${ }^{2}$, H. Hernandez-Vargas', E. Brambilla ${ }^{5}$, E. J. M. Speel', N. Girard', S. Lantuejoul', J. McKay', M. Foll', L. Fernandez-Cuesta ${ }^{*}$, Lung NEN Network

${ }^{1}$ International Agency for Research on Cancer, Lyon, France, ${ }^{2} \mathrm{Health}$ Research Institute La Fe, Valencia, Spain, ${ }^{3}$ Maastricht University Medical Centre, Maastricht, Netherlands, ${ }^{4}$ Cancer Research Centre of Lyon, Lyon, France, ${ }^{5}$ Institut Albert Bonniot, Grenoble, France, ${ }^{6}$ Institut Curie, Paris, France, ${ }^{7}$ Centre Leon Berard, Lyon, France

Background. Typical and atypical pulmonary carcinoids belong to the group of lung neuroendocrine neoplasms (NENs) that also includes smallcell lung cancer (SCLC) and large-cell neuroendocrine carcinomas (LCNEC). Comprehensive genomic studies are limited for typical and inexistent for atypical carcinoids.

Aims. We aimed to provide a comprehensive molecular characterization of atypical carcinoids and to analyse them in the context of the other lung NENs

Methods. We have generated the first multi-omic dataset for atypical carcinoids. Through machine-learning and multi-omics factor analysis of newly generated and previously published data, we have compared and contrasted the genomic profiles of 116 pulmonary carcinoids (including 35 atypical), 75 LCNEC, and 66 SCLC.

Results. Integrative multi-omic analyses on 257 lung NENs stratified atypical carcinoids into two prognostic groups with a 10-year overall survival of $88 \%$ and $20 \%$, respectively. We identified therapeutically relevant molecular groups of pulmonary carcinoids, suggesting DLL3 and the immune system as candidate therapeutic targets. We also confirmed the value of OTP expression levels for the prognosis and diagnosis of these diseases. We additionally unveiled the group of supra-carcinoids, comprising samples with carcinoid-like morphology yet with molecular and clinical features of the deadly LCNEC. Whether these supra-carcinoids might constitute 
a separate entity in the lung, analogous to the well-differentiated grade- 3 gastroenteropancreatic tumours remains to be further explored. Conclusions. These results further demonstrate the utility of integrating molecular and histopathological data for the classification and clinical management of tumours, as well as for identifying novel entities.

This study is part of the lungNENomics project. This work has been funded by the US NIH, the French INCa, and the French LNCC. NA, NL, and AG equally contributed to this work. LFC and MF jointly supervised this work.

\section{DGP21.04}

Germline-testing in tumor patients: Who should be tested and what to do with the results?

\section{E. Schröck*}

Medizinische Fakultät Carl Gustav Carus, Technische Universität Dresden, Institut für Klinische Genetik, Dresden, Deutschland

The era of precision oncology brings with it an increasing amount of molecular data from tumor-sequencing in research and diagnostic settings, confronting physicians with the question of whether to initiate germline analysis for mutations initially identified in tumor tissue. While there are specific testing criteria for frequent cancer predisposition syndromes such as hereditary breast and ovarian cancer or hereditary colorectal cancer, there are no guidelines for the more than 300 mostly rare

cancer predispositions, neither for germline testing nor for clinical patient care.

Here we will present germline data from diverse sequencing projects, including germline whole genome and whole exome sequencing data from $>1000$ cancer patients generated within the framework of NCT DKTK MASTER (Molecularly Aided Stratification for Tumor Eradication Research), a nation-wide precision oncology research project. We will further present the European Reference

Network for Genetic Tumour Risk Syndromes (ERN GENTURIS), a consortium of 25 centers from 12 countries set in place to improve clinical care, establish guidelines for clinical patient management, prepare individual treatment recommendations in weekly tumorboards and foster international research projects.

Data are derived from several projects, including sequencing of familial cancer cohorts (e.g. hereditary breast and ovarian cancer, familial colorectal cancer, hereditary pheochromocytoma paraganglioma syndrome, familial pancreatic cancer) as well as data from MASTER.

\section{Nationales Netzwerk Genomische Medizin (nNGM)}

\section{DGP22.04}

\section{nNGM - Tak Force Forschung}

\section{W. Weichert*}

Institut für Allgemeine Pathologie und Pathologische Anatomie der Technischen Universität München, München, Germany

Das nationale Netzwerk Genomische Medizin (nNGM) hat sich zum Ziel gesetzt, aufbauend auf einer harmonisierten molekularen Diagnostik und Behandlung von Lungenkarzinomen eine gemeinsame Datenbank unter Vorhaltung molekular-klinischer Daten und in einem zweiten Schritt auch Prozesse für eine projektbezogene Zusammenstellung von Biomaterialien zu entwickeln. Auf der Basis dieser Ressourcen wird das Netzwerk gemeinsam Forschungsfragen adressieren, die neue Erkenntnisse zum Lungenkarzinom und hier insbesondere zu möglichen neuen Diagnostik- und Therapieansätzen generieren werden. Die entsprechenden Konzepte werden in einer eigenen Netzwerktaskforce entwickelt und umgesetzt, bereits angelaufene Projektprototypen und langfristige Konzepte werden in diesem Vortrag vorgestellt.

\section{Präzisionsonkologie - Aktuelle Entwicklungen in der Sarkompathologie I}

\section{DGP23.01}

\section{Knochentumoren}

\section{W. Hartmann*}

Gerhard-Domagk-Institut für Pathologie, Universitätsklinikum Münster, Sektion für Translationale Pathologie, Münster, Deutschland

Die Gruppe der primären Knochentumoren umfasst ein heterogenes Spektrum von Erkrankungen, welche mit zwei Altersgipfeln im Kindesbzw. Jugendalter und im Erwachsenenalter auftreten. Auch aufgrund der relativen Seltenheit von Knochentumoren stellen diese Läsionen häufiger eine diagnostische Herausforderung dar, die einen interdisziplinären Ansatz unter Beteiligung von Pathologen, Radiologen und Tumororthopäden erforderlich macht. Während die konventionelle Morphologie in Synopse mit der Radiologie Goldstandard in der Diagnostik von Tumorerkrankungen des Knochens bleibt, konnten jüngere molekulare Befunde inzwischen als diagnostische Marker verankert werden, welche bei schwierigen Differentialdiagnosen unterstützen können: Translokationen von USP6 in aneurysmatischen Knochenzysten, Amplifikationen von MDM2 in bestimmten Osteosarkomtypen, IDH1/2-Mutationen in Subgruppen chondrogener Tumoren und Punktmutationen in den H3F3-Genen in Chondroblastomen und Riesenzelltumoren des Knochens. Darüber hinaus wurden in den vergangenen Jahren unter den rundzelligen Ewing-ähnlichen Sarkomen neue Subgruppen mit BCOR- bzw. CIC-Rearrangements identifiziert, welche sich biologisch von klassischen Ewing Sarkomen unterscheiden. Neben der Beleuchtung des Stellenwerts dieser bereits etablierten molekularen Marker mit Blick auf die klinisch-pathologische Differentialdiagnostik und die unterschiedliche Biologie der Erkrankungen werden auch neuere molekulare Befunde in ossären Läsionen diskutiert, welche zum besseren Verständnis ihrer Pathogenese beitragen.

\section{DGP23.03 \\ Epithelioid, biphasic and mixed tumors of soft tissue}

M. Evert*

Universität Regensburg, Institut für Pathologie, Regensburg, Germany

Epitheloid soft tissue tumors consist exclusively of epitheloid tumor cells. Biphasic tumors are composed both of a spindle-cell as well as an epithelioid component. The rare mixed tumors of soft tissue show a broader variety of cellular and stromal differentiation but also include at least one, possibly several, epitheloid portions. The close morphological similarity of some of these entities among each other but particularly also to the more frequent soft tissue metastases of carcinomas, carcinosarcomas and melanomas, to malignant mesothelioma and to certain lymphomas, can make the correct diagnosis often extremely difficult. Recent advances in detection of certain molecular alterations (mostly chromosomal translocations) have contributed to changes in tumor classification but also to improved pathological diagnostics (e.g. through the development of potent diagnostic antibodies) and biological understanding. This overview should help the pathologist to diagnose these rare tumors in the classical approach of morphological pattern recognition. The most important entities are discussed and illustrated, whereby the latest immunohistochemical and molecular aspects are incorporated and the differential diagnosis of similar tumors is appreciated. 
DGP23.05

\section{Präzisionsonkologie - Aktuelle Entwicklungen in der} Sarkompathologie: Gastrointestinale Stromatumoren (GIST)

\author{
E. Wardelmann*, S. Elges, T. Schmitz, J. Sperveslage, M. Trautmann, \\ W. Hartmann, S. Huss \\ Gerhard-Domagk-Institut für Pathologie, Münster, Deutschland
}

Gastrointestinale Stromatumoren (GIST) stellen ein Paradigma für eine oft erfolgreiche molekular zielgerichtete Therapie dar. Eine Heilung fortgeschrittener GIST gelingt allerdings nach wie vor nur in wenigen Ausnahmefällen. Viele Patienten entwickeln mit zunehmender Therapiedauer Sekundärmutationen vor allem im KIT-Gen, was neue Therapiestrategien erfordert.

In GIST ohne KIT- oder PDGFRA-Mutation (10 bis $15 \%$ aller GIST) kristallisieren sich neue GIST-Subgruppen heraus: GIST mit Alterationen des RAS/RAF-Signalwegs oder solche mit einer Defizienz von einer von vier Succinatdehydrogenase (SDH)-Isoformen (SDHA, -B, -C oder -D). Erstgenannte können z. B. sporadische BRAF-Mutationen tragen und sind zumeist im Dünndarm lokalisiert. Ein Ansprechen auf BRAF-Inhibitoren ist in Einzelfällen beschrieben. Störungen im RAS/RAF-Signalweg treten auch bei der Neurofibromatose Typ 1 (NF1) auf. Neben den für NF1 typischen Tumoren treten im Laufe des Lebens multiple (bis > 100) GIST vor allem im Dünndarm auf. Eine SDH-Defizienz kann entweder hereditär oder sporadisch auftreten, wobei beide Varianten viele Parallelen aufweisen. Die Tumoren finden sich deutlich gehäuft bei jungen Frauen, sind bevorzugt gastral lokalisiert und wachsen multinodulär. Nicht selten treten im oft protrahierten Verlauf Lymphknotenmetastasen auf, was bei den anderen GIST-Subgruppen eine exzeptionelle Ausnahme darstellt. Zwei Konstellationen sind möglich: Bei der familiären Form (Carney-Stratakis-Syndrom) fällt eine der vier SDH-Isoformen (SDHA, -B, -C oder -D) durch eine Keimbahnmutation aus, und Succinat akkumuliert im Zytoplasma. Neben GIST treten auch Paragangliome auf. Bei der sporadischen Form (Carney-Triade) ist SDHC epigenetisch herunterreguliert, außer Paragangliomen werden auch pulmonale Chondrome beobachtet. Beide Varianten zeigen immunhistochemisch einen Ausfall von SDHB, was als Screening-Methode verwendet werden kann.

Den nicht KIT/PDGFRA-mutierten GIST ist gemein, dass sie nicht auf die klassische Imatinib-Therapie ansprechen. Diese Resistenz tritt in der Gruppe der KIT/PDGFRA-mutierten GIST sonst nur bei der Punktmutation p.D842V in Exon 18 des PDGFRA-Gens auf und ist Gegenstand einer intensiven Suche nach alternativen Therapieansätzen.

Zusammengefasst ist das Krankheitsbild GIST komplexer geworden. Wegen der unterschiedlichen Prognose und Therapieoptionen ist eine entsprechende molekulare Analyse bei GIST heute unverzichtbar.

\section{Präzisionsonkologie - Aktuelle Entwicklungen in der Sarkompathologie II}

\section{DGP24.01 \\ Präzisionsonkologie bei pädiatrischen und AYA-Sarkomen: die klinische Sicht}

U. Dirksen*

Universitätsklinikum Essen, West Deutsches Tumorzentrum, DKTK Standort Essen, Kinderklinik III, Essen, Deutschland

Präzisionsonkologie birgt das Versprechen durch besseres Verständnis neue Möglichkeiten der Tumorbehandlung zu etablieren. Wir erleben in jedem Fall gerade eine fundamentale Transformation der Tumordiagnostik. Für seltene Malignome, wie den Sarkomen, bieten solche Ansätze prinzipiell eine große Chance, da zielgerichtete Substanzen tumoragnostisch eingesetzt werden können. Unter der heterogenen Gruppe der Sarkome stellen die pädiatrischen Sarkome und die Sarkome von jugendlichen und jungen Erwachsenen eine besondere Herausforderung dar. Die typischen Sarkome der Altersgruppe sind hochbösartige Tumoren. Vor allem für die disseminierten Erkrankungen und im Fall eines Rezidivs gehen die Heilungsaussichten für die Patientinnen und Patienten gegen Null. Was erwarten die Klinikerinnen und Kliniker also von der Präzisionsonkologie? Sarkome sind, als seltene Erkrankungen, nach wie vor nicht gut erforscht

Wir benötigen für die bereits klassifizierbaren Sarkome valide prospektive oder prädiktive Biomarker.

Wir benötigen anerkannte Referenzpathologien, die zur Mitbeurteilung und für eine ergänzende Diagnostik konsultiert werden. Dieses ist für pädiatrische Sarkome umgesetzt, für AYA-Sarkome aber nicht.

Wir benötigen einen Triage-Katalog der Diagnostik, so kann ein gut behandelbares, eindeutig zu diagnostizierendes Sarkom nach einem schlanken Algorithmus diagnostiziert werden. Für Sarkome, bei mit einer à priori ungünstigen Prognose müssen andere Algorithmen greifen, um diese Tumoren besser charakterisieren zu können. Neben Genomik und Epigenetik werden Proteomik/Metabolomik etc. eine Tiefencharakterisierung der seltenen und schwer behandelbaren Sarkome ermöglichen. Ein Netzwerk aus Klinik, translationaler Forschung und Pathologie ist unabdingbar, um Fortschritte in der Behandlung der jungen Patienten zu erzielen. Enge interdisziplinäre Kommunikation - Standortübergreifendes Tumorboard - ist hier zwingend vonnöten, um die Fälle und Fragestellungen exakt zu charakterisieren.

Wir benötigen Biobanken und die Bereitschaft der Pathologien, deren Schwerpunkt nicht auf der Sarkomforschung liegt, übriges Material zur Verfügung zu stellen.

Sarkome entstehen nicht selten auf dem Boden von Tumorprädispositionssyndromen. Eine strukturierte Erfassung der häufigsten wäre einfach und sollte in die Routinediagnostik eingebaut werden. Für häufige Marker wie p53 oder DICER1 gilt, dass hier eine Diagnostik am Tumormaterial ausreichend ist.

\section{DGP24.03}

\section{Aberrant YAP1 signaling in myxoid liposarcoma}

M. Trautmann ${ }^{1 *}$, Y.-Y. Cheng ${ }^{2}$, P. Jensen ${ }^{2}$, N. Azoitei' ${ }^{3}$ I. Brunner ${ }^{2}$, J. Hüllein'2, M. Slabicki', I. Isfort ${ }^{1}$, M. Cyra', R. Berthold', E. Wardelmann ${ }^{4}$, S. Huss ${ }^{4}$, B. Altvater ${ }^{5}$, C. Rossig ${ }^{5}$, S. Hafner ${ }^{6}$, T. Simmet ${ }^{6}$, A. Ståhlberg ${ }^{7}$, P. Åman ${ }^{7}$, T. Zenz ${ }^{2}$, U. Lange ${ }^{8}$, T. Kindler', C. Scholl', W. Hartmann' ', S. Fröhling ${ }^{2}$

'Division of Translational Pathology, Gerhard-Domagk-Institute of Pathology, Münster University Hospital, Münster, Germany, ${ }^{2}$ Department of Translational Medical Oncology, National Center for Tumor Diseases (NCT) Heidelberg and German Cancer Research Center (DKFZ), Heidelberg, Germany, ${ }^{3}$ Department of Internal Medicine I, Ulm University Hospital, Ulm, Germany, ${ }^{4}$ Gerhard-Domagk-Institute of Pathology, Münster University Hospital, Münster, Germany, ${ }^{5}$ Department of Pediatric Hematology and Oncology, University Children's Hospital Münster, Münster, Germany, 'Institute of Pharmacology of Natural Products and Clinical Pharmacology, Ulm University Hospital, Ulm, Germany, ${ }^{7}$ Sahlgrenska Cancer Center, Department of Pathology and Genetics, Institute of Biomedicine, Sahlgrenska Academy at University of Gothenburg, Gothenburg, Sweden, ${ }^{8}$ Department of Hematology, Medical Oncology and Pneumology, University Medical Center of Mainz, Mainz, Germany, ${ }^{9}$ Division of Applied Functional Genomics, DKFZ, Heidelberg, Germany

Aim. Myxoid liposarcomas (MLS) are malignant tumors of adipocyte origin with a high rate of local recurrence and particular propensity to develop distant metastases in approximately $40 \%$ of patients. The majority of MLS tumors are characterized by a reciprocal $\mathrm{t}(12 ; 16)(\mathrm{q} 13 ; \mathrm{p} 11)$ translocation. The resulting chimeric FUS-DDIT3 fusion protein plays an oncogenic role as aberrant transcription factor in MLS pathogenesis; however, the specific molecular mechanisms whereby FUS-DDIT3 modulates oncogenic signaling pathways are incompletely understood, and strategies to selectively target MLS cells remain elusive.

Material and methods. In this study, we employed an unbiased functional genomic-scale screening approach to identify signaling pathways that are selectively essential in human mesenchymal stem cells engineered to express the FUS-DDIT3 fusion transcript. Based on this screen, we per- 
formed extensive functional analyses in MLS cell lines and correlated the findings with results of immunohistochemical analyses in a large set of human MLS tissue samples.

Results. Large-scale RNA interference (RNAi) screening identified dependence on YAP1, a transcriptional co-activator that is physiologically inhibited by the Hippo pathway responsible for the limitation of tissue growth and organ size, as specific liability of FUS-DDIT3-expressing mesenchymal stem cells. Immunohistochemical analyses of MLS tissue specimens $(n=223)$ demonstrated that nuclear YAP1 expression was significantly more prevalent in MLS compared to other liposarcoma subtypes. RNAi-based YAP1 depletion resulted in significant suppression of MLS cel viability, cell cycle arrest, cellular senescence and induction of apoptosis Mechanistically, FUS-DDIT3 promoted YAP1 expression, its nuclear localization as well as its transcriptional activity. Pharmacologic inhibition of YAP1 activity significantly impaired MLS cell viability/proliferation and YAP1 target gene expression. The anti-proliferative effects of YAP1 knockdown and verteporfin treatment could be recapitulated in MLS cell linebased xenograft models in vivo.

Conclusions. Our preclinical study identifies aberrant YAP1 activity as specific liability of FUS-DDIT3-driven MLS cells and substantially contributes to the understanding of MLS pathogenesis. We provide preclinical evidence that YAP1-mediated signal transduction represents a novel candidate target for therapeutic intervention in vitro and in vivo.

\section{DGP24.04}

\section{Effizientere Reduktion der Zellviabilität in Chordomzelllinien bei Kombination von Palbociclib mit Imatinib oder Erlotinib in vitro}

T. Luxenhofer*, P. Möller, T.F. E. Barth, K. Mellert

'Universität Ulm, Institut für Pathologie, Ulm, Deutschland

Ziel. Chordome sind seltene maligne Knochentumoren des Achsenskeletts, die gehäuft im Clivus und in der sakralen Wirbelsäule auftreten und Eigenschaften einer notochordalen Differenzierung aufweisen. Es ist bekannt, dass Chordome häufig eine Deletion des CDKN2A-Genlocus aufweisen. Dies führt zu einer Überexpression von CDK4 und CDK6 und folglich zu einer verstärkten Aktivierung dieses Signalweges. In in-vitroInhibitionsversuchen sowie im Xenograft-Modell konnte bereits nachgewiesen werden, dass mit dem CDK4/6-Inhibitor Palbociclib eine signifikante Reduktion der Zellzahl erzielt werden kann. Unser Ziel war es, in vitro zu untersuchen, ob die Therapieeffizienz von Palbociclib durch eine Kombinationstherapie mit den Tyrosinkinase-Inhibitoren Imatinib und Erlotinib gesteigert werden kann.

Methoden. Die drei von uns etablierten stabilen Chordomzelllinien U$\mathrm{CH}-17 \mathrm{P}, \mathrm{U}-\mathrm{CH}-17 \mathrm{M}$ und U-CH-17S wurden mittels FISH und Western

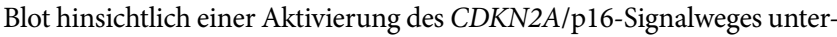
sucht. Für die Inhibitionsversuche wurden die Zelllinien in 96-well-plates ausgesät und nach $48 \mathrm{~h}$ mit aufsteigenden Konzentrationen der o.g. Inhibitoren über einen Zeitraum von $72 \mathrm{~h}$ inkubiert. Im Anschluss wurde im MTS-Assay die Zellviabilität bestimmt.

Ergebnisse. Mittels FISH und Western Blot konnte in den Chordomzelllinien U-CH-17P, U-CH-17M und U-CH-17S der Verlust von CDKN2A/ p16 bestätigt werden. Zudem wurde eine deutliche Expression von CDK4 und CDK6 sowie der Tyrosinkinasen PDGFR $\alpha$, PDGFR $\beta$ und EGFR-1 nachgewiesen. Im Rahmen der Inhibitionsversuche konnte eine konzentrationsabhängige Reduktion der Zellviabilität erreicht werden. Dabei konnten wir zeigen, dass eine Kombinationsbehandlung mit reduzierten Konzentrationen von Palbociclib und Imatinib bzw. Erlotinib zu einer signifikanten Reduktion der Zellviabilität gegenüber einer alleinigen Behandlung mit Palbociclib führt.

Fazit. Palbociclib, Imatinib und Erlotinib wirken im Rahmen einer in-vitro-Inhibition von Chordomzellen synergistisch. Eine Kombinationsbehandlung führt zu einer signifikant stärkeren Abnahme der Zellviabilität gegenüber einer ausschließlichen Behandlung mit Palbociclib. Diese Ergebnisse suggerieren, dass die Kombination von Palbociclib mit den beiden Tyrosinkinaseinhibitoren möglicherweise einen neuen gezielten Therapieansatz in der Behandlung von Chordomen darstellen könnte.

\section{DGP24.05}

Next-Generation Sequencing zur Differentialdiagnose von Myxomen und Myxofibrosarkomen

F. Zurek-Leffers ${ }^{1 *}$, J. Sperveslage ${ }^{1}$, E. Hekeler ${ }^{2}$, M. Trautmann ${ }^{3}$, W. Hartmann ${ }^{3}$, E. Wardelmann'

'Gerhard-Domagk-Institut für Pathologie, Uniklinik Münster, Münster, Deutschland, '2Institut für Pathologie, Klinikum Stuttgart, Katharinenhospital, Stuttgart, Deutschland, ${ }^{3}$ Gerhard-Domagk-Institut für Pathologie, Uniklinik Münster, Translationale Pathologie, Münster, Deutschland

Ziel. Myxoide Weichgewebstumoren bereiten insbesondere in bioptischem Material aber auch in Resektaten häufiger differentialdiagnostische Schwierigkeiten. Dies gilt insbesondere für die Unterscheidung von Myxomen und low grade Myxofibrosarkomen. Bislang sind keine immunhistochemischen Markerpanels etabliert, die eine sichere Unterscheidung erlauben. Molekularpathologisch findet sich in intramuskulären Myxomen in einem Teil der Fälle eine GNAS1-Mutation. Misslingt der Mutationsnachweis, fällt die Abgrenzung zum Myxofibrosarkom nicht selten schwer. Wegen der biologischen und therapeutischen Konsequenzen wurde in der vorgelegten Studie nach Unterscheidungskriterien beider Entitäten gesucht.

Methoden. Das Gesamtkollektiv wurde aus den seit 2001 im Archiv des Gerhard-Domagk-Instituts für Pathologie vorhandenen Fällen zusammengestellt und umfasste 15 low grade Myxofibrosarkome, 36 intramuskuläre und 2 juxtaartikuläre Myxome. Mittels NGS erfolgte die Analyse von 27 Genen mit einem Fokus auf potentiell therapierelevante Genorte sowie unter Inklusion von GNAS1. Klinische Daten wurden zur Korrelation erhoben.

Ergebnisse. Bei 31 der 38 verfügbaren Myxome war die DNA-Qualität für eine valide Auswertung ausreichend. In 27 Fällen (87\%) gelang der Nachweis einer GNAS1-Mutation, insbesondere durch Berücksichtigung von GNAS1-Mutationen mit Allelfrequenzen im niederfrequenten Bereich zwischen $1 \%$ und 4,5\%. Bezogen auf die intramuskulären Myxome allein erhöht sich die Mutationsfrequenz auf $93 \%$. Neben dem bekannten hot spot p.R201 kodiert von Exon 8 wurden in zwei Myxomen außerdem Punktmutationen in Exon 9 gefunden (p.Q227), die bislang nur beim McCune-Albright-Syndrom beschrieben sind. Bei keinem der untersuchten Myxofibrosarkome konnten derartige niederfrequente GNAS1-Mutationen nachgewiesen werden.

Fazit. Die Analyse von intramuskulären Myxomen mittels Tiefensequenzierung erlaubt durch die erhöhte Sensitivität der Methode und die zusätzliche Analyse von Exon 9 neben dem hot spot in Exon 8 in über $90 \%$ der Fälle die Detektion einer GNAS1-Mutation. Dies gilt insbesondere bei Berücksichtigung auch niederfrequenter Basenabweichungen. Derartige niederfrequente GNAS1-Mutationen wurden hingegen in den differentialdiagnostisch abzugrenzenden Myxofibrosarkomen in keinem von 9 untersuchten Fällen gefunden. Die GNAS1-Mutationsanalyse unter Inklusion von Exon 8 und 9 sollte daher zum diagnostischen Basisrepertoire vor allem bei zellulären Myxomen gehören.

\section{Transplantationspathologie IV - Infektionen bei Organtransplantationen}

\section{DGP25.03 \\ Seltene Virusinfektionen bei Organtransplantationen (Tollwutvirus, Borna-Virus, West-Nil-Virus)}

\section{Tappe}

Bernhard-Nocht-Institut, Hamburg, Deutschland

Neuartige oder ungewöhnliche zoonotische Virusinfektionen stellen Kliniker und labordiagnostisch tätige Ärzte oft vor Herausforderungen bei der Ermittlung der Ätiologie und Behandlung der Infektion. Dies trifft insbesonders auf ungewöhnliche Übertragungswege zu, wie etwa im Rah- 
men von Organtransplantationen. Zusätzlich können solche Infektionen aufgrund der Immunsuppression der Patienten ein klinisch verändertes Krankheitsbild verursachen, welches entweder schwächer oder stärker als bekannt oder erwartet ausfallen kann. Aufgrund eben jedener Immunsuppression können auch serologische Testergebnisse nur bedingt verwertet werden, sodass dem Erregerdirektnachweis aus Körperflüssigkeiten und dem transplantierten Organ durch bespielsweise PCR und NGS, aber auch mittels Immunhistochemie, eine besondere Bedeutung zukommt. Es werden beispielhaft drei zoonotische neurotrope Virusinfektionen dargestellt, die über unerkannt infizierte Organe in der Posttransplantphase zentralnervöse, lebensbedrohliche bzw. letale Erkrankungen in den immunsupprimierten Transplantatempfängern ausgelöst haben.

\section{DGP25.04}

\section{Pilzinfektionen bei der Organtransplantation}

\section{Theegarten*}

Universitätsklinikum Essen, Institut für Pathologie, Essen, Deutschland

Infektionen stellen bei der Organtransplantation neben der Abstoßung eine wesentliche Herausforderung dar. Hierbei können prinzipiell alle Infektionserreger vorkommen. Infolge der Immunsuppression ergibt sich jedoch ein besonderes Erregerspektrum mit Einschluß von opportunistischen Infektionen [1,2]. Relevant sind die epidemiologische Exposition des Empfängers und des Spenders einschließlich aktueller, nosokomialer und zukünftiger Erregerkontakte und der Status der Immunsuppression. Risikofaktoren für Pilzinfektionen sind Kolonisation, Neutropenie, Intensität der Immunsuppression, T-Zell-Depletion, virale Koinfektionen, Diabetes, Breitspektrum-Antibiose, renale und hepatische Dysfunktion, Leukopenie und kritische Erkrankung. Nach der Auswertung des USamerikanischen TRANSNET $(n=1208,3)$ dominieren insgesamt invasive Candidosen (53\%) vor Aspergillosen (19\%), danach folgen Kryptokokkosen (8\%), Infektionen durch andere Schimmelpilze (8\%), endemische Pilzinfektionen (5\%), Zygomykosen (2 \%) und Pneumocystis-Infektionen (1\%). Die Zeitachse und die Art des transplantierten Organs spielen eine wichtige Rolle. Hinsichtlich der Infektionsfrequenz berichten verschieden Studien von sehr unterschiedlichen Raten (1,57-19\%). Tendenziell ergibt sich eine leichte Zunahme von Pilzinfektionen, insbesondere der aggressiven Spezies (Zygomykosen, Scedosporium, Fusarium, Penicillum sp.). Die Überlebensrate (12 Monate) schwankt je nach Erreger zwischen $59 \%$ (Aspergillose) und $79 \%$ (Kryptokokkose). Pilzinfektionen erfordern eine adäquate mikrobiologische Diagnostik. Bei Kenntnis von Morphologie und Klinik kann auch der Pathologe anhand der Zytologie und Histologie relevante Aussagen treffen. Eine weitere Einordnung kann anhand von molekularbiologischen Untersuchungen erfolgen.

\section{Literatur}

1. Fishman JA (2017) Infection in Organ Transplantation. Am JTransplant 17(4):856879

2. Theegarten D, Anhenn O, Müller KD (2011) Infektionen bei der Organtransplantation. Pathologe 32(2):159-164

3. Pappas PG et al (2010) Invasive fungal infections among organ transplant recipients: results of the Transplant-Associated Infection Surveillance Network (TRANSNET). Clin Infect Dis 50(8):1101-1111

\section{Präzisionsonkologie - Pankreas- und biliäres Karzinom}

\section{DGP26.02}

MEK-Inhibition führt zu reduziertem Wachstum des cholangiozellulären Karzinoms durch Hemmung der Proliferation und Modulation des Tumormikromilieus

K. Utpatel ${ }^{1 *}$, P. Wang ${ }^{2,3}$, X. Song ${ }^{2,3}$, R. Shang ${ }^{2,4}$, M. X $u^{4}$, L. Che ${ }^{2}$, J. Gordon', X. Hu ${ }^{3}$, X. Chen ${ }^{2}$, M. Evert ${ }^{1}$, D. F. Calvisi'

'Universität Regensburg, Institut für Pathologie, Regensburg, Deutschland, 'University of California, Department of Bioengineering and Therapeutic Sciences and Liver Center, San Francisco, United States, ${ }^{3}$ Volksrepublik China Agricultural University, Beijing Advanced Innovation Center for Food Nutrition and Human Health, College of Food Science and Nutritional Engineering, Beijing, Volksrepublik China, ${ }^{4}$ Air Force Military Medical University, Department of Hepatobiliary Surgery, Xi'an, Volksrepublik China, ${ }^{5}$ University of California, Department of Medicine, San Francisco, United States

Ziel. Das cholangiozelluläre Karzinom (CCA) ist ein aggressiver Tumor mit eingeschränkten Therapiemöglichkeiten. PD901 ist ein MEK-Inhibitor, der eine therapeutische Wirksamkeit bei CCA mit onkogenen Mutationen im K-Ras-Gen zeigt. Die meisten CCAs weisen jedoch keine K-RasMutationen auf. Wichtig aber bisher unklar ist daher, ob MEK-Inhibitoren auch wirken, wenn Wildtyp-K-Ras-Allele vorliegen.

Methoden. In dieser Studie untersuchten wir das therapeutische Potenzial des MEK-Inhibitors PD901, allein oder in Kombination mit dem PanmTOR-Inhibitor MLN0128, für die Behandlung von K-Ras Wildtyp CCA in vitro und in vivo mit humanen CCA-Zelllinien bzw. im CCA-Mausmodell nach hydrodynamischer Geninjektion von AKT/YapS127A.

Ergebnisse. In vitro führte die Behandlung mit einem MEK-Inhibitor zur starken Reduktion der Zellproliferation, während die kombinierte MEK/ mTOR-Inhibition über eine zusätzliche Apoptoseinduktion das Wachstum der Tumorzellen supprimierte. Im Mausmodell bewirkte die alleinige PD901-Behandlung bereits eine Tumorregression, die durch die kombinierte Behandlung von PD901 mit MLN0128 nicht gesteigert werden konnte. Mechanistisch hemmte PD901 effizient die ERK-Aktivierung in vitro und in vivo, was zu einer starken Hemmung der Progression des Tumorzellzyklus führte. Interessanterweise konnten wir zeigen, dass die Behandlung mit PD901, aber nicht mit MLN0128, zu einer verstärkten Vaskularisierung und einer Reduktion von SMA positiven krebsassoziierten Fibroblasten im AKT/YapS127A murinen CCA-Modell führte.

Fazit. Zusammenfassend zeigt unsere Studie, dass die MEK-Inhibitoren für die Behandlung von K-Ras Wildtyp CCA durch Hemmung der Tumorzellproliferation und Modulation des Tumormikromilieus wirksam sein könnten.

\section{DGP26.03}

Whole exome sequencing of pancreatic and biliary intraductal tubulo-papillary neoplasms reveals a distinct genetic landscape

C. Groß ${ }^{* 1}$, T. Engleitner' ${ }^{2}$, J. Weber' ${ }^{2}$, M. Jesinghaus' ${ }^{1}$, B. Konukiewitz', A. Muckenhuber ${ }^{1}$, K. Steiger ${ }^{1}$, W. Weichert ${ }^{1}$, N. V. Adsay ${ }^{3}$, G. Klöppel', I. Esposito ${ }^{4}$, R. Rad ${ }^{2}$, A. M. Schlitter

'Institut für Allgemeine Pathologie und pathologische Anatomie, Technische Universität München, Munich, Germany, ${ }^{2}$ Institute of Molecular Oncology and Functional Genomics/Technical University Munich, TUM School of Medicine, Munich, Germany, ${ }^{3}$ Department of Pathology, Koc University School of Medicine, Istanbul, Turkey, ${ }^{4}$ Institute of Pathology/ University Hospital of Duesseldorf, Düsseldorf, Germany

Aim. Pancreato-biliary adenocarcinomas (PBAC) are highly aggressive neoplasms with poor prognosis. In contrast, intraductal tubulo-papillary neoplasms (ITPN), recently described rare PBAC precursor lesions, show a favorable prognosis despite the frequent occurrence of associated invasive $\mathrm{PBAC}$ at the time of diagnosis. ITPN molecular carcinogenesis as well as 
its relation to the cancer genes driving PBAC carcinogenesis are poorly understood. The aim of the present study was to analyze the mutational profile of ITPN using whole exome sequencing (WES) in order to identify driver genes and potential therapeutical targets.

Methods. In this study the genetic landscape of 17 ITPN of the pancreato-biliary system (11 biliary and 6 pancreatic cases) was examined. Tumor tissue and matching normal tissue were whole-exome sequenced to determine single nucleotide variants (SNV), Indels and copy-number variants (CNV).

Results. The identified somatic mutations predominantly involved few core signaling pathways despite high genetic heterogeneity with diverse mutational spectra: chromatin remodeling (e.g. ARID1A/1B/2), Wnt-pathway (e.g. recurrent $B C L 9$ mutations), MAPK signaling and TGF- $\beta$ signaling (e.g. FGFR2). No somatic SNV were found in classical cancer genes KRAS, CDKN2A and GNAS, TP53 and SMAD4 were affected in a minority of cases ( $6 \%$, respectively).

Identified chromosomal variations primarily affected four major pathways: chromatin remodeling, cell cycle, Wnt-signaling and mTOR-signaling. Recurrent chromosomal deletions were predominantly identified on chromosome 1p36, 3p14-22 (restricted to biliary ITPN), 6q21-22 and 14q2122 , whereas chromosomal gains were found on chromosome $1 \mathrm{q}, 8 \mathrm{p} / \mathrm{q}$, $15 \mathrm{q}$ and $20 \mathrm{q}$.

Conclusion. Our study reveals for the first time the genetic landscape of biliary ITPN and highlight that the genetic profile of ITPN of the pancreato-biliary system profoundly differs from PBAC molecular carcinogenesis. ITPN largely lack alterations of the PBAC driver genes. Instead the genetic changes of ITPN focus on key signaling pathways (in particular chromatin remodeling and Wnt-pathway), recurrent chromosomal aberrations as well as recurrent alterations of drugable targets (e.g. BCL9).

\section{DGP26.04 \\ Morphological and immunophenotypical subtypes of pancreatic ductal adenocarcinoma: Role of the CK81-positive „squamous" subtype}

\section{Häberle ${ }^{*}$, L. Ingenhoff', M. Schlensog ', S. A. Safi', I. Esposito'}

${ }^{1}$ Heinrich-Heine-Universität Düsseldorf und Universitätsklinikum Düsseldorf, Institut für Pathologie, Düsseldorf, Germany, ${ }^{2}$ Universitätsklinikum Düsseldorf, Klinik für Allgemein-, Viszeral- und Kinderchirurgie, Düsseldorf, Germany

Aim. Pancreatic ductal adenocarcinoma (PDAC) is increasingly recognized as heterogeneous entity. Prognostic relevant molecular subtypes have been proposed and can at least partly be recapitulated by immunohistochemistry (IH). CK81 positivity seems to correlate with the more aggressive "squamous" subtype, while HNFlalpha positivity is reported as a marker for the less aggressive non-"squamous" PDAC. However, a clear correlation between these subtypes and histomorphology is lacking. The aim of this study was a detailed histomorphological and immunohistochemical analysis of PDACs from a well-characterized patient cohort.

Methods. Tumor samples of patients resected for PDAC $(n=223)$ were analysed regarding histomorphology and immunoprofile. An in-depth histomorphological analysis of whole slides has been completed in 157 cases so far. Immunohistochemistry for HNF1alpha, CK81, p40 and p53 was performed on TMAs (tissue microarrays) of all cases.

Results. 124/157 cases (79\%) were classified as conventional PDACs, while 13/157 complex PDACs (8.2\%), 6/157 adenosquamous PDACs (3.8\%), 4/157 anaplastic PDACs (2.5\%), 3/157 colloid PDACs (2\%), 3/157 papillary PDACs (2\%), 2/157 large-duct-type PDACs (2.3\%) and 1/157 medullary and $1 / 157$ undifferentiated PDAC $(0.6 \%$ each) were also found. At $\mathrm{IH}, 78 / 214$ (36.4\%) tumors were CK81 positive, 38/214 (17.8\%) were HNF1alpha positive, 52/214 (24.3\%) were double negative and 46/214 (21.5\%) were double positive, according to previously published criteria. $\mathrm{P} 40-\mathrm{IH}$ was positive in all PDACs classified as adenosquamous by morphology, but also in conventional PDACs with squamous component $<30 \%(10 / 157$; $6.4 \%$ ) and in 10 cases without a distinct squamous component in morphology. P53-IH revealed an aberrant p53 expression in 130/221 cases
(59\%) in the whole cohort and in $24 / 33$ cases $(73 \%)$ in the p40-positive cohort, respectively. CK81-positivity was not correlated with p40-positivity nor with aberrant p53 expression or classical prognostic factors, such as grading. Of note, neither CK81 nor HNF1alpha status correlated with survival in this cohort.

Conclusion. Our preliminary results confirm that PDAC is a highly heterogeneous entity both morphologically and regarding its immunoprofile. So far, there appears to be no relationship between CK81-positive/"squamous" subtype and histomorphological features. Further analyses are needed to elucidate the link between morphology and immunohistochem$\mathrm{ical} /$ molecular subtypes.

\section{DGP26.05}

Bildgebende Massenspektrometrie zur Unterscheidung von Adenokarzinomen des Pankreas und der Gallenwege

\section{Bollwein ${ }^{1 *}$, A. Jacob 1 , J. Pereira Lopes Goncalves' ${ }^{1}$, R. Casadonte ${ }^{2}$} M. Kriegsmann ${ }^{3}$, W. Weichert ${ }^{1}$, K. Schwamborn ${ }^{1}$

${ }^{1}$ Technische Universität München, Institut für Allgemeine Pathologie und Pathologische Anatomie, München, Deutschland, ${ }^{2}$ Proteopath $\mathrm{GmbH}$, Trier, Deutschland, ${ }^{3}$ Universität Heidelberg, Institut für Allgemeine Pathologie, Heidelberg, Deutschland

Ziel. Das Pankreaskarzinom sowie das Cholangiokarzinom repräsentieren zwei aggressive Karzinomarten, die sich beide vom Epithel des pankreatobiliären Systems ableiten. Aufgrund ihrer starken histomorphologischen Ähnlichkeit stellen insbesondere pankreato-biliär differenzierte Raumforderungen in der Leber eine diagnostische Herausforderung bezüglich der Entitätseinordnung dar.

Im Rahmen dieser Arbeit untersuchten wir, ob eine korrekte Klassifikation von Adenokarzinomen des Pankreas und der Gallenwege anhand des massenspektrometrisch gewonnenen Peptidexpressionprofils vorgenommen werden kann.

Methoden. Sechs tissue microarrays (TMA) aus dem Formalin-fixierten und Paraffin-eingebetteten Material (FFPE) von insgesamt 107 Pankreaskarzinom- und 122 Cholangiokarzinomfällen (jeweils drei Tumorproben pro Patient) wurden mittels bildgebender Massenspektrometrie (MALDIIMS, matrix assisted laser desorption ionisation-imaging mass spectrometry) analysiert. Dabei erfolgte nach Entfernung des Paraffins und der Antigendemaskierung ein tryptischer Verdau des Gewebes mit anschließender Messung in einem Flugzeitmassenspektometer (rapifleX, Bruker Daltonik, Bremen, Deutschland) mit einer Ortsauflösung von $50 \mu \mathrm{m}$ in einem Massenbereich von $\mathrm{m} / z$ 600-3200. Die Datenanalyse wurde mit FlexImaging 5.1 und SCILS (Bruker) durchgeführt.

Ergebnisse. Das Studienkollektiv wurde zunächst in ein Trainingsset $(60 \%$ der Fälle) zur Generierung des Klassifikationsalgorithmus (lineare Diskriminanzanalyse), in ein Validierungsset (20\% der Fälle) zur Anpassung des Algorithmus und in ein Testset ( $20 \%$ der Fälle) zur eigentlichen Klassifikation unterteilt. 21 der 22 Pankreaskarzinomfälle sowie 23 der 27 Cholangiokarzinomfälle wurden im Testset jeweils korrekt als solche identifiziert. Es ergab sich damit eine korrekte Zuordnung für 95,45 \% der Pankreaskarzinomfälle und 85,19\% der Cholangiokarzinomfälle.

Fazit. Die bildgebende Massenspektrometrie stellt ein effizientes und verlässliches Verfahren zur Einordnung histomorphologisch ähnlicher Tumore dar und bietet in Zukunft eine vielversprechende Ergänzung oder Alternative zu bereits etablierten Methoden. 


\section{Aktuelle Habilitationen II}

\section{DGP27.01 \\ Von der präzisen Diagnostik zur Präzisionsmedizin - Die Rolle der Pathologie \\ V.-W. Sailer* \\ Institut für Pathologie des Universitätsklinikums Schleswig Holstein Campus Lübeck und des Leibniz Forschungszentrums Borstel, Borstel, Deutschland}

Ziel. Die exakte Diagnose von Tumoren und die integrative Analyse gewebsbasierter prognostischer und prädiktiver Biomarker mittels eines breiten Methodenspektrums sind der ureigenste Aufgabenbereich der Pathologie und bilden die Grundlage jeglichen onkologischen Handelns. Methoden. In der Diagnostik des Prostatakarzinoms am prätherapeutischen Stanzbiopsat können immunhistochemische Untersuchungen einen diagnostischen Nutzen bringen. Immunhistochemische Proteinexpressionsanalysen wurden durchgeführt, um neue diagnostische Marker von Basalzellen $(\Delta \mathrm{Np} 63, \mathrm{p} 40)$ und neoplastischen Prostataepithels (GSTpi) zu untersuchen

Prognostische Biomarker wurden am Beispiel des Plattenepithelkarzinoms der Kopf-Hals-Region (HNSCC) evaluiert. Mittels einer quantitativen, methylierungsspezifischen real-time Polymerase Chain Reaction (qMSP) wurde der DNA-Methylierungsstatus von Genen der Homeobox-Familie (PITX2, PITX3) untersucht und mit dem Gesamtüberleben korreliert.

Moderne Präzisionsmedizin ist für Sequenzierungsanalysen auf qualitativ hochwertiges Gewebe angewiesen. Für Prostatakarzinompatienten mit Knochenmetastasen wurde ein Biobank-Protokoll zur Gewebeasservierung von Knochenstanzbiopsaten für DNA-Sequenzierungsanalysen (Whole Exome Sequencing) entwickelt und prospektiv getestet. Zur besseren Charakterisierung von Gewebe vor Entwicklung von dreidimensionalen Zellkulturen (Organoiden) wurde ein zytologisches Protokoll entwickelt und prospektiv validiert.

Ergebnisse. Basalzellen der Prostata lassen sich zuverlässig mit dem Antikörper p40 darstellen, der auch dem etablierten p63-Antikörper hinsichtlich der Sensitivität überlegen ist. Die Markierung neoplastischen Prostataepithels mit einem Antikörper gegen GSTpi brachte keinen zusätzlichen diagnostischen Vorteil. Der DNA-Methylierungsstatus von PITX2 und PITX3 ist in der multivariaten Analyse ein unabhängiger prognostischer Parameter für das Gesamtüberleben von Patienten mit HNSCC nach kurativer Therapie. Sowohl das Biobank-Protokoll zur Gewebeasservierung von Stanzbiopsaten als auch das zytologische Protokoll für die gezielteren Anzucht von Organoiden konnten erfolgreich in der Präzisionsmedizin etabliert werden.

Diskussion. Die Pathologie hat als wichtigste Partnerin der Onkologie eine außergewöhnliche Evolution von einem rein diagnostisch orientierten Fach hin zur therapieleitenden molekularpathologischen Expertise durchlebt. Diese Evolution lässt sich beispielhaft an der vorliegenden Habilitationsschrift nachvollziehen.

\section{DGP27.02}

\section{The Amyloid Precursor Protein (APP) regulates iron and redox} homeostasis in neurons and cancer

\section{Venkataramani*}

Universitätsmedizin Göttingen, Institut für Pathologie und Klinik für Hämatologie und medizinische Onkologie, Göttingen, Germany

Aim. The amyloid precursor protein (APP) plays a pathophysiological key role in Alzheimer disease (AD) due to its neurotoxic proteolytic amyloid- $\beta$ $(A \beta)$ fragments. However, full-length APP as well as its large N-terminal soluble sAPP $\alpha$ processing product exert neuroprotective features that are intricately involved in iron metabolism. Yet, the functional attributes of APP in neurons and outside the nervous system as well as downstream pathways remain unclear.
Methods. Metallotoxicity was studied using Manganese $\left(\mathrm{Mn}^{2+}\right)$ in SHSY5Y neuronal-like cells and in two rodent models mimicking acute and chronic $\mathrm{Mn}^{2+}$ exposure. MTS, CFU and CAM-Assay was used to determine proliferation, clonal survival and ex vivo tumorigenicity. A new $\mathrm{CE}-$ ICP-MS based method was used to quantify the redox-pair $\mathrm{Fe}^{2+} / \mathrm{Fe}^{3+}$ in cell and tissue lysates. Data were confirmed using two new and specific $\mathrm{Fe}^{2+}$-specific probes (RhoNox-1 and IP-1). Cellular and Lipid-ROS (reactive oxygen species) were analyzed using DCF and BODIPY ${ }^{581 / 591}-\mathrm{C} 11$ dyes.

Results. Here, we show that APP functions as iron and redox homeostatic protein that promotes the export of redox-active $\mathrm{Fe}^{2+}$ and thus shields neurons against metallotoxicicity in vitro and in vivo. We further demonstrate that APP is overexpressed in several cancers and promotes tumorigenesis by regulating iron homeostasis. On the molecular level, we discovered a previously unrecognized mechanisms by which APP suppresses pro-oxidative iron $\left(\mathrm{Fe}^{2+}\right)$ accumulation that results in deleterious oxidative stress-induced DNA damage in cancer cells, with $\mathrm{p} 38^{\mathrm{MAPK}}$ stress signaling as a crucial mediator of this process. Consonant with these findings, in human data set analyses of prostate cancers, high levels of APP are significantly associated with a poor event-free survival rate and negatively correlated with tumor suppressive $\mathrm{p} 38^{\mathrm{MAPK}}$ activation. As proof of concept, pharmacological disruption of APP increased levels of redox-active $\mathrm{Fe}^{2+}$ and $\mathrm{p} 38^{\mathrm{MAPK}}$-dependent DNA damage and significantly reduced tumor cell clonogenicity in vitro and tumor growth in a xenograft model.

Conclusion. Taken together, our results demonstrates that APP plays an important role in the neuronal iron homeostasis and can attenuate metal-induced neurotoxicity. We further uncover that APP depletion represents a potential novel approach to disrupt iron homeostasis, releasing unchecked pro-oxidative $\mathrm{Fe}^{2+}$ that hinders survival and propagation of oncogenic transformed cells and cancer cells.

\section{DGP27.03}

\section{Makrophagen als Effektorzellen bei mykobakteriellen Infektionen} und fibrotischen Lungenerkrankungen

M. Kühnel*

Medizinische Hochschule Hannover, Institut für Pathologie, Hannover, Deutschland

Makrophagen sind an der Pathogenese von Erkrankungen beteiligt, welche zu den häufigsten Todesursachen weltweit gehören, der Tuberkulose und der fibrotischen Lungenerkrankungen, obwohl sie eigentlich als spezialisierte Zellen des Immunsystems auf die Abwehr von Bakterien und die Regeneration von Wunden spezialisiert sind. In meinen Arbeiten konnte ich zeigen, dass die gestörte Reifung des Phagosoms, welches die Ursache für das Versagen des Makrophagen bei der Beseitigung der Erreger darstellt, in einer gestörten Bildung von Aktinfilamenten begründet ist. Diese Aktinfilamente sind essentiell für die zielgerichtete Wanderung von Lysosomen zum Phagosom, deren Fusion und in der Folge Ansäuerung und bakterieller Verdau. Durch Manipulation der Lipide in der Phagosomenmembran war es möglich, die Bildung von phagosomalem Aktin wieder zu aktivieren und somit auch Pathogene, wie M. tuberculosis, zu töten. Die Funktionsweise dieser Lipide wurde von mir dabei eingehend qualitativ und quantitativ untersucht. Es gelang 1) die Prozesse, die dabei in der phagosomalen Membran ablaufen in einem in silico Modell abzubilden und 2) die Wirkungsweise von Sphingosin-1-Phosphat und seinem „Downstream“ Effektor, dem purinergen Rezeptor P2X7, in der Regulation von Aktin aufzuklären.

In der Folge erweiterte ich mein Betätigungsfeld, durch die Möglichkeiten an der Medizinischen Hochschule von Hannover, auf das Studium der Makrophagen in ihrem natürlichen Umfeld, der Lunge. Hier konnte ich zunächst erfolgreich die neu entwickelte Mikroskopiemethode zur Darstellung von Maus- und Rattenlungen im Bleomycinmodell der Lungenfibrose etablieren und auch auf die Darstellung von humanen Lungenbiopsien anzuwenden. Außerdem gelang es, CRISTAL, einen Kunstharz, zu entwickeln und zu patentieren, welcher die korrelative Analyse von 3DMorphologie mit der Molekularbiologie erlaubt. In der Folge studierten 
wir als Anwendungsbeispiel die AFE, welche nach LuTx, HSCT, RC oder als iPPFE vorkommt und mit einer schlechten Prognose für Patienten einhergeht. Dabei konnten die Genexpressionsprofile im krankhaft umgebauten Lungengewebe charakterisiert und erstmalig ein Evolutionsmodell der Erkrankung herausgearbeitet werden. Hierdurch konnte ein atypischer Abbau von Fibrin durch Makrophagen als Ursache des fibrotischen Umbaus des Lungenparenchyms identifiziert werden. Dieser dient nun als Basis für weitere aktuelle Studien.

\section{DGP27.05 \\ Bildgebende Massenspektrometrie - Neue Methode in der Pathologie?}

\section{K. Schwamborn*}

Institut für Allgemeine Pathologie und Pathologische Anatomie der Technischen Universität München, München, Deutschland

Ziel. Die bildgebende Massenspektrometrie stellt eine Analysemethode dar, die es ermöglicht, eine Vielzahl an Analyten (z. B. Proteine und Peptide) gleichzeitig und ortsaufgelöst zu untersuchen. Denn im Gegensatz $\mathrm{zu}$ klassischen proteomischen Methoden wird das Gewebe nicht in Lösung gebracht, sondern bleibt intakt. Somit können Verteilungs- und Expressionsmuster von Analyten mit der Histologie direkt korreliert werden. Durch die Kombination mit statistischen Algorithmen gelingt es, objektive Klassifizierungen verschiedener Gewebetypen oder Krankheitszustände zu erhalten.

Methoden. Formalin fixierte, Paraffin eingebettete (FFPE) Gewebe, Mikroarrays, zytologisches Material und Gefriergewebeproben von verschiedenen Organen/Krankheitszuständen (u. a. Prostata, Lymphome, Pankreaskarzinome, Gallengangskarzinome und Ergusspunktate) wurden mittels bildgebender Massenspektrometrie analysiert. Hierfür wurden die Schnitte auf elektrisch leitfähige, mit Poly-L-Lysin beschichtete Objektträger aufgezogen und mit Matrix beschichtet. Im Falle der FFPE-Proben waren der Matrixapplikation zusätzlich folgende Schritte vorgeschaltet: Entparaffinierung, Antigendemaskierung enzymatischer Verdau mittels Trypsin. Im Anschluss erfolgten die Analyse im Massenspektrometer, statistische Analysen sowie die Identifizierung relevanter Peptide/Proteine.

Ergebnisse. Mittels bildgebender Massenspektrometrie gelingt die Analyse einer Vielzahl unterschiedlicher Proben, inklusive FFPE Gewebe und zytologischem Material. Es lassen sich reproduzierbar und zuverlässig Protein-/Peptidmuster erzeugen, die durch die Anwendung statistischer Analyseverfahren eine objektive Klassifizierung verschiedener Gewebetypen oder Erkrankungen erlauben. Zudem konnten Proteine identifiziert werden, deren Bedeutung für die Klassifizierung auch durch externe Validierung mittels Immunhistologie belegt werden konnte.

Fazit. Die bildgebende Massenspektrometrie stellt eine vielsprechende Methode dar, die in Zukunft auch in der Routinediagnostik Anwendung finden könnte.

\section{Präzisionsonkologie - Leber}

\section{DGP28.02 \\ Hepatocellular polarity-a key regulator of liver cancer development}

M. Tóth*, S. Wan, S. Weiler, J. Schmitt, P. Schirmacher, K. Breuhahn Universitätsklinikum Heidelberg, Abt. Allgemeine Pathologie und path. Anatomie, Heidelberg, Germany

Aim. Hepatocytes are highly polarized cells with distinct apical, lateral, and basal domains, which are separated by junctional structures (e.g. tight and adherens junctions). This multipolar organization allows the directional transport of molecules, the formation of spatial structures including bile canaliculi and subendothelial sinusoidal spaces. Disturbance of this unique hepatic polarity is detectable in many liver diseases and first genetic data illustrate that the loss of junctional proteins such as E-cadherin is causative for the development of hepatocellular carcinoma (HCC).

Methods. To dissect relevant cell polarity structures in hepatocarcinogenesis, we used different approaches including the analysis of transcriptomic data derived from HCC patients and siRNA screens performed with HCC cell lines.

Results. These approaches identified factors involved in the formation of baso-lateral polarity (e.g. Scribble) and apical polarity (e.g. MPP5/PALS1), which contribute to liver cancer development via different molecular mechanisms. While Scribble overexpression in hepatocytes promotes tumor development and proliferation in a PI3K/AKT-dependent manner, MPP5/PALS1 binds the Hippo pathway effector yes-associated protein (YAP) and affects its subcellular localization. Findings of these in vitro and in vivo studies were confirmed in different cohorts of HCC patients. Conclusion. These data illustrate that the disturbance of hepatocellular polarity in earliest phases of hepatocarcinogenesis can affect tumor initiation and progression via distinct and independent mechanisms.

\section{DGP28.03}

Kerninklusionen in hepatozellulären Karzinomen enthalten Autophagie-assoziierte Proteine und korrelieren mit verlängerter Überlebenszeit

S. Schwertheim ${ }^{1 *}$, D. Westerwick', H. Jastrow'2, S. Theurer', C. M. Schaefer', J. Kälsch ${ }^{1,3}$, D. Möllmann ${ }^{1}$, M. Schlattjan ${ }^{1}$, H. Wedemeyer ${ }^{3}$, K. W. Schmid', H.A. Baba'

'Institut für Pathologie/Universitätsklinikum Essen, Essen, Deutschland, ${ }^{2}$ Institut für Anatomie/Universitätsklinikum Essen, Essen, Deutschland, ${ }^{3}$ Institut für Gastroenterologie und Hepatologie/Universitätsklinikum Essen, Essen, Deutschland

Ziel. Kerninklusionen wurden schon in vielen normalen und neoplastischen Geweben nachgewiesen. Über den Ursprung oder die Funktion dieser nukleären Veränderungen ist wenig bekannt. Es wird angenommen, dass sie durch Invaginationen des Zytoplasmas in den Zellkern entstehen und dass deren Auftreten ein eher unspezifisches morphologisches Merkmal ist. Ziel war es, Kerninklusionen in hepatozellulären Karzinomen (HCC) hinsichtlich Herkunft, Inhalt und mögliche Funktionen zu charakterisieren.

Methoden. Es wurden die Kerninklusionen in 75 in Paraffin eingebetteten HCC Patientenproben untersucht. Dabei wurden Inklusionen nur als positiv gewertet, wenn diese durch eine mit Lamin AC (Kernmembranmarker) gefärbte, intakte Membran begrenzt und vollständig geschlossen waren. Wir führten Untersuchungen mittels Transmissionselektronenmikroskopie (TEM), Immunhistochemie und Immunfluoreszenz (IF) durch, um den Inhalt der Inklusionen zu analysieren. Eine 3D-Rekonstruktion isolierter Kerne diente zur genaueren Charakterisierung der Form der Kerninklusionen.

Ergebnisse. Auf einer standardisierten Fläche waren durchschnittlich 124 Inklusionen/Probe im Lebertumorgewebe und 5 Inklusionen/Probe im angrenzenden nicht-tumorösen Abschnitt zu finden; dabei hatten $89 \%$ der HCCs mindestens eine membranbegrenzte Kerninklusion. TEM zeigte degenerative Materialien wie Rückstände von Lysosomen, RER und Golgi-Apparaten innerhalb der Einschlüsse. 3D-Rekonstruktion isolierter, IF gefärbter Kerne zeigte, dass sich diese Inklusionen durch die Kernmembran begrenzt (Lamin B positiv) und vollständig geschlossen im Zellkern befanden ohne eine Verbindung zum Zytoplasma. Die Inklusionen waren in $19-58 \%$ der Proben positiv für die Autophagie-assoziierten Proteine LC3B, Ubiquitin, Cathepsin D, p62 und Cathepsin B. IF-Dreifachmarkierung und 3D-Rekonstruktionen zeigten hier eine Kolokalisation von p62, Ubiquitin und LC3B. Kerninklusionen waren positiv mit dem Patientenüberleben assoziiert ( $\mathrm{P}=0,020$; Log-Rank-Test).

Fazit. Diese Studie zeigt Kerninklusionen beim HCC, die vollständig von einer Kernmembran umgeben sind und keinen Kontakt zum Zytoplasma aufweisen. Wir vermuten, dass diese sich unter anderem durch den Verschluss/Abschluss zytoplasmatischer Invaginationen entwickeln. Das Vorhandensein Autophagie-assoziierter Proteine zusammen mit degenerier- 
ten Organellen und lysosomalen Proteasen in den Kerninklusionen zeigt eine mögliche Rolle im Rahmen der Autophagie und Proteolyse.

\section{DGP28.04}

\section{Lipid droplet-associated proteins in alcoholic and non-alcoholic steatohepatitis in patients with polymorphisms in PNPLA3}

H. R. Witzel' ${ }^{1 *}$, I. Schwittai', L.M. Pawella', V. Rausch ${ }^{3}$, S. Mueller ${ }^{3}$, J. Schattenberg ${ }^{4}$, P. Schirmacher', W. Roth', B. K. Straub'

'Institut für Pathologie Universitätsmedizin Mainz, Mainz, Germany, ${ }^{2}$ Institut für Pathologie Universitätsklinikum Heidelberg, Heidelberg, Germany, ${ }^{3}$ Krankenhaus Salem, Innere Medizin, Heidelberg, Germany, ${ }^{4}$ Universitätsmedizin Mainz, Innere Medizin, Mainz, Germany

Aim. Lipid droplets (LDs) are crucial organelles that play a central role in lipid homeostasis.

A particular lipase associated with LDs is the patatin-like phospholipase domain containing protein 3 (PNPLA3). The I148M single nucleotide polymorphism of PNPLA3 has been shown to be associated with all facets of non-alcoholic fatty liver disease (NAFLD) and the development of hepatocellular carcinoma.

Aim of the study is to investigate the underlying molecular mechanism driving the progression of the disease.

Methods. To unravel the interplay between PNPLA3 and the LD-associated proteins of the perilipin-family in regulating LDs, (immuno)-histochemical analysis of a collective of $47 \mathrm{ASH}$ - and $25 \mathrm{NASH}$-patients with known $P N$ $P L A 3$-status was undertaken. In addition, co-immunoprecipitation experiments were performed to identify novel PNPLA3 binding partners. Finally, the impact of the polymorphism on the lipolytic activity was determined. Results. Histologically, livers of I148M carriers showed enhanced ballooning, acinar inflammation, microgranulomas and increased fibrosis with a prominent staining for perilipin 2 at ballooned hepatocytes. Perilipin $5 \mathrm{lo}-$ calized less to LDs, but showed a more cytoplasmic and partially nuclear localization instead. Interestingly, hepatocytes that were strongly positive for PNPLA3 showed diminished perilipin 1-expression.

Furthermore, we identified perilipin 5 and the lipase PNPLA2 as novel interaction partners of PNPLA3 that co-localized at LDs. In addition, we could show that perilipin 5, PNPLA3, and PNPLA2 are part of the same complex and that perilipin 5 is enhancing the binding of PNPLA3 with PNPLA2 dramatically. Strikingly, we could show dimerization of PNPLA2, a process inhibited by PNPLA3. Addressing the lipolytic activity of PNPLA2 revealed an inhibitory effect of PNPLA3, which is strongest for PNPLA3(I148M).

Conclusion. In summary, our data indicate that PNPLA3 regulates lipolysis by repressing the lipolytic activity of PNPLA2 in a perilipin 5-dependent manner most likely via disrupting active PNPLA2 homo-dimers/oligomers. The enzymatically inactive PNPLA3(I148M) even further reduces PNPLA2-mediated lipolysis and increases toxic accumulation of lipids. We have thereby unraveled a mechanism of PNPLA3 in the progression of steatotic liver diseases. Concerning the long-standing debate on why and when bland steatosis progresses to steatohepatitis, our data point to a critical step in lipolysis rather than in lipogenesis itself.

\section{DGP28.05}

Nukleoporin Nup155 ist Bestandteil des p53-Netzwerks im hepatozellulären Karzinom (HCC)

K. Holzer ${ }^{1 * 2,2}$, A. Ori ${ }^{3}$, A. Cooke ${ }^{4}$, D. Dauch ${ }^{5,6}$, E. Drucker ${ }^{2}$, P. Riemenschneider', A. Andres-Pons ${ }^{7}$, A. L. DiGuilio, , , M.-T. Mackmull, J. Baßler ${ }^{10}$, S. Roessler ${ }^{2}$, K. Breuhahn' ${ }^{2}$, L. Zender', J. S. Glavy ${ }^{8,11}$, E. Hurt ${ }^{10}$, F. Dombrowski', P. Schirmacher ${ }^{2}$, M. Beck ${ }^{7,12}$, S. Singer ${ }^{1,2,7}$

'Universitätsmedizin Greifswald, Pathologisches Institut, Greifswald, Deutschland, ${ }^{2}$ Universitätsklinikum Heidelberg, Pathologisches Institut, Heidelberg, Deutschland, ${ }^{3}$ Leibniz Institute on Aging - Fritz Lipmann Institut (FLI), Jena, Deutschland, 'European Molecular Biology Laboratory, Directors' Research Unit, Heidelberg, Deutschland, ${ }^{5}$ Universitätsklinikum Tübingen, Innere Medizin III, Tübingen, Deutschland, ${ }^{6}$ Deutsches Konsortium für Translationale Krebsforschung, Partnerstandort Heidelberg, Heidelberg, Deutschland, ${ }^{7}$ European Molecular Biology Laboratory, Structural and Computational Biology Unit, Heidelberg, Deutschland, ${ }^{8}$ Stevens Institute of Technology, Hoboken, United States, ${ }^{9}$ The University of Chicago, Chicago, United States, ${ }^{10}$ Universität Heidelberg, BZH, Heidelberg, Deutschland, ${ }^{11}$ Ben and Maytee Fisch College of Pharmacy, Tyler, United States, ${ }^{12 M a x-P l a n c k-~}$ Institut für Biophysik, Frankfurt am Main, Deutschland

Ziel. Der Kernporenkomplex (NPC) besteht aus multiplen Kopien von $\sim 30$ verschiedenen Nukleoporinen (Nups). Der NPC stellt die wesentliche Transportverbindung zwischen Zellkern und Zytoplasma dar. Daten der letzten Jahre deuten daraufhin, dass vor allem periphere Nups über Transport-abhängige und - unabhängige Mechanismen krebs-relevante Signalwege (bspw. den p53-Signalweg über die p53-Zielgeninduktion) in der (Hepato-)Karzinogenese modulieren können. Die diesbezügliche Funktion von zentral im NPC lokalisierten Nups, wie Nup155, wurde bislang kaum erforscht und ist Gegenstand der vorliegenden Studie.

Methoden. Nach siRNA vermitteltem knockdown von Nup155 in Nutlin3a behandelten HepG2-Zellen wurden 3500 Proteine (darunter 48 p53 targets) mit Massenspektrometrie (LC/MS-MS) quantifiziert, um Nup155abhängige Veränderungen der p53 Zielgen/-protein-Induktion zu erfassen. Sich daran anschließende mechanistische Analysen umfassten u.a. Polyribosomenfraktionierungen, (Co-)Transfektionsexperimente (cDNA und siRNA) und einen fokusierten RNA $i$ Screen. Ferner wurden die in vitro erhobenen Ergebnisse mit Daten von murinen und humanen HCC Proben korreliert.

Ergebnisse. Nach Nup155 knockdown wurde eine selektiv verringerte Induktion des Zellzyklusregulators p21 nach Nutlin-3a-vermittelter p53 Aktivierung beobachtet. Über Polyribosomenanalysen konnte ein Translationsdefekt der p21 mRNA nach Nup155 knockdown als Ursache der verringerten p21 Induktion ermittelt werden. Als wichtiger Faktor wurde hierbei über einen fokusierten RNA $i$ Screen die t-RNA Methyltransferase FTSJ1 identifiziert. Darüber hinaus konnte auch eine p53-vermittelte Repression von Nup155 und FTSJ1 auf transkriptioneller Ebene festgestellt werden. In Übereinstimmung mit diesen Ergebnissen fand sich eine Korrelation zwischen dem p53-Status und der Expression von Nup155 und FTSJ1 in murinen und humanen HCC.

Fazit. Unsere Daten weisen auf einen komplexen Regelkreis zwischen der zentral lokalisierten NPC Komponente Nup155 und dem p53 Signalweg im HCC hin. 


\section{Junges Forum III - Rising Stars und NWA-Alumni-Treff}

\section{DGP29.01 \\ Deep learning-augmented methylation profiling distinguishes primary lung squamous cell carcinomas from head and neck metastases}

P. Jurmeister ${ }^{1 * 2,2,3}$, M. Bockmayr ${ }^{1,4,5}$, P. Seegerer ${ }^{6}$, T. Bockmayr ${ }^{1}$, D. Treue ${ }^{1}$,

G. Montavon ${ }^{6}$, C. Vollbrecht ${ }^{7}$, A. Arnold' , D. Teichmann ${ }^{7}$, K. Bressem $^{8}$, U. Schüller ${ }^{4,5,9}$, K.-R. Müller ${ }^{6,10,11}$, D. Capper ${ }^{3,7}$, F. Klauschen ${ }^{1,3}$

${ }^{1}$ Charité-Universitätsmedizin Berlin, Institut für Pathologie, Berlin, Germany, ${ }^{2}$ Charité Comprehensive Cancer Center, Berlin, Germany, ${ }^{3}$ German Cancer Consortium (DKTK), Partner Site Berlin, German Cancer Research Center (DKFZ), Berlin, Germany, ${ }^{4}$ University Medical Center Hamburg-Eppendorf, Department of Pediatric Hematology and Oncology, Hamburg, Germany, ${ }^{5}$ Research Institute Children's Cancer Center Hamburg, Hamburg, Germany, ${ }^{6}$ Technical University of Berlin, Machine-Learning Group, Department of Software Engineering and Theoretical Computer Science, Berlin, Germany, ${ }^{7}$ Charité-Universitätsmedizin Berlin, Department of Neuropathology, Berlin, Germany, ${ }^{8}$ Charité-Universitätsmedizin Berlin, Department of Radiology, Berlin, Germany, ${ }^{9}$ University Medical Center Hamburg-Eppendorf, Institute of Neuropathology, Hamburg, Germany, ${ }^{10} \mathrm{Korea}$ University, Department of Brain and Cognitive Engineering, Seoul, Republic of Korea, "Max-PlanckInstitute for Informatics, Saarbrücken, Germany

Head and neck cancer (HNSC) patients are at risk of suffering from both pulmonary metastases or a second squamous cell carcinoma of the lung (LUSC). Differentiating pulmonary metastases from primary lung cancers is of high clinical importance, but not possible in most cases with current diagnostics. To address this, we used DNA methylation profiling of primary lung and head and neck tumors in combination with three differen machine learning methods. A deep neural network was able to correctly classify $96.4 \%$ of cases of a validation cohort, outperforming support vector machines (95.7\%) and random forests (87.8\%). By introducing a rejection option based on the confidence of the classifier, the accuracy was increased to over $99 \%$. These results were confirmed in a clinical cohort of 44 patients with a history of HNSC and a second lung tumor. In summary, our approach facilitates the reliable diagnostic differentiation of pulmonary metastases of HNSC from LUSC to guide therapeutic decisions.

\section{DGP29.02}

\section{CD15 expression in clear cell renal cell carcinoma: prognostic value and potential predictive biomarker of propranolol therapy}

\section{P. Stenzel ${ }^{1 *}$, S. Schecher ${ }^{1}$, K. Tagscherer', M. Schindeldecker ${ }^{2}$, E. Herpel', W. Roth', S. Macher-Göppinger \\ 'Universitätsmedizin Mainz, Institut für Pathologie, Mainz, Germany, ${ }^{2}$ Universitätsmedizin Mainz, Biobank des Instituts für Pathologie, Mainz, Germany, ${ }^{3}$ Heidelberg University Hospital, Institut für Pathologie, Heidelberg, Germany}

Introduction. Propranolol, a non-selective beta-adrenergic receptor blocker, induces an involution of pediatric tumors, e.g. infantile hemangioma, and of von-Hippel-Lindau disease associated tumors, e. g. retinal hemangioblastoma. These propranolol-sensitive tumors share a CD15+ phenotype. CD15 is a carbohydrate structure on the cell surface, which has been shown to be of prognostic value in various tumor entities.

Methods. Propranolol effects on renal cell carcinoma (RCC) were investigated on RCC cell lines in vitro and on clear cell RCC (ccRCC) tissue ex vivo. CD15 expression and intracellular pathways involved in Propranolol-mediated effects were examined. Furthermore, CD15 expression was examined in a large hospital-based series of ccRCC with long-term follow-up information, using tissue micro array technique and digital image analysis. Relationship between CD15 expression and patient/tumor characteristics was examined.

Results. Propranolol treatment led to reduced tumor growth and increased apoptosis. These effects were markedly stronger in the CD15-positive sub- set of RCC cell lines. CD15 expression in ccRCC tissue was significantly associated with cancer-specific survival and correlated with clinicopathologic parameters.

Discussion. Our data reveal that propranolol treatment exhibits anti-tumor effects in ccRCC. CD15 expression significantly correlates with cancer-specific survival. Therefore CD15 expression may be used as a prognostic marker in clear-RCC patients and is a potential new predictive marker for propranolol therapy.

\section{DGP29.03}

\section{Dissecting immunogenetic evolution of bladder cancer: the role of defective DNA repair}

J. Leichsenring ${ }^{1 *}$, M. Jenzer ${ }^{2}$, A.-L. Volckmar', M. Kirchner', O. Neumann', V. Endris', M. Hohenfellner ${ }^{3}$, P. Schirmacher', S. Duensing ${ }^{3}$, A. Stenzinger' 'Pathologisches Institut, Universitätsklinikum Heidelberg, Heidelberg, Germany, ${ }^{2}$ National Center for Tumor Diseases (NCT), Heidelberg, Germany, ${ }^{3}$ Universitätsklinikum Heidelberg, Urologie, Heidelberg, Germany

Aim. The majority of patients with urothelial cancer will inevitably progress from locally controlled MIBC to advanced disease and metastatic spread. We aim to obtain a comprehensive molecular profile of real-life bladder cancer cases during the various steps of tumor evolution under different therapies and to link these data to clinical response and outcome data. Methods. Each major step in tumor evolution is mirrored by a carefully assembled cohort of tissue materials, i.e. at baseline (prior to 1st therapy) and under disease progression (prior to and after 2nd therapy), which provides unique temporal snap shots of the evolving tumor during its clinical course of disease. Alongside homologous repair deficiency and TMB measurements, we will analyze the tumor microenvironment prior to and following each line of therapy based on RNA expression levels. These data will yield an evolutionary landscape at the individual case level.

Results. An initial patient cohort with several lines of therapy at the NCT in Heidelberg has been assembled and analyses are ongoing. Progress regarding tissue acquisition and establishment of molecular profiling methods as well as first results will be presented.

Conclusion. This project will provide unprecedented and comprehensive insights into genetic and immunological evolutionary profiles of real-life bladder cancer cases associated with clinical outcomes. These data will be a source for mechanistic follow-up work and will identify evolutionary molecular signatures associated with clinical Response.

\section{Experimentelle endokrine Pathologie}

\section{DGP31.02}

\section{Thyrocyte-specific Mct8 deficiency in a mouse model}

K. Renko ${ }^{1}$, K. W. Schmid ${ }^{2}$, E. Rijntjes ${ }^{1}$, U. Schweizer ${ }^{3}$, J. Spranger ${ }^{1,4}$, J. Köhrle ${ }^{1}$ E.K. Wirth ${ }^{*, 4}$

${ }^{1}$ Charité-Universitätsmedizin Berlin, Institut für Experimentelle Endokrinologie, Berlin, Germany, ${ }^{2}$ Universitätsklinikum Essen, Institut für Pathologie, Essen, Germany, ${ }^{3}$ Rheinische Friedrich-Wilhelms Universität Bonn, Institut für Biochemie und Molekularbiologie, Bonn, Germany, ${ }^{4}$ Charité-Universitätsmedizin Berlin, Klinik für Endokrinologie, Diabetes und Ernährungsmedizin, Berlin, Germany

Monocarboxylate transporter (Mct) 8 deficiency leads to papillary thyroid carcinoma (PTC) in a knockout mouse model and altered thyroid morphology in a patient carrying a non-functional missense mutation. To test whether the development of PTC depends on thyrocyte-specific processes or is potentially mediated by systemic factors such as the increased Tsh concentration in Mct8 deficiency, we generated thyrocyte-specific Mct8-deficient mice and performed thyroid function tests. Thyroid morphology was assessed by histology. The removal of functional Mct8 from thyrocytes leads to low circulating $\mathrm{T}_{4}$ concentrations, while $\mathrm{T}_{3}$ and Tsh are not significantly altered. Thyrocyte-specific $M c t 8$-deficient mice do 
not develop PTC at the age of 6 or 15 months. The development of PTC in global Mct8 deficiency is therefore not mediated by a specific lack of Mct8 in thyrocytes, but likely is a result of continuous stimulation through elevated Tsh. Our data support earlier conclusions that low circulating $\mathrm{T}_{4}$ concentrations upon $M c t 8$ deficiency are mediated by disturbed export of $\mathrm{T}_{4}$ from the thyroid gland.

\section{DGP31.03}

\section{Thyroxine promotes tumor growth in an orthotopic lung cancer mouse model}

\section{S. Latteyer', S. Christoph', S. Theurer ', G. S. Hönes', K. W. Schmid' , D. Führer',} L.C. Moeller ${ }^{1 *}$

'Universitätsklinikum Essen, Endokrinologie, Diabetologie und Stoffwechsel, Essen, Germany, ${ }^{2}$ Universitätsklinikum Essen, Klinik für Stammzelltransplantation, Essen, Germany, ${ }^{3}$ Universitätsklinikum Essen, Institut für Pathologie, Essen, Germany

Introduction. Thyroid hormones are important for physiology and homeostasis. Besides the nuclear thyroid hormone receptors, a plasma membrane protein, integrin $\alpha v \beta 3$, acts as a receptor for both T3 and T4. Our hypothesis was that thyroid hormone signaling via av $\beta 3$ promotes tumor growth. Material and methods. To test this hypothesis, murine lung carcinoma cells (3LL), stably transfected with luciferase, were injected into mouse lungs. Mice then remained untreated or were rendered hypothyroid and treated with T3 or T4 with or without the av $\beta 3$ inhibitor Tetrac. Tumor growth was determined by serial in vivo imaging of bioluminescence emitted from the injected luciferase expressing $3 \mathrm{LL}$ cells. Tumor weight and neoangiogenesis were determined at the end of the experiment.

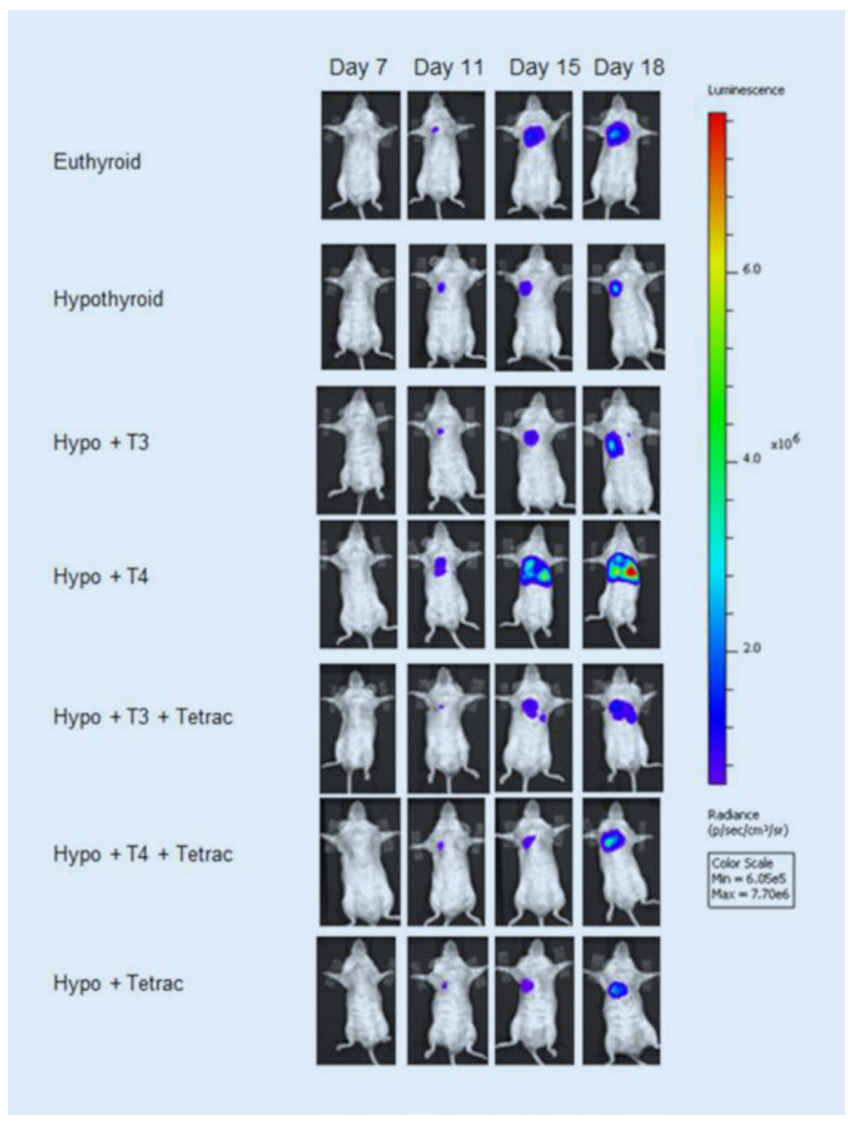

Fig. 1 | DGP31.03 $\Delta$ T4 treatment promotes tumor growth. Exemplary illustration of bioluminescence intensity in one mouse per treatment group over time
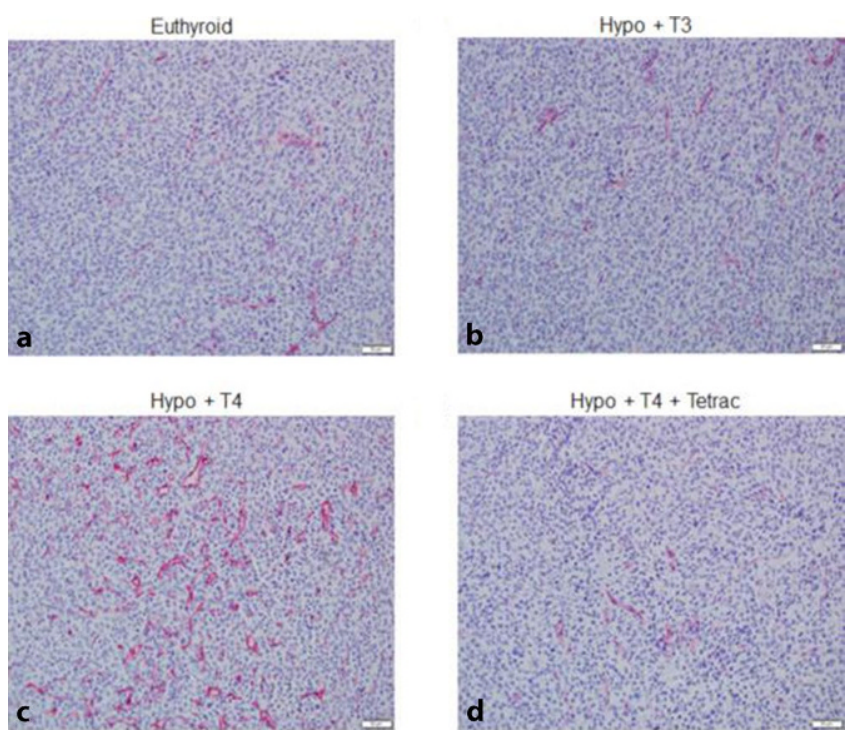

Fig. 2 | DGP31.03 $\Delta$ Increased CD31+ staining after T4 treatment. Immunohistochemistry staining of CD31+ from formalin-fixed paraffinembedded tumor of euthyroid mice

Results. Tumor growth was reduced in hypothyroid mice and increased in T4 treated mice. Strikingly, only T4, but not T3, treatment promoted tumor growth (- Fig. 1|DGP31.03). This T4 effect was completely abrogated by co-treatment with the $\alpha v \beta 3$ inhibitor Tetrac. Tumor weight and neoangiogenesis were increased only in tumors of T4 treated mice (- Fig. 2 |DGP31.03). Again, the T4 effect was abolished by Tetrac. Conclusion. We demonstrate that thyroid hormone promotes tumor growth in an orthotopic lung cancer mouse model. This tumor promoting effect includes increased neoangiogenesis and is exclusively mediated by $\mathrm{T} 4$ via the plasma membrane integrin av $\beta 3$. Such effects of T4 need to be considered in cancer patients on T4 substitution.

\section{DGP31.04}

\section{D primary cell culture: A new promising pre-clinical model for} pancreatic neuroendocrine tumors (PanNETs)

S. L. April-Monn', T. Wiedmer', M. Skowronska', R. Maire', A. Di Domenico', M. Schiavo Lena ${ }^{2}$, V. Andreasi ${ }^{3}$, F. Muffatti ${ }^{3}$, S. Partelli ${ }^{3,4}$, D. Doglioni ${ }^{2,4}$, M. Falconi ${ }^{3,4}$, A. Perren $^{1 *}$, I. Marinoni ${ }^{1}$

'Institute of Pathology/University of Bern, Bern, Switzerland, ${ }^{2}$ Unit of Pathology San Raffaele Scientific Institute, Milan, Italy, ${ }^{3}$ Pancreatic Surgery Unit, Pancreas Translational \& Clinical Research Center, San Raffaele Scientific Institute, Milan, Italy, ${ }^{4}$ Università, Vita e Salute', Milan, Italy

Background. Establishing better in vitro preclinical models is an urgent need for PanNET research. Currently used pre-clinical mouse and cell line models do not reflect the genetic background of human PanNETs and they do not address intertumoral heterogeneity found in PanNET patients. Consequently, advances in novel treatment regimens and development of more personalized therapies in PanNETs are impeded.

Aim. To establish a 3D primary PanNET in vitro model that adequately reflects tumor characteristics of specific patients and that can be further exploited for a personalized in vitro drug testing.

Methods. Tumor cells are isolated either directly after tumor resection or after thawing cryopreserved specimens. Following tissue dissociation, isolated cells are cultured in Ultra-Low-Attachment plates. Culture medium is supplemented with PanNET specific growth factors and biomaterial in order to enhance culture of target cells. Cell growth and cell viability is monitored on a daily basis during an experimental series. Cellular composition and tumor content is determined at several time points during experiment. 
Thereby, neuroendocrine markers, proliferation and cell death are assessed in FFPE tumoroids by IHC and compared to IHC of original tumor tissue. Results. Isolated cells from cryopreserved and fresh PanNET specimen are alive and form PanNET tumoroids resembling islet-like structures. The success rate of PanNET tumoroid formation lies at 70\% (7/10 cases). In 5 out of these 7 cases a sufficient cellular yield was obtained to perform growth curve and treatment experiments. PanNET tumoroids sustain viable for an extended in vitro culture time and reflect original tumor characteristics such as expression of endocrine markers, hormone expression, and proliferation rate. PanNET tumoroids from distinctive patients respond specifically to different pharmacological drug treatments and thus may reflect patient response. Conclusion. 3D human primary PanNET culture is a promising new pre-clinical model with the potential to pace the way for personalized health pipelines in clinics. We present a tailored 3D culture method for PanNETs using fresh and cryopreserved specimen allowing multi-centre sample collection. We show that 3D human primary PanNET is feasible. This tool might therefore be exploited for testing novel therapies and predict patient therapy response in absence of other instruments for therapy selection.

\section{DGP31.05}

\section{Charakterisierung chemisch induzierter papillärer Schilddrüsenkarzinome im Tiermodell}

\section{B. Koelsch, S. Theurer, M. Staniszewska, J. Heupel, A. Koch, S. Mergener, F. Walk, A. Kutritz, K. W. Schmid, A. Kindler-Röhrborn* Universitätsklinikum Essen, Universität Duisburg-Essen, Institut für Pathologie, Essen, Deutschland}

Ziel. Bis heute ist die molekulare Basis für die Entstehung papillärer Schilddrüsenmikrokarzinome (PTMC), die erratische Progression zu PTCs sowie der ungünstige klinische Verlauf bei einer Untergruppe von Patienten mit klinisch relevanten PTCs weitgehend unbekannt. Deshalb ist die Etablierung eines Tiermodells als Plattform für die präklinische Entwicklung von PTC Präventionsstrategien and zielgerichteten Therapien besonders für aggressive Formen wünschenswert.

Methoden. Schilddrüsen von ingezüchteten Ratten der BD Stämme, die am ersten Postnataltag mit dem chemischen Karzinogen N-ethyl N-nitrosoharnstoff (ENU) behandelt worden waren, wurden histologisch begutachtet. PTC Gewebe wurde durch laser-gestützte Mikrodissektion aus Gewebeschnitten gewonnen und daraus DNA isoliert. Durch PCR Amplifikation des Mutationshotspots im Exon 15 des Braf Gens und anschließende DNA Sequenzierung wurde der Mutationsstatus des Gens bestimmt. Die Expression des Braf Wildtyp-Proteins und der mutierten Form wurde durch Immunhistochemie mit den Antikörpern pBR1 und VE1 nachgewiesen.

Ergebnisse. 56 \% der BD Ratten (317/565) hatten Schilddrüsentumoren entwickelt, die ein sehr ähnliches histologisches Bild zeigten wie humane PTCs. Nur in einen Fall konnte eine extrathyroidale Ausdehnung nachgewiesen werden. Lymphknoten- oder Fernmetastasen wurden nicht beobachtet und keines der Tiere erlag einem PTC. Die Größe der Tumoren stand in keiner Relation zum Alter. Aufgrund dieser Charakteristika handelt es sich hier eher um biologisch indolente papilläre Mikrokarzinome (PTMC). $86 \%$ der PTMC von Ratten unter einem Alter von 200 Tagen, bzw. 81 \% der PTMC älterer Tiere (insgesamt 93/112) wiesen die V600E Mutation des Braf Gens auf. Daher scheint die V600E Mutation ein frühes Ereignis während der Kanzerogenese zu sein. Überraschenderweise konnte jedoch in den meisten PTMCs keine Expression des mutierten Braf Proteins nachgewiesen werden.

Fazit. ENU-induzierte Tumoren der Rattenschilddrüse entsprechen menschlichen PTMCs in Bezug auf Histologie, genetische Veränderungen und Verhalten. Im Gegensatz zu PTC aus BrafV600E transgenen Tieren entwickeln sie sich aus einzelnen Thyreozyten, die die Braf Mutation als Folge der Exposition gegenüber ENU tragen und von normalen Follikelzellen umgeben sind. Da BrafV600E eine Treibermutation darstellt könnte die fehlende Expression des mutanten Proteins am geringen Progressionsrisko von PTMCs beteiligt sein

\section{Bewerbungen Doktoranden-Preis}

\section{DGP33.03 \\ PRSS23 drives HCC development in context of activated MYC and AKT signaling}

Z. Abadi ${ }^{\text {* }}$, F. Pinna', O. Neumann ${ }^{1}$, A. Neumann', S. Klotz², C. De la Torre 3 , N. Gretz ${ }^{3}$, P. Schirmacher', L. Zender', R. Pellegrino', T. Longerich'

'Heidelberg University Hospital, Institute of Pathology, Heidelberg, Germany, ${ }^{2}$ University Hospital Tubingen, Department of Internal Medicine VIII, Tubingen, Germany, ${ }^{3}$ University of Heidelberg, Medical Faculty Mannheim, Medical Research Center, Mannheim, Germany

Aim. Human hepatocarcinogenesis represents a step-wise process, which involves premalignant Dysplastic Nodules (DN) developing in cirrhotic liver tissue. Macroscopically evident nodule-in-nodule growth represents a morphological hallmark of malignant transformation into hepatocellular carcinoma (HCC). In this study we identified clonally expanded driver mutations in a well-differentiated HCC evolving from a DN.

Methods. Exome sequencing of cirrhotic, DN, and HCC areas was performed and clonally expanded genetic lesions were identified using the AnnoVar pipeline. To screen for loss-of function mutations, in vivo shRNA screening was performed using a p53 heterozygous mouse model and hydrodynamic tail vein injection of an shRNA library delivered via transposable vectors. The Library was delivered together with a c-myc-MyrAKT1 transposon vector. Next Generation Sequencing was used to identify enriched shRNAs within the murine HCC nodules following tumor growth. To individually validate the driving potential of candidate genes targeted by enriched shRNAs, single gene validation was performed using transposon vectors carrying either the wildtype or the mutant alleles of the candidate genes. In addition, isogenic cell lines expressing the wildtype or the mutated candidate gene were generated. Biochemical and functional assays as well as expression profiling were carried out for further characterizations.

Results. Exome sequencing data revealed 17 clonally expanded mutations in the human HCC. In vivo shRNA screening validated mutated PRSS23 as a candidate gene to promote hepatocarcinogenesis, which was confirmed by overexpression of PRSS23 mut in c-myc-overexpressing p 53 heterozygous mice. The proliferative capacity of PRSS 23 mut was significantly higher compared to PRSS23 wt expressing murine HCC cells (CaMCaA). Expression profiling of PRSS23 mut, PRSS23 wt, and parental control cells revealed that PRSS23 is involved in the regulation of the PI3K/mTOR pathway via a switch involving AMPK and dysregulation of NFkB and COX2 signaling in vitro.

Conclusion. Integration of exome sequencing and in vivo RNAi screening identified a new driver gene of human hepatocarcinogenesis. Mutated PRSS23 provides a growth advantage to hepatocytes in context of activated myc- and AKT1-signalling and promotes HCC development in c-myc-overexpressing, p53 heterozygous mice. PRSS23 mut allows for a more efficient use of nutrients and affects inflammation-associated cellular signaling.

\section{DGP33.04}

Immune modulatory miRNAs as tools for a reliable stratification of patients with Myelodysplastic Syndrome

C. Vaxevanis' ${ }^{*}$, M. Bauer ${ }^{2}$, H. K. Al-Ali', C. Wickenhauser ${ }^{2}$, B. Seliger ${ }^{1}$

${ }^{1}$ Martin Luther University Halle-Wittenberg, Institut für Medizinische Immunologie, Halle (Saale), Germany, ${ }^{2}$ Martin Luther University Halle-Wittenberg, Institut für Pathologie, Halle (Saale), Germany, ${ }^{3}$ Universitätsklinikum Halle (Saale), Universitätsklinik und Poliklinik für Innere Medizin IV, Halle (Saale), Germany

Aim. MDS patient risk determination is a difficult endeavor using only the currently available approaches. Due to post-translational regulation the patients' cytogenetic score might not be solely indicative for cellular changes. Analysis of non-coding RNAs have demonstrated a differential expres- 
sion pattern of miRNAs in AML and MDS samples, which might have an effect on stem cell survival, maturation and immune response. Preliminary results demonstrated a differential expression of immune modulatory miRNAs in different AML and MDS cell lines, which could be correlated to certain cytokine profiles, further suggesting a miRNA dependent and independent regulation mediated by immune escape and inflammation. Therefore, the aim of this study is to determine the role of these immune modulatory miRNAs in bone marrow (BM) biopsies of MDS patients with different prognostic scores and blast cell counts, as indicators of changes in the BM that might lead to AML progression.

Methods. $50 \mathrm{BM}$ biopsies from MDS patients with different blast cell counts and 10 sequential biopsies with transformed AML were analysed for the expression of immune modulatory miRNAs related to inflammation (NF-kB, IL-1b, TLR4 pathways) and antigen presentation (MHC molecules) using qPCR. Clinical parameters, cytogenetic data and results from multispectral immune cell characterization were available for all patients. Clinical relevance was determined by correlating the miRNA expression pattern with immune cell infiltration and patient characteristics.

Results. Expression of some selected miRNAs in the BM varied between MDS, secondary AML patients and healthy controls. Patients with generally low miRNA expression had an increased presence of FOXP3+ cells, while the majority of the patients that progressed to AML exhibited a

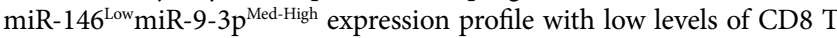
cell infiltration. By combining miR-146a expression and the presence of FOXP3+ cells a more prominent correlation between a higher IPSS score and FOXP3 infiltration was found.

Conclusion. The combination of histopathological data with miRNA signatures might be an effective way of determining patient risk and allow for better patient classification. Analysis of the molecular characteristics of the BM in MDS and secondary AML patients might give insights about the underlying molecular mechanisms of the altered immune cell infiltration and even might provide therapeutic alternatives.

\section{Zytologie - (Molekulare) Marker und neue Tumorklassifikationen}

\section{DGP34.02}

\section{Zytologie des Pankreas - Morphologie und Zusatzmarker}

\section{E. Hewer*}

Universität Bern, Institut für Pathologie, Bern, Schweiz

Das Diagnosesystem der Papanicolaou Society of Cytopathology bildet einen konzeptuellen Rahmen für die Befundung zytologischer Proben aus dem pankreatobiliären Trakt. Analog anderen zytologischen Diagnosesystemen fasst es den aktuellen Wissenstand bezüglich der diagnostischen Kriterien der relevanten Entitäten zusammen. Darüber hinaus stellt es eine konsistente Terminologie für diagnostisch unsichere (d.h. atypische oder malignitätsverdächtige) Befunde sowie Minimalkriterien für repräsentative Proben zur Verfügung.

Eine besondere Herausforderung in der Zytologie des Pankreas sind zystische Läsionen, da diese oftmals rein zytomorphologisch nicht adäquat diagnostiziert werden können. Aus konzeptueller Sicht wegweisend ist die Einbindung nicht-morphologischer Methoden im Papanicolaou Society System: Laborchemische (CEA > $192 \mathrm{ng} / \mathrm{ml}$ ) oder molekulare (KRAS und/oder GNAS-Mutation) Befunde an der Zystenflüssigkeit sind Bestandteil der formalen diagnostischen Kriterien neoplastischer Zysten. Die Berner Erfahrungen zeigen, dass ein solcher integrativer Ansatz zu einem erheblichen Gewinn an diagnostischer Aussagekraft führt. In einer Analyse von 83 Fällen konnte in 79 Fällen (95\%) adäquate DNA aus der Zystenflüssigkeit extrahiert werden. Pathogene Mutationen waren mittels Next generation sequencing in 46 Fällen (58 \%) nachweisbar. Davon wäre in 35 Fällen (76 \%) die Diagnose einer neoplastischen Zyste rein morphologisch nicht möglich gewesen.
Diese Erfahrungen eröffnen neue Perspektiven für die die Einbindung von Zusatztechniken an Stellen, wo die reine zytomorphologische Diagnostik an ihre Grenzen stösst. In diesem Sinne sollte die Liquid biopsy nicht als Konkurrenz zur, sondern als Erweiterung der zytologischen Diagnostik gesehen werden, entsprechend dem Motto „Doing more with less“.

\section{DGP34.03 \\ Überlegungen zur Schilddrüsenzytologie - nach der Einführung der nicht-invasiven follikulären Neoplasie mit PTC-äquivalenten Kernmerkmalen (NIFTP)}

M. Tötsch ${ }^{1 * 2,}$, K. W. Schmid ${ }^{3}$

'Institut für Zytologie, Graz, Österreich, 'nstitut für Pathologie, LKH Hochsteiermark, Leoben, Österreich, ${ }^{3}$ Institut für Pathologie und Neuropathologie, Universitätsklinikum Essen, Universität Duisburg-Essen, Essen, Deutschland

Die Diagnose eines papillären Schilddrüsenkarzinoms (PTC) kann aufgrund charakteristischer Kernveränderungen auch in der Zytologie (FNB) mit so hoher Spezifität erfolgen, dass dies in vielen Fällen Einfluss auf die Operationsplanung hat. Die FNB hat somit beim PTC eine diagnostische Zielsetzung, während sie als Screeninginstrument zur Identifikation follikulärer Neoplasien (Adenome, follikuläre Karzinome) eingesetzt wird, deren Dignität nur am Operationspräparat bestimmt werden kann.

Die Einführung der NIFTP in der 4. Auflage der WHO-Klassifikation der Schilddrüsentumoren (2017) erfolgte mit dem expliziten Ziel, Patienten mit der Diagnose dieser Subgruppe gekapselter und vollständig follikulär strukturierter "papillärer Karzinome“ mit indolentem klinischen Verlauf sowohl Übertherapien als auch die psychisch belastende Krebsdiagnose zu ersparen. Da die NIFTP und das klassische PTC dieselben charakteristischen Kernmerkmale aufweisen, sind neben einer Neudefinition der Diagnosekriterien des papillären Karzinoms (WHO 2017) auch grundlegende Änderungen in der zytologischen Bewertung bei der Feinnadelbiopsie (FNB) der Schilddrüse notwendig gemacht haben.

Zytologisch ist ein PTC nur mehr eindeutig zu diagnostizieren (Befundgruppe $\mathrm{V}$ nach Ting et al.), wenn neben den charakteristischen Kernmerkmalen eindeutige papilläre Strukuren, Psammomkörper und/oder eine BRAF V600E-Mutation nachgewiesen werden kann. Dadurch ist eine Zunahme der Befundgruppe IV (Verdacht auf Malignität) bedingt, wobei in dieser Befundgruppe zumeist Neoplasien mit „PTC-äquivalenten Kernveränderungen “ zu finden sind. In Konsequenz ist für diese Befundgruppe eine geringeres Malignitätsrisikos als bisher zu erwarten (früher 60-75\%, jetzt $45-60 \%$ ).

Die Einführung der NIFTP hat aufgrund dieser Neubewertung auch zu einem Update bei der Bethesda Klassifikation geführt. Die Bethesda-Befundgruppen III (Atypien mit unklarer Bedeutung/follikuläre Veränderungen mit unklarer Bedeutung [AUS/FLUS]) und IV (follikuläre Neoplasie/verdächtig auf follikuläre Neoplasie [FN/SFN]) weisen nunmehr ein sehr ähnliches Malignitätsrisiko auf, ihre Abgrenzung ist somit unserer Meinung nach von keinerlei Nutzen für das Management der betroffenen Patienten/innen. Die notwendig gewordene Anpassung der zytologischen Gegebenheiten nach der Einführung der NIFTP ist in dem von uns verwendeten 5-stufigen Befundschema demgegenüber problemlos umzusetzen.

\section{DGP34.04 \\ Harnzytologie - Markeranalysen im Kontext der Paris Klassifikation}

T. Vlajnic*

Universitätsspital Basel, Institut für Pathologie, Basel, Schweiz

Die Paris Klassifikation wurde vor einigen Jahren in die diagnostische Routine eingeführt, um ein international standardisiertes Befundungssystem für die Urinzytologie zu etablieren und somit die Aussagekraft der Urinzytologie zu verbessern. Die diagnostischen Kategorien der Paris Klassifikation basieren auf definierten morphologischen Kriterien in Hin- 
sicht auf einen möglichst hohen positiven prädiktiven Wert für die Diagnose des klinisch relevanten „high-grade“ Urothelkarzinoms (HGUC). Ein weiteres wichtiges Ziel der Paris Klassifikation ist die Reduktion beziehungsweise Eingrenzung der bisher uneinheitlich genutzten Diagnose von „Atypien“ in der Urinzytologie. Für die Paris Kategorie „atypische urotheliale Zellen" (AUC) wurden deshalb strenge morphologische Kriterien festgelegt, um die Häufigkeit dieser Diagnose möglichst tief zu halten. Für eine weitere Abklärung der unklaren AUC Kategorie hinsichtlich Unterscheidung zwischen urothelialer Neoplasie und reaktiven Veränderungen bietet sich der diesbezüglich am besten validierte Test UroVysion (AbbottDiagnostics, Santa Clara, CA, USA; Uro-Fluoreszenz-in-situHybridisierung, Uro-FISH) an. Dabei ist die gezielte Indikationsstellung ebenso wie die richtige Interpretation der Resultate entscheidend für eine hohe Sensitivität und Spezifität dieser molekularen Zusatzuntersuchung.

\section{DGP34.05}

\section{Prognostic stratification of malignant pleural effusion patients by immune profiling of their cytologic cell blocks}

\section{Wu ${ }^{1 *}$, F. Mairinger ${ }^{2}$, A. Soltermann}

'University Hospital Zurich, Pathologie und Molekularpathologie, Zürich, Switzerland, ${ }^{2}$ University Hospital Essen, Institute of Pathology, Essen, Germany

Aim. Malignant pleural effusion (MPE) is a common but severe clinical condition with no effective therapy. The aim of our study was to perform a comprehensive immune cells and immunomodulators profiling of MPE patients with most frequent pleural effusion malignancies using cytologic cell blocks prepared from centrifuged pleural liquid sediment.

Methods. Hybrid cytology-tissue microarrays (c-TMA) were constructed from MPE cell blocks of 158 patients. PD-L1 protein expression was evaluated by immunohistochemistry (IHC) using antibody clone E1L3N Immune cells markers: CD3, CD4, CD8, CD20, CD45, CD68 and myeloperoxidase (MPO) were assessed by IHC and quantified using a computational pathology approach. Immune cells phenotyping and immunomodulatory genes expression analyses were performed for $72 \mathrm{MPE}$ patients' samples by NanoSting. Immune profiling data were correlated with clinicpathologic parameters.

Results. Within all immune cell subpopulations, B cells (CD20+) to leukocytes $(\mathrm{CD} 45+)$ ratio (hazard ratio $(\mathrm{HR}) 0.70, p$-value $=0.04)$ and neutrophils $(\mathrm{MPO}+)$ to leukocytes ratio $(\mathrm{HR} 1.75, p$-value $=0.003)$ were potential prognosticators for MPE patients. Positive expression of TTF-1 was a favorable prognostic parameter for MPE lung adenocarcinoma patients (HR 0.42, $p$-value $=0.008)$. mRNA expression of 17 immunomodulatory markers varied among tumor entities, and displayed diverse correlation patterns.

Conclusion. The proposed immune profiling strategy offers new insights into pathologic-cytologic evaluation and might be valuable readouts for personalized therapeutic strategies and health care for MPE patients.

\section{DGP34.06}

\section{Plasma-thrombin cytoblock protocol for the pathological evaluation of urine and liquor}

\section{Petersen*, R. Rustamov}

SRH Poliklinik Gera GmbH - Waldklinikum Gera, Institut für Pathologie, Gera, Germany

Aim. Several years ago we introduced a plasma-thrombin cytoblock protocol in the routine evaluation of cytological specimens (Weihmann et al 2012, PubMed 22592699). It was adopted by other pathology Institutes in Germany. However, in its classical application it was not suitable for the analysis of urine samples probably due to fibrinolytic activity of urokinase within the urine. In addition, it was not applied to cerebrospinal fluids so far.

Methods. For the urine samples, the classical protocol was extended by a washing step with $\mathrm{PBS} /$ isotonic $\mathrm{NaCl}$ solution after the primary centrif- ugation step for the generation of the cell pellet for the plasma-thrombin clot to eliminate urine remnants and the urokinase. For the liquores, the original protocol was applied, however, the plasma volume was reduced to enrich the cellularity of the cell block.

Results. The protocol was successful to analyze urine samples as well as liquores by the cytoblock technique. This enabled the "immunohistochemical" analysis of the cytological specimen which did help to better differentiate the cells and to reach a final diagnosis.

Conclusion. Cytoblock analysis of urine samples and liquores is possible and useful to perform ancillary tests like immunocytology and to establish a cancer diagnosis in these specimens. In addition, it provides a mean for long term storage of cytology samples and retrospective molecular analysis.

\section{Digitale Pathologie I}

\section{DGP35.01 \\ Comparison of deep learning with pathologists for non-small cell lung cancer histologic subtyping}

\section{R. Casanova' , E. Murina ${ }^{2}$, O. Dürrr', B. Sick², A. Soltermann ${ }^{1 *}$}

'Universitätsspital Zürich, Institut für Pathologie und Molekularpathologie, Zürich, Switzerland, 'Zürcher Hochschule für Angewandte Wissenschaften, Institut für Datenanalyse und Prozessdesign, Winterthur, Switzerland

Background. Non-small cell lung cancer (NSCLC) encompasses an heterogeneous groups of histological subtypes. Typically, adenocarcinoma (LADC) and squamous cell carcinoma (LSCC), can be distinguished by trained pathologists based on distinctive histologic features such the formation of glandular structures for LADC and the presence of keratin and/ or intercellular desmosomes for LSCC.

Methods. In this study, we have developed a convolutional neural network to differentiate LADC from LSCC, on a cohort consisting of 208 NSCLC patients. Histologic slides were prepared from formalin-fixed paraffin embedded tumor blocks, stained by Hematoxylin and Eosin. Slides were scanned and 50 frames $(128 \times 128$ pixels $)$ were prepared for each tumor with a spatial resolution of $1.15 \mu \mathrm{m} /$ pixel.

Results. Patients cohorts were split into a training set ( $n=140$ patients) and validation set $(n=68)$. The performances of the $\mathrm{CNN}$ were evaluated on the validation set and are compared with the results of three experienced pathologists. Training and validation accuracy reached 91 and $93 \%$, respectively. Among the validation set, artificial intelligence misclassified $2 / 68$ cases and pathologists $1 / 68$. However, at least 1 of 3 pathologists classified 29/68 cases (43\%) based on the HE image frames as NSCLC NOS. Correct classification by $\mathrm{CNN}$ was correlated with better-differentiated tumors, in particular lepidic-type adenocarcinoma and keratinizing squamous cell carcinoma; and therefore with better overall survival.

Conclusions. Automated frameworks for histologic subtyping of cancer tissues using deep learning algorithms, could serve as potential analytic companion tools for pathologists in order to support and speed-up routine diagnostic tasks.

\section{DGP35.02}

\section{Deep Learning in der Diagnostik des kolorektalen Karzinoms}

S. Foersch ${ }^{1 *}$, J. Geiger 1,2, K. Tserea ${ }^{1}$, A. Fernandez', F. Gach', E. Hüttermann ${ }^{3}$, A. Heintz ${ }^{3}$, W. Roth ${ }^{1}$, M. Wand ${ }^{2}$

'Universitätsmedizin Mainz, Institut für Pathologie, Mainz, Deutschland, ${ }^{2}$ Johannes Gutenberg-Universität Mainz, Institut für Informatik, Mainz, Deutschland, ${ }^{3}$ Katholisches Klinikum Mainz, Klinik für Allgemein- und Viszeralchirurgie, Mainz, Deutschland

Ziel. Bösartige Neoplasien des unteren Gastrointestinaltrakts gehören zu den häufigsten Krebserkrankungen überhaupt und sind mit einer hohen Morbidität und Mortalität assoziiert. Dem Fachgebiet der Pathologie kommt im klinischen Management dieser Erkrankung (z. B. Diagnostik 
nach Probeentnahme während der Vorsorgekoloskopie) eine Schlüsselrolle zu. Hierbei könnten Verfahren der digitalen Pathologie und des maschinellen Lernens helfen, eine schnellere und genauere Charakterisierung des Gewebes zu erzielen.

Methoden. Im Rahmen des Projekts sollen Algorithmen des maschinellen Lernens dazu verwendet werden, um 1) zwischen normaler und tumorös veränderter Dickdarmschleimhaut zu unterscheiden, 2) den klinischen Verlauf zu prognostizieren, 3) ein Aussage über mögliche genetische Veränderungen des Gewebes zu treffen und 4) ein mögliches Ansprechen auf eine neoadjuvante Therapie vorherzusagen. Hierzu wurden drei Kohorten mit insgesamt 1422 Patienten zusammengestellt, zu welchen uns detaillierte klinisch-pathologische Informationen, Überlebensdaten sowie molekularpathologische Daten vorliegen. Zu jedem dieser Patienten verfügen wir außerdem über mindestens einen Hämatoxylin \& Eosin gefärbten, digitalisierten Ganztumorschnitt.

Ergebnisse. Zunächst wurde Tumor- und Normalgewebe digital annotiert. Dann erfolgte die Generierung von $512 \times 512$ Pixeln großen Bildausschnitten. Diese wurden darüber hinaus augmentiert, d. h. leicht abgeändert kopiert, um den Datensatz zusätzlich zu erweitern. Daraufhin wurden die jeweiligen Bildausschnitte in ein Trainings- $(80 \%)$ und ein Validierungsset (20 \%) aufgeteilt. Nach der Implementierung der Algorithmen (sog. Convolutional Neural Networks wie z. B. Inception V3 und ResNet50) wurden erste Trainingsläufe durchgeführt. Hierbei konnte mit einer Genauigkeit (validation accuracy) von bis zu 99,43\% zwischen Tumor- und Normalgewebe unterschieden werden. Die AUC der ROC lag bei nahezu 1,0.

Fazit. Verfahren des maschinellen Lernens sind dazu in der Lage mit hohen Genauigkeitswerten zwischen gesunder Dickdarmschleimhaut und Karzinomgewebe zu unterscheiden. Diese Fähigkeit könnte z. B. im Rahmen eines Clinical Decision Support Systems (CDSS) zu einer schnelleren und genaueren Routinediagnostik eingesetzt werden. Weitere Analysen zielen darauf ab, diese Deep Learning Verfahren dazu zu verwenden, andere klinisch-pathologische Parameter vorherzusagen, wie z. B. das Gesamtüberleben oder aber bestimmte, Therapie-relevante Mutationen.

\section{DGP35.03}

Feedback-based self-improving CNN algorithm for breast cancer lymph node metastasis detection in real clinical environment

M. Sadeghi ${ }^{1 *}$, I. Maldonado Zambrano ${ }^{2}$, N. Abele ${ }^{3}$, J. Haybaeck ${ }^{3,4,5}$, M. Friebe ${ }^{1,2}$ 'Otto-von-Guericke University, Magdeburg, Germany, ${ }^{2}$ Intelligente Katheter Institute, Magdeburg, Germany, ${ }^{3}$ Otto-von-Guericke University, Department of Pathology, Magdeburg, Germany, ${ }^{4}$ Medical University of Innsbruck, Department of Pathology, Neuropathology, and Molecular Pathology, Innsbruck, Austria, ${ }^{5}$ Diagnostic \& Research Center for Molecular BioMedicine, Institute of Pathology, Medical University of Graz, Graz, Austria

Aim. Over the last decade the emergence of whole slide digital scanners has resulted in a substantial amount of clinical and research interest in digita pathology. Machine learning and Image processing techniques can now be applied to Whole Slide Images (WSI), providing pathologists with tools assisting in the diagnostic processes. However, the current workflow in digital pathology, is only a forward path from the classification algorithm to the pathologist through a Graphical User Interface (GUI). Additionally needed is a backward path from the pathologist to the classification algorithm in order to improve the performance of the classification algorithms on real clinical images. Our study employing such an algorithm is focused on H\&E stained histopathological WSI of lymph nodes containing breast cancer metastasis.

Methods. As the first step a Convolutional Neural Network (CNN) algorithm was developed, trained and validated on 400 WSI of lymph node slides containing normal and metastasis regions. Slides were processed in patches of $128 \times 128$ pixels with $40 \times$ magnification.

In the second step, a GUI was created to acquire feedback-input from the pathologist doctors on the validity of the prediction of the classification algorithm on 20 new slides.

In the final step, the patches with false positive (FP) and false negative (FN) predictions of the CNN algorithm, based on the pathologists' feed- back, were extracted. The number of extracted patches were increased using data augmentation techniques. The feedback-input was then added to the primary training set and the new set was used to re-train the network and the impact was evaluated.

Results. A total number of 2447 patches from 20 slides were evaluated by two clinical pathologists. The $\mathrm{CNN}$ algorithm was tested on a set of 10,000 tumor patches before and after considering the feedback-input. The accuracy of the CNN algorithm prediction showed significant improvement by this addition.

With the mentioned approach, the $25 \%$ quantile of the probability score of the predictions increased from 0.48 to 0.89 and the median of the data increased from 0.95 to 0.99 .

Conclusion. The method showed significant improvement in the classification performance of the applied CNN algorithm. This method might also be used to improve the future diagnostic accuracy on real clinical images by providing a feedback-path from the pathologist to the classification algorithms through the GUI.

\section{DGP35.04}

\section{Deep learning-basiertes tool für morphometrische Analyse des} Nierenparenchyms und Kategorisierung der pathologischen Veränderungen

\section{C.-A. Weis ${ }^{1 *}$, J. Voigt ${ }^{2}$, S. Porubsky ${ }^{3}$}

'Universitätsmedizin Mannheim, Pathologisches Institut, Brühl-Rohrhof, Deutschland, 'Pathologisches Institut Mannheim, Brühl-Rohrhof, Deutschland, ${ }^{3}$ Pathologisches Institut Mannheim, Mannheim, Deutschland

Ziel. Die drei Kompartimente des Nierenparenchyms (Glomeruli, Gefäße und Tubulointerstitium) weisen unterschiedliche Veränderungen auf, die verschiedenen Erkrankungen und deren unterschiedlichen Stadien zugeordnet werden können. Für die Diagnosestellung sowie auch für die Auswertung von Tierversuchsserien ist daher eine aufwendige diagnostische Evaluation aller Kompartimente notwendig. Das Ziel dieses Projektes ist es, mit den Methoden des Maschinenlernens ein tool zu entwickeln: das (1) eine vollautomatisierte Zerlegung des digitalisierten histologischen Bildes in die drei typischen Kompartimente ermöglichen; um (2) diese anschließend einer morphometrischen Analyse zu unterziehen; und um (3) mittels Maschinenlernen-basierte die jeweiligen Veränderungen definierten Krankheiten zuzuordnen.

Methoden. Anhand der in Schnittstufen vorhandenen Archivbiopsien des Nierenparenchyms wurde ein Bilddatensatz mit mehreren Tausenden Varianten jedes Kompartiments vorbereitet und zuerst mittels unüberwachten Lernens (Kohonen-Netz) in die verschiedenen Kompartimente zerlegt. Im zweiten Schritt werden die zuvor segmentierten Glomeruli mit einem convolutional neural networks $(\mathrm{CNN})$ klassifiziert bzw. den definierten Krankheitsbildern zugeordnet.

Ergebnisse. Mithilfe des unüberwachten Lernens konnte eine automatisierte Erkennung der drei Nierenkompartimente bzw. Segmentierung erreicht werden. Somit können Glomeruli, Gefäße und das Tubulointerstitium maschinell aus einem digitalisierten Bild isoliert werden und sind für weitere morphologischen Analysen, die sich zum Zeitpunkt des Einreichens noch in Ausbau befinden, verfügbar.

Fazit. Maschinenlernen (insbesondere $\mathrm{CNN}$ ) scheint für die bildmorphologische Evaluation und Diagnostik am Nierenparenchym grundsätzlich geeignet zu sein. Weitere Erfahrungen mit diesem Ansatz sind jedoch erforderlich.

\section{DGP35.05}

Multimodal imaging coupled with machine learning as frozen section analysis tool for pathologists

T. Bocklitz ${ }^{*, 2}$, T. Meyer ${ }^{2}$, M. Schmitt ${ }^{1}$, G. Ernst ${ }^{3}$, F. von Eggeling ${ }^{3}$, M. Vieth ${ }^{4}$, O. Guntinas-Lichius ${ }^{3}$, J. Popp ${ }^{1,2}$

${ }^{1} \mathrm{IPC} /$ Universität Jena, Jena, Germany, ${ }^{2}$ Leibniz IPHT, Jena, Germany, ${ }^{3}$ Universitätsklinikum Jena, Jena, Germany, ${ }^{4}$ Institut für Pathologie/Klinikum Bayreuth, Bayreuth, Germany 
Aim. In head and neck resections the R-status is determined by an experienced pathologist via the visual inspection of Hematoxylin and eosin (H\&E) stained frozen-sections of small specimen. Due to more or less pronounced freezing artifacts of frozen-sections and the often large amount of margin-biopsies taken in such an operation the diagnostic sensitivity is lower than the sensitivity of H\&E stained sections of formalin fixed paraffin embedded material. Thus, an alternative diagnostic tool is needed for the pathologist, which ensures a fast and accurate clinical decision making while an operation is ongoing.

Methods. In this study we combined machine learning (ML) tools such as classical machine learning $(\mathrm{CML})$ and deep learning $(\mathrm{DL})$ to extract diagnostic relevant informations from multimodal imaging (MMI), which is the combination of CARS (coherent anti-Stokes Raman-scattering), TPEF (two-photon excited auto-fluorescence) and SHG (second harmonic generation). The advantage of MMI is that is a non-invasive imaging technique allowing for additional tests with the same material after the multimodal images were acquired.

Results. The ML methods we are using were tailored to extract maximal information from the multimodal images and two application cases for the present study. The first case is the translation of the multimodal images into a computational (H\&E) staining, which can be faster acquired and shows a higher quality as conventional frozen-sections. The second application case is the direct extraction of information on the tissue present and if a certain area is tumor free.

Conclusions. The combination of ML methods, such as classical machine learning and deep learning, with non-invasive imaging modalities like CARS, SHG and TPEF form a perfect tool for pathologists to extract diagnostic relevant information form frozen-sections. This additional tool would allow a reduced frozen-section workflow without sending biopsies to the pathologists rather than the computational generated staining images or marker values. This would allow a reduction of the pathologist's workload and may improve the lower sensitivity in a frozen-section consultation

Acknowledgment. Financial support of the EU, the TMWWDG, the TAB, the BMBF, the DFG, the Carl-Zeiss Foundation and Leibniz association is greatly acknowledged.

\section{Digitale Pathologie II}

\section{DGP36.01}

\section{Radiomics: KI basierte Bildanalyse}

\section{A. Demircioglu*}

Uniklinik Essen, Institut für Diagnostische und Interventionelle Radiologie und Neuroradiologie, Essen, Deutschland

Radiomics beschäftigt sich mit der statistischen Analyse von radiologischen Bilddaten. Dabei werden quantitative Merkmale extrahiert und mittels Machine Learning prädiktive Modelle konstruiert. In diesem Vortrag werden einige bei dieser Analyse verwendeten Techniken und Resultate dargestellt, wobei insbesondere die Beziehung zur Digitalen Pathologie diskutiert wird. Abschließend wird auf die zukünftige Rolle der künstlichen Intelligenz in der Radiologie eingegangen.

\section{DGP36.02}

\section{Ein neuronales Netzwerk zur zytomorphologischen} Differenzierung von Leukozyten in der Diagnose Akuter Myeloischer Leukämien

\section{Matek ${ }^{1 * 2}$, C. Marr ${ }^{2}$, K. Spiekermann ${ }^{1}$}

'Klinikum der LMU München, Medizinische Klinik III, München, Deutschland, ${ }^{2}$ Helmholtz Zentrum München, Institute of Computational Biology, München, Deutschland

Ziel. Die mikroskopische Differenzierung der Zytomorphologie physiologischer und pathologischer Leukozyten spielt eine wesentliche Rolle in der Diagnostik der akuten myeloischen Leukämie (AML). Die Qualität der Methode beruht auf der Erfahrung menschlicher Befunder und ist damit vergleichsweise schwierig zu standardisieren. Der Fortschritt auf dem Gebiet neuronaler Netzwerke erlaubt die Entwicklung leistungsfähiger und Systeme zur Bildklassifikation, die als Unterstützungssysteme für die zytomorphologische Differenzierung eingesetzt werden können. In diesem Beitrag wird die Generierung eines Datensatzes aus peripheren Blutausstrichen der klinischen Routinediagnostik vorgestellt, auf dessen Basis ein Klassifikationsnetzwerk trainiert und evaluiert wird.

Methoden. Für die Entwicklung eines Convolutional Neural Network (CNN) zur Klassifikation von Leukozyten wurden periphere Blutausstriche von 100 AML-Patienten und 100 Normalbefunde bei 100-facher Vergrößerung digitalisiert. Die Ausstriche wurden von zytomorphologisch erfahrenen Befundern anhand des Standardschemas der klinischen Routinediagnostik differenziert. Die resultierende Datenbank aus Einzelzellbildern wird verwendet um ein $\mathrm{CNN}$ zu trainieren, das die Klassifikation von Leukozyten in ein Klassifikationsschema aus 16 morphologischen Kategorien erlaubt. Das Netzwerk wird mithilfe verschiedener Metriken getestet. Auch wird die innere Funktionsweise des Netzwerks analysiert. Ergebnisse. Das Netzwerk erkennt den blastären Charakter einzelner Zellen mit sehr hoher Genauigkeit (AUC=0,99). Ein Vergleich mit der Varianz zwischen zwei Annotatoren zeigt, das diese Präzision an die Annotationsgenauigkeit menschlicher Annotatoren heranreicht. Die wichtigsten Zelltypen werden mit hoher Sensitivität und Spezifität erkannt, für im Datensatz in geringerer Zahl vertretene Zelltypen ist die Klassifikationsgenauigkeit allerdings geringer. Saliency maps zur Analyse der Vorhersagen des Netzwerks zeigen, dass die Klassifikation der Einzelzellbilder auf morphologisch relevanten Bereichen der Bilddaten beruht.

Fazit. Auch in der zytomorphologischen Diagnostik der AML setzt der erfolgreiche Einsatz von CNNs zur Klassifikation mikroskopischer Bilddaten eine ausreichen hohe Qualität sowohl der Digitalisierung als auch des Annotation voraus. Sind diese Anforderungen erfüllt, so kann eine sehr hohe Vorhersagequalität, etwa in Bezug auf den blastären Charakter von Leukozyten, erreicht werden.

\section{DGP36.03 \\ Hochgenaue Erkennung von Gewebearten an histologischen Schnitten mit convolutional neural networks (CNNs)}

\section{A. Turzynski ${ }^{1 *}$, U. Jacobs', J. Lotz' ${ }^{2}$ S. Heldmann ${ }^{2}$, A. Lebeau' \\ ${ }^{1}$ Gemeinschaftspraxis für Pathologie, Lübeck, Deutschland, ${ }^{2}$ Fraunhofer- Institut für Digitale Medizin MEVIS, Lübeck, Deutschland}

Ziel. Umfassende Erkennung von Gewebearten an Bildausschnitten gescannter histologischer Schnitte (WSI; whole slide images) durch einen auf neuronalen Netzen basierten TissueClassifier.

Methoden. Bildkacheln mit einer Kantenlänge von 1024 Pixeln $(=512 \mu \mathrm{m})$ aus WSI (Scanner: Pannoramic MIDI, Fa. Sysmex) wurden bezüglich der Gewebeart annotiert. Die Gewebeklassen umfassten im Pilotdatensatz 27, im Endausbau 46 verschiedene Gewebearten. Sie deckten damit weitgehend alle Gewebearten ab, die in der Routinehistologie vorkommen. Mit diesem Datensatz von zunächst 30.000, schließlich über 70.000 Einzelbildern wurden verschiedene Netzarchitekturen (VGG 16, ResNet 50, InceptionV3, MobileNetV2, DenseNet121, DenseNet201 und andere) durch Transferlernen mit Tensorflow/Keras trainiert. Die neuronalen Netze wurden durch verschiedene Anpassungen, Datenaugmentation und Regularisation optimiert. Die Erkennungsgenauigkeit wurde im Trainings-, Validierungs- und Testdatensatz gemessen. Die Einzelergebnisse wurden in Kontingenztabellen ausgewertet.

Ergebnisse. Mit allen verwendeten Netzwerkarchitekturen konnte in der Pilotphase mit 27 Klassen eine Vorhersagegenauigkeit von 97,8 bis 99,19\% im Testdatensatz erreicht werden. Keines der verwendeten Netze zeigt eine nennenswerte Überanpassung im Validierungsdatensatz. Nach Korrektur von Annotationsfehlern und Ausweitung der Trainingsdaten auf über 70.000 Bilder in 46 Klassen ließ sich eine Erkennungsgenauigkeit des TissueClassifiers auf Basis von DenseNet121 (TCDN46) von 99,5\% erzielen. Ein zweiter separat erstellter Datensatz als Testdatensatz mit 18.000 Bil- 
dern lieferte eine Erkennungsgenauigkeit von 97,9 \%. Die Erkennungsfehler betrafen dabei überwiegend eng verwandte Gewebe.

Fazit. Die Gewebeerkennung an Bildkacheln aus gescannten Schnittpräparaten ist mithilfe von neuronalen Netzen mit hoher Zuverlässigkeit möglich. Auch komplexe Multiclass-Klassifikationsaufgaben in der Histologie lassen sich prinzipiell mit neuronalen Netzen lösen. Der vorgestellte TissueClassifier ermöglicht eine semantische gewebliche Feinkartierung von WSI und den Einstieg in eine gewebeangepasste computerbasierte Diagnostik.

\section{DGP36.04}

\section{Zuverlässige Detektion der Färbung von gescannten} Schnittpräparaten durch konvolutionelle neuronale Netze

\section{A. Turzynski ${ }^{*}$, A. Lebeau', U. Jacobs' ${ }^{1}$, J. Lotz'2, S. Heldmann ${ }^{2}$ \\ ${ }^{1}$ Gemeinschaftspraxis für Pathologie, Lübeck, Deutschland, ${ }^{2}$ Fraunhofer- Institut für Digitale Medizin MEVIS, Lübeck, Deutschland}

Ziel. Im Rahmen einer Computer-assistierten Diagnostik an histologischem Bildmaterial muss das Assistenzsystem Wissen über die verwendete Färbung erlangen, um entsprechende angepasste Diagnostikalgorithmen anwenden zu können. Es soll geprüft werden, ob konvolutionelle neuronale Netze $(\mathrm{CNN})$ unabhängig von der verwendeten Vergrößerung in der Lage sind, die verwendete Färbung direkt aus dem Bild zu bestimmen.

Methoden. Unterschiedliche Gewebearten (Dünndarm, Kolon, Mamma und Gewebe des Bewegungsapparates) wurden mit verschiedenen Färbungen gefärbt: HE, PAS, PAS-Alzian, Giemsa, Berliner Blau, EvG, Masson-Goldner, Feulgen und Immunfärbungen mit DAB und Hämatoxilin. Die Schnitte wurden mit dem Scanner Pannoramic MIDI (Fa. Sysmex) bei 20 -facher Vergrößerung (nativ) gescannt. Aus den Scans wurden bei 20-, 10- und 5-facher Vergrößerung Bilder aus allen Wandschichten (bei den Hohlorganen 60 \% Mukosa, 20 \% Submukosa und $20 \%$ Muscularis propria) fotografiert, die dann in Kacheln á 256 Pixel Kantenlänge zergliedert wurden. Mit dem Datenmaterial wurden verschiedene Netzarchitekturen mit Tensorflow/Keras trainiert. Es wurde die Verlustfunktion und die Vorhersagegenauigkeit der Netze in den Trainings-, Validierungs- und Testdatensätzen erfasst. Zusätzlich wurde die Präzision im Testdatensatz mithilfe einer Kontingenztabelle (confusion matrix) untersucht.

Ergebnisse. Relativ unabhängig von der verwendeten Netzarchitektur ist mit allen verwendeten Netzen eine zuverlässige Klassifikation der verwendeten Färbung anhand des Bildmaterials an sehr kleinen Bildausschnitten möglich. Die Vorhersagegenauigkeit erreichte in dem balancierten Testdatensatz je nach Netzarchitektur bis über $99 \%$. Die wenigen Zuordnungsfehler betrafen die Klassifikation der PAS- und PAS-Alzian-Färbung, die insbesondere an den nicht-mukosalen Bildern tw. nicht differenziert wurden.

Fazit. Die Klassifikation von verschiedenen Färbungen aus histologischen Bildmaterial ist relativ einfach und zuverlässig mithilfe von CNN an sehr kleinen Bildausschnitten und unabhängig von der gewählten Vergrößerung möglich. Damit lässt sich eine Fragestellung, die klassischerweise mit Methoden der konventionellen Bildanalyse zu lösen wäre, relativ einfach durch Training mit neuronalen Netzen bewerkstelligen. Ein solches neuronales Netz kann im Rahmen einer Computer-assistierten Diagnostik den Einstieg in färbungsspezifische computerbasierte Auswertungsalgorithmen darstellen.

\section{DGP36.05}

\section{Digitale Organquerschnitt-Rekonstruktion aus Einzelschnitten}

\section{C.-A. Weis* ${ }^{*}$ T. Gaiser}

Pathologisches Institut Mannheim, Mannheim, Deutschland

Ziel. In der Pathologie ist die Größe des zu untersuchenden Bereichs in der Regel an die Kapselgröße im Zuschnitt gebunden. Es gibt zwar die Möglichkeit der Großflächenschnitte, aber diese sind technisch anspruchsvoll, teuer und bezogen auf die Größe limitiert.

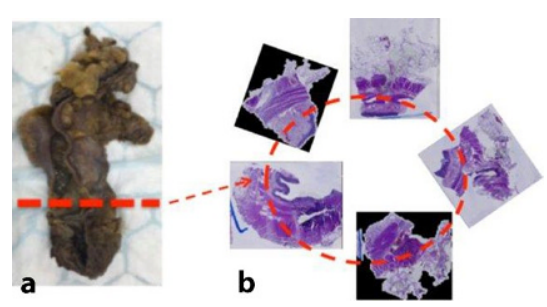

Abb. 1 | DGP36.05 Ein Organ-Querschnitt (a) wurde komplett in fünf Blöcken (b) aufgearbeitet

Unser Ziel ist es daher aus mehreren Gewebefragmenten digital einen Großflächenschnitt zu rekonstruieren. Die Methodik dafür wird in der Archäologie zum Teil erfolgreich eingesetzt, wo Artefakt-Fragmente zusammen gefügt werden, und muss daher für die Anforderungen der Digitalen Pathologie adaptiert und modifiziert werden.

Methoden. Mit bereits publizierten Methoden lassen sich dabei Kantenform- und Textur-basierte Ansätze kategorisieren. Für unsere Arbeit adaptieren wir die von Tsamoura et al. publizierte Methode „Digital Reconstruction and Mosaicing of Cultural Artifacts“ [1]. Diese löst das „Puzzleproblem“ indem die Kanten als eine Farbsequenz dargestellt werden und anschließend die Übereinstimmung der Sequenzen mit in der Bioinformatik etablierten Methoden wie dem Needleman-Wunsch-Algorithmus berechnet wird. Auf Basis der lokalen Übereinstimmung bzw. der besten Übereinstimmung der Kanten-Sequenzen werden dann die Schnittpräparate zusammen gefügt (• Abb. 1 |DGP36.05).

Ergebnisse und Fazit. Es werden Ergebnisse aus der färbungsunabhängigen Generierung von Kanten-Sequenzen, die Identifikation der relevanten, zusammengefügten Ränder und die Berechnung der globalen und lokalen Sequenz-Übereinstimmung für Miniaturansichten („thumbnails“) präsentiert.

\section{Literatur}

1. Stanco F, Battiato S, Gallo G (2017) Digital Reconstruction and Mosaicing of Cultural Artifacts. Digital Imaging for Cultural Heritage Preservation: Analysis, Restoration, and Reconstruction of Ancient Artworks. Crc Press: Florida, USA

\section{Digitale Pathologie III}

\section{DGP37.01 \\ Deep Learning zur Prädiktion der Qualität von Epitopen}

\section{F.D. Mairinger*}

Universitätsklinikum Essen, Institut für Pathologie, Essen, Deutschland

Die wohl fortschrittlichsten therapeutischen Ansätze bei einer Vielzahl an Tumoren stellen zurzeit immunmodulatorische Moleküle, allen voran sogenannte Immun-Checkpoint-Inhibitoren, dar. Das Konzept beruht aus einer Aktivierung der körpereigenen T-Zell anti-Tumorantwort, die gegen sog. Tumorneoantigene gerichtet ist. Diese Neoantigene entstehen vor allem durch mutierte und damit in Ihrer chemischen Komposition veränderte Proteine. Dennoch bilden sich bei einem Gutteil der Patienten, je nach Quelle bis zu $60 \%$, Resistenzen gegen diese Art der Therapie aus. Eine mögliche Erklärung dieser Resistenzen basiert vor allem auf der Qualität der entstandenen Neoantigene. Um eine funktionierende Immunantwort auslösen zu können, müssen diese erst ordnungsgemäß zu Epitopen prozessiert und dann zur Zelloberfläche aktiv transportiert werden. Dort werden die neuen Epitope an MHC I gebunden und können dann durch den TCR erkannt werden. Unter dem Selektionsdruck eines stark immunogenen Milieus werden Tumorzellen vor allem auf Passenger-Mutationen selektieren, welche nicht in der Lage sind, ordnungsgemäß prozessiert bzw. transportiert oder präsentiert zu werden. Darüber hinaus können diese Epitope ihre Affinität zum TCR verlieren du somit keine Antwort auslösen.

Durch den Einsatz verschiedener auf neuronalen Netzwerken beruhender Algorithmen konnten wir in unterschiedlichen Tumorentitäten (NSCLC, 
SCLC, NET, UC) die Qualität der durch Mutationen entstandenen Neoantigene hinsichtlich Ihrer Aktivierung vorhersagen und somit wichtige Indizien für ein Ansprechen auf eine Immun-Checkpoint Inhibition gewinnen. Vor allem Tumoren mit einer starken Selektion solcher Mutationen, die nicht in der Lage sind, eine anti-Tumor Immunreaktion auszulösen, zeigten deutlich verringerte Ansprech- und Überlebensraten bzw. eine deutlich verminderte Immunantwort.

Basierend auf diesen "Processing-Escapes", ggf. im Zusammenspiel mit anderen Biomarkern wie zum Beispiel einer PDL1-Expression, könnte in Zukunft die Stratifizierung von Patienten für eine Immuntherapie verbessert werden.

\section{DGP37.02}

\section{Maschinelles Lernen in der Analyse prädiktiver Marker in der Immunonkologie}

\section{Wiesweg*}

Universitätsklinikum Essen, Universität Duisburg-Essen, Innere Klinik (Tumorforschung), Westdeutsches Tumorzentrum, Essen, Deutschland

Immunonkologische Therapeutika, insbesondere PD-1/PD-L1-Antikörper, sind klinischer Standard in der Therapie zahlreicher maligner Erkrankungen. Ein objektives Ansprechen unter immunonkologischer Monotherapie erreichen jedoch etwa beim metastasierten nicht-kleinzelligen Lungenkarzinom (NSCLC) nur die Minderheit der Patienten. Verfügbare und etablierte Biomarker wie PD-L1 oder Tumormutationslast erlauben lediglich die grobe Eingrenzung der Wahrscheinlichkeit eines Ansprechens. Nach aktuellen Modellen wird die Wirksamkeit der Immuntherapie durch ein komplexes Zusammenspiel von Tumor, Microenvironment, dem Zustand des Immunsystems und möglichen Resistenzmechanismen bestimmt.

Genexpressionsanalysen aus Tumorbiopsien erfassen sowohl den Tumor als auch das umgebende Mikromilieu und erlauben einen Einblick in den Immunkontext des Tumors zu gewinnen.

Unabhängig von der eingesetzten Methodik erfordern Expressionsdaten in der Größenordnung von mehreren hundert bis Tausenden von Genen bei gleichzeitig beschränkter Kohortengröße den Einsatz geeigneter Analyseverfahren aus dem Bereich des maschinellen Lernens. Da die Anzahl der Features (Gene) die der Samples (Patienten) typischerweise weit übersteigt, sind geeignete Ansätze zur Featureauswahl zu wählen. Hier bieten einige Methoden des maschinellen Lernens implizit eine Reduktion auf die am besten geeignete Untergruppe an Features. Durch eine Kombination mit Ensemble-basierten Ansätzen kann die prinizipielle Eignung der Daten für den gewünschten Zweck geprüft und die Verallgemeinerbarkeit der Featureauswahl gesteigert werden.

Für die Erzeugung von prädiktiven Modellen sind prinzipiell zahlreiche verschiedene Methoden des maschinellen Lernens verfügbar, ohne dass vor vorneherein die beste Methode gewählt werden könnte. Sobald aus den Messdaten eine kleine Untergruppe an Features ausgewählt wurde, muss daher anhand der vorliegenden Messdaten durch Kreuzvalidierung diejenige Kombination von Methode und assoziierten Parametern gewählt werden, die die besten Ergebnisse liefert.

Durch die geschilderte Vorgehensweise konnten auf der Nanostring nCounter-Plattform prädiktive Modelle für Immuntherapie beim NSCLC (Trainingskohorte: $n=55$ ) erzeugt werden, die in einer Validierungskohorte $(n=36)$ eine Subgruppe identifizierte, die von Immuntherapie profitierte $(\mathrm{HR}=0.32, p=0.035)$. Die gewonnene Information war komplementär zum PD-L1-Status.

\section{DGP37.03}

Liquid-Biobanking: Deep learning unterstütze Eingangskontrollen als Ansatz zur Verbesserung der Probenqualität

N. Buschhüter', S. Asman', E. Kusak' ${ }^{\text {, }}$, P. Hossner', J. N. Kather', E. Dahl' 'RWTH centralized Biomaterial Bank (RWTH CBMB), Medizinische Fakultät, Uniklinik RWTH Aachen, Aachen, Deutschland, ${ }^{2}$ Internal Medicine III, RWTH University Hospital, Aachen, Deutschland
Ziel. Bereits kleine Abweichungen von Standard Operating Procedures (SOPs) in präanalytischen Probenverarbeitungsprozessen humaner Biomaterialien können einen Einfluss auf spätere Analysen und Forschungsergebnisse nehmen (vgl. [1, 2]). Im Rahmen der Blutentnahmen betreffen diese Abweichungen z. B. die korrekte Befüllung des Entnahmeröhrchens. Es erscheint daher sinnvoll, bereits möglichst früh im Probengewinnungsprozess konsequent Qualitätsparameter zu erfassen (vgl. [3]). Im Rahmen dieses Forschungsprojekts sollen mit Hilfe von mobilen Apps sowie histopathologischen Scans (teil-)automatisierte Qualitätsparameter erhoben werden, die zu einer Steigerung der Probenqualität und des Wertes für die Forschung führen.

Methoden. In die Biobank eingehendes Biomaterial wird sofort bei Probeneingang mit Hilfe einer mobilen App registriert und dokumentiert (sog. „Eingangskontrolle“). Dabei wird für Flüssigproben (Blut, Urin) der Typ des Entnahmeröhrchens sowie das Volumen mittels Deep Learning erkannt und dokumentiert. Hierzu wird ein Convolutional Network (Unet) [4] auf verschiedene Typen von Entnahmeröhrchen und Füllstände trainiert. Zusätzlich wird eine optische Begutachtung auf mögliche präanalytische Störfaktoren (u. a. Hämolyse, Lipämie) durchgeführt. Für Gewebeproben wird neben der makroskopischen Begutachtung ein Gefrierschnitt angefertigt und gefärbt, welcher anschließend digital eingescannt und histopathologisch beurteilt wird.

Ergebnisse. Die Verwendung einer mobilen App ermöglicht eine fließende Integration der anfallenden Dokumentation in den laufenden Probenverarbeitungsprozess. Durch die gewonnenen Qualitätsparameter lassen sich zu jeder in die Biobank eingelagerten Biomaterialprobe genauere Informationen zur Eignung für bestimmte Analysen ableiten, so dass der Wert der Proben für die Forschung steigt. Mit Hilfe von Analysetools lassen sich außerdem Verbesserungspotentiale im Verarbeitungsprozess aus den gewonnenen Daten identifizieren.

Fazit. Durch den Einsatz von Deep Learning lassen sich sowohl für Flüssigproben als auch Gewebeproben verschiedenste Qualitätsparameter automatisiert erfassen, jedoch momentan noch nicht alle potentiellen Fehler vor Probeneingang in die Biobank erfassen. Zukünftig sollten gerade im Liquid Biobanking über cut-off Werte klar definierte Qualitätskriterien Anwendung finden, um den oft begrenzten Lagerplatz ausschließlich für qualitativ hochwertige Proben vorzuhalten.

\section{DGP37.04}

\section{Automatisierte Tumor Bud Quantifizierung in Pan-Cytokeratin gefärbtem Kolonkarzinom}

M. Bergler', M. Benz', D. Rauber', D. Hartmann', V. Bruns', T. Wittenberg',

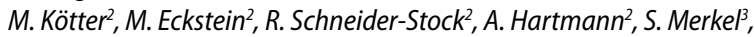
C. Geppert ${ }^{2 *}$

${ }^{1}$ Fraunhofer-Institut für Integrierte Schaltungen IIS, Bildverarbeitung und Medizintechnik, Erlangen, Deutschland, ${ }^{2}$ Institute of Pathology, University Hospital Erlangen, Friedrich-Alexander Universität Erlangen-Nürnberg, Erlangen, Deutschland, ${ }^{3}$ Department of Surgery, University Hospital, Friedrich-Alexander-University Erlangen-Nürnberg, Erlangen, Deutschland

Ziel. In der Pathologie wird überwiegend visuell mit einem Mikroskops diagnostiziert. Routinemäßige Aufgaben wie das Zählen von Zellen sind daher aufwändig. Das Tumor-Budding wird aktuell als ein neuer, unabhängiger prognostischer Faktor für das Kolonkarzinom diskutiert. Dafür müssen die Zellen an der Invasionsfront zunächst für das Budding geschätzt, in einem Sichtfeld von $0,785 \mathrm{~mm}^{2}$ (Hotspot) ausgezählt und klassifiziert werden. Da diese Methodik einen hohen Aufwand darstellt, wurde ein automatisiertes Analyseverfahren entwickelt, das den Pathologen unterstützen soll.

Methoden. Zur automatisierten Quantifizierung wird ein dreistufiges Verfahren angewendet, basierend auf Methoden der klassischen Bildverarbeitung und des Deep Learnings. Im ersten Schritt werden in den digitalisierten Slides mögliche Kandidaten für Buds detektiert: Dazu wird zunächst ein Grauwertbild aus dem B-Kanal des RGB-Raums erstellt, geglättet und ein Binärbild berechnet, um Masken der immun-histochemisch markierten Zellen zu erhalten. Anschließend werden aus den Masken anhand geo- 
metrischer Merkmale potenzielle Buds detektiert. Die Abstände der Buds zu benachbarten Zellclustern oder dem Tumor werden mittels morphologischer Operatoren überprüft. Zudem wird die Kontur des möglichen Tumor Buds bestimmt. Im zweiten Schritt wird ein Convolutional Neural Network verwendet um die Kandidaten in die Klassen „Bud“ bzw. „Kein Bud“" zu klassifizieren und Cluster von fünf oder mehr Zellen und Artefakte auszuschließen. Im dritten Schritt wird aus den Positionen der resultierenden Tumor Buds die zugehörigen Hotspots berechnet und visualisiert. Ergebnisse. Für die Entwicklung des Verfahrens wurden 87 Objektträger (OT) des UKER zur Verfügung gestellt. Diese wurden mit zwei Scannern (3DHISTECH, Pannoramic P250 \& Pannoramic Scan) mit einem $40 \times$ Plan-Achromat Objektiv und einer VCC-FC60FRI19CL Kamera (CIS) digitalisiert und annotiert. Die Datenbank wurde in Trainings- (51 OTs mit 27.980 Buds), Validierungs- (18 OTs, 4362 Buds) und Testdatensatz (18 OT, 8169 Buds) aufgeteilt. Die Tumor Buds des Testdatensatzes wurden mit einer Genauigkeit von $98 \%$ und einer Sensitivität von $93 \%$ detektiert. Die Evaluierung, bezogen auf die daraus abgeleiteten Hotspots, erfolgt derzeit. Fazit. Die Ergebnisse zeigen, dass die Methodik automatisch und zuverlässig Tumor Buds in einer Pan-Cytokeratin Färbung detektieren kann. Die Evaluierung der Quantifizierung der Tumor Buds anhand der Hotspots wird derzeit durchgeführt.

\section{German-Hungarian Workshop I}

\section{DGP38.01}

\section{Liquid biopsy to detect synovial sarcoma: can we use it as a diagnostic/prognostic tool?}

\section{Z. Sápi*, D. Mihály, G. Papp}

Semmelweis University, First Department of Pathology and Experimental Cancer Research, Budapest, Hungary

Synovial sarcoma is a rare soft tissue tumor which contains the unique SS18-SSX1, SS18-SSX2-or, rarely, SS18-SSX4-fusion transcripts. It is well known that some soft tissue tumors, like Ewing sarcomas and myxoid liposarcomas, can spread via the blood with free circulating tumor cells (CTC); this can be detected by several sensitive molecular biology methods. Here we report a study of fifteen synovial sarcoma patients with varied clinical backgrounds. After blood withdrawal and nucleic acid isolation, we attempted to detect the SS18-SSX fusion genes from circulating tumor cells or cell-free nucleic acids with nested PCR and droplet digital PCR. SS18SSX2 fusion transcript was identified in a small copy number with droplet digital PCR in one case. Nested PCR could not detect any of the fusion transcripts in the examined 15 synovial sarcoma cases. Heretofore two case reports could detect CTCs in synovial sarcoma-in the first paper, the patient was diagnosed with poorly differentiated type while the other had a rare primary gastric synovial sarcoma. However, until now no other studies have detected CTCs in the peripheral blood of synovial sarcoma patients. Based on our findings, we can conclude that detection of the chimeric SS18-SSX fusion gene after surgical excision and/or chemotherapy/radiotherapy is a rare circumstance and hence in itself is not sufficient for monitoring the tumor recurrence. Therefore, monitoring of other possible biomarkers-for example synovial sarcoma specific miRNAs-is recommended.

\section{DGP38.02}

\section{Establishment of a human mesenchymal SS18-SSX1 expressing} cell line

\section{Mihály*, G. Papp, Z. Sápi}

1st Department of Pathology and Experimental Cancer Research, Budapest, Hungary

Synovial sarcoma is the third most common malignant soft tissue tumor, linked with the specific SS18-SSX (SYT-SSX) translocation. Multiple model systems including mouse cell lines expressing SS18-SSX, and genetically engineered mouse models of synovial sarcoma have been developed to elucidate the role of the chimeric gene in synovial sarcomagenesis. Although several cell lines stably expressing human SS18-SSX exist, there is an ongoing need for cell culture models that enable researchers to investigate the molecular mechanism of SS18-SSX action in a relevant cellular context.

In this study we report the establishment of a novel SS18-SSX1-expressing cell line created from immortalized human adipose tissue-derived mesenchymal stem cells via lentiviral transduction of the chimeric gene. The cell line, termed SS-iASC, has been characterized by STR analysis and karyotyping. Stable expression of the fusion transcript SS18-SSX1 has been proved using RT-PCR, nested PCR, immunofluorescence, and immunoblotting. Both RT-PCR and nested PCR verified the stable expression of SS18-SSX1 fusion gene. Focal cytokeratin positivity characteristic of synovial sarcoma but no $\beta$-Catenin, Bcl-2 or cyclin D1 expression was observed in SS-iASC.

The novel cell line expressing SS18-SSX1 on a human adipose-derived stromal cell background is expected to be helpful in addressing the question whether the chimeric gene alone is sufficient to trigger the formation of synovial sarcoma.

\section{DGP38.03}

\section{Epigenetic silencing of TFPI-2 in cervical cancer}

I. Kovalszky*, A. Fullár, K. Karászi

Semmelweis University, 1st Institute of Pathology \& Experimental Cancer Research, Budapest, Hungary

Background. TFPI2 a Kunitz type serine protease inhibitor was described in 1994. The protein resides in the extracellular matrix and binds heparin/ HS with high affinity. In the last ten years more and more evidence were gathered, indicating the role of TFPI2 in the inhibition of tumor invasion. These data resulted in the conclusion that TFPI2 acts as a tumor suppressor molecule. In our studies comparison of mRNA microarray of normal fibroblasts from uterus cervix to cervical cancer derived cancer associated fibroblasts (CAF) revealed, that the expression of TFPI2 is twelve times lower in the latter, being the most downregulated mRNA of CAFs.

Aims. Our aim was to clarify if cancer cells are capable to downregulate TFPI2 expression in normal and cancer associated fibroblast and if they do so, what is the mechanism they utilize for that purpose?

Methods. Immunohistochemistry, Western blots, promoter methylation, of the gene and miR profile of tumor cells, and normal and tumor associated fibroblast were studied.

Results. Immunohistochemistry revealed that surgically removed cervical cancer specimens progressively lose TFPI 2 protein. Western blot of primary CAF cultures showed considerable, significant decrease of protein expression, as well. Direct co-culture of cervical cancer cells with normal, TFPI2 expressing, and tumor associated fibroblast proved the potential of cancer cells to downregulate the protease inhibitor in fibroblasts.

Promoters of TFPI 2 in cancer cells were fully methylated, however, only modest or no promoter methylation was found in CAF samples.

MicroRNA regulation has been expected, as an alternative option for TFPI2 mRNA inactivation. Studying a series of miRNA, mir616, 646, 554 and 3629 showed partial agreement with the changes in TFPI2, whereas full correlation was found with miR-23a, indicating its possible role in the regulation of TFPI 2 expression. Four from six miR database confirmed the regulatory role of miR23a, furthermore it has has a binding site at the 3 ' untranslated region of TFPI2. The regulatory role of miR 23a was further supported by administering its mimic and inhibitory compound. It is a further question how tumor cells are able to upregulate the promoter activity of miR23? This is the first report on the regulatory role of miR 23a on cancer associated fibroblasts of cervical cancer. 


\section{DGP38.04}

\section{Elevated Ki-67 and claudin-1 expression in penile squamous cell carcinoma depending on HPV status}

\section{E. Kontsek*, A. Budai, J. Karczub, P. Törzsök, Z. Schaff, A. Kiss \\ Semmelweis University, II. Institute of Pathology, Budapest, Hungary}

Introduction. Approximately $40-70 \%$ of penile cancers are HPV-associated. Several intercellular adhesion proteins are described as having a significant role in the process of carcinogenesis, with Claudins being prominent members of these. Possible association has also been raised between Claudin-1 and HPV.

Aims. Our aims were to investigate the expression of Claudin-1, E-Cadherin, Ki-67, p16 and p53 in penile carcinomas and precancerous lesions with respect of HPV infection and typing.

Methods. Tissue Microarrays (TMAs) were assembled from surgical biopsies of 28 patients with penile Squamous Cell Carcinomas (SCC), 5 patients with verrucous penile cancer (VERR), and 3 cases of lichen sclerosus (LS). Surrounding non-cancerous tissues were also available in 18 of the 28 SCCs and 4 of the 5 VERRs. Age matched circumcision specimens of 6 patients were used as controls. TMAs were stained for Claudin-1, E-Cadherin, Ki-67, p16 and p53 using a Benchmark XT automated IHC system. Claudin-1/Ki-67 and p16/Ki-67 dual IHC staining procedures were also performed. HPV status was determined using PCR (Genoid/Synlab). Results. The Ki-67 index in SCCs was significantly higher when compared with their surrounding non-cancerous tissue (SCC_SURR) and normal skin $(p<0.01)$. E-Cadherin expression was significantly reduced in SCCs $(p<0.01)$ and VERRs $(p<0.01)$ in comparison to controls. Claudin-1 expression was significantly elevated in SCCs and in SCC_SURR when compared with controls $(p<0.01)$. Further, VERR exhibited decreased expression of Claudin-1 in SCC_SURR $(p<0.05) 71.43 \%$ of SCCs tested negative for HPV while $28.57 \%$ was HPV-positive. All 5 cases of VERR proved HPV-negative. Expression of Claudin-1 was significantly higher in HPV-positive SCCs when compared with HPV-negative cases $(p=0.03)$. Claudin-1/Ki-67 dual IHC staining was negative in 1 of $20 \mathrm{HPV}$-negative SCCs, while only being positive for one of $8 \mathrm{HPV}$ positive cases. $55 \%$ of HPV-negative SCCs were positive for p16/Ki-67 dual IHC staining, while $87.5 \%$ of HPV-positive cases stained positive with p16/Ki-67.

Conclusions. Ki-67 and Claudin-1 expression is significantly elevated in penile squamous cell carcinoma, while surrounding non tumorous tissue showed only increased expression of Claudin-1. Therefore, elevated Claudin-1 expression might indicate higher risk for malignant transformation. In this present study, p16/Ki-67 dual IHC staining had higher association with squamous cell carcinoma then Claudin-1/Ki-67.

\section{DGP38.06 \\ Diagnostic programmed death-ligand1 testing in triple negative breast cancer: the pathologists' perspective}

\section{A. Bankfalvi* \\ University Hospital Essen, Institute of Pathology, Essen, Germany}

Over the last few years, immune checkpoint Inhibitors, particularly those that act by blocking the programmed cell death receptor-1 (PD-1) and its ligand the programmed death ligand-1 (PD-L1), have emerged as novel treatment strategies in patients with several types of advanced stage cancer. Expression of PD-L1 by immunohistochemistry (IHC) staining has been the core strategy to select patients for PD-(L)1 inhibitors. As each PD1/ PD-L1 inhibitor has its own PD-L1 assay that has been developed and approved parallel with the therapeutic agents, PD-L1 testing is puzzled by multiple unsolved issues such as the use of different antibodies and staining platforms, the type of cells in which PD-L1 is assessed (tumor versus immune cells), thresholds used for PD-L1-positivity, or the source and timing for sample collection. A number of studies have examined, others have reviewed comprehensively the comparability and interchangeability of different PD-L1 tests across various types of cancers.

In breast cancer, the pace of development of immunotherapies has long been dampened by the enormous heterogeneity and the significant pro- portion of non-immunogenic subtypes of this difficult to treat disease. The first immunotherapy regimen for breast cancer has gained accelerated approval by the US Food and Drug Administration (FDA) in March 2019. The regulatory approval applies to the PD-L1 inhibitor atezolizumab in combination with nab-paclitaxel for PD-L1 positive unresectable locally advanced or metastatic triple-negative breast cancer (TNBC), together with Roche's Ventana PD-L1 (SP142) assay as first companion diagnostic. Approval was based on significantly increased progression-free survival upon this therapy in the Impassion 130 trial (Schmid P et al.; NEJM 2018). As a consequence, pathologists can expect rapidly increasing demand for PD-L1 testing also in breast cancer. Therefore, expertise in performing proper PD-L1 IHC assays by appropriately trained pathologists is critical for helping the clinicians distinguishing responders from non-responders for different regimes of immunotherapy.

This short methodology centered review discusses practical issues of test performance, scoring method and interpretation of results using the Ventana PD-L1 (SP142) assay (Roche) as companion diagnostic device for selecting TNBC patients for atezolizumab based combined immunotherapy from the pathologists' point of view.

\section{German-Hungarian Workshop II}

\section{DGP39.01 \\ Methylselenocysteine-sorafenib co-treatment results in severely decreased cell viability of liver cancer cell}

A. Kiss' ${ }^{1 *}$, T. Szekerczés', G. Lendvai', E. Kontsek', Z. Schaff', A. Szakos², M. Björnstedt ${ }^{2}$

'Semmelweis University, II. Institute of Pathology, Budapest, Hungary, ${ }^{2}$ Karolinska Institutet and Karolinska University Hospital, Stockholm, Sweden

Background. Methylselenocysteine (MSC) is a naturally occurring selenium compound. Nevertheless, it shows high efficacy against tumor cells as its metabolites, methylselenol, has anti-tumoral effects. In the cell, MSC is metabolized by kynurenine aminotransferases (KYAT) and the metabolite methylselenol seems to be a potent inducer of apoptosis in cancer cells independent of TP53. Normal cells, in contrast, with their balanced metabolic processes are protected and can avoid this harmful effect. In the present study, we aimed to investigate the combination of MSC treatment with sorafenib, whether the cytotoxicity could be further increased.

Methods. The investigation was performed on HepG2 (hepatocellular carcinoma) and HLE (hepatoma) cells using 96-well plates and 6000 cell seeding density. After a $24 \mathrm{~h}$ long seeding, the medium was replaced by fresh medium containing the following drugs: MSC, MSC together with different KYAT1 activators (A1, A2, A3, A4), sorafenib, MSC + sorafenib and the combination of MSC with activators + sorafenib. The concentration range was chosen based on the IC50 values of each single treatment. The cells were incubated for 24,48 and $72 \mathrm{~h}$. The inhibitory effect of the drugs was detected by sulforhodamine B colorimetric test and was expressed as cell viability compared to the proliferation percentage of normal, untreated cells (100\%).

Results. Although we tested different time points, the highest effect was seen at $72 \mathrm{~h}$ time point. The KYAT1 activators have basically no inhibitory effect, but when these were administered together with MSC, the cell viability was further decreased in HepG2 but not in HLE cells. In contrast, when sorafenib was added to MSC or to MSC supplemented with activators, a further remarkable decline was observed in cell viability.

Conclusion. Combination treatment of MSC with KYAT activators and sorafenib is more effective than single treatments or MSC and KYAT activator dual treatment. 


\section{DGP39.03}

\section{Human liver regeneration following massive hepatic necrosis}

\section{K. Dezsö* , S. Paku, P. Nagy}

Semmelweis University, First Department of Pathology and Experimental Cancer Research, Budapest, Hungary

Massive hepatic necrosis (MHN) characterized by extensive loss of hepatocytes is a critical event underlying acute liver failure. Elevated serum alpha-fetoprotein (AFP) levels are frequently associated with better prognosis and some of the patients can recover spontaneously without liver transplantation. It is known that surviving hepatocytes and/or progenitor cells can participate in this regenerative process, but the mechanism of hepatic recovery is vague.

We examined thirteen explanted human livers removed for acute liver failure. The evaluation of the specimens was performed blindly to the clinical data. Combined immunohistochemistry, digital image analysis and 3D reconstruction of serial sections were applied. Based on the histological reactions the cases could be classified into 3 groups:

1. The first group of livers was characterized by centrilobular necrosis and no signs of regeneration in the surviving parenchyma.

2. In the second group of livers, the morphological pattern was also dominated by centrilobular necrosis. However, the surviving periportal hepatocytes started to proliferate and arranged into acinar structures and surprisingly expressed AFP.

3. The third group of livers was characterized by almost complete parenchymal loss and intense ductular proliferation. The cells at the distal pole of the ductules differentiated into hepatocytes, which later formed foci organized by branches of the portal vein. The expanding foci containing complete portal triads were arranged around surviving central veins. The fusion of these foci could be an attempt to re-establish the hepatic lobules.

Conclusion. While the first group of livers might represent the initial phase of liver injury, the other groups represent two alternative patterns of regeneration. We propose that regeneration is driven by surviving, AFP positive "dedifferentiated" hepatocytes in the second group of livers, but by ductular/progenitor cells in the third group.

\section{DGP39.04}

\section{ALPPS: Failures at the energetic level}

\section{A. Budai ${ }^{*}$, A. Fülöp ${ }^{2}$, P. Anker², A. Kiss' ${ }^{1}$ A. Szijártó2}

'Semmelweis University, 2nd Department of Pathology, Budapest, Hungary, ${ }^{2}$ Semmelweis University, 1st Department of Surgery, Budapest, Hungary

Background and aims. Associating Liver Partition and Portal vein Ligation for Staged hepatectomy (ALPPS) is a novel two-staged hepatectomy strategy, which induces immense regeneration in the remnant liver. However, the fast volume gain has the benefit for resectability, this technique presents alarmingly high mortality and morbidity rates. The aim of this study was to evaluate the background of this significant vulnerability of patients underwent ALPPS by assessing mitochondrial function, biogenesis and morphology during ALPSS induces liver regeneration.

Methods. Male Wistar rats $(n=100)$ underwent portal vein ligation (PVL) or ALPPS. The animals were sacrificed at 0 (without operation) and 24 , 48,72 or $168 \mathrm{~h}$ after the interventions. Regeneration rate was calculated and proliferation index was assessed. Mitochondrial oxygen consumption was evaluated using high-resolution oxygraphy and ATP production was measured by spectrophotometry. Mitochondrial biogenesis was evaluated by the western blot measurement of the protein levels of the peroxisome proliferator-activated receptor gamma coactivator 1-alpha (PGC1- $\alpha)$ nuclear respiratory factor- 1 and -2 (NRF1, NRF2) and mitochondrial transcription factor alpha (mTFA). In addition, mitochondrial morphology was evaluated by electron microscopy.

Results. The regeneration rate and the Ki-67 index were significantly elevated in the ALPPS group compared to the PVL group. $(p<0.01)$ In the ALPPS group mitochondrial state 3 and state 4 ATP production and oxygen consumption levels were significantly lower $48 \mathrm{~h}$ after the inter- ventions comparing to the PVL group. $(p<0.05)$ Along with this, mitochondrial biogenesis was diminished, as PGC1- $\alpha$ and NFR1 levels were significantly decreased 48 and $72 \mathrm{~h}$ after ALPPS compared to the PVL group $(p<0.05)$. Besides, mitochondrial size was significantly decreased in the ALPPS treated group.

Conclusion. The deteriorations in mitochondrial function and biogenesis alongside with the fast and energy demanding cell proliferation can cause the energetic destabilization of the hepatocytes, which might be a significant factor in the higher vulnerability of patients underwent ALPPS.

\section{DGP39.06}

\section{Soluble and living biomarkers derived from pleural dissemination}

B. Hegedüs ${ }^{*}$, A. Bankfalvi', T. Plönes' ${ }^{1}$ P. Stockhammer ${ }^{3}$, L. Hegedüs', Ö. Okumus', C. Ho ${ }^{4}$, D. Rittler ${ }^{5}$, G. Lotz ${ }^{5}$, I. Kovacs', B. Döme', F. Bonella', K. W. Schmidt ${ }^{2}$, M. Schuler ${ }^{4}$, A. Schramm ${ }^{4}$, C. Aigner ${ }^{7}$

'Universitätsmedizin Essen-Ruhrlandklinik, Thoraxchirurgie, Essen, Germany, ${ }^{2}$ Universitätsklinikum Essen, Pathologie, Essen, Germany, ${ }^{3}$ Medical University Vienna, Thoraxchirurgie, Vienna, Austria, ${ }^{4}$ Universitätsklinikum Essen, Onkologie, Essen, Germany, ${ }^{5}$ Semmelweis Universität, II Pathologie, Budapest, Hungary, ${ }^{6}$ National Institute of Pulmonology, Tumorbiologie, Budapest, Hungary, ${ }^{7}$ Universitätsmedizin Essen-Ruhrlandklinik, Pulmonologie, Essen, Germany

Pleural dissemination is a major challenge in cancer therapy and the treatment options for patients with malignant pleural effusions and carcinosis are rather limited. Not only the estimation of prognosis remains to be burdensome but personalized therapeutic strategies require predictive biomarkers. Between June 2016 and February 2019 sixty malignant pleural mesothelioma, 53 lung and 34 extrathoracic primary cancer patients with pleural involvement was included. We characterized two novel biomarkers for mesothelioma both in plasma and effusion and compared to soluble mesothelin related protein (SMRP). Additionally, the sensitivity against currently approved therapeutic agents has been tested in 9 out of the 22 novel pleural effusion or carcinosis derived cell models. Finally, we also established 4 novel xenograft models to explore tumorigenicity and later determine in vivo drug efficacies. Altogether the comprehensive analysis of soluble and cellular components of pleural effusion and carcinosis can identify novel biomarkers and resistance mechanisms as well as potentially predict sensitivity against systemic therapeutic drugs.

\section{Vortrag des Rudolf-Virchow-Preisträgers 2018}

\section{DGP40 \\ MIF in Nierenerkrankungen. Eine Geschichte über Dr. Jekyll und Mr. Hyde}

P. Boor*

RWTH Aachen, Aachen, Deutschland

Hintergrund. Macrophage migration inhibitory factor (MIF) ist ein Zytokin, das bei einer Vielzahl von Erkrankungen, einschließlich Atherosklerose, Autoimmunkrankheiten, Sepsis und Glomerulonephritiden eine proinflammatorische Rolle spielt.

Material und Methoden. In unseren Studien haben wir die Funktion von MIF auf die residenten Nierenzellen, insbesondere die renalen Tubulusepithelien untersucht.

Ergebnisse. Wir konnten zeigen, dass MIF direkte lokale Effekte auf die pathologische Proliferation von glomerulären Zellen ausübt, insbesondere auf die parietalen Epithelzellen und Mesangialzellen, und dadurch den Krankheitsverlauf einer immunvermittelten Glomerulonephritis aggraviert. Im Gegensatz dazu haben wir in einer Reihe von Tier- und in vitro-Experimenten gezeigt, dass MIF im Rahmen einer chronischen Nierenerkrankung eine unerwartet stark antifibrotische und entzündungshemmende Wirkung hat. Dies ist mechanistisch durch Förderung der Regeneration und Hemmung des Zellzyklusarrestes der tubulären Epi- 
thelzellen vermittelt. Schließlich haben wir in einem kombinierten Ansatz unter Verwendung von klinischen Studien und von Tiermodellen sowie mittels in vitro-Experimenten gezeigt, dass MIF auch im Rahmen der akuten Nierenschädigung renoprotektiv wirkt. In diesem Kontext modulierte MIF den programmierten Zelltod, d.h. Nekroptose und Ferroptose, und verringerte dadurch die Nekroinflammation und den Nierenschaden. Schlussfolgerungen. MIF hat eine duale Rolle bei Nierenerkrankungen, einerseits fördert es immunvermittelte glomeruläre Erkrankungen, andererseits limitiert es tubulären Zellschaden bei akuten und chronischen Nierenerkrankungen. Diese Daten weisen auf mögliche Nebenwirkungen von systemischen MIF-gerichteten Therapien hin, eröffnen aber auch neue Möglichkeiten einer Tubuluszell-gerichteten Therapie von MIF oder seinen Analoga.

\section{Vortrag der Rudolf-Virchow-Preisträgerin 2019}

\section{H04.04 \\ Dynamik genomischer Alterationen in der Morbus Crohn- assoziierten kolorektalen Karzinogenese}

D. Hirsch ${ }^{1 * 2}$

'Universitätsmedizin Mannheim, Pathologisches Institut, Mannheim, Deutschland, ${ }^{2}$ National Institutes of Health, National Cancer Institute, Center for Cancer Research, Bethesda, USA

Ziel. Ähnlich wie bei Colitis ulcerosa haben auch Patienten mit Morbus Crohn und entzündlicher Beteiligung des Kolons ein erhöhtes Risiko für die Entstehung eines kolorektalen Karzinoms (KRK). Hauptsächlich auf Colitis ulcerosa basierende Daten weisen auf TP53-Mutationen als initialen Schritt in der Progression von entzündeter Kolonmukosa zu KRK hin. Um Einblicke in die kolorektale Tumorevolution bei Morbus Crohn zu gewinnen, untersuchten wir multiple synchrone, präkanzeröse Läsionen in verschiedenen Stadien der Tumorentwicklung und Morbus Crohnassoziierte KRK.

Methoden. Wir analysierten 73 Gewebeproben von 28 Patienten mit Morbus-assoziiertem KRK einschließlich Vorläuferläsionen mittels Sequenzierung der nächsten Generation (563-Gen-Panel) und Array-basierter komparativer genomischer Hybridisierung. Die Ergebnisse verglichen wir mit eigenen Daten und Daten des „The Cancer Genome Atlas“ zu sporadischen KRK.

Ergebnisse. Morbus Crohn-assoziierte KRK wiesen signifikant häufiger Zugewinne von Chromosomarm $5 p$ auf, zeigten ansonsten aber ein ähnliches Muster chromosomaler Aneuploidien wie sporadische KRK. Auch das Mutationsspektrum unterschied sich, wobei TP53 das mit Abstand am häufigsten mutierte Gen in Morbus Crohn-assoziierten KRK war, während $A P C$ - und KRAS-Mutationen im Vergleich zu sporadischen KRK seltener auftraten. In der Tumorprogression bei Morbus Crohn traten TP53-Mutationen und chromosomale Aneuploidien früh auf und waren gelegentlich bereits in Kolonmukosa ohne histologischen Nachweis von Dysplasien nachweisbar (okkulte Tumorevolution). Phylogenetische Analysen multipler synchroner Läsionen ergaben zwei Mechanismen der Progression bei Morbus Crohn: Feldkanzerisierung und klonaler Mosaizismus.

Fazit. Die Morbus Crohn-assoziierte kolorektale Karzinogenese zeigte ein entzündungsassoziiertes Muster genomischer Alterationen mit Zugewinnen von $5 \mathrm{p}$ und TP53-Mutationen als frühe Ereignisse in der Tumorentwicklung. Die Detektion dieser Aberrationen in Vorläuferläsionen kann möglicherweise helfen die Krankheitsprogression vorherzusagen und unterscheidet Morbus Crohn-assoziierte von sporadischen Neoplasien.

\section{Arbeitsgemeinschaften der Deutschen Gesellschaft für Pathologie e.V.}

\author{
AG Gastroenteropathologie I
}

AG01.01

Die molekularen Subgruppen beim Adenokarzinom des Magens zeigen keine Korrelation mit einem Durchbruch durch die Lymphknotenkapsel

R. Todorova ${ }^{1 *}$, F. Bösch', T. Kirchner', M. Angele ${ }^{2}$, J. Neumann ${ }^{1}$

'Pathologisches Institut der LMU, München, Deutschland, ${ }^{2}$ Klinik für Allgemein-, Viszeral- und Transplantationschirurgie am Klinikum der Universität München, München, Deutschland

Ziel. Ein Durchbruch durch die Lymphknotenkapsel mit konsekutivem extrakapsulärerem Wachstum (ECG) bei lymphogen metastasierten Adenokarzinomen des Magens ist mit einer schlechteren Prognose assoziiert. Genomweite Studien konnten zeigen, dass das Magenkarzinome in vier molekulare Subgruppen (Ebstein-Barr Virus- (EBV) assoziiert, MSI-Typ, Chromosomal instabiler Typ (p53-aberrant) und genomisch stabiler Typ (EBV negativ, p53 reguliert und MSS)) unterteilt werden können. Ziel dieser Studie war es zu untersuchen ob eine Korrelation zwischen den molekularen Subtypen des Magenkarzinoms und einem ECG besteht.

Methoden. Im Rahmen der Studie wurden insgesamt 189 lymphogen metastasierte Adenokarzinome des Magens (102 vom intestinalen, 65 vom diffusen und 22 vom Mischtyp nach Lauren) untersucht. Davon zeigten 68 ein ECG der Lymphknotenmetasten. Die Expression von p53, der mismatch-repair-genprodukte MLH1, PMS2, MSH2 und MSH6 sowie von E-Cadherin wurde immunhistochemisch untersucht. Für die Evaluation einer EBV-Assoziation wurde eine EBER in situ Hybridisierung durchgeführt.

Ergebnisse. In unserem Kollektiv konnte keine Korrelation der vier molekularen Subgruppen mit einem ECG der Lymphknotenmetastasen nachgewiesen werden $(p=0,528)$. Zudem konnte keine signifikante Korrelation der molekularen Subgruppen mit dem Gesamtüberleben nachgewiesen werden $(p=0,355)$. Passend zu Ergebnissen aus der Literatur zeigte die Gruppe der Magenkarzinome mit MSI ein tendenziell besseres Gesamtüberleben.

Fazit. Wir konnten in unserer Studie herausarbeiten, dass ein ECG von Lymphknotenmetastasen beim Magenkarzinom keine Korrelation mit den publizierten molekularen Subgruppen zeigt. Somit stellt der morphologische Nachweis eines ECG einen von dieser Klassifikation unabhängigen prognostisch relevanten Biomarker dar. Aus diesen Daten lässt sich zudem ableiten, dass dem morphologisch aggressiveren Phänotyp, der einem Kapseldurchbruch zugrunde liegt, andere als die in dieser Studie analysierten Alterationen zugrunde liegen müssen.

\section{AG01.02}

Molekulare Subgruppen beim Magenkarzinom: Prognostische und prädiktive Relevanz von EBV-Infektion und hoher und niedriger Mikrosatelliteninstabilität

M. Kohlruss ${ }^{1 *}$, B. Grosser', M. Krenauer', J. Slotta-Huspenina', M. Jesinghaus', S. Blank ${ }^{2}$, A. Novotny ${ }^{3}$, M. Reiche', T. Schmidt', L. Ismani', A. Hapfelmeier', D. Mathias', P. Meyer', M. Gaida ${ }^{5}$, L. Bauer', K. Ott ${ }^{6}$, W. Weichert ${ }^{1,7}$, G. Keller ${ }^{1}$

${ }^{1}$ Technische Universität München, Institut für Pathologie, München, Deutschland, ${ }^{2}$ Uniklinikum Heidelberg, Chirurgische Klinik, Heidelberg, Deutschland, ${ }^{3}$ Technische Universität München, Klinik und Poliklinik für Chirurgie, München, Deutschland, ${ }^{4}$ Technische Universität München, Institut für Medizinische Informatik, Statistik und Epidemiologie, München, Deutschland, ${ }^{5}$ Universitätsklinikum Heidelberg, Institut für Pathologie, Heidelberg, Deutschland, ${ }^{6}$ Klinikum Rosenheim, Klinik für Allgemein-, Gefäß- und Thoraxchirurgie, Rosenheim, Deutschland, ${ }^{7}$ German Cancer Consortium (DKTK), Partner Site München, München, Deutschland 
Ziel. Ziel unserer Studie war es die prognostische und prädiktive Relevanz der molekularen Subgruppen - EBV Positivität (+) und Mikrosatelliteninstabilität (MSI) - für Magenkarzinome im Kontext einer Platinum/5-Fluorouracil-basierten präoperativen Chemotherapie (CTx) zu bestimmen. Methoden. Wir analysierten 760 Karzinome des Magens und des gastro-ösophagealen Übergangs (617 Tumorresektate primär resezierter als auch neoadjuvant chemotherapierter Patienten und 143 Tumorbiopsien vor neoadjuvanter CTx). EBV Positivität wurde mit einem PCR basierten Assay und in situ Hybridisierung ausgewählter Fälle bestimmt. MSI wurde mit einer Multiplex-PCR von 5 Mikrosatellitenmarkern (BAT25, BAT26, D2S123, D5S346, D17S250) untersucht. Die Tumoren wurden in folgende vier molekulare Subgruppen eingeteilt: EBV positiv(+), hochgradig MSI (MSI-H), niedriggradig MSI (MSI-L) und mikrosatellitenstabil (MSS)/EBV negativ(-).

Ergebnisse. In den Tumorbiopsien waren 4,2 \% der Fälle EBV(+), 10,5 \% waren MSI-H und 4,9\% MSI-L. EBV(+) und MSI-H korrelierten nicht mit dem Ansprechen auf CTx. MSI-L war jedoch statistisch signifikant mit einem besseren Ansprechen assoziiert $(p=0,01)$. In den Tumorresektaten waren 3,9 \% der Fälle EBV(+), 9,6 \% waren MSI-H und 4,5 \% waren MSI-L. In der Gruppe der nicht-CTx Tumoren war das Überleben der vier molekularen Subgruppen signifikant unterschiedlich (log rank $p=0,01$ ). Patienten mit EBV $(+)$ Tumoren zeigten das beste Überleben, gefolgt von MSI-H. MSI-L war signifikant mit einem schlechten Überleben assoziiert (Hazard Ratio [HR], 2,21; $p=0,01$ ). In der Subgruppenanalyse entsprechend dem klinischen Tumorstatus (cT) war MSI-L auch in der cT2 Gruppe mit dem schlechtesten Überleben assoziiert (HR, 3,88; $p=0,02)$. In der CTx-Gruppe war MSI-H mit einem besseren Überleben assoziiert (HR, 0,54; $p=0,09)$. In der Subgruppenanalyse entsprechend dem Tumorregressionsgrad zeigten Patienten mit MSI-H Tumoren ein signifikant besseres Überleben auch bei geringer oder keiner Tumorregression nach CTx (HR, 0,$43 ; p=0,04$ ).

Fazit. MSI-H und EBV(+) sind in Magenkarzinomen prognostisch relevant, aber nicht prädiktiv für das Ansprechen auf neoadjuvante CTx. MSIL ist prädiktiv für ein gutes Ansprechen und der negative prognostische Effekt in der nicht chemotherapierten Patientengruppe weist darauf hin, dass insbesondere Patienten mit MSI-L Tumoren von einer präoperative Platin/5-Fu-basierten Chemotherapie profitieren könnten.

\section{AG01.03}

\section{Positive Berliner-Blau-Reaktion bei Lanthan-Gastropathie}

\section{P. Döring ${ }^{1 *}$, S. Stracke ${ }^{2}$, A. Tannapfel ${ }^{3}$, N. Hosten ${ }^{4}$, F. Dombrowski ${ }^{1}$} 'Universitätsmedizin Greifswald, Institut für Pathologie, Greifswald, Deutschland, ${ }^{2}$ Universitätsmedizin Greifswald, Nephrologie, Greifswald, Deutschland, ${ }^{3}$ Ruhr-Universität Bochum, Institut für Pathologie, Bochum, Deutschland, ${ }^{4}$ Universitätsmedizin Greifswald, Institut für diagnostische Radiologie, Greifswald, Deutschland

Wir möchten auf die noch nicht in den Lehrbüchern erwähnte und wahrscheinlich noch wenig bekannte und doch relativ häufige Lanthan-Gastropathie aufmerksam machen. Lanthancarbonat (LC) ist ein bei niereninsuffizienten Patienten häufig verschriebener Phosphatbinder, der sich in der Magenschleimhaut in Form kleiner Fremdkörperkristalle ablagert und jahrelang persistieren kann. Wir haben innerhalb eines Jahres sieben Fälle gesehen, in jedem Einzelfall auch ein überraschendes Ergebnis für den Gastroenterologen. Nach Yabuki et al. waren bei 44 von 45 untersuchten LC einnehmenden Patienten Lanthangranulome in der Magenschleimhaut zu finden (Biol Trace Elem Res 2018:187;36-47). Lanthan gehört zu den Übergangsmetallen und ist auch radiologisch im Gastrointestinaltrakt darstellbar.

Gastrointestinale Symptome wie Appetitlosigkeit mit Gewichtsverlust, Übelkeit und Diarrhoe sind sehr häufige Nebenwirkungen von LC. Die meisten Patienten haben bereits mehrere Kilogramm LC zu sich genommen, bis sie gastroskopiert werden, manchmal erst mehrere Monate nach Absetzen des LC. Weiße Flecken in der Mukosa wurden von den Endoskopikern entweder beschrieben oder manchmal für Erosionen gehalten.
Histologisch erkennt man Grüppchen von Makrophagen im Schleimhautstroma mit kristallinen Einschlüssen, die sich in der energiedispersiven Röntgenspektroskopie im Rasterelektronenmikroskop (REM-EDX) als Lanthan bestätigt haben. An der Kristalloberfläche war dabei kein Eisen nachweisbar und doch reagieren die Kristalle innerhalb der Granulome in der Berliner-Blau-Reaktion positiv, was in der Literatur gelegentlich erwähnt und mit dem Vorkommen von Mikroblutungen diskutiert wird. Da nur die Kristalle und nicht die Makrophagen oder die Umgebung zu Berliner Blau reagieren, hielten wir diese Theorie für unwahrscheinlich. LC reagiert in vitro nicht sofort, sondern erst über Nacht mit dem gelben Blutlaugensalz zu Berliner-Blau. Wedekind et al. beschrieben 1927, dass Lanthanhydroxid an das Berliner-Blau-Sol bindet. Außerdem kann sich aus der Nahrung stammendes Kaliumhexacyanoferrat mit dem LC zu Lanthankaliumhexacyanoferrat verbunden haben und zu Berliner-Blau reagieren.

Die Berliner-Blau-Reaktion kann also im Fall der Lanthangranulome „falsch positiv“ ausfallen.

Bei unserem ersten Patienten hatte neun Monate nach dem Erstbefund und nach Absetzen des LC in Kontrollbiopsien die Zahl der Lanthangranulome erheblich abgenommen, sie waren aber noch histologisch nachweisbar.

\section{AG01.04 \\ Low BUB1 expression is an adverse prognostic marker in gastric adenocarcinoma}

D. Stahl' ${ }^{1 *}$, M. Braun ${ }^{1}$, A. J. Gentles 2 , P. Lingohr ${ }^{3}$, A. Walter', G. Kristiansen', I. Gütgemann ${ }^{7}$

'University Hospital Bonn, Institute of Pathology, Bonn, Germany, ${ }^{2}$ Stanford University, Center for Cancer Systems Biology (CCSB), Stanford, United States, ${ }^{3}$ University Hospital Bonn, Department of General, Visceral, Thoracic and Vascular Surgery, Bonn, Germany, ${ }^{4}$ University Hospital Bonn, Department of Gynecology and Obstetrics, Bonn, Germany

Aim. Although the incidence rates are steadily declining, gastric cancer (GC) is the third most common cause of cancer-related death worldwide. It is associated with a poor prognosis due to the fact that the tumor is often diagnosed at an advanced stage. Biomarkers are urgently needed to predict patients' prognosis and tailor treatment. The aim of this study was to examine the expression of the mitotic spindle checkpoint protein BUB1 (budding uninhibited by benzimidazoles 1 ) and Ki-67 and correlation with clinic-pathological data and prognosis.

Methods. We analyzed the expression of BUB1 and Ki- 67 by immunohistochemistry on tissue microarrays in 218 patients with primary GC. Frequency of positive tumor nuclei was quantified using the image analysis software "Tissue studio" by Definiens. Results were compared with gene expression data from The Cancer Genome Atlas (TCGA) regarding BUB1 transcripts and correlated with survival.

Results. Frequency of BUB1 expression in tumor nuclei ranged from 0.5 to $81 \%$ with a median expression level of $16 \%$. Tumors with low frequency of BUB1 expression were associated with larger tumor size $(p<0.001)$, higher incidence of lymph node and distant metastases $(p=0.027, p=0.006$ respectively) and higher UICC stages $(p<0.001)$. Furthermore, BUB1 protein expression correlated positively with Ki-67 protein expression

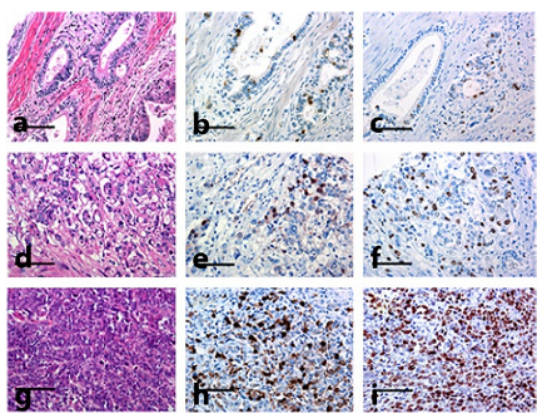

Fig. 1 | AG01.04 IHC staining: Low $(\mathbf{b})$, medium (e) and high (h) BUB1 expression, $H \& E(\mathbf{a}, \mathbf{d}, \mathbf{g}), \mathrm{Ki}-67$ $(c, f, i)$ 


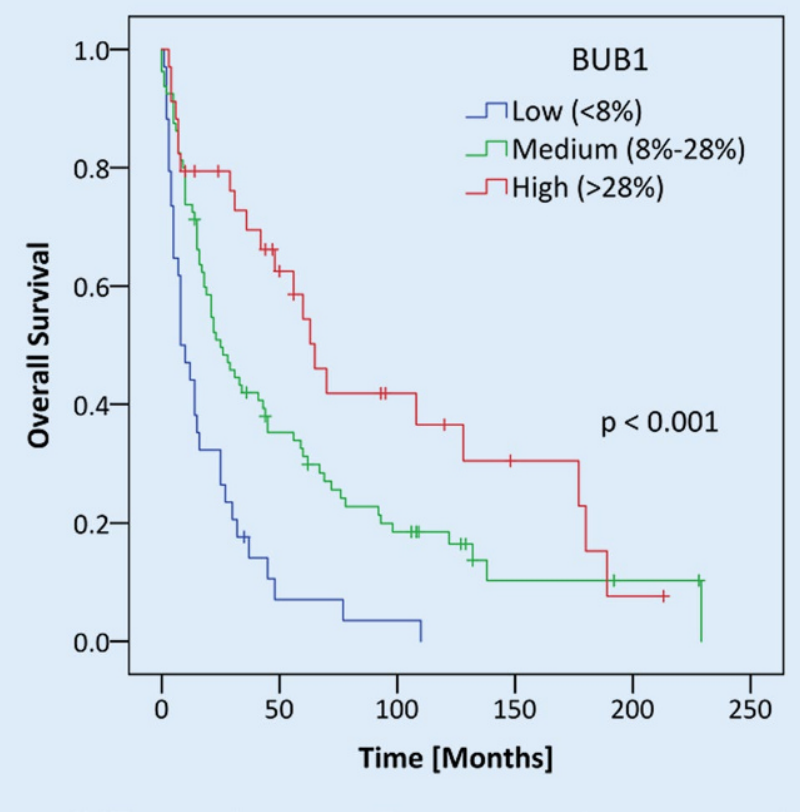

Fig. 2 | AG01.04 $<$ BUB1 expression correlates with overall survival in gastric adenocarcinoma

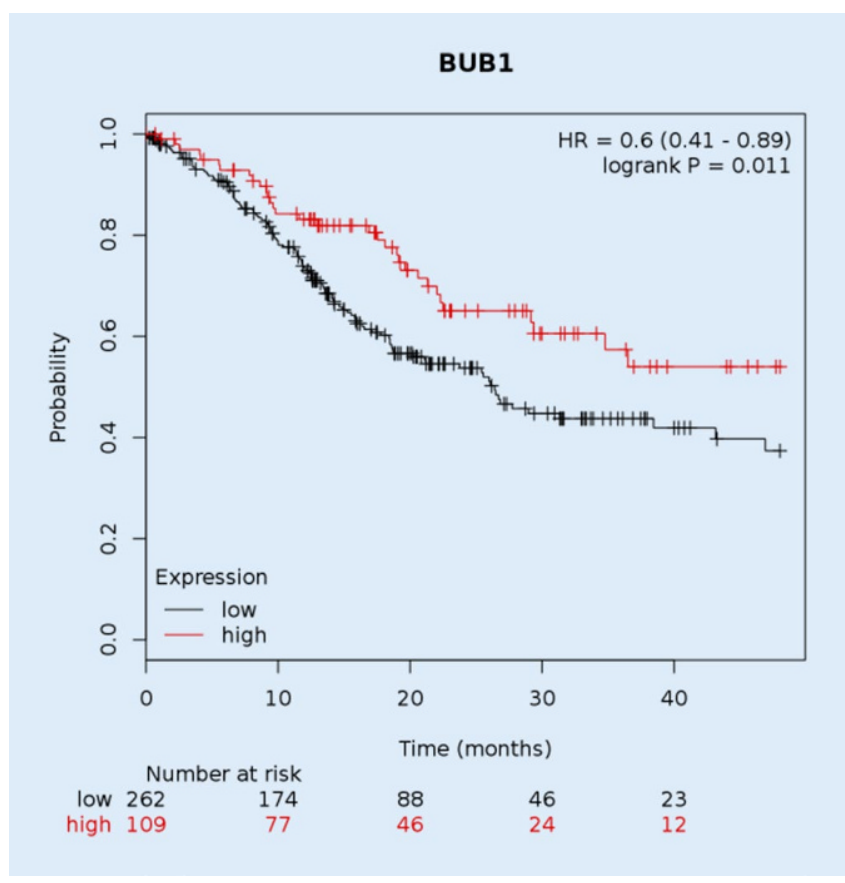

Fig. 3 | AG01.04 $\triangleleft$ TCGA gene expression data analysis (kmplot.com)

$(p<0.001)$ (• Fig. $1 \mid$ AG01.04). Overall survival (OS) analysis revealed that low BUB1 expression is associated with a shorter OS $(p<0.001)$ with a difference of 57 months for the median OS between the low and high BUB1 expression groups (• Fig. 2|AG01.04). Univariate and multivariate analyses confirmed that BUB1 is an independent prognostic marker $(p=0.021)$. The TCGA analysis supported the prognostic value of BUB1 in GC on mRNA level ( $p=0.011)$ (• Fig. 3|AG01.04).

Conclusion. In this study we can show that low BUB1 expression is an adverse prognostic marker in GC. In addition, patients with low BUB1 expression present at advanced tumor stage $(\mathrm{T})$, with higher risk of metasta- sis $(\mathrm{N}$ and $\mathrm{M})$ and higher UICC stage. These findings indicate that BUB1 is a potential and clinically relevant prognostic marker in GC. As part of the mitotic spindle checkpoint BUB1 plays an important role during metaphase-to-anaphase transition and could act as a regulator of cell cycle control in GC. The use as a prognostic marker needs to be established in further clinical studies.

\section{AG01.05}

Varying practices in tumor regression grading of gastrointestinal carcinomas after neoadjuvant therapy-results of a world wide survey

\section{Westerhoff', M. Osecky' ${ }^{2}$ R. Langer ${ }^{2 *}$ \\ 'Institute of Pathology, University of Michigan, Ann Arbor, United States, ${ }^{2}$ Institut für Pathologie, Universität Bern, Bern, Switzerland}

Aim. Tumor Regression Grading (TRG) is routinely performed on gastrointestinal (GI) cancers resected after neoadjuvant therapy. Challenges in the practice of TRG include standardization for grossing, multiple grading systems, and difficulty interpreting therapy-induced changes. We surveyed GI pathologists around the World for their practices in handling neoadjuvantly treated GI cancer specimens and TRG reporting.

Materials and methods. A 23-question online survey was distributed through various national and international GI pathology working groups. Topics addressed grossing, histologic work-up, TRG systems used, and difficulties in identifying and estimating residual cancer within a background of treatment effect.

Results. 182 completed questionnaires were received from North America $(n=52)$, Europe $(n=92)$, and other continents $(n=38) .93 \%$ routinely report TRG and have standardized grossing and histologic work-up with $25 \%$ always completely embedding the entire tumor bed, and 55\% completely embedding the tumor site if not a grossly apparent, large mass. $60 \%$ use $\mathrm{HE}$ alone for assessment; the remaining are using additional immunohistochemistry (27\%) or special stains (13\%). In North America, the AJCC/Ryan system is routinely used for gastroesophageal (77\%) and rectal carcinomas (86\%). Outside of North America, a variety of TRG systems are implemented: for example, for gastroesophageal tumors the Mandard system is common (44\%), followed by AJCC/Ryan (30\%), and Becker (17\%); for rectal CA, the AJCC/Ryan (40\%) is followed by the Mandard (24\%), and Dworak system (21\%). Overall, most pathologists would prefer a 4 -tiered system (52\%). There was no significantly preferred concept of TRG (residual tumor descriptive 26\%; fibrosis/tumor descriptive $19 \%$; fibrosis/residual tumor $26 \%$; residual tumor $\% 28 \%$; other $1 \%$ ). $67 \%$ considered that regressive changes in lymph nodes should be part of TRG. Most considered identifying residual tumor easy $(60 \%)$ but estimating therapy-induced fibrosis difficult (44\%). Free comments raised issues of costs for detailed pathology work-up \& clinical relevance.

Conclusion. This survey provides a comprehensive overview about TRG in GI cancers performed by multinational surgical pathologists. Grossing and histopathology is highly standardized. TRG reporting is standardized in North America, where national guidelines recommend a specific TRG system (i.e AJCCI), but is heterogenous around other geographic regions, in particular Europe. 


\section{AG Gastroenteropathologie II}

\section{AG01.06 \\ Die Antikörper mAbEm2G11 und mAbEmG3 unterscheiden zuverlässig zwischen der alveolären und zystischen Echinokokkose}

J. Grimm ${ }^{1 *}$, A. Beck', J. Nell', A. Hillenbrand ${ }^{2}$, D. Henne-Bruns', J. Schmidberger ${ }^{3}$, W. Kratzer ${ }^{3}$, B. Grüner, T. Gräter ${ }^{5}$, M. Reinehr ${ }^{6}$, A. Weber ${ }^{6}$, P. Deplazes ${ }^{7}$, P. Möller', T. Barth

${ }^{1}$ Institut für Pathologie, Universität Ulm, Ulm, Deutschland, ${ }^{2}$ Allgemeinund Viszeralchirurgie, Universitätsklinikum Ulm, Ulm, Deutschland, ${ }^{3}$ Innere Medizin I, Universitätsklinikum Ulm, Ulm, Deutschland, ${ }^{4}$ Innere Medizin III, Universitätsklinikum Ulm, Ulm, Deutschland, ${ }^{5}$ Diagnostische und Interventionelle Radiologie, Universitätsklinikum Ulm, Ulm, Deutschland, ${ }^{6}$ Institut für Pathologie und Molekularpathologie, Universitätsspital Zürich, Zürich, Schweiz, 'Institut für Parasitologie, Universitätsspital Zürich, Zürich, Schweiz

Ziel. Die histologische Unterscheidung der zystischen und der alveolären Echinokokkose stellt eine Herausforderung dar. Die korrekte Diagnose ist entscheidend für das weitere therapeutische Vorgehen.

Methoden. Untersucht wurden aus dem Archiv des pathologischen Instituts der Universität Ulm 205 Proben von 178 Patienten mit alveoläre Echinokokkose (Leber: $n=145$; Lymphknoten: $n=43$; Aspirate: $n=5$; Knochen: $n=1$; weitere: $n=11$ ) sowie 175 Positionen von 86 Patienten mit zystischer Echinokokkose (Leber: $n=93$; Knochen: $n=17$, Lymphknoten: $n=17$; Lunge: $n=16$; Muskel: $n=8$; weitere: $n=24)$.

Neben der Morphologie und Histochemie (PAS) wurde die immunhistochemische Anfärbung mittels der Primärantikörper mAbEm2G11 (IgG1) und mAbEmG3 (IgM) (Prof. Deplazes, Institut für Parasitologie, UZH) etabliert. Hierzu wurden die optimalen Färbebedingungen getestet und mögliche Kreuzreaktionen in humanem Material (Leber, Mamma, Muskel, Knochen) und anderen parasitären Erkrankungen (Trichuris suis, Taenia solium, Strongyloides stercoralis, Oxyuriase) untersucht.

Ergebnisse. Der neu etablierte Antikörper mAbEmG3 bindet spezifisch Antigene der alveolären und zystischen Echinokokkose. Der mAbEm2G11 markiert selektiv den Lamellarkörper der alveolären Echinokokkose. Unspezifische Färbungen in humanen Geweben oder bei anderen parasitären Erkrankungen konnten nicht festgestellt werden. Dabei konnten 7 bisher unsichere Diagnosen der zystischen Echinokokkose bestätigt werden. "Small particles of Echinococcus granulosus" (spegs), sowie die schon beschriebenen und sich gleich manifestierenden „small particles of Echinococcus multilocularis" (spems), konnten mit dem mAbEmG3 nachgewiesen werden (Barth et al., PLoS Negl Trop Dis, 2012; Ricken et al., PLoS Negl Trop Dis, 2017). Hierbei ist der Nachweis von „spems“ (36/43) und "spegs" (17/17) in Lymphknoten interessant. Ebenfalls zeigte sich im Vergleich zum mAbEm2G11 mit dem neuen Antikörper eine sensitivere Anfärbung von parasitären Material bei Fällen der alveolären Echinokokkose Fazit. Durch den kombinierten Einsatz der beiden Antikörper mA bEm2G11 und mAbEmG3 ist die Differenzierung der alveolären und zystischen Echinokokkose anhand von immunhistochemischer Verfahren sicher möglich. Es konnten „spems“ und „spegs" bei der alveolären und zystischen Echinokokkose im umliegenden Gewebe und Lymphknoten beschrieben werden, was auf eine sehr viel größere Interaktion als angenommen zwischen dem Parasiten mit dem Organismus hinweist.

\section{AG01.07 \\ Untersuchungen zur Expression von CLDN18.2 im Magenkarzinom}

\section{Dottermusch*, S. Krüger, H.-M. Behrens, C. Röcken}

Institut für Pathologie, Universitätsklinikum Schleswig-Holstein, Kiel Deutschland

Ziel. Das tight junction-Protein Claudin-18.2 (CLDN18.2) wurde kürzlich als vielversprechendes therapeutisches Ziel in der Antikörpertherapie des fortgeschrittenen Magenkarzinoms beschrieben. Dennoch existiert derzeit eine geringe Datenlage zur Expressionshäufigkeit und Bedeutung von CLDN18.2 hinsichtlich Tumorgenese, Krankheitsverlauf oder klinisch-pathologischer Charakteristika. Ziel dieser Studie war es, das CLDN18.2Expressionsverhalten in Magenkarzinomen einer großen Kohorte zu untersuchen und Zusammenhänge mit klinisch-pathologischen Faktoren aufzuzeigen.

Methoden. In Formalin fixiertes und Paraffin eingebettetes Material aus 481 Magenkarzinom-Fällen wurde immunhistochemisch mit einem gegen CLDN18.2 (clone EPR19202) gerichteten Antikörper gefärbt. Expressionsintensitäten wurden mittels Histoscore quantifiziert und mit klinischpathologischen Parametern korreliert.

Ergebnisse. Die Magenkarzinome unserer Kohorte zeigten zu einem überwiegenden Anteil eine geringe Expression von CLDN18.2. In 278 der 481 Fälle $(57,8 \%)$ fanden sich keine CLDN18.2-positiven Tumorzellen. CLDN18.2-Expression korrelierte mit dem Mucin-Phänotyp $(p<0,001)$ und EBV-Status $(p<0,001)$, jedoch nicht mit der Patientenprognose.

Fazit. Derzeit vorliegende Studien suggerieren zumeist eine Herabregulation von CLDN18.2 im invasiven Magenkarzinom. Da dies auch dem durchweg schwachen Expressionsverhalten unserer kaukasischen Kohorte entspricht, werden weitere Studien notwendig sein, um den Stellenwert von CLDN18.2 als therapeutisches Ziel zu untermauern. Die Korrelationen mit dem Mucin-Phänotyp und EBV-Status liefern möglicherweise Anhaltspunkte für die Rolle von CLDN18.2 in der Entstehung verschiedener Tumorentitäten.

\section{AG01.08}

Pathologie der Echinokokkose - Eine Studie mit Fokus auf der Differentialdiagnose zwischen zystischer und alveolärer Echinokokkose

M. Reinehr ${ }^{*}$, C. Micheloud ${ }^{2}$, F. Grimm ${ }^{3}$, P. A. Kronenberg ${ }^{3}$, J. Grimm ${ }^{4}$, A. Beck ${ }^{4}$, J. Nell ${ }^{4}$, C. Meyer zu Schwabedissen ${ }^{5}$, E. Furrer' ${ }^{2}$, B. Müllhaupt ${ }^{5}$, T. Barth ${ }^{4}$, P. Deplazes ${ }^{3}$, A. Weber

'Institut für Pathologie und Molekularpathologie, Universitätsspital Zürich, Zürich, Schweiz, ${ }^{2}$ Institut für Epidemiologie, Biostatistik und Prävention, Universität Zürich, Zürich, Schweiz, İInstitut für Parasitologie, Universitätsspital Zürich, Zürich, Schweiz, ${ }^{4}$ Institut für Pathologie, Universität Ulm, Ulm, Deutschland, ${ }^{5}$ Klinik für Hepatologie und Gastroenterologie, Universität und Universitätsspital Zürich, Zürich, Schweiz

Ziel. Eine Infektion des Menschen durch das Larvenstadium von Echinococcus granulosus oder Echinococcus multilocularis beim Menschen verursacht eine zystische (CE) bzw. alveoläre Echinokokkose (AE), die in vielen Teilen der Welt eine erhebliche gesundheitliche Belastung darstellt. Zystische Läsionen, sind das häufigste klinisch-pathologische Korrelat, sowohl von $\mathrm{AE}$ als auch von CE. Der Verlauf, die Prognose und das Patientenmanagement unterscheiden sich jedoch entscheidend. Aufgrund der teils überlappenden Morphologie, der Seltenheit der Erkrankung, des Fehlens eindeutig definierter morphologischer Kriterien und des häufig erschwerten Zugangs zu teurer molekularer Diagnostik (wie PCR) ist die korrekte Diagnosestellung für Pathologen eine Herausforderung. Ziel dieser Studie ist es, dieses Problem zu lösen und einen diagnostischen Algorithmus zu entwickeln. Methodik. Wir haben das pathologische Spektrum in einer klinisch und molekular definierten Echinokokkose-Kohorte (138 Proben von $112 \mathrm{~Pa}-$ tienten) umfassend und systematisch analysiert. Ein neu entwickelter monoklonaler Antikörper (mAbEmG3) wurde in immunhistochemischen Untersuchungen getestet, insbesondere auf seine kombinierte Anwendung zusammen mit dem vorbeschriebenen mAbEm2G11. Eine Reihe von Proben wurde durch PCR-Untersuchungen vergleichend getestet. Zudem ist eine ausgedehnte statistische Aufarbeitung der Ergebnisse erfolgt.

Ergebnisse. Wir haben folgende morphologische Kriterien identifiziert, um bereits konventionell-histologisch in den meisten Fällen sicher zwischen einer CE und einer AE unterscheiden zu können: Kleinster Zystendurchmesser, Zystenanzahl, größter Zystendurchmesser, Dicke und Streifung des Lamellarkörpers sowie Dicke der Fibrosekapsel einer einzelnen peripheren Zyste. Ein Entscheidungsbaum, der auf zwei Kriterien (Dicke 
des Lamellarkörpers und Dicke der Fibrosekapsel einer Zyste) beruht, erlaubte bereits in $93 \%$ unserer Fälle eine ausreichende Unterscheidung zwischen CE und AE. Die kombinierte Immunhistochemie mit mAbEm2G11 und $\mathrm{mAbEmG} 3$ erwies sich als eine ebenso sensitive und spezifische $\mathrm{Zu}$ satzuntersuchung wie die als Goldstandard genutzte PCR-Methode. Ein diagnostischer Algorithmus wurde entwickelt.

Fazit. Wirhaben morphologische Kriterien identifiziert, die robust zwischen $\mathrm{CE}$ und $\mathrm{AE}$ unterscheiden, und ein empfindliches und spezifisches immunhistochemisches Panel eingeführt. Wir erwarten, dass unsere Ergebnisse die Diagnostik der Echinokokkose wesentlich verbessern werden.

\section{AG01.09 \\ chREBP ist ein tumorigener Faktor in der hormonell induzierten Hepatokarzinogenese der diabetischen Maus}

V. Nürnberger*, C. Metzendorf, F. Dombrowski, S. Ribback

Universitätsmedizin Greifswald, Institut für Pathologie, Greifswald, Deutschland

Ziel. Carbohydrate-response element-binding protein (ChREBP) spielt als Glukose-abhängiger Transkriptionsfaktor v. a. für Glykolyse und Lipogenese und als Teil der protoonkogenen AKT/mTOR-Signalkaskade eine wichtige Rolle in der Karzinogenese der nicht-zirrhotischen Leber. In Kurzzeitexperimenten entstanden nach intraportaler Pankreasinseltransplantation klarzellige, glykogenspeichernde Leberherde, deren veränderte
Hepatozyten nach einem ChREBP-Knockout eine geringere Wachstumstendenz aufwiesen.

Methoden. Die intraportale Pankreasinseltransplantation wurde bei diabetischen ChREBP-KO- $(n=136)$ sowie Wildtyp-Mäusen $(n=178)$ fortgesetzt (• Tab. 1|AG01.09).

Es erfolgten histologische (HE, PAS), proliferationskinetische (BrdU-Labeling Index), immunhistochemische, elektronenmikroskopische Untersuchungen und Westernblot-Analysen.

Ergebnisse. Nach 6 Monaten entstehen weiterhin klarzellige Leberherde im Abstromgebiet der transplantierten Pankreasinseln, die bei den Wildtyp-Mäusen eine vermehrte Glykogen- und Fettspeicherung aufweisen. In den ChREBP-KO-Mäusen ist hingegen eine massive Glykogenspeicherung bei fehlender Lipidspeicherung aufgrund der verminderten Aktivität des glykogenolytischen Enzyms Glukose-6-Phosphatase und der Lipogenese charakteristisch.

Die Proliferationsaktivität war in den Leberherden nach 6 Monaten bei den ChREBP-KO- (Mittelwert \pm S. E.M: $21,77 \pm 3,38 \%$ ) tendenziell geringer als bei den Wildtyp-Mäusen (29,04 11,97 \%) (• Abb. 1 | AG01.09).

Nach 6 und 12 Monaten entstanden bei den transplantierten, diabetischen Wildtyp-Mäusen mehrere hepatozelluläre Adenome und Karzinome, bei den korrespondierenden KO-Gruppen hingegen nur ein einziges hepatozelluläres Karzinom (• Abb. 2 | AG01.09).

Sowohl die Glykolyse und de novo-Lipogenese als auch der protoonkogene Signalweg AKT/mTOR sind in den Herden und Tumoren von KO-Mäusen im Vergleich zu den Wildtyp-Mäusen herunterreguliert.

Tab. 1 |AG01.09 Übersicht der Versuchsgruppen

\begin{tabular}{lllll}
\hline C57BI/6J & 1. HG 6M, diabetisch, Tx & 1. KG 6M, diabetisch, Tx & 5. KG 6M, nicht diab., Tx & 9. KG 6M, nicht diabetisch \\
\hline Wildtyp & $n=36$ & $n=20$ & $n=20$ & $n=19$ \\
ChREBP-Knockout & 2. HG 6M, diabetisch, Tx & 2. KG 6M, diabetisch & 6. KG 6M, nicht diab., Tx & 10. KG 6M, nicht diabetisch \\
& $n=18$ & $n=18$ & $n=19$ & $n=20$ \\
C57BI/6J & 3. HG 12M, diabetisch, Tx & 3. KG 12M, diabetisch & 7. KG 12M, nicht diab., Tx & 11. KG 12M, nicht diabetisch \\
Wildtyp & $n=33$ & $n=13$ & $n=19$ & $n=20$ \\
ChREBP-Knockout & 4. HG 12M, diabetisch, Tx & 4. KG 12M, diabetisch & 8. KG 12M, nicht diab., Tx & 12. KG 12M, nicht diabetisch \\
& $n=12$ & $n=13$ & $n=19$ & $n=21$
\end{tabular}

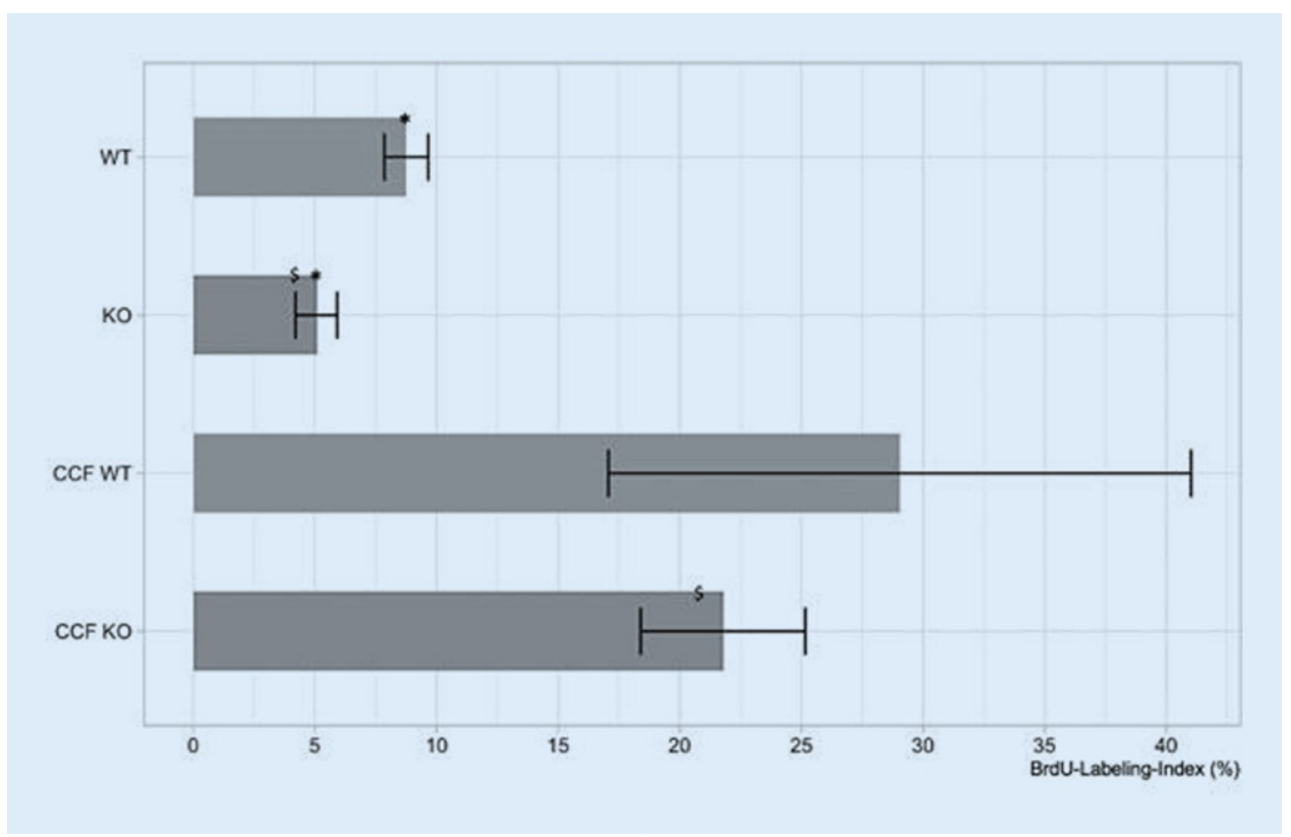

Abb. 1 | AG01.09 $<$ Proliferationsaktivität als BrdU-Labeling-Index von gesundem Lebergewebe und klarzelligen Leberherden (CCF) in Wildtyp (WT)- vs. ChREBP-Knockout (KO)-Mäusen nach 6 Monaten. ${ }^{*} p=0,018,{ }^{5} p=0,01$ 


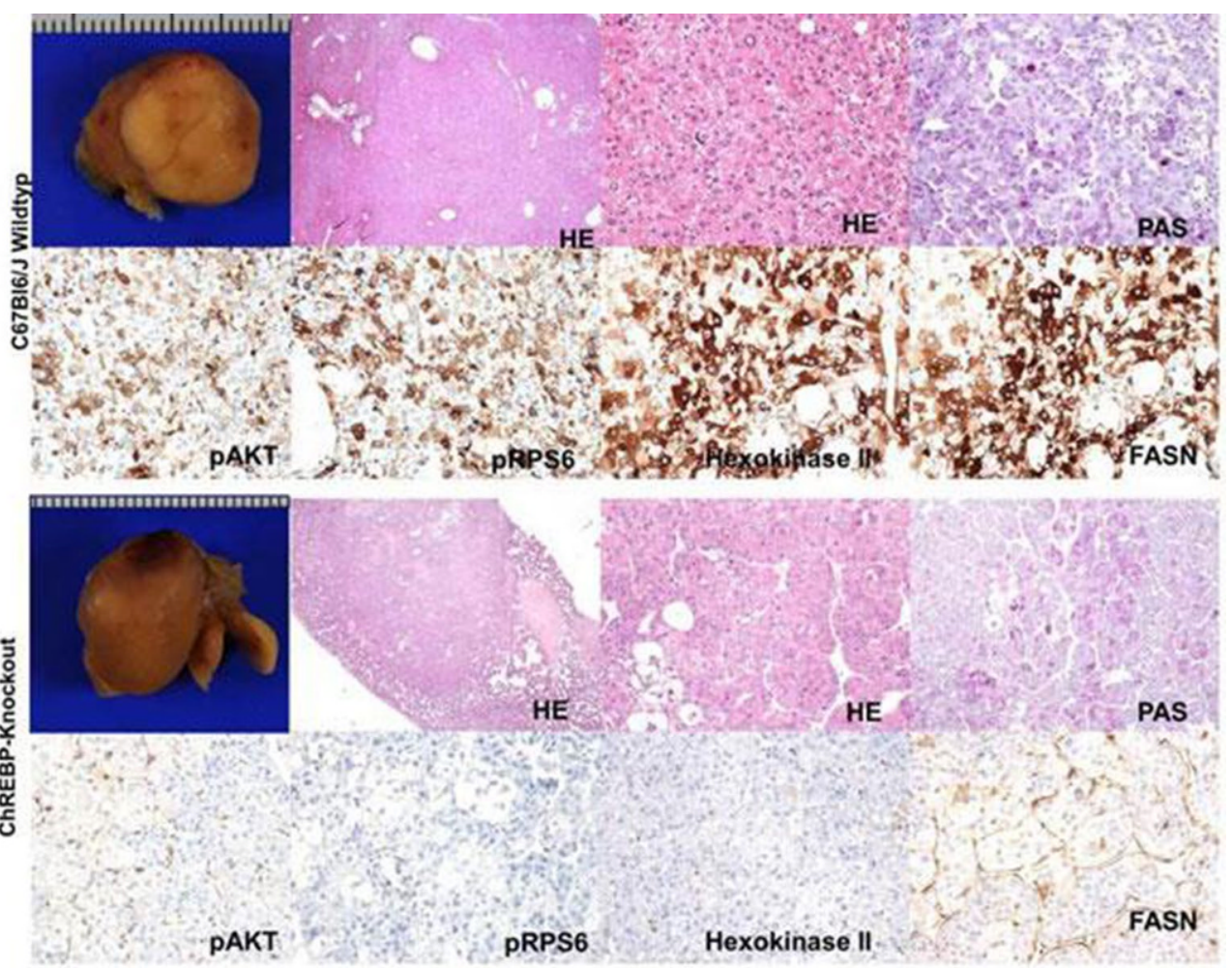

Abb. 2 | AG01.09 $\varangle$ Vergleich zweier hepatozellulärer Karzinome. Oben: Wildtyp-Maus (diabetisch, 6 Monate nach Transplantation); unten ChREBP-Knockout (diabetisch, 12 Monate nach Transplantation)
Des Weiteren ist auch das Starch-binding domain containing protein 1 (STBD1) bei den ChREBP-KO-Herden vermindert exprimiert, was eine Ursache der massiven Glykogenspeicherung durch eine verminderte lysosomale Glykogendegradation darstellen könnte.

Fazit. In der hormonell induzierten Hepatokarzinogenese verzögert und verringert ein ChREBP-Knockout die Tumorentstehung, sodass ChREBP eine wesentliche onkogene Komponente der AKT/mTOR-vermittelten Proliferation und des metabolischen Switches von einem glykogenotischen zu einem lipogenen Phänotyp in der Hepatokarzinogenese darstellt.

\section{AG01.10 \\ Die Axin1-induzierte Hepatokarzinogenese in Mäusen benötigt $\boldsymbol{\beta}$-Catenin aber ist Notch-unabhängig}

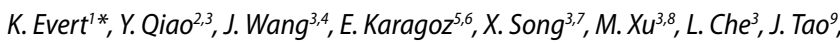
B. Wang ${ }^{5}$, S. P. Monga ${ }^{9}$, X. Chen ${ }^{3}$, M. Evert ${ }^{1}$, D. F. Calvisi'

'Universität Regensburg, Institut für Pathologie, Regensburg, Deutschland, ${ }^{2}$ Beijing Hospital, National Center of Gerontology, Department of Oncology, Peking, Volksrepublik China, ${ }^{3}$ University of California, Department of Bioengineering and Therapeutic Sciences and Liver Center, San Francisco, United States, ${ }^{4}$ School of Life Sciences, Beijing University of Chinese Medicine, Peking, Volksrepublik China, ${ }^{5}$ University of California, Department of Medicine and Liver Center, San Francisco, United States, ${ }^{6}$ Acibadem Mehmet Ali Aydinlar University, School of Medicine, Istanbul, Türkei, ${ }^{7}$ Beijing Advanced Innovation Center for Food Nutrition and Human Health, College of Food Science and Nutritional Engineering, Peking, Volksrepublik China Agricultural University, Peking, Volksrepublik China, ${ }^{8}$ The First Affiliated Hospital of Xi'an Jiaotong University, Department of Hepatobiliary Surgery, Xi'an, Volksrepublik China, 'University of Pittsburgh School of Medicine, and Pittsburgh Liver Research Center, Department of Pathology, Pittsburgh, United States

Hintergrund. Mit einer Frequenz von 10 \% gehören inaktivierende Mutationen von Axin1 zu den häufigsten genetischen Ereignissen beim Hepatozellulären Karzinom (HCC) des Menschen. Axin1 ist ein Inhibitor der Wnt $/ \beta$-Catenin-Kaskade, indem es den Abbau von $\beta$-Catenin erleichtert.
Allerdings bleibt beim humanem HCC unklar, ob durch die Inaktivierung von Axin 1 der Wnt $/ \beta$-Catenin-Signalweg induziert wird.

Methoden. Wir haben ein murines HCC-Modell über die CRISPR/Cas9basierte Gendeletion von Axin1 (sgAxin1) in Kombination mit der Transposon-basierten Überexpression von c-Met in der Mausleber (c-Met/ sgAxin1) generiert und auf die Entwicklung von Lebertumoren morphologisch und molekular untersucht. Als Vergleich diente ein weiteres Mausmodell mit kombinierter hepatozellulärer Überexpression von c-Met und $\Delta$ N90- $\beta$-Catenin nach hydrodynamischem Gentransfer.

Ergebnisse. Komparative globale Genexpressionsanalysen der normalen Lebern und der von Tumoren in beiden Mausmodellen zeigten die Aktivierung des Wnt/ $\beta$-Catenin- und des Notch-Signalweges in c-Met/sgAxin1 HCCs. Allerdings wurden nur wenige der kanonischen Wnt/ $\beta$-CateninZielgene in c-Met/sgAxin1 HCCs im Vergleich zu entsprechenden Läsionen von $c-M e t / \Delta N 90-\beta$-Catenin-Mäusen induziert. Um zu untersuchen, ob endogenes $\beta$-Catenin für die c-Met/sgAxin1-gesteuerte HCC-Entwicklung benötigt wird, exprimierten wir c-Met/sgAxin1 in leberspezifischen Ctnnb1-Null-Mäusen, was die HCC-Entwicklung vollständig inhibierte. In Axin1-mutierten menschlichen HCC-Zelllinien, führte die Inaktivierung von $\beta$-Catenin zu einer starken Hemmung der Zellproliferation. Im Gegensatz dazu führt das Blockieren der Notch-Kaskade über die Expression entweder der dominanten negativen Form von RBP-J oder der Ablation von Notch2 zu keinem signifikanten Einfluss auf die c-Met/sgAxin1induzierte Hepatokarzinogenese.

Fazit. Der Verlust von Axin1 führt zusammen mit c-Met zu einer Induktion von HCC bei Mäusen, die abhängig vom $\beta$-Catenin-Signalweg ist, aber unabhängig von der Notch-Kaskade. 
AG01.11

\section{Detection of human polyomavirus 6 and 7 in the human cholangiocarcinoma tissues}

F. Klufah ${ }^{1 * 2,}$, E. Chteinberg ${ }^{1}$, R. A. Alharbi ${ }^{2}$, A. K. Kurz ${ }^{3}$, V. Winnepenninckx', E.-J.Speel', A. zur Hausen'

'Maastricht University, Maastricht UMC+/Department of Pathology, Maastricht, Netherlands, ${ }^{2}$ Albaha University, Department of Laboratory Medicine, Albaha, Saudi Arabia, ${ }^{3}$ University Hospital Aachen, Department of Internal Medicine IV, Aachen, Germany

Aim. Cholangiocarcinoma (CCA) is a rare biliary duct neoplasm with poor prognosis. Recently, the presence of human polyomavirus 6 (HPyV6) has been reported in the bile of different hepatobiliary diseases including the bile of CCA patients (Chan et al., 2017). Here, we investigated the prevalence of HPyV 6 and 7 in CCA by using diverse molecular techniques to assess their possible role in neoplastic hepatobiliary diseases.

Methods. We tested 61 formalin fixed and paraffin embedded tissues of 21 CCA patients. PCR screening for HPyVs were conducted using a pair of degenerated HPyV primers. In addition, specific PCRs for HPyV 6 and 7 was performed targeting LTAg and sTAg. All PCR products were sequenced. DNA Fluorescence in situ hybridization (ISH), RNA(ISH) and immunohistochemistry (IHC) were used to assess the presence of $\mathrm{HPyV}$ 6 and 7 on the DNA, transcriptional and transitional level.

Results. Screening with degenerated primers revealed the presence of HPyV 7 in 4 out of 21 CCAs (19\%) and HPyV 6 in 2 CCAs (9.5\%). The presence of HPyV 7 and 6 DNA was confirmed by specific FISH. RNAISH confirmed the presence HPyV 6 and 7 on the single cell level within the histomorphological context. In addition, IHC using monoclonal antibodies (HPyV 7 STAg 2T10 and HPyV 6 STAg 1T1, both kindly supplied by Dr. C. Buck, NCI, Bethesda, USA) revealed the specific nuclear expression of viral proteins within these tissues, which to our surprise was more prevalent in the peritumoral non-neoplastic hepatocytes and only occasionally and to a far lesser extent in the CCA cells.

Conclusion. HPyV 6 and 7 are hepatotropic and can be specifically found in peritumoral non-neoplastic hepatocytes and to a lesser extent in neoplastic CCA cells. The expression pattern of these viral proteins shares a reminiscent pattern as observed for Hepatitis B virus. In our patient cohort, HPyV 7 was found to be more prevalent than HPyV6.

Based on our results, HPyV6 and 7 are yet unlikely to play an important role in the etiopathogenesis of CCA. Since we tested only a small number of cases follow-up studies are needed to assess the possible pathogenic roles of these viruses in the liver. In addition, further studies on the potential contribution of these viruses to other inflammatory liver diseases are warranted.

\section{AG01.12}

\section{Heterogenität molekularer Subtypen im duktalen Adenokarzinom des Pankreas}

K. Steiger ${ }^{1 *}$, B. Konukiewitz' , A. Muckenhuber', G. Kaissis², R. Braren', W. Weichert ${ }^{1}$

'Institut für allgemeine Pathologie und pathologische Anatomie, Technische Universität München, München, Deutschland, ${ }^{2}$ Institut für Diagnostische und Interventionelle Radiologie, Klinikum rechts der Isar, München, Deutschland

Ziel. Das duktale Adenokarzinom des Pankreas (PDAC) ist hinsichtlich seiner DNA Mutationsprofile weitgehend homogen, therapierelevante Mutationen spielen bisher lediglich sehr selten eine Rolle. Allerdings wurden molekulare Subtypen auf Genexpressionsebene nachgewiesen (Collisson et al. Nat. Med. 2011, Moffitt et al., Nat. Gen. 2015, Bailey et al. Nat. 2016), die möglicherweise einen Einfluss auf Therapieansprechen und Überlebenszeit haben, wodurch die PDAC-Therapie individualisiert werden könnte. In allen diesbezüglichen Untersuchungen war stets ein „klassischer" (oder „progenitor") und ein „quasi-mesenchymaler" (entsprechend dem „basal-like“ oder „squamous“) Subtyp nachweisbar, die
Existenz weiterer Subtypen (z. B. „exocrine like“/,immunogenic“/ADEX) ist bisher nicht sicher belegt.

Frühere Untersuchungen unserer und anderer Arbeitsgruppen zeigten, dass die Expression von Surrogatmarkern auf Protein- (KRT81 und HNF1a) bzw. mRNA (Gata6)-Ebene mit den auf Genexpressionsebene identifizierten Subtypen korrespondiert. Ziel dieser Arbeit ist die Untersuchung der intratumoralen Heterogenität hinsichtlich des Subtyps in PDAC-Resektaten, um eine Aussage zur individuellen Subtyp-Stabilität treffen zu können.

Methoden. PDAC Resektate von 15 Patienten wurden komplett in 0,5 cm Abständen histologisch, immunhistochemisch (KRT81, HNF1a) sowie mittels RNA in situ Hybridisierung (Gata6) aufgearbeitet. Ein Subtyp-Areal wurde definiert als Areal von mindestens $1 \mathrm{~cm}$ Durchmesser, welches in sich homogen eine Expression der Surrogatmarker aufwies (entsprechend der Definition von Muckenhuber et al. (Clin. Cancer Res. 2018)).

Ergebnisse. Bei sechs von 15 Patienten waren zwei unterschiedliche Subtypareale (IHC) nachweisbar. Heterogene Neoplasien wiesen stets ein KRT81-positives Subtypareal (IHC) auf. Bei 5 Patienten fanden sich doppelt-negative Areale neben KRT81-positiven, bei einem Patient war ein HNF1a-positives Areal neben dem KRT81-positiven Areal nachweisbar. Die Neoplasien mit homogener IHC-Expression waren in 7 Fällen doppelt-negativ und in 2 Fällen KRT81 positiv.

Fazit. Die mittels immunhistochemischer Surrogatmarker ermittelten Subtypen zeigten bei $40 \%$ der Patienten eine intratumorale Heterogenität, wobei in diesen Fällen stets der prognostisch ungünstigere KRT81 positive Subtyp nachweisbar war.

\section{AG Gastroenteropathologie III}

\section{AG01.13 \\ Targeting cellular metabolism to improve the outcome of pancreatic cancer}

L. Mainz' ${ }^{1}$ A. Schulze ${ }^{2}$, E. Wolf ${ }^{2}$ S. Walz ${ }^{3}$, A. Rosenwald ${ }^{4}$, M. Rosenfeldt ${ }^{4 *}$

${ }^{1}$ Comprehensive Cancer Center Mainfranken, Würzburg University, Würzburg, Germany, ${ }^{2}$ Biozentrum, Lehrstuhl für Biochemie und Molekularbiologie, Würzburg, Germany, ${ }^{3}$ Biozentrum, Comprehensive Cancer Center Core Unit Bioinformatics, Würzburg, Germany, ${ }^{4}$ Universität Würzburg, Institut für Pathologie, Würzburg, Germany

Aim. Pancreatic cancer (PDAC) has a dismal survival rate that has not changed in decades. Novel therapeutic concepts are urgently needed to improve outcome. In recent years it has become evident that PDAC relies on specific metabolic traits for proliferation and survival. Thus, targeting cellular metabolism is a potentially promising approach to treat PDAC. Our aim is to identify metabolic liabilities of PDAC that can be exploited for therapeutic benefit.

Methods. We employ a number of highly sophisticated in vitro and in vivo approaches to understand the metabolic complexity of PDAC such as mass spectrometry profiling of cellular metabolites, next generation sequencing and various imaging modalities.

Results. PDAC cells depend on the semi essential amino acid arginine for cell growth. Specific arginine depletion via dietary or pharmacological means induces a robust and sustainable growth arrest. Further characterization revealed that a specific arrest program termed senescence is executed upon arginine deprivation. Most strikingly, arginine depleted PDAC cells are highly susceptibly to a novel drug class called senolytics. These compounds specifically eradicate senescent cells but not proliferating cells. Furthermore, we used next generation sequencing to compare the RNA expression profiles of arginine depleted cells to cells grown under normal culture conditions. This revealed a very specific RNA expression profile in arginine starved cells such as activation of the ER-stress-response program which holds promise to identify additional metabolic vulnerabilities that can be targeted pharmacolocically. 
Conclusion. We specifically identified a novel synergism of arginine depletion and senolysis to effectively eradicate PDAC cells. Furthermore, we discovered a characteristic RNA expression profile upon arginine depletion that has potential to lead to additional very promising treatment concepts. Targeting cellular metabolism holds promise to improve the dismal survival rate of PDAC for the first time in decades.

\section{AG01.14}

Pathomorphologie des exokrinen Pankreasgewebes bei MEN-1Syndrom

\section{P. Döring ${ }^{1 *}$, A. Steveling ${ }^{2}$, A. A. Aghdassi ${ }^{2}$, F. Dombrowski'}

'Universitätsmedizin Greifswald, Institut für Pathologie, Greifswald, Deutschland, ${ }^{2}$ Universitätsmedizin Greifswald, Gastroenterologie und Endokrinologie, Greifswald, Deutschland

Die Beteiligung der endokrinen Pankreasinseln an dem Syndrom multipler endokriner Neoplasien Typ 1 (MEN-1) ist typisch. Über Veränderungen der Pankreasazinuszellen bei MEN-1 wurde bisher noch nicht berichtet.

Pankreas-Feinnadelpunktate und -Resektate von sechs MEN-1-Patienten (vier davon aus einer Familie) wurden licht- und zwei auch elektronenmikroskopisch untersucht und mit 100 Kontrollfällen (duktale Adenokarzinome, Inseltumoren, Pankreatitiden, kongenitaler Hyperinsulinismus) verglichen.

Nur bei den MEN-1-Pankreata fanden sich leuchtend eosinophile Zellkerneinschlüsse in den Azinuszellen. Bei einem Fall waren die Kerneinschlüsse selten, in den anderen fünf Fällen im niedrigen einstelligen Prozentbereich häufig. Die Kerneinschlüsse stellten sich als direkte (nicht membranumsäumte) Amylase-positive Zymogengranula heraus. Solche Kerneinschlüsse kamen weder bei reparativ aktivierten Pankreata noch in der Umgebung von Karzinomen und auch nicht bei kongenitalem Hyperinsulinismus vor. Auch die Inseltumoren und die übrigen Inselzellen, die Gangepithelien und die zentroazinären Zellen wiesen keine Zellkerneinschlüsse auf. Die betroffenen Azinuszellen hatten keine besondere topographische Beziehung zu den Inseltumoren oder zu den übrigen Inseln, sondern waren gleichmäßig über das Pankreasgewebe verteilt. Zusätzlich fanden sich schachbrettartig verteilte Gruppen von Azinuszellen mit azidophilem, amphophilem oder basophilem Zytoplasma, bei denen die Amylase und die Lipase entweder besonders stark oder besonders wenig nachweisbar waren. Diese Zytoplasmaveränderungen waren unabhängig von den Zellkerneinschlüssen, das heißt sie konnten mit Kerneinschlüssen kombiniert sein. Bei den MEN-1-Patienten wurden sämtliche verfügbare Gewebsproben aus anderen Organen auf ähnliche Veränderungen untersucht, jedoch keine vergleichbaren Veränderungen gefunden. Ob die veränderten Azinuszellgruppen präneoplastischer Natur sind, ist unklar. Es gibt keine Berichte über das Auftreten von Azinuszelltumoren bei MEN1-Syndrom.

Über die Funktion von Menin, dem Genprodukt von MEN1, ist noch wenig bekannt. Es wird nukleär exprimiert und interagiert unter anderem mit JunD und SMAD3. Bei duktalen Adenokarzinomen ist MEN1 nicht selten mutiert oder über eine Methylierung inaktiviert.

Da bei einem der sechs MEN-1-Fälle die Veränderungen der Azinuszellen sehr diskret waren, halten wir es für wahrscheinlich, dass es abhängig vom Genotyp zu unterschiedlichen Ausprägungen des Phänotyps kommt.

\section{AG01.15 \\ Eliciting an anti-tumor response by targeting macrophage efferocytosis in pancreatic cancer}

\section{R. Sohini', S. Dutta', N. S. Polavaram², K. Datta', M. Muders ${ }^{3 *}$}

'Department of Biochemistry and Molecular Biology, University of Nebraska Medical Center, Omaha, United States, ${ }^{2}$ Department of Pathology, University of Nebraska Medical Center, Omaha, United States, ${ }^{3}$ Institut für Pathologie, Universitaetsklinikum Bonn, Rudolf-Becker-Labor am Biomedizinischen Zentrum, Bonn, Germany
Aim. Despite considerable progress and the development of novel combination chemotherapy regimens for pancreatic cancer, therapeutic success remain limited and novel therapeutic options are urgently needed. While targeted therapies including gene knockdown strategies have largely focused on the tumor cells so far, it has now become obvious that tumor-associated macrophages (TAMs) are major contributors to tumor progression, therapy resistance, immunosuppression and metastasis. In this study, we evaluated the effects of efferocytosis inhibition by targeting macrophage derived neuropilin- 2 in a genetically engineered mouse model on the immune cells in the tumor stroma.

Methods. For the generation of macrophages, bone marrow from either C57/BL6 or CSF1R-iCre; NRP2 ${ }^{\mathrm{f} / \mathrm{f}}$ was used. For subcutaneous transplantation a syngeneic pancreatic cancer cell line was used. RNAseq was used to detect expression profiles after depletion of NRP2 in tumor associated macrophages. Immunhistology was used to characterize the immune cell infiltrate.

Results. We have already reported a novel function of neuropilin- 2 in mediating tumor associated macrophage efferocytosis. Depletion of NRP2 from TAMs resulted in impaired clearance of apoptotic cells. Blocking macrophage efferocytosis by targeting NRP2 in vivo resulted in decreased tumor growth and initiated anti-tumor immune responses detected by increased CD8-T-lymphocyte and NK cell infiltration inside the tumor. RNAseq from TAMs revealed that depletion of NRP2 upregules immunostimulatory mediators in the tumor environment.

Conclusion. Targeting macrophage efferocytosis by blocking NRP2 re-initiates anti-tumor response and results in decreased pancreatic cancer growth. This might pave the way for developing effective and new immunotherapies against pancreatic cancer.

\section{AG01.16}

Lymphknotenmapping zur strukturierten Erfassung von Lymphknotengröße und Lymphknotenmetastasen und ihrer Verteilung beim Kolonkarzinom

\section{Geppert ${ }^{1 *}$, L. Federle ${ }^{2}$, S. Merkel', A. Hartmann ${ }^{1}$, R. Croner ${ }^{4}$}

'Universitätsklinikum Erlangen, FAU Erlangen-Nürnberg, Institut für Pathologie, Erlangen, Deutschland, ${ }^{2}$ Universitätsklinikum UIm, Neurochirurgische Klinik, Neurochirurgie am Bezirkskrankenhaus Günzburg, Günzburg, Deutschland, ${ }^{3}$ Universitätsklinikum Erlangen, FAU ErlangenNürnberg, Chirurgische Klinik, Erlangen, Deutschland, ${ }^{4}$ Universitätsklinikum Magdeburg, Chirurgische Klinik für Allgemein- und Viszeralchirurgie, Magdeburg, Deutschland

Ziel. Bei der operativen Therapie des Kolonkarzinoms werden die Länge des Resektats und die zentrale LK-Dissektion mit kompletter Mesokolonexzision (CME) diskutiert. Die genaue Erfassung der LK und deren Metastasen mittels 2D-Mapping kann die Theorie der CME stützen. Methoden. 1168 Lymphknoten aus 44 Operationspräparaten von Patienten mit Adenokarzinom des Kolon wurden mit exakter Lage in Bezug zum Tumorzentrum in einem „2D-mapping“ erfasst. LK-Größen und ihr Status (histologisch und molekularpathol. mittels OSNA-Verfahren, Sysmex, Germany) wurden erfasst. Alle LK jedes Patienten wurden gruppiert: Histologisch negativ, histologisch positiv oder positiv mittels OSNA-Analyse. Die klinischen Daten sowie Tumorfläche und -Stadium wurden inkl. Korrelation bestimmt.

Ergebnisse. In 1168 Lymphknoten fanden sich 56 Metastasen (36 nur mit Histologie, 20 nur mit OSNA). Die Metastasen lagen zu 89,3 \% in einem Abstand von $<10 \mathrm{~cm}$ nach oral/aboral sowie max. $11,5 \mathrm{~cm}$ nach zentral (im Mesokolon) vom Tumor. Größe $(p=0,0164)$ und Anzahl $(p=0,0146)$ der LK nahmen in Abständen von $0-5 \mathrm{~cm},>5-10 \mathrm{~cm}$ und $>10 \mathrm{~cm}$ zum Tumor jeweils signifikant ab. Entlang des zentralen Gefäßes befanden sich 24 der 36 histologisch erfassten $(66,67 \%)$ sowie 11 der 20 durch OSNA erfassten Metastasen (55 \%). Die durch Histologie oder OSNA nodal-positiven, waren nicht signifikant größer $(p=0,141)$ als die -negativen LKs. Im Median betrug die LK-Größe der positiven $0,8 \mathrm{~cm}(0,3$ bis $2,2 \mathrm{~cm})$, die nodal-negativen LKs waren im Median $0,5 \mathrm{~cm}$ groß $(0,1$ bis $2,2 \mathrm{~cm})$. Bei nodal-positiven Fällen war die Gesamtanzahl der LKs nicht signifikant er- 
höht ( $p=0,3783$ ), Median: 33 LKs (12 bis 47), bei nodal-negativen betrug die Anzahl im Median 27 (15 bis 45).

Fazit. Es zeigt sich, dass der größte Anteil der Metastasen in einem Abstand von jeweils $10 \mathrm{~cm}$ nach oral/aboral und nach zentral liegt. Einzelne Metastasen jedoch lagen $>10 \mathrm{~cm}$ nach oral/aboral entfernt. Bei einer weniger radikalen Resektion als der CME könnten somit in ca. $11 \%$ aller nodal-positiven Fälle nicht alle Metastasen entfernt sein oder gar ein Fal als nodal-negativ befundet werden. Ein „understaging“ und eine ausbleibende adjuvante Therapie mit nachteiligem Überleben könnten folgen. Eine Aussage zum Nodalstatus anhand der LK-Größe und -Anzahl kann vor Operation somit nicht getroffen werden (Bildgebung). Daher ist die histologische Untersuchung einer möglichst großen Lymphknotenanzahl aus einer CME unverzichtbar.

\section{AG01.17 \\ Prognostisch relevante proteogenomische Subtypisierung des Analkarzinoms}

M. Jesinghaus', B. Stroucken ', A. Stenzinger' , L. Taverna ${ }^{2}$, M. Reuschenbach ${ }^{2}$, M. Boxberg', S. Müller', S. Lichtenthaler ${ }^{3}$, N. Pfarr' ', W. Weichert', P.-H. Kuhn ${ }^{1 *}$ ${ }^{1}$ Technische Universität München, Institut für Allgemeine Pathologie und Pathologische Anatomie, München, Deutschland, ${ }^{2}$ Institut für Pathologie Heidelberg, Heidelberg, Deutschland, ${ }^{3}$ Deutsches Zentrum für Neurodegenerative Erkrankungen (DZNE e.V.), Neuroproteomik, München, Deutschland

Das Plattenepithelkarzinom des Analkanals hat in den letzten Jahren bezüglich Therapie und Diagnostik einen Paradigmenwechsel erlebt. Ana$\log$ zu Plattenepithelkarzinomen in anderen anatomischen Lokalisationen, konnte gezeigt werden, dass ein Teil der analen Plattenepithelkarzinome auf Infektionen mit Hochrisiko HPV-Stämmen wie z.B. 16 und $18 \mathrm{zu}-$ rückzuführen ist. Im Bereich der Therapie wurde die ausschließlich chirurgische Resektion durch das Nigro-Protokoll, eine neoadjuvante Radiochemotherapie mit anschließender Resektion bei Tumorresiduen ersetzt. Dies hat die Prognose von Analkarzinompatienten deutlich verbessert. Nichtsdestotrotz gibt es augenblicklich keine prognostischen Biomarker, welche verlässlich den Krankheitsverlauf vorhersagen können.

Im Rahmen dieser Studie konnten mittels der massenspektrometrischen Analyse des Proteoms und einer Hot-Spot Analyse des Genoms von 31 Analkarzinompatienten prognostisch relevante proteogenomische Profile erstellt werden, welche zwischen Patienten mit schlechter und guter Prognose hinsichtlich Gesamtüberleben, krankheitsspezifischem Überleben und krankheitsfreien Überleben trennen.

In einem zweiten Schritt wurden die am stärksten prognostisch relevanten Proteine in Tumor Microarrays der gleichen Patienten untersucht, um Sie hinsichtlich ihrer Eignung für die Routine zu testen.

\section{AG01.18 \\ Prognoseabschätzung von UICC Stage I/II Kolonkarzinomen mittels bildgebender Massenspektrometrie}

B. Martin ${ }^{1 *}$, C. Bollwein'2, A. Jacob 2, W. Weichert², B. Märkl', K. Schwamborn ${ }^{2}$ 'Institut für Pathologie, Universitätklinikum Augsburg, Augsburg, Deutschland, ${ }^{2}$ Institut für Allgemeine Pathologie und Pathologische Anatomie der Technischen Universität München, München, Deutschland

Ziel. Obwohl der Großteil der UICC Stage I und II Kolonkarzinome eine gute Prognose aufweist, zeigen 10-20 \% einen schlechteren Verlauf. Während bei Karzinomen der Stadien I/II primär keine Indikation zur adjuvanten Therapie gegeben ist, könnte die Identifikation eines Risikokollektivs von einer entsprechenden Therapie profitieren. Es existiert bislang kein allgemein akzeptierter Biomarker zur Identifizierung dieser Risikopopulation, der ein adaptiertes therapeutisches Konzept erlauben würde. Das Ziel der Studie besteht in der Identifikation von unterschiedlichen Risikogruppen anhand des massenspektrometrischen Profils mittels bildgebender Massenspektrometrie (MALDI-IMS (Matrix Assisted Laser Desorption Ionisation Imaging Mass Spectrometry)).
Methoden. In einem ersten Schritt wurde ein 276 Patienten umfassendes Kollektiv erstellt und die entsprechenden klinischen follow-up Daten erfasst. Es wurden insgesamt sieben Tissue Micro Arrays (TMAs) aus je 1-2 Tumorproben pro Patienten angefertigt. Anschließend erfolgte eine Untersuchung der in situ erzeugten tryptischen Peptide mittels MALDI-IMS mit einem Flugzeitmassenspektrometer (rapifleX ${ }^{\circledR}$, Bruker Daltonik Bremen, Deutschland). Die Messung erfolgte in einem Massenbereich von $m / z 600-3200$ und bei einer lateralen Ortsauflösung von $50 \mu \mathrm{m}$. Eine erste Auswertung erfolgte mit SCILS ${ }^{\circledR}$ sowie dem Statistikprogramm R.

Ergebnisse und Fazit. In ersten Auswertungen konnten mittels KaplanMeier Analysen mehrere spezifische $m / z$-Werte identifiziert werden, die mit dem Auftreten einer Fernmetastasierung signifikant assoziiert sind. Aktuell werden weitere umfangreichere Analysen (inklusive Identifizierung und Validierung der Peptide/Proteine) durchgeführt, die diesbezüglichen Ergebnisse sind in Kürze verfügbar. Die bildgebende Massenspektrometrie erwies sich als hochleistungsfähige und effiziente Methode zur Identifizierung prognostisch bedeutsamer Kandidatenproteine. Sofern signifikant prognostische Ergebnisse validiert werden können, ist eine Überführung der Technik in die Praxis mit hoher Wahrscheinlichkeit gut realisierbar.

\section{AG01.19}

Expression des desmosomalen Proteins Desmoglein 3 als negativer prognostischer Risikofaktor beim kolorektalen Karzinom

I. Liou', M. Guenther', L. Steinke', J. Neumann', D. Horst ${ }^{2}$, T. Kirchner', S. Ormanns ${ }^{1 *}$

'Pathologisches Institut der LMU, München, Deutschland, ${ }^{2}$ Institut für Pathologie - Charité Universitätsmedizin Berlin, Berlin, Deutschland

Ziel. Das kolorektale Karzinom (KRK) ist geschlechterübergreifend die dritthäufigste Tumorerkrankung in entwickelten Ländern mit bedeutsamer Krankheitslast. Trotz der Weiterentwicklungen in Früherkennung und multimodaler Therapie bleibt eine hohe Letalität in den fortgeschrittenen Stadien, was den kontinuierlichen Bedarf nach präzisen prognostischen Markern und neuer potentieller Therapieziele verdeutlicht. Das desmosomale Protein Desmoglein 3 (DSG3) wird in Zell-Zell-Kontakten epithelialer Gewebe exprimiert, scheint jedoch auch eine Rolle in verschiedenen Karzinomerkrankungen zu spielen, in denen es mit schlechter Prognose assoziiert ist. Wir haben daher mit diesem Projekt die prognostische Bedeutung von DSG3 im KRK untersucht.

Methoden. Wir haben die Assoziation der DSG3-Expression zum Gesamtüberleben (OS) und progressionsfreien Überleben (PFS) in einem Kollektiv von 224 resezierten KRK im Stadium UICC II mittels Immunhistochemie (IHC) untersucht. Gleichsam wurde die DSG3-Expression in einem Fall-Kontroll Kollektiv aus 42 Paaren rechtsseitiger Kolonkarzinome mit bzw. ohne Fernmetastasen in fünf Jahren nach Operation untersucht. Zur Bestätigung haben wir die prognostische Bedeutung der DSG3-Expression in einer großen öffentlich zugänglichen Expressionsdatenbank von Kolonkarzinomen (Colon Metabase) getestet.

Ergebnisse. DSG3 wurde in $28,1 \%$ der 224 KRK Tumoren nachgewiesen und war signifikant mit kürzerem OS und PFS assoziiert ( $p=0,006$ bzw. $p=0,021)$. DSG3 war zudem ein unabhängiger negativer Prognosemarker in multivariaten Analysen $(p=0,046)$. Signifikant mehr Tumoren mit Fernmetastasen zeigten sich DSG3-positiv ( $50,0 \%$ vs. $28,3 \%, p=0,027)$. Diese Ergebnisse wurden durch die Daten der Colon Metabase bestätigt, wobei DSG3 hochsignifikant mit kürzerem OS und PFS korrelierte ( $n=482$ Patienten für OS, $n=545$ Patienten für DFS, jeweils $p<0,001)$. Fazit. DSG3 ist ein unabhängiger negativer Prognosemarker im KRK und mit Fernmetastasierung assoziiert. Die Aufschlüsselung der molekularen Mechanismen und assoziierten Signaltransduktionswege in DSG3-positiven KRK könnte die Ursachen der erhöhten Malignität dieser Tumoren erklären und die Identifikation neuer Therapieziele ermöglichen. 


\section{AG Gastroenteropathologie IV}

\section{AG01.21 \\ Mitophagie und Lysosomale Membran Permeabilisation in Darmepithelzellen induzieren effektive anti-Tumor Immunität während Tumorentstehung \\ P. Ziegler ${ }^{1 * 2}$, F. Greten ${ }^{2}$ \\ 'Senckenbergisches Institut für Pathologie, Uniklinikum Frankfurt, Frankfurt, Deutschland, ${ }^{2}$ Georg-Speyer-Haus, Institut für Tumorbiologie und experimentelle Therapie, Frankfurt, Deutschland}

Ziel. Die Prognose von Patienten mit kolorektalem Karzinom ist von der Infiltration von T-Zellen im Tumorgewebe abhängig. Insbesondere zytotoxische T-Zellen haben einen positiven Effekt auf das Überleben der Patienten. Wir wollten Strategien finden, um T-Zell-Infiltration ins Tumorgewebe therapeutisch zu beeinflussen und diese in präklinischen Modellen testen. Methoden. Experimentelle Inaktivierung von STAT3 in Darmepithelzellen während der Tumorentwicklung im Mausmodell führt zu verringerter Entstehung von Tumoren in Abhängigkeit von CD8+ T-Zellen.

Ergebnisse. Die T-Zell-Infiltration wird durch metabolische Veränderungen in Stat3-defizienten Tumorzellen hervorgerufen, wie gesteigertem mitochondrialem Abbau, der über Autophagie zu lysosomaler Eisenüberladung führt. Dies löst die Freisetzung von lysosomalen Proteasen ins Zytoplasma aus, die zu einer verstärkten Antigen-Prozessierung in Tumorzellen führt. Diese Antigene können auch über „cross-dressing“ an Dendritische Zellen übertragen werden und führen zu effektiver anti-Tumor Immunität. Im Mausmodell vermindert die lysosomotrope Substanz Chloroquin das Tumorwachstum in Abhängigkeit von zytotoxischen T-Zellen. Fazit. Wir beschreiben hier einen zuvor unbekannten Mechanismus, der den Stoffwechsel von Tumorzellen mit anti-Tumor Immunität verbindet. Aktivierung von Mitophagie, Lysosomaler Membran Permeabilisierung oder Inhibition von STAT3 könnten wirksame Therapiestrategien in der Therapie von Darmkrebs darstellen.

\section{AG01.22}

Die Makrophagen bei der Entstehung und Prävention intraperitonealer Adhäsionen - ihre pathophysiologische Relevanz

\section{A. Mamilos ${ }^{1 *}$, V. H. Schmitt' ${ }^{2}$ D. Hollemann ${ }^{3}$, T. K. Rajab ${ }^{4}$, H. Hierlemann ${ }^{5}$, C. J. Kirkpatrick, C. Brochhausen}

'Institut für Pathologie, Universität Regensburg, REPAIR-Lab, Regensburg, Deutschland, ${ }^{2}$ Kardiologie I, Universitätsmedizin Mainz, Mainz, Deutschland, ${ }^{3}$ Institut für klinische Pathologie und Molekularpathologie, Landesklinikum Horn, Horn, Österreich, ${ }^{4}$ Department of Surgery, Brigham and Women's Hospital, Harvard Medical School, Boston, United States, ${ }^{5}$ nstitut für Textilund Verfahrenstechnik, Denkendorf, Deutschland, ${ }^{6}$ Sahlgrenska Academy, Department of Biomaterials, University of Gothenburg, Gothenburg, Schweden

Ziel. Peritoneale Adhäsionen sind häufige postoperative Komplikationen. Für deren Prävention wurden verschiedene Barrierematerialien entwickelt, bislang jedoch ohne die optimale Barriere zu finden. Makrophagen sind in die Pathogenese der peritonealen Adhäsionen involviert. Heutzutage sind zwei große Makrophagensubpopulationen bekannt, die M1- und M2-Makrophagen. Ziel der Studie war es, die Effekte der Makrophagen und ihre Subpopulationen bezüglich der Fibrose und der Gewebereaktion bei der Adhäsionsentstehung und nach Einlage verschiedener Barrierematerialien besser zu verstehen.

Methoden. Für die Studie wurden 42 Wistarratten untersucht, bei denen standardisierte peritoneale Defekte induziert wurden. Die Tiere wurden dann in 6 Gruppen unterteilt: jeweils eine von fünf Gruppen wurde mit einem Barrierematerial versorgt (Adept $t^{\oplus}: n=7$, Intercoat ${ }^{\circ}: n=7$, Spraygel ${ }^{\circ}$. $n=7$, Seprafilm $: n=7$, SupraSeal ${ }^{\circ}: n=7$ ), eine Gruppe blieb als Kontrollgruppe unbehandelt. Das Ausmaß der Fibrose (EvG-Färbung) und die Anzahl an Lymphozyten (HE-Färbung) sowie die Anzahl an Makropha- gen (CD68), M2-Makrophagen (CD163) und M1-Makrophagen wurden ermittelt und miteinander verglichen.

Ergebnisse. In allen Gruppen wurde eine peritoneale Adhäsion ausgebildet. Alle Gruppen zeigten eine unterschiedliche Anzahl an Makrophagen, M2-Makrophagen und M1-Makrophagen sowie ein unterschiedliches Ausmaß der Fibrose. Es zeigte sich keine Korrelation zwischen dem Ausmaß der Fibrose und der Gesamtanzahl von Makrophagen sowie von M1- und M2-Makrophagen. Die Gesamtanzahl der Makrophagen korrelierte mit der Anzahl M2-Makrophagen.

Fazit. Insgesamt konnte in dieser tierexperimentellen Studie zum ersten Mal gezeigt werden, dass im hier verwendeten Tier- und Adhäsionsinduktionsmodell das

Ausmaß der Fibrose nicht mit der Anzahl eines Makrophagensubtyps korreliert. Die unterschiedliche Anzahl der Makrophagen und ihrer Subtypen in den unterschiedlichen Gruppen lassen annehmen, dass die Materialeigenschaften der verwendeten Barrierematerialien einen Einfluss auf das Polarisieren der Makrophagen zu M1- oder M2-Makrophagen haben. In diesem Zusammenhang werden wir die weiteren Subtypen von Makrophagen (M2a, M2b und M2c) weiter analysieren. Weiterhin sollten zukünftige Untersuchungen auch das Mikromilieu des Gewebes zu unterschiedlichen Zeitpunkten untersuchen, um die Verteilung der unterschiedlichen Makrophagensubtypen im zeitlichen Verlauf besser zu verstehen.

\section{AG Uropathologie I - Prostata, Blase}

\section{AG02.01}

\section{The new ISUP 2014/WHO 2016 prostate cancer grade group} system-first résumé 5 years after introduction

A. Offermann ${ }^{1 *}$, M. C. Hupe ${ }^{2}$, V. Sailer ${ }^{1}$, A. S. Merseburger ${ }^{2}$, S. Perner ${ }^{7}$

'Universitätsklinikum Schleswig-Holstein, Campus Lübeck und Forschungszentrum Borstel, Leibniz Lungenzentrum, Institut für Pathologie, Lübeck, Germany, ${ }^{2}$ Universitätsklinikum Schleswig-Holstein, Campus Lübeck, Abteilung für Urologie, Lübeck, Germany

Purpose. To systematically and comprehensively review and summarize the most recent literature assessing the value of the new grading system introduced by the International Society of Urological Pathology (ISUP) in 2014 and accepted by the World Health Organization (WHO) in 2016. Methods. A systematic literature search in the PubMed database was performed up to November 2018. Overall, 15 studies in the period from 2016 to 2018 evaluating the new grading system have been selected for evidence synthesis.

Results. The main goals of the new ISUP 2014/WHO 2016 grading system were to establish (I) a more accurate and simplified grade stratification, (II) less overtreatment of indolent prostate cancer as well as (III) an improved patient communication. The majority of the studies chose biochemical recurrence as an endpoint for evaluation and statistically assigns the new ISUP 2014/WHO 2016 grading system a higher prognostic accuracy than the former Gleason grading. However, in only a subset of studies it was clearly evident that the historical samples were not only re-grouped according to the new grade groups but also re-graded according to the new histomorphological 2014 ISUP criteria.

Conclusions. The vast majority of the studies support an improved prognostic accuracy of the ISUP 2014/WHO 2016 grade groups and endorse its worldwide application. 
AG02.02

\section{Proteinexpressionsprofile zur Vorhersage strahlenresistenter Prostatakarzinome}

T. Nestler ${ }^{*}$, M. Wittersheim ${ }^{2}$, M. Hellmich ${ }^{3}$, D. Pfister ${ }^{1}$, M. Odenthal $^{2}$, R. Büttner' ${ }^{2}$, S. Schäfer ${ }^{2}$, A. Heidenreich ${ }^{1}$

'Universitätsklinik Köln, Klinik für Urologie, Köln, Deutschland, ${ }^{2}$ Universitätsklinik Köln, Institut für Pathologie, Köln, Deutschland, ${ }^{3}$ Universität zu Köln, Institut für Medizinische Statistik und Bioinformatik, Köln, Deutschland

Ziel. Rezidive nach Strahlentherapie bei Prostatakarzinomen (PCa) sind relativ häufig. Jedoch gibt es bis dato keine klinischen Modelle oder Biomarker, um Patienten mit einem hohen Strahlenresistenzrisiko zu identifizieren. Bisher wurden hierzu nur In-vitro-Studien und Untersuchungen an Xenograft-Modellen durchgeführt. In-vivo-Untersuchungen an humanen Prostatakarzinompräparaten zur Identifizierung von Genexpressionsmustern, die mit die mit Strahlenresistenz verbunden sind, fehlen.

Um potenzielle Biomarker für die Strahlenresistenz zu identifizieren verglichen wir Proteinexpressionsprofile von radioresistenten PCa mit PCa von primär prostatektomierten Patienten.

Methoden. Zwei Gruppen, bestehend aus: I) 30 Patienten, die mittels Salvage-Prostatektomie behandelt wurden, und II) 94 primär prostatektomierte Patienten. Gewebe-Microarrays wurden aus den PCa konstruiert und Expressionsunterschiede von 15 Proteinen immunhistochemisch analysiert, die in In-vitro-Studien mit strahlenresistentem PCa assoziiert wurden. Der Kruskal-Wallis-Test wurde für den Vergleich mehrerer Gruppen verwendet, der Dunn-Bonferroni-Test um Unterschiede zwischen den Gruppen zu identifizieren und Cohens d zur Berechnung der Intergruppeneffektgröße. Ergebnisse. Die meisten analysierten Proteine zeigten keine signifikanten Unterschiede zwischen strahlenresistenten PCa und primären PCa. Der Vergleich von Expressionsmustern zwischen radioresistenten PCa und primären PCa, die nach Gleason-Risikogruppen separiert wurden, zeigte eine ausgeprägte Expression von AR (Androgenrezeptor) in radioresistenten PCa $(89,7 \%)$ und in $87,8 \%$ von primären PCa der Hochrisiko-Gruppe (Gleason $>7 \mathrm{a})(p=0,851$, Cohens $\mathrm{d}=0,05)$, wohingegen nur 67,3\% der PCa der niedrigen Risikogruppe (Gleason $\leq 7 \mathrm{a})(p=0,017$, Cohens $\mathrm{d}=0,55) \mathrm{AR}$ exprimierten. Separiert nach dem höchsten Gleason-Muster pro Patient war nur AKR1C3 (Aldo-keto reductase family 1 member C3) in strahlenresistenten PCa und primären PCa mit den hohen Gleason-Mustern 4 oder $5(p=0,827$, Cohens $\mathrm{d}=0,05$ und $p=0,893$, Cohens $\mathrm{d}=0,10)$ ähnlich stark exprimiert, im Vergleich zu der deutlich geringeren Expression des Gleason-Musters $3(p=0,20$, Cohens $\mathrm{d}=0,69)$ in primärem PCa.

Fazit. Dies ist die erste Studie, in der Proteinexpressionsprofile zur Vorhersage der Radioresistenz in PCa untersucht wurden, wobei AR und AKR1C3 die vielversprechendsten Proteinmarker darstellten.

\section{AG02.03}

\section{Androgen receptor pathway alterations and DNA repair in prostate cancer: transcriptional profiling of the primary and treated prostate cancer}

\section{Y. Tolkach ${ }^{*}$, A. Kremer' ${ }^{1}$, G. Lotz' ${ }^{2}$, J. Ellinger ${ }^{3}$, C. Ohlmann ${ }^{4}$, G. Kristiansen ${ }^{1}$}

'University Hospital Bonn, Institute of Pathology, Bonn, Germany,

${ }^{2}$ Semmelweis Universität, Budapest, Hungary, ${ }^{3}$ University Hospital Bonn, Clinic of Urology, Bonn, Germany, ${ }^{4}$ Malteser Hospital Seliger Gerhard Bonn/ Rhein-Sieg, Clinic of Urology, Bonn, Germany

Aim. Recently, interdependencies between androgen receptor (AR) signalling, androgen deprivation therapy (ADT) and alterations of the DNA repair machinery in prostate cancer (PCA), have been described which can have therapeutic implications. The aim of our study was to analyse the associations between AR pathway activation, presence of AR splice variants and transcriptional status of DNA repair genes in patients with primary hormone-naïve PCA, patients on ADT without and with castration resistance (CRPC).

Methods. One hundred ninety-one patients were included (• Table 1) AG02.03) with overall 277 samples representing matched primary and metastatic lesions (including multiple samples from primary and metastatic tumors with different morphology) or consecutive samples from patients on ADT (palliative TURPs). All samples were retrieved from formalin-fixed paraffin-embedded archived tissues.

nCounter platform (NanoString Technologies, Seattle, WA, USA) was used for mRNA expression analysis. A custom gene panel consisting of 56 genes was constructed including AR transcriptional targets, AR splice variants (AR-V1/V3/V7/V9, AR45, Arv567es), panel of 26 DNA repair genes, proliferation markers, and PCA-relevant genes. AR pathway activity as well as composite DNA repair activity scores were calculated based on expression of genes from corresponding signatures.

Results. The main results are:

1. AR-V1/3/7/9-splice variants were expressed in $14 \%, 19 \%, 50 \%$, and $64 \%$ of primary hormone-naïve, metastatic hormone-naïve, ADT non-CRPC, and CRPC samples, respectively.

3. The dominating AR-splice variant in primary tumors was AR-V1 (79\%), in ADT/CRPC-AR-V7 (100\%). Six of 17 primary tumors expressing AR-Vs were histologically ductal adenocarcinomas.

4. AR pathway activity is different at different disease stages and still preserved in CRPC, dependent on presence of AR-Vs. Different AR-Vs could probably have different functional load at different disease stages. 5. Activity of DNA repair is dependent on disease stage (primary/ADT/ CRPC), AR pathway activity and presence of splice variants and ADT. Conclusions. AR pathway alterations are common in patients on ADT and with CRPC, however, to some extent already present in primary PCA. AR pathway activity is preserved in CRPC patients and dependent on presence of splice variants. This study found associations between the AR pathway and DNA repair in PCA which appear to be stage dependent.

\section{AG02.04}

Identifizierung potentieller prädiktiver Biomarker und therapeutischer Zielstrukturen im urothelialen Carcinoma in situ der Harnblase

S. Garczyk*, N. Ortiz-Brüchle, U. Schneider, I. Lurje, N. T. Gaisa, K. LindemannDocter, R. Knüchel

Uniklinik RWTH Aachen, Pathologie, Aachen, Deutschland

Ziel. Das Carcinoma in situ (CIS) ist eine aggressive Urothelläsion, aus der sich die Mehrzahl der muskelinvasiven Urothelkarzinome entwickelt. Die Bacillus-Calmette-Guérin (BCG)-basierte Immuntherapie nach transurethraler Resektion ist der Goldstandard in der Therapie des CIS. Jedoch ist die Therapie in $>50 \%$ der Fälle nicht erfolgreich, zurückzuführen auf Toxizität und Resistenz. Auch die Zweitlinientherapie, die radikale Zystektomie, ist mit einer hohen Übertherapie-Rate und drastischen Änderungen in der Lebensführung der Patienten assoziiert. Effektive zielgerichtete Therapien für das CIS mit reduzierter Toxizität werden daher benötigt. Das CIS ist unzureichend molekular charakterisiert, so dass wir in der vorliegenden Studie darauf abzielen, mögliche therapeutisch nutzbare genetische Alterationen in CIS-Zellen zu identifizieren.

Methoden. Mittels Laser-Capture-Mikrodissektion wurden 25 CIS- und 5 Muskel-Kontrollproben aus 26 kryokonservierten Zystektomie-Präpa-

Table 1| AG02.03 Characteristics of study cohort

\begin{tabular}{llllllll}
$\begin{array}{l}\text { Primary Prosta- } \\
\text { te Carcinoma }\end{array}$ & $\begin{array}{l}\text { Primary, meta- } \\
\text { stases }\end{array}$ & $\begin{array}{l}\text { ADT, non-CRPC, } \\
\text { prostate }\end{array}$ & $\begin{array}{l}\text { ADT, non-CRPC, } \\
\text { metastases }\end{array}$ & $\begin{array}{l}\text { ADT, CRPC, } \\
\text { prostate }\end{array}$ & $\begin{array}{l}\text { ADT, CRPC, } \\
\text { metastases }\end{array}$ & BPH & BPH \\
\hline 78 & 19 & 32 & 9 & 28 & 5 & 10 & 10
\end{tabular}


raten ohne neoadjuvante Chemotherapie isoliert und eine Panel-Sequenzierung durchgeführt (Mutationen, CNVs in 33 Genen). Der Fokus lag auf der Detektion genetischer Alterationen in Genen, die bekannte therapeutische Zielstrukturen codieren oder deren Veränderungen als prädiktive Marker für das Ansprechen auf zielgerichtete Therapien beschrieben sind, die entweder zugelassen sind oder in registrierten klinischen Studien. Filterkriterien für detektierte Varianten: Frequenz in der Probe ist $\geq 5 \%$, Frequenz in der Bevölkerung ist $<2 \%$. Bekannte benigne sowie intronische und stumme Varianten außerhalb von Splice-Positionen wurden nicht berücksichtigt.

Ergebnisse. In 88 \% (22/25) der Fälle wurde mindestens eine Variante identifiziert, die eine Therapierbarkeit mit zielgerichteten Therapeutika anzeigen könnte. Betroffene Gene sind der DNA Damage Response (DDR), dem TP53/Zellzyklus-, dem PI3K/MAPK-Signalweg sowie Chromatin-modifizierenden Prozessen zuzuordnen. Die häufigsten Mutationen wurden im TERT-Promoter (64 \%;14/22), TP53 (44\%;11/25), in den Chromatin-modifizierenden Genen ARID1A (28 \%;7/25) und KDM6A $(24 \% ; 6 / 25)$ sowie den DDR-Genen ATM, BRCA1 und BRCA2 (jeweils $20 \% ; 5 / 25)$ detektiert.

Fazit. Der Großteil der untersuchten CIS-Fälle wies Mutationen in Genen therapeutischer Zielstrukturen, wie ERBB2 und PIK3CA, sowie potentiellen prädiktiven Markern für zielgerichtete Therapieansätze, wie BRCA1/ $B R C A 2$, auf. Ihre Bedeutung für die Therapie des CIS bedarf der weiteren Validierung in Folgestudien.

\section{AG02.05}

\section{Charakterisierung des papillären de novo High-Grade Urothelkarzinoms der Harnblase und Ableitung möglicher Therapieimplikationen}

T. Schnitzler ${ }^{1 *}$, N. Ortiz-Brüchle ${ }^{1}$, U. Schneider' , I. Lurje ${ }^{1}$, A. Buchner ${ }^{2}$, N. T. Gaisa', R. Knüchel', S. Garczyk'

${ }^{1}$ Uniklinik RWTH Aachen, Pathologie, Aachen, Deutschland, ${ }^{2}$ Klinikum der LMU München, Urologische Klinik, München, Deutschland

Ziel. Nicht-muskelinvasive Urothelläsionen (NMIUC) der Harnblase sind weiterhin unzureichend charakterisiert. pTaHG-Tumoren entwickeln sich nach derzeitigem Kenntnisstand aus einer Low-Grade (LG)-Komponente. Beobachtungen legen jedoch nahe, dass pTaHG-Tumoren potentiell auch de novo entstehen könnten, ohne LG-Komponente in der Vorgeschichte. Innerhalb dieser Studie zielen wir darauf ab, potentielle de novo pTaHGTumoren immunhistochemisch und molekular zu charakterisieren. Insbesondere sollen so potentielle zielgerichtete Therapieoptionen identifiziert werden.

Methoden. Ein FFPE-Kollektiv bestehend aus 73 papillären HG-Tumoren (41 pTa HG und 32 pT1 HG) aus 46 Patienten ohne vorheriges oder synchrones pTaLG- oder muskelinvasives Karzinom der Harnblase, wurde immunhistochemisch analysiert: luminale Marker (KRT20, GATA3, HER2, ERbeta), basale Marker (KRT5/6, KRT14) sowie p53. Für eine Sequenzierung (Mutationen und CNVs, 33 Gene) wurde der exophytische Anteil aus 19 pTaHG-Tumoren sowie 4 Muskel-Kontrollproben isoliert. Der Fokus lag auf der Detektion von Alterationen in Genen, die therapeutische Zielstrukturen codieren oder deren Veränderungen als prädiktive Marker für das Ansprechen auf zielgerichtete Therapien beschrieben sind. Filterkriterien für detektierte Varianten: Frequenz in der Probe $\geq 5 \%$, Frequenz in der Bevölkerung $<2 \%$. Bekannte benigne sowie intronische und stumme Varianten außerhalb von Splice-Stellen wurden nicht berücksichtigt.

Ergebnisse. De novo pTaHG-Tumoren sind charakterisiert durch eine starke Expression luminaler Proteine im exophytischen Anteil (KRT20+: $75 \%$ (55/73), medianer GATA3 Remmele Score 12, ERbeta+: 96 \% (70/73), HER2 Dako Score 3+: 29 \% (21/73)) bzw. eine Expression basaler Marker in nur wenigen Fällen (KRT5/6+: 4 \% (3/73), KRT14+: 12 \% (9/73)). In $95 \%$ (18/19) der Fälle wurde mindestens eine Variante identifiziert, die eine Therapierbarkeit mit zielgerichteten Therapien anzeigen könnte. Häufige Mutationen wurden detektiert in: TERT (71 \%, 10/14), KDM6A (47\%;9/19), PIK3CA (37\%;7/19), ERCC2, ATM, ARID1A und CREBBP (jeweils $32 \% ; 6 / 19)$. TP53- und FGFR3-Mutationen wurden in gleicher Frequenz detektiert (jeweils $16 \% ; 3 / 19$ ).

Fazit. Potentielle de novo pTaHG-Tumoren sind durch eine luminale Markerexpression und eine ausgeglichene Frequenz an TP53- und FGFR3Mutationen charakterisiert. Die große Mehrheit der Fälle weist Veränderungen auf, die eine Therapierbarkeit mit zielgerichteten Therapeutika ermöglichen könnten.

\section{AG02.06}

mRNA based marker gene expression in muscle invasive, nodal positive bladder cancer

M. Kriegmair', C. Boehmer', J. Jarczyk', R. M. Wirtz' ${ }^{2}$, T. Worst', J. Breyer ${ }^{3}$, M. Eckstein ${ }^{4}$, C. A. Weis' ${ }^{5}$ A. Hartmann ${ }^{4}$, P. Erben' 1 , S. Porubsky ${ }^{5 *}$

${ }^{1}$ Klinik für Urologie, Medizinische Fakultät Mannheim, Universität Heidelberg, Mannheim, Germany, ${ }^{2}$ Stratifyer Molecular Pathology, Köln, Germany, ${ }^{3}$ Klinik für Urologie, Universität Regensburg, Regensburg, Germany, ${ }^{4}$ Pathologisches Institut, Universitätsklinikum Erlangen, Erlangen, Germany, ${ }^{5}$ Pathologisches Institut, Medizinische Fakultät Mannheim, Universität Heidelberg, Mannheim, Germany

Introduction. In muscle invasive and metastasized bladder cancer, the origin of tumor samples might influence marker gene assessment. The aim of this study was to compare mRNA based marker gene expression (ERBB2, ESR1, ESR2, CK5 and CK20) between TUR-B, radical cystectomy (RC) and lymphadenectomy (LAD) samples.

Materials and methods. 44 patients with muscle invasive and nodal positive bladder cancer $(\geq \mathrm{pN} 2)$ treated with RC were included. Gene expression was measured using routine FFPE tissue from TUR-B sample, RC specimen and lymph node metastases by two step RT-qPCR ( $\Delta \Delta$ Cq method).

Results. A positive and significant correlation of the expression of ERBB2, CK5, CK20 and ESR1 between TUR-B and RC as well as LAD specimen $(\rho>0.62, p<0.003)$ was observed. For ESR2 the correlation between TUR-B and RC specimen was negative $(\rho=-0.44, p=0.002)$. ERBB2 expression was higher in the TUR-B compared to RC and LAD specimen $(p=0.006$ and $p=0.04)$, which were not different. For CK20, measured expression levels were higher in the TUR-B compared to the RC tissue $(p=0.037)$. CK5 expression was higher in the TUR-B compared to the lymph node metastases $(p=0.002)$. No differences between RC and LAD specimens were observed for CK20 and CK5. ESR1 and ESR2 expression was not different between the distinct specimens. Patients with a high ERBB2 expression in the RC specimen showed an inferior overall survival (OS) (Log-rank, $p=0.005)$. Regarding the TUR-B specimen a high ERBB2 expression was associated with an improved OS $(p=0.002)$. Patients with a high ERBB2 expression in the RC and a low in the TUR-B had the worst survival with an OS of less than 6 months $(p<0.001)$. Similar results were obtained for ESR2 expression.

Conclusion. Assessment of mRNA based gene expression levels depend on the respective tumor specimen. Although there seems to be a good correlation between absolute expression levels between TUR-B, RC and LAD tumor tissue, expression of some genes (e.g. ERBB2) differs between the specimens with contrary prognostic relevance. 


\section{AG Uropathologie II - Blase}

\section{AG02.08 \\ Large nested variant of urothelial carcinoma: a prime example of a FGFR3-mutated, luminal tumor}

V. Weyerer ${ }^{1 *}$, M. Eckstein ${ }^{1}$, E. Compérat ${ }^{2}$, H. Juette ${ }^{3}$, Y. Allory ${ }^{4,5}$, R. Stoehr ${ }^{1}$, B. Wullich ${ }^{6}$, M. Roupret ${ }^{7}$, A. Hartmann', S. Bertz ${ }^{1}$

${ }^{1}$ Institut für Pathologie, University Hospital Erlangen, Friedrich-Alexander Universität Erlangen-Nürnberg, Erlangen, Germany, ${ }^{2}$ Hopital Tenon, HEUP, Sorbonne University, Paris, France, ${ }^{3}$ Institute of Pathology, Ruhr-University Bochum, Bochum, Germany, ${ }^{4}$ Department of Pathology, Hôpital Foch, Université Versailles-Saint-Quentin-en-Yvelines, Université Paris-Saclay, Suresnes, Paris, Germany, ${ }^{5}$ Institut Curie, CNRS, UMR144, Paris, France, ${ }^{6}$ Department of Urology and Paediatric Urology, University Hospital Erlangen, Friedrich-Alexander Universität Erlangen-Nürnberg, Erlangen, Germany, ${ }^{7}$ Service d'Urologie, Hôpital La pitié-Salpetrière, Sorbonne University, Paris, France

Background and objective. Urothelial carcinoma (UC) of the bladder may present with distinct histomorphological features and rare histologic subtypes have been defined. Since 2016 large nested urothelial carcinoma (LNUC), has been included within the World Health Organization Classification among the nested type UC. Little is known about LNUC. However, the very limited reports with mainly small case numbers confirm the fully malignant and life-threatening behavior despite the bland morphological appearance. In this study we evaluated FGFR3 mutational status as well as the molecular subtype of this specific variant by using a simplified panel of immunohistochemical markers.

Materials and methods. 26 cases diagnosed as LNUC were collected and histomorphologically reevaluated. DNA was extracted after manual microdissection of the tumor, including separation of morphologically distinct areas. SNaPshot analysis of the hot spot regions of the FGFR3 gene was done. Immunohistochemical basal and luminal markers CK14, CK5, CD44 FOXA1, GATA3, CK20 and Uroplakin were tested to elucidate the molecular subtype.

Results. Of 26 cases eight were pure LNUC, 12 showed an additional exophytic (non-invasive) papillary component, four presented areas of classical nested type variant and three a component of conventional UC. 7/7 evaluable pure cases were FGFR3-mutated. 8/10 LNUC with papillary component were mutated in both areas. No mutations were found in $3 / 3$ LNUC combined with classical nested type UC. LNUC cases showed predominantly high protein expression levels of luminal markers.

Conclusion. LNUC either pure or combined with a papillary component is a prime example of a luminal, FGFR3 mutated tumor. However, LNUC combined with classical nested type UC seems to represent a different molecular pathway. Regarding the unique molecular features our findings are of particular interest since FGFR-pan inhibitors are currently tested in clinical Trials.
AG02.09

Tumor immune microenvironment drives prognostic relevance correlating with bladder cancer subtypes

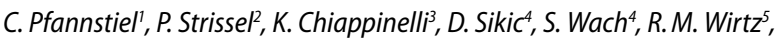
A. Wullweber', H. Taubert, J. Breyer 6 , W. Otto , T. S. Worst ${ }^{7}$, M. Burger ${ }^{6}$, B. Wullich ${ }^{4}$, C. Bolenz ${ }^{8}$, N. Fuhrich ${ }^{1}$, C. Geppert ${ }^{7}$, V. Weyerer', R. Stoehr', S. Bertz' , B. Keck ${ }^{4}$, F. Erlmeier ${ }^{9}$, P. Erben ${ }^{7}$, A. Hartmann ${ }^{1}$, R. Strick ${ }^{2}$, M. Eckstein ${ }^{1 *}$, BRIDGE Consortium Germany

${ }^{1}$ Friedrich-Alexander Universität Erlangen-Nürnberg, Institute of Pathology, Erlangen, Germany, ${ }^{2}$ Friedrich-Alexander Universität Erlangen-Nürnberg, Department of Gynecology and Obstetrics, Erlangen, Germany, ${ }^{3}$ George Washington University School of Medicine and Health Sciences, Department of Microbiology, Immunology and Tropical Medicine, Washington D.C., United States, ${ }^{4}$ Friedrich-Alexander Universität ErlangenNürnberg, Department of Urology and Pediatric Urology, Erlangen, Germany, ${ }^{5}$ Stratifyer Molecular Pathology, Cologne, Germany, ${ }^{6}$ University of Regensburg, Caritas Hospital St. Josef, Department of Urology, Regensburg, Germany, ${ }^{7}$ Ruprecht-Karls-University Heidelberg, Department of Urology, Mannheim, Germany, ${ }^{8}$ University of Ulm, Department of Urology, Ulm, Germany, ' University Hospital TU Munich, Institute of Pathology, Munich, Germany

Background. Muscle-invasive bladder cancer (MIBC) represents approximately two thirds of invasive urothelial bladder cancers (UBC) and has high morbidity and mortality. We conducted this study to gain further insights in the immunological tumor microenvironment (TIME).

Material and methods. sTILs were scored continuously on HE slides in a cohort of 135 patients with MIBC treated by radical cystectomy according to current recommendations (Salgado et al., 2015). Intrinsic subtypes were assessed by Nanostring (MDACC-approach). Tertiary lymph structures were assessed by immunohistochemistry of CD3, CD8, CD68, and CD79a. Spatial immune profiling was carried out on regionally designed TMAs by CD3, CD8, CD56 (NK-Cells), CD68, PD-1 and PD-L1 and revealed spatial organized immune phenotypes. Results were validated in 407 MIBC (TCGA) cohort by hierarchical clustering analysis, immune cell population analysis via CIBERSORT and sTIL-scoring. Tumor mutational burden, neoantigen load and mutational patterns as well as mutational signatures were correlated with immune phenotypes (TCGA).

Results. We demonstrate that quantity and spatial distribution of stromal tumor infiltrating lymphocytes (sTILs) within the tumor immune microenvironment (TIME) predict stages of tumor inflammation, subtypes, patient survival and correlate with expression of immune checkpoints. High sTILs indicate an inflamed subtype with 80\% 5-year DSS. A lack of immune infiltrates identifies an uninflamed subtype with a survival rate of less than $25 \%$. A separate immune evading phenotype with upregulated immune checkpoints associated with poor survival. Within the TIME are tertiary lymph node structures (TLS), which can mediate anti-tumor activity via active immune cells. High TLS amounts and close tumor distance correlated significantly with an inflamed phenotype and favorable survival. The uninflamed and evasion phenotypes showed lowest TLS numbers and farthest tumor distances and shortest survival. High inflammation also correlated with increased neoantigen load, high TMB and specific mutational patterns (TCGA-MSig1, TCGA-MSig3/4). Patients treated with adjuvant chemotherapy showed a favorable prognosis dependent on high sTILs.

Conclusions. sTILs and tumor subtypes may stratify therapy success and patient survival. Considering sTILs can easily be quantified morphologically, sTILs scoring can be implemented for predicting patient survival and outcome after adjuvant platinum containing chemotherapy. 
AG02.10

\section{Immunological microenvironment of FGFR3 altered muscle invasive bladder cancer}

\section{Weyerer ${ }^{1 *}$, R. Stoehr ${ }^{1}$, C. Bolenz ${ }^{2}$, A. Hartmann 1 , P. Erben ${ }^{3}$, M. Eckstein ${ }^{1}$, BRIDGE Consortium e. V., Mannheim, Germany \\ 'University Hospital Erlangen, Friedrich-Alexander Universität Erlangen- Nürnberg, Institute of Pathology, Erlangen, Germany, ${ }^{2}$ University of Ulm, Department of Urology, Ulm, Germany, ${ }^{3}$ Medical Faculty Mannheim, Heidelberg University, Department of Urology, Mannheim, Germany}

Background and objective. Muscle-invasive bladder cancer (MIBC) is a complex disease and perioperative chemotherapy followed by radical cystectomy is standard of care. In the recent years new systemic therapy options for advanced urothelial tumors emerged and pave the way to personalized medicine. Among them targeted therapies against Fibroblast growth factor receptor $(F G F R)$ as well as disrupting the immune-microenvironment by using PD-1/PD-L1 inhibitors are promising and currently evaluated in clinical trials. Here we aimed to assess the relationship of FGFR3-, PD-L1/PD-1-status, immune cells and immune related gene expressions in MIBC to gain insights into potential differential expression of these targets. Materials and methods. We used the TCGA cohort $(n=407)$. First we identified tumors with activating FGFR3-gene alterations. We compared tumor mutational burden (TMB), neoantigen load and gene expression of key immune checkpoints, immune genes as well as important immune cel populations derived by the CIBERSORT-algorithm in these two groups (FGFR3-altered vs. not altered).

Results. FGFR3 altered tumors showed significantly less TMB and neoantigen load compared to not altered cases $(p=0.037$ and $p=0.04)$. Tumors with high expression of PD-1, PD-L1, CTLA4 and IDO1 were predominately not FGFR3 altered $(p<0.0001)$. Additionally, gene expression analysis of immune related genes such as CD3Z, CD8A, FOXP3 as well as the amount of specific immune cell populations were significantly inversely associated with FGFR3 alteration status.

Conclusion. Taken together, our analysis demonstrated that FGFR3-mutated tumors showed low PD-1/PD-L1 expression as well as low amount of immune cells. Moreover, gene expression data revealed the association with an uninflamed tumor environment. Therefore, FGFR3- and PD-1/ PD-L1 seem to be elusive, inversely associated and combination of therapy regimens might not be effective. To further investigate these hypotheses they will be validated in another consecutive muscle invasive cohort.

\section{AG02.11 \\ Proteasomale Immunescape-Mechanismen beim Urothelkarzinom}

M. Wessolly', F.D. Mairinger', T. Herold', K. Worm', P. Nyirády², B. Hadaschik', K. W. Schmid' T. Szarvas ${ }^{2,3}$, H. Reis ${ }^{1 *}$

'Institut für Pathologie, Universitätsmedizin Essen, Universität DuisburgEssen, Essen, Deutschland, ${ }^{2}$ Klinik für Urologie, Semmelweis Universität, Budapest, Ungarn, ${ }^{3}$ Klinik für Urologie, Universitätsmedizin Essen, Universität Duisburg-Essen, Essen, Deutschland

Ziel. Cisplatin-haltige Chemotherapie-Konzepte waren für etwa drei Jahrzehnte der Standard beim fortgeschrittenen Urothelkarzinom. Allerdings spricht ein Teil der Patienten kaum bzw. nur unvollständig auf ein solches Therapieschema an. Die zugrundeliegenden Mechanismen sind dabe nicht ausreichend verstanden. Hier scheint die anti-tumorale Immunsystem-Antwort einen signifikanten Einfluss zu haben. Vor diesem Hintergrund berichten wir über einen neuen „Immunescape“-MechanismusAnsatz beim Urothelkarzinom.

Methoden. Formalin-fixiertes und Paraffin-eingebettetes (FFPE) Tumormaterial von 26 Muskel-invasiven Urothelkarzinomen der Harnblase (MIBC) wurden mittels zielgerichteter, Amplikon-basierter Massiv-Parallelsequenzierung untersucht. Nach Filterung wurden 43 dominante $\mathrm{Mu}$ tationen identifiziert (Tumor-Allelfrequenz $>25 \%$ ). Diese wurden mittels „Deep-Learning“ Algorithmen hinsichtlich Ihres Einflusses auf proteasomale Schnittstellen der Epitop-Prozessierung und die damit verbundene
Immunpräsentation/-aktivierung untersucht. Eine umfassende explorative Datenanalyse mit kliniko-pathologischen Kovariaten folgte.

Ergebnisse. Erhöhtes Auftreten und vermehrte Anzahl von alternativprozessierten Epitopen waren signifikant mit einem reduzierten Gesamtüberleben $(p=0,025)$ und schlechterem Progressions-freiem Überleben $(p=0,008)$ unter Platin-haltiger Chemotherapie assoziiert. Zudem wurde eine Gruppe von „Non-Respondern“ identifiziert, die multivariat unabhängig einen schlechten Verlauf zeigten (Eintritt einer Progression sowie des Todes innerhalb der ersten beiden Jahre). Der Effekt war unabhängig von der allgemeinen Tumor-Mutationslast.

Fazit. Proteasomale „Immunescape“-Mechanismen scheinen beim MIBC eine signifikante Rolle zu spielen und zeigen Eigenschaften eines relevanten Prädiktors für die Kompetenz der Neoplasie zur Vermeidung einer anti-tumoralen Immunantwort. Das letztere ist besonders vor dem Hintergrund der Erfassung therapieprädiktiver Marker für die beim Urothelkarzinom eingesetzten Immuntherapien relevant.

\section{AG Uropathologie III - Niere, Hoden}

\section{AG02.12}

\section{Der Transkriptionsfaktor chREBP verzögert und verringert die Tumorentstehung in der Mausniere}

\section{S. Ribback*, C. Burkert, C. Metzendorf, F. Dombrowski}

Universitätsmedizin Greifswald, Institut für Pathologie, Greifswald, Deutschland

Ziel. Klarzellige, glykogenspeichernde Nierentubuli, die Armanni-Ebstein-Läsionen (AEL), stellen Vorläuferläsionen des Nierenzellkarzinoms im Rahmen der experimentellen diabetisch-induzierten Nephrokarzinogenese dar. Sie treten auch häufig sporadisch in humanem Nierengewebe auf. Die AEL weisen eine erhöhte Proliferationsaktivität sowie eine Überexpression des protoonkogenen Signalweges AKT/mTOR mit einer damit verbundenen gesteigerten Glykolyse und de-novo-Lipogenese auf, was durch den Transkriptionsfaktor carbohydrate responsive element binding protein (chREBP) vermittelt sein könnte.

Methoden. Zur Induktion eines Insulinmangeldiabetes erhielten C57BL/6J-Wildtyp-(WT) und chREBP-knockout (chREBP-KO)-Mäuse eine einmalige intraperitoneale Injektion von Streptozotocin. Kontrolltiere blieben nicht diabetisch. Nach einer Versuchsdauer von 1 Woche $(N=168), 4$ Wochen $(N=149), 3$ Monaten $(N=196)$ und 6 Monaten $(N=178)$ wurde das Nierengewebe histologisch, immunhistochemisch (BrdU-labeling-index) und elektronenmikroskopisch untersucht.

Ergebnisse. Glykogenspeichernde AEL entstanden bei diabetischen chREBP-KO-Mäusen häufiger und ausgeprägter als bei den diabetischen WT-Mäusen (Häufigkeit diabetisch chREBP-KO vs. WT: nach 1 Woche 97 vs. $65 \%$, nach 4 Wochen $100 \%$ vs. $67 \%$ ). Die Proliferationsaktivität der AEL der ChREBP-KO Tiere ist gegenüber denen der WT-Mäuse erhöht (BrdU-LI \%, ChREBP-KO vs. WT, nach 4 Wochen: $2,28 \pm 0,54 \%$ vs. $0,60 \pm 0,23 \%, p<0,05)$. Desweiteren traten die AEL bei den WT-Tieren häufiger in den distalen Tubuli (• Abb. 1 | AG02.12), bei den chREBP-KOMäusen hingegen häufiger in den proximalen Tubuli (• Abb. 2 | AG02.12) auf.

Nach 3 und 6 Monaten entstanden bei den chREBP-KO-Mäusen häufiger manifeste basophile Nierentumoren im Vergleich zu den WT-Tieren (Häufigkeit chREBP-KO vs. WT: 3 Monate $12,7 \%$ vs. 0,45 \%, 6 Monate $24,1 \%$ vs. $10,5 \% ; p<0,05)$. Dabei entwickelten sich häufig auch spontane Tumoren bei nicht-diabetischen chREBP-KO-Mäusen, die bei nicht-diabetischen WT-Mäusen nicht auftraten (• Abb. 3|AG02.12).

Fazit. Bislang wurde für den Transkriptionsfaktor chREBP eine onkogene Wirkung im Rahmen der Aktivierung des AKT/mTOR-Signalweges angenommen. Unsere aktuellen Befunde einer verringerten Proliferationsaktivität von präneoplastischen Tubulusläsionen und verminderten Tumorentstehung bei intaktem chREBP in der Niere diabetischer und 


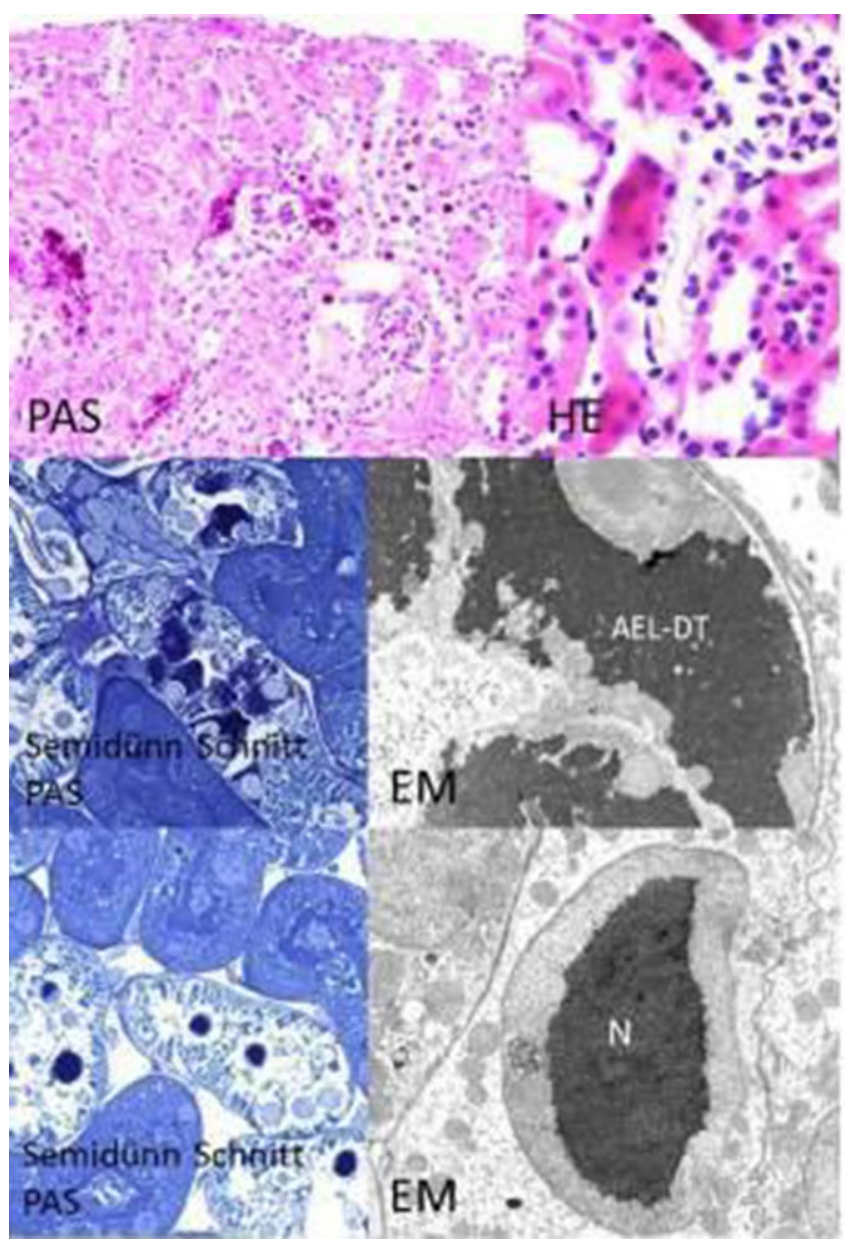

Abb. 1 | AG02.12 $\Delta$ WT diabetisch nach 4 Wochen: Wenige glykgenspeichernde AEL in distalen Tubuli (DT) und glykgenspeichernde Nuclei (N) in der PAS-Reaktion, entsprechende a-Glykogenpartikel in der elektronenmikroskopischen Untersuchung (EM)

nicht-diabetischer Mäuse deuten hingegen auf eine tumorsuppressive Funktion von chREBP in der Niere hin.

\section{AG02.13}

\section{Expression and mutation patterns of PBRM1, BAP1 and SETD2 mirror specific evolutionary subtypes in clear cell renal cell carcinoma}

J. H. Rüschoff' *, S. Bihr' ${ }^{2}$, R. Ohashi ${ }^{3}$, A. L. Moore ${ }^{4}$, C. Beisel', T. Hermanns', A. Mischo' ${ }^{2}$ C. Corrò' ', J. Beyer ${ }^{2}$, N. Beerenwinkel', H. Moch', P. Schraml' 'Department of Pathology and Molecular Pathology, University Hospital Zurich, Zurich, Switzerland, 'Department of Oncology, University Hospital Zurich, Zurich, Switzerland, ${ }^{3}$ Histopathology Core Facility, Niigata University Faculty of Medicine, Niigata, Japan, ${ }^{4}$ Department of Biosystems Science and Engineering, ETH, Zurich, Switzerland, ${ }^{5}$ Department of Urology, University Hospital Zurich, Zurich, Switzerland

Aims. Bi-allelic inactivation of the VHL gene on chromosome $3 p$ is the characteristic feature in most clear cell renal cell carcinomas (ccRCC). Frequent gene alterations were also identified in SETD2, BAP1 and PBRM1, all of which are situated on chromosome $3 p$ and encode histone/chromatin regulators. The relationship between gene mutation, loss of protein expression and the correlations with clinicopathological parameters is important for the understanding of renal cancer progression.

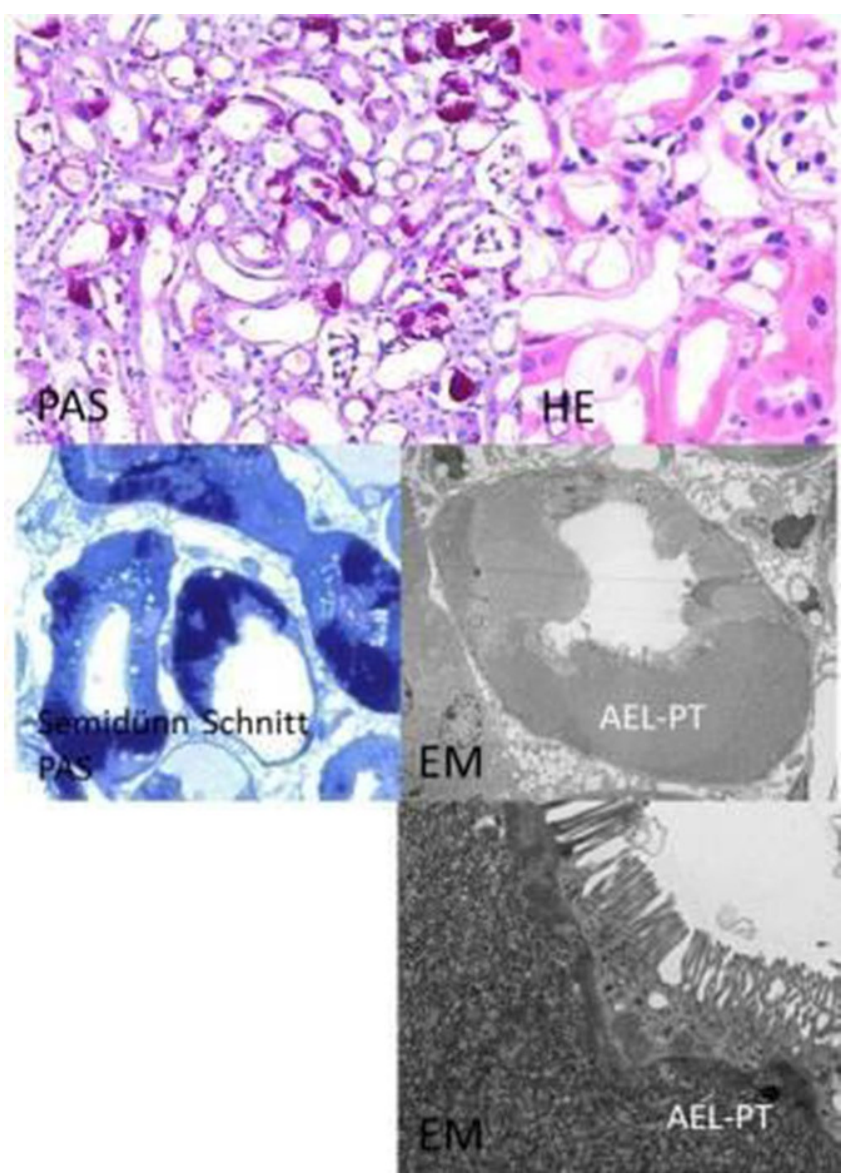

Abb. 2 | AG02.12 $\Delta$ ChREBP-KO diabetisch nach 4 Wochen: Ausgeprägte glykgenspeichernde AEL in proximalen Tubuli (DT) in der PAS-Reaktion, entsprechende a-Glykogenpartikel in der elektronenmikroskopischen Untersuchung (EM)

Methods. We analyzed PBRM1 and BAP1 protein expression as well as the trimethylation state of $\mathrm{H} 3 \mathrm{~K} 36$ as a surrogate marker for SETD2 activity in more than 700 RCC samples. $83 \mathrm{ccRCC}$ samples were sequenced using targeted next generation sequencing.

Results. In ccRCC loss of nuclear PBRM1 (68\%), BAP1 (40\%) and H3K36me3 (47\%) expression was significantly correlated with each other, advanced tumor stage, poor tumor differentiation $(p<0.0001$ each), and necrosis $(p<0.005)$. Targeted next generation sequencing demonstrated a significant association of genetic mutations in PBRM1, BAP1, and SETD2 with absence of PBRM1, BAP1, and HEK36me3 protein expression $(p<0.05$, each). By assigning the protein expression patterns to evolutionary subtypes, we revealed similar clinical phenotypes as suggested by TRACERx Renal.

Conclusion. Given their important contribution to tumor suppression, we conclude that combined functional inactivation of PBRM1, BAP1, SETD2 and $\mathrm{pVHL}$ is critical for ccRCC progression. 

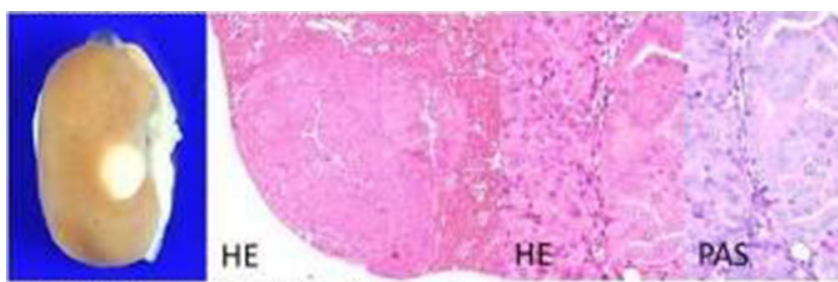

a
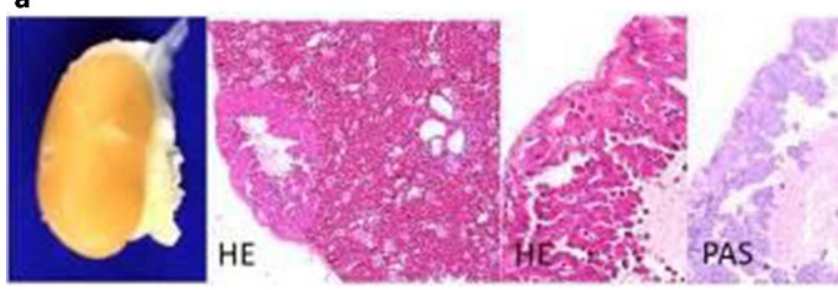

b
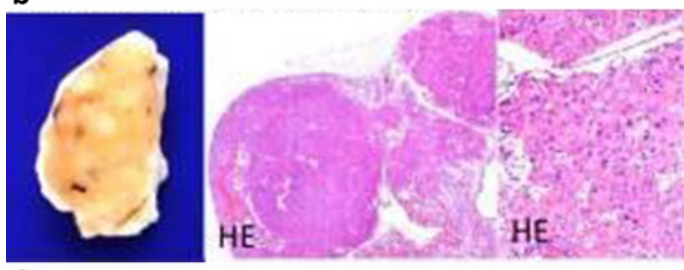

Abb. 3 | AG02.12 $\Delta$ Nierentumoren: Wenige kleine basophile epitheliale Nierentumoren bei diabetischen WT-Mäusen nach 12 Monaten; nichtdiabetische ChREBP-KO-Mäuse mit spontanen ähnlichen kleinen Tumoren bereits nach 3 Monaten sowie multiple große Nierenzellkarzinome nach 6 Monaten

\section{AG02.14}

Konstruktion von Antikörper-Panels zur Unterstützung der Subtypisierung von chromophoben Nierenzellkarzinomen und Onkozytomen

C. G. Stöhr ${ }^{1 *}$, N. Maurer' , F. Erlmeier ${ }^{1,2}$, H. Moch ${ }^{3}$, K. Junker', R. Hinze ${ }^{5}$, S. Steffens ${ }^{6}$, A. Agaimy', A. Hartmann', Deutsches Netzwerk Nierenzelltumoren

'Institut für Pathologie, Friedrich-Alexander-Universität Erlangen-Nürnberg, Erlangen, Deutschland, ${ }^{2}$ Institut für Pathologie, Pathologie München-Nord, München, Deutschland, ${ }^{3}$ Institut für Pathologie und Molekularpathologie, Universitätsspital Zürich, Zürich, Schweiz, ${ }^{4}$ Klinik für Urologie und Kinderurologie, Universitätsklinikum des Saarlandes, Homburg/Saar, Deutschland, ${ }^{5}$ Helios Kliniken Schwerin, Institut für Pathologie, Schwerin, Deutschland, ${ }^{6}$ Klinik für Urologie und Kinderurologie, Universitätsklinikum Münster, Münster, Deutschland

Ziel. Chromophobe (CP) Nierenzellkarzinome werden als maligne Tumoren mit niedrigem Metastasierungspotential eingestuft. Gelegentlich überlappen ihre histologischen Merkmale mit denen benigner renaler Onkozytome (O) u. erschweren die Subtypisierung. Trotz zahlreicher Studien existieren derzeit keine verlässlichen Marker zur Unterscheidung beider Tumorarten.

Methoden. Für 24 Marker a. d. Literatur wurden Antikörper (Ak) an $3 \mu \mathrm{m}$ FFPE-Schnitten eines Tissue Micro Arrays (TMA) mit O $(n=86)$ u. CP $(n=92)$ gefärbt (Kohorte 1). Scoring erfolgte analog Remmele, $p$-Wert-Bestimmung mittels $\chi 2$-Test. Bei $p<0,05$ wurden Korrektklassifikationsrate (KKR), Sensitivität, Spezifität, Likelihood ratio (LR)+ u. LR- berechnet. Hierauf basierend wurden je $3 \mathrm{Ak}$ zusammengestellt ( \pm -Hale-Färbung), die daraus resultierende Zuordnung der TMA-Fälle zu CP u. O, sowie LR+, LR- und KKR ermittelt. Im Anschluss wurden Marker u. Markerkombinationen (MK)an einer unabh. Kohorte (Kohorte 2; O: $n=60$, CP: $n=81$ ) auf Reproduzierbarkeit geprüft. Schließlich erfolgte anhand von gepaarten Student's t-Tests der Vergleich von KKR Mittelwerten (MW) und Standardabweichung (Stabw) mit dem Ergebnis der Hale-Einzelfärbung beider Kohorten.

Ergebnisse. 15 Markern zeigten signifikanten Zusammenhang zwischen Färbung u. Tumortyp in Kohorte 1. Davon waren 11 Marker in Kohorte 2 reproduzierbar. Hale-Färbung erwies sich als spezifischster CP-Marker (0,97 bzw. 0,88; KKR 62,83 \% bzw. 86,96\%), bei jedoch sehr schwankender Sensitivität $(0,34$ bzw. 0,86$)$. S100A1 zeigte von allen getesteten O-Markern die höchste KKR mit sehr geringer Schwankung (74,71 \% bzw. 76,98 \%). Von 20 Ak-Kombinationen, die alleine o. zusammen mit Hale getestet wurden, konnten $3 \mathrm{MK}(\mathrm{Ck} 7+\mathrm{S} 100 \mathrm{~A} 1+\mathrm{SDCBP} 2$, Claudin7+S100A1+SDCBP2 und Ck7+S100A1+Caveolin) ohne Hale mit höherem KKRMW \pm Stabw $(84,50 \% \pm 2,26 ; 83,10 \% \pm 2,20 ; 83,07 \% \pm-$ $0,51)$ im Vergleich zu Hale $(74,89 \% \pm 12,07)$ identifiziert werden. MK mit Hale erwies sich gegenüber alleiniger Hale-Färbung als noch besser, allerdings mit stärkeren Schwankungen zwischen den Kohorten (KKRMW $88,78 \% \pm 5,88 ; 87,18 \% \pm 6,66 ; 87,96 \pm 4,95)$. Jedoch unterschieden sich die KKRMW bei allen getesteten Panels nicht signifikant gegenüber der Hale-Färbung.

Fazit. Die identifizierten MK könnten die Unterscheidung zwischen CP u. O erleichtern, da sie deutlich mehr Fälle als Hale richtig klassifizieren u. konsistent sind. Insgesamt zeigten sich MK ohne Hale-Färbung deutlich stabiler. Ob sie auch in der DD v. eosinophilen CP helfen, muss getestet werden.

\section{AG02.15}

\section{PD-1 und CTLA-4: negative Prognosemarker beim} Nierenzellkarzinom

A. Kahlmeyer', C. Stöhr', A. Hartmann', P. Goebell', B. Wullich', S. Wach', H. Taubert ${ }^{1}$, F. Erlmeier ${ }^{2 *, 3}$

'Universitätsklinikum Erlangen, Urologische und Kinderurologische Klinik, Erlangen, Deutschland, ${ }^{2}$ Friedrich-Alexander-Universität Erlangen, Pathologisches Institut, Comprehensive Cancer Center Erlangen-EMN, Erlangen, Deutschland, ${ }^{3}$ Institut für Pathologie, München, Deutschland

Ziel. Die immunonkologische Therapie mit Checkpoint-Inhibition (CI) hat sich zu einer neuen Standardtherapie beim metastasierten Nierenzellkarzinom (NZK) entwickelt. Der prognostische Wert der Expression von CI-Therapiemolekülen ist jedoch nach wie vor umstritten. Ziel dieser Studie war es, die prognostische Bedeutung von PD-1, PD-L1 und CTLA-4 in einer NZK-Kohorte darzustellen.

Methoden. Ein Kollektiv bestehend aus 342 NZK-Proben wurde hinsichtlich seiner PD-1, PD-L1 und CTLA-4-Expression mittels Immunhistochemie (IHC) analysiert. Der prognostische Wert für das krankheitsspezifische (CSS) und das Gesamtüberleben (OS) wurde untersucht.

Ergebnisse. Die Expression von PD-1 für tumorinfiltrierende mononukleäre Zellen (TIMC) und PD-L1 für Tumorzellen wurde in 9,4 \% bzw. 12,3 \% der Fälle nachgewiesen. Darüber hinaus wurde die PD-L1-Expression für TIMC und die CTLA-4-Expression im Tumorgewebe in 4,8 \% und 6,3 \% der Fälle detektiert. Die PD-1-Expression und die CTLA-4-Expression waren signifikant mit einem schlechteren OS und CSS in der LogRank-Überlebensanalyse und in der univariaten Cox-Regressionsanalyse verbunden. Die CTLA-4-Expression ist ein prognostischer Marker, der in der multivariaten Cox-Regressionsanalyse in der gesamten Kohorte (OS: $p=0,013$; CSS: $p=0,048)$ sowie in einer nicht-metastatischen Subgruppenanalyse unabhängig voneinander mit einem schlechteren klinischen Verlauf assoziiert ist (OS: $p=0,028$; CSS: $p=0,022$ ). Patienten mit kombinierter CTLA-4-Expression und PD-1-Expression weisen das kürzeste OS und CSS auf.

Fazit. Bei NZK-Patienten ist die PD-1-Expression für TIMC und die CTLA-4-Expression für Tumorzellen mit einem schlechteren OS und CSS assoziiert. Die Kombination der PD-1-Expression für TIMC- und die CTLA-4-Expression für Tumorzellen könnte einen Hochrisikomarker darstellen. 
AG02.16

\section{Die multi-tasking Sertoli Zelle}

\section{G. Mikuz*}

Medizinische Universität Innsbruck, Institut für Pathologie,

Molekularpathologie und Neuropathologie, Innsbruck, Österreich

Die Sertoli Zelle spielt in der embryonalen Phase der Organogenese der männlichen Geschlechtsorgane eine zentrale Rolle. Die intrauterine Zerstörung dieser Zellen führt zu Fehlbildungen der Geschlechtsorgane. Nach der Pubertät verursacht eine Schädigung dieser Zelle zu schweren Störungen der Spermatogenese und zur männlichen Infertilität.

Ob die Sertoli Zellen aus dem Coelom-Epithel oder aus dem mesonephrischen Blastem oder sogar aus beiden stammen ist unklar. Die Tatsache, dass sie im fetalen Hoden bis zur 20. Schwangerschaftswoche sowohl Cytokeratin als auch Vimentin und anfänglich auch Desmin exprimieren, würde für die Entstehung aus beiden sprechen.

Die Sertoli Zellen synthetisieren ca. 60 verschiedeneProteine, die mit der Reproduktion in Verbindung stehen. Die bekanntesten davon sind das Inhibin, das Androgen-binding-protein (ABP) und das Anti-Müller-Hormon (AMH). Das AMH ist für kann schon sehr früh in der Entwicklungsphase der Hodendifferenzierung nachgewiesen werden und erreicht sein Maximum während der Rückbildung des Müllerschen Ganges. Inhibin hemmt die Sekretion von FSH. ABP hat eine große Affinität zu Testosteron und Dihydrotestosteron und ermöglicht somit eine Konzentration von Androgenen in der Lichtung der Hodenkanälchen, die weit über deren normale Löslichkeit liegt. Neuerdings wurde in einigen Sertoli-ZellTumoren auch die Produktion neuroendokriner Substanzen festgestellt. Die normale Spermatogenese wäre ohne eine funktionierende Blut-TestisSchranke nicht denkbar. Sie wird aus tight Junctions (TJ), gap Junctions, Desmosomen und testisspezifischen adherens Junctions aufgebaut. Zwei benachbarten Sertoli Zellen, die ein Spermatogonium dicht umschließen, sind lumenwerts durch tight Junctions miteinander verbunden. So entstehen im Hodenkanälche ein basales Kompartiment mit Spermatogonien, und ein adluminales Kompartiment in dem alle anderen Zellen der Spermatogenese zu finden sind. Durch diese Funktion wird ein einzigartiges Milieu für die Reifung der Keimzellen im apikalen Anteil der Tubuli erzeugt. Die Schranke ist auch eine immunologische Barriere, die den Eintritt von Immunglobulinen und Immunzellen in das Lumen der Hodenkanälchen verhindert.

Die zellulären Reste der die bei der Ausreifung der Spermatozoen (Spermiogenese) aus den Spermatiden übrigbleiben werden von Sertoli Zellen phagozytiert. Weniger bekannt ist, dass diese Zellen auch Bakterien phagozytieren und töten können.

\section{AG Uropathologie IV - Consensus}

\section{AG02.17 \\ Performance of FDA approved PD-L1 assays in urothelial cancer with emphasis on therapy stratification for first-line use of Atezolizumab/Pembrolizumab}

M. Eckstein ${ }^{1 *}$, P. Erben ${ }^{2}$, M. C. Kriegmair ${ }^{2}$, T. S. Worst ${ }^{2}$, C.-A. Weiß ${ }^{3}$, R. M. Wirtz ${ }^{4}$, S. Wach ${ }^{5}$, R. Stoehr', D. Sikic ${ }^{5}$, C. Geppert', V. Weyerer', S. Bertz', J. Breyer ${ }^{6}$, W. Otto , B. Keck ${ }^{5}$, M. Burger ${ }^{6}$, H. Taubert ${ }^{5}$, W. Weichert 7 , B. Wullich ${ }^{5}$, C. Bolenz $z^{8}$, A. Hartmann', F. ErImeier? BRIDGE-Consortium Germany

${ }^{1}$ University Hospital Erlangen, Friedrich-Alexander University ErlangenNürnberg, Institute of Pathology, Erlangen, Germany, ${ }^{2}$ Medical Faculty Mannheim, University of Heidelberg, Department of Urology, Mannheim, Germany, ${ }^{3}$ Medical Faculty Mannheim, University of Heidelberg, Institute of Pathology, Mannheim, Germany, ${ }^{4}$ STRATIFYER Molecular Pathology, Cologne, Germany, ${ }^{5}$ University Hospital Erlangen, Friedrich-Alexander University Erlangen-Nürnberg, Department of Urology and Pediatric Urology, Erlangen, Germany, ${ }^{6}$ University of Regensburg, Department of Urology, Regensburg, Germany, ${ }^{7}$ Technical University Munich, Institute of Pathology, Munich, Germany, ${ }^{8}$ University of Ulm, Department of Urology, Ulm, Germany

Background. Recently, the FDA/EMA restricted first-line use of Atezolizumab and Pembrolizumab in metastasized urothelial carcinoma patients by defining distinct PD-L1 cut-offs. We analyzed the diagnostic performance of all FDA/EMA approved PD-L1 assays with emphasis on new restrictions for first line treatment with Atezolizumab and Pembrolizumab. Patients and methods. 251 urothelial carcinomas were analyzed on tissue microarrays with four cores of each tumor. Stains were read on an assay-by-assay basis by two pathologists. Overall percentage agreement (OPA) was calculated across preset cut-offs. Positive (PPA) and negative percentage agreements (NPA) were calculated across different scoring algorithms. Venn diagrams were constructed to illustrate discordance according to the recent FDA/EMA guidelines.

Results. The Dako 28-8, 22c3 and the Ventana SP263 assays showed high inter-assay correlation ( $r$-range $0.83-0.91$ ). Inter-assay correlation between the SP142 and the three other assays was moderate (r-range 0.66-0.75). OPA of $93.3 \%$ was achieved between the Dako $28-8,22 \mathrm{c} 3$ and Ventana SP263 assays. OPA including the SP142 was $84.1 \%$. Pooled PPA and NPA of different scoring algorithms was $89.4 \%$ and $95.3 \%$ for the Dako $28-8$, $22 \mathrm{c} 3$ and the SP263 assays. With the SP142 assay pooled PPA was $59.1 \%$. The SP142 assay identifies fewer eligible patients for first line treatment with Atezolizumab (0.47-fold to 0.55 -fold less patients). The other three assays would classify more patients as eligible for first line treatment with Pembrolizumab than the SP142 (2.14-2.39-fold more patients). Inter-algorithm variability between CPS10 (combined positive score) and 5\%IC (immune cells) lead to concordant positive classification rate of just $58.4 \%$ ( $n=73$; eligible for both drugs), while 15 (12\%) patients would be exclusively eligible for Pembrolizumab and 37 (29.6\%) exclusively for Atezolizumab.

Conclusion. Dako 28-8, 22c3 and SP263 assays show interchangeable performance. The SP142 shows comparable performance regarding IC staining, but diverging results in TC detection. Inter-assay variability leads to different detection rates of eligible patients for first-line treatment with Atezolizumab and Pembrolizumab. Furthermore, inter-algorithm variability between CPS10 and 5\%-IC lead to large number of patients exclusively identified as eligible for one of both biomarker restricted drugs. 
AG02.18

Status der Verfügbarkeit und Anwendung von Next-GenerationSequencing (NGS) in der Uropathologie - eine Umfrage in der AG Uropathologie

N. Ortiz Brüchle', M. Muders', M. Toma', I. Esposito ${ }^{3}$, A. Hartmann 4 , R. Stöhr', H. Reis ${ }^{5}$, P. Wild ${ }^{6}$, F. Bremmer ${ }^{7}$, J. Leichsenring ${ }^{8}$, A. Stenzinger ${ }^{8}$, S. MerkelbachBruse $^{9}$, J. Kirfel ${ }^{10}$, S. Perner ${ }^{10}$, N. Hartmann ${ }^{11}$, W. Roth ${ }^{11}$, A. Jung ${ }^{12}$, T. Kirchner ${ }^{12}$, K. Schwamborn ${ }^{13}$, J. Koellermann ${ }^{14}$, E. Dahl' ${ }^{1}$, R. Knüchel', N. T. Gaisa ${ }^{1 *}$ 'Institut für Pathologie RWTH Aachen, Aachen, Deutschland, ${ }^{2}$ Institut für Pathologie Universitätsklinikum Bonn, Bonn, Deutschland, ${ }^{3}$ Institut für Pathologie Universitätsklinikum Düsseldorf, Düsseldorf, Deutschland, ${ }^{4}$ Institut für Pathologie Universitätsklinikum Erlangen, Erlangen, Deutschland, ${ }^{5}$ Institut für Pathologie Universitätsklinikum Essen, Essen, Deutschland, ${ }^{6}$ Senckenbergisches Institut für Pathologie, Uniklinikum Frankfurt, Frankfurt, Deutschland, ${ }^{7}$ Institut für Pathologie Universitätsklinikum Göttingen, Göttingen, Deutschland, ${ }^{8}$ Institut für Allgemeine Pathologie Universität Heidelberg, Heidelberg, Deutschland, ${ }^{9}$ Institut für Pathologie Universität zu Köln, Köln, Deutschland, ${ }^{10}$ Institut für Pathologie Universitätsklinikum Lübeck Lübeck, Deutschland, ${ }^{11}$ Institut für Pathologie Universitätsklinikum Mainz, Mainz, Deutschland, ${ }^{12}$ Pathologisches Institut der LMU München, München, Deutschland, ${ }^{13}$ Institut für Allgemeine Pathologie und Pathologische Anatomie der Technischen Universität München, München, Deutschland, ${ }^{14}$ Institut für Pathologie Offenbach, Offenbach, Deutschland

Ziel. Aufgrund der zunehmenden molekularen Subtypisierung von Harnblasenkarzinomen und dadurch entstehenden Möglichkeiten der Präzisionsonkologie sollte im Rahmen der AG Uropathologie und assoziierten Kooperationspartnern die Verfügbarkeit und Anwendung von NGS-Diagnostik bei Harnblasenkarzinompatienten überprüft werden.

Methoden. Die Daten wurden durch einen Fragebogen zur Fallzahl von Harnblasenkarzinomen, sowie der Ausstattung und den diagnostischen Möglichkeiten an den jeweiligen Instituten erhoben. Bei bereits etablierter NGS-basierter Diagnostik wurden zusätzlich die Sequenzierergebnisse von Harnblasenkarzinomfällen erfragt.

Ergebnisse. Es haben sich 13 universitäre Institute und ein nicht-universitäres Institut an der Umfrage beteiligt. Alle universitären Institute halten eine NGS-basierte Diagnostik vor und verfügen über verschiedene PanelDiagnostikmöglichkeiten welche zwischen 15 und 170 Gene umfassen. Bislang (Stand Dezember 2018) wurden insgesamt in allen Instituten nur 21 Harnblasenkarzinomfälle NGS-basiert untersucht. Dabei ergaben sich in zehn Fällen Möglichkeiten einer zielgerichteten Therapie.

Fazit. Obwohl zumindest auf universitärer Ebene NGS-Diagnostik zumeis gut etabliert ist, werden nur wenige Harnblasenkarzinomfälle sequenziert. Aufgrund zunehmender therapeutischer Möglichkeiten sollte zumindest eine FGFR-Diagnostik häufiger angewendet werden.

\section{AG Kinder- und Fetalpathologie I}

\section{AG03.01 \\ Plötzliche Todesfälle von Kindern - Intrauteriner Fruchttod und Neugeborene \\ S. Banaschak* \\ Institut für Rechtsmedizin, Köln, Deutschland}

Die Untersuchung von Kindern nach einem intrauterinen Fruchtod ist eine Domäne der Kinderpathologie. In seltenen Fällen werden diese Untersuchungen in der Rechtsmedizin durchgeführt, wenn eine forensische Fragestellung besteht (z. B. nach einer Gewalteinwirkung auf die Mutter). Sind histologische Untersuchungen der Plazenta erforderlich, werden diese regelmäßig durch (Kinder)pathologen durchgeführt. Dies gilt auch für die Untersuchung toter Neugeborener. Wird ein Neugeborenes in einer Wohnung oder in der Öffentlichkeit aufgefunden, werden rechtsmedizinische Untersuchungen u. a. mit der Frage des Gelebthabens durchgeführt. Die Untersuchungsmethoden und Ergebnisse werden im Vortrag dargestellt.
AG03.02

Plötzliche Todesfälle von Kindern - Säuglinge und Kleinkinder

\section{S. Banaschak*}

Institut für Rechtsmedizin, Köln, Deutschland

Werden Kinder tot aufgefunden, bei denen keine schwere Vorerkrankung bekannt war, so sollten die den Tod feststellenden Ärzte zumindest eine ungeklärte Todesart bescheinigen. Denn in dieser Altersgruppe können auch bei schweren und todesursächlichen Verletzungen äußerlich erkennbare Befunde fehlen. Anhand von Fallbeispielen werden typische Befunde beim plötzlichen Kindstod, bei natürlichen und nicht natürlichen Todesfällen dieser Altersgruppe vorgestellt.

AG03.03

\section{Anforderungen an die morphologische Diagnostik von Neugeborenen-Herzen nach kardiochirurgischen Eingriffen}

\section{J. Preuße ${ }^{1 *}$, A. Macion ${ }^{2}$, A. Delis ${ }^{3}$, A. Müller ${ }^{4}$}

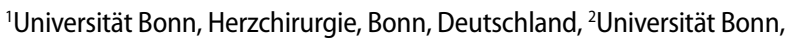
Bonn, Deutschland, ${ }^{3}$ Universität Bonn, Anästhesie, Bonn, Deutschland, ${ }^{4}$ Universität Köln, Köln, Deutschland

Ziel. Ein intra- bzw. frühpostoperatives Myokardversagen nach Herzoperationen im ersten Lebensmonat kann an einer unzureichenden intraoperativen Myokardprotektion liegen. Aufgrund der strukturellen Besonderheiten des neonatalen bzw. frühkindlichen Herzens sind die Herausforderungen an die intraoperative Myokardprotektion vielfältiger als bei adulten Herzen. Da das ischämische neonate Herz z. B. wesentlich mehr Laktat bei gleicher Ischämiebelastung als das adulte Herz bildet, muss es entweder häufiger mit der Protektionslösung reperfundiert werden oder aber mit einer gepufferten Lösung geschützt werden. Zur Evaluation der verschiedenen Perfusionslösungen bieten sich routinemäßig die histologische sowie die ultrastrukturelle Untersuchung am Elektronenmikroskop an. Letztere ist derzeit immer seltener verfügbar. Untersucht wurde im Tierversuch, ob die verschiedenen Lösungen zu manifesten zellulären Schädigungen führen und ob die Ektronenmikroskopie heute noch eine relevante Untersuchungsmethode darstellt.

Methoden. Untersucht wurden 6 neonate Ferkel-Herzen (je 3 pro Gruppe, $4 \mathrm{~d}$ alt), die mit denam häufigsten verwendeten Lösungen (HTK und Del Nido) über 180 min protektioniert wurden. Die in-situ perfundierten Herzen wurden nach Entnahme bei $25^{\circ} \mathrm{C}$ inkubiert. Zu definierten Zeitpunkten wurden Proben vom linken Ventrikel für die lichtmikroskopische (HE, EvG) und elektronenmikroskopische Untersuchung entnommen.

Ergebnisse. Die histologische Analyse der Proben zeigte zwischen den beiden Gruppen kaum Unterschiede. Ultrastrukturell zeigte sich mit fortschreitender Ischämiedauer im Vergleich zur Del-Nido-Gruppe in der HTK Gruppe eine geringere mitochondriale Schädigung bzgl. Cristolyse, Matrix- und Membranbeschaffenheit. Hingegen war die Ischämie-bedingte Schädigung der Sarkomere („Ödem-Bildung“) in der HTK-Gruppe ausgeprägter.

Fazit. Die ultrastrukturellen Untersuchungen zeigten eine bessere Kardioprotektion des neonaten Herzens durch die HTK-Lösung. Diese Befunde konnten nur mittels Elektronenmikroskopie erhoben werden. Parallel laufende physiologische und elektrophysiologische Untersuchungen erlaubten keine eindeutigen Rückschlüsse darauf, welche subzellulären Strukturen im Einzelnen hier geschädigt waren. Die Untersuchungen belegen somit auch, dass gerade bei strukturellen Fragestellungen dem Elektronenmikroskop weiterhin eine zentrale Bedeutung zukommt. 


\section{AG03.04}

\section{Prognostic profiling of the immune cell microenvironment in Ewing sarcoma/PNET}

D. Stahl' ${ }^{*}$, R. Thiele' ${ }^{2}$ A. J. Gentles ${ }^{3}$, S. Schönberger', G. Kristiansen', I. Gütgemann ${ }^{1}$

'University Hospital Bonn, Institute of Pathology, Bonn, Germany, 'BonnRhine-Sieg University of Applied Sciences, Department of Computer Science, Sankt Augustin, Germany, ${ }^{3}$ Stanford University, Center for Cancer Systems Biology (CCSB), Stanford, United States, ${ }^{4}$ University Hospital Bonn, Department of Pediatric Hematology and Oncology, Bonn, Germany

Aim. Ewing sarcoma (EwS) and peripheral neuroectodermal tumor (PNET) belong to the same molecular group of EWS translocated mesenchymal tumors of bone and soft tissue in children and young adults. The tumor microenvironment (TME) provides insights into tumor evolution as well as treatment options. However, the scarcity of immune infiltrates in EwS/PNET has hindered a comprehensive analysis of immune cell subtypes with prognostic and predictive relevance.

Methods. CIBERSORT is a computational algorithm that can assess the relative immune cell infiltration based on archived mRNA expression data.
We analyzed microarray gene expression datasets (Gene Expression Omnibus) of EwS/PNET tumor samples using CIBERSORT to comprehensively assess frequent and rare immune cell subsets and their prognostic role.

Results. Microarray gene expression data sets of $209 \mathrm{EwS} / \mathrm{PNET}$ were analyzed by CIBERSORT analysis. In primary EwS/PNETs $41 \%$ (mean) of all tumor infiltrating leucocytes represented macrophages with immunsuppressive macrophages (M2) being the predominant population. The second most prominent cell fraction are T-cells (23\%) (follicular helper T-cells $>$ CD4 memory T-cells $>$ CD8 T-cells $>$ CD4 naïve T-cells $>$ gamma-delta T-cells). Interestingly, B-cells (7\%) and plasma cells (5\%) as well as neutrophils (3\%) and mast cells (11\%) represent small but significant immune cell subsets (- Fig. 1 | AG03.04). Relative immune cell content does not correlate with age at disease onset $(n=149)$. Clinical follow up was available for 32 patients with EwS/PNET: Similar to other tumors, infiltrating CD8+ T-cells correlated with favorable outcome by overall survival (OS) analysis $(p=0.047)$ and abundant B-cells were associated with a worse outcome by OS as well as event-free survival (EFS) analysis $(p=0.04, p=0.021$ respectively) (- Fig. 2 |AG03.04). By EFS analysis activated mast cells correlat-

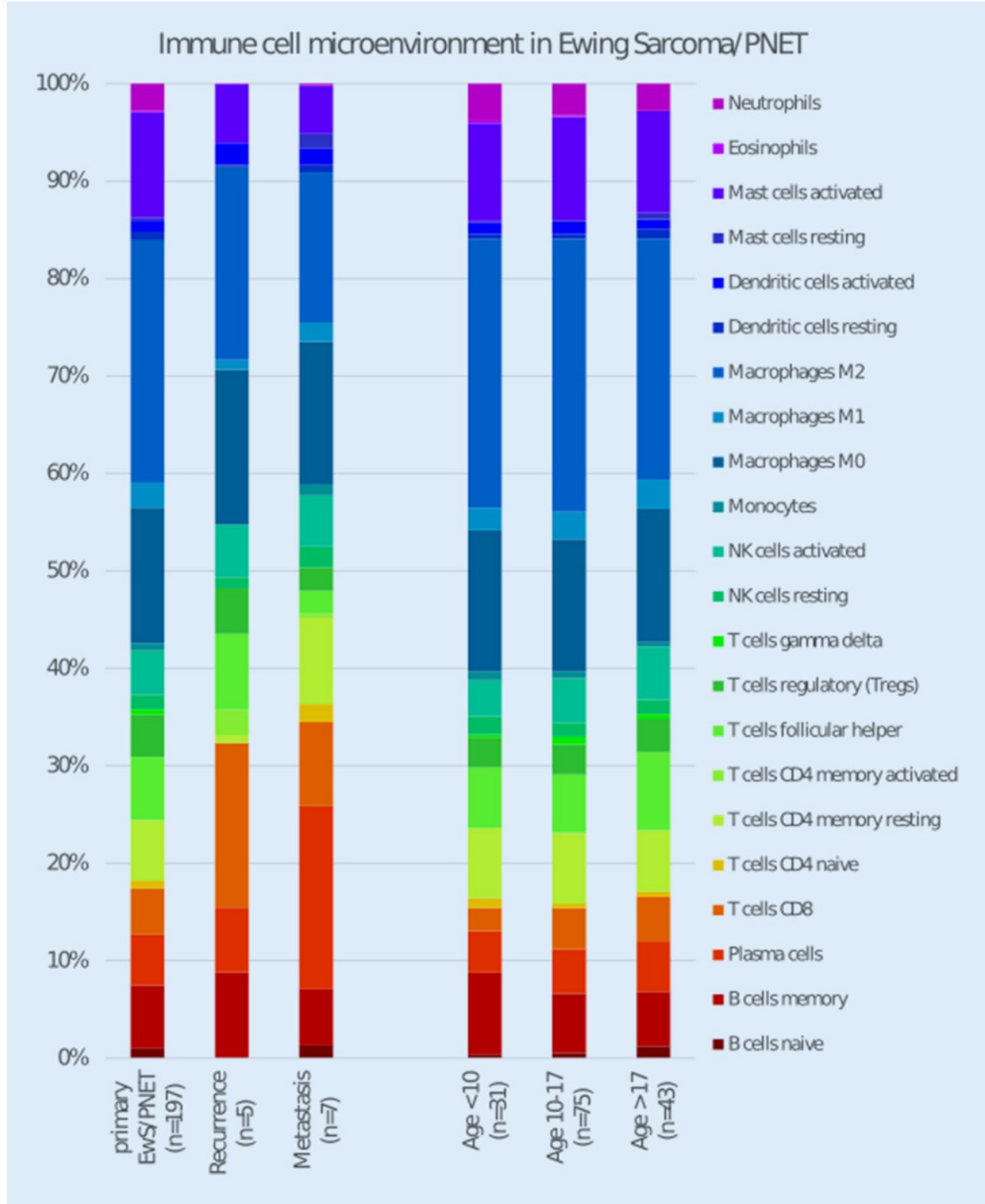

Fig. 1 | AG03.04 $\triangleleft$ The immune cell microenvironment in Ewing sarcoma/PNET 

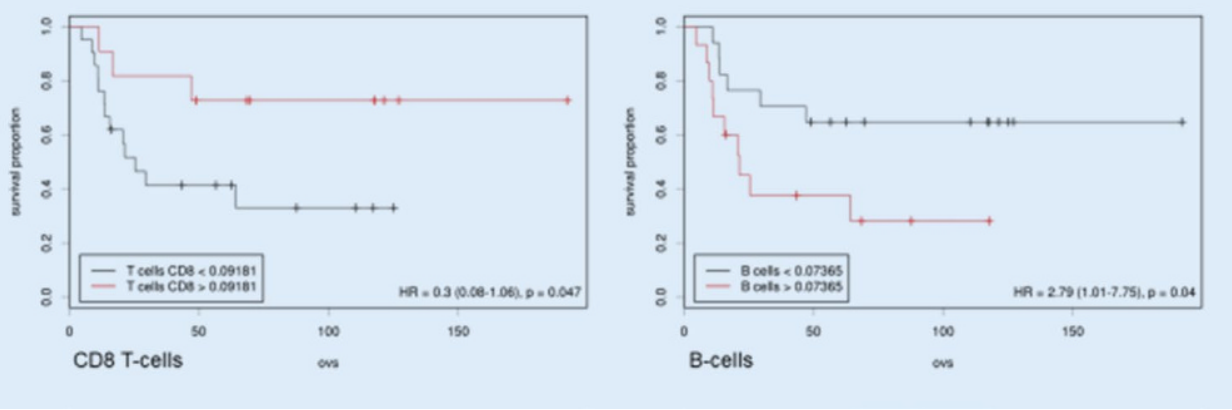
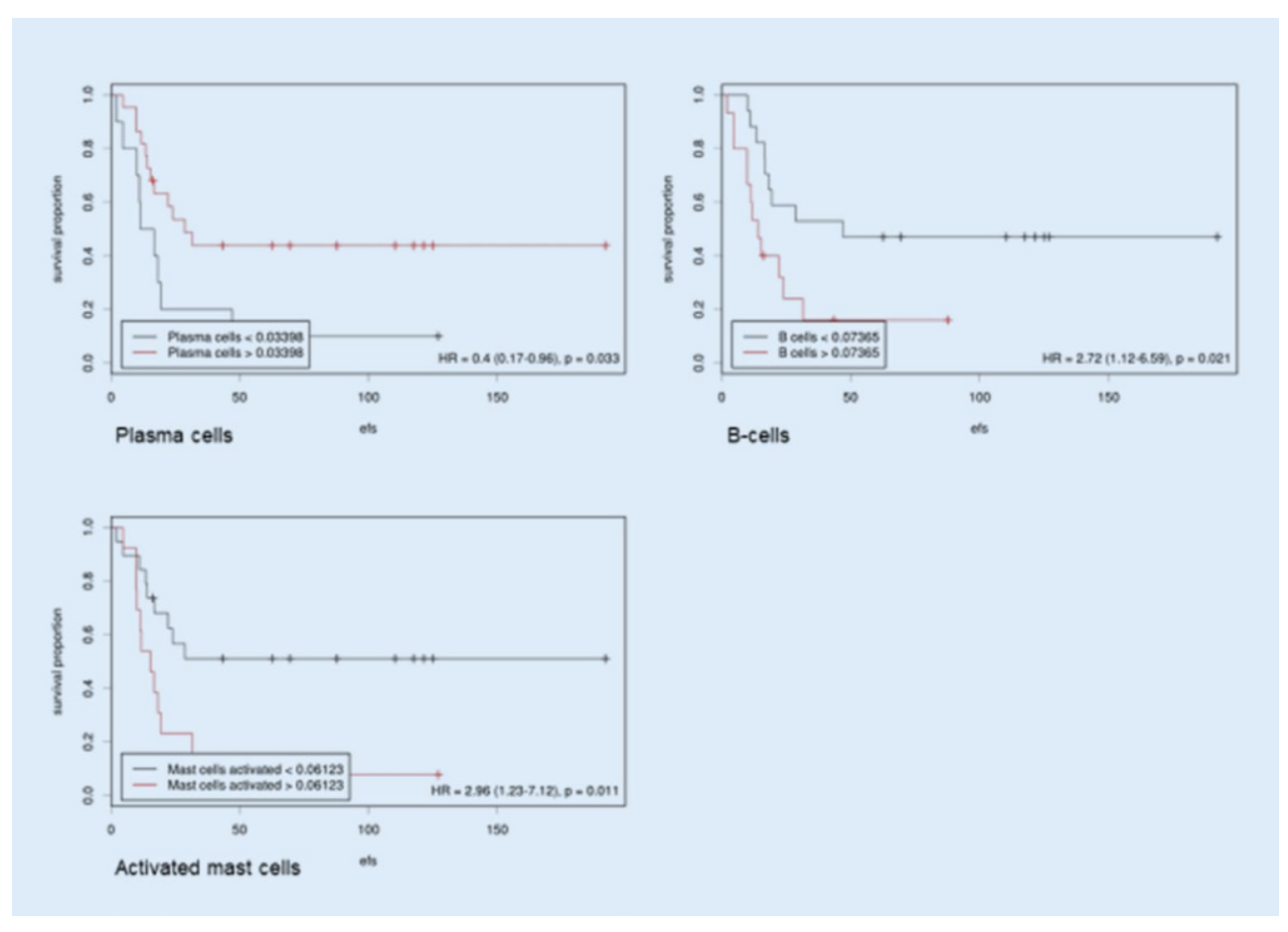

Fig. 2 | AG03.04 $\triangleleft$ Overall survival analysis (molpath.charite.de/ cutoff/)
Fig. 3 | AG03.04 $<$ Event-free survival analysis (molpath.charite.de/ cutoff/) ed with poor prognosis $(p=0.011)$, while plasma cells showed a favorable outcome ( $p=0.033)$ (• Fig. 3 | AG03.04).

Conclusion. To conclude, immune cells have a distinct composition in EwS/PNET including rare subsets such as mast cells and B-cells within the TME. Concordant with previous findings, frequent plasma cells and CD8 T-cells are associated with a good prognosis. Surprisingly, B-cells have a poor prognostic value and mast cells implicate a shorter EFS. Further studies are necessary to confirm these findings and to assess whether this opens up novel immunotherapeutic treatment strategies.

\section{AG03.05}

\section{Genetische und immunhistochemische Untersuchungen von} Klarzellsarkomen der Niere

J. Andersson*, C. Vokuhl, I. Oschlies, I. Leuschner ( $t$ )

Universitätsklinikum Schleswig-Holstein, Campus Kiel, Institut für Pathologie, Kiel, Deutschland

Ziel. Das Klarzellsarkom der Niere (CCSK) ist ein seltener Nierentumor unbekannter Histogenese des jüngeren Kindesalters. Bislang ist nur eine Genmutation (BCOR-Duplikation) als spezifische Veränderung dieser Neoplasie bekannt, ansonsten zeigen sich viele Überschneidungen mit der Histopathologie anderer kindlicher Nierentumoren wie beispielsweise dem mesoblastischen Nephrom. Diese Differenzierung ist jedoch äußerst therapierelevant. Mittels immunhistochemischer und genetischer
Charakterisierung sollte eine große Kohorte kindlicher CCSK zur Frage diagnostisch und möglicherweise prognostisch und therapeutisch relevanter Merkmale analysiert werden.

Methoden. Es wurden 86 pädiatrische Fälle von Klarzellsarkomen der Niere aus den Jahren 1981-2009 aus dem Archiv des Kindertumorregisters der Deutschen Gesellschaft für Pädiatrische Onkologie und Hämatologie $(\mathrm{GPOH})$ retrospektiv untersucht. Immunhistochemisch wurde an TissueMicro-Arrays nach Proteinen des PI3K/pAKT/mTOR-Signalwegs gefahndet. Zudem wurden die Zellzyklus-relevanten Moleküle Cyclin D1 und p16 wie auch der Transkriptionsfaktor SIX1 untersucht. Daneben wurde die Expression der Wachstumsfaktoren EGFR, NGFR sowie IGF-R analysiert. Als positiv wurden Fälle mit einem aus Zellzahl und Expressionsstärke errechneten Mindestscore gewertet.

Des Weiteren erfolgte eine Fluoreszenz-in-situ-Hybridisierung zur Frage einer EGFR-Genamplifikation und einer vorbeschriebenen Translokation $\mathrm{t}(10 ; 17)(\mathrm{q} 22 ; \mathrm{p} 13)$.

Ergebnisse. Eine Expression von PI3K/pAKT/mTOR zeigte sich in jeweils 1/11/0 \% der Tumore, ein weiteres Molekül dieses Signalweges, p4E-BP1, wurde in $5 \%$ nachgewiesen. Ein Großteil der Tumoren exprimierte Cyclin D1 (47\%) sowie die Wachstumsfaktoren (NGFR in $63 \%$, EGFR in $57 \%$, IGF1R in $42 \%$ ). Eine P16-Expression konnte in $13 \%$, SIX1 in $47 \%$ gezeigt werden.

Eine EGFR-Genamplifikation oder eine t(10;17)(q22; p13) Translokation wurde in keinem Fall nachgewiesen. 
Fazit. In kindlichen CCSK scheint der PI3K/pAKT/mTOR-Signalweg eine untergeordnete Rolle zu spielen. Relevanter scheint die Cyclin D1-Aktivierung, welche zusammen mit den Wachstumsfaktoren typisches Merkmal der Neoplasie ist und heutzutage auch differentialdiagnostisch eingesetzt wird.

Eine Genamplifikation als Ursache für die nachgewiesene EGFR-Überexpression wurde durch unsere Studie ausgeschlossen. Daneben ließ sich eine in Voruntersuchungen postulierte $\mathrm{t}(10 ; 17)(\mathrm{q} 22 ; \mathrm{p} 13)$ Translokation nicht reproduzieren.

\section{AG03.06}

\section{Successful targeted therapy in a STRN-ALK rearranged malignant peritoneal mesothelioma}

E. Gradhand ${ }^{*}$, J. H. Rüschoff ${ }^{2}$, H. Rees ${ }^{3}$, J. Ferguson ${ }^{4}$, A. C. Curioni ${ }^{5}$,

A. Kahraman'2, M. Zoche', B. Vrugt ${ }^{2}$

${ }^{1}$ Severn Pathology, Histopathology, Bristol, United Kingdom, ${ }^{2}$ University Hospital Zurich, Department of Pathology and Molecular Pathology, Zurich, Switzerland, ${ }^{3}$ Bristol Royal Hospital for Children, University Hospitals Bristol NHS Foundation Trust, Department of Paediatric Oncology, Bristol, United Kingdom, ${ }^{4}$ Royal Devon and Exeter NHS Foundation Trust, Department of Radiology, Exeter, United Kingdom, ${ }^{5}$ University Hospital Zurich, Department of Medical Oncology, Zurich, Switzerland

Aims. Malignant peritoneal mesothelioma is a rare, aggressive tumor usually induced by asbestos, therapeutic radiation, or germline mutations. This tumour occurs usually in older male patients.

We present a case of a 13-year old girl suffering from recurrent ascites of unknown etiology with no history of asbestos exposure.

Methods. The clinical workup included physical examination and MRIscan. Peritoneal biopsies were obtained by an explorative laparoscopy. Pathological examinations included immunohistochemical staining, FISH analyses and FoundationOne sequencing.

Results. The MRI-scan revealed a diffuse intra-abdominal mass in the pelvis, peritoneum and liver. The peritoneal biopsies show histological ap pearances in keeping with a malignant epithelioid mesothelioma, which was supported by positive staining for Calretinin, CK5/6, WT- 1 and D2-40 whereas expression of BerEp4 and Claudin-4 was absent. Th A FoundationOne sequencing analysis demonstrated an $A L K-S T R N$ rearrangement only. The $A L K$-rearrangement was confirmed by both immunohistochemistry with strong expression of ALK-5A4 and ALK-FISH revealing a 5' deletion in $96 \%$ of the tumor cells.

Conclusion. This case report illustrates a recently described new subset of peritoneal malignant mesotheliomas showing unique $A L K$-rearrangements which primarily affect young female patients with no history of asbestos exposure and absence of mutations/deletions of $p 16, B A P-1$ and NF2. Initially, the patient did not respond to Cisplatin and Pemetrexed chemotherapy and surgical reduction was impossible due to the extensive tumour load. The detection of $A L K$-fusions represents a novel pathogenetic mechanism of malignant peritoneal mesotheliomas which in this case, was promising for a targeted therapy. The patient is now on her 4th cycle of ceritinib, which is a tyrosine kinase inhibitor, with particular activity against anaplastic lymphoma kinase (ALK). The girl shows a significant response with reduction of tumour burden and resolution of the ascites. With this good treatment response, the clinical outcome for this young patient has shifted from a palliative to a curative care plan.
AG03.07

\section{Eukaryotic initiation factor 4A1 might represent a novel therapeutic target in neuroblastoma}

C. Wodlej ${ }^{1,2}$, S. Krassnig' , F. Kleinegger ', A. M. Birkl-Toeglhofer ${ }^{1,3}$, G. Singer', H. Till ${ }^{4}$, M. Benesch ${ }^{5}$, E. Izycka-Swieszewska ${ }^{6}$, P. Czapiewski', J. Haybaeck ${ }^{1 * 3,7}$

'Medical University of Graz, Diagnostic and Research Center for Molecular BioMedicine, Diagnostic and Research Institute of Pathology, Graz, Austria, ${ }^{2}$ Center for Biomarker Research in Medicine, Graz, Austria, ${ }^{3}$ Medical University Innsbruck, Department of Pathology, Neuropathology and Molecular Pathology, Innsbruck, Austria, ${ }^{4}$ Medical University of Graz, Department of Pediatric and Adolescent Surgery, Graz, Austria, ${ }^{5}$ Medical University of Graz, Division of Pediatric Hemato-Oncology, Graz, Austria, ${ }^{6}$ Medical University of Gdańsk, Department of Pathology and Neuropathology, Gdansk, Poland, ${ }^{7}$ Medical Faculty Otto von Guericke University Magdeburg, Department of Pathology, Magdeburg, Germany

Aim. Neuroblastoma (NB) is the second most frequent pediatric solid tumor arising from early nerve cell forms. The 5 -year survival rate of children in the high risk group is around $40 \%$, and new therapeutic approaches are urgently needed. Many studies have shown that overexpression and/or malfunction of eukaryotic translation initiation factor 4A1 (eIF4A1) and proteins modulating its function play a crucial role in malignant tumor development. Targeting eIF4A1 has revealed anti-tumorigenic effects in vitro and in vivo, arousing great interest in targeting the translational machinery. We hypothesize that altered activity/expression of eIF4A1 plays an important role during NB tumorigenesis.

Methods. eIF4A1 expression was evaluated in human NB tissue samples $(n=17)$ and compared with non-neoplastic tissue (NNT) $(n=18$; temporal cortex and thoracic spinal cord) on mRNA (qRT-PCR) and protein (immunoblot) level. Furthermore, eIF4A1 was targeted in NB cell lines SH-SY5Y and Kelly using a rocaglate derivative (kindly provided by Prof. Jerry Pelletier, McGill University) followed by cell viability determination. Results. Comparing tumor tissue with NNT, we found that eIF4A1 expression was significantly increased on mRNA and protein level $(p<0.0001)$, emphasizing the utility of targeting eIF4A1 in NB. Viability of SH-SY5Y cells treated with the eIF4A1 targeting agent was significantly reduced using concentrations greater than $25 \mathrm{nM}$ after 24,48 and $72 \mathrm{~h}$, whereas in Kelly cells concentrations greater than $5 \mathrm{nM}$ were already sufficient for significant viability reduction.

Conclusion. Our study shows that eIF4A1 is overexpressed in NB when compared to NNT, and might therefore represent a new therapeutic target for NB treatment. As usage of a certain rocaglate derivative reduced NB cell viability significantly at low $\mathrm{nM}$ dosage, it is worth the effort to deepen these first insights in future experiments.

\section{AG Kinder- und Fetalpathologie II}

\section{AG03.08 \\ Bedeutung von TRK-Fusionen in pädiatrischen Neoplasien}

\section{B. Märkl*}

Universitätsklinikum Augsburg, Augsburg, Deutschland

Ziel. Tropomyosin-Rezeptor-Kinasen (TRK) spielen vor allem für neurophysiologische Vorgänge (Schmerz, Thermoregulation, Bewegung, Gedächtnis, Propriozeption u.a.) eine wichtige Rolle. Die drei Kinasen A, $B$ und $C$ werden von den Genen NTRK1, -2 und -3 reguliert. Fusionen aller drei Gene treten in niedriger Frequenz als tumortreibende Aberration in einer Vielzahl von verschiedenen Tumoren auf. Für einzelne seltene Tumoren sind sie jedoch pathognomonisch. Mehrere spezifische Tyrosinkinase Inhibitoren zur Therapie derartiger Tumoren sind derzeit in Entwicklung oder besitzen bereits eine Zulassung der amerikanischen Gesundheitsbehörde (FDA).

Methoden. Basierend auf einer Literaturrecherche wird die Bedeutung von NTRK wird die Bedeutung von NTRK in der pädiatrischen Onko- 
logie analysiert. Die Beurteilung der histo- und molekularpathologischen Implikationen beruht ebenfalls auf einer Literaturrecherche und eigenen Ergebnissen.

Ergebnisse. Das infantile Fibrosarkom und das kongenitale Nephrom stellen Tumorentitäten dar, für die entsprechenden NTRK-Fusionen diagnostisch sind. Daneben treten NTRK Fusionen in zahlreichen weiteren Tumoren vor allem in Gliomen und mesenchymalen Tumoren auf. Für die Identifikation von NTRK-Fusionen stehen immunhistochemische und molekulare (FISH und NGS) Methoden zur Verfügung. Die sinnvolle Kombination dieser Methoden stellt eine Möglichkeit zur sicheren Detektion der therapeutisch hochrelevanten Fusionen dar.

Fazit. Insbesondere durch die Verfügbarkeit von hochwirksamen TKI is die NTRK-Fusionsdetektion von außerordentlich hoher Bedeutung. Entsprechende diagnostische Algorithmen erlauben einen spezifischen Nachweis mit hoher Sensitivität.

\section{AG03.11}

\section{SOX2 expression identifies Ewing sarcoma patients with high risk for tumor relapse and poor survival}

G. Sannino', A. Marchetto' ', A. Ranft' ${ }^{2}$ S. Jabar', C. Zacherl', R. Alba-Rubio', S. Stein', F. Wehweck', M. Kiran', T. Hölting', J. Musa', L. Romero-Pérez', F. Cidre-Aranaz', M. Knott' ${ }^{1}$, J. Li', H. Jürgens ${ }^{3}$, A. Sastre, , J. Alonso ${ }^{5}$, W. Da Silveira ${ }^{6}$, G. Hardiman', J. Gerke', M. Orth', W. Hartmann ${ }^{8}$, T. Kirchner', S. Ohmura', U. Dirksen², T. Grünewald ${ }^{1 *}$

'Pathologisches Institut der LMU München, Munich, Germany, ${ }^{2}$ Westdeutsches Tumorzentrum, Universitätsklinikum Essen, Universität Duisburg-Essen, Essen, Germany, ${ }^{3}$ Kinderklinik Universität Münster, Münster, Germany, ${ }^{4}$ Hospital Infantil Universitario La Paz, Madrid, Spain, ${ }^{5}$ Instituto de Salud Carlos III, Madrid, Spain, ${ }^{6}$ Center for Genomics Medicine, Medical University of South Carolina, Charleston, United States, ${ }^{7}$ Queen's University Belfast, Belfast, United Kingdom, ${ }^{8}$ Gerhard-Domagk-Institut für Pathologie, Uniklinik Münster, Münster, Germany

Background. Up to $30-40 \%$ of Ewing sarcoma (EwS) patients with non-metastatic disease develop local or metastatic relapse within a time range of 2-10 years. This is in part caused by the absence of prognostic biomarkers that can identify high-risk patients to assign them to risk-adapted monitoring and treatment regimens. Since cancer stemness has been associated with tumor relapse and poor outcome, we investigated in the current study the prognostic potential SOX2 (sex determining region Y box 2)-a major transcription factor involved in development and stemness-previously described to contribute to the undifferentiated phenotype of EwS.

Methods. Two independent patient cohorts, one consisting of 189 retrospectively collected EwS tumors with corresponding mRNA expression data (test cohort) and the other of 141 prospectively collected formalin-fixed and paraffin embedded resected tumors (validation cohort), were employed to analyze SOX2 expression levels by DNA microarrays or immunohistochemistry, respectively, and to compare them with clinical parameters and patient outcome. Two methods were employed to test the validity of the results at both mRNA and protein levels.

Results. Both cohorts showed that only a subset of EwS patients (16-20\%) express high SOX 2 mRNA or protein levels, which significantly correlated with poor overall survival. Multivariate analyses of our validation cohort revealed that high SOX2 expression represents a major risk-factor for survival $(\mathrm{HR}=3.19 ; 95 \% \mathrm{CI} 1.74-5.84 ; p<0.01)$ that is independent from metastasis and other known clinical risk-factors at time of diagnosis. Univariate analysis demonstrated that SOX2-high expression correlated with tumor relapse $(p=0.001)$. Median first relapse was at 14.7 months (range: 3.5-180.7)

Conclusions. High SOX2 expression constitutes an independent prognostic biomarker for EwS patients with poor outcome, which may help to identify patients with localized disease who are at high risk for tumor relapse within the first two years after diagnosis.

\section{AG Kinder- und Fetalpathologie III}

\section{AG03.12 \\ Choriocarcinoma-one morphology, two different entities}

S. Wessman', U. Joneborg'², B. Gürtl-Lackner ${ }^{*}$, J. Carlson ${ }^{1}$

'Karolinska Institutet and Karolinska University Hospital, Department of Oncology-Pathology and Department of Pathology and Cytology, Stockholm, Sweden, ${ }^{2}$ Karolinska Institutet and Karolinska University Hospital, Department of Women's and Children's Health and Department of Gynecologic Oncology, Stockholm, Sweden

Aim. Chorionic carcinomas are highly malignant tumors of trophoblastic cells. These tumors can arise either from placental tissues, typically complete hydatidiform mole, or as a malignant component of a germ cell tumor. The former group is termed "gestational" tumors because their genetic content is partially or completely non-maternal (i.e. derived from a gestation). The latter group is termed "non-gestational" because their genetic content is maternal. Diagnostic distinction of these two types is critical because their treatment and prognosis are markedly different. Distinction can only be made using genetic analysis of the tumor tissue. Genetic analysis can further link chorionic carcinoma with the preceding gestational tissue.

Methods. Genomic DNA was extracted from separate fractions of maternal and fetal tissue. Microsatellite loci were amplified in a multiplex PCR followed by analysis using quantitative capillary electrophoresis, followed by interpretation of the peaks.

Results. In our series we analyzed 3 cases of chorionic carcinoma in order to determine the possible origin of the tumor. One of the cases had 2 previous complete moles; the chorionic carcinoma showed corresponding genetic material. The other 2 cases had the same alleles in normal endometrium and chorionic carcinoma resulting in the diagnosis of a non-gestational chorionic carcinoma.

Conclusion. Genotyping of chorionic carcinoma is an essential and valuable tool in establishing the origin, treatment and prognosis of this tumor.

\section{AG03.13}

\section{Do we need to analyze the genotype of partial hydatidiform} moles?

\section{S. Wessman 1', U. Joneborg ${ }^{2}$, B. Gürtl-Lackner ${ }^{1 *}$, J. Carlson ${ }^{1}$}

${ }^{1}$ Karolinska Institutet and Karolinska University Hospital, Department of Oncology-Pathology and Department of Pathology and Cytology, Stockholm, Sweden, ${ }^{2}$ Karolinska Institutet and Karolinska University Hospital, Department of Women's and Children's Health and Department of Gynecologic Oncology, Stockholm, Sweden

Aim. Diagnosis of partial hydatidiform moles (PHM) is improved through the use of diagnostic methods such as ploidy or genotyping. The purpose of this study was to compare the utility of these methods in routine clinical practice with the goal of providing data to allow evaluation and comparison of these methods. We therefore compared results we obtained from ploidy analysis with the corresponding genotypes.

Methods. DNA ploidy analysis was performed by image-based cytometry. Genomic DNA was extracted from separate fractions of maternal and fetal tissue. Microsatellite loci were amplified in a multiplex PCR followed by analysis using quantitative capillary electrophoresis, followed by interpretation of the peaks.

Results. In our series we analyzed 42 cases of partial hydatidiform moles in parallel. Ploidy analysis of 13 cases was difficult to interpret but shown to be triploid with genotyping. In 2 cases no genotyping results could be obtained, and in one case genotyping results revealed a normal biparental genome.

Conclusion. Genotyping of cases of suspected PHM contributes to an increased quality of diagnosis and has a direct impact on patient care and follow-up. 
AG03.14

\section{Histopathologische Korrelate zum Graftversagen im rechtsventrikulären Ausflusstrakt des Kindes}

A. D. Peivandi ${ }^{*}$, M. Seiler ${ }^{1}$, K.-M.Müller ${ }^{2}$, S. Martens' ${ }^{1}$, E. Malec ${ }^{1}$, B. Asfour ${ }^{3}$, S. Lück

'Universitätsklinikum Münster, Klinik für Herz- und Thoraxchirurgie, Münster, Deutschland, ${ }^{2}$ Universitätsklinikum Münster, Gerhard-Domagk-Institut für Pathologie, Münster, Deutschland, ${ }^{3}$ Deutsches Kinderherzzentrum Sankt Augustin, Kinderherzchirurgie, Sankt Augustin, Deutschland

Ziel. Die chirurgische Rekonstruktion des rechtsventrikulären Ausflusstraktes bei Patienten mit angeborenem Herzfehler erfolgt über die Implantation eines klappentragenden Konduits. Eine der am häufigsten eingesetzten Prothesen ist die industriell aufbereitete bovine Jugularvene der Firma Medtronic plc. (Contegra ${ }^{\circledR}$ ). Trotz zahlreicher klinischer Studien gibt es nur wenige histologische Analysen explantierter Prothesen, sodass diese Studie eine systematische Aufarbeitung möglicher Pathomechanismen bei Graftversagen zum Ziel hatte. Zugleich erfolgte ein histologischer Vergleich des kommerziell erhältlichen Konduits mit der nativen Jugularvene eines Jungbullen, um Veränderungen durch den Aufarbeitungsprozess darzulegen.

Methoden. Bei Reoperationen wurden insgesamt 13 Präparate gewonnen. $69,2 \%$ der Studienteilnehmer waren männlich [ $n=9$ ], 30,8 \% weiblich $[n=4]$. Nach standardisierter Aufbereitung der Proben kamen folgende Färbemethoden zur Anwendung: Hämatoxylin und Eosin sowie Elastika van Gieson. Radiographische Aufnahmen gaben Aufschluss über den Verkalkungsgrad der einzelnen Präparate. Bei besonders verkalkten Proben kam Chelaplex-Entkalkungsreagenz zum Einsatz.

Ergebnisse. Die native Jugularvene des Jungbullen hatte eine Wanddicke von 1,4 bis $2,7 \mathrm{~mm}$ mit drei voneinander abgrenzbaren Schichten. Auffällig waren insbesondere ca. 20 Schichten dicht gepackter elastischer Fasern in der Intima. Im Vergleich dazu zeigte die aufbereitete Prothese deutliche Veränderungen. Diese waren durch eine Abnahme der elastischen Fasern bei gleicher Intimadicke (ca. 0,3 $\mathrm{mm}$ ) sowie einer generellen Gewebeauflockerung gekennzeichnet. Als histopathologische Korrelate zum Graftversagen konnten zwei grundsätzliche formale Pathomechanismen identifiziert werden: einerseits zeigte sich eine Elastikadegeneration, andererseits eine Intimahyperplasie. Die Regression des elastischen Fasernetzwerkes in unterschiedlicher Ausprägung war begleitet von einem Umbau durch interfibrilläre Matrixstrukturen. Fibröse Gewebeauflagerungen, Kalzifikationen und heterotope Ossifikationen waren Bestandteile der Intimahyperplasie.

Fazit. Die Regression des elastischen Fasernetzwerkes führt zur Rigidität des Konduits. In den untersuchten Proben konnten atherosklerose-ähnliche Veränderungen als Hauptursachen des klinisch beobachteten Graftversagens identifiziert werden. Beide Mechanismen - Elastikadegeneration und Intimahyperplasie - führen regelmäßig zur Reoperationen bei Kindern mit angeborenem Herzfehler.

\section{AG Hämatopathologie I}

\section{AG04.01 \\ Integrative molecular profiling identifies key pathogenic concepts in primary mediastinal large B-cell lymphoma}

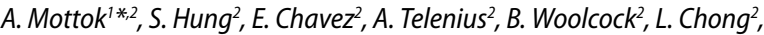
R. Gascoyne $e^{2}$, J. Connors ${ }^{3}$, D. Scott ${ }^{2}$, K. Savage ${ }^{3}$, A. Mungall', M. Marra ${ }^{4}$, R. Siebert ${ }^{1}$, C. Steidl ${ }^{2}$

'Ulm University and Ulm University Medical Centre, Institute of Human Genetics, Ulm, Germany, ${ }^{2 B C}$ Cancer, Lymphoid Cancer Research, Vancouver, Canada, ${ }^{3} \mathrm{BC}$ Cancer, Centre for Lymphoid Cancers, Vancouver, Canada, ${ }^{4} \mathrm{BC}$ Cancer, Michael Smith Genome Science Centre, Vancouver, Canada

Aim. Primary mediastinal large B-cell lymphoma (PMBL) is recognized as a distinct entity in the WHO classification. Molecular studies have pro- vided evidence, that PMBL can be distinguished from diffuse large B-cell lymphoma (DLBCL) and supported a relationship with classical Hodgkin lymphoma (cHL). Since diagnosis usually relies on integration of clinical characteristics, we recently described a molecular assay for the distinction of PMBL from DLBCL using archival biopsies. We here aimed at a comprehensive description of genetic alterations and perturbed pathways in molecularly defined PMBL, as targeted sequencing studies in the past have mainly been focused on single genetic lesions.

Methods. We performed whole-exome sequencing of 95 centrally reviewed PMBL cases, using the SureSelect Human All Exon V6+UTR bait (Agilent) followed by massively parallel sequencing. For 21 cases paired germline DNA was available. Somatic SNV/indel variants were identified using the intersection of predictions by VarScan, Strelka and MuTect, and annotated with SnpEff. We inform on oncogenic driver genes (MutSigCV) and recurrent copy number alterations (CNVkit and GISTIC). For 69 patients global gene expression profiling performed on the DASL platform (Illumina) was available and 90 cases have been molecularly classified using the Lymph3Cx assay. The impact of somatic mutations on gene expression was assessed using xseq.

Results. Analysis of somatic alterations in tumor-normal pairs yielded 50 putative driver genes recurrently mutated in PMBL. Beside mutations in the JAK-STAT (SOCS1, STAT6, IL4R, PTPN1) and NFkB-pathway (TNFAIP3, NFKBIE, TRAF3), we provide additional evidence of the importance of immune evasion in this disease (CIITA, CD58, B2M) and identified the IRF-pathway as a putative novel hallmark. As expected, the most significant regions of copy number gain predicted by GISTIC were located on $9 p(72 \%)$. The most frequent regions of loss were mapped to $10 \mathrm{q}$, $14 q, 8 p, 1 p$, and $7 \mathrm{p}$. PMBL driver genes, with the exception of $E Z H 2$, were significantly more frequently mutated in comparison to DLBCL, whereas only three genes were significantly different between PMBL and cHL. Conclusion. A comprehensive characterization of lymphoma subtypes is warranted to support a correct classification for patient risk stratification and therapeutic decision making. Here we identified candidate driver genes with clear evidence of somatic mutations in PMBL, the majority being distinct from DLBCL.

\section{AG04.02}

\section{Targeted sequencing reveals high specificity of TNAFAIP3- and prognostic role of BCL10 mutations in ocular adnexal marginal zone B-cell lymphomas}

A. Tzankov'*, V. Vela', M. M. Gerlach', P. Meyer', A. Graber', G. Cathomas², S. Dirnhofer', D. Juskevicius'

'Universitätsspital Basel, Institut für Medizinische Genetik und Pathologie, Basel, Switzerland, ${ }^{2}$ Kantonsspital Basel Land, Pathologie, Liestal, Switzerland

Aims. We aimed to comprehensively characterize ocular adnexal (OA) lymphomas (OAL) and reactive lymphoid lesions of the OA by high throughput sequencing (HTS).

Methods. Targeted HTS encompassing 146 genes recurrently mutant in B-cell lymphomas was performed on 34 OA-MZL in comparison with 11 chronic conjunctivitides, 9 "low grade" B-cell lymphomas spreading to the OA, 5 diseases with increase of IgG4+ plasma cells, 3 Burkitt lymphomas (BL), 3 OA diffuse large B-cell lymphomas (DLBCL), 3 orbital pseudotumors, 3 lymphoid hyperplasias of the OA and 2 mantle cell lymphomas. All cases were analyzed for Chlamydia-infection by PCR.

Results. All cases were negative for Chlamydia. The mean number of mutations was highest in BL (4) and lowest in orbital pseudotumors (0). The most commonly mutant gene in OA-MZL was TNFAIP3 (10/34, 29\%). Mutations of this gene were the only exclusive to OA-MZL and the only one reaching a statistically significant discriminatory power between OAMZL and the other studied OAL ( $\mathrm{p}^{\text {Fisher's }}=0.008$ ). Altogether 20/34 patients (59\%) harbored mutually exclusive mutations of either TNFAIP3, BCL10, MYD88, ATM, BRAF or NFKBIE, non-exclusive mutations of IRF8, TNFRSF14 and KLHL6 well as mutation of TBL1XR1, all being of functional

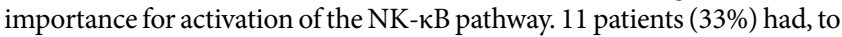




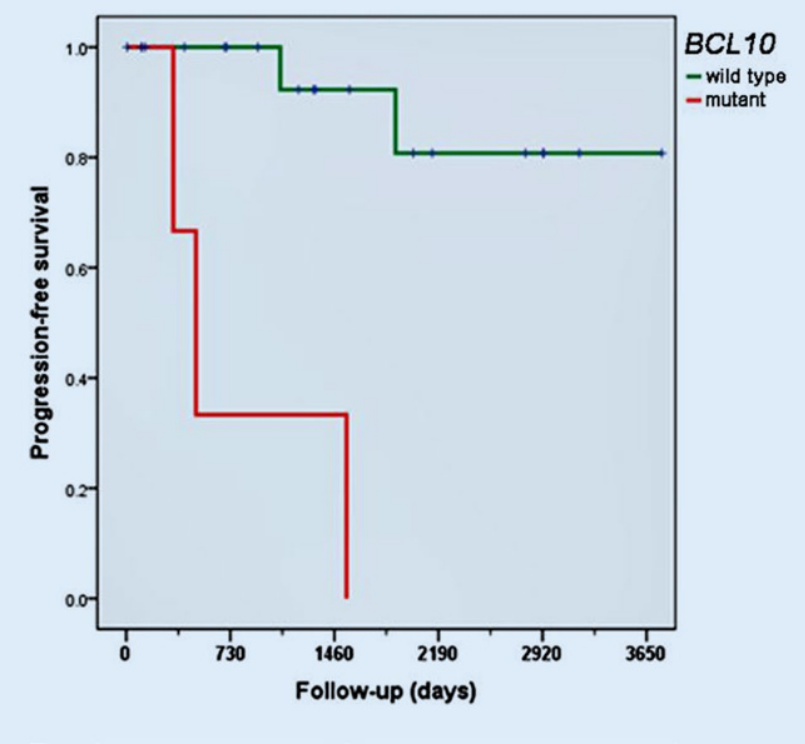

Fig. 1 | AG04.02 $\triangle$ Progression-free survival of OA-MZL with respect to BCL10 status

a great part, mutually exclusive mutations of genes encoding for chromatin modifiers: KMT2D, CREBBP, BCL7A, DNMT3A, EP300 or HIST1H1E. Only 4 patients (12\%) harbored mutations of NK- $\mathrm{kB}$ compounds and of chromatin modifiers, 2 in combination with $M Y D 88$ and each 1 in combination with BCL10 and TNFRSF14. BCL10 mutations were of independent prognostic importance: all 3 mutant patients relapsed (median relapse-free survival 489 days), while there were 2 relapses in the 21 wild type instances (median survival not reached, $p^{\text {log-rank }}=00.000033$; - Fig. $1 \mid$ AG04.02). Conclusions. All in one $80 \%$ of OA-MZL display rather non-overlapping mutations of either NK- $\mathrm{kB}$ compounds or chromatin modifiers. The most frequently mutant gene in OA-MZL is TNFAIP3. Lymphoid lesions of the OA bearing NF- $\mathrm{kB}$ compound mutations and/or mutations of acetyltransferase-encoding genes highly likely represent lymphomas. This is not the case for PTEN, KMT2D, PRDM1 and HIST1H2BK mutations, which can be observed in reactive lesions. Mutations of MYD88, BRAF, CREBBP and probably $T B L 1 X R 1$ are potentially actionable and clinical studies for specific interference are currently performed in lymphomas.

\section{AG04.03 \\ Untersuchungen zu der Frequenz neu hinzugewonnener $\mathrm{N}$-Glykosylierungsmotive in $\mathrm{t}(\mathbf{1 4} ; \mathbf{1 8})$-positiven und negativen follikulären Lymphomen}

C. Maier', R. Bomben' ${ }^{2}$ A. Zamo 3 , F. Vit ${ }^{2}$, H. Horn', V. Gattei', G. Ott ${ }^{5}$, A. Rosenwald', E. Leich-Zbat ${ }^{1 *}$

'Pathologisches Institut der Universität Würzburg, Würzburg, Deutschland, ${ }^{2} \mathrm{CRO}$ National Cancer Institute, SOC Clinical and Experimental OncoHematology Unit, Aviano, Italien, ${ }^{3}$ University of Turin, Department of Oncology, Torino, Italien, ${ }^{4} \mathrm{Dr}$. Margarete Fischer-Bosch-Institut für Klinische Pharmakologie, Stuttgart, Deutschland, ${ }^{5}$ Robert-Bosch-Krankenhaus, Stuttgart, Deutschland

Die Mehrheit der follikulären Lymphome (FL) zeichnet sich durch N-Glykosylierung des B-Zell Rezeptors (BCR) aus. Über die Bindung der Zuckerreste an Lektine, die z. B. von dendritischen Zellen exprimiert werden, kann die Aktivierung des BCR erfolgen. In einer vorherigen Studie zeigten wir an wenigen Fällen, dass $t(14 ; 18)$-negative FL seltener neue NGlykosylierungsmotive hinzugewinnen. Ziel der aktuellen Studie war daher, eine größere Anzahl an t(14;18)-negativen FL mit frühem (I/II) und fortgeschrittenem (III/IV) klinischen Stadium auf neu hinzugewonnene $\mathrm{N}$-Glykosylierungsmotive hin zu untersuchen und mit einer vergleichba- ren Anzahl an t(14;18)-positiven FL zu vergleichen. Wir untersuchten den BCL2-Bruch- und t(14;18)-Status von 29 FL I/II und 61 FL III/IV zum Zeitpunkt der Primärdiagnose und von 42 FL I-IV zum Zeitpunkt eines Rezidivs mittels FISH. Des Weiteren untersuchten wir an DNA aus Gefriermaterial die IGV mit dem LymphoTrack Dx IGH FR1 MiSeq Assay kit. Die Analyse erfolgte mit der LymphoTrack Software und einer selbstetablierten „Pipeline“. Klonale Amplifikation wurde in 7/9 t(14;18)-positiven und 8/9 $\mathrm{t}(14 ; 18)$-negativen FL III/IV und in 12/15 $\mathrm{t}(14 ; 18)$-positiven und 10/12 t(14;18)-negativen FL I/II zum Zeitpunkt der Primärdiagnose sowie in 11/12 $t(14 ; 18)$-positiven und 11/11 $t(14 ; 18)$-negativen rezidivierten FL I-IV erreicht. Während sich der Anteil an Patienten mit neu hinzugewonnenen N-Glykosylierungsmotiven zwischen $\mathrm{t}(14 ; 18)$-positiven und negativen FL I/II nicht nennenswert unterschied, war er zwischen $t(14 ; 18)$-positiven und negativen FL III/IV deutlich erkennbar (67 vs $20 \%$, $p=0,029)$. Des Weiteren wurde das Gen IGHV4-34 von t(14;18)-negativen FL zum Zeitpunkt der Primärdiagnose signifikant häufiger verwendet als von $\mathrm{t}(14 ; 18)$-positiven FL ( $63 \%$ vs $0 \%)(p=0,003)$. Bei rezidivierten FL wurde hingegen weder bei $t(14 ; 18)$-positiven noch bei $t(14 ; 18)$-negativen FL die Verwendung von IGHV4-34 beobachtet $(p=0,016)$. In Zusammenschau mit Resultaten aus vergangenen Studien, die eine Anreicherung von Immun- (v. a. T-Zell-) und NFkB-Signaturen in t(14;18)-negativen FL postulierten, deuten diese Untersuchungen darauf hin, dass ein signifikanter Teil dieser Subgruppe die Lektin-vermittelte Aktivierung des BCR umgeht und diese durch ein verstärktes alternatives NFkB-Signaling und ein verändertes Microenvironment kompensiert. Die deutlich höhere Verwendung von IGHV4-34 in t(14;18)-negativen FL deutet zudem auf eine Aktivierung des BCR durch Autoantigene hin.

\section{AG04.04}

\section{Genetic characterization of two variants of primary cutaneous follicle center lymphoma}

R. Wagener ${ }^{*}$, S. Vogelmann', K. Kleinheinz' ${ }^{2}$ J. Altmüller ${ }^{3}$, H. Thiele, P. Nürnberg ${ }^{3}$, M. Schlesner ${ }^{5}$, M. Brüggemann ${ }^{6}$, W. Klapper ${ }^{7}$, R. Siebert ${ }^{1}$, I. Oschlies

'Institute of Human Genetics, Ulm University and UIm University Medical Center, Ulm, Germany, ${ }^{2}$ Institute of Pharmacy and Molecular Biotechnology and Bioquant, University of Heidelberg, Heidelberg, Germany, ${ }^{3}$ Cologne Center for Genomics, Center for Molecular Medicine Cologne (CMMC), University of Cologne, Cologne, Germany, ${ }^{4}$ Cologne Center for Genomics, University of Cologne, Cologne, Germany, ${ }^{5}$ Bioinformatics and Omics Data Analytics, German Cancer Research Center (DKFZ), Heidelberg, Germany, ${ }^{6}$ Sektion für Hämatologische Spezialdiagnostik, Klinik für Innere Medizin II, Universitätsklinikum Schleswig-Holstein, Kiel, Germany, ${ }^{7}$ Hematopathology Section, Christian-Albrechts-University, Kiel, Germany

Primary cutaneous follicle center lymphoma (PCFCL), including a rare histological spindle cell variant (PCFCL, sc-variant), belong to the cutaneous B-cell lymphomas. As the molecular genetic alterations of PCFCL are sparsely studied, we aimed at characterizing the mutational landscape of the PCFCL also including sc-variants.

We recruited 11 PCFCL, non-sc-variant, and 9 PCFCL, sc-variant, cases. All cases were analyzed for BCL2 rearrangements by fluorescence in situ hybridization and clonality of the immunoglobulin heavy chain rearrangements by NGS-based and/or conventional IGHV sequence analysis. Copy number alterations (CNA) were analyzed in 20 PCFCL cases using the OncoScan ${ }^{\mathrm{TM}} \mathrm{CNV}$ FFPE array. Moreover, the mutational profile was analyzed in 7 PCFCL, non-sc-variant and 6 PCFCL, sc-variant cases by whole-exome sequencing and in 2 PCFCL, non-sc-variant cases, which were studied within the framework of the ICGC MMML-Seq project, by whole-genome sequencing.

None of the 19/20 evaluable PCFCL cases harbored a BCL2 rearrangement. The IGH clonality was confirmed in 7/9 PCFCL, sc-variant and 9/10 PCFCL, non-sc-variant cases. The PCFCL, non-sc-variant cases harbored a comparable number of CNA as the PCFCL, sc-variant cases (median 5.5 (range 2-24) CNA vs. median 6 (range 0-17) CNA, respectively). We identified 22 regions affected by CNA in $\geq 3 / 19$ PCFCL cases. None of these 
regions occurred exclusively in one of both PCFCL variants. Alterations affecting 1p36, described in PCFCL and systemic follicular lymphomas were present in 11/19 PCFCL cases.

In line, the amount of potentially protein-changing mutations was similar with a median of 122 (range 78-208) mutations in PCFCL, non-sc-variant and 155 (range 87-369) mutations in PCFCL, sc-variant cases. Overall 32 genes were mutated $\geq 2 / 6$ PCFCL, sc-variant, cases and 56 genes in $\geq 2 / 9$ PCFCL, non-sc-variant', cases including genes frequently mutated in systemic follicular lymphoma. Only two genes were recurrently affected in both variants.

In summary, we could show that the CNA and number of mutations were comparable between both PCFCL variants, which supports the WHO-classification of PCFCL, sc-variant, as morphological variation of PCFCL. Some recurrent molecular alterations in PCFCL were shared with systemic FL. The morphological variants nevertheless harbored different patterns of recurrent mutations indicating molecular differences.

\section{AG04.05 \\ Prognostic implications of the microenvironment in follicular lymphoma treated withe rituximab (R) or $\mathbf{R}+$ lenalidomide: results of the SAKK35/10 trial}

A. Tzankov' ${ }^{1 *}$, T. Menter', E. Zucca' ${ }^{2}$, S. Hayoz ${ }^{3}$, A. Vanazzi', B. Østenstad ${ }^{5}$, U.J.M. Mey ', D. Rauch', B.E. Wahlin', F. Hitz', M. Hernberg ${ }^{10}$, A.-S. Johansson ${ }^{11}$, P. de Nully Brown ${ }^{12}$, H. Hagberg ${ }^{13}$, E. Kimby' ${ }^{8}$, S. Dirnhofer ${ }^{1}$

'Universitätsspital Basel, Institut für Medizinische Genetik und Pathologie, Basel, Switzerland, ${ }^{2}$ Oncology Institute of Southern Switzerland, Bellinzona, Switzerland, ${ }^{3}$ SAKK Coordinating Center, Bern, Switzerland, ${ }^{4}$ European Institute of Oncology, Milano, Italy, ${ }^{5}$ Oslo University Hospital, Oslo, Norway, ${ }^{6}$ Kantonsspital Graubünden, Chur, Switzerland, ${ }^{7}$ Spital Thun Simmenthal, Thun, Switzerland, ${ }^{8}$ Karolinska Institutet, Stockholm, Sweden, ${ }^{9}$ Kantonsspital St. Gallen, St. Gallen, Switzerland, ${ }^{10}$ Comprehensive Cancer Center, Helsinki, Finland, ${ }^{11}$ Norrlands Universitetssjukhus, Umeå, Sweden, ${ }^{12}$ Rigshospitalet, Copenhagen, Denmark, ${ }^{13}$ Uppsala University Hospital, Uppsala, Sweden

Aims. Follicular lymphoma (FL) constitutes a significant disease burden of lymphomas and is prone to relapses after therapy. Lately, new therapeutic approaches beyond conventional chemotherapy have emerged which focus on the interplay between lymphoma cells and the surrounding reactive cells of the microenvironment.

Methods. We performed immunophenotypic investigation focusing on the microenvironment of a clinically well characterized cohort (study SAKK35/10) of 135 evaluable treatment naïve FL patients in need of therapy, who have been treated with either R only or a combination of $\mathrm{R}$ and the immunomodulatory drug lenalidomide $\left(\mathrm{R}^{2}\right)$.

Results. After initial large-scale phenotypic (BCL2, CD3, CD4, CD5, CD8 CD21, CD68, CD163, Cereblon, CMYC, FOXP3, GATA3, granzyme B, PD1, PDL1, perforin, pSTAT5, T-bet, TIA1) analysis of 34 tissue-microarrayed cases focusing on prognostic impact, several promising markers for T-cell subgroups were selected for further evaluation of the whole cohort of 135 patients. High ratio of CD4- to CD8-positive T cells $(p=0.009)$ and an increased amount of PD1-positive T-cells $(p=0.007)$ were associated with inferior Progression-free survival (PFS) in the whole cohort. These findings remained significant in the multivariate analysis taking into consideration FLIPI. Interestingly, the prognostic impact of PD1-positive T-cells and the CD4/CD8 ratio was lost in the subgroup treated with $\mathrm{R}^{2}$. In the latter group, high amounts of GATA3-positive TH2-equivalents was associated with better PFS $(p<0.001)$ and also overall survival $(p=0.030)$.

Conclusions. Based on data from this prospective clinical trial on FL, we identified tumor microenvironmental characteristics allowing prognostic stratification with respect to immuno- and combined immuno- and immunomodulatory therapy. Our analysis implicates that lenalidomide in $\mathrm{R}^{2}$ might help to overcome the adverse prognostic implication of higher amounts of regulatory $\mathrm{T}$ cells in the microenvironment of $\mathrm{FL}$ and that it has particularly favorable effects in cases with higher amounts of TH2-equivalents.
AG04.06

\section{A distinct pattern of eukaryotic initiation factors impact on the pathogenesis of follicular lymphoma}

K. Skrobar', J. Unterluggauer ${ }^{2}$, K. Prochazka' , J. Waldhart ${ }^{3}$, P. Neumeister', C. Beham-Schmid'2, J. Haybaeck', A. Deutsch ${ }^{1 *}$

'LKH-Univ. Klinikum Graz, Innere Medizin - Hämatologie, Graz, Austria, ${ }^{2}$ LKH-Univ. Klinikum Graz, Pathologie, Graz, Austria, ${ }^{3}$ Medizinische Universität Innsbruck, Institut für Pathologie, Neuropathologie und Molekularpathologie, Innsbruck, Austria, ${ }^{4}$ Universitätsklinik, Pathologie, Magdeburg, Germany

Introduction and aim. Follicular lymphoma (FL) is characterized as an indolent and the second most common non-Hodgkin's lymphoma. Progression of disease within 24 months (POD24) is the most accurate predictor of worse clinical outcome but specific parameters useful for risk stratification before therapy-start are lacking. Since our group clearly demonstrated that eukaryotic initiation factors (eIFs) were significantly associated with clinical course of aggressive lymphomas, we aim to comprehensively study these factors in FL.

Material and methods. The expression levels of mRNA of 16 eIFs were analyzed by quantitative real-time PCR in a cohort of 64 FL patients (no relapse $(n=27)$, with relapse later than 24 months $(n=24)$ and with POD24 $(n=13))$. Non-neoplastic germinal center B cell specimens (GC-B) served as controls $(n=5)$.

Results. Higher expression of EIF1A (2.1 fold, $p=0.023)$, EIF2B3 (6.8-fold, $p=0.014), E I F 3 J$ (11.4-fold, $p=0.012)$ and EIF4E (21.7-fold, $p=0.002)$ and lower expression of EIF1 (3.1-fold, $p=0.003$ ), EIF2A ( 29.3 -fold, $p<0.001$ ) and EIF4G3 (3.8-fold, $p=0.046$ ) were detected in FL compared to GC-B. Interestingly, we observed that low expression of EIF1A $(p=0.014)$ and EIF3D ( $p=0.007)$ was associated with poor clinical outcome of FL patients. Finally, by comparing the expression levels of the investigated eIF subunits between FLs with and without POD24, we detected a lower expression of EIF2B4 (4.1-fold, 0.015) and EIF4G3 (9.9-fold, $p=0.008$ ) the POD24 group.

Conclusion. Our data indicate that eIFs play an important role in pathogenesis of follicular lymphoma. Thus, the expression pattern of the eIF subunits might serve as a useful clinical prognostic marker for risk stratification.

\section{AG04.07}

\section{Tumorbiologie Follikulärer Lymphome vom pädiatrischen Typ}

L. Frauenfeld ${ }^{*}$, J. Steinhilber', I. Salaverria ${ }^{2}$, E. Campo ${ }^{3}$, E. Jaffe ${ }^{4}$, F. Fend ${ }^{7}$ I. Bonzheim ', L. Quintanilla-Martínez'

IInstitut für Pathologie Univ. Tübingen, Allgemeine und molekulare Pathologie, Tübingen, Deutschland, ${ }^{2} \mathrm{Hospital}$ Clinic, Institut d'Investigacions Biomèdiques August Pi i Sunyer, Barcelona, Spanien, ${ }^{3} \mathrm{Hospital}$ Clinic of the University of Barcelona, Anatomic Pathology, Barcelona, Spanien, ${ }^{4}$ National Cancer Institute, Center for Cancer Research, Laboratory of Pathology, Hematopathology Section, Bethesda, United States

Ziel. Follikulärer Lymphome vom pädiatrischen Typ (PTFL) sind t(14;18) negative follikuläre Lymphome (FL) mit besonderen klinisch-pathologischen Eigenschaften. PTFLs zeigen im Vergleich zum klassischen Follikulären Lymphom (cFL) ein spezifisches Mutationsprofil. Einige immunogenetische Eigenschaften wie somatische Hypermutation, IGV-Gene-usage und Nachweis einer positiven Antigenselektion wurden bislang nicht untersucht. cFL $t(14 ; 18)+$ zeigen fast durchgehend den Erwerb von N-Glykosylierungsstellen während der somatischen Hypermutation (SHM), welche einen Aktivierungsmechanismus für Antigen-abhängige BCR-Signalinduktion darstellt. Das Ziel der unserer Studie ist, die immunogenetischen Eigenschaften der PTFL zu untersuchen und Einblicke in den Pathomechanismus dieses Lymphoms zu gewinnen.

Methoden. 38 gut charakterisierte PTFL Fälle wurden mit NGS-basierter Klonalitätsanalyse auf den Ion Torrent PGM und S5 Plattformen untersucht. NGS libraries wurden mit DX IGH FR1 Assay, DX IGH FR2 Assay oder DX IGK Assay (invivoscribe, San Diego, CA) erstellt. Die Rohdaten wurden mit LymphoTrack ${ }^{\circledR}$ DX IGHVisualization software analysiert. 
Ergebnisse. Von 38 Fällen waren 29 auswertbar. Der IGHV-Gebrauch war ähnlich zu normalen B-Zellen, am häufigsten VH3 (17/27), gefolgt von VH1 (5/27), VH4 (4/27), VH5 (1/27) und VH2 (1/27). Es konnte keine Überrepräsentation von spezifischen V-Genen beobachtet werden, die auf Auto-Antigen Selektion hinweisen würde. Wie für ein Keimzentrumslymphom erwartet zeigten 28/29 Fälle SHM (<97 \% identische Aminosäuresequenz zur Keimbahn) des V-Gens. N-Glycosylierungs-Stellen (Asn-X-Ser/ Thr) wurden in lediglich 3/28 Fällen gefunden, nur 2 davon als Resultat der SHM, davon eine in der CDR3 Region, die andere im hochkonservierten FR3 Areal. Die dritte Stelle stellte eine Keimbahnvariante dar. Eine potentielle Rolle für positive Antigen-Selektion konnte in keinem der Fälle gezeigt werden. „Ongoing“ SHM fand sich in allen 10 untersuchten Fällen. Fazit. Diese Studie zeigt, dass PTFL grundlegende immunogenetische Unterschiede zum BCL2+cFL aufweisen. Das Fehlen eines erhöhten Vorkommens von N-Glykosylierungsstellen und einer positiven AntigenSelektion, beides Mechanismen zur Aktivierung des BCR Signalling und damit zum Überleben im Keimzentrum im PTFL könnten eine Rolle für das besondere Verhalten dieses Lymphomtyps spielen. Weiterführende Studien sind nötig um die immunogenetischen Eigenschaften des PTFL und den indolenten Verlauf der Erkrankung zu verstehen.

\section{AG Hämatopathologie II}

\section{AG04.09 \\ Nr4a1 is implicated in the regulation of the Pd1-PdI1-Pdl2 and Ctla4-Cd80-Cd86 axis in aggressive lymphomas}

K. Pansy', K. Fechter ${ }^{1}$, K. Wenzl', K. Prochazka' , C. Beham-Schmid' ${ }^{2}$, P. Neumeister', J. Haybaeck ${ }^{3}$, A. Deutsch ${ }^{4 *}$

'LKH-Univ. Klinikum Graz, Hämatologie, Graz, Austria, ${ }^{2}$ LKH-Univ. Klinikum Graz, Pathologie, Graz, Austria, ${ }^{3}$ Universitätsklinik, Pathologie, Magdeburg, Germany, ${ }^{4}$ LKH-Univ. Klinikum Graz, Innere Medizin-Hämatologie, Graz, Austria

Introduction and aim. In aggressive lymphomas, low expression of $N R 4 A 1$ is associated with poor cancer-specific survival and its overexpression suppressed lymphoma cell growth in vitro indicating its tumor suppressor properties. The aim of this study was to comprehensively study the function of Nr4al in vivo.

Material and method. Therefore, we used a murine model and intercrossed the E $\mu M y c$ transgenic mouse with the Nr4a1-/-mouse. To translate our main findings into human DLBCL patients, we determined the expression levels of the immune regulatory genes by RQ-PCR in our DLBCL cohort with known NR4A1 expression levels.

Results. Loss of Nr4a1 in E $\mu M y c$ transgenic mice accelerated lymphomagenesis. RNA-Seq revealed that genes implicated in immune regulation, especially immune checkpoint and ligands, were significantly higher expressed in E $\mu \mathrm{MycNr} 4 a$ 1-/-lymphomas. Transplanting lymphoma cells with or without Nr4a1 loss into immune-competent mice led to a faster lymphoma-development and a decreased survival in the absence of Nr4a1, whereas no differences in lymphomagenesis and survival were detected by transplantation of the same lymphoma cells into immune-incompetent mice. Gene expression analysis of primary and engrafted lymphomas revealed that Nr4a1 is implicated in the regulation of Pd1-Pdl1-Pdl2 and Ctla4-Cd80-Cd86 axis. In the human setting, we detected a significantly higher expression of $P D 1, P D L 1, P D L 2, C T L A 4, C D 80$ and $C D 86$ in NR4A 1 low expressing DLBCL confirming our mouse data.

Conclusion. Our data suggest that loss of $\mathrm{Nr} 4 a \mathrm{l}$ is implicated in the regulation of Pd1-Pdl1-Pdl2 and Ctla4-Cd80-Cd86 axis in aggressive lymphomas and thereby, potentially contributes to the immune evasion of aggressive lymphomas.
AG04.10

\section{Der Knockdown von CARD9 reduziert die Proliferation der Richter} Transformation-Zellline U-RT1

J. Maier*, R. Marienfeld, T. F. Barth, P. Möller, K. Mellert

Universität Ulm, Institut für Pathologie, Ulm, Deutschland

Ziel. Bei der chronisch lymphatischen Leukämie (CLL) handelt es sich um eine indolente, kleinzellige B-Zell-Neoplasie. Ungefähr $5 \%$ der CLL Patienten entwickeln im Verlauf eine Transformation in ein aggressives, diffuses großzelliges B-Zell Lymphom (Richter Transformation, RT). Die Prognose der RT ist schlecht und die therapeutischen Optionen sind limitiert. Die der Transformation zugrunde liegenden Mechanismen sind noch weitgehend unverstanden.

U-RT1 ist die erste stabile Zelllinie einer Richter Transformation. Diese Zelllinie zeigt in Microarray Expressionsanalysen eine unerwartet hohe Expression von CARD9, welches eine wichtige Rolle in der NFKBAktivierung in nicht-lymphoiden Zellen der angeborenen Immunantwort spielt. Ziel dieser Arbeit ist es, die Rolle von CARD9 in der Zelllinie U-RT1 zu untersuchen, um Hinweise auf potentielle bisher unbekannte Mechanismen der Pathogenese der Richter Transformation zu erhalten.

Methoden. Die Expression von CARD9 wurde mittels Microarray, qPCR, Western Blot, Immunhisto- und Immunzytochemie, sowie Doppelimmunfluoreszenzmikroskopie untersucht. Für die funktionellen Analysen in U-RT1 wurden Co-Immunpräzipitation (Co-IP), siRNA Knockdown, MTT Proliferations Assay und Western Blot angewandt.

Ergebnisse. Anhand von qPCR und Western Blot Analysen konnte die starke Expression von CARD9 in der U-RT1 auf mRNA- und Proteinebene bestätigt werden. Im Gegensatz dazu zeigte sich keinerlei CARD9 Expression in sieben getesteten de novo DLBLC Zelllinien. Mittels Co-IP konnte gezeigt werden, dass in der U-RT1 ein CBM-Komplex aus BCL10, MALT1 und CARD9 anstelle von CARD11 gebildet wird. Interessanterweise konnte in der U-RT1 eine konstitutive NFkB Aktivität festgestellt werden. Darüber hinaus führte der Knockdown von CARD9 durch siRNA Transfektion zu einem signifíkanten Proliferationsrückgang der U-RT1 $(p=0,0018)$. Fazit. CARD9 spielt eine wichtige Rolle für die Proliferation der Zelllinie U-RT1. Die Überexpression von CARD9 könnte über die Bildung eines CBM-Komplexes und konstitutive NFKB Aktivierung zur Pathogenese der Richter Transformation beitragen.

\section{AG04.11 \\ High elF2B5 expressing DLBCLs possess an enrichment of AKT and JNK target genes}

A. Deutsch'* , J. Unterluggauer ${ }^{2}$, K. Pansy', K. Fechter', C. Beham-Schmid ${ }^{2}$, P. Neumeister', J. Haybaeck ${ }^{3}$

'LKH-Univ. Klinikum Graz, Innere Medizin-Hämatologie, Graz, Austria, ${ }^{2}$ LKHUniv. Klinikum Graz, Pathologie, Graz, Austria, ${ }^{3}$ Universitätsklinik, Pathologie, Magdeburg, Germany

Introduction and aims. Dysregulation of protein synthesis is a major step in cancer development and progression. Eukaryotic translation initiation factors (eIFs) are involved in the regulation of protein synthesis. Recently, we have demonstrated that eIF2B5 is associated with poor cancer-specific survival in DLBCL. To further gain some knowledge on the regulation of this factor, we comprehensively studied the activation of the AKT, JNK, and ERK1/2 pathways-known to regulate protein translation-in eIF2B5 low and high expressing lymphomas.

Methods. By quantitative real-time PCR, we analyzed the mRNA expression levels of targets of AKT, JNK and ERK1/2 in eIF2B5 low and high expressing DLBCL ( $n=10$ per group). The expression levels were compared between the two groups by using the Mann-Whitney test.

Results. Analysis on mRNA levels revealed an at least 2.5-fold higher expression of five of nine investigated AKT targets $(p<0.05)$ and an at least 3.5-fold higher expression of five of nine investigated JNK targets $(p<0.021)$. In stark contrast, none of the investigated ERK1/2 targets was significantly differentially expressed. 
Conclusion. Our data indicate that high eIF2B5 expression is associated with higher activation of the AKT and JNK pathways in DLBCL. Together with the observation that high eIF2B5 expression is linked to poor prognosis, it seems that inhibition of these pathways might serve as a potential target for future lymphoma therapy.

\section{AG04.12 \\ Klinische und histopathologische Charakterisierung von Primär kutanen CD4+ klein/mittelgroßzelligen T-Zell Lymphoproliferationen (CD4LPD)}

T. Wüseke ${ }^{1 *}$, K. Koch' ${ }^{1}$ W. Klapper' I. Oschlies ${ }^{1}$

'Institut für Pathologie, Universitätsklinikum Schleswig-Holstein, Campus Kiel, Sektion Hämatopathologie und Lymphknotenregister, Kiel, Deutschland

Ziel. In dieser Studie sollte eine klinische und histopathologische Charakterisierung von Primär kutanen CD4+ klein/mittelgroßzelligen T-Zell Lymphoproliferationen (CD4LPD) erfolgen, speziell interessierte uns die zelluläre Zusammensetzung und Frage einer Cyclin D1 Expression, die in manchen T-Zell Lymphomen vorbeschrieben ist.

Methoden. Wir untersuchten 70 formalinfixierte und in Paraffin eingebettete Biopsate (FFPE) aus dem Archiv des Lymphknoten Registers Kiel mit histopathologisch diagnostizierten und molekular klonalen CD4LPDs. Klinische Daten wurden retrospektiv erhoben. Der B- und T-Zellgehalt (CD20/CD3) sowie der Anteil PD1-positiver und Cyclin D1-positiver lymphatischer Zellen wurde erfasst. In Fällen mit einem geschätzten Anteil von $>10 \%$ Cyclin D1 positiven lymphatischen Zellen wurde der Anteil Cyclin D1 und PD1-koexprimierender Zellen in einer Doppelfärbung quantifiziert. Mittels Fluoreszenz-in-situ Hybridisierung wurde nach $C y$ clin D1-Alterationen gefahndet.

Resultate. Die Proben stammten von 67 Patienten $(32 \mathrm{~m}, 35 \mathrm{w})$ mit einem Altersmedian von 60 (23-82 Jahre). In $n=24$ Fällen lagen retrospektiv klinische Daten vor. 23/24 zeigten eine solitäre Läsion in Form einer Plaque oder eines kleinen Knotens $(0,6-6 \mathrm{~cm})$. N=18/24 wurde eine lokal Therapie (Exzision, Kortikoide) angegeben, in keinem Fall erfolgte eine Bestrahlung oder Chemotherapie. Der B-Zellgehalt lag im Median bei $20 \%$ (Intervall 5-70\%), der T-Zellgehalt im Median bei $80 \%$ (Intervall 30-95 \%). Der Gehalt PD1-positiver Zellen im Infiltrat lag im Median bei $20 \%(n=63$, Intervall 5-90 \%) mit Clusterbildung in knapp $50 \%$ der Fälle. In 22/51 Fällen mit Cyclin D1-Färbung fanden sich $>10$ \% Cyclin D1 positiven lymphatischen Zellen. Die Doppelfärbung bestätigte die Koexpression von Cyclin D1 und PD1 (gemittelter Anteil CyclinD1+PD1+ Zellen/PD1-positive Zellen bei $17 \%$ ). Es fanden sich weder Amplifikationen noch Brüche des Cyclin D1-Gens. In Pseudolymphomen, die PD1positive Zellen enthielten, konnte keine Koexpression von Cyclin D1/PD1 nachgewiesen werden $(n=6)$.

Fazit. CD4LPDs zeigen eine gemischtzellige Zusammensetzung, ein Teil zeigen Cyclin D1/PD1-koexprimierende T-Zellen. Dieses Merkmal könnte für die diagnostische Abgrenzung von CD4LPDs und Pseudolymphomen nützlich sein. Klinisch präsentierten sich die CD4LPDs in unserer Analyse wie erwartet als überwiegend solitäre Läsionen ohne Disseminationstendenz, die mit lokaler Therapie kontrolliert werden können.

\section{AG04.13}

Verwendung eines neuen spezifischen monoklonalen anti-SOCS1Antikörpers zur Charakterisierung der SOCS1-Expression in B-Zell Lymphomen

\section{P. Kürten*, S. E. Weissinger, M. Zahn, R. Marienfeld, P. Möller IInstitut für Pathologie, Universitätsklinikum, Ulm, Deutschland}

Ziel. SOCS1 (Suppressor of Cytokine Signaling 1) ist als Negativregulator des JAK/STAT-Signalweges in der Lage durch seine antiproliferative Wirkung funktionell als Tumorsuppressor zu agieren. Folglich können inaktivierende SOCS1-Mutationen durch konsekutive Aktivierung dieses Signaltransduktionsweges unter anderem Proliferation und Überleben verschiedenster Lymphomentitäten begünstigen und somit auch prognostisch von Bedeutung sein. Zur Ermittlung des SOCS1-Proteinstatus sind verlässliche Antikörper erforderlich. Ziel dieser Arbeit war es, die aktuell vier kommerziell erhältlichen sowie zwei institutseigene monoklonale anti-SOCS1-Antikörper auf Spezifität und hinsichtlich ihrer Zuverlässigkeit, SOCS1 nachzuweisen, zu testen.

Methoden. Zur Untersuchung des SOCS1-Proteinstatus mittels verschiedener Antikörperklone (s. Tab. 1 |AG04.13) wurden Western Blot-Experimente durchgeführt. Die hierbei verwendeten Proteinextrakte wurden sowohl aus zuvor mit Wildtyp-SOCS1-DNA transfizierten HEK 293T Zellen, als auch aus sieben weiteren Zelllinien gewonnen. Letztere exprimieren SOCS1 wildtypisch (LCL, U-MM1b, HBL-1, L540) oder in mutierter Form (Karpas1106, L428, MedB1). Die transfizierten HEK 293T Zellen dienten als Positivkontrolle, die biallelisch SOCS1-defiziente Zelllinie Karpas1106 wurde als Negativkontrolle verwendet.

Ergebnisse. Die Western Blot-Ergebnisse der Transfektionen zeigen, dass die verwendeten Antikörperklone SOCS1 nachweisen können. Mit ab-

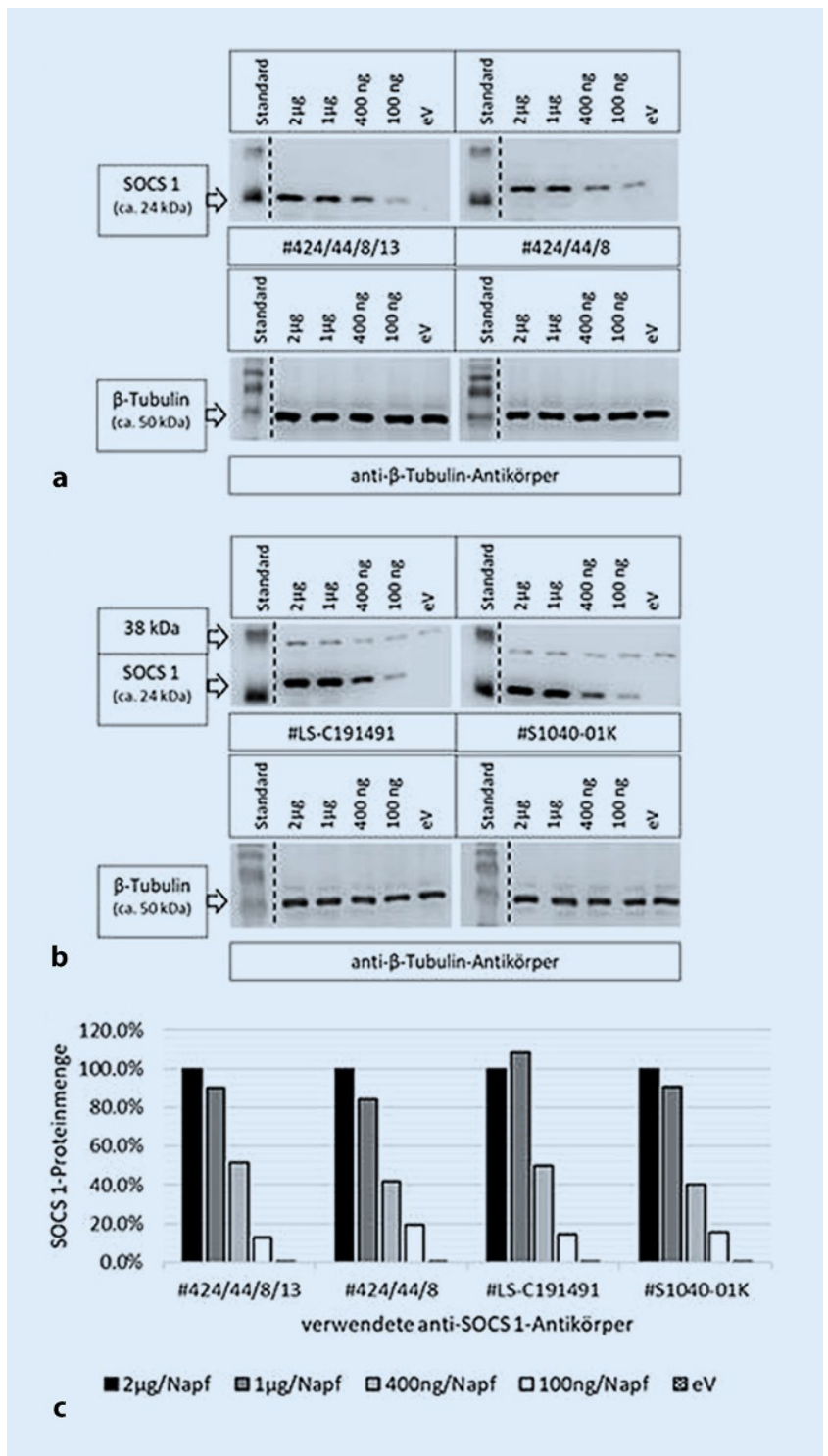

Abb. 1 | AG04.13 $\Delta$ Western Blot-Ergebnisse einer Transfektion von HEK 293T Zellen mit Wildtyp-SOCS1-DNA (a,b) bzw. zugehörige Quantifizierung der detektierten Bandensignale (c). Transfizierte Wildtyp-SOCS1-DANNMenge: $2 \mu \mathrm{g}-1 \mu \mathrm{g}-400 \mathrm{ng}-100 \mathrm{ng}$ je pro ca. $10 \wedge 4$ HEK 293T Zellen; eV: empty vector 
Tab. 1 | AG04.13 Übersicht der verwendeten monoklonalen anti-SOCS1-Antikörper

\begin{tabular}{lllll} 
Antikörper & Klon & Hersteller & $\begin{array}{l}\text { Immunisierungssequenz (SOCS1- } \\
\text { Protein) }\end{array}$ & Epitop \\
\hline \#424/44/8/13 & $424 / 44 / 8 / 13$ & institutseigen & aa 104-211 & bekannt \\
$\# 424 / 44 / 8$ & $424 / 44 / 8$ & institutseigen & aa 104-211 & bekannt \\
\#LS-C191491 & TS106 & LifeSpan BioSciences, Inc. & aa 2-78 & n.a. \\
$\# S 1040-01 K$ & $11 \mathrm{n} 174$ & as $2-78$ & n.a. \\
$\#$ \#1040-01C & $4 \mathrm{H} 314$ & USBiological & aa 2-78 & n.a. \\
\#4H1 & $4 \mathrm{H} 1$ & ThermoFisher Scientific & aa 2-78 & n.a.
\end{tabular}

nehmender Menge transfizierter Wildtyp-SOCS1-DNA reduziert sich erwartungsgemäß die von den HEK 293T Zellen produzierte SOCS1-Menge. Dieser Zusammenhang wird von den verwendeten Antikörperklonen weitestgehend erfasst (s.• Abb. $2 \mid$ AG04.13). Für die weiteren Zelllinien zeigen sich unter Berücksichtigung der jeweiligen Immunisierungssequenzen ebenfalls überwiegend die zu erwartenden Ergebnisse. Von L540-Zellen produziertes Wildtyp-SOCS1 wird wider Erwarten von keinem der verwendeten Antikörper erkannt. Darüber hinaus fällt auf, dass alle kommerziell erworbenen Antikörper regelmäßig unspezifische Banden erzeugen.

Fazit. In den durchgeführten Experimenten liefern die verwendeten monoklonalen anti-SOCS1-Antikörper überwiegend vergleichbare Ergebnisse. Die institutseigenen Antikörper weisen im Gegensatz zu den kommerziell erhältlichen Klonen eine höhere Spezifität auf. Zudem legen die Ergebnisse nahe, dass die institutseigenen Antikörper Wildtyp-SOCS1 im Rahmen der Transfektionsexperimente insgesamt zuverlässiger nachweisen können.

\section{AG Hämatopathologie III}

\section{AG04.15}

Genotypisierung zirkulierender Tumor DNA pädiatrischer Hodgkin Lymphome zur Erkennung pathogener Mechanismen und zum Therapie Monitoring

\section{K. Hartung ${ }^{1 *}$, A.-K. Desch', T. Jox', R. Schmitz', C. Mauz-Körholz², D. Körholz²} S. Gattenlöhner', A. Bräuninger

'Justus Liebig Universität, Pathologie, Giessen, Deutschland, ${ }^{2}$ Justus Liebig Universität, Pädiatrische Hämatologie und Onkologie, Giessen, Deutschland

Ziel. Der Nachweis somatischer Tumor-assoziierter Mutationen in zirkulierender Zell-freier DNA (ccfDNA) aus Blut-Plasma ist bei vielen TumorEntitäten ein geeignetes Verfahren zum Therapie Monitoring. Wir untersuchen, ob der Nachweis von somatischen Mutationen der Hodgkin-Reed/ Sternberg (HRS) Zellen in ccfDNA bei pädiatrischen Hodgkin Lymphom (PHL) Patienten möglich und zum Therapie Monitoring geeignet ist.

Methoden. Hybrid capture basiertes targetiertes next generation sequencing mit ccfDNA

Ergebnisse. Bei 72 von 96 Patienten wurden in der ccfDNA vor TherapieBeginn somatische single nucleotide Varianten (SNV) und kleine Insertionen und Deletionen (indels), 1-21 je Patient mit Allel-Frequenzen von 0,6-42 \%, nachgewiesen. Durch die Abdeckung der Immunoglobulin Loci wurden außerdem 9 Translokationsbruchpunkte, von denen 7 SOCS1 betrafen, detektiert, sowie clonotypische Fragmente von $16 \mathrm{VH}-\mathrm{DH}-\mathrm{JH} \mathrm{Um}-$ lagerungen nachgewiesen. Der HRS-Ursprung der SNVs, indels, Translokationsbruchpunkte und VH-DH-JH Umlagerungen wurde exemplarisch bei 14 Patienten durch Mikrodissektion einzelner HRS-Zellen und anschließender PCR und Sanger Sequenzierung verifiziert. Direkte Vergleiche zwischen ccfDNA und genomischer DNA aus diagnostischen Biopsien oder mononuklären Blutzellen ergaben, dass ccfDNA die geeignetste Quelle zum Nachweis somatischer Mutationen der HRS-Zellen ist. Am häüfigsten von Aberrationen betroffen waren Gene des JAK/STAT Signalwegs, der NFkB Regulation, des PIK3 Signalweges und Gene, die für die Antigen Präsentation essentiell sind.

Die Untersuchung konsekutiver ccfDNA Proben individueller Patienten ergab, dass bei Patienten mit gutem Ansprechen auf 2 Zyklen OEPA Chemotherapie bereits nach dem 1. Zyklus keine Mutationen mehr nachweisbar waren, während bei nicht ansprechenden Patienten Mutationen in der ccfDNA persistierten.

Fazit. ccfDNA aus Blut-Plasma von PHL Patienten ist zum Nachweis somatischer Mutationen geeignet und unsere Resultate deuten darauf hin, dass der Nachweis der Mutationen zur frühen Erkennung Chemotherapieresistenter Patienten geeignet sein kann.

\section{AG04.16}

Fibroblasts from classical Hodgkin lymphoma exhibit a specific phenotype and rescue Hodgkin cells from apoptosis induced by Brentuximab-Vedotin

K. Bankov ${ }^{1 * 2}$, C. Döring ${ }^{1}$, N. Becker', M. Giefing ${ }^{3}$, A. Ustaszewski ${ }^{3}$, M. Herling ${ }^{4}$, S. Zeuzem², P. Wild', M.-L. Hansmann 1,5,6, S. Hartmann ${ }^{1,5}$

'Dr. Senckenberg Institute of Pathology, University Hospital Frankfurt, Frankfurt, Germany, ${ }^{2}$ Department of Internal Medicine 1, Hospital of the J.W. Goethe University, Frankfurt, Germany, ${ }^{3}$ Institute of Cancer Genetics, Polish Academy of Sciences, Poznan, Poland, ${ }^{4}$ Department of Internal Medicine I, University of Cologne, Laboratory of Lymphocyte Signaling and Oncoproteome, Cologne, Germany, ${ }^{5}$ Reference and Consultant Center for Lymph Node and Lymphoma Pathology, Goethe University, Frankfurt, Germany, ${ }^{6}$ Frankfurt Institute of Advanced Studies, Frankfurt, Germany

Aims. Classical Hodgkin lymphoma cHL is one of the most common malignant lymphomas in Western Europe. Particularly the nodular sclerosing subtype of cHL (NS cHL) is frequently observed in adolescents and young adults. Histologically, it is characterized by a proliferation of fibroblasts in the tumor microenvironment, leading to fibrotic bands surrounding the lymphoma infiltrate. Several studies have described a crosstalk between the tumour cells of cHL, the Hodgkin- and Reed-Sternberg (HRS) cells, and these cancer-associated fibroblasts (CAFs). However, to data a deep molecular characterization of these CAFs is lacking. Aim of the present study therefore was a comprehensive characterization of these CAFs.

Methods. Gene expression profiling of CAFs isolated from primary lymph node suspensions and cultured for five to six passages revealed persistant differences between NS cHL CAFs and fibroblasts obtained from lymphadenitis (LA CAF). These differences were even more prominent in the methylation profiles obtained from the same cultures.

Results. Prominent deregulated transcripts such as CNN1, MYOCD, TIMP3, INHBA and IL6 were proved to be upregulated in primary cultures and enriched in patient material via immune-based staining. The alteration might cause differentiation of cells into a specific activated fibroblastic cell with a strong Extracellular Matrix (ECM) secretion. Methylation analysis revealed a stable unsupervised clustering of NS CHL CAFs and LA CAFs. Co-cultivation of primary NS cHL CAFs with HRS cell line L-428 revealed a strong and stable interaction of non-adherent HRS cells with the stroma monolayer CAFs. Once HRS cells underwent persistent interaction 
with CAFs, susceptibility to Brentuximab-Vedotin (BV)-an antibody drug conjugate to treat $\mathrm{CHL}$-was decreased. CAF-conditioned media alone could not rescue HRS cultures from BV-induced apoptosis. The flavonoid Luteolin can inhibit growth and proliferation of CAFs. Luteolin also down-regulated CNN1 and TIMP3 that were identified previously to be specifically upregulated among NS cHL CAFs. Interestingly, HRS-conditioned media restored proliferation and growth of CAFs after Luteolin treatment.

Conclusions. Taken together, NS cHL derived CAFs show specific and stable alterations in their gene expression and epigenetic profile. The activated network of CAFs in cHL offers niches, which give HRS cells advantages in proliferation.

\section{AG04.17}

CD30-expression in neoplastic T cells of follicular T-cell lymphoma is a helpful diagnostic tool in the differential diagnosis to Hodgkin lymphoma

S. Hartmann ${ }^{1 *}$, O. Goncharova' ${ }^{1}$ A. Portyanko ${ }^{2}$, J. Meinel', R. Küppers ${ }^{4}$, C. Agostinelli ${ }^{5}$, E. Sabattini ${ }^{5}$, S. Pileri ${ }^{6}$, M.-L. Hansmann ${ }^{7}$

${ }^{1}$ Goethe Universität, Frankfurt, Germany, ${ }^{2}$ National Cancer Institut, Minsk, Belarus, ${ }^{3}$ Carl Gustav Carus Universität, Dresden, Germany, ${ }^{4}$ Universität Duisburg-Essen, Institut für Zellbiologie, Essen, Germany, ${ }^{5}$ University of Bologna, Bologna, Italy, ${ }^{6}$ European Institute of Oncology, Milan, Italy

Aims. Follicular T-cell lymphoma is derived from follicular T helper cells. In many cases, neoplastic $\mathrm{T}$ cells form rosettes around Hodgkin-ReedSternberg-like cells, which can lead to the misdiagnosis of classical Hodgkin lymphoma. The aim of the present study was to obtain a better understanding of this rosetting phenomenon and to recognize features that are helpful in the differential diagnosis of classical Hodgkin lymphoma. Methods. 16 usually elderly FTCL patients (mean 66 years) were analyzed by morphology, immunohistochemistry and clonality assays.

Results. Fifteen of the 16 follicular T-cell lymphoma cases presented with Hodgkin-Reed-Sternberg-like cells, which were CD20-positive in $27 \%$ of the cases and Epstein-Barr virus-infected in nearly all cases. Frequently, the immunophenotype of rosetting neoplastic $\mathrm{T}$ cells differed from the bulk neoplastic cells with less numerous T-follicular helper cell markers expressed, suggesting a modulation of T-follicular helper cell marker expression in the neoplastic T cells. In $75 \%$ of the cases, variable CD30-expression was encountered in the neoplastic T cells, likely reflecting an activation state in these cells. Hodgkin-Reed-Sternberg-like cells were positive for CCL17, and follicular T-cell lymphoma tumor cells expressed its receptor CCR4 at variable intensity, thus potentially explaining the phenomenon of the tumor cells' rosetting around Hodgkin-Reed-Sternberg-like cells. Conclusion. In summary, this study confirms the presence of HodgkinReed-Sternberg-like cells in a high number of cases of follicular T-cell lymphoma, suggesting that Hodgkin-Reed-Sternberg-like cells may contribute to the development of this lymphoma. Hodgkin-Reed-Sternberg-like cells in follicular T-cell lymphoma cannot reliably be differentiated from the Hodgkin-Reed-Sternberg cells of classical Hodgkin lymphoma based on their immunophenotype. In contrast, demonstration of a T-follicular helper cell phenotype with CD10 and frequent CD30 expression in the neoplastic T-cell population can help to establish the diagnosis of follicular T-cell lymphoma, and may even indicate CD30 as a therapeutic target for these patients.

\section{AG04.18}

\section{Vergleichende Charakterisierung der Chromatinlandschaft von Hodgkin-Lymphom Ziellinien mittels ATAC-Seq}

T. Jox ${ }^{1 *}$, T. Zimmermann ${ }^{2}$, M. Bartkuhn³ , S. Gattenlöhner', D. Körholz', A. Bräuninger ${ }^{1}$

'UKGM, Pathologie, Gießen, Deutschland, ${ }^{2}$ Justus Liebig Universität, Bioinformatik, Gießen, Deutschland, ${ }^{3}$ Justus Liebig Universität, Genetik, Gießen, Deutschland, ${ }^{4}$ UKGM, Pädiatrische Hämatologie und Onkologie, Gießen, Deutschland
Ziel. Genomweite Untersuchung der Hodgkin-Lymphom (HL)-spezifischen Chromatinlandschaft und Korrelation mit dem Transkriptom, zum verbesserten Verständnis der Pathogenese des HL und zur Identifikation Hodgkin-spezifischer Marker.

Methoden. Mittels ATAC-Seq (Assay for Transposase Accessible Chromatin using Sequencing) wurden die Zugänglichkeit des Chromatins von HL-, B-Zell-Non-Hodgkin- (BNHL-), T-Zellleukämie- und myeloischen Leukämie-Ziellinien ermittelt und untereinander verglichen. Anhand der Chromatinlandschaft konnten mittels bioinformatische Algorithmen regulatorische Sequenzen identifiziert und untersucht werden. Außerdem konnte das HL-Transkriptom mittels RNA-Seq beschrieben und mit den Daten zur Chromatinstruktur korreliert werden.

Ergebnisse. Die Untersuchung der Chromatinlandschaft zeigte, dass die Zugänglichkeit des Chromatins sich in HL-, BNHL-, Myeloischen und TZelllinien deutlich unterscheidet. In einem unsupervised Clustering der Chromatindaten ergab sich eine Einordnung der Linien nach dem jeweiligen Linienursprung. Dabei stellten die HL-Linien eine distinkte Gruppe dar. Beim Vergleich der Chromatinstruktur der HL- mit den BNHL-Linien konnte der Verlust der B-Zellidentität der HL-Linien, durch die Abwesenheit von B-zellspezifischen Faktoren/Markern im offenen Chromatin (PAX5, CD20, CD79A/B), auch mittels GO-Analyse bestätigt werden. Zudem war es möglich im Bereich des zugänglichen Chromatins Gene zu identifizieren, die mit Oberflächenstruktur, Motilität und Angiogenese assoziiert sind. Eine offene Motiv-Analyse innerhalb der zugänglichen Chromatinbereiche zeigte eine Anreicherung der Motive HL-spezifischer Transkriptionsfaktoren (JUN/FOS, NFkB, STAT). Auch die Analyse von weiteren regulatorischen Sequenzen außerhalb des Promotors ergab, dass sich diese Elemente stark in HL- und BNHL-Linien unterscheiden und sich zum Teil zu übergeordneten regulatorischen Einheiten, den Superenhancern, zusammenfassen lassen. Zusätzlich ließ sich eine positive Korrelation zwischen der Zugänglichkeit des Chromatins und dem Transkriptom feststellen.

Fazit. Die Chromatinlandschaft von HL-Zelllinien unterscheidet sich deutlich von der, anderer Lymphzelllinien und reflektiert die HL-spezifische Genexpression. Durch die umfassenden Daten wird es mögliche sein, Faktoren oder regulative Sequenzen zu identifizieren, die bei der Pathogenese von HL eine wichtige Rolle spielen.

(Das Projekt wird gefördert durch den Elternverein für krebskranke Kinder in Gießen.)

\section{AG04.19}

\section{Genetische Alterationen in CD30-positiven T-Zell-} Lymphoproliferationen

K. Maurus ${ }^{1 *}$, S. Roth', S. Appenzeller', M. Goebeler ${ }^{3}$, A. Rosenwald ${ }^{1}$, M. Wobser ${ }^{3}$, E. Geissinger ${ }^{1}$

${ }^{1}$ Institut für Pathologie, Würzburg, Deutschland, ${ }^{2}$ Comprehensive Cancer Center Mainfranken, Würzburg, Deutschland, ${ }^{3}$ Klinik und Poliklinik für Dermatologie, Venerologie und Allergologie, Würzburg, Deutschland

Ziel. Die Gruppe der CD30-positiven Lymphome umfasst die Lymphomatoide Papulose, eine spontan abheilende gutartige Lymphoproliferation, und das großzellige anaplastische T-Zell-Lymphom, welches selten vorzugsweise in regionäre Lymphknoten disseminiert und dennoch meist eine exzellente Prognose aufweist.

Um die zugrunde liegenden Mechanismen der molekularen Pathogenese der kutanen CD30-positiven Lymphoproliferationen zu eruieren, wurden integrative next-generation-Sequenzierungen durchgeführt.

Methoden. Exomsequenzierungen waren in Anbetracht des speziell für die lymphomatoide Papulose typischerweise nur geringen Tumorzellgehalts für eine verlässliche Variantendetektion nicht sensitiv genug. Für die zuverlässige Detektion von genetischen Alterationen entschieden wir uns daher für die Targetanreicherung mittels eines Hybridisierungs-basierten DNA Customer Panels und eines Anchored-Multiplex-PCR-basierten RNA Panels mit molekularen Barcodes. Diese Technologien erzielten die erforderliche Sensitivität für einen verlässlichen Nachweis von Punktmutationen, kleinen Indels, Kopienzahlveränderungen und Fusionen. 
Ergebnisse. Innerhalb der Gruppe der CD30-positiven kutanen Lymphome konnten wir mit dieser Methodik aktivierende Mutationen im JAKSTAT-Signalweg detektieren. Des Weiteren konnten verschiedene Fusionstranskripte nachgewiesen werden, die ebenfalls zu einer Aktivierung des JAK-STAT-Signalwegs führen. Diese Mutationen konnten mittels Sangersequenzierung validiert werden.

Fazit. Unsere Daten zeigen, dass die Panelsequenzierung eine geeignete Methode zur Detektion von genetischen Alterationen sowohl auf Ebene der genomischen DNA als auch auf mRNA-Ebene darstellt. Gerade im Hinblick auf Patientenproben mit einem geringen Anteil an neoplastischen Zellen erscheint diese Methode vielversprechend.

Die Detektion potentieller Treibermutationen in den CD30-positiven kutanen Lymphomen kann zukünftig den Einsatz personalisierter Behandlungsstrategien ermöglichen.

\section{AG Hämatopathologie IV}

\section{AG04.20 \\ A new role of RUNX1 as recombinase cofactor for physiological (T-cell receptor) and aberrant (ETV6-RUNX1 Acute Lymphoblastic Leukemia) deletions \\ V. Seitz ${ }^{*, 2}$, K. Kleo', A. Dröge' ${ }^{2}$ S. Schaper', S. Elezkurtaj', N. Bedjaoui', L. Dimitrova', A. Sommerfeld', E. Berg', E. von der Wall', U. Müller', \\ M. Joosten', D. Lenze', M. M. Heimesaat ', C. Baldus', C. Zinser ${ }^{7}$, A. Cieslak', E. Macintyre ${ }^{3}$, C. Stocking ${ }^{8}$, S. Hennig ${ }^{2}$, M. Hummel' \\ ${ }^{1}$ Charité University Medicine Berlin, Institute of Pathology, Berlin, Germany, ${ }^{2} \mathrm{HS}$ Diagnomics GmbH, Berlin, Germany, ${ }^{3}$ Université Paris Descartes Sorbonne Cité, Institute Necker-Enfants Malades (INEM), Paris, France, ${ }^{4}$ Heinrich-Pette-Institute, Leibniz-Institute for Experimental Virology, Hamburg, Germany, ${ }^{5}$ Charité University Medicine Berlin, Institute of Microbiology, Infectious Diseases and Immunology, Berlin, Germany, ${ }^{6}$ University Medical Center Schleswig-Holstein, Department of Internal Medicine II, Kiel, Germany, ${ }^{7}$ Intrexon Bioinformatics Germany GmbH, Munich, Germany, ${ }^{8}$ University Medical Center Eppendorf, Department of Stem Cell Transplantation, Hamburg, Germany}

Aim. RUNX1 is well known for its role as a transcription factor. Interesting ly, an additional function of RUNX1 as a recombinase cofactor for human T-cell receptor (TCR) $\delta$ gene rearrangements has recently been suggested. Our aim was to evaluate if this activity was also relevant for the proper rearrangements of the TCR $\beta$ gene locus. Moreover, we analyzed a possible role of RUNX1 as recombinase cofactor for recurrent deletions reported in Acute Lymphoblastic Leukemia (ALL).

Methods. We investigated the effect of heterozygous and homozygous Runx1 knock-out on B- and T-cell composition and TCR $\beta$ gene rearrangements in a mouse model in thymus and spleen tissues. To this end we employed immunohistology and TCR $\beta$ multiplex PCR followed by high-throughput sequencing. Furthermore we performed Chromatin Immunoprecipitation (ChIP) to analyze RUNX1 binding to the initiation sites of TCR $\beta$ rearrangements in developing T-cells. To compare the mouse model results to the situation in ALL we analyzed TCR $\beta$ rearrangements in T-ALL samples with heterozygous RUNX1 mutations in comparison to T-ALLs harboring a wildtype RUNX1. To assess if RUNX1 is additionally involved in pathological deletions we performed an in-depth analysis of published ETV6-RUNX1 ALL sequence data.

Results. We demonstrate that (i) Runx1 is expressed in the thymus region of TCR $\beta$ rearrangement initiation, (ii) that Runxl binds to the overlapping Runx $1 /$ Rag binding sites at the initiation site of TCR $\beta$ rearrangements and (iii) that homozygous Runx1 inactivation induces severe structural changes of the rearranged TCR $\beta$ gene and the T-cell repertoire, whereas a heterozygous Runxl knockout had almost no impact on the TCR $\beta$ composition. Comparable to the Runx $1^{ \pm}$mouse model, heterozygous RUNX1 mutations display no detectable impact on the TCR $\beta$ architecture in T-ALL patients. Most interestingly we found a significant overrep- resentation of overlapping RUNX1/RAG binding sites at the borders of deletions present in ETV6-RUNX1 B-ALL, arguing for a role of RUNX1 in this molecular deletion mechanism.

Conclusion. RUNX1 needs to be taken into consideration as a recombinase cofactor for a better understanding of physiological (DNA excision during TCR rearrangements) and aberrant (ETV6-RUNX1 ALL) deletions.

AG04.21

Multispectral Imaging (MSI) des Immunzellinfiltrats von Beckenkammbiopsien bei MDS und SAML

M. Bauer ${ }^{*}$, C. Vaxevanis ${ }^{2}$, J. Schaffrath ${ }^{3}$, H. K. Al-Ali', B. Seliger', C. Wickenhauser ${ }^{1}$

'Universitätsklinikum, Institut für Pathologie, Halle (Saale), Deutschland, ${ }^{2}$ Universitätsklinikum, Institut für Medizinische Immunologie, Halle (Saale), Deutschland, ${ }^{3}$ Universitätsklinikum, Klinik für Innere Medizin IV, Hämatologie und Onkologie, Halle (Saale), Deutschland

Ziel. Myelodysplastische Syndrome (MDS) sind heterogene Erkrankungen hämatopoetischer Stammzellen, assoziiert mit einer durch eine ineffektive Hämatopoese induzierten peripheren Zytopenie und einem variablen Progressionsrisiko in eine sekundäre akute myeloische Leukämie (AML). Da die Stammzellnische zuletzt vermehrt in den Forschungsfokus gerückt ist, ist das Ziel unserer Studie, die Zusammensetzung und räumliche Verteilung des Immunzellrepertoires in Zusammenspiel mit den hämatologischen Stammzellen bei MDS und sAMLs zu untersuchen.

Methoden. Es wurden 50 Beckenkammbiopsien (KMP) von MDS-Patienten untersucht, wobei für 10 Patienten mit Progress sequentielle KMP mit zunehmendem Blastengehalt und manifester sAML vorhanden waren. Als Kontrolle dienten $10 \mathrm{KMP}$ von Patienten mit normalem Blutbild ohne Hinweise auf ein MDS. Zu allen Patienten waren klinische, laborchemische, molekularpathologische und zytogenetische Daten sowie Daten zum IPSS-R-Score, zur Therapie und zum Verlauf erfasst. Mittels multispektraler Bildgebung wurden die Marker CD3, CD8, CD4, FOXP3, MUM1p und CD34 analysiert, die räumliche Nähe von Immun- und Stammzellen bestimmt und die Resultate mit den klinischen Parametern korreliert. Ergebnisse. Während in der Kontrollpatientengruppe die Anzahl der untersuchten immunmodulatorischen Zellen im Knochenmark erheblich variierte, zeigte sich im MDS-Kollektiv mit zunehmender Blastenzahl ein Anstieg der Frequenz von CD8+ T-Zellen, FOXP3+ T-Zellen und Postkeimzentrums-B-Zellen. Dabei korrelierte insbesondere die Anzahl der CD3-, MUM1p+ Postkeimzentrums-B-Zellen und Plasmazellen signifikant mit dem Blastengehalt, dem Comprehensive Cytogenetic Scoring System (CCCS) und dem Revised International Prognostic Scoring System (IPSS-R). Zusätzlich waren in den Knochenmarkbiopsien von Patienten, die im Verlauf eine sAML entwickelten, bereits in den Erstbiopsien mehr CD4+, aber weniger CD8+ sowie FOXP3+ T-Zellen vorhanden als bei Patienten ohne sAML-Progression im Untersuchungszeitraum. Bei manifester sAML nahm die durchschnittliche Immunzellzahl generell ab.

Fazit. Im Erkrankungsverlauf zeigen sich bei MDS signifikante Alterationen des Immunzellrepertoires in Abhängigkeit vom Akzelerationsrisiko und dem Blastengehalt, wobei vermutlich der Interferon regulierende Faktor 4 für die Stammzellfunktion und -kontrolle im Rahmen des Erkrankungsbilds des MDS eine wichtige Rolle spielt.

AG04.22

Myelodysplastisches Syndrom oder reaktive Zytopenie? Einsatz des targeted NGS am Knochenmarktrepanat für ein häufiges diagnostisches Dilemma

A. Rau' ${ }^{*}$, J. Steinhilber', V. Meca', I. Bonzheim', W. Vogel', L. QuintanillaFend $^{1}$, B. Federmann', F. Fend ${ }^{1}$

'Institut für Pathologie und Neuropathologie, Allgemeine und Molekulare Pathologie und Pathologische Anatomie, Tübingen, Deutschland, ${ }^{2}$ Universitätsklinikum Tübingen, Medizinische Klinik II für Onkologie, Hämatologie, Immunologie, Rheumatologie und Pulmologie, Tübingen, Deutschland 
Ziel. Myelodysplastische Syndrome (MDS) sind eine heterogene Gruppe von klonalen Stammzellerkrankungen, die durch eine ineffektive Hämatopoese und periphere Zytopenien gekennzeichnet sind. Die diagnostische Abgrenzung von MDS gegenüber reaktiven Veränderungen und idiopathischen Zytopenien unklarer Signifikanz (ICUS) stellt eine Herausforderung dar. In den letzten Jahren wurde das Mutationsprofil vom MDS umfassend charakterisiert und das Konzept der klonalen Zytopenie (CCUS) entwickelt. Ziel der vorliegenden Studie war es, die Rolle der Mutationsanalyse von Paraffin-eingebetteten Knochenmarkbiopsien mittels NGS für die Differentialdiagnose von reaktiven und klonalen Zytopenien sowie bei der Prognoseabschätzung von MDS zu bestimmen.

Methoden. In der Studie wurden 80 Knochenmarkbiopsien von $49 \mathrm{~Pa}-$ tienten eingeschlossen, die eine periphere Zytopenie aufwiesen. Bei 21 Patienten lag ein Biopsat vor, bei 28 Patienten mindestens eine Verlaufsbiopsie. Für die Analyse auf dem Ion GeneStudio S5 wurde ein custom AmpliSeq NGS Panel entwickelt, welches die 32 am häufigsten mutierten Gene im MDS abdeckt.

Ergebnisse. Die Fälle wurden laut WHO 2016 reklassifiziert und mit klinischen und zytologischen Befunden korreliert. Die am häufigsten mutierten Gene waren SRSF2, ASXL1 und TET2. In der Gruppe der reaktiven Zytopenien wurden keine Mutationen in den untersuchten Genen gefunden. Die Gruppe der ICUS und low grade MDS zeigten vor allem Mutationen in SF3B1, DNMT3A und ASXL1. Die Hochrisikofälle von MDS-EB und MDS mit Übergang in AML wiesen durchschnittlich mehr Mutationen auf, insbesondere in den Genen RUNX1, ZRSR2, SRSF2, KRAS und IDH2. Fazit. Die NGS-basierte Mutationsanalyse ist ein robustes Werkzeug zur molekularen Charakterisierung von Zytopenien am Knochenmarktrepanat. Während reaktive Zytopenien keine Mutationen in MDS assoziierten Genen aufweisen, zeigen ICUS teilweise Mutationen in den Genen ZRSR2, ASXL1 und DNMT3A. Mutationen in RUNX1, ZRSR2, SRSF2, KRAS und $I D H 2$ wurden vor allem in MDS-EB und MDS mit Übergang zur AML gefunden. Insbesondere für Fälle von Zytopenien mit minimaler Dysplasie und MDS mit unsicherer Risikostratifizierung anhand konventioneller Parameter bietet die Mutationsanalyse wertvolle diagnostische Informationen, kann aber derzeit in Anbetracht der aktuellen WHO Klassifikation nicht als allein entscheidendes diagnostisches Werkzeug eingesetzt werden.

\section{AG Gynäko- und Mammapathologie I}

\section{AG05.02 \\ PD-L1 Expression und tumor-infiltrierende Lymphozyten zur Prädiktion des Ansprechens auf neoadjuvante Chemo- und Immuntherapie beim Mammakarzinom}

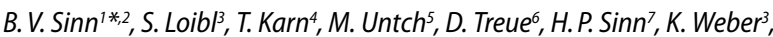
F. Klauschen 6 , C. Hanusch ${ }^{8}$, C. Kunze ${ }^{6}$, K. Wagner ${ }^{8}$, P. A. Fasching ${ }^{9}$,

J. Huober ${ }^{10}$, M. Zahm ${ }^{11}$, C. Jackisch ${ }^{12}$, J. Thomalla ${ }^{13}$, J. U. Blohmer', M. van Mackelenbergh ${ }^{14}$, K. Rhiem ${ }^{15}$, B. Felder ${ }^{3}$, G. von Minckwitz ${ }^{3}$, N. Burchardi ${ }^{3}$, A. Schneeweiss ${ }^{16}$, C. Denkert ${ }^{6,17}$

${ }^{1}$ Charité - Universitätsmedizin Berlin, Institut für Pathologie, Berlin, Deutschland, ${ }^{2}$ Berlin Institute of Health, Berlin, Deutschland, ${ }^{3}$ German Breast Group, Neu-Isenburg, Deutschland, ${ }^{4}$ Universitätsklinikum Frankfurt, Frankfurt, Deutschland, ${ }^{5}$ Helios Klinikum Berlin-Buch, Berlin, Deutschland, ${ }^{6}$ Charité - Universitätsmedizin Berlin, Berlin, Deutschland, 'Universitätsklinikum Heidelberg, Heidelberg, Deutschland, ${ }^{8}$ Rotkreuzklinikum München, München, Deutschland, ${ }^{9}$ Universitätsklinikum Erlangen, Erlangen, Deutschland, ${ }^{10}$ Universitätsklinikum Ulm, Ulm, Deutschland, "11SRH Wald-Klinikum Gera, Gera, Deutschland, ${ }^{12}$ Sana Klinikum Offenbach, Offenbach, Deutschland, ${ }^{13}$ Praxisklinik für Haematologie und Onkologie, Koblenz, Deutschland, ${ }^{14}$ Universitätsklinikum Kiel, Kiel, Deutschland, ${ }^{15}$ Uniklinik Köln, Köln, Deutschland, ${ }^{16}$ Nationales Centrum für Tumorerkrankungen, Heidelberg, Deutschland, ${ }^{17}$ Universitätsklinikum Marburg, Marburg, Deutschland
Ziel. In der GeparNuevo-Studie führte die neoadjuvante Gabe des PD-L1Inhibitors Durvalumab zu besserem Ansprechen auf neoadjuvante Chemotherapie beim frühen triple-negativen Mammakarzinom, wenn die erste Dosis vor dem Beginn der Chemotherapie erfolgte (61 \% pCR vs. $41 \%$ mit Placebo; $p=0,048$; Loibl et al. ASCO 2018). Wir untersuchen den prognostischen Wert der PD-L1 Expression und der Dynamik tumor-infiltrierender Lymphozyten (TIL) anhand serieller Biopsien. Ergänzend wurden Genexpressionssignaturen evaluiert.

Methoden. 174 Patientinnen wurden randomisiert (Chemotherapie mit oder ohne Durvalumab). In der Window-Substudie erfolgte die erste Dosisgabe vor Beginn der Chemotherapie. Biopsien wurden prätherapeutisch ( „A“; $N=174)$, nach dem Window („B“; $N=88)$, und nach 4 Zyklen Chemotherapie („C“; $\mathrm{N}=33$ ) entnommen. PD-L1 wurde immunhistologisch an den A-Biopsien (Ventana SP263) als Prozent der Tumor- und Immunzellen mit membranärer Färbung ausgewertet, stromale (sTIL) und intratumorale Lymphozyten (iTIL) histologisch quantifiziert. Verfügbare Biopsien wurden mittels RNA-Sequenzierung untersucht (HTG EdgeSeq, Oncology Biomarker Panel, 2560 Gene; N=162 A, 79 B, 31 C).

Ergebnisse. PD-L1 auf Tumorzellen $(\geq 1 \%)$ war prognostisch für das Ansprechen unter Durvalumab (OR 2,63; CI 1,02-6,77; $p=0,045$ ). Auf mRNA-Ebene zeigten Fälle mit positiver Immunhistologie eine erhöhte Expression immun-assoziierter Gene. Prätherapeutische sTIL, nicht iTIL, waren mit besserem Ansprechen in der gesamten Kohorte verbunden (OR $1,34$; CI 1,15-1,56; $p<0,001)$. Der Vergleich von A- und B-Biopsien zeigte ein besseres Ansprechen bei Patientinnen mit einer Zunahme der iTIL (OR 5,14; CI 1,10-24,05; $p=0,037$ ). Eine mRNA-Analyse bestätigte eine zytotoxische Antwort. In einer globalen Analyse führte die einzelne Dosis Durvalumab zu wenig differentieller Expression, wobei ein immunologisches Signal zu erkennen war. Vier Zyklen Chemotherapie führten zu massiven Veränderungen.

Fazit. PD-L1 auf Tumorzellen ist prognostisch für das Ansprechen unter Durvalumab und der $1 \%$-cutoff spiegelt ein immunologisches Signal wider. Die dynamische Umverteilung der TIL unter Therapie ist prognostisch als mögliches morphologisches Korrelat einer zytotoxischen Antwort. Eine einzelne Dosis Durvalumab führt zu einer Zunahme immun-assoziierter Expression. Insgesamt ist die dynamische Analyse der Genexpression ein vielversprechender Ansatz für die Entdeckung von Mechanismen des Therapieansprechens.

\section{AG05.03}

\section{Juvenile papillomatosis of the breast (Swiss cheese disease) has} frequent association with PIK3CA and AKT1 mutations

C. Guillet ${ }^{1}$, M. Rechsteiner ${ }^{2}$, E. Bellini' ${ }^{2}$, M. Choschzick2 , L. Moskovszky², K. Dedes ${ }^{3}$, B. Papassotiropoulos 4 , Z. Varga ${ }^{2 *}$

${ }^{1}$ Klinik für Dermatologie, Universitätsspital Zürich, Zürich, Switzerland, ${ }^{2}$ Institut für Pathologie und Molekularpathologie Universitätsspital Zürich, Zürich, Switzerland, ${ }^{3}$ Klinik für Gynäkologie, Universitätsspital Zürich, Zürich, Switzerland, ${ }^{4}$ Brustzentrum Seefeld, Zürich, Switzerland

Aim. Juvenile papillomatosis (JP) of the breast (so-called Swiss cheese disease) is a rare disease characterized by multinodular cystic breast mass lesions, often with associated calcifications on imaging. The histological picture comprises multiple intraductal papillomas, pronounced ductal hyperplasia (UDH), ductectasia and perifocal sclerosing adenosis and calcification. Patients have an excellent follow-up with virtually no development of breast cancer, however there is often a positive family history for breast cancer, up to $28 \%$ of JP patients. Molecular background of this biological association is not fully understood until now. In this study, we addressed mutational analysis of JP cases and correlated results with follow-up and clinico-pathological findings.

Materials and methods. We identified 13 cases with JP fulfilling the histological and imaging criteria of JP. All patients were female with a median age of 38 years ( 22 to 49 years). Follow-up information was available in all patients (median follow up was 9 years). Sufficient paraffin embedded tissue for next generation sequencing (NGS) was available in 11 patients. 
Paraffin blocks were punched in the area of proliferative disease and tissue cores underwent NGS analysis using Oncomine comprehensive panel. Results. In 6 of 11 patients, we found PIKC3A mutations, in 2 of 11 patients AKT1 mutations in known hotspot regions. Several further mutations in genes such as ALK, ARID1A, ATM, BRAF, KRAS, RAD50, NOTCH 1,2,3, BRCA1/2 were found in individual patients. These mutations were mostly present at low variant allele frequency $(<10 \%)$ and not at known hotspots. Conclusions. These results support existing literature data on mutational status of normal or proliferative breast tissue, however JP has not been linked to any of these mutations so far. Especially the presence of identical PIK3CA mutations were described in DCIS and adjacent normal breast tissue. To what extent these data explain the link between JP and positive family history, needs further larger studies.

\section{AG05.04 \\ Cyclin-dependent kinase 5 (CDK5) as a novel immunotherapeutic target in triple-negative breast cancer \\ X. Yang ${ }^{1}$, D. Yao ${ }^{2}$, S. Pereira Ribeiro ${ }^{1}$, X. X $u^{1}$, M. Tunc ${ }^{1}$, A. Petrosiute ${ }^{3,4}$, A. Huang ${ }^{3,4}$, S. Avril ${ }^{1 * 4}$ \\ 'Department of Pathology, Case Western Reserve University School of Medicine, Cleveland, United States, ${ }^{2}$ Department of Medicine/Hematology and Oncology, Case Western Reserve University School of Medicine, Cleveland, United States, ${ }^{3}$ Department of Pediatrics/Hematology and Oncology, Case Western Reserve University School of Medicine, Cleveland, United States, ${ }^{4}$ University Hospitals Cleveland Medical Center and Case Comprehensive Cancer Center, Cleveland, United States}

Aims. Triple-negative breast cancers (TNBC) have the highest rate of distant metastasis and lack effective targeted treatments. Despite these limitations, TNBC appear to have the requisite features to render them sensitive to immunotherapy; namely, genomic instability, production of neo-antigens and increased tumor infiltrating lymphocytes. Our group recently discovered that CDK5 critically regulates anti-tumor immunity in solid tumors. We hypothesize that blocking CDK5 abolishes tumor immune evasion of TNBC through immune checkpoint regulation and/or intratumoral cytokine/chemokine production.

Methods. Using CRISPR/Cas9 we established a CDK5-deficient murine 4T1 TNBC cell line (crCdk5) and control (crNeg). Tumor allografts were grown subcutaneously in syngeneic or immunodeficient mice. Differences in primary tumor growth and lung metastasis served as reference endpoint. In addition, tumors were analyzed by high-density flow cytometry to assess immune checkpoints, immune cell differentiation/activation, cytokine/chemokine profiles, glycolytic metabolism and immune-signaling pathways.

Results. There was no difference in tumor volume between CDK5-deficient (crCdk5) versus control and wildtype cells when grown in immunodeficient Nude mice. In contrast, crCdk5 demonstrated a significant reduction in tumor volume and lung metastases compared to control and wildtype when grown in immuno-competent syngeneic Balb/c mice. Flow cytometry identified several differentially expressed clusters of immune cells in crCdk 5 versus control tumors, with a marked enrichment of effector CD4 T cells characterized by increased glycolysis and STAT-phosphorylation. In human breast cancer samples, increased expression of tumor CDK5 by immunohistochemistry was associated with decreased intratumoral CD3+ T cells, with the strongest association observed in cancers containing PD-L1+ intratumoral lymphocytes. Patients with higher Cdk5 gene expression demonstrated significantly shorter survival.

Conclusions. Together, our studies of TNBC patient cohorts with associated outcome data combined with preclinical studies in a syngeneic mouse model demonstrate a role for CDK5 in mediating tumor immune evasion of TNBC. CDK5 blockade presents a promising novel immunotherapeutic target for TNBC which may enhance the efficacy of cytotoxic therapies and established immunotherapies. Preclinical studies assessing the mechanism and in-vivo efficacy of a novel CDK5-selective inhibitor are ongoing.

\section{AG Gynäko- und Mammapathologie II}

\section{AG05.06 \\ Characterization of the immune infiltrate of breast cancer and correlation with BRCA status}

C. Massa ${ }^{1 *}$, M. Wunderle ${ }^{2}$, P. Fasching ${ }^{2}$, A. Hein ${ }^{2}$, M. Ruebner ${ }^{2}$, H. Hübner ${ }^{2}$, M. Beckmann ${ }^{2}$, A. Hartmann ${ }^{3}$, C. Wickenhauser', B. Seliger ${ }^{1}$

${ }^{1}$ Martin Luther University Halle-Wittenberg, Institute of Medical Immunology, Halle, Germany, ${ }^{2}$ Erlangen University Hospital, Department of Gynecology and Obstetrics, Erlangen, Germany, ${ }^{3}$ Erlangen University Hospital, Institute of Pathology, Erlangen, Germany, ${ }^{4}$ Martin Luther University Halle-Wittenberg, Institute of Pathology, Halle, Germany

Aim. In the last decades different immunotherapeutic approaches have been implemented in cancer therapy, leading to an improved outcome for some of the treated patients. In order to better stratify patients with respect to therapy, different techniques have been implemented to characterize cancer patients in the search for predictive and prognostic factors. Among them the tumor mutational burden seems to be a good candidate. The aim of this study was to evaluate the immune landscape of tumors characterized by a wild type DNA repair system or with mutation in either BRCA1 or BRCA2, two enzymes involved in the DNA repair system.

Methods. Paraffin-embedded tissues from breast cancer patients with wildtype (12 patients), BRCA1 (6) or BRCA2 mutated status (4) were evaluated by multispectral imagining for the presence and reciprocal localization of different immune cell subsets. In particular, the slides were stained with $\mathrm{CD} 3, \mathrm{CD} 8$ and FoxP3 Ab to detect cytotoxic, helper and regulatory T cells, CD20 for B cells, CD163 for macrophages and panCK for the tumor cells. Results. A high heterogeneity in the frequency, composition and localization with respect to the tumor mass of the immune cell subpopulations was detected among the different patients. Deeper evaluation is ongoing to find possible correlations with the BRCA status of the patients.

Conclusion. Using multispectral imaging it is possible to have a deeper evaluation of the immune landscape than with normal immunohistochemistry leading possibly to the development of more accurate predictive or prognostic markers than the immunoscore based on only two different markers.

\section{AG05.07}

Immune phenotypes and PD1/LAG-3 expression patterns in different metastatic sites of breast cancer

\section{B. Sobottka* H. Moch, Z. Varga}

'Institut für Pathologie und Molekularpathologie, UniSpital Zürich, Zurich, Switzerland

Background. Novel immune checkpoint targets like lymphocyte activation gene 3 (LAG-3) are currently being investigated either alone or in combination with conventional immune checkpoint inhibitors. Despite its indication in advances disease little is known about LAG-3 or programmed cell death protein 1 (PD1) expression within metastatic sites.

Methods. In a retrospective cohort of 95 breast cancer patients with intra-patient matched primary tumors and distant metastases we compared the CD8+ T cell immune phenotype with PD1/LAG-3 expression using immunohistochemistry. Analyses included general expression comparison and disease free survival analyses.

Results. Primary tumors either displayed an excluded or inflamed CD8+ T cell immune phenotype which was mostly recapitulated at the corresponding site of metastasis. Expression of PD1/LAG-3 was associated with significantly impaired disease free survival, particularly illustrative in inflamed tumors. Brain and soft tissue metastases significantly more often displayed an exhausted phenotype when compared to liver or bone metastases.

Conclusions. The immune phenotype and immune checkpoint expression is recapitulated to some extent at the site of distant metastasis yet with a distinct pattern at sites like brain. Particularly inflamed tumors with signs of $\mathrm{T}$ cell exhaustion displayed decreased disease free survival possibly reflecting tumor immune evasion. 
AG05.08

\section{Expression des Rezeptors für Insulin-like growth factor in Mamma} Karzinomen und Modell-Zelllinien

\author{
N. Nass ${ }^{1 *}$, L. Drewes ${ }^{1}$, C. Weissenborn' ${ }^{2}$, D. K. Vo ${ }^{7}$, A. Ignatov ${ }^{2}$, J. Haybaeck', \\ T. Kalinski \\ 'Otto von Guericke Universität Magdeburg, Institut für Pathologie, \\ Magdeburg, Deutschland, ${ }^{2}$ Otto von Guericke Universität \\ Magdeburg, Universitätsklinik für Frauenheilkunde, Geburtshilfe und \\ Reproduktionsmedizin, Magdeburg, Deutschland
}

Ziel. Die Expression des Rezeptors für IGF-1(IGF1R) hat variable Bedeutung für die unterschiedlichen Subtypen des Mamma Karzinoms und wird als Therapietarget diskutiert. Wir haben die prognostische Relevanz des IGF1R in unserer Patientinnen Kohorte reevaluiert und die Sensitivität von Modell-Zelllinien auf IGF-1 und IGF1R-Inhibition im Hinblick auf mögliche Relevanz einer anti-IGF1R Therapie untersucht.

Methoden. Die IGF1R Abundanz wurde immunhistochemisch in ca. 200 Patientinnenproben bestimmt und nach Lokalisation, Intensität und Zahl positiver Tumorzellen ausgewertet und ein immunoreaktives Score berechnet. Für Östrogenrezeptor-positive (MCF-7, T47D, Tamoxifen-adaptierte MCF-7), HER2-überexprimierende (SKBR3) sowie Triple-negative (MDA-MB-231 und 468) Zell-Linien wurde die Abundanz des IFGF1R, die proliferative Wirkung von IGF-1 und die Sensitivität gegenüber dem spezifischen Inhibitor Linsitinib durch Western-Blot und Proliferations/ Viabilitäts Tests bestimmt.

Ergebnisse. Kaplan-Meier Analyse ergab eine schwache Korrelation hoher zytoplasmatischer IGF1R Expression mit ungünstigem Rezidiv-freiem Überleben $(\log$ rank $p=0,15)$ für die Gesamtkohorte. Dies war deutlicher für prämenopausale Fälle $(p=0,08)$, Progesteron-Rezeptor negative$(p=0,09)$ und Östrogen-Rezeptor-negative Fälle $(p=0,03)$. ER-positive Fällen unter Aromatase-Inhibitor Behandlung zeigten ebenfalls statistische Signifikanz $(p=0,03)$. Ferner zeigte IGF1R hohe Korrelation mit der Expression anderer prognostischer Marker in der Kohorte, insbesondere TMEM26 $(p=0,02)$ und VEGF $(p=0,004)$. IGF-1 zeigte den größten proliferativen Effekt auf MCF-7 und MCF7 ${ }^{\text {TamR }}$ aber kaum Wirkung auf MDA-MB-468 Zellen. MCF-7 reagierte auch am sensitivsten auf Linsitinib $\left(\mathrm{EC}_{50}=5 \mu \mathrm{M}\right)$ wogegen die Triple-negativen Zellen 4-5-fach höhere $\mathrm{EC}_{50}$-Werte zeigten.

Fazit. Die Bedeutung der IGF1R-Abundanz konnte für einige Subgruppen unserer Kohorte verifiziert werden. Die Modell-Zelllinien zeigten variable Reaktionen auf IGF1 und Linsitinib.

\section{AG05.09}

The mechanism of MCF-7 breast cancer cell death induced by G-protein-coupled estrogen receptor (GPER)-specific agonist G1

\section{K. Vo ${ }^{1 *}$, R. Hartig ${ }^{2}$, J. Haybaeck ${ }^{1,3,4}$, N. Nass ${ }^{1}$}

'Otto-von-Guericke Magdeburg University, Department of Pathology, Magdeburg, Germany, ${ }^{2}$ Otto-von-Guericke Magdeburg University, Institute of Molecular and Clinical Immunology, Magdeburg, Germany, ${ }^{3}$ Medical University of Innsbruck, Department of Pathology, Neuropathology and Molecular Pathology, Innsbruck, Austria, ${ }^{4}$ Medical University of Graz, Diagnostic and Research Center for Molecular BioMedicine, Department of Pathology, Graz, Austria

Aim. The G-protein-coupled estrogen receptor (GPER), which is located not only in the plasma membrane but also in endoplasmic reticulum (ER), is considered to mediate rapid non-genomic effects of estrogen. The high expression levels of GPER in breast cancer (BC) and other cancers patients are favorable for patients' survival, indicating that GPER is a potential tumor suppressor. The stimulation of GPER with its specific agonist G1 in BC and colorectal cancer led to the inhibition of cell proliferation and GPER expression is regulated by epigenetic mechanisms. Therefore, GPER may act as a potential therapeutic target in breast cancer, however the precise mechanism remains unclear. The purpose of the present study is to elucidate the molecular mechanism of GPER-specific agonist G1-induced MCF-7 BC cell death. We observed calcium $\left(\mathrm{Ca}^{2+}\right)$ efflux from ER and the activation of unfolded protein response (UPR) induced by G1, which might be the main causes of apoptosis in BC.

Methods. Human BC MCF-7 cells were used in this study. $\mathrm{Ca}^{2+}$ efflux from ER stimulated by G1 was measured by flow cytometry. The expression levels of UPR signaling were shown by Western Blot. Several selective inhibitors of different kinase proteins were applied. Cell viability was measured by LDH or resazurin assay.

Results. We found that $\mathrm{Ca}^{2+}$ was rapidly released from the ER in G1-stimulated cells. The depletion of ER $\mathrm{Ca}^{2+}$ stores by thapsigargin (TG), the well-established ER stress inducer, was also observed in MCF-7 cells. These results led us to hypothesize that ER stress might be induced and involved in G1-induced cell death. We showed that the phosphorylation of IRE1a and PERK and the cleavage of ATF6 were induced by different concentrations of G1, indicating the UPR is activated. We also studied the involvement of p38_MAPK and JNK, the main downstream effector in ER stress-induced cell death. p38 and JNK were activated and selective inhibitor of $p$-JNK inhibited G1-induced cell death. Moreover, we found that inhibition of PERK inhibited the phosphorylation of JNK and prevented G1-induced cell death in MCF-7 cells. These data indicate that ER stress plays important roles in G1-induced cell death, and JNK is activated as an apoptotic inducer.

Conclusions. G1 triggers a mobilization of $\mathrm{ER} \mathrm{Ca}^{2+}$ stores, and this event leads to the UPR activation in MCF-7 cells. The activation of PERK but not of IRE1a in turn induces the phosphorylation of JNK, triggering apoptosis.

\section{AG05.10}

Höhere Frequenz nodaler Metastasen und besseres Überleben beim CD34+ Stromafibrozyten-freien Subtyp des invasiven lobulären Mammakarzinoms

\section{C. Westhoff ${ }^{*}$, C. O. Jacke ${ }^{2,3}$, U.-S. Albert ${ }^{2,4}$, S. Ebrahimsade ${ }^{1,5}$, P. J. Barth ${ }^{6}$,} R. Moll ${ }^{1}$

'Philipps-Universität Marburg/UKGM GmbH Standort Marburg, Institut für Pathologie, Marburg, Deutschland, ${ }^{2}$ Philipps-Universität Marburg/UKGM GmbH Standort Marburg, Brustzentrum Regio, Klinik für Frauenheilkunde und Geburtshilfe, Marburg, Deutschland, ${ }^{3}$ Wissenschaftliches Institut der PKV, Köln, Deutschland, ${ }^{4}$ Klinikum Kassel GmbH, Frauenklinik, Bereich Senologie und konservative Gynäkoonkologie, Kassel, Deutschland, ${ }^{5}$ Facharzt-Praxis für Pathologie, Berlin, Deutschland, ${ }^{6}$ Universitätsklinikum Münster, Gerhard-Domagk-Institut für Pathologie, Münster, Deutschland

Ziel. CD34-positive Fibrozyten $(\mathrm{CD} 34+\mathrm{Fz})$ sind konstitutive Bestandteile im Stroma der meisten Organe, auch der Mamma. CD34+Fz sind in Matrixsynthese, Antigenpräsentation und den Tumor-assoziierten Stromaumbau involviert. In invasiven lobulären Mammakarzinomen (ILC) beschrieben wir den partiellen Erhalt von CD34+Fz im Gegensatz zu invasiven Mammakarzinomen NST ${ }^{1}$. An mehreren kleineren ILC-Kollektiven ergaben sich widersprüchliche Ergebnisse hinsichtlich einer möglichen Korrelation zwischen dem stromalen Verlust von CD34+Fz und positivem Lymphknotenstatus ${ }^{2,3}$. Hier untersuchen wir die pathologische und prognostische Relevanz von stromalen CD34+Fz und $\alpha$-Glattmuskelaktinpositiven Myofibroblasten (ASMA+Mfb) an einem größeren Kollektiv mit Langzeitbeobachtung.

Methoden. Das Archiv des Instituts für Pathologie Marburg wurde auf alle verfügbaren primären ILC-Fälle mit Operationsdatum zwischen 01.04.1996 und 31.12.2004 durchsucht, die zugehörigen klinischen Daten extrahiert und der Vitalstatus erhoben (Beobachtungszeit bis 21 Jahre). Retrospektiv wurden Paraffinblöcke von 140 Patientinnen semiquantitativ auf CD34+Fz und ASMA+Mfb untersucht. Die Datenanalyse erfolgte explorativ hinsichtlich der Parameter TNM-Stadium (Tumorgröße in cm, pT, pN, pM) und Grading mittels des t-, $\chi^{2}$ - oder Fisher's Exact Test sowie bezüglich der Assoziation zum Gesamtüberleben (OS) und erkrankungsfreiem Überleben (DFS) mit Kaplan-Meier-Kurven und log-rank Tests. Ergebnisse. Die Abwesenheit von CD34+Fz im Tumorstroma von ILC zeigte eine signifikante Korrelation mit dem Vorkommen von ASMA+Mfb $(p<0,001)$ und positivem Lymphknotenstatus $(p=0,003)$ bzw. dem pNStadium $(p=0,005)$. OS und DFS unterschieden sich nicht signifikant 
für ASMA+Mfb, zeigten aber signifikante Unterschiede hinsichtlich der TNM-Parameter. Patientinnen mit stromalem Verlust von $\mathrm{CD} 34+\mathrm{Fz}$ wiesen bei dichotomer Auswertung ein besseres OS $(p=0,023)$ und DFS $(p=0,047)$ auf.

Fazit. Die Untersuchung eines großen ILC-Kollektivs bestätigte den partiellen Erhalt von $\mathrm{CD} 34+\mathrm{Fz}$ und die Korrelation des CD34+Fz-Verlusts mit dem Auftreten von ASMA+Mfb. Die Korrelation zwischen Verlust von $\mathrm{CD} 34+\mathrm{Fz}$ und positivem Lymphknotenstatus wurde an der großen Kohorte bestätigt. CD34+Fz-Negativität im Tumorstroma von ILC könnte als möglicher prognostischer Surrogatmarker für Lymphknotenmetastasen in weiteren Studien untersucht werden.

\section{Literatur}

1. Ebrahimsade et al (2007) Pathol Res Pract 203:695

2. Westhoff et al (2016) Pathologe 37:123

3. Westhoff et al (2018) Pathologe 39:142

\section{AG05.11}

Die prognostische Relevanz der Protein Deglycase PARK7/DJ-1 beim Mamma Karzinom

N. Nass ${ }^{1 *}$, S. Sprung' ${ }^{2}$, L. Andreas' ${ }^{1}$, C. Scherfele', W. Cui' ${ }^{3}$, J. Haybaeck ${ }^{1,2,4}$, T. Kalinski ${ }^{1}$

'Otto von Guericke Universität Magdeburg, Institut für Pathologie, Magdeburg, Deutschland, ${ }^{2}$ Medizinische Universität Innsbruck, Institut für Pathologie, Neuropathologie und Molekularpathologie, Innsbruck, Österreich, ${ }^{3}$ First Affiliated Hospital of Xinjiang Medical University, Department of Pathology, Ürümqi, Volksrepublik China, ${ }^{4}$ Medizinische Universität Graz, Institut für Pathologie, Graz, Österreich

Ziel. Glykierungsendprodukte (AGEs) akkumulieren in Tumoren als Folge hoher glykolytischer Aktivität und oxidativem Stress. Die wichtigsten Abwehrmechanismen gegen diese AGE-Akkumulation beruhen auf den Glyoxalasen 1 und -2, die reaktive $\alpha$-oxo Aldehyde Glutathion -abhängig abbauen. PARK7 (DJ-1) ist eine Glutathion unabhängige Protein-Deglycase, die Aldehyd-Adukte entgiftet. Wir postulierten daher eine erhöhte Expression in Tumorzellen als Reaktion auf Aldehyd-Stress und untersuchten in diesem Projekt die Rolle der PARK7/DJ-1 Protein Deglycase für die Prognose beim Mamma-Karzinom und den Zusammenhang mit der AGE-Akkumulation.

Methoden. PARK7/DJ-1 Abundanz wurde in 150 Tumorproben immunhistochemisch bestimmt und daraus ein Immunreaktivitäts Score (IRS) berechnet. Der Grenzwert für hohe bzw. niedrige Expression wurde über Kaplan-Meier Überlebensanalyse optimiert. Mit diesem Grenzwert wurden dann weitere Überlebens- und Korrelationsanalysen durchgeführt. Untersuchungen zur RNA Abundanz wurden mittels der KM-Plot Webseite durchgeführt

Ergebnisse. PARK7/DJ-1 Expression war in Tumorzellen gegenüber dem Normalgewebe nicht signifikant erhöht. Dennoch korrelierte hohe Abundanz mit besserer Prognose für das Rückfall-freie Überleben (log rank $p=0,06$ ). Dies wurde deutlicher beim duktalen Mamma Karzinom $(p=0,004)$, da das Ergebnis für die lobulären Karzinome entgegengesetzt ausfiel ( $p=0,02$, lediglich 21 Fälle). Die Signifikanz für Rezidiv-freies Überleben war auch deutlich in Östrogen-positiven Tumoren $(p=0,04)$. Hohe PARK7/DJ-1 Expression war signifikant korreliert mit der Abundanz des AGEs Carboxy-Methyl-Lysin (CML, $p=0,04)$ und Östrogenrezeptor-Positivität $(p=0,03)$. In HER2-Überexprimierenden Fällen gab es nur einen statistischen Trend $(p=0,07)$, ebenso für die Korrelation mit dem TumorGrading $(p=0,12)$. In einer multivariaten Cox-Regressions Überlebensanalyse mit den Faktoren Lymphknoten-Metastasen, Östrogen- und Progesteron-Rezeptor sowie CML-Akkumulation stellte sich PARK7/DJ-1 nicht als unabhängiger Risikofaktor für Rezidiv-freies Überleben dar. Die PARK7/DJ-1 RNA-Abundanz korrelierte mit schlechter Prognose in basal-Typ Brustkrebs. Für Chemotherapie, aber nicht für endokrine Therapie, korrelierte PARK7/DJ-1 mit besserer Prognose.

Fazit. PARK7/DJ-1 ist ein potentieller Prognosemarker für das duktale Mamma-Karzinom. Die Korrelation der Expression von PARK7/DJ-1 mit der Akkumulation des AGEs CML spricht für eine Rolle bei der Aldehydentgiftung in Tumorzellen.

AG05.12

\section{Modeling the aggressiveness of triple-negative breast cancer in} an alternative in vivo xenograft system

J.K. Muenzner ${ }^{1 *}$, R. Erber', R. A. Ranjan', M. Eckstein', P. Kunze', C. I. Geppert', M. Ruebner', T. Baeuerle', A. Hartmann', R. Schneider-Stock'

'Institute of Pathology, University Hospital, Friedrich-Alexander Universität Erlangen-Nürnberg, Erlangen, Germany, ${ }^{2}$ Department of Gynaecology and Obstetrics, University Hospital, Friedrich-Alexander University ErlangenNürnberg, Erlangen, Germany, ${ }^{3}$ Preclinical Imaging Platform Erlangen (PIPE), Institute of Radiology, University Hospital, Friedrich-Alexander-University Erlangen-Nürnberg, Erlangen, Germany

Aim. High inter- and intratumoral heterogeneity make breast cancer a complex disease with strong variation in behavior, clinical outcome and therapy response. Histological stratification primarily according to the presence of estrogen (ER) and progesterone receptors (PR) as well as the expression/amplification of HER2/neu has laid the basis for breast cancer classification and targeted therapy approaches for hormone receptor (HR) expressing and HER2/neu amplified tumors. However, patients bearing tumors that lack both HR expression and HER2/neu, i. e. triple negative breast cancers (TNBCs), display a rather poor outcome, particularly if not responding to neoadjuvant therapy. Thus, gaining more insights into the molecular mechanisms underlying the highly aggressive behavior of TNBCs by application of pre-clinical model systems remains a major focus of translational breast cancer research.

Methods. Phenotypical and functional characteristics of a $\mathrm{HR}^{+}$and a TNBC breast cancer cell line, MCF-7 and MDA-MB-231 respectively, were assessed. Invasiveness of the two model cell lines was investigated both in vitro by $3 \mathrm{D}$ spheroid invasion assay as well as in vivo in the chorioallantoic membrane (CAM) xenograft assay. In the latter, we also histologically evaluated tumor growth and gene expression patterns. Metastasis formation was determined via a human-specific Alu-PCR method and in vivo imaging.

Results. The TNBC cell line MDA-MB-231 generated larger CAM micro-tumors when compared to those derived of the $\mathrm{HR}^{+} \mathrm{MCF}-7$ cell line, showing the distinct growth pattern of a poorly differentiated adenocarcinoma. We could observe a highly infiltrative growth of MDA-MB-231 cells into the CAM as detected by strong tumor budding (clusters of $\leq 5$ cells) at the tumor invasion front. We showed an extremely invasive potential of the TNBC cells in vitro as well as strong metastasis formation in the CAM assay. The TNBC specific protein expression was further compared with primary TNBC tissues.

Conclusion. From our data we suggest that tumor aggressiveness of TNBC can reliably be modeled in the in vivo CAM xenograft assay. For the first time, we correlated tumor budding to metastasis formation in this alternative xenograft system. We believe that our model system is highly suitable for further studies regarding the underlying molecular characteristics of TNBCs and may be applied in the search of new treatment options. 


\section{AG Gynäko- und Mammapathologie III}

\section{AG05.13 Methylation based classification of endometrial stromal sarcomas \\ F. Kommoss ${ }^{1 *}$, F. Kommoss², D. Schmidt ${ }^{3}$, H.-A. Lehr' ${ }^{2}$, D. Schrimpf ${ }^{4}$, K. Chang ${ }^{5}$, T. Grünewald ${ }^{6}$, M. Gessler', S. Pfister ${ }^{8}$, P. Sinn', G. Mechtersheimer', P. Schirmacher ${ }^{1}$, A. von Deimling ${ }^{4}$, C. Kölsche ${ }^{7}$ \\ 'Department of Pathology, Institute of Pathology, Heidelberg University Hospital, Heidelberg, Germany, ${ }^{2}$ Institute of Pathology, Medizin Campus Bodensee, Friedrichshafen, Germany, ${ }^{3}$ Institute of Pathology, Viersen, Germany, ${ }^{4}$ Department of Neuropathology, Institute of Pathology, Heidelberg University Hospital, Heidelberg, Germany, ${ }^{5}$ Department of Pathology and Laboratory Medicine, KK Women's and Children's Hospital, Singapore, Singapore, ${ }^{6}$ Max-Eder Research Group for Pediatric Sarcoma Biology, Institute of Pathology, Faculty of Medicine, LMU Munich, Munich, Germany, ${ }^{7}$ Comprehensive Cancer Center Mainfranken, Würzburg University, Würzburg, Germany, ${ }^{8}$ Hopp Children's Cancer Center at the NCT Heidelberg (KiTZ), Heidelberg, Germany}

Aim. Endometrial stromal sarcoma (ESS) is a mesenchymal tumor derived from endometrial stromal cells. As classified by the WHO (2014) histomorphology, immunohistochemistry and specific chromosomal rearrangements define low-grade (LGESS) and high-grade (HGESS) tumors. Recently a new type of ESS with recurrent $B C O R$ alterations has been described. We aimed to define subtype specific DNA-methylation signatures of uterine sarcomas in a retrospective cohort of tumors, previously diagnosed as LGESSs and HGESSs.

Methods. DNA-methylation analysis (850K) and RNA sequencing from formalin-fixed paraffin-embedded material was performed on a retrospective multicenter cohort of tumors primarily diagnosed as LGESS and HGESS. Data were analyzed by unsupervised clustering and t-distributed stochastic neighbor embedding analysis and compared with a reference methylation data set of well-characterized prototypical sarcomas encompassing over 16 subtypes, among them potential histopathological mimics of ESS.

Results. In a cohort of 17 LGESS and 8 HGESS DNA-methylation clustering revealed two homogenous methylation groups clearly separating LGESS and HGESS. LGESS carried the specific JAZF1-SUZ12 gene fusion in 11 cases and clustered in close proximity with uterine leiomyomas, irrespective of their individual gene fusion status. In contrast, tumors previously diagnosed as HGESS carried specific gene rearrangements, namely YWHAE-NUTM2 in five cases, ZC3H7B-BCOR in two cases and $B C O R$ $L P P$ in one case. These tumors were epigenetically homogenous and similar to clear-cell sarcoma of the kidney, central nervous system high-grade neuroepithelial tumors, and small blue round cell tumors with BCOR alteration, independent of their individual chromosomal translocation. Conclusion. ESS with YWHAE-NUTM2 and ZC3H7B-BCOR gene fusion represent epigenetically similar entities, which supports the notion of both types of ESS to be biologically similar. Also, clear-cell sarcoma of the kidney (CCSK), central nervous system high-grade neuroepithelial tumors, and small blue round cell tumors with BCOR alteration share similar methylation profiles with the latter. Array-based DNA-methylation analysis of ESS is a powerful tool to more reliably classify uterine mesenchymal tumors, thus possibly contributing to more specific treatment algorithms and approaches in uterine sarcoma research.
AG05.14

Immunologic microenvironment including PD-L1/PD-1 axis in endometrial cancer-correlation with baseline genetics and analysis of prognostic impact

M. Boxberg ${ }^{1 *}$, B. Willvonseder ${ }^{1}$, K. Steiger', H. Bronger ${ }^{2}$, G. Keller', B. Haller ${ }^{3}$, W. Weichert ${ }^{1}$, A. Noske ${ }^{1,4}$

${ }^{1}$ Technische Universität München, Institut für Allgemeine Pathologie und pathologische Anatomie, Munich, Germany, ${ }^{2}$ Klinikum Rechts der Isar der Technischen Universität München, Gynäkologie und Geburtsheilkunde, Munich, Germany, ${ }^{3}$ Technische Universität München, Institut für Epidemiologie und medizinische Statistik, Munich, Germany, ${ }^{4}$ Institut Pathologie der Medica, Zurich, Switzerland

Aim. Advanced endometrioid endometrial cancer (EC) has a poor prognosis. Immune checkpoint blockage (ICB) has emerged as a therapeutic option, but response rates in EC vary between $13-48 \%$ indicating a need for predictive biomarkers. Mismatch repair (MMR) defects, PD-L1 and density of tumor-infiltrating lymphocytes (TILs) have been linked to ICB response. Meanwhile, studies provided insights into eEC genetics identifying distinct molecular subgroups. We aimed to determine the immunologic microenvironment (iTME) of EC including PD-L1/PD-1 axis, to correlate immunologic parameters with genetics and to analyse the prognostic impact of the iTME.

Methods. We investigated molecular parameters (MMR proteins, $\mathrm{P} 53$ status, ARID1 A status, estrogen receptor (ER) expression) and proliferation in 142 therapy-naïve EC by staining with immunohistochemical antibodies. We quantified the density of intraepithelial and stromal TILs (Pan T-cells; CD3+/T-killer cells; CD8+/regulatory T-cells; FoxP3+/PD-1+ TILs) and analysed PD-L1 expression in TCs und immune cell (IC) infiltrate. Invasive front (IF) and tumor center (TCe) were evaluated separately. Results. Microsatellite-stable ECs were correlated with low PD-L1 in ICs and low density intraepithelial/stromal IC infiltrate (CD3+, CD8+, FoxP3+). ER+ EC were associated with low PD-L1 in TCs. Low proliferation was associated with low PD-L1 in TCs, ICs and low density stromal IC infiltrate. IC density and PD-L1 in ICs were higher at the IF, PD-L1 in TCs was higher within TCe $(p<0.05)$. We identified high density PD- $1+$ stromal TILs as an independent prognostic factor for favorable disease-specific (DSS) and disease-free survival (DFS; $p<0.05)$ in the whole cohort. In P53-mutant EC, low density stromal FoxP3+ TILs and in ARID1A wildtype cases low proliferation was independently prognostic for favorable overall survival (OS), DSS and DFS $(p<0.04)$.

Conclusion. Immunologic parameters and baseline genetics in EC are closely intertwined. Spatially resolved analysis of iTME including PD-L1/ PD-1 axis revealed significant differences between IF and TCe and identifies stromal PD-1+ TILs to be of independent prognostic significance. Furthermore, prognostic biomarkers for P53-mutant and ARID1A wildtype ECs were uncovered. In summary, our study provides a detailed, spatially resolved description of iTME including PD-1/PD-L1 axis and molecular alterations in $\mathrm{EC}$ and provides a rationale for investigation of potentially predictive biomarkers.

\section{AG05.15}

\section{Frequency of p53-, p16-, KRAS- and BRAF-mutations in ovarian} high-grade and low-grade serous cancer

\section{E. Schmoeckel*, F. Rieger, A. Jung, T. Kirchner, D. Mayr}

Institute of Pathology, Faculty of Medicine, LMU, Munich, Germany

Aim. According to the dualistic model of carcinogenesis serous ovarian cancer can be divided into two types: Type- 1 carcinomas, referring to low-grade serous carcinomas (LGSC) that develop stepwise according to the adenoma-borderline-carcinoma sequence and often show KRASund BRAF-mutations. Type- 2 carcinomas, representing serous high-grade carcinomas (HGSC), are characterized by p53-mutations. However single cases make an exception from this dualistic model, giving rise that LGSC may progress into HGSC. 
The purpose of this study was to assess the frequency of p53-, p16-, KRASand BRAF-mutations in a cohort of 152 high-grade and 33 low-grade cases of ovarian serous cancer.

Methods. 152 cases of HGSC and 33 cases of LGSC (diagnosed between 1981-2003) were analyzed for expression of p53 and p16 by immunohistochemistry. All cases were screened for KRAS- (exon 2, c.35 g>A-p. G12D and c.35G>T-p. G12V) and BRAF- (exon 15, c.1799T< A p. V600E) mutations by pyrosequencing. Immunohistochemistry for $\mathrm{p} 53$ and p 16 were evaluated by using the immune reactive score (IRS). An IRS of $0-4$ and 9-12 was considered as an "aberrant" expression, according to p53 nonsense (IRS 0-4) or missense (IRS 9-12) mutations. IRS 6-8 was interpreted as "wildtype" for p53. An IRS of 12 was considered positive for p16.

Results. Regarding the group of HGSC 12 out of 152 cases (8\%) were p53-wildtype by immunohistochemistry. P16-positivity was assessed in 86 cases (57\%). KRAS-mutation was detected in in 6 cases (4\%). BRAF-mutation was found in one case $(0.7 \%)$. All cases containing KRAS- or BRAF-mutations showed an aberrant expression of $\mathrm{p} 53$.

Among the group of LGSC 5 out of 33 cases (15\%) showed an aberrant expression of p53. KRAS-mutation was present in 6 cases (18\%). BRAF-mutation was found in one case (3\%). 22 cases (66\%) were neither aberrant for p53 nor showed a KRAS- or BRAF-mutation.

Conclusion. This study shows some cases that do not fit in the dualistic model of carcinogenesis of serous ovarian cancer: In the group of HGSC $8 \%$ were p53-wildtype and another $5 \%$ showed KRAS- or BRAF-mutations. Furthermore $15 \%$ of LGSC cases presented an aberrant expression of p53 while the majority of LGSC were negative for KRAS- or BRAF-mutations. These findings indicate that the dualistic theory does not apply to every case of ovarian serous cancer. Further pathogenetic pathways should be investigated to complete this model of carcinogenesis.

\section{AG05.16 \\ High grade serous carcinoma of the female genital tract- experience with an immunohistochemical classifier in a large clinical cohort \\ A. K. Fischer', N. Neudeck', M. Gruber'2, S. Brucker', A. Taran'2, D. Wallwiener', S. Kommoss' ${ }^{2}$ A. Staebler ${ }^{1 *}$ \\ 'Universitätsklinikum, Institut für Pathologie, Tübingen, Germany, \\ ${ }^{2}$ Universitätsfrauenklinik Tübingen, Tübingen, Germany}

Introduction. High grade serous tubo-ovarian carcinoma (HGSC) is still one of the most lethal carcinomas of the female genital organs, but may be difficult to discern from other ovarian carcinoma histotypes. However correct diagnosis of histotype is indispensable as it influences tumor grading, prognosis and inclusion in histotype-specific studies. In this study, we present our experience with re-classification of a large consecutive cohort of ovarian carcinomas previously classified as HGSC carcinomas according to archival records. We apply stringent criteria according to WHO Classification (2014) and use a combination of four immunohistochemical stains to separate the major histotypes of ovarian carcinoma.

Methods and Material. A consecutive series of 435 cases diagnosed as HGSC and treated at the Womens' Hospital of the University Tuebingen from 2000 until 2016 was reviewed by two independent pathologists. Tissue microarrays (TMAs) with two sets of triplicate cores per case were stained for a panel of four markers including WT1, p53, progesterone receptor and Napsin-A.

Results. In $86 \%$ of cases $(n=374 / 435)$, the diagnosis of HGSC was confirmed unequivocally (WT1+, p53 aberrant, Napsin-A neg.). Based on immunohistochemistry and morphology 38 cases $(8.7 \%)$ were reclassified: 12 (2.7\%) low-grade serous, 23 (5.3\%) endometrioid, 1 (0.2\%) clear cell carcinoma and $2(0.4 \%)$ atypical proliferative serous tumors (APSTs). 23 cases (5.3\%) showed equivocal results by immunohistochemistry and will be subjected to mutational analysis by NGS.

Conclusions. Within our collective, $86 \%$ of HGSC could be verified by a four marker immunohistochemical classification. 38 (8.7\%) cases were successfully reclassified in other histotypes. Therefore, in $95 \%$ of cases a conclusive classification was reached, which is consistent with recently published larger studies, which were successful in $87-93 \%$. Further analysis with NGS is currently performed in equivocal cases to identify mutations or aberrations typical of distinct ovarian cancer histotypes. Taken together we show that a reproducible, cost-efficient and practical classification of ovarian carcinomas according to WHO classification of 2014 is possible in the vast majority of cases. This approach is particularly important when the goal is to establish well-defined cohorts for translational research aiming at histotype-specific prognostic markers and therapeutic targets.

\section{AG05.17}

\section{Expression of PD-L1 in squamous carcinoma of the vulva is} associated to tumor-infiltrating lymphocytes but not to the HPV-

\section{Status}

E. Schmoeckel ${ }^{1 *}$, D. Pham ${ }^{1}$, T. Kirchner', U. Jeschke², D. Mayr ${ }^{1}$

'Institute of Pathology, Faculty of Medicine, LMU, Munich, Germany,

2Department of Gynecology and Obstetrics, LMU, Munich, Germany

Background. Squamous carcinoma of the vulva is the 4th most frequent gynecologic cancer, which can be either HPV-associated or -independent. Although most patients can be curatively treated by radical local excision and radiation, systemic therapy is needed in advanced tumor-stages. At present several different cancer entities can be targeted effectively by PD-L1-inhibitors. Thereby the expression of the PD-L1 is not only an indicator for the responsiveness to this therapy, but can also be of prognostic impact.

In this study we asked the question if squamous carcinomas of the vulva might be also targetable by PD-L1-inhibitors and if the expression of PD-L1 is correlated to the HPV-status (via p16) and/or to the amount of tumor-infiltrating lymphocytes (TILs). In addition, PD-L1, p16 and TILs were analyzed for prognostic information.

Methods. 129 cases of squamous carcinomas of the vulva (diagnosed between 1987-2009) were analyzed for PD-L1 (clone SP263), p16 (clone E6H4) and TILs. Whole sections were stained for PD-L1 and p16 in each case. Survival data were available in $100 \%$. PD-L1-status was evaluated by using the cologne-score, the immune-cell-score (IC-score) and the combined-positive-score (CPS). P16 was considered positive in cases with a strong, block-like staining. TILs were analyzed by HE.

Results. 50 cases (39\%) were p16-positive and 79 cases (61\%) were p16-negative. P16-positivity was associated to a significant better overall-survival in both univariate $(p=0.009)$ and multivariate analysis $(p=0.04)$. TIls $\geq 50 \%$ were present in 31 cases $(20 \%)$ and showed a tendency to a better overall-survival $(p=0.05)$. However this could not be verified in a multivariate analysis $(p=0.396)$. PD-L1 expression in $\geq 50 \%$ of tumor cells was found in 25 cases (16\%). Both CPS and IC-score did not correlated to the patients survival ( $p=0.274$ resp. $p=0.245$ ). CPS $\geq 50$ was correlated significantly to TILs $\geq 50 \%$ ( $p=0.001$ ), but was not associated to p16-status $(p=0.526)$.

Conclusions. High expression of PD-L1 ( $\geq 50 \%)$ was present in $16 \%$ of the cases, suggesting that PD-L1 inhibitors could be viable in these patients. Furthermore, high CPS correlated to high numbers of TILs, but was not associated to HPV-status. Regarding this study group, HPV-associated squamous carcinomas of the vulva showed significant a better overall-survival. High amount of TILs tend to be associated with a better prognosis, too. However, PD-L1-status was not of prognostic impact. 


\section{AG Geschichte und Ethik der Pathologie}

\section{AG06.01 \\ Die verfolgten Pathologen im Nationalsozialismus: Vorläufige Ergebnisse einer soziodemographischen Querschnittstudie \\ S. Kaiser*, J. Sziranyi, D. Groß \\ Institut für Geschichte, Theorie und Ethik der RWTH Aachen, Aachen, Deutschland}

Der Vortrag referiert die Zwischenergebnisse des Forschungsprojekts „Pathologie und Pathologen im Nationalsozialismus“ - namentlich des Teilprojektes, das die Ermittlung der Opfer von Verfolgung, Vertreibung und Entrechtung unter den Pathologen zum Gegenstand hat.

Er führt (1) in die praktizierte Methode der Personenrecherche und die Quellenproblematik ein, referiert (2) die ermittelten Opferzahlen, versucht (3) übergreifend gültige Charakteristika dieser Opfergruppe herauszuarbeiten („soziodemografisches Profiling“) und führt (4) einzelne biografische Beispiele an, um die ermittelten Befunde zu vertiefen und zu illustrieren.

Ein abschließender Blick gilt den Lebensläufen der Betreffenden nach 1945 und der Frage, wie viele dieser Pathologen remigrierten.

\section{AG06.02}

\section{Die DGP-Vorstandsmitglieder und ihre Rolle im „Dritten Reich": Vorläufige Ergebnisse einer soziodemographischen Querschnittstudie}

\section{Gräf*, S. Lang, D. Groß}

'Institut für Geschichte, Theorie und Ethik der RWTH Aachen, Aachen, Deutschland

Der vorliegende Vortrag beschäftigt sich im Rahmen des laufenden Forschungsprojekts „Pathologie und Pathologen im Nationalsozialismus“ mit den „DGP-nahen“ Pathologen und ihrer Rolle im „Dritten Reich“. Insgesamt konnten 28 Pathologen ermittelt werden, die dem DGP-Vorstand angehörten oder z. B. aufgrund einer Ehrenmitgliedschaft eng mit der DGP verbunden und zudem während des Dritten Reiches als Pathologe tätig waren.

Dabei ließ sich bislang für 10 dieser Personen eine NSDAP-Mitgliedschaft nachweisen, also für ca. ein Drittel der untersuchten Pathologen; hinzu kommen in einigen Fällen weitere NS-Mitgliedschaften sowie die Übernahme von Ämtern in NS-nahen Gremien.

Der Vortrag bemüht sich um eine Analyse und Einordnung der ermittelten Befunde und gibt anhand einzelner Biografien Beispiele für charak- teristische Verhaltensmuster sowie für bestehende Handlungsspielräume von Ärzten, die keine Parteimitglieder waren.

\section{AG06.03}

\section{Düsseldorfer Sektionsprotokolle 1919-1923}

E. Winand ${ }^{1 *}$, S. Janßen', I. Esposito', G. Babaryka

'Universitätsklinik Düsseldorf, Institut für Pathologie, Düsseldorf, Deutschland, ${ }^{2}$ Klinikum Landshut, Institut für Pathologie, Landshut, Deutschland

Ziel. Die Analyse der Sektionen der Düsseldorfer Pathologie der Jahre 1919 bis 1923 soll anhand der Betrachtung der häufigsten Grunderkrankungen und Todesursachen, der Altersstruktur des Kollektivs und der Geschlechterverteilung die Nachwirkungen des Ersten Weltkriegs beleuchten.

Methoden. Für die vorliegende Untersuchung wurden 3462 Obduktionsprotokolle der Jahre 1919 bis 1923 ausgewertet. Die Parameter Alter, Geschlecht, Body Mass Index (BMI), einweisende Klinik, Obduzent, Liegezeit und autoptische Todesursache wurden analysiert. Die Todesursache wurde nach ICD-10 Klassifikation kodiert. Die Obduktionsprotokolle wurden handschriftlich oder maschinengeschrieben in Sektions- und Obduktionsbücher eingetragen. Die Sektionsbücher enthielten das ausführliche Sektionsprotokoll, die Obduktionsbücher fassten dieses tabellarisch nach Organsystemen zusammen. In 107 Fällen (3 \%) fehlte das Sektionsprotokoll, weshalb die o.g. Informationen dem Obduktionsbuch entnommen wurden. Zurzeit befinden sich die Bücher im Archiv des Instituts für Pathologie der Uniklinik Düsseldorf.

Ergebnisse. Im behandelten Untersuchungszeitraum wurden 1443 $(41,7 \%)$ weibliche und 1996 (57,7 \%) männliche Verstorbene untersucht. Bei 23 Obduktionen (0,6 \%) war das Geschlecht nicht angegeben.

Die Leichname von 1598 (46 \%) Erwachsenen und 1837 (53,2 \%) Kindern wurden obduziert, bei 27 Fällen $(0,8 \%)$ fehlte die Altersangabe. Die Erwachsenen waren im Schnitt 44,26 Jahre alt, die Kinder waren im Schnitt 1,31 Jahre alt.

Die Infektionen waren mit 988 Fällen $(28,5 \%)$ die häufigste Todesursache (- Abb. 1|AG06.03). Von diesen entfiel die Hälfte auf die Tuberkulose. Zweithäufigste Todesursache war die Pneumonie mit 831 Fällen (24\%). Die Zahl der Totgeborenen und verstorbenen Säuglinge war im Jahr 1921 am Höchsten. Bei den Säuglingen waren „Darmkatarrh“ und „Mehlnährschaden" häufige Befunde.

Bei 1400 Erwachsenen (88 \%) konnte der BMI bestimmt werden. Nach heutigen Normwerten waren 41,4\% der verstorbenen Erwachsenen untergewichtig, 5,3\% waren übergewichtig.

Fazit. Die Analyse der Sektionsprotokolle aus der Nachkriegszeit des Ersten Weltkriegs in Düsseldorf illustriert ein Vorherrschen der Infektionskrankheiten und der Todesfälle in der Perinatalperiode. Durch Mangeler-

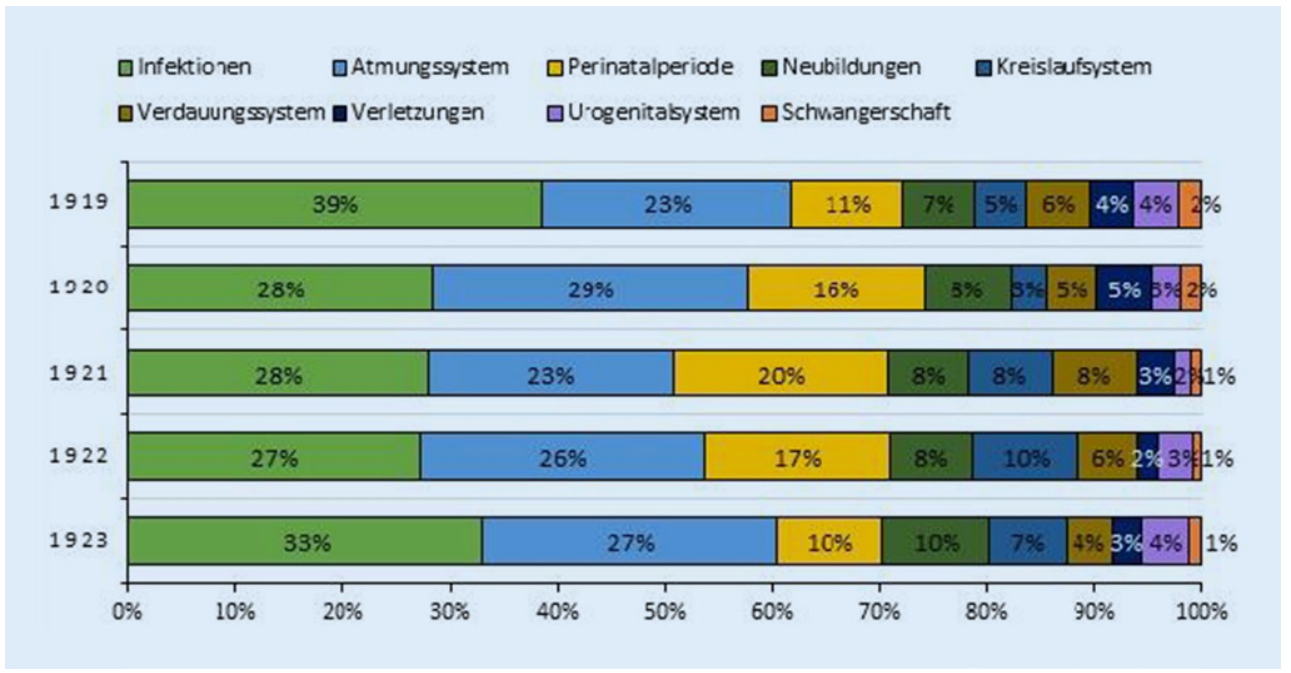

Abb. 1 | AG06.03 $<$ Todesursachen der Jahre 1919-1923 prozentual 
nährung und die schlechte wirtschaftliche wie hygienische Lage zur dieser Zeit erklärt sich die hohe Infektanfälligkeit der Düsseldorfer Bevölkerung. Diese Probleme spiegeln sich auch in der hohen Säuglingssterblichkeit im untersuchten Kollektiv wider.

\section{AG06.04}

\section{Leonhard Riedmüller - Schweizer Staatsfeind oder Bauernopfer?}

\section{A. Pospischil*}

Universität Zürich, Institut für Veterinärpathologie, Zürich, Schweiz

Mit der Begründung Mitglied der NSDAP zu sein, verwies die Regierung des Kantons Zürich Prof. Dr. med. vet. Leonhard Riedmüller (1898-1976) und seine Ehefrau Helena (1910-1990), beide deutsche Staatsangehörige, am 9. Juni 1945 auf Lebenszeit aus der Schweiz. Riedmüller war Direktor des veterinärbakteriologischen Instituts der Universität Zürich. Seit 1926 war er dort Assistent und habilitierte 1929, Extraordinarius wurde er 1938. Sein Schwiegervater Hans Eltze (1880-1952), NSDAP Mitglied mit niedriger Mitgliedsnummer, war in der Geschäftsleitung bei Rheinmetall tätig, zu der auch eine Patronenfabrik in der Schweiz gehörte. Riedmüller gelangte über ihn in Kontakt mit höchsten nationalsozialistischen Kreisen. Seit 1940 wurde er vom Nachrichtendienst der Kantonspolizei Zürich überwacht, da er sich öffentlich sehr positiv über Hitler äusserte und nach der Mobilmachung der Schweiz häufig mit Berlin telefonierte. Trotzdem wählte man ihn 1942 zum Ordinarius. Bei Vernehmungen in den Jahren 1944/45 bestätigte er alle Angaben, bezeichnete sich aber als unbedeutendes Parteimitglied. Seine Ausreise erfolgte am 3. März 1946 über Portugal nach Brasilien, wo er am Instituto de Biologia Animal (IBA) des Ministério da Agricultura tätig war.

Nach Auswertung von Archivalien ist es heute schwer zu entscheiden, ob man Leonhard Riedmüller als Schweizer Staatsfeind oder als Bauernopfer bezeichnen muss.

\section{AG06.05 \\ The geo-political influence on the development of academic pathology-a historical view}

\section{A. Lechermeier, C. Brochhausen* Universität Regensburg, Institut für Pathologie, Regensburg, Germany}

Aim. It is accepted that the development of academic institutions is embedded in its historical context $[1,2]$. We analysed how the development of academic pathology is dependent on the fact, that the university is located in a military strategic significant region.

Method. We analysed the historical development of pathology and that of the Institute of Pathology in Mainz with view to the historical background in the region. Since the Roman empire the city of Mainz represents a strategic important city at the river Rhine and hosted several armies and thus was arena of several wars.

Results. In the $18^{\text {th }}$ century the medical faculty earned high recognition since it was possible to appoint Thomas Soemmering to the chair of anatomy, who already was interested in pathological analyses. His plan for an anatomical theatre failed due to the chaos of the revolutionary war. During the regency of Napoleon and the Napoleonic wars Mainz was arena for huge military hospitals, located in buildings planned for further development of Anatomy and Pathology. As a consequence, Soemmering leaves Mainz. In the $19^{\text {th }}$ century a private association was found, which was aimed to trigger the research of basis of diseases due to the performance of autopsies [4]. Approximately 100 years after Soemmerings plans to promote pathology in Mainz the Institute of Pathology was founded by a donation of Jacob Hochgesand, the director of the civil hospital in Mainz. Since the university was always closed at that time, the institute were not an academic one. Not before the re-opening of the university in 1946 the Institute of Pathology became part of the Johannes Gutenberg-University of Mainz.

Conclusions. The development of pathology in Mainz clearly demonstrates a significant dependency from the fact to be located at a military strategic position. We could demonstrate that in setting priorities during academic development the needs for an academic pathology was postponed in periods of social instabilities. In future projects we will compare the development of further Institutes of Pathology located in strategic regions to understand better which strategies were developed by pathologists to cope unfavourable situations.

\section{References \\ 1. Fleck L (1994) Suhrkamp, Frankurt/Main \\ 2. Kuhn T (1996) Suhrkamp, Frankurt/Main \\ 3. Gruber GB (1923) Virchows Arch 247:187-201}

\section{AG06.06}

\section{Historical macro-pathological specimens in current medical teaching-transfer into the digital world}

P. Eichhorn ${ }^{1 *}$, T. Rau ${ }^{2}$, C. Schmidt ${ }^{3}$, U. Andraschke ${ }^{4}$, C. Geppert ${ }^{1}$, A. Hartmann ${ }^{1}$ 'Pathologisches Institut/Universitätsklinikum Erlangen, Erlangen, Germany, ${ }^{2}$ Institut für Pathologie, Universität Bern, Bern, Switzerland, ${ }^{3}$ Institut für LernInnovation, Friedrich-Alexander-Universität Erlangen-Nürnberg, Erlangen, Germany, ${ }^{4}$ Körperschaftshaushalt und Stiftungen, Friedrich-AlexanderUniversität Erlangen-Nürnberg, Erlangen, Germany

Background. The heritage of the Pathological Institute of the Friedrich-Alexander-University Erlangen-Nuremberg comprises an extensive collection of macroscopic pathologico-anatomical specimens reaching back over 150 years. After a successful project integrating these specimens in current medical teaching the purpose of this work is to examine the impact and perception of integrating them into digital teaching.

Materials and methods. The preparations employed in the regular student courses were professionally digitalized. In a first step the specimens were photographed from various angles. The image data were used to build a $360^{\circ}$-model with free horizontal rotational and zoom function. In a second step the digital $360^{\circ}$-images were integrated into the regular digital student course. A first evaluation was carried out on a student cohort without digitalized historical specimens by means of a questionnaire with 23 items and two free text fields. A second evaluation on a cohort with digitalized historical specimens is ongoing.

Results. Although the results are preliminary the students appreciate the link between histological and gross findings. Using digital images makes it very easy to quickly switch between the macroscopic and the microscopic view. Furthermore the students have now the opportunity to study the specimens beyond the limited, regular time slots. That was not possible until now. However, the advantage of totally free movement of real specimens partly vanishes as the $360^{\circ}$-model does not provide entirely free movement.

Conclusion. One of the most valuable qualities of historical pathological specimens in teaching is the fact, that they often allow a view onto untreated tissue and therefore an unbiased access to a specific case. Although the process of digitalization takes the advantage of a stereoscopic and free movable sight, students benefit at most by the combined use of histological and gross findings. Therefore the integration of digital macro-pathological specimens into the already existing digital course of microscopy seems very promising. In conclusion, historical specimens regain didactic value not only in in-house teaching, but although in the additional digital online courses. 


\section{AG Informatik, Digitale Pathologie und Biobanking}

\section{AG07.01 \\ Einsatz der Blockchain als Methode zur revisionssicheren Probenverfolgung und Qualitätssicherung im Biobanking}

\section{Bauer, S. Asman, C. F. Thomas*, N. Buschhüter, E. Dahl RWTH centralized Biomaterial Bank (RWTH cBMB), Medizinische Fakultät, Uniklinik RWTH Aachen, Aachen, Deutschland}

Ziel. Eine standardisierte und dokumentierte Prozessierung ist essenziel für die Reproduzierbarkeit und Aussagekraft von Forschungsergebnissen basierend auf humanen Biomaterialproben. Zwar ist das Arbeiten nach Standard Operating Procedures (SOPs) mittlerweile Standard, jedoch können bereits kleine Abweichungen einen großen Einfluss auf die Qualität der Proben haben [1]. Um die möglichen Abweichungen bei der Verarbeitung zu erfassen, soll in diesem Forschungsprojekt eine Software-Lösung entwickelt werden, welches eine lückenlose Verfolgbarkeit der an die Biomaterialbank eingesendeten Proben sicherstellt und so eine genauere Beurteilung der Qualität einer Probe ermöglicht.

Methoden. Eine Blockchain ist eine kontinuierlich erweiterbare Liste von Daten, die mittels kryptographischer Verfahren miteinander verkettet sind. Sie stellt eine fälschungssichere Datenstruktur dar, in welcher Transaktionen in der Zeitfolge protokolliert, nachvollziehbar und unveränderlich abgebildet sind $[2,3]$. Der Probeneingang im Labor, sowie Beginn und Ende eines jedes Verarbeitungsschrittes, bis hin zur Ausgabe der Probe, wird mittels einzelner Transaktionen in einem Block gespeichert und kontinuierlich zur Kette hinzugefügt.

Ergebnisse. Die für den Anwendungsfall zugeschnittene Implementierung einer Blockchain ermöglicht eine lückenlose Nachverfolgbarkeit der Probenverarbeitung. Durch die Verkettung mittels kryptographischer Verfahren wird die Historie einer jeden Probe dauerhaft und durch digitale Signaturen beglaubigt gespeichert. Dadurch wird die Rückverfolgbarkeit und Fälschungssicherheit der Daten eines Biomaterials im Sinne eines AuditTrails sichergestellt.

Fazit. Durch die Implementierung einer Blockchain-Struktur wird die Möglichkeit zur Manipulation der Daten auf ein Minimum reduziert [4], da der gespeicherte Hash-Wert im Falle einer nachträglichen Änderung der Nutzdaten nicht mehr zu den veränderten Daten passt oder bei einer nachträglichen Änderung des Hash-Wertes die Validität der Kette verletz wird. Mit Hilfe dieser Vorgehensweise wird jede Statusänderung einer Bio materialprobe (z.B. der Zeitpunkt der Zentrifugation, der Aliquotierung oder des Einfrierens) revisionssicher gespeichert, sodass sich alle Zeitpunkte der Verarbeitung bis hin zur Ausgabe der Probe lückenlos nachvollziehen lassen. Zukünftig soll die Software eine Paketverfolgung für Biomaterialproben innerhalb der Uniklinik Aachen abbilden.
AG07.02

Evaluation der Konkordanz zwischen semi-automatisierter und konventioneller Quantifizierung des Tumorzellgehalts in pulmonalen Adenokarzinomen

D. Kazdal ${ }^{1 * 2}$, A. Harms ${ }^{1,2}$, K. Holzer ${ }^{3}$, E. Kohlwes', S. Ormanns ${ }^{5}$, L. Fink ${ }^{6}$, J. Kriegsmann", M. Leichsenring ${ }^{8}$, F. Stögbauer ${ }^{9}$, L. Tavernar', J. Leichsenring ${ }^{1}$, A.-L. Volckmar ${ }^{1}$, K. Kriegsmann ${ }^{10}$, W. Weichert ${ }^{9,11}$, P. Schirmacher ${ }^{1}$, A. Stenzinger ${ }^{1,2,11}$, A. Warth ${ }^{6}$, M. Kriegsmann

${ }^{1}$ Institut für Pathologie, Universitätsklinikum Heidelberg, Heidelberg, Deutschland, ${ }^{2}$ Deutsche Zentrum für Lungenforschung (DZL), Translational Research Center (TLRC), Heidelberg, Deutschland, ${ }^{3}$ Institut für Pathologie, Universität Greifswald, Greifswald, Deutschland, ${ }^{4}$ Institut für Pathologie, Universitätsmedizin Mainz, Mainz, Deutschland, ${ }^{5}$ Institut für Pathologie, Ludwig-Maximilians Universität München, München, Deutschland, ${ }^{6}$ Institut für Pathologie, Zytologie und Molekularpathologie, ÜGP MVZ, Giessen/Wetzlar/Limburg, Deutschland, ${ }^{7}$ MVZ für Histologie, Zytologie und Molekulare Diagnostik Trier, Trier, Deutschland, ${ }^{8} \mathrm{Gemeinschaftspraxis}$ für Pathologie Gütersloh, Gütersloh, Deutschland, ${ }^{9}$ Institut für Pathologie, Technische Universität München, München, Deutschland, ${ }^{10}$ Zentrum für Innere Medizin V, Universitätsmeizin Heidelberg, Heidelberg, Deutschland, ${ }^{11}$ Deutsches Konsortium für Translationale Krebsforschung, Heidelberg, Deutschland

Ziel. Die exakte Bestimmung des Tumorzellgehalts in dem zu untersuchendem Probenmaterial ist für viele molekularbiologische Analysen (z. B. NGS) notwendig um aussagekräftige Ergebnisse ableiten und Fehlinterpretationen vermeiden zu können. Mittlerweile stehen verschiedene computergestützte Analysemethoden zur Verfügung, die immun-/histopathologische Auswertungen unterstützen und erweitern können. In der hier vorgestellten Studie wurde die Konkordanz zwischen einer semi-automatisierten digitalen Quantifizierung und einer konventionellen Evaluationen des Tumorzellgehalts pulmonaler Adenokarzinome betrachtet.

Methoden. Der Tumorzellgehalt, das heißt die Anzahl an Tumorzellen pro Gesamtzellzahl, wurde an jeweils $60 \mathrm{H \& E}$ - und TTF-1 gefärbten digitalisierten Schnittpräparaten pulmonaler Adenokarzinome bestimmt. Für die digitalpathologische Auswertung wurden zwei Softwarelösungen eingesetzt: Das kommerziell erhältliche HALO (Indica Labs, Corrales, NM, USA) und das Opensource Programm QuPath (Bankhead et al. 2017). Die konventionelle Evaluation wurde über ein WebInterface von 19 Teilnehmern aus 9 verschiedenen pathologischen Instituten durchgeführt.

Ergebnisse. Die Berechnung der Intra-Klassen-Korrelation zeigte eine gute bzw. exzellente Konkordanz zwischen der semi-automatisierten digitalen Tumorzellquantifizierung und den Mittelwerten der konventionellen Abschätzungen für H\&E- bzw. TTF1-gefärbte Schnittpräparate. Dabei waren die Abweichungen zwischen den beiden digitalpathologischen Programmen gering und signifikant kleiner als innerhalb der Gruppe der Teilnehmer. Hier kam es besondere bei H\&E gefärbten Schnitten gehäuft zu einer Überschätzung des Tumorzellgehalts. Anhand von wiederholt aber um $180^{\circ}$ gedreht vorgelegten Präparaten kam eine signifikant höhere Konsistenz der computer-gestützten Analysen, mit einer mittleren Differenz von $1 \%$ gegenüber $9 \%$ für die konventionelle Evaluation, zur Darstellung. Fazit. Der durch den Einsatz semi-automatisierter digitaler Methoden ermittelte Tumorzellgehalt war mit dem Mittelwert der ungestützten konventionellen Abschätzungen konkordant. Dabei stehen signifikant verringerte Varianz und erhöhte Reproduzierbarkeit der Auswertung einem größeren Zeitaufwand gegenüber.

AG07.03

Quality control and biomarker stability studies using unique tumour tissue samples exposed to different ischemic conditions

J. Slotta-Huspenina*, K.-F. Becker

Technische Universität München, Pathologie, Munich, Germany

Although there are recommendations, guidelines, and institutional standard operating procedures for numerous steps in research and the daily routine, recommendations for the entire process for biomarker development 
and analysis, starting from collection of the specimen from the patient to the final assay result in the in vitro diagnostic laboratory were missing. Currently, national and European projects aim to improve the situation. In addition, International Standards have been published to guide specimen handling. "Stressed material" will be needed to demonstrate stability of novel biomarkers.

The distinctive feature of a novel tissue collection at our tissue bank is that the samples have been exposed in a controlled fashion to different ischemic conditions from zero up to $180 \mathrm{~min}$ before freezing or formalin fixation, and that the samples are extensively annotated. Parameters documented for each sample include: TNM staging, medication before surgery, anaesthesia, start of surgery, time of ischemia-relevant vessel ligation (begin of warm ischemia), time of hand-over to pathologist (start of cold ischemia), time of preservation (liquid nitrogen or formalin).

So far, 1411 samples from 128 patients, composed of 495 and 440 frozen tumour and reference samples, respectively, have been collected. In addition, from many patients FFPE samples were collected as well (252 tumour, 224 reference samples). The tissue types represented in our collection include 30 colon cancers, 15 gastric cancers, 14 liver cancers, 17 pancreatic cancers, 8 rectum cancers, 8 oesophagus cancers, and 32 others. The main characteristics of this unique tissue collection are:

- Extensive documentation (clinical data, warm and cold ischemia times) - Malignant and matched normal reference tissue samples

- Additional experimentally delayed cold ischemia times up to $180 \mathrm{~min}$ - Impact of different preservation methods (liquid nitrogen, FFPE) Studies based on this unique tissue collection for improving accurate quantitative measurements of the activation state of signalling pathways and for analysing the stability of biomarkers during the pre-analytical phase are envisaged and currently being performed. These studies will be essential for the development of reliable biomarkers for targeted therapies aiming to inhibit deregulated signalling pathways in tumours. Truly robust markers are likely to be reliable regardless of sample processing and type.

\section{AG07.04}

\section{RBP7 is a clinically prognostic biomarker and linked to tumor} invasion and EMT in colon cancer

\section{Elmasry ${ }^{1 * 2}$, L. Brandl' ', J. Engel ${ }^{3}$, A. Jung ${ }^{1,4,5}$, T. Kirchner 1,4,5, D. Horst4, 4,6 'Ludwig Maximilians University, Institute of Pathology, Munich, Germany, ${ }^{2}$ Mansoura University/Faculty of Medicine, Department of Pathology, Mansoura, Egypt, ${ }^{3}$ Ludwig Maximilians University/Munich Cancer Registry (MCR), Department of Medical Information Processing, Biometry and Epidemiology (IBE), Munich, Germany, ${ }^{4}$ German Cancer Consortium (DKTK), Heidelberg, Germany, ${ }^{5}$ German Cancer Research Center (DKFZ), Heidelberg, Germany, ${ }^{6}$ Charité-Universitätsmedizin Berlin, Institute of Pathology, Berlin, Germany}

Background and aims. Colon cancer is a common human malignancy. RBP7 is a member of the cellular retinol-binding protein (CRBP) family, required for vitamin A stability and metabolism. Some CRBP members are linked to tumor progression in cancer. However, its clinical significance and biological role in colon cancer remain unclear. This study aimed to investigate the potential relationship between RBP7 expression and tumor progression and to determine its function in colon cancer cells.

Methods. Immunostaining was used to detect RBP7 expression in colorectal cancer tissues. Then, a digital quantitative scoring approach using QuPath image analysis software was applied. Afterwards, Kaplan-Meier analysis and multivariate Cox regression analysis were performed to verify the prognostic and predictive values of RBP7 in colon cancer. Analysis results were validated based on The Cancer Genome Atlas (TCGA) database. Gene set enrichment assay (GSEA) was performed to investigate the biological characteristics of RBP7. Functional analysis was done by establishing RBP7 overexpression and studying its effects on migration and invasion of colon cancer cell lines HCT116 and SW1222 by transwell assays. Results. High RBP7 expression indicated significantly worse cancer-specific survival $(p=0.003)$ in a collection of 219 colorectal cancer cases. Furthermore, high RBP7 mRNA expression in a TCGA data set of 457 colon cancers had a strong positive correlation with poor cancer specific survival $(p=0.00007)$. GSEA analyses revealed that RBP7 was linked to epithelial mesenchymal transition in colon cancer. Finally, RBP7 overexpression increased migration and invasion of colon cancer cells in vitro.

Conclusions. Our study gives novel insights into the clinical significance of RBP7 expression in patients with colon cancer and suggests a potential link of retinol metabolism and EMT.

\section{AG Knochen-, Gelenk- und Weichgewebspathologie I}

\section{AG08.01}

Morphologische Besonderheiten primärer Zilien in murinem Kreuzbandgewebe - Erste Ergebnisse einer elektronenmikroskopischen Untersuchung

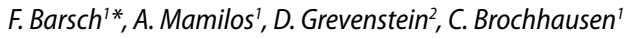

${ }^{1}$ REPAIR-Lab, Institut für Pathologie, Universität Regensburg, Regensburg, Deutschland, ${ }^{2}$ Universität zu Köln, Klinik und Poliklinik für Orthopädie und Unfallchirurgie, Köln, Deutschland

Ziel. Die Zilienforschung hat mit dem technischen Fortschritt nach der Jahrtausendwende große Fortschritte und Entdeckungen gemacht. In zahlreichen Studien konnte gezeigt werden, dass neben „motilen“ Zilien auch „primäre" Zilien existieren, die sich ultrastrukturell, funktionell und in ihrer Ausprägung in unterschiedlichen Geweben und Spezies voneinander unterscheiden. Im Binde- und Stützgewebe wird primären Zilien dabei eine intra- und interzelluläre mechano- und chemosensorische Funktion zugesprochen, die eine maßgebliche Rolle in der embryonalen Morphogenese und Gewebehomöostase zu spielen scheint. In der Literatur wird unter anderem eine Beteiligung zu pathomorphologischen Veränderungen des arthrotischen Gelenkknorpels diskutiert. In adultem Kreuzbandgewebe ist das Vorkommen, die Struktur und die physiologische und pathophysiologische Bedeutung der primären Zilien vor dem Hintergrund mangelnder Untersuchungen bisher ungeklärt. Ziel ist es dieser Wissenslücke zu entgegnen.

Methoden. Elektronenmikroskopische Untersuchung adulter Kreuzbänder von 5 Wildtiermäusen. Nach Präparation des Kniegelenkes wurden die Gewebeproben in Karnowskylösung fixiert und nach standardisierten Labormethoden für die Transmissionselektronenmikroskopische Untersuchung aufgearbeitet.

Ergebnisse. Vorläufige Ergebnisse zeigen, dass ein kleiner Anteil der Ligamentozyten im Gewebeverband der Kreuzbänder Zentriolen unter der Zellmembran besitzen, die jedoch kein primäres Zilium exprimiert haben. Auch die typische orthogonale Zuordnung von Mutter- und Tochterzentriole scheint aufgehoben zu sein.

Fazit. Erstmalig wird Kreuzbandgewebe ultrastrukturell hinsichtlich des Vorkommens und der Struktur von primären Zilien untersucht. Bisher konnten keine elongierten primären Zilien detektiert werden, obwohl die substrukturellen Voraussetzungen dafür gegeben wären. In laufenden experimentellen Untersuchungen soll geklärt werden, ob das gesamte Zilium nur passager exprimiert wird und ob primäre Zilien auch in humanem Kreuzbandgewebe detektiert werden können.

\section{AG08.02}

\section{Histopathologische Infektionsdiagnostik der} Periimplantatinfektion sowie der Infekt-Persistenz

\section{König ${ }^{1 *}$, V. Krenn ${ }^{2}$, V. Krenn ${ }^{2}$}

${ }^{1}$ Medizinische Universität Sofia, Sofia, Bulgarien, ${ }^{2}$ MVZ für Histologie, Zytologie und Molekulare Diagnostik Trier, Trier, Deutschland

Ziel. Der CD15 Focus Score gilt als Scoring-System für die Diagnostik der periimplantären Infektionen (Kölbel B. et al. 2015, Krenn VT. et al. 2017). Zur Vereinfachung wurde eine interaktive Quantifizierungs-Software entwickelt (CD15 Quantifier) (Kölbel B. et al. 2015). Mit Hilfe des 
CD15 Quantifiers sollen Grenzwerte ermittelt werden, um die Diagnostik periimplantärer Gelenkinfektionen sowie die Keim-Beständigkeit (bei zweizeitigen Gelenkendoprothesen-Wechsel) in einer reproduzierbaren Form zu ermöglichen.

Methoden. In dieser Untersuchung wurden 27 Fälle einer Periimplantatmembran bei periprothetischen Infekt und 16 Fälle bei zweizeitigen Gelenkendoprothesenwechsel untersucht und bewertet mithilfe des CD15 Focus Score $\left(0,266 \mathrm{~mm}^{2}\right)$. Als Vergleich wurden 15 Fälle von nicht infektiösen Periimplantatmembranen herangezogen. Bei den zweizeitigen Prothesenwechsel wurden 18 nicht keimbeständige Fälle herangezogen. Ergebnisse. Die CD15 Focus Score Werte und die mikrobiologischen Befunde weisen eine signifikante Korrelation (Sensitivität 94,1\%, Spezifität 93,3\%, negativer prädiktiver Wert 93,3\% positiver prädiktiver Wert 94,1\%) bei der periimplantären Gelenkinfektion auf. Ebenso besteht eine signifikante Korrelation bei der Keimbeständigkeit (Sensitivität $50 \%$, Spezifität 88,9\%, negativer prädiktiver Wert 66,7\% und positiver prädiktiver Wert $80 \%$ ). Ein positiver bakterieller Befund besteht für periimplantäre Infektionen ab einem Grenzwert von 88 und bei Keimbeständigkeit ab 86. Bei der periimplantären Infektion zeigte sich, dass niedrig-virulente Keime einen CD15 Fokus-Score von $\sim 219$ und hochvirulente Keime von 391 vorwiesen. Die Zählzeit mittels Software unterscheidet sich erheblich von der direkten Zählzeit (28,31s und 87,64s). In 8 von 76 Fällen konnte der CD15 Quantifier kein plausibles Resultat erzielen, da Abriebpartikel, Makrophagenpräsenz oder fibrinpräzipitate den korrekten Quantifizierungsvorgang nicht ermöglichten.

Fazit. Mittels CD15 Quantifier ist es möglich durch eine schnelle Auswertung mit hoher Sensitivität $(94,1 \%)$ und Spezifität $(93,3 \%)$ eine periimplantäre Infektion und eine Infektpersistenz bei zweizeitigen Prothesenwechsel (Sensitivität 50 \%, Sensitivität 88,9 \%) zu diagnostizieren. Mit Hilfe der Software wurde der Auswertungsprozess deutlich vereinfacht, verkürzt und eine Reproduzierbarkeit ist vorhanden.

\section{AG08.03 \\ A genetic variation associated with height and osteoarthritis highlights the importance of Interleukin-11 protein stability}

J. Lokau' ${ }^{*}$, P. Arnold ${ }^{2}$, J. Grötzinger ${ }^{3}$, C. Garbers ${ }^{1}$

'Otto-von-Guericke University Magdeburg, Department of Pathology, Magdeburg, Germany, ${ }^{2}$ Kiel University, Institute of Anatomy, Kiel, Germany, ${ }^{3}$ Kiel University, Institute of Biochemistry, Kiel, Germany

Background. The cytokine Interleukin-11 (IL-11) has essential functions in bone remodelling, and loss of IL-11 signalling is associated with craniofacial malformations in humans and mice. Furthermore, mice devoid of IL11 signalling display decreased osteoclast numbers and impaired bone formation, while transgenic overexpression of IL-11 results in increased bone formation accompanied by increased thickness and strength of long bones. Recently, the single nucleotide polymorphism (SNP) rs4252548 within the IL11 gene was identified, which leads to an exchange of Arg-112 to His-112 in the IL-11 protein (IL-11_R112H). This SNP correlates with an increased risk of hip osteoarthritis and reduced human height. Given the fundamental role of IL-11 in bone homeostasis, we aimed to understand the molecular mechanisms that alter IL-11 biology in the IL-11_R112H variant. Methods. We recombinantly produced IL-11 wildtype (wt) and IL-11_ $\mathrm{R} 112 \mathrm{H}$ in $E$. coli and determined their secondary structure. We analyzed the biological activity of the variants with an IL-11-dependent cell line and used a combination of molecular modeling and in vitro experiments to examine receptor binding and thermal stability. Finally, we performed ex vivo differentiation of osteoclasts in order to detect effects on osteoclastogenesis.

Results. We found that the SNP R112H does not compromise the biological activity of IL-11. We detected an increase in intramolecular flexibility due to loss of the positively charged arginine side chain, which results in a reduced stability of IL-11_R112H. Due to the decreased stability, IL-11_ $\mathrm{R} 112 \mathrm{H}$ failed to support the survival of osteoclast progenitor cells.

Conclusion. The SNP rs4252548 results in a decreased stability of IL-11. The compromised stability might be relevant in osteoclastogenesis and bone turnover, which offers an explanation for the observed bone phenotypes. Furthermore, our data also indicate that carriers of the minor allele might bear an increased risk for other diseases caused by an imbalanced osteoclast activity.

\section{AG08.04 \\ Inhibition of YAP/TAZ is a novel therapeutic strategy to counteract SS18-SSX-driven tumorigenesis}

I. Isfort ${ }^{1 *}$, R. Berthold', M. Cyra' , A. Hildebrand', S. Kailayangiri', B. Altvater', C. Rossig', J.-H. Mikesch', A. Wozniak', P. Schöffski ${ }^{4}$, E. Wardelmann ${ }^{5}$,

M. Trautmann', W. Hartmann'

'Division of Translational Pathology, Gerhard-Domagk-Institute of

Pathology, Münster University Hospital, Münster, Germany, ${ }^{2}$ Departments of Pediatric Hematology and Oncology, University Children's Hospital Münster, Münster, Germany, ${ }^{3}$ Department of Medicine A, Hematology, Oncology and Respiratory Medicine, University Hospital Münster, Münster, Germany,

${ }^{4}$ Laboratory of Experimental Oncology, Department of Oncology, KU Leuven, and Department of General Medical Oncology, University Hospitals Leuven, Leuven Cancer Institute, Leuven, Belgium, ${ }^{5}$ Gerhard-DomagkInstitute of Pathology, Münster University Hospital, Münster, Germany

Introduction. Synovial sarcoma (SySa) is a soft-tissue malignancy driven by a specific reciprocal translocation $t(X ; 18)$. Representing the major oncogenic hallmark, the resulting SS18-SSX fusion protein dysregulates cellular gene transcription associated with SySa pathogenesis; however, it remains challenging to target the fusion protein itself. Therefore, the discovery of novel specific molecular targets is of particular importance. Against the background of recent studies showing frequent activation of the transcriptional coactivators YAP and TAZ in soft-tissue sarcomas, the aim of this study was to analyze their role in SySa tumorigenesis, to decipher the underlying regulatory mechanism and to evaluate potential therapeutic options.

Experimental procedures. Immunohistochemical evaluation of nuclear YAP/TAZ expression was performed in a large cohort of SySa tissue specimens $(n=65)$. The mesenchymal stem cell line SCP- 1 stably expressing the SS18-SSX fusion protein and five SySa cell lines were employed for in vitro analyses addressing the question of SS18-SSX-dependency and the associated regulatory mechanism. To modulate YAP/TAZ transcriptional activity, RNAi-mediated knockdown and the small molecule inhibitor verteporfin were applied. Finally, the therapeutic impact of YAP/TAZ inhibition was tested in vivo using a SySa cell line-based and patient-derived xenograft approach.

Results. The immunohistochemical analyses revealed strong expression of nuclear YAP/TAZ in the majority of SySa tissue specimens. Implementation of RNAi-mediated knockdown and overexpression of the SS18-SSX fusion protein demonstrated a dependency of nuclear YAP/TAZ expression on the fusion protein. This regulatory connection was at least partly realized through an IGF-II/IGF-IR signal transduction loop. Inhibition of YAP/TAZ transcriptional activity by RNAi or verteporfin resulted in a significant suppression of SySa cell growth in vitro and in vivo.

Conclusions. We here for the first time provide systematic evidence of a molecularly based mechanism of YAP/TAZ activation in SySa. Given the high efficacy of YAP/TAZ-directed pharmacological approaches in SySa xenografts, this preclinical study may constitute the basis for a novel therapeutic strategy to inhibit SS18-SSX-driven tumorigenesis. 


\section{AG08.05}

\section{The CAMP response element-binding protein (CREB) is a potential therapeutic target in myxoid liposarcoma}

M. Cyra ${ }^{1 *}$, S. Huss ${ }^{2}$, M. Schulte', R. Berthold ', I. Isfort ${ }^{1}$, S. Hafner ${ }^{3}$, T. Simmet ${ }^{3}$, T. Kindler', P. Åman ${ }^{5}$, E. Wardelmann'2, W. Hartmann', M. Trautmann'

'Division of Translational Pathology, Gerhard-Domagk-Institute of Pathology, Münster University Hospital, Münster, Germany, ${ }^{2}$ GerhardDomagk-Institute of Pathology, Münster University Hospital, Münster, Germany, ${ }^{3}$ Institute of Pharmacology of Natural Products \& Clinical Pharmacology, Ulm University, Ulm, Germany, ${ }^{4}$ Department of Hematology, Medical Oncology and Pneumology, University Medical Center of Mainz, Mainz, Germany, ${ }^{5}$ Sahlgrenska Cancer Center, University of Gothenburg, Gothenburg, Sweden

Aim. Myxoid liposarcoma (MLS) is an aggressive soft tissue tumor, clinically accompanied by the development of distant metastases and a high rate of local recurrence. The molecular hallmark is a specific reciprocal $t(12 ; 16)$ translocation, which results in a chimeric FUS-DDIT3 fusion protein that acts as an oncogenic transcription factor; however, the exact mechanisms of FUS-DDIT3 mediated MLS pathogenesis are incompletely understood. We here investigate the relevance of the transcription factor cAMP response element-binding protein (CREB) in MLS in vitro and in vivo. Methods. A large cohort of MLS tissue specimens $(n=92)$ was immunohistochemically analyzed regarding the phosphorylation of CREB (S133) and the expression of CREB related downstream targets Rb, Cyclin D1, PCNA, Bcl-xL. The dependence of CREB on FUS-DDIT3 was analyzed by induced expression of the FUS-DDIT3 transcript in human mesenchymal stem cells and by RNAi-mediated knockdown of FUS-DDIT3 in MLS cells. CREB-mediated transcriptional activity was modulated through small molecule inhibitors (666-15, KG-501, NASTRp, Ro-318220) and $C R E B$-specific siRNA, and the biological effects were monitored by immunoblotting, real time cell viability and apoptosis assays. A MLS cell line-based chorio-allantoic membrane model was used for in vivo confirmation.

Results. By immunohistochemistry, elevated CREB phosphorylation (S133) levels were detected in approximately $60 \%$ of MLS tissue specimens. In MLS cells, RNAi-mediated knockdown of FUSDDIT3 led to decreased phosphorylation levels of CREB (S133), accompanied by reduced transcriptional activity. RNAi-mediated knockdown of CREB resulted in significantly reduced cell viability and transcriptional activity in MLS cells. Induced expression of FUS-DDIT3 was associated with CREB (S133) phosphorylation and increased CREB downstream target expression in mesenchymal stem cells. Stimulation of MLS cells with IGF-II led to elevated phosphorylation levels of CREB (S133), while RNAi-mediated knockdown of IGF-1R reduced CREB (S133) phosphorylation. Application of small molecule inhibitors (666-15, KG-501, NASTRp, Ro-318220) significantly reduced MLS cell viability in vitro and MLS tumor growth in vivo. Conclusion. Our preclinical study demonstrates the essential role of FUS-DDIT3-dependent CREB-mediated transcriptional activity in MLS tumorigenesis and provides a molecularly based rationale for a novel targeted therapeutic approach.

\section{AG08.06 \\ IGF-IR-dependent signals promote YAP activity in myxoid liposarcoma}

R. Berthold ${ }^{*}$, I. Isfort', M. Cyra' , A. Hildebrand ${ }^{1}$, D. Brandes' ${ }^{1}$, T. Kindler ${ }^{2}$, P. Åman ${ }^{3}$, I. Grünewald', S. Huss', E. Wardelmann', M. Trautmann', W. Hartmann ${ }^{7}$

'Division of Translational Pathology, Gerhard-Domagk-Institute of Pathology, Münster University Hospital, Münster, Germany, ${ }^{2}$ Department of Hematology, Medical Oncology and Pneumology, University Medical Center of Mainz, Mainz, Germany, ${ }^{3}$ Sahlgrenska Cancer Center, Department of Pathology and Genetics, Institute of Biomedicine, Sahlgrenska Academy at University of Gothenburg, Gothenburg, Sweden, ${ }^{4}$ Gerhard-DomagkInstitute of Pathology, Münster University Hospital, Münster, Germany
Aim. Myxoid liposarcoma (MLS) is a soft tissue sarcoma clinically characterized by a propensity to local recurrence and metastasis occurring in up to $40 \%$ of patients, highlighting the need for novel tailored therapeutic approaches. Genetically, $>95 \%$ of MLS tumors harbor a reciprocal $t(12 ; 16)$ translocation which encodes a chimeric FUS-DDIT3 fusion protein. Acting as a transcriptional dysregulator, FUS-DDIT3 was previously shown to mediate activation of IGF-IR/PI3K/Akt signaling. Recently, aberrant expression of the Hippo effector YAP was described as an oncogenic hallmark driving MLS pathogenesis. In this study, we aimed to investigate whether the IGF-IR/PI3K/Akt- and MAPK signaling pathways contribute to aberrant YAP expression/activity to identify an expedient set of molecular targets that might be addressed in a combined therapeutic strategy for MLS cancer patients.

Methods. Immunohistochemical analysis of the IGF-IR/PI3K/Akt, MAPK- and Hippo signaling pathways was performed in a comprehensive cohort of MLS tumor specimens $(n=56)$. A stable cell culture model of FUS-DDIT3 expressing mesenchymal stem cells was employed. In MLS cell lines, signaling interactions between the involved pathways were investigated using RNAi approaches and pharmacologic inhibition with different small molecule compounds. Effects on the Hippo signaling pathway were analyzed by immunoblotting and YAP/TAZ-TEAD luciferase reporter assays. MLS cell viability was assessed by MTT assays.

Results. Immunohistochemical staining of MLS tissue specimens demonstrated a concomitant activation of the Hippo effectors YAP/TAZ, the IGFIR/PI3K/Akt- and MAPK signaling pathways in a significant subset of MLS tumors. Both, IGF-IR-dependent signals and YAP expression were shown to be functionally dependent on FUS-DDIT3. In MLS cell lines, inhibition of the IGF-IR/PI3K/Akt signaling cascade promoted downregulation of YAP, accompanied by a reduced YAP/TAZ-TEAD transcriptional activity. Dual inhibition of the central signaling nodes PI3K and MEK1/2 resulted in enhanced downregulation of YAP, associated with an increased suppression of MLS cell viability.

Conclusion. Our study indicates a mechanism of activation/stabilization of oncogenic YAP through FUS-DDIT3-dependent kinase signaling inputs, mediated by an integrated regulatory network of IGF-IR/PI3K/Akt- and MAPK signaling. Overall, these findings suggest the conception of a combinatorial therapeutic approach to effectively target YAP in MLS.

\section{AG08.07 \\ FUS-DDIT3 drives FOXM1 transcriptional activity in myxoid liposarcoma}

A. Hildebrand ${ }^{1 *}$, I. Isfort ${ }^{1}$, M. Cyra', R. Berthold' ${ }^{1}$, T. Kindler' ${ }^{2}$, E. Wardelmann ${ }^{3}$, M. Trautmann", W. Hartmann

'Division of Translational Pathology, Gerhard-Domagk-Institute of Pathology, Münster University Hospital, Münster, Germany, ${ }^{2}$ Department of Hematology, Medical Oncology and Pneumology, University Medical Center of Mainz, Mainz, Germany, ${ }^{3}$ Gerhard-Domagk-Institute of Pathology, Münster University Hospital, Münster, Germany

Introduction. Myxoid liposarcoma (MLS) is a rare soft-tissue tumor, however, representing the most common type of liposarcomas in adolescents and young adults. It is driven by a reciprocal translocation $\mathrm{t}(12 ; 16)$ resulting in the chimeric FUS-DDIT3 fusion protein which acts as a transcriptional dysregulator. Due to the existence of different fusion variants direct therapeutic targeting of the fusion protein itself represents a particular challenge. Against the background of high expression levels of the transcription factor FOXM1 in liposarcomas this study aimed to understand the functional role of FOXM1 in MLS and to decipher the functional link to the FUS-DDIT3 fusion protein.

Methods. FOXM1 expression levels were analyzed via immunohistochemical stainings in a large cohort of MLS tissue specimens. Three MLS cell lines and a mesenchymal stem cell line (SCP-1) stably transfected with the FUS-DDIT3 fusion gene were used for in vitro analyses. To further decipher the impact of FUS-DDIT3 with regard to FOXM1 expression levels, RNAi approaches targeting FUS-DDIT3 were performed in MLS cell lines. Eventually, FOXM1 was depleted by RNAi or functionally antagonized 
through the proteasome inhibitors Thiostreptone and Siomycin A, and cellular proliferation was measured with MTT assays.

Results. In MLS tissue specimens, strong expression of the transcription factor FOXM1 was detectable. While the overexpression of the FUSDDIT3 fusion protein in SCP-1 cells induced aberrant FOXM1 expression, siRNA-mediated knockdown of FUS-DDIT3 in MLS cell lines revealed a significant reduction of FOXM1 expression. Inhibition of FOXM1 via siRNA or Thiostreptone/Siomycin A treatment resulted in a significant reduction of FOXM1 downstream target expression as well as tumor cell viability.

Conclusions. Our study reveals that FUS-DDIT3 driven expression of the transcription factor FOXM1 plays a significant role in MLS tumor cell viability. Therefore, inhibition of FOXM1 might contribute to novel therapeutic strategies in myxoid liposarcoma.

\section{AG Knochen-, Gelenk- und Weichgewebspathologie II}

\section{AG08.08 \\ Aberrant expression of the developmental transcription factor SOX6 creates a therapeutic vulnerability in Ewing sarcoma}

A. Marchetto', S. Ohmura', M. Orth' ', D. Saucier' ${ }^{2}$, C. Arrigoni' ${ }^{3}$, J. Li', F. Wehweck', J. Gerke', M. Baldauf', M. Dallmayer', M. Knott', J. Musa', S. Stein', T. Hölting' ', L. Romero-Pérez', F. Cidre-Aranaz', M. Moretti”, J. Amatruda ${ }^{2}$, T. Kirchner', G. Sannino', T. Grünewald ${ }^{1 *}$

'Pathologisches Institut der LMU München, Munich, Germany, ${ }^{2}$ University of Texas Southwestern Medical Center and Children's Medical Center, Dallas, United States, ${ }^{3}$ Regenerative Medicine Technologies Lab, Ente Ospedaliero Cantonale (EOC), Lugano, Switzerland

Background. Ewing sarcoma (EwS) is an aggressive bone or soft-tissue cancer likely originating from mesenchymal stem cells or early-committed osteo-chondrogenic progenitors. Genetically, EwS is characterized by gene fusions involving EWSR 1 and members of the ETS-family of transcription factors (in 85\% FLI1). EWSR1-FLI1 induces many of its target genes by diverting GGAA-microsatellites (mSats) as enhancers, whose activity increases with the number of GGAA-repeats. However, which EWSR1-FLI1 targets contribute to the highly proliferative phenotype of EwS remains largely unknown

Methods \& Results. Combining comprehensive microarray and immunohistochemistry analysis of cancer and normal tissues, we identified the developmental transcription factor SOX6 that physiologically promotes proliferation of osteo-chondrogenic progenitors as strongly overexpressed in EwS. ChIPSeq analysis revealed a prominent EWSR1-FLI1 peak in intron 1 of SOX6 that overlaid with regulatory histone marks and mapped to a GGAA-mSat. This GGAA-mSat showed EWSR1-FLI1-dependent enhancer activity in reporter assays, and the number of its GGAA-repeats correlated with SOX6 expression levels in EwS cell lines. Transcriptome-profiling followed by gene-set enrichment analyses revealed that SOX6 expression induces pro-proliferative signatures in EwS cells. Consistently, RNA interference-mediated SOX6 knockdown significantly reduced proliferation, spheroidal growth, and tumorigenicity of EwS cells. Through integration of published drug-screen data and functional in vitro and in vivo drug-response assays, we discovered that SOX6 confers sensitivity toward the small molecule Elesclomol in EwS via upregulation of reactive oxygen species (ROS), which may be exploited clinically.

Conclusions. Collectively, our results demonstrate that SOX6 is a direct EWSR1-FLI1 target gene contributing to proliferation and tumor growth of EwS cells, and that high SOX6 expression may constitute a druggable vulnerability of EwS.

\section{AG08.09}

ZFP36-FOSB-fusioniertes spindelzelliges epitheloides Hämangiom des Knochens: Hinweise für eine Verwandtschaft mit Pseudomyogenen Hämangioendotheliomen

F. Keil ${ }^{1 *}$, W. Dietmaier ${ }^{2}$, A. Hillmann ${ }^{3}$, P. Hoffstetter' ${ }^{4}$, M. Evert ${ }^{1}$

IInstitut für Pathologie der Universität Regensburg, Regensburg, Deutschland, ${ }^{2}$ Institut für Pathologie der Universität Regensburg, Molekularpathologische Diagnostik, Regensburg, Deutschland, ${ }^{3}$ Asklepios Fachkrankenhaus, Zentrum für Sarkome und Muskuloskelettale Tumoren, Bad Abbach, Deutschland, ${ }^{4}$ Asklepios Fachkrankenhaus, Institut für Radiologie, Bad Abbach, Deutschland

Ziel. Vaskuläre Knochentumoren sind eine diagnostisch schwierige Entität. Neue molekulare Erkenntnisse können die Diagnoseführung erleichtern und das Spektrum der Entitäten durch molekulare Definition verändern. Das epitheloide Hämangiom $(\mathrm{EH})$ ist eine benigne vaskuläre Neoplasie mit charakteristischen ,tomb-stone“-förmigen neoplastischen Endothelzellen. Einem Teil der EH liegen FOSB-Fusionen zugrunde, meist mit dem Fusionspartner ZFP36. Das pseudomyogene Hämangioendotheliom (PHE) hingegen ist ein rein spindelzelliger Gefäßtumor, der sich ebenfalls durch FOSB-Rearrangements aber mit anderen Fusionspartnern auszeichnet. Wir präsentieren einen „Hybrid-Tumor“, der morphologisch dem PHE, aber molekular dem EH nähersteht und dadurch die Frage nach einem durch FOSB-Translokationen definierten Tumorspektrum aufwirft, an dessen Enden das EH und das PHE anzusiedeln sind.

Methoden. Fallbericht eines Knochentumors, der klinisch, radiologisch und umfangreich histopathologisch, immunhistochemisch und molekularpathologisch aufgearbeitet wurde.

Ergebnisse. Ein 31-jähriger Mann mit Schmerzen im Bereich des rechten Unterschenkels und Sprunggelenks wies radiologisch multiostotisch osteolytische Herde auf, von denen mehrere in kurzen Zeitabständen biopsiert wurden. Histologisch zeigte sich ein fast rein spindelzelliger Tumor mit Expression von CD31, diffus Pan-Cytokeratin (AE1/3) und FOSB (- Abb. 1 |AG08.09). Lediglich fokal fanden sich abortive neoplastische epitheloide Gefäßstrukturen. Klinik, Bildgebung (• Abb. 2 |AG08.09), Histomorphologie und Immunhistochemie waren typisch für ein PHE. Molekularpathologisch fand sich aber eine ZFP36-FOSB-Fusion, die für bestimmte $\mathrm{EH}$ typisch ist und somit zur finalen Diagnose eines multiostotischen hämorrhagischen und spindelzelligen $\mathrm{EH}$ führte. Ein solcher Tumor wurde erstmals von Keel und Rosenberg beschrieben. Die hier

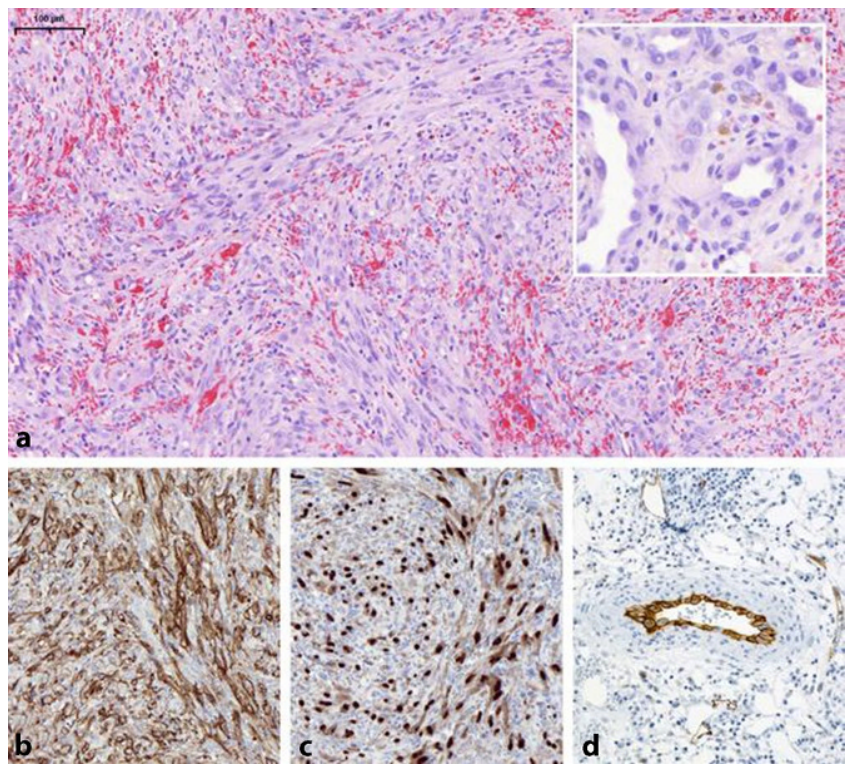

Abb. 1 | AG08.09 $\triangle$ Spindelzelliger Tumor HE (Inset: tomb-stone Gefäße, $\mathrm{x} 400)(\mathbf{a})$, CD31 (b), FOSB (c), CD34 (d), x200 

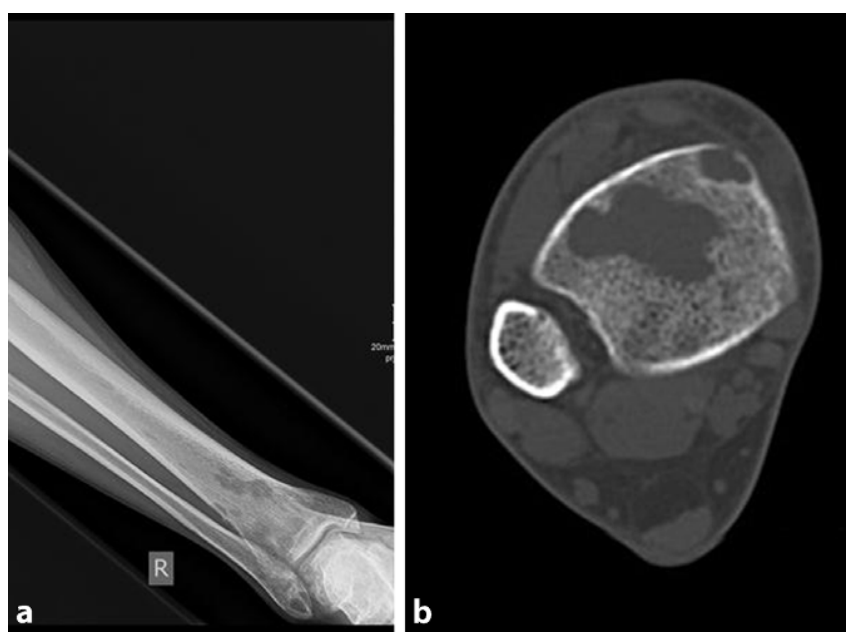

Abb. 2 | AG08.09 ^ Multiple lytische Läsionen ohne Periostreaktion und ohne sklerotischen Randsaum (a Röntgen, b CT)

erstmals beschriebene ZFP36-FOSB-Fusion legt die genetische Verwandtschaft zum EH nahe.

Fazit. Das PHE und das EH sind zumindest im Knochen sehr nahestehende Tumoren, die möglicherweise Bestandteil einer Familie vaskulärer Neoplasien sind, die durch FOSB-Translokationen gekennzeichnet sind. Morphologisch stellen sie die Enden eines Differenzierungsspektrums von entweder epitheloiden vasoformativen (EH) oder spindelzelligen Tumoren ohne Lumenbildung (PHE) mit unterschiedlichen klinischen Verläufen dar. Weitere Fallberichte und -serien sind notwendig, um diese Hypothese zu stützen und die Klassifikation FOSB-rearrangierter Gefäßtumoren ggf. zu adaptieren.

\section{AG08.10}

\section{Clivale und sacrale Chordomzelllinien weisen eine differentielle DNA-Methylierung an HOX Genorten auf}

\section{Holley ${ }^{1 * 2,}$, J. Vogt' ${ }^{2}$, R. Siebert ${ }^{2}$, P. Möller ${ }^{1}$, K. Mellert ${ }^{1}$, T. F. E. Barth ${ }^{1}$}

${ }^{1}$ Universität Ulm, Institut für Pathologie, Ulm, Deutschland, ${ }^{2}$ Universität UIm, Institut für Humangenetik, Ulm, Deutschland

Ziel. Chordome sind seltene primär maligne Knochentumoren, die eine notochordale Differenzierung aufweisen und sich vorwiegend am Clivus und Os sacrum manifestieren. Vorarbeiten an stabilen Chordomzelllinien zeigten, dass unter anderem $H O X$ Gene in clivalen im Vergleich zu sacralen Chordomen geringer exprimiert werden (Jäger et al.; Sci Reports; 2017). Ziel der Arbeit ist es, genomweit die DNA-Methylierung in Chordomzelllinien zu ermitteln und diesen mit Expressionsdaten zu korrelieren.

Methoden. In die DNA-Methylierungsanalysen wurden 17 stabile Chordomzelllinien eingeschlossen, darunter 14 sacrale und drei clivale. Zudem wurden publizierte DNA-Methylierungsdaten von 22 Chordomen (Hasselblatt; et al.; Acta Neuropathol; 2016) eingeschlossen. Als Vergleichsproben dienten mesenchymale Stammzellen (MSCs) dreier gesunder Probanden. Mit Hilfe des Infinium-MethylationEPIC BeadChip wurde die DNA-Methylierung von über 800.000 CpG Loci gemessen. Die Auswertung der DNA-Methylierungsanalysen erfolgte mit dem Programm Qlucore Omics Explorer. Einige ausgewählte differentiell methylierte Gene wurden mit Expressionsdaten unter Verwendung der Software Genespring verglichen.

Ergebnisse. Bei der Gegenüberstellung von MSCs und Chordomgewebeproben erwiesen sich in einer unsupervidierten Analyse $\left(\sigma / \sigma_{\max }\right.$ $\geq 0,4) 65.461 \mathrm{CpG}$ Stellen, in einer supervidierten Analyse $\left(\sigma / \sigma_{\max } \geq 0,4\right.$, $\mathrm{q} \leq 1 \mathrm{e}^{-7}$ ) 2457 CpG Stellen als differentiell methyliert. In Chordomen fiel im Vergleich zu MSCs u. a. eine Hypermethylierung im Promotor des miRNA199A Gens auf, das eine Rolle in der Skelettentwicklung hat. Auch in den Chordomzelllinien zeigte sich dieses Gen gegenüber den mesenchymalen Stammzellen hypermethyliert. Die Gegenüberstellung clivaler und sacraler Chordome $\left(\sigma / \sigma_{\max } \geq 0,4, \mathrm{q} \leq 0,05\right)$ zeigte 126 differentiell methylierte Loci. Innerhalb dieser CpG Loci fielen 22 Loci auf, die eine Hypermethylierung im Promotor einiger Vertreter des HOXA Clusters in clivalen Chordomen aufwiesen. Die Hypermethylierung korreliert mit der geringeren Expression verschiedener HOXA Gene $(A 2, A 5, A 7, A 10)$ in clivalen im Vergleich zu sacralen Chordomen.

Fazit. Das im Vergleich zu MSCs in Chordomen hypermethylierte miRNA199A Gen könnte eine Rolle in der Pathogenese dieser Tumorentität spielen, da es eine Bedeutung in der Skelettentwicklung hat und im Notochord exprimiert wird. Die geringere Expression von Vertretern des HOXA Clusters in clivalen Chordomen korreliert mit der Hypermethylierung im Promotor dieser Gene.

AG08.11

Die miRNA196a-5p reguliert über HOXB7 und BMP4 die WNT1 Expression in Chordomzellen

C. Seeling*, P. Möller, T. F. E. Barth, K. Mellert

Universität Ulm, Institut für Pathologie, Ulm, Deutschland

Ziel. Chordome sind maligne, primär ossäre Tumoren mit notochordaler Differenzierung. Charakterisiert werden Chordome durch die Expression des Transkriptionsfaktors Brachyury.

Wir konnten zeigen, dass sich Chordome des Clivus und des Sakrums durch die Expression verschiedener HOX-Gene unterscheiden (Jäger et al.; Sci Reports; 2017). Diese Gene werden durch microRNAs der Familie miRNA-196 mitreguliert.

Daraus leitet sich die Hypothese ab, dass eine stark reduzierte Expression der miRNA196a-5p zu gesteigerten HOXB7 mRNA Leveln führt, was in einer Expressionssteigerung von BMP4 resultiert. BMP4 könnte so über die Phosphorylierung von SMAD1/5 den WNT1/ $\beta$-catenin Signalweg aktivieren und an der Regulierung der Expression von Brachyury beteiligt sein.

Methoden. Die Expression der miRNA196a-5p und HOXB7 wurde mittels qPCR in jeweils drei stabilen Chordom-Zelllinien clivalen und sakralen Ursprungs analysiert.

Um den regulatorischen Einfluss der reifen miRNA196a-5p auf HOXB7 zu untersuchen, wurde diese in der Zelllinie U-CH1 durch Transfektion mit einem miRNA-Mimic überexprimiert und auf Unterschiede in der Expression des Zielgens durch qPCR und Western Blot Analysen überprüft. Mit einem siRNA induzierten Knockdown von HOXB7 wurde die Wirkung auf BMP4 bestimmt.

Die Proteinmengen von pSMAD1/5 und WNT1 wurden in Chordomzellen quantifiziert, welche mit rekombinantem BMP4 und in Kombination mit dem BMP4-Antagonisten Noggin behandelt worden waren.

Ergebnisse. Die Expression der miR196a-5p ist in Zelllinien sakralen Ursprungs signifikant schwächer als in Linien clivaler Lokalisation und korreliert invers mit der Expression von HOXB7. Re-expression der miRNA führte zu einer Verminderung der HOXB7 und BMP4 Expression.

Folglich ist es wahrscheinlich, dass BMP4 ein Zielgen von HOXB7 ist, da durch einen siRNA induzierten HOXB7-Knockdown geringere BMP4 Level gemessen wurden.

Die Behandlung von Chordomzellen mit rekombinantem BMP4 induzierte die Phosphorylierung von SMAD1/5 und ist durch Noggin antagonisierbar.

Zudem waren erhöhte Mengen des WNT1-Proteins nachweisbar. Dies lässt vermuten, dass WNT1 eine Zielstruktur des BMP4-Signalweges ist. Fazit. Die miR196a-5p wird von sakralen, jedoch nicht in clivalen Chordomen vermindert exprimiert. Sie reguliert sie über HOXB7 die Expression von $B M P 4$, welches eine Phosphorylierung von SMAD1/5 induziert und zu erhöhten WNT1 Proteinmengen führt. Diese Ergebnisse weisen auf weitere fundamentale Unterschiede clivaler und sakraler Chordome hin. 
AG08.12

\section{Die Hypermethylierung der Gene EGR3, ETV1, IGFBP3 und UCHL1 definiert den Riesenzelltumor des Knochens}

\author{
J. P. Giesche ${ }^{1 *}$, R. Wagener ${ }^{2}$, S. Geißler ${ }^{3}$, K. Mellert $^{1}$, R. Marienfeld ${ }^{1}$, R. Siebert ${ }^{2}$, \\ P. Möller', T.F.E. Barth ${ }^{1}$ \\ 'Institut für Pathologie, Universitätsklinikum Ulm, Ulm, Deutschland, \\ ${ }^{2}$ Institut für Humangenetik, Universitätsklinikum Ulm, Ulm, Deutschland, \\ ${ }^{3}$ Berlin-Brandenburger Centrum für Regenerative Therapien \& Julius Wolff \\ Institut, Charité - Universitätsmedizin Berlin, Berlin, Deutschland
}

Ziel. Riesenzelltumoren des Knochens (RZTK) sind charakterisiert durch die H3F3A-Mutation G34 W, die als entscheidende Treibermutation in diesem Tumor angesehen wird. Ziel war es zu untersuchen, ob die Expression bestimmter Gene invers mit der entsprechenden Promotormethylierung korreliert.

Methoden. Es wurden 23 Fälle H3F3A-mutierter RZTK hinsichtlich der genomweiten DNA-Methylierung analysiert. Darunter waren 12 Primärtumoren und 4 Rezidive aus FFPE-Gewebe sowie 7 stabile RZTK-Zelllinien. Außerdem wurden FFPE-Gewebeproben anderer riesenzellhaltiger Knochenläsionen (RZKL) (3 aneurysmatische Knochenzysten (AKZ), 3 braune Tumoren (BT), 3 Chondroblastome (CB) und 3 nicht ossifizierende Fibrome (NOF)) untersucht. Als physiologische Vergleichszellen wurden 21 mesenchymale Stammzellen (MSC) und 3 Osteoblasten (OB) von tumorfreien Patienten inkludiert. Die DNA-Methylierung wurde mit Infinium HumanMethylationEPIC BeadChip Arrays der Firma Illumina untersucht, mit denen der Methylierungsstatus von mehr als 850.000 Loci ermittelt werden kann. Die Auswertung der DNA-Methylierungsdaten erfolgte mit der GenomeStudio- und der Qlucore Omics Explorer-Software. Die Expressionsrate einiger Gene, die in der entsprechenden Promotorregion in RZTK signifikant stärker methyliert waren als in MSC und OB, wurde in RZTK-Zelllinien, kultivierten MSC und kultivierten OB mittels quantitativer Echtzeit-PCR bestimmt.

Ergebnisse. Durch einen supervidierten Zweigruppenvergleich zwischen 12 RZTK-Primärtumoren, 1 RZTK-Rezidiv, 6 RZTK-Zellinien in der einen Gruppe und 21 MSC, 3 OB in der anderen Gruppe konnten 1543 signifikant differenziell methylierte Loci identifiziert werden $\left(\sigma / \sigma_{\max }=0,4\right.$; $\mathrm{q}<10^{-17}$ ). Darunter waren 18 in RZTK hypermethylierte Loci in den Promotorregionen der Gene EGR3, ETV1, IGFBP3 und UCHL1 lokalisiert. Die Expressionsanalysen zeigten, dass diese 4 Gene in RZTK-Zelllinien signifikant niedriger exprimiert sind als in kultivierten MSC und OB. Auch die anderen RZKL zeigten in den 18 Loci eine schwächere Methylierung als RZTK, was sie differenzialdiagnostisch von RZTK abgrenzt.

Fazit. RZTK haben ein tumorspezifisches DNA-Methylierungsmuster, das sich von dem anderer RZKL, MSC und OB unterscheidet. RZTK-Zelllinien sind in den Promotorregionen der Gene EGR3, ETV1, IGFBP3 und UCHL1 stärker methyliert als andere RZKL, MSC und OB, was mit einer niedrigeren Genexpression einhergeht.

\section{AG08.13 \\ Epigenetische Fingerabdrücke in Sarkomen - vom Methylom zur Diagnose \\ C. Kölsche* \\ Pathologie des Universitätsklinikums Heidelberg, Heidelberg, Deutschland}

Sarkome sind maligne Tumore mesenchymalen Ursprungs. Für viele dieser Sarkom-Subtypen existiert bislang keine sichere Zuordnung mithilfe konventioneller Methoden. Im klinischen Alltag führt dies mitunter zu einem diagnostischen Dilemma.

Einen neuen Ansatz zur Charakterisierung von Tumorgewebe bietet die Untersuchung epigenetischer Veränderungen. Neuartige, Array-basierte Analyseverfahren generieren genomweite Methylierungsdaten unter Verwendung geringster DNA-Mengen. Erst dies ermöglicht eine sinnvolle Anwendung im diagnostischen Alltag.

Aus genomweiten DNA-Methylierungsdaten lässt sich die Differenzierung eines Gewebes ableiten. Dieses Charakteristikum lässt sich für die Tumordiagnostik nutzen. So lassen sich DNA-Methylierungsprofile zur
Klassifikation der meisten Tumoren des Nervensystems verwenden. Auf Grundlage dieser Vorarbeit haben wir ein auf Methylierung basierendes Klassifikationswerkzeug für Weichgewebs- und Knochentumoren entwickelt. Fälle mit ähnlichem DNA-Methylierungsprofil gruppieren sich, sie bilden sogenannte Cluster. Die vorliegenden Daten in Sarkomen sprechen für Subtypen-spezifische Methylierungssignaturen (= epigenetische „Fingerabdrücke").

Prototypische Sarkome bilden die Grundlage für den Klassifikations-Algorithmus und werden als Referenzset in einer Datenbank hinterlegt. Sie dienen als Orientierungspunkte für die Zuordnung einer individuellen Tumorprobe. Hierzu wird der „Random-Forest“-Classifier-Algorithmus verwendet. Dieser Algorithmus erlernt anhand des Referenzsets eine Klassifikationsregel, um Tumorproben jeweils einer Klasse zuzuordnen.

Wir haben die Möglichkeit geschaffen, Standort-unabhängig Tumorproben mit der Datenbank des Sarkom-Classifiers abzugleichen. Hierzu wurde von uns das Webportal www.molecularsarcomapathology.org entwickelt. Der Anwender lädt die Methylierungsdaten der zu untersuchenden Tumorprobe über diese Webpage auf unseren Server. Bereits nach wenigen Minuten hat der Klassifikationsalgorithmus die Probe mit der Referenzdatenbank abgeglichen. Das Ergebnis wird dem Nutzer in Form eines molekularen Befunds übermittelt.

Zukünftig werden neuartige molekulare Analysen, möglicherweise auch die hier präsentierte DNA-Methylierungsanalysen, in bestehende Klassifikationsalgorithmen von Sarkomen berücksichtig werden. Es besteht die begründete Hoffnung, dass innovative Klassifikationswerkzeuge die diagnostische Fehlerrate in Sarkomen reduzieren werden.

\section{AG Dermatopathologie I}

\section{AG09.01 \\ Merkel cell carcinoma}

I. Moll*

DermatoMed Hamburg, Hamburg, Germany

Merkel cell carcinoma (MCC) is a rare and aggressive neuroendocrine carcinoma of the skin. Originally it was described as trabecular carcinoma of eccrine glands but later by the typical ultrastructure-dense-core granules-identified as a neuroendocrine tumor and named MCC thereafter. The neuroendocrine Merkel cell was previously believed to be the cell of origin. However, Merkel cells are postmitotic and thus probably not the cell of origin of MCC. During the last years the embryological and adult histogenesis of Merkel cells has been elucidated. It is an epithelial cell and derived from an epidermal stem cell, which also might represent the cell of origin of MCC. Moreover, a dermally derived stem cell has been discussed, also because the tumors develop within the dermis. Further putative cells of origin are the pre/pro-B-cells, which show some markers-PAX-5, TdT, monoclonal IgH and Igk rearrangement-in common with MCC.

In Europe about $80 \%$ of MCC are induced by the integration of the DNA of the Merkel cell polyoma virus (MCPyV) into the genome. On the other hand about $20 \%$ of MCC are UV induced because they show an extremely high amount of mutations mostly with the typical UV signature.

In routine histology the MCC is monomorphic and the diagnosis is confirmed by immunohistochemistry showing CK20 arranged in typical paranuclear dots, together with the presence of neurofilaments and chromogranin A. In contrast, there is absence of TTF-1, which is positive in small cell carcinoma of the lung, the most frequent differential diagnosis. Virus-positive and virus-negative MCC are not different histologically. Circulating tumor cells (CTCs) seem to be helpful in tumor tracking.

UV-induced, MCPyV-negative tumors exhibit one of the highest numbers of mutations known and the virus-positive tumors host viral neoantigens. This gives rise to the immunogenicity of MCC, which is reflected by the prevalence of the MCC in immunoincompetent and elderly patients. Moreover, during the last years the presence of PD-L1 has been demonstrated within tumors and the microenvironment mostly in low 
and variable amounts, in line with the efficacy of checkpoint inhibitors. For pembrolizumab and avelumab responses of about $60 \%$ have been shown interestingly both in virus-positive and virus-negative cases. Further immunological and molecular studies are necessary to find biomarkers for the about $40 \%$ non-responders for future individual therapies.

\section{AG09.03 Imaging mass spectrometry analysis enables in situ detection of HPV in FFPE tissues}

R. Casadonte ${ }^{*}$, M. Esser ${ }^{2}$, M. Kriegsmann ${ }^{3}$, K. Kriegsmann ${ }^{4}$, J. Kriegsmann ${ }^{1,2}$

${ }^{1}$ Proteopath $\mathrm{GmbH}$, Trier, Germany, ${ }^{2}$ Center for Histology, Cytology and Molecular Diagnostic Trier, Trier, Germany, ${ }^{3} U$ niversity of Heidelberg, Institute of Pathology, Heidelberg, Germany, ${ }^{4}$ University of Heidelberg, Department of Hematology, Oncology and Rheumatology, Heidelberg, Germany

Aim. Cutaneous warts are benign papillomas of the skin caused by infection with human papillomavirus (HPV). HPV comprise a family of more than 130 types. Most warts are associated with low-risk HPV strains, and habour no or little potential for malignant progression. Warts typically continue to increase in size and distribution and may become more resistant to treatment. Diagnostic tests are required to detect high-risk but also low-risk HPV subtypes with high specificity and sensitivity. We developed a proteomic-based imaging mass spectrometry (IMS) approach to investigate HPV molecular signals directly from host specimens.

Methods. Formalin-fixed paraffin-embedded (FFPE) tissue sections from skin warts were deparaffinized, antigen retrieved, in-situ trypsin digested and covered with alpha-cyano-4-hydroxycinnamic acid matrix for IMS analysis using a rapifleX MALDI Tissuetyper (Bruker Daltonik). Clinical examination of warts including appearance, size, consistency and distribution were recorded. Mass spectra were exported from regions of interest and compared with histopathological diagnosis.

Results. IMS allowed to obtain several molecular signals directly from tissue sections in a spatially-targeted approach. Collected mass spectra from HPV infected and non-infected tissue regions were compared and evaluated. More than fifty peptide signals were identified in the HPV infected tissue regions. Interestingly, specific peptide signals correlated with the virus location moving from the lower to the top epidermis skin layers. Conclusion. We detected specific peptides related to HPV directly from the host specimens using IMS. The ability to rapidly identify signatures specific to microorganisms in tissue is a major advantage that greatly decrease both time and cost.

\section{AG09.04 \\ Drugs, mechanisms and pathological patterns in skin biopsies with adverse cutaneous reactions}

I. Petersen ${ }^{1 *}$, A. Hryb ${ }^{1}$, M. Kaatz ${ }^{2}$

'SRH Poliklinik Gera GmbH, Waldklinikum Gera, Institut für Pathologie, Gera, Germany, ${ }^{2}$ SRH Poliklinik Gera GmbH, Waldklinikum Gera, Klinik für Dermatologie, Gera, Germany

Aim. Skin biopsy is an established procedure to resolve the underlying cause of dermatological changes. Drug eruptions represent an important differential diagnosis and the (dermato-) pathologist may provide considerable help to the clinician. However, the issue is highly complex..

Methods. The different morphological patterns of cutaneous drug eruptions were retrieved from dermatopathology books and review articles. Then a PubMed keyword search was performed to identify drugs that have been associated with these patterns. All identified drugs were summarized within Excel tables. Drugs were then listed according to the number of publications in which they were mentioned as causative agent. Mechanisms of actions were retrieved from the literature.

Results. Classical cutaneous patterns associated with drugs are fixed drug eruption, urticaria, Stevens-Johnson-Syndrome/Toxic Epidermal Necrolysis, acute generalized exanthematous pustulosis and drug-induced hy- persensitivity syndrome/drug reaction with eosinophlia and systemic symptoms. Drug reaction may also include photosensitivity, hyperpigmentation, acneiform eruptions, lichenoid reactions, alopecia, erythema multiforme, granulomatous dermatitis or lymphcytic dermatitis. However, almost any skin pathology like psoriasis, pemphigus, pemphgoid, spongiosis or granuloma anulare may be induced by drugs. Causative agents are for instance antibiotics (penicillins, tetracyclins), benzothiadiazines (chlorothiazide), phenothiazines (chlorpromazine), antimycotics (voriconazole and terbinafin), angiotensin II receptor blockers (sartans), ACE-inhibitors (captopril), allopurinol and carbamazepine. Furthermore, monoclonal antibodies and targeted Inhibitors frequently cause drug eruptions as anti-TNF antibodies, anti-PD1 immune checkpoint Inhibitors (nivolum$a b$, pembrolizumab), kinase inhibitors (vemurafenib). There are certains correlations between specific drugs and histopathological patterns, e.g. anti-TNF Inhibitors and psoriasis-like eruptions. However, many drugs are associated with multiple patterns.

Conclusion. Cutaneous drug eruptions represents a challenging and fascinating field in (dermato-) pathology. It requires knowledge in pharmacology, immunology, cell biology, biochemistry, genetics, histopathology and more as the molecular mechanisms relate to drug hypersensitivity reactions as well as drug metabolism, distribution and host-specific effects of the drugs on the effector cells in the skin.

\section{AG Dermatopathologie II}

\section{AG09.05 \\ Hängt die Gewebereaktion vliesartiger Biomaterialien von der Filamentstärke ab? - histopathologische Ergebnisse aus einer tierexperimentellen Studie}

\section{F. Barsch ${ }^{*}$, A. Mamilos ${ }^{1}$, V. Schmitt ${ }^{2}$, W. Wagner ${ }^{3}$, M. Benckendorff,} H. Hierlemann ${ }^{5}$, C. Brochhausen ${ }^{1}$

'REPAIR-Lab, Institut für Pathologie, Universität Regensburg, Regensburg, Deutschland, ${ }^{2}$ Universitätsmedizin Mainz, Kardiologie I, Mainz, Deutschland, ${ }^{3}$ Ruprecht-Karl Universität Heidelberg, Klinik für Diagnostische und Interventionelle Radiologie, Heidelberg, Deutschland, ${ }^{4}$ Universitätsmedizin Mainz, Klinik für Anästhesiologie, Mainz, Deutschland, ${ }^{5}$ Polymedics GmbH, Denkendorf, Deutschland

Ziel. Während epidermale Schädigungen ohne Zerstörung der Basalmembran sehr gute kutane Regeneration bei geringem therapeutischen Aufwand bedeuten, kann es bei tieferer und großflächiger Zerstörung des Gewebes zu ungünstiger Narbenbildung und gravierenden Funktionseinschränkungen der Haut kommen. Aufwendige Therapien stehen hierbei in ungünstigem Verhältnis zu kosmetischen und funktionellen Ergebnissen der dermalen Regeneration. Dieser Problematik versuchen interdisziplinäre Forschungsgruppen im Bereich des Tissue Engineerings der Haut mit neu konzipierten Hautersatzstoffen entgegenzutreten. Dabei werden Biomaterialien erforscht, die als Matrix der Geweberegeneration dienen sollen. An der Schnittstelle zwischen Biomaterial und Gewebe kann es zur Fremdkörperreaktion kommen. Ziel ist die Untersuchung des Einflusses der Biomaterialkonstruktion auf die zellulären Prozesse der Fremdkörperreaktion. Hierbei interessiert vor allem, ob sich die Filamentstärke vliesartiger Biomaterialien auf die granulozytäre Entzündungsreaktion auswirkt. Methoden. Im Tierversuch wurden 8 verschieden konzipierte, vliesartige Biomaterialien aus semikristallinen Lactidglykolid-Blockpolymeren s.c. implantiert. Die Filamentstärken betrugen dabei $22 \mu \mathrm{m}, 23 \mu \mathrm{m}, 26 \mu \mathrm{m}$, $68 \mu \mathrm{m}, 105 \mu \mathrm{m}$ und $176 \mu \mathrm{m}$. Am 25. Tag erfolgte die Explantation und Gewebefixierung. Anschließend wurden die Präparate zugeschnitten und HE gefärbt. Nach der Digitalisierung der mikroskopischen Präparate wurden in 400-facher Vergrößerung pro Schnitt 50 zufällig ausgewählte Bilder aus dem zentralen Biomaterialbereich angefertigt. Jedes Bild wurde zweimal auf die Anzahl von Granulozyten untersucht.

Ergebnisse. Es konnte gezeigt werden, dass die Filamentstärke auf einem Signifikanzniveau von 0,01 mit der Anzahl an Granulozyten pro Bild 
korreliert (Korrelation nach Pearson). Während die Filamentstärken bis $68 \mu \mathrm{m}$ einen eher geringen Unterschied aufwiesen, so bedeuteten größere Filamentstärken ab $105 \mu$ m eine erkennbar größere Anzahl an Granulozyten pro Bild.

Fazit. In einer Pilotstudie wurde der Einfluss der Biomaterialarchitektur auf die Fremdkörperreaktion untersucht. Die Ergebnisse deuten darauf hin, dass hierbei die Filamentstärke die granulozytäre Entzündungsreaktion beeinflussen kann. Dennoch muss bedacht werden, dass weitere Parameter (z.b. Porengröße, Implantatdicke etc.) das Ergebnis beeinflusst haben könnten. Hierzu werden weitere Untersuchungen erfolgen.

\section{AG Thoraxpathologie I}

\section{AG10.01 \\ POU2F3 expression in thymic carcinoma \\ Y. Yamada ${ }^{1 *}$, D. Belharazem-Vitacolonna ${ }^{1}$, P. Ströbel ${ }^{2}$, K. Simon-Keller ${ }^{1}$, A. Marx ${ }^{1}$}

'Institute of Pathology, University Medical Centre Mannheim, Heidelberg University, Mannheim, Germany, ${ }^{2}$ Institute of Pathology, University Medical Center Göttingen, University of Göttingen, Göttingen, Germany

Background. In spite of in depth molecular characterization of thymic epithelial tumors (TETs) in The Cancer Genome Atlas (TCGA) project, a better understanding of TET biology and potential biomarkers is needed. Recently two papers have reported on the great heterogeneity among medullary thymic epithelial cells, including a subgroup showing some features to tuft cells at mucosal barriers. Therefore, we wondered whether TETs might express tuft cell-related genes.

Methods. First, we examined the expression status of tuft cell-related genes of 117 TETs in the TCGA data (type A, 10 cases; AB, 48; B1, 12; B2, 25; B3, 10; thymic carcinoma (TC), 10; micronodular thymoma, 2). Since we found that POU2F3, regarded as a master regulator of tuft cells, are specifically expressed in TC (see below), we next examined its mRNA expression level with qPCR in our cohort (type A, 7 cases; B3, 8; TA, 8)(house keeping gene was beta2 microglobulin and the expression level of tonsil was set to 1). Also, we evaluated its protein expression status with immunohistochemistry (IHC) in another our cohort including squamous cell carcinomas (SCCs) from other organs: 17 TETs (type A, 6 cases; B3, 6; TC, 5) and 25 SCCs (head and neck, 10 cases; lung, 5; esophagus, 5; skin, 5). IHC was assessed by the proportion of stained tumor cells ( 0 to $100 \%)$ and by the predominant staining intensity $(0=$ negative, $1=$ weak, $2=$ moderate, and 3 =strong). IHC was interpreted as positive when $50 \%$ or more of the tumor cells exhibited intensity 2 or 3 .

Results. In the TCGA data, POU2F3 mRNA expression $\mathrm{Z}$ scores were: type $A,-0.08 ; \mathrm{AB},-0.21 ; \mathrm{B} 1,-0.35 ; \mathrm{B} 2,-0.34 ; \mathrm{B} 3,-0.27$; $\mathrm{TC}, 3.49 ; \mathrm{MN}$, 0.23 , and the $\mathrm{Z}$ score of TC was significantly higher than any other subtypes $(\mathrm{P}<0.01$, T-test). In our cohort, POU2F3 mRNA expression level in each subtype were: type A, 0.84; type B3, 0.83; TC, 5.64, and the expression level of TC was significantly higher than any other subtypes $(\mathrm{P}<0.01$, T-test). In IHC, 4 among 5 cases of TC were positive for POU2F3, while type A thymomas, type B3 thymomas, and SCCs from other organs were negative for POU2F3.

Conclusion. POU2F3 expression is a unique feature of thymic carcinoma. Immunohistochemistry of POU2F3 would contribute to its more accurate diagnosis.
AG10.02

The role of the anti-apoptotic factors $\mathrm{Mcl}-1$ and $\mathrm{BCl}-2$ in the treatment resistance of malignant thymoma and thymic carcinoma

\section{Müller ${ }^{1 *}$, S. Küffer ${ }^{1}$, R. Koch', V. Venkataramani', A. Marx ${ }^{3}$, P. Ströbel ${ }^{1}$}

${ }^{1}$ Universitätsmedizin Göttingen, Institut für Pathologie, Göttingen, Germany, ${ }^{2}$ Universitätsmedizin Göttingen, Klinik für Hämatologie und Medizinische Onkologie, Göttingen, Germany, ${ }^{3}$ Universitätsmedizin Mannheim, Institut für Pathologie, Mannheim, Germany

Aim. Thymic epithelial tumors (TET) are the most common neoplasms of the anterior mediastinum. According to the WHO classification of TET, thymomas are sub classified into the clinically indolent types $A, A B, B 1$ and the aggressive types $\mathrm{B} 2$ and $\mathrm{B} 3$. In general, complete surgical removal is the most important prognostic factor and only curative treatment of malignant TET. Advanced and recurrent TET that cannot be completely resected require neoadjuvant or adjuvant systemic treatment, often in combination with radiotherapy. Cisplatin-based regimens such as the PAC scheme (cisplatin, adriamycin, cyclophosphamide) are most often used. TET have been described as the tumors withthe lowest mutational burden among adult cancers. However, next to the enrichment of non-targetable HRAS, NRAS, TP53, and GTF2I mutations, copy number gain (18q21.33) and overexpression of Bcl-2 go along with decreased survival in TET. Therefore, targeting Bcl-2 has been suggested as a combinatorial treatment of malignant TET. We investigated the cell death mechanism of Bcl-2 inhibition in the TP53 mutated thymic carcinoma cell line 1889c.

Methods. 1889c was treated with different Bcl-2 and Mcl-1 inhibitors in combination with Cisplatin, Etoposide, Oxaliplatin, Sorafinib and Sunitinib. Cell viability was analyzed $48 \mathrm{~h}$ and $72 \mathrm{~h}$ after treatment with MTS. Cytochrome $\mathrm{C}$ release was measured using a panel of $\mathrm{BH} 3$ domain peptides. Apoptotic and anti-apoptotic signaling factors including Casp3, $-7,-8,-9$, XIAP, PARP, $\gamma \mathrm{H} 2 \mathrm{AX}, \mathrm{Bcl}-2$, Mcl-1, AIF and Calpain were monitored by western blot. Tissue microarrays (TMAs) with $140 \mathrm{TH}$ and TC samples were immunohistochemically stained for Bcl-2, Mcl-1 and TP53.

Results. The inhibition of Bcl-2 and Mcl-1 reduced cell viability of $1889 \mathrm{c}$ up to $80 \%$. However, $\mathrm{BH} 3$ profiling resulted in almost no cytochrome C release. In addition, the combination of Bcl-2 and Mcl-1 inhibitors with chemotherapeutics did not show any additional cell lethality effect. Cell death was induced without activation of any effector caspases while a strong activation of AIF was monitored.

Conclusion. The inhibition of Bcl-2 and Mcl-1 in 1889c induces a strong caspase-independent apoptosis via AIF. A combined treatment of Bcl-2 amplified and TP53 mutated TETs with regular chemotherapy and inhibitors for Bcl-2 and Mcl- 1 should be taken into consideration as a new therapeutic option in advanced or chemoresistant cases.

\section{AG10.03}

A kinase activity array predicts IGF1R and TYR03 as biomarkers for response prediction in sunitinib treated malignant thymomas and thymic carcinomas

S. Küffer ${ }^{*}$, X. von Hahn', D. Müller', H. Bohnenberger', N. Sojka', J. Tebroke', C. Sauer', A. Marx ${ }^{3}$, P. Ströbel'

'Universitätsmedizin Göttingen, Institut für Pathologie, Göttingen, Germany, ${ }^{2}$ Universitätsmedizin Göttingen, Diagnostische Radiologie, Göttingen, Germany, ${ }^{3}$ Universitätsmedizin Mannheim, Institut für Pathologie, Mannheim, Germany

Aim. Metastatic and recurrent malignant thymomas (TH) and thymic carcinomas (TC) are generally refractory to current empiric radio-chemotherapies, warranting search for novel and personalized second line therapeutic strategies. The multi-target tyrosine kinase inhibitor sunitinib has been shown to induce a remission and prolong overall survival of progressive TH and TC patients. However, although sunitinib has been proposed as an alternative treatment option in refractory disease the response is partial and not all patients are profiting equally. For a more personalised med- 
icine and accurate response prediction to sunitinib different approaches of biomarker discovery are required.

Methods. The PamGene@ technology was used to analyze tyrosine phosphorylation patterns in the sunitinib-resistant cell lines TAB1-R and Caki2-R. A Sunitinib Response Index (SRI) was calculated to predict sunitinib response. The SRI was tested for functional relevance in a variety of different tumor cell lines treated with sunitinib by comparing SRI to reduction of viable tumor cells. Finally, the SRI was determined in whole tissue protein extracts malignant $\mathrm{TH}$ and $\mathrm{TC}$ with sunitinib spike-in into the lysate. Prediction of upstream kinases indicated IGF1R and TYRO3 as potentially critical targets of sunitinib response.

Results. The application of the SRI to native malignant TH and TC samples defined a potential sunitinib responsive and a resistant group. Within the predicted upstream kinases of the SRI IGF1R and TYRO3/Dtk belonged to the top candidates. Quantification in tissue resulted in significant higher levels of IGF1R in the Sunitinib responsive group. Functional knock down in the resistant TAB1 and over-expression in TC cell line 1889c confirmed the functional relevance of IGF1R in the sunitinib resistance.

Conclusion. Here we present a novel experimentally validated predictor of sunitinib response (SRI) in malignant TH and TC. We identified IGF1R and TYRO3 as single biomarkers and possible sunitinib resistance indicators. Sunitinib has previously been shown to be active against the IGF1R, therefore future clinical trials should include IGF1R and TYRO3 to validate the SRI.

\section{AG10.04}

\section{Alternative proteasomale Prozessierung beeinflusst den} klinischen Verlauf in nicht-kleinzelligen Lungenkarzinomen

\section{Wessolly ${ }^{1 *}$, A. Steubel ${ }^{2}$, R. Werner ${ }^{3}$, S. Borchert ${ }^{1}$, S. Stephan-}

Falkenau' ${ }^{2}$, S. Griff', E. Mairinger', J. Schmeller', R. F.H. Walter ${ }^{1,4}$, T. Bauer ${ }^{5}$, W. E. E. Eberhardt', , T. G. Blum ${ }^{5}$, K. W. Schmid' , J. Kollmeier ', F.D. Mairinger', T. Mairinger ${ }^{2}$

'Universitätsklinikum Essen, Institut für Pathologie, Essen, Deutschland, ${ }^{2}$ Helios Klinikum Emil von Behring, Institut für Gewebediagnostik, Berlin, Deutschland, ${ }^{3}$ Helios Klinikum Emil von Behring, Institut für Pathologie, Berlin, Deutschland, ${ }^{4}$ Ruhrlandklinik, Westdeutsches Lungenzentrum am Universitätsklinikum Essen $\mathrm{GmbH}$, Essen, Deutschland, ${ }^{5}$ Helios Klinikum Emil von Behring, Klinik für Pneumologie, Berlin, Deutschland, ${ }^{6}$ Westdeutsches Tumorzentrum, Universitätsklinikum Essen, Universität Duisburg-Essen, Medizinische Onkologie, Essen, Deutschland

Ziel. Moderne immuntherapeutische Ansätze zur Krebstherapie beinhalten die Modulation der Immunregulation mittels Immun-Checkpoint-Inhibition. Dennoch bilden sich bei bis zu 80 \% der Langzeit-Therapierten Resistenzen gegen diese Therapie aus. Vorangegangene Arbeiten in neuroendokrinen Lungentumoren (NETs) wiesen auf eine verminderte AntiTumor Antwort basierend auf alternativer Antigenprozessierung von $\mathrm{Tu}-$ morantigenen (sogenannte „Processing-Escapes“) und damit verbunden verringerter Überlebensrate, hin. Die Auswirkungen dieser „ProcessingEscapes" auf das Ansprechen einer Immun-Checkpoint-Inhibition, wurden in einem Kollektiv nicht-kleinzelliger Lungenkarzinome (NSCLCs) überprüft.

Methoden. 48 NSCLC-Patienten mit mindestens einem Zyklus Nivolumab wurden mittels zielgerichteter Amplikon-basierter Sequenzierung untersucht. Darüber hinaus wurden Whole-Exom-Sequenzdaten von ca. 400 NSCLC-Patienten als Kontrolle gewählt, um die Verteilung von alternativer Prozessierung in den erwähnten Entitäten zu bestätigen. Die Anzahl an Mutationen in Assoziation mit „Processing-Escapes“ wurde mit verschiedenen klinisch-pathologischen Parametern korreliert. Cox-Regressionen wurden genutzt, um die Überlebensverläufe in Abhängigkeit analysierter Parameter abzubilden.

Ergebnisse. Cox-Regressions-Modelle zeigten keinen signifikanten Einfluss durch Mutationslast (Gesamtmutationen, basierend auf der Größe des Gen-„Panels“), „Processing-Escapes“, PD-L1 Expression oder dem histologischen Typ des Tumors auf das Gesamtüberleben der Patienten. Jedoch, zeigten „Processing-Escapes“ in Anwesenheit einer PDL-1 Expres- sion eine deutlich schlechtere Prognose $(p=0,02)$ als „Processing-Escapes“ ohne PDL1 Expression oder gänzliches Fehlen von „Processing-Escapes“. Fazit. Basierend auf dieser Arbeit, sollten bei Therapieentscheidung mehrere Biomarker und deren Wechselwirkung berücksichtigt werden. Im Fall der Immun-Checkpoint-Inhibition von NSCLCs scheinen „ProcessingEscapes“ im Zusammenspiel mit einer PDL1-Expression einen potenziell negativ-prädiktiven Marker darzustellen.

\section{AG10.05}

\section{Somatic mitochondrial mutations as link between relapse and primary pulmonary adenocarcinoma}

D. Kazdal ${ }^{1 * 2}$, , V. Endris', A.-L. Volckmar', M. Kirchner', J. Budczies', J. Leichsenring', O. Neumann', R. Brandt', S. B. Talla', E. Rempel', C. Plöger', H. Winter ${ }^{2,3}$, M. Allgäuer', A. Harms', M. Kriegsmann', R. Penzel', P. Schirmacher', A. Stenzinger ${ }^{1,2,4}$

'Institut für Pathologie Heidelberg, Heidelberg, Germany, ${ }^{2}$ Deutsche Zentrum für Lungenforschung (DZL), Translational Research Center (TLRC), Heidelberg, Germany, ${ }^{3}$ Thoraxklinik-Heidelberg, Chirurgie, Heidelberg, Germany, ${ }^{4}$ Deutsches Konsortium für Translationale Krebsforschung, Heidelberg, Germany

Aim. The potential role of cancer-associated somatic mutations of the mitochondrial genome (mtDNA) is controversial and still poorly understood. In a recent study (Kazdal et al. 2018) we found that somatic mtDNA mutations in pulmonary adenocarcinoma (ADC) were either ubiquitously distributed throughout a tumor or restricted to specific regions. These findings suggest that somatic mtDNA mutations can be an interesting tool to delineate tumor evolution and have great potential to assess progression risk. Here, we sequenced the whole mtDNA of relapse samples and corresponding primary ADC in a multiregional manner in order to compare the mtDNA mutational status.

Methods. So far, non-neoplastic tissue samples, relapse sample material and systematically segmented central sections of four pulmonary adenocarcinoma (63 samples in total) were analyzed as follows:

- Histomorphological characterization (e.g. growth pattern)

- Total DNA and mitochondrial DNA quantification (QuBit, qPCR)

- Detection of somatic mitochondrial mutations (targeted whole mtDNA NGS)

Hierarchical clustering and phylogenetic tree analysis were calculated based on somatic mtDNA mutations for each case.

Results. Somatic mitochondrial mutations were either ubiquitously present in all samples of a primary tumor or restricted to specific tumor regions. The ubiquitous mtDNA mutations could also be detected in the corresponding relapse sample, while only some of the regional restricted mutations were present. Further, no private mutations were detected in the relapse samples. In two of the four cases hierarchical clustering and phylogenetic analyses enabled an association of the relapse sample to a specific region of the primary tumor.

Conclusion. Somatic mtDNA mutations can be used to delineate subclonal structures of pulmonary ADC and to link clinical relapse to specific regions of the primary tumor. Further, ubiquitous mutations seem to be persistent through recurrence and could therefore be employed as a potential marker for the early detection of a relapse.

\section{AG10.07}

\section{Molekulare Lungenkrebsdiagnostik im Verbund am Universitätsspital Zürich}

A. Soltermann ${ }^{1 *}$, M. Rechsteiner ${ }^{1}$, M. Zoche ${ }^{1}$, A. Curioni-Fontecedro ${ }^{2}$, A. Weber ${ }^{1}$, H. Moch ${ }^{7}$

'Universitätsspital Zürich, Institut für Pathologie und Molekularpathologie, Zürich, Schweiz, ${ }^{2}$ Universitätsspital Zürich, Klinik für Medizinische Onkologie und Hämatologie, Zürich, Schweiz

Ziel. Prädiktive Testungen beim nicht-kleinzelligen Lungenkarzinom werden am UniversitätsSpital Zürich seit mehr als 10 Jahren durchgeführt. 
Um technologischen Entwicklungen Rechnung zu tragen, wurde für 2019 ein zeit-effektiver Algorithmus erarbeitet, welcher für umliegende Spitäler modular gehalten werden kann und eine lokale Kostenvergütung ermöglicht.

Methoden. Idylla EGFR, KRAS, BRAF (Biocartis) Testungen werden in einem multiplex PCR Ansatz durchgeführt mit Sensitivität von 1-5\%. Der Oncomine Comprehensive Focus Assay detektiert alle therapie-relevanten genetischen Alterationen. Die Sensitivität beträgt $5 \%$ für Mutationen, Deletionen oder Insertionen, für Amplifikationen 4-8 Kopien und für Fusionen sowie Translokationen $1 \%$. Der Oncomine cf (cell free) Assay hat eine Sensitivität von $0,5 \%$ für $\mathrm{M} / \mathrm{D} / \mathrm{I}$ bei DNA Isolation aus fixiertem Gewebe und von 0,1 \% für Liquid Biopsy. Der FoundationOneCDx Test (FOneCDx) detektiert Mutationen, InDels, Amplifikationen und Fusionen/Translokationen bei 324 Genen. Zusätzlich werden die immunonkologischen Biomarker Tumor Mutational Burden (TMB) und Mikrosatelliteninstabilität (MSI) bestimmt. Der Bericht gibt einen Überblick über die genomischen Alterationen, Therapieoptionen in klinischen Studien und die in der Schweiz zugelassenen Medikamente.

Resultate. Unser Algorithmus umfasst 3 Hauptteile: 1) Diagnostik inklusive Klassifikations-Immunhistochemie, 2) Prädiktion bei Ersterkrankung und 3) Prädiktion im Rezidiv. Bei Ersterkrankung eines Adenokarzinoms erfolgt eine Anmeldung von Idylla (EGFR, KRAS und BRAF) und paralleler prädiktiver IHC für ROS1, ALK, PD-L1 auf Leerschnitten. Dies ermöglicht eine schnelle therapeutische Entscheidung. Anschliessend wird eine FOneCDx Testung gestartet. Falls zu wenig DNA vorliegt, wird umgestellt auf Oncomine Focus Assay oder Oncomine cf Panel. Im Rezidiv erfolgt der gleiche Ansatz, wobei ein FOneCDx Test nur veranlasst wird, wenn bei Ersterkrankung keine Testung durchgeführt wurde. Bei schwer zu biopsierenden Rezidiven, multiplen Metastasen oder Therapiekontrolle wird eine Liquid Biopsy Analyse durchgeführt. Die Ergebnisse werden am molekularen Tumorboard besprochen.

Fazit. Dieser neugestaltete Algorithmus erlaubt eine zügige Diagnostik für Lungenkrebspatienten mit fortgeschrittener Erkrankung, welche eine sofortige onkologische Therapie benötigen. Der modulare Ansatz ermöglicht eine optimale Therapie nach neuesten wissenschaftlichen Erkenntnissen und klinischen Behandlungsmethoden.

\section{AG Thoraxpathologie II}

\section{AG10.08 \\ Frequency and significance of pathologic pulmonary findings in postmortal diagnostics}

S. Berezowska*, A. Schmid, M. Trippel, A. Blank, Y. Banz, A. Lugli, R. Langer Institut für Pathologie, Universität Bern, Bern, Switzerland

Clinical diagnostics of pulmonary diseases is challenging and the discrepancy between clinical and postmortal pathologic findings is a well-known issue. Histopathological evaluation of the lungs may be affected by artifacts due to suboptimal macroscopic work up, autolysis or poor fixation. We performed a comprehensive analysis of postmortal pulmonary findings in adults obtained applying a highly standardized and elaborated pathological examination in correlation with clinical diagnoses and questions. Methods. As a standard approach, the lungs were instilled with formalin for at least $24 \mathrm{~h}$ followed by preparation of large tissue sections with subsequent standardized histological work-up including macroscopically conspicuous areas.

Results. In total, 189 consecutive patients from a two-year period were included: 66 cases from the University Hospital Bern and 123 from peripheral hospitals. 130 patients had significant primary pathologic findings in the lung (congestion due to cardiac failure excluded): 13 cases showed diffuse alveolar damage (DAD), 29 cases inflammatory conditions, 46 cases emphysema or degenerative changes, 27 cases primary or secondary tumors, and 15 cases other pathologies. Pulmonary or combined cardiopulmonary disease was the primary cause of death in 40 cases. A complete correlation between clinical and pathological diagnoses was present in 75 cases. In 57 cases a specific finding was clinically suspected and confirmed by autopsy. In 16 cases unclear clinical findings were clarified upon autopsy. Discrepant findings were seen in 31 cases. These comprised cases with previous suspicion for a specific finding, which could not be confirmed at autopsy or entirely new findings not diagnosed before death, including major diagnostic discrepancies according to the Goldman criteria in 24 cases. DAD was more frequent in patients from the intensive care unit compared to other clinics and peripheral hospitals $(p=0.044)$. Besides this, there were no other significant differences between the different clinics, in particular regarding the diagnoses and discrepancies.

Conclusion. Pulmonary pathologies are a common finding in postmortem diagnostics. Careful examination is important to ensure a high quality of postmortem diagnostics and a solid clinicopathologic correlation. This correlation should focus not only on discrepancies, but also on the confirmation and clarification of clinically unclear findings.

\section{AG10.09}

\section{Untersuchung pulmonaler und gastrointestinaler Amyloidosen mit Hilfe der bildgebenden Massenspektrometrie (MALDI-IMS)}

\section{J. Schürmann ${ }^{1 *}$, A. Tholey ${ }^{2}$, C. Röcken ${ }^{1}$}

${ }^{1}$ Christian-Albrechts-Universität Kiel, Institut für Pathologie, Kiel, Deutschland, ${ }^{2}$ Christian-Albrechts-Universität Kiel, Institut für Experimentelle Medizin, Kiel, Deutschland

Ziel. Das im Gewebe abgelagerte Amyloid besteht aus dem fibrillenbildenden Amyloidprotein und weiteren krankheitsspezifischen Komponenten (z.B. Proteine, Lipide und Glykosaminoglykane). Die bildgebende Massenspektrometrie (MALDI-IMS) bietet die Möglichkeit, dieses krankheitsspezifische Gemisch räumlich aufzulösen, für die Diagnostik nutzbar zu machen und bislang unbekannte, krankheitsassoziierte Moleküle zu identifizieren.

Methoden. Formalin fixierte und in Paraffin eingebettete Gewebeproben von 115 Patienten wurden mit Hilfe der Matrix-unterstützten LaserDesorption/Ionisations Massenspektrometrie (MALDI-IMS) analysiert. Dieser Messung war ein Trypsinverdau der Gewebeproben vorangegangen. Bei den Proben handelte es sich um Lungen-, Magen-, Dünn- und Dickdarmgewebe, die AL- $\lambda$-, AL- $\kappa-$, ATTR-, AA-Amyloid und Fälle ohne Amyloid aufwiesen. Die Auswertung erfolgte mit dem Peptidfilter (s.u.), der in einem dreistufigen Prozess 19 Amyloidproteine, die durch MS/MSExperimente ermittelt wurden, mit den Patientenproben abgleichen konnte.

Ergebnisse. In den insgesamt 109 Amyloidosefällen konnte gezeigt werden, dass das bisher nur an Herzpräparaten validierte Verfahren der bildgebenden Massenspektrometrie auch auf die Organsysteme Lunge und Gastrointestinaltrakt übertragbar ist. Bei diesem Verfahren wurde der Peptidfilter angewendet, der mittels Korrelationskoeffizienten, Driftzeit und Massengenauigkeit eine amyloidspezifische Peptidsignatur generiert. Dabei zeigte sich, dass die Peptidsignatur nicht nur Amyloid-, sondern auch Organ-spezifisch ist. Somit wiesen die 19 Amyloidproteine in den Lungenproben eine andere Auftrittswahrscheinlichkeit als in den Proben aus dem Gastrointestinaltrakt auf.

Zusätzlich konnten in MS/MS-Experimenten zwei weitere $\mathrm{m} / \mathrm{z}$-Werte identifiziert werden, die ebenfalls den Amyloid-spezifischen Proteinen Apolipoprotein E (ApoE) und Vitronektin (VTN) zugeordnet werden konnten.

Fazit. Unsere Studie zeigt, dass sowohl in Lungen- als auch in gastrointestinalen Amyloidosen eine spezifische Amyloidsignatur mittels MALDI-IMS zu finden ist. Diese Signatur ist nicht nur spezifisch für die seltene Krankheit Amyloidose, sondern auch für jedes einzelne Organ.

Somit lässt sich zusammenfassen, dass mittels MALDI-IMS ein neues Werkzeug gefunden wurde, den Pathomechanismus verschiedener Amyloidosen in komplexen Organsystemen weiter aufzuschlüsseln und somit vielen Patienten eine bessere Diagnose und Therapie zur Verfügung stellen zu können. 
AG10.10

\section{Classification and molecular pathology of neuroendocrine neoplasms (esp. GEP-NET)}

G. Rindi*

Fondazione Policlinico Universitario A. Gemelli IRCCS-Università Cattolica, Institute of Anatomic Pathology, Roma, Italy

In year 2000 \& 2004 the World Health Organization (WHO) set the morphological criteria for well and poorly differentiated neuroendocrine neoplasms (NEN) of the gasteroenteropancreatic tract. To better orientate clinicians, in 2010 WHO introduced a three-tiers grading system (G1G3) based on mitotic count and Ki67 index. Well-differentiated neoplasms were defined as neuroendocrine tumors (NET), G1 or G2, and poorly differentiated neuroendocrine carcinomas (NEC) by default G3. At the application of WHO 2010 evidence of NET with high Ki67 index posed a classification and clinical problem. In 2017 WHO applied the three tiers grading to the NET group and introduced the NET G3 class for pancreas. This new formulation replaces the WHO 2010 definition and will be adopted for all GEP sites by WHO 2019. In both NET and NEC, markers of neuroendocrine differentiation including chromogranin A and synaptophysin are expressed, as well as the various subtypes of somatostatin receptors (usually subtype 2). Neuroendocrine markers expression reflects differentiation, with lower intensity in NEC. Some high-grade NETs may be difficult to separate from poorly differentiated NEC based on sole morphology. Additional clinical-diagnostic steps are required for a conclusive diagnosis and include the search for Rb, P53 proteins (usually not detected in NET) and of the gene products of DAXX and ATRX (usually retained in NEC). The molecular basis of GEP NETs vary according to their anatomical site. In the pancreas cluster of genes and by various modality (copy number variation, mutation, silencing, etc.) are involved and variably related to chromatin modification, telomere maintenance and remodeling, DNA damage repair and mTOR signaling. In the small intestine a limited number of somatic alterations is observed mainly involving chromosome 18 and abnormalcyclin-dependent kinase inhibitor CDKN1B gene encoding for p27. Of interest in both the pancreas and small-intestine NETs germline mutation of MUTYH gene have been described. NEC molecular basis involves key proliferation gate genes like $R b$ and $P 53$ at variance vs NETs. WHO 2017 introduced the new Mixed NEuroendocrine non-Neuroendocrine neoplasm (MiNEN) class to define hybrid exocrine-neuroendocrine neoplasm. The $30 \%$ rule set by WHO 2010 is kept however each component is potentially graded for an effective clinical management. All the above concepts are now proposed for a common classification frame for NENs at all anatomical sites.

\section{AG Kopf-Hals-Pathologie I}

\section{AG11.01 HPV-negative orale Plattenepithelkarzinome: die prognostische Rolle des Immunsystems in Abhängigkeit von Tumorgröße und HLA Klasse I Herunterregulation}

D. Bethmann ${ }^{*}$, C. Wickenhauser', M. Kappler', J. Bukur ${ }^{3}$, A. Steven ${ }^{3}$, B. A. Fox ${ }^{4}$, J. Beer', A. Eckert', B. Seliger ${ }^{3}$

'Universitätsklinikum Halle (Saale), Institut für Pathologie, Halle (Saale), Deutschland, ${ }^{2}$ Universitätsklinikum Halle (Saale), Klinik für Mund-, Kiefer- und plastische Gesichtschirurgie, Halle (Saale), Deutschland, ${ }^{3}$ Universitätsklinikum Halle (Saale), Institut für medizinische Immunologie, Halle (Saale), Deutschland, ${ }^{4}$ Providence Cancer Center, Earle A. Chiles Research Institute, Portland, United States

Ziel. Die Progression oraler Plattenepithelkarzinome (OSCC) ist u. a. auf immune escape-Strategien zurückzuführen, die mit dem Verlust der Tumorkontrolle und lokaler/systemischer Dissemination assoziiert sind. Die Identifizierung von Mechanismen zur Wiederherstellung der immunologischen Tumorkontrolle ist Ziel der immunonkologischen Forschung. In der vorliegenden Untersuchung wurde der Einfluss des Expressionsprofils von Komponenten der HLA-Klasse-I-Antigenprozessierungsmaschinerie (APM) auf den klinischen Verlauf der Patienten überprüft und mit der TZellinfiltration korreliert.

Methoden. 160 HPV-negative OSCC-Tumorproben wurden immunhistochemisch und über multispektrale Bildgebung auf die Expression von HLA-Klasse-I-schwerer Kette (HC), $\beta_{2}$-Mikroglobulin $\left(\beta_{2}-\mathrm{m}\right)$ sowie sechs APM-Komponenten untersucht, mit der Frequenz und räumlichen Nähe von T-Zellpopulationen sowie klinischen Daten korreliert.

Ergebnisse. (i) Die OSCC zeigten eine signifikante Herunterregulierung von HLA-Klasse-I- und APM-Komponenten. (ii) Die OSCC Zelllinien zeigten eine niedrige basale mRNA- und Proteinexpression dieser Faktoren, die durch IFN-y induziert werden kann. (iii) Die OSCC wurden in drei Hauptkategorien mit konkordanter (HLA ${ }^{\text {high }} / \mathrm{APM}^{\text {high }}$, HLA ${ }^{\text {low }}$ $\mathrm{APM}^{\text {low }}$ ) und diskordanter Expression (HLA ${ }^{\text {low }} / \mathrm{APM}^{\text {high }}$ ) eingeordnet. (iv) Bezüglich des Überlebens zeigten sich signifikante Unterschiede in der Gruppe der Karzinome limitierter Größe mit dem prominentesten Überlebensvorteil bei T2 Tumoren in der HLA ${ }^{\text {low }} / \mathrm{APM}^{\text {low }}$ im Vergleich zur HLA ${ }^{\text {high }} /$ APM $^{\text {high }}$ Gruppe. (v) Die HLA-/APM-Expression war direkt mit der Frequenz intratumoraler CD8+ T-Zellen sowie $\mathrm{CD}^{+} \mathrm{FoxP}^{+}$regulatorischer T-Lymphozyten (Tregs) Immunzellen assoziiert. (vi) Eine hohe Dichte suppressiver Tregs innerhalb von $30 \mu \mathrm{m}$ von intratumoralen $\mathrm{CD}^{+}$CTL war signifikant mit der Gruppe HLA ${ }^{\text {high }} / \mathrm{APM}^{\text {high }}$ und unabhängig von der Dichte der intratumoralen CTL mit einem schlechten Gesamtüberleben (OS) der Patienten assoziiert. (viii) In silico Analysen von TCGA-Daten bestätigten die Assoziation einer hohen Anzahl an intratumoralen $\mathrm{CD}^{+}, \mathrm{CD}^{+}$und FoxP3 ${ }^{+} \mathrm{T}-Z$-Zllen mit HLA ${ }^{\text {high }} / \mathrm{APM}^{\text {high }}$ Tumoren. Fazit. Jenseits der bekannten immune escape-Mechanismen via HLAKlasse-I- und APM-Herunterregulation existiert ein komplexes Netzwerk weiterer intra- und peritumoralen immunologischer Regelkreise, die das biologische Verhalten von OSCC bestimmen und die offenbar in Abhängigkeit von der Tumormasse unterschiedlich zu werten sind.

\section{AG11.02}

\section{Klinisch-pathologische Fallserie einer weiteren Kohorte von} SMARCB1- (INI-1) defizienten Karzinomen des Sinonasal-Traktes

\section{N. J. Rupp ${ }^{* *}$, E. J. Rushing ${ }^{2}$, R. Rodriguez ${ }^{3}$, D. Holzmann ${ }^{4}$, G. B. Morand ${ }^{4}$} 'Institut für Pathologie und Molekularpathologie, UniversitätsSpital Zürich, Zürich, Schweiz, ${ }^{2}$ Institut für Neuropathologie, UniversitätsSpital Zürich, Zürich, Schweiz, ${ }^{3}$ Institut für Pathologie, Kantonsspital St. Gallen, St. Gallen, Schweiz, ${ }^{4}$ Klinik für Ohren-, Nasen-, Hals- und Gesichtschirurgie, UniversitätsSpital Zürich, Zürich, Schweiz

Ziel. Das SMARCB1 (INI-1) defiziente Karzinom des Sinonasaltrakts wurde kürzlich beschrieben und wird provisorisch im WHO Klassifikationsband der Kopf-Hals-Tumoren 2017 unter den undifferenzierten sinonasalen Karzinomen (SNUC) aufgeführt. Ziel dieser Studie war es, weitere Fälle dieser Tumorentität aus einem Zentrum für Kopf-Hals-Tumore zusammenzustellen, morphologisch bzw. immunhistochemisch zu charakterisieren und mit der Behandlungsstrategie sowie dem klinischen Verlauf zu korrelieren.

Methoden. Retrospektiv wurden undifferenzierte und wenig differenzierte Karzinome des Sinonasaltraktes morphologisch reevaluiert und mittels weiteren immunhistochemischen Zusatzuntersuchungen charakterisiert. Weiterhin wurden seit 2014 initial als INI-1-defiziente Karzinome diagnostizierte Fälle und konsiliarisch eingesendete Fälle eingeschlossen. Klinische Parameter wie Alter, Lokalisation, Ausdehnung, Behandlung und Überlebensdaten wurden erfasst. Als Vergleichskohorte dienten im gleichen Zeitraum diagnostizierte, nach Kriterien der WHO definierte SNUC. Ergebnisse. Es fanden sich 6 Fälle mit einem immunhistochemischen Verlust der INI-1-Expression bei positiver interner Kontrolle. Die Morphologie umfasste squamoide, basaloide, plasmazytoide/rhaboide, eosinophile und pseudoglanduläre Differenzierung mit (pseudo-)papillärem und trabekulären Wachstumsmuster sowie Komedonekrosen. Das mediane Alter betrug 58 Jahre. Patienten mit INI-1-defizienzen Karzinomen stellten sich häufiger mit Epistaxis vor als SNUC-Patienten $(p=0,045)$. Die Mehrheit 
präsentierte sich mit einem lokal fortgeschrittenen Tumor bei Diagnosestellung. Die Behandlungen umfassten die Kombination von Operation, Radio- und Chemotherapie. Das mediane Überleben war für die gesamte Kohorte 13 Monate (95 \% CI 5,4-20,5). Klassische SNUC und INI-1-defiziente Karzinome wiesen ein vergleichbares loko-regionäres Rezidiv-freies, Fernmetastasten-freies, und gesamtes Überleben (jeweils $p>0,05$ ) auf. Fazit. Unsere Resultate deuten darauf hin, dass INI-1-defiziente sinonasale Karzinome nicht selten unter wenig/undifferenzierten sinonasalen Karzinomen zu finden sind und mittels der INI-1-Immunhistochemie zuverlässig diagnostizierbar sind. Das morphologische Spektrum ist variabel, so dass die INI-1-Immunhistochemie generell in ein Panel zur Charakterisierung sinonasaler Karzinome aufgenommen werden sollte, um auch zukünftig weitere Charakteristika dieser distinkten molekularen Subgruppe erfassen zu können.

\section{AG11.03}

\section{In silico analyses reveal histone acetyltransferase EP300 as} a panCancer inhibitor of anti-tumor immune response by modulating tumor metabolism

\section{R. Krupar ${ }^{*}$, C. Watermann ${ }^{1}$, J. Ribbat-Idel', C. Idel' ${ }^{2}$, S. Perner ${ }^{1}$ \\ 'Pathologie des Universitätsklinikums Schleswig-Holstein, Campus Lübeck und des Forschungszentrums Borstel, Leibniz Lungenzentrum, Lübeck, Germany, ${ }^{2}$ Universitätsklinikum Schleswig-Holstein, Campus Lübeck, Abteilung für Hals-, Nasen- und Ohrenheilkunde, Lübeck, Germany}

Aim. The tumor immune microenvironment (TIME) is a key determinant of therapy response and prognosis. Among other factors, it depends on the tumor mutational burden and defects in DNA repair enzymes. But little is known about specific mutations leading to anti-tumor immune response. Using The Cancer Genome Atlas (TCGA) database we defined altered genes, which are associated with different TIME types and might represent new prognostic markers or targets for immuno-therapeutic approaches. Methods. Based on the HNSCC (head and neck squamous cell carcinoma) TCGA cohort 2 different TIME types (immune-activated/i-a, immune-excluded/i-e) were defined using the expression of 10 immune-related genes $(z$-Score $=0)$. Mutation frequencies of genes mutated in at least 10 HNSCC (1.95\%) were correlated to the 2 TIME types. For panCancer studies cytolytic activity (high granzyme/perforin expression, $\mathrm{z}$-Score $=0$ ), as surrogate marker of anti-tumor immune response, was correlated to EP300 up-/ downregulation (z-Score =1) (• Fig. 1 |AG11.03). Glycolysis-dominant and oxidative phosphorylation (OXPHOS)-dominant tumor metabolisms were based on upregulation $(\mathrm{z}-\mathrm{Score}=0)$ of 24 and 31 genes involved in glycolysis or OXPHOS.

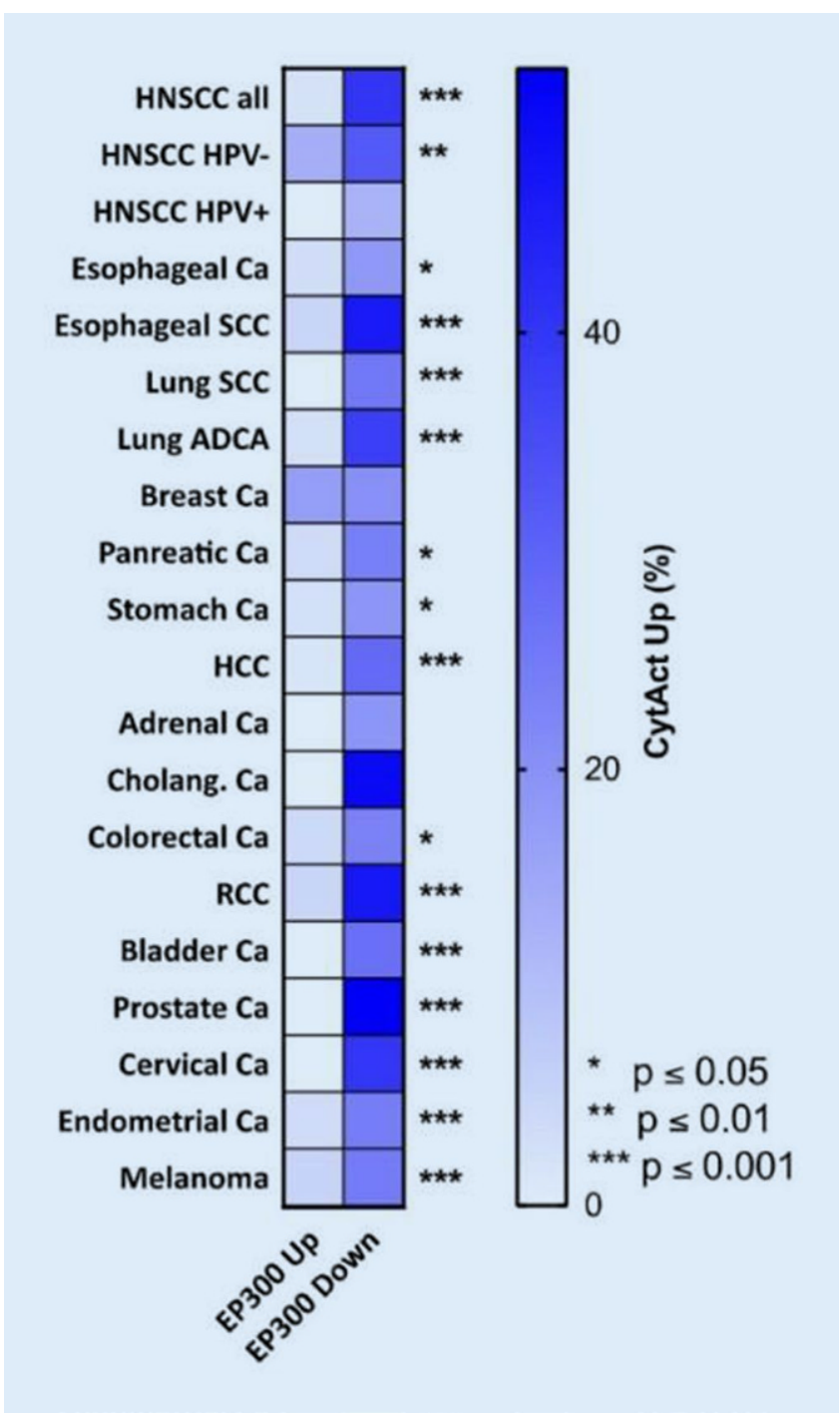

Fig. 2 | AG11.03 $<$ PanCancer correlation of EP300 mRNA expression with cytolytic activity (CytAct Up)

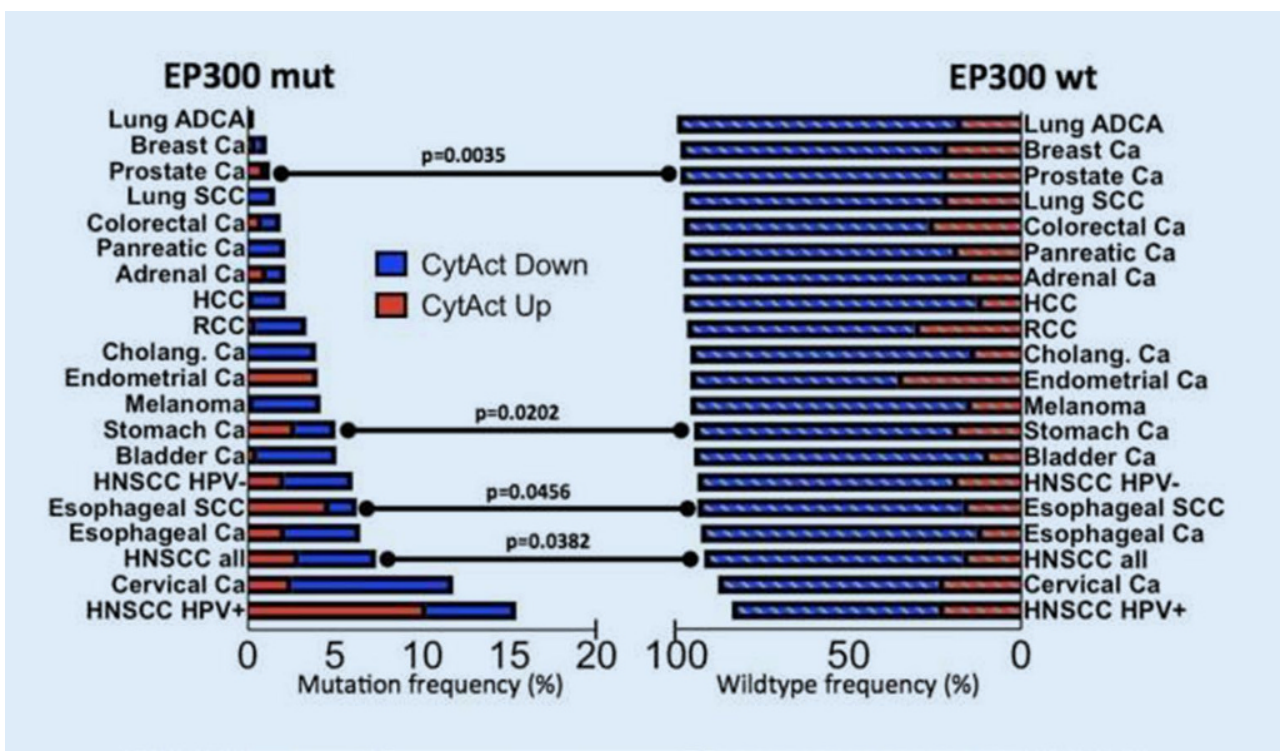

Fig. 1 | AG11.03 $<$ PanCancer analysis of EP300 mutation frequencies and association with cytolytic activity (CytAct Up) 

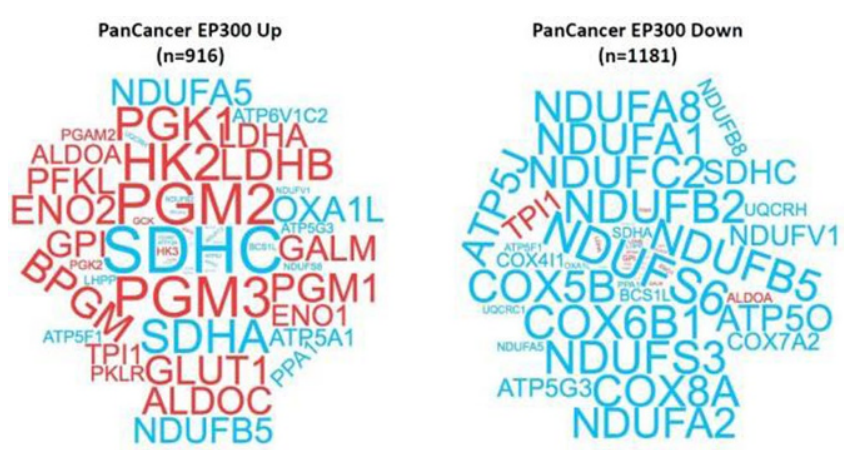

Fig. 3 | AG11.03 $\varangle$ Characterization of tumor metabolism relative to EP300 expression (red $=$ glycolytic/blue $=$ OXPHOS genes)

Results. Overall survival was better in the i-a group (hazard ratio 0.53 , $p=0.06$ ). Mutation frequencies of 1519 genes yielded 9 significantly differentially mutated genes in the 2 TIME types with strongest differences for TP53 and the histone-acetyltransferase EP300. While TP53 was more frequently mutated in i-e tumors, EP300 mutations were strongly associated with an i-a TIME, independent of HPV status. Assessing 17 other solid malignancies, cytolytic activity was significantly increased in EP300 mutated esophageal, stomach and prostate cancers. Downregulation of EP300 mRNA was associated with higher cytolytic activity in 17 of 18 evaluated tumor types (- Fig. 2 | AG11.03). Since EP300 is a promoter of glycolysis and a glycolysis-dominant tumor metabolism negatively affects anti-tumor immune response, we analyzed the metabolic association of EP300 (• Fig. 3 | AG11.03). In HNSCC as well as in the panCancer group $(n=2097)$ metabolism was strongly shifted towards OXPHOS $(2.4 \times)$ in tumors with downregulated EP300 $(p<0.001)$.

Conclusion. Our study reveals associations of specific gene alterations with different TIME types. In detail, we defined EP300 as a panCancer inhibitor of the TIME via metabolic modulation. In this context EP300 represents a promising target for predictive biomarker studies or new immuno-therapeutic approaches.

\section{AG11.04}

Primary and recurrent head and neck squamous carcinomas are strikingly different regarding their immune microenvironment

C. Watermann ${ }^{1 *}$, R. Krupar', J. Ribbat-Idel', C. Idel' , B. Wollenberg', M. P. Kühnel', D. Jonigk', J. Brägelmann ${ }^{4}$, J. Kirfel', H. Pasternack', S. Perner ${ }^{1}$

'University Medical Center Schleswig-Holstein, Campus Lübeck and Research Center Borstel, Leibniz Lung Center, Pathology, Lübeck, Germany, ${ }^{2}$ University Hospital Schleswig-Holstein, Department of Otorhinolaryngology, Lübeck, Germany, ${ }^{3}$ Hannover Medical School, Department of Pathology, Hannover, Germany, ${ }^{4}$ University of Cologne, Molecular Pathology, Institute of Pathology, Cologne, Germany

Objectives. The tumor immune microenvironment (TIME) has a crucial impact on cancer progression and patients' survival for various cancer entities. In head and neck squamous cell carcinoma (HNSCC) the development of recurrences in up to $60 \%$ is one main factor leading to poor prognosis. We aimed to reveal changes in the TIME of primary tumors and their corresponding recurrences, hypothesizing that recurrent $\mathrm{HN}$ SCC have successfully escaped anti-tumor immune response.

Methods. Tissue microarrays were constructed from representative formalin fixed paraffin embedded (FFPE) tissue samples of HNSCC primary tumors and their corresponding local recurrences for two independent patient cohorts: the Lübeck cohort (LC) consisting of 31 primary tumors with matched recurrences and the Bonn cohort (BC) including 266 primary tumors and 46 recurrences. All patients from the LC received (chemo-)radiation therapy between the resection of the primary tumor and the development of recurrence. The TIME was characterized via immunohistochemical staining for the markers CD4, CD8, CD20, FOXP3,

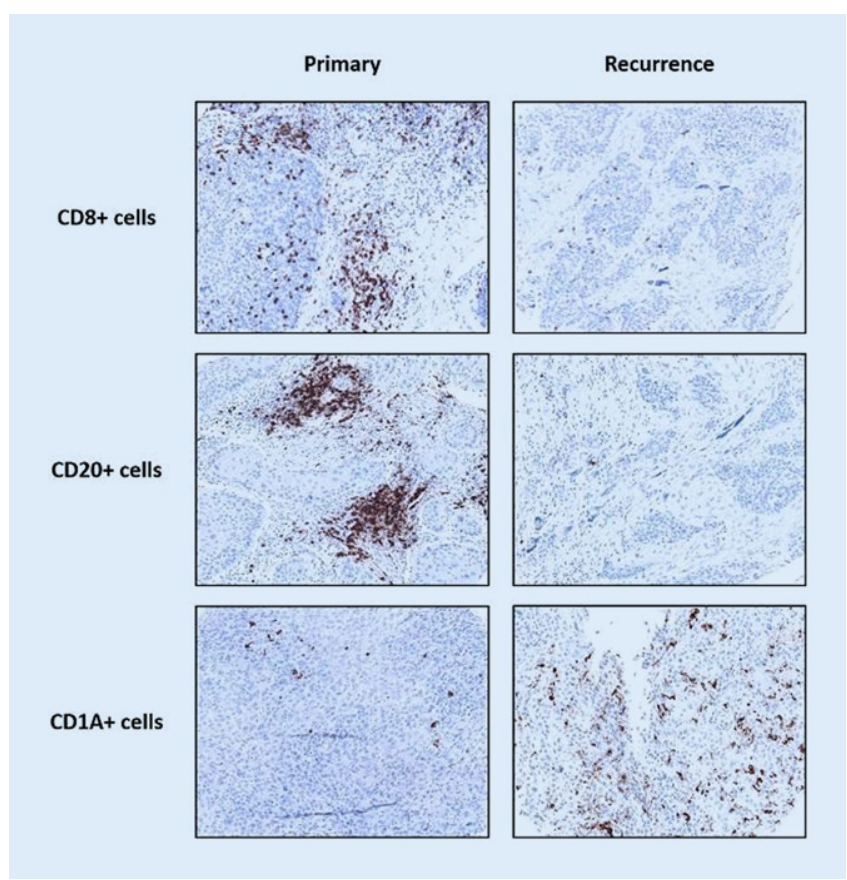

Fig. 1 | AG11.04 $\Delta$ Representative immunohistochemical staining of matched primary and recurrent tumors (Lübeck cohort)

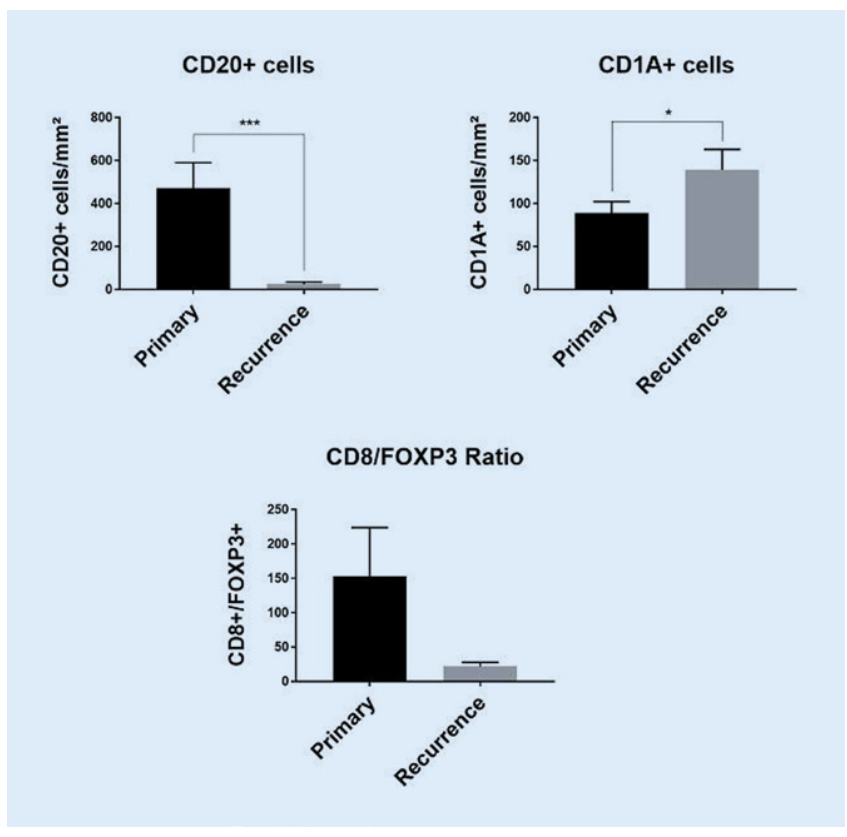

Fig. 2 | AG11.04 $\triangle$ Statistical analysis of IHC characterization $\left({ }^{*} p<0.05,{ }^{* * *}\right.$ $p<0.001$; paired t-test) (Lübeck cohort)

CD1A, PD1, CD68 and CD56 and a semi-automated image analysis software (Definiens). For 18 patients from the LC, RNA was extracted and RNA expression levels of 770 immune related genes were identified by $n a-$ nostring $n$ Counter ${ }^{\circledast}$ PanCancer Immune Profiling Panel and assessed with the $n$ Solver ${ }^{\text {rm }}$ Analysis Software.

Results. The immunohistochemical TIME analysis demonstrated a decrease of CD20+ B lymphocytes (LC: $p<0.001 ; \mathrm{BC}: p<0.0001$ ) and CD8/ FOXP3 T-cell ratio (LC: $p=0.19$; $\mathrm{BC}: p=0.06$ ) in recurrences compared to their primary tumors. CD8+ cytotoxic cells were decreased in recurrences of the BC $(p<0.0001)$ and CD1A+ dendritic cells were increased in re- 


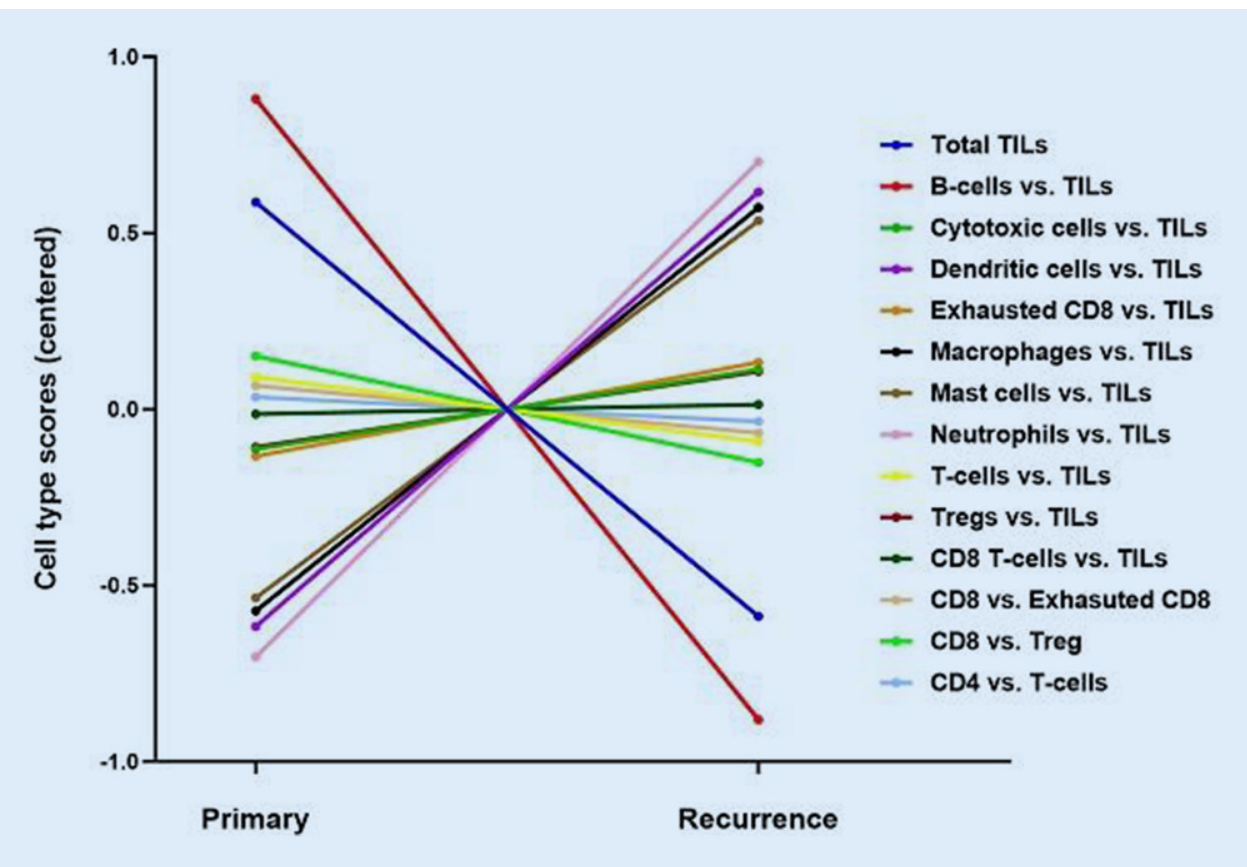

Fig. 3 | AG11.04 $<$ Quantification of tumor infiltrating leukocytes (TILs) via RNA expression profiling (Lübeck cohort) currences of the LC ( $p=0.04)$ (• Fig. $1 \mid$ AG11.04 and $\bullet$ Fig. 2 | AG11.04). RNA expression analysis (nanostring) confirmed depletion of B lymphocytes and additionally revealed a strong decrease in the total number of tumor infiltrating lymphocytes (TILs) as well as an increase in dendritic cells, mast cells, neutrophils and macrophages in HNSCC recurrences (- Fig. 3 |AG11.04). In summary, 141 immune related genes of the nanostring Panel were identified to be significantly differentially expressed with the majority being downregulated in HNSCC recurrences.

Conclusion. Our results reveal significant differences in the TIME of HNSCC primary tumors and recurrences, characterized by a loss of B lymphocytes and an overall shift from anti-tumor immune response to an increase in pro-tumor immune factors in recurrences.

\section{AG11.05}

\section{Expression levels of eukaryotic initiation factors (elFs) are} significantly altered in head and neck squamous cell carcinomas (HNSCC)

\section{A. Cyran ${ }^{*}$, S. Sprung ${ }^{2}$, N. Naß3, M. Naumann 4 , C. Arens', J. Haybäck ${ }^{2,3,5}$ 'Otto von Guericke University, Department for Otorhinolaryngology, Head and Neck Surgery, Magdeburg, Germany, ${ }^{2}$ Medical University of Innsbruck, Department of Pathology, Neuropathology, and Molecular Pathology, Innsbruck, Austria, ${ }^{3}$ Otto von Guericke University, Department of Pathology, Magdeburg, Germany, ${ }^{4}$ Otto von Guericke University, Experimental Internal Medicine, Magdeburg, Germany, ${ }^{5}$ Medical University of Graz, Diagnostic \& Research Center for Molecular BioMedicine, Institute of Pathology, Graz, Austria}

Aim. Head and neck squamous cell carcinomas (HNSCCs) are characterised by an exceptional intra- and inter-tumour genetic heterogeneity, which presents a major obstacle in introducing targeted therapies for $\mathrm{HN}$ SCCs. One way of overcoming this problem is developing therapies targeting molecules deregulated in all cancer cells within the tumour, such as the eukaryotic initiation factors (eIFs), which are a complex system of proteins regulating the first phase of translation. In our study we set out to evaluate, whether the eIFs could be potential molecular markers and therapy targets in HNSCC.

Methods. mRNA expression data from 528 patients with HNSCC, available at cBioportal.com was analyzed and correlated with overall survival (OS) and other clinical parameters. Next, immunohistochemical staining
(IHC) was performed on 105 paraffin samples to determine the protein levels of the most promising factor, namely eIF $2 \alpha$ in tumor and normal tissue. P-value $<0.05$ was considered significant.

Results. Based on mRNA expression, eIFs can be subdivided into functional groups i.e. clusters. mRNA expression of multiple eIFs was shown to be significant for overall survival rates. In particular, overexpression of the eIF2 subunits a, band g( $p$-values respectively: $0.0048 ; 0.0050 ; 0.0002)$. The expression of regulatory kinases and other proteins affecting the activity of eIF2 $\alpha$ was also significant, albeit differentially. In IHC a higher protein abundance of eIF2 $\alpha$ in tumour samples than in normal tissue was seen $(p=0.039)$.

Conclusion. mRNA expression of eIFs is tightly regulated and has prognostic significance in HNSCC. In the light of significant correlation of eIF2amRNA-expression in HNSCC and overexpression in tumor samples, we postulate eIF2 $\alpha$ as a potential molecular marker and therapeutic target in HNSCC.

\section{AG11.06}

Immunhistochemische Untersuchung odontogener Läsionen - ein nützliches Werkzeug für den diagnostischen Alltag?

\section{F. Steib ${ }^{1 * *}$, M.-A. Cassataro' ${ }^{1}$ S. Handt ${ }^{2}$, R. Knuechel-Clarke', T. Braunschweig'}

'RWTH Uniklinik Aachen, Institut für Pathologie, Aachen, Deutschland,

${ }^{2}$ Gemeinschaftspraxis Institut für Pathologie, Aachen, Deutschland

Ziel. Odontogene Läsionen zeigen in ihrer morphologischen Vielfalt eine große Bandbreite. Zudem weisen - unter anderem - zystische odontogene Läsionen eine große und sich teils überlappende morphologische Variationsbreite in ihrer Erscheinung auf. Da sie zudem ein häufiges Einsendegut darstellen, hat ihre sichere Einordnung Relevanz für die alltägliche diagnostische Arbeit. Dabei kann im Idealfall zur besseren diagnostischen Einordnung auf vorliegende Befunde der Bildgebung und des klinischen Bildes zurückgegriffen werden. Häufig liegen diese Informationen jedoch nicht vor, so dass eine sichere Einordnung allein durch Rückgriff auf alltagstaugliche diagnostische Werkzeuge, wie etablierte immunhistochemische Färbungen, wünschenswert erscheint. Aus diesem Grund wurden sowohl bereits bekannte, als auch noch wenig etablierte Färbungen an einem Kollektiv getestet und bewertet.

Methoden. Es wurden die am Institut für Pathologie der RWTH Aachen eingesandten odontogenen Läsionen aus den Jahren 2010-2014 (insge- 
samt 877) erfasst. Davon wurden von repräsentativen Fällen insgesamt 12 Tissue Microarrys hergestellt. Untersucht wurden in der Literatur bereits regelmäßig beschriebene Zielstrukturen wie Keratine (5/6, 7, 8, 10, 13, 17, $18,19)$ oder andere diagnostisch etablierte Marker (BCL2, Ki-67), aber auch bisher nur in kleineren Kollektiven getestete oder tierexperimentell beschriebene Antikörper (CD10, CD56, GLUT-1, BMP-2, BMP-4).

Ergebnisse. Gefundene Fälle stellen sich aus radikulären und odontogenen Zysten, aber auch seltenere odontogene Läsionen (u. a. Ameloblastom sowie klarzelliges odontogenes Karzinom). Als gesonderte Gruppe wurden alle Läsionen im Gesamtkollektiv erfasst, die von Patienten stammen, die zum Zeitpunkt der operativen Gewebeentnahme maximal 18 Jahre alt waren.

Hinsichtlich der Ergebnisse der Re-Evaluation bereits bekannter Antikörper, decken sich unsere Untersuchungsergebnisse überwiegend mit bereits publizierten Ergebnissen. Jedoch zeigt sich an zusätzlich untersuchten Zielstrukturen, dass das immunhistochemische Profil odontogener Läsionen noch nicht vollständig erfasst ist.

Fazit. Die bisher etablierte immunhistochemische Aufarbeitung odontogener Läsionen ist bereits von großer Hilfe, gerade wenn keine näheren Angaben zum klinischen/radiologischen Bild vorliegen. Damit nicht eindeutig fassbare Subgruppen sollen durch die hier erarbeiteten Markerprofile eingeordnet werden können.

\section{AG11.07}

\section{EVI1-Expression in Plattenepithelkarzinomen der Kopf-Hals-} Region als möglicher Indikator für Lymphknotenmetastasen

\section{P. Kuppler ${ }^{1 *}$, J. Ribbat-Idel', C. Idel', R. Krupar ${ }^{3}$, W. Vogel', B. Wollenberg ${ }^{2}$} S. Perner

'Universitätsklinikum Schleswig-Holstein, Campus Lübeck und Forschungszentrum Borstel, Leibniz Lungenzentrum, Institut für Pathologie, Standort Lübeck, Lübeck, Deutschland, ${ }^{2}$ Universitätsklinikum SchleswigHolstein, Campus Lübeck, Klinik für Hals-, Nasen- und Ohrenheilkunde, Lübeck, Deutschland, ${ }^{3}$ Universitätsklinikum Schleswig-Holstein, Campus Lübeck und Forschungszentrum Borstel, Leibniz Lungenzentrum, Institut für Pathologie, Standort Borstel, Borstel, Deutschland

Ziel. Ecotropic virus integration site 1 protein homolog (EVI1) ist als onkogener Transkriptionsfaktor bekannt. In vielen soliden Tumorentitäten ist eine hohe EVI1-Expression mit einer schlechten Prognose verbunden, wie z. B. im Prostatakarzinom. Wir beschreiben hier zum ersten Mal die Rolle von EVI1 in Kopf-Hals-Plattenepithelkarzinomen (HNSCC).

Methoden. In einer Kohorte aus 411 primären HNSCC verschiedener Lokalitäten (26,9 \% HPV+, 73,1 \% HPV-)wurde Karzinomgewebe der Patienten in Tissue Micro Arrays (TMA) zusammengefasst und immunhistochemisch mit einem Antikörper gegen EVI1 gefärbt. Die Tumorzell-Areale wurden markiert und dort die EVI1-Expression mit einer semi-automatischen Bildanalyse-Software (Definiens) bestimmt. Die Expressionsstärken der verschiednenen Subgruppen wurden mithilfe der Statistik-Software SPSS verglichen.

Ergebnisse. Primärtumore, die bereits eine Lymphknoten-Metastase gesetzt haben, exprimieren EVI1 stärker als diejenigen ohne LymphknotenMetastase. Im Primärtumor wiederrum ist die EVI1-Expression höher als in der zugehörigen Lymphknoten-Metastase. Die EVI1-Expression in p16 positiven Karzinomen ist signifikant erhöht im Vergleich zu p16 negativen Karzinomen $(p=0,014)$.

Fazit. EVI1 begünstigt in Kolon-Karzinomen eine Metastasierung, so dass die oben genannten Ergebnisse eine Rolle von EVI1 für die lymphogene Metastasierung in HNSCC vermuten lassen. Die höhere Expression in den Primärtumoren im Vergleich zu den zugehörigen Lymphknoten-Metastasen zeigt, dass die Metastase keine exakte Kopie des Primärtumors darstellt und tumorbiologisch gesondert betrachtet werden muss. Die höhere EVI1-Expression in den HPV-positiven Karzinomen könnte entweder durch die durchschnittlich höhere Metastasierungsrate dieser im Vergleich zu den HPV-negativen HNSCC erklärt werden oder gerade diese erhöhte Metastasierungsrate begünstigen. HPV positive Karzinome wiederrum haben eine bessere klinische Prognose als HPV negative, so dass unsere
Ergebnisse einer erhöhten EVI1-Expression in den p16 positiven Karzinomen mit der besseren zu erwartenden Prognose gegenüber den p16 negativen Karzinomen im Widerspruch zu den Ergebnissen zu anderen soliden Tumorentitäten stehen, in denen eine erhöhten EVI1-Expression eine schlechtere Prognose anzeigt. Gegebenenfalls kann jedoch eine erhöhte EVI1-Expression auf eine okkulte lymphogene Metastasierung bei klinischem cN0-Status hinweisen.

\section{AG11.08}

Morpho-molecular assessment indicates new prognostic aspects and personalized therapy options in sinonasal melanoma

S. N. Freiberger ${ }^{1 * 2,}$, G. B. Morand ${ }^{2,3}$, P. Turko ${ }^{2,4}$, R. Dummer, ${ }^{2,4}$, D. Holzmann ${ }^{2,3}$, N.J. Rupp ${ }^{1,2}$, M. P. Levesque ${ }^{2,4}$

'University Hospital Zurich, Department of Pathology and Molecular Pathology, Zurich, Switzerland, ${ }^{2}$ University of Zurich, Zurich, Switzerland, ${ }^{3}$ University Hospital Zurich, Department of Otorhinolaryngology, Head and Neck Surgery, Zurich, Switzerland, ${ }^{4}$ University Hospital Zurich, Department of Dermatology, Zurich, Switzerland

Aim. Sinonasal melanoma is a rare subtype of melanoma and little is known about its molecular fingerprint. Systemic treatment options are limited, and currently, metastatic sinonasal melanoma is being treated according to the guidelines of cutaneous melanoma. Here, we aimed to correlate the molecular profile of primary sinonasal melanoma with histological and clinical features. This allowed us to further characterize this rare and aggressive type of melanoma and screen for prognostic markers and treatment options.

Methods. We selected a cohort of 19 primary sinonasal melanomas that were diagnosed and treated between 2006 and 2018 at the University Hospital Zurich, Switzerland. Molecular profiling was done by target-capture sequencing using the MelArray, a customized NGS panel of 190 genes. Libraries were sequenced on Illumina ${ }^{\circledR}$ HighSeq4000. Sequencing data were analyzed with a custom bioinfomatics pipeline and open-source software. Histological features, and immunohistochemical staining (CD4, CD8, PDL1) were evaluated by a senior board certified head \& neck pathologist. Molecular findings, histological features and clinical parameters were correlated using log rank test or Fisher's exact test where indicated.

Results. Mutation analysis revealed a heterogeneous profile of the cohort with an overall low mutational burden and a trend towards prolonged distant metastasis-free survival in NRAS mutant patients. Copy number analysis divided the cohort into two groups (CNV-low and CNV-high), the latter with alterations in DNA repair genes. Molecular alterations revealed possible off-label or compassionate use treatment options or clinical trial opportunities. Histological evaluation showed a prolonged disease-free survival in patients with pleomorphic tumors. Furthermore, all patients who were allocated to palliative care turned out to have monomorphic tumors. Pigmentation and apoptosis did not correlate with disease outcome. However, amelanotic melanoma were associated with older patients. PDL1 staining was low or absent in the tumors of our cohort, while positive in some immune cells of most patients.

Conclusion. The mutational profile of primary sinonasal melanoma is heterogeneous, with some patients carrying targetable alterations, which may justify molecular testing in a respective clinical setting. Patients with monomorphic tumors were associated with worse prognosis. A larger sample size is needed to clarifying the prognostic impact of molecular alterations. 


\section{AG Kopf-Hals-Pathologie II}

\section{AG11.09 \\ Assembly of a large and comprehensively characterized head and neck cancer cohort}

J. Ribbat-Idel' *, P. Kuppler', C. Idel', R. Krupar', W. Vogel', C. Watermann', A. Offermann ${ }^{1}$, B. Wollenberg ${ }^{2}$, S. Perner ${ }^{1}$

'Universitätsklinikum Schleswig-Holstein, Campus Lübeck und Forschungszentrum Borstel, Leibniz Lungenzentrum, Institut für Pathologie, Lübeck, Germany, ${ }^{2}$ Universitätsklinikum Schleswig-Holstein, Campus Lübeck, Klinik für Hals-, Nasen- und Ohrenheilkunde, Lübeck, Germany

Aim. The aim of this study was to set up a clinico-pathologically well characterized FFPE cohort of patients suffering from head and neck squamous cell carcinoma (HNSCC).

Methods. In collaboration with the on-site Department of Head and Neck Surgery, HNSCC patients diagnosed from 2010-2013 were identified and updated for the latest TNM classification (8th edition). Immunohistochemical p16 status was completed as surrogate marker for Human Papilloma Virus (HPV) related cancer. Tumor tissue from primary tumors, recurrent tumors, lymph node metastases and distant metastases was arranged on a tissue microarray (TMA). Clinical data was obtained by researching the hospital patient care database (ORBIS).

Results. The cohort is now represented by two arms: patients with a local recurrent disease $(25 \%)$ versus patients that did not experience a cancer relapse (75\%). Our cohort consists of 411 patients $(77.1 \%$ male, $22.9 \%$ female) with $26.7 \%$ being p16 positive. The majority of HNSCC were located in the oropharynx $(n=133)$, larynx $(n=111)$, oral cavity $(n=97)$ and hypopharynx ( $n=48) .15$ cases were cancers of unknown primary (CUP). According to TNM classification in the 8 th edition, $54.2 \%$ of patients were classified T1/T2 and $45.7 \%$ were classified T3/4. 57.2\% of patients had a nodal positive HNSCC. $3.9 \%$ of patients had distant metastasis. The majority of patients had an advanced stage when first diagnosed (29\% UICC stage I/II; $70.9 \%$ UICC stage II/V).

Conclusion. We have recruited a large HNSCC tumor tissue and patient data cohort that reflects the aggressive biology of this cancer. Our data is in accordance with the well renowned epidemiological and prognostic data regarding sex, age and place of origin. In comparison with data from the German Krebsregister there are less T1 cancers included than epidemiologically expected. This may be due to the fact that the tumor mass is often too small to be used for Research research purposes. The cohort has been characterized in detail by cataloging comprehensive clinical and tumor data. In terms of sex, HPV status and tobacco history our cohort is comparable with statistical data worldwide. Regarding the place of origin our cohort is comparable with European epidemiology data, but there is a slight difference compared to the US and Asia.

We therefore have access to a valuable and powerful tool that shall allow us to further characterize HNSCC in the future. Further studies to investigate cellular and nuclear markers are following.

\section{AG11.10 \\ Defective maturation of the interleukin-11 receptor causes craniosynostosis}

B. Kespohl ${ }^{1 *}$, M. Agthe ${ }^{2}$, J. Lokau' ', C. Garbers'

'Otto-von-Guericke University, Department of Pathology, Magdeburg,

Germany, ${ }^{2}$ Kiel University, Institute of Biochemistry, Kiel, Germany

Introduction. Craniosynostosis describes the premature closure of one or more cranial sutures, which often occurs prenatally and is diagnosed at a rate of 1:2500 among newborns. Skull growth and suture closure is a regulated and dynamic process that involves the concerted activity of multiple signaling pathways and crucially depends on the activity of osteoblast precursor cells located at the sutures. Causative mutations in several genes have been identified in craniosynostosis patients, e.g. FGFR1, FGFR2, FGFR3 and TWIST1. Recently, several point mutations within the
IL11RA gene, which encodes the receptor of the cytokine interleukin-11 (IL-11R), have been described. Since IL-11R signaling is involved in bone remodeling and required for proper bone formation, we aimed to investigate how the reported mutations in the IL-11R influence IL-11R function and IL-11 signaling.

Methods. We analysed the impact of mutations found in craniosynostis patients on the function of the IL-11R. Therefore, we generated expression plasmids encoding the different IL-11R mutations and expressed the IL$11 \mathrm{R}$ variants heterologously in mammalian cells. We analyzed maturation, intracellular transport and cell surface expression of the IL-11R variants compared to the wildtype IL-11R. Furthermore, we stably transduced all variants in cytokine-dependent cell lines and were thereby able to determine their biological activity using proliferation assays and analysis of intracellular signaling cascades.

Results. Our results show that some of the patient mutations lead to impaired maturation and trafficking of the IL-11R to the cell surface, which compromises the biological activity of the receptor. These IL-11R variants were retained within the endoplasmic reticulum quality control system, suggesting a folding defect of the IL-11R caused by the mutation. In contrast, other IL-11R variants were able to leave the ER and to reach the cell surface, although at reduced amounts compared to the unaltered IL-11R. Conclusion. IL-11R mutations that are found in craniosynostosis patients differently impair the biological function of the IL-11R, ranging from complete biological inactivity to reduced maturation and cell surface appearance.

\section{AG11.11}

Die S-100 positive reaktive stromale Hyperplasie des Mittelohrs eine bisher unbeschriebene tumorartige Läsion in Assoziation mit Cholesteatomen

\section{N.J.Rupp ${ }^{*}$, C. Röösli' ${ }^{2}$ E.J. Rushing ${ }^{3}$, B. Bode-Lesniewska}

'Institut für Pathologie und Molekularpathologie, UniversitätsSpital Zürich, Zürich, Schweiz, ${ }^{2}$ Klinik für Ohren-, Nasen-, Hals- und Gesichtschirurgie, UniversitätsSpital Zürich, Zürich, Schweiz, ${ }^{3}$ Institut für Neuropathologie, UniversitätsSpital Zürich, Zürich, Schweiz

Ziel. Das Cholesteatom ist eine häufige Erkrankung des Mittelohrs und zeigt histologisch das klassische Bild membranartigen Plattenepithels mit fein-lamellärer Verhornung. In dieser Studie beschreiben wir 4 Fälle, in denen in Exzisaten bei Patienten mit Cholesteatom oder chronischer Mastoiditis eine histologisch tumorartige mesenchymale, S-100-positive, nicht sicher einordenbare Läsion beobachtet wurde.

Methoden. Es wurden routine-histologische Fälle gesammelt, die im Rahmen einer Mittelohr- oder Mastoid-Operation entnommen wurden und histologisch eine auffallende, tumorartige, mesenchymale, nicht näher klassifizierbare Läsion zeigten. Diese wurden morphologisch sowie immunhistochemisch mittels der folgenden Marker charakterisiert: S-100, SMA, Desmin, Sox10, Melan A, Synaptophysin, CD34, Panzytokeratin, EMA. Als Kontrolle dienten Exzisate von Patienten mit Cholesteatom und üblicher angrenzender Stromamorphologie, ohne Tumoraspekt.

Ergebnisse. Es fanden sich 4 Fälle, in denen histologisch entweder angrenzend an klassische fein-lamellär verhornende Plattenepithelstreifen oder isoliert eine knotig imponierende mesenchymale Proliferation auffielen. Diese zeigte zumeist eine ovoid-spindelzellige Morphologie, einen fibrillären Hintergrund, teilweise nukleäre Pseudoinklusionen sowie stellenweise ein retikulär-myxoides Wachstumsmuster. Alle Fälle zeigten untermischte Mastzellen, Lymphozyten sowie eine konstante, überwiegend kräftige Expression von S-100 und Koexpression von SMA bei Negativität für Desmin und die übrigen untersuchten Marker. Im Verlauf fanden sich keine Anhaltspunkte für eine Persistenz/Rezidiv. Die Kontrollgruppe zeigte im morphologisch ähnlichen Stroma ebenfalls eine konstante Koexpression von S-100- und SMA.

Fazit. Die hier beschriebene, in der Literaur unbekannte, reaktive, S100positive, stromale Hyperplasie (RSH) kann tumorartig imponieren und zeigt dabei überwiegend ein ovoid-spindelzelliges, fibrilläres und gelegentlich retikulär-myxoides Bild, teils mit auffallenden Kernveränderungen 
wie nukleären Pseudoinklusionen. Die immunhistochemische S-100-Positivität kann dabei ein Fallstrick zur Diagnose eines neurogenen Tumors sein. Die konstante Koexpression von SMA, wie sie auch in üblichem Mittelohrstroma beobachtet wird, und die gleichartige Zellmorphologie wie das ortstypische Stroma unterstützen die Einordnung als reaktive Veränderung, um die Überdiagnose eines benignen oder gar low-grade malignen Tumors zu verhindern.

\section{AG11.12}

\section{NUT-Karzinome: Eine Fallserie}

A. Harms*, D. Kazdal, M. Kriegsmann, J. Leichsenring, B. Goeppert, M. Allgäuer, A.-L. Volckmar, O. Neumann, M. Kirchner, P. Schirmacher, A. Stenzinger

Universitätsklinikum Heidelberg, Institut für Pathologie, Heidelberg, Deutschland

Ziel. Die Diagnostik des NUT-Karzinoms erfordert eine Kombination aus Erfahrung, immunhistochemischen Markern und molekularpathologischen Methoden für die Detektierung der molekularen Alterationen. In Zukunft hat die Diagnose nicht nur prognostische sondern auch eine spezifische Therapie als Konsequenz. Insofern ist es essentiell die Wahrnehmung für diese hochmaligne Entität zu steigern und mit klinischen Daten zu korrelieren.

Methode. Bislang wurden insgesamt neun NUT-Karzinome am Institut für Pathologie der Universität Heidelberg diagnostiziert und in diese Untersuchungen eingebracht. Die im Rahmen des MASTER Programms detektierten genetischen Veränderungen (mittels WGS und Transkriptomanaytik) wurden in der Molekularpathologie Heidelberg mittels orthogonaler Methoden wie Sangersequenzierung oder AMP (Anchored multiplex PCR; Archer ${ }^{\text {twa }}$ ) überprüft. Hierbei wurde u. a. mittels konventioneller RT-PCR das Vorhandensein der NUT-Fusion bestätigt. In einem zweiten Fall wurde mittels AMP der unbekannte Fusionspartner identifiziert. Ergebnisse. Fünf NUT-Karzinome traten im Thorax, drei im oberen aerodigestiven Trakt und eines in der Niere auf. Insgesamt vier Fälle wurden initial als NUT-Karzinome identifiziert. Lichtmikroskopisch zeigten alle Fälle in der H\&E-Färbung ein charakteristisches angedeutet biphasisches Bild bestehend aus einer kleinen, runden und blauen Tumorzellkompente mit einem recht abrupten Übergang in kleine Nester polygonaler und eosinophiler, deutlich größerer Tumorzellen mit einer oftmals gut erkennbaren Verhornung. Immunhistochemisch zeigten alle Fälle eine kräftige nukleäre Reaktion für NUT sowie eine Expression von AE1/3, CK5/6, CK7 und p63. In fünf Fällen lag die Translokation von BRD4-NUT, in zwei Fällen die Translokation BRD3-NUT und in zwei weiteren Fällen die seltene Translokation von NSD3-NUT vor.

Fazit. NUT-Karzinome sind seltene, hochaggressive und häufig diagnostisch verkannte maligne Neoplasien. Sie sind durch die drei charakteristischen und spezifischen Translokationen BRD3/4-NUT und NSD3-NUT gekennzeichnet, was eine definitive Diagnostik ermöglicht. Spezifische Therapeutika werden zurzeit in klinischen Studien erprobt, sodass zusätzlich eine gezielte Therapie ermöglicht werden kann. Um die diagnostische Eingrenzung der Entität weiter zu verbessern, haben wir ein genau charakterisiertes Kollektiv von NUT-Karzinomen umfassend immunhistologisch und molekularpathologisch analysiert und mit klinischen Verlaufsdaten korreliert.

\section{AG Molekularpathologie I - What's new?}

\section{AG12.01 \\ Bestimmung der Tumor-Mutationslast(TMB) in der Realdiagnostik: Parameter, Einflussgrößen und Fallstricke für eine präzise TMB-Analytik}

V. Endris*, M. Allgäuer, E. Rempel, D. Kazdal, J. Leichsenring, A.-L. Volckmar, M. Kirchner, O. Neumann, R. Penzel, P. Schirmacher, J. Budczies, A. Stenzinger Institut für Pathologie/Universitätskrankenhaus Heidelberg, Molekularpathologisches Zentrum, Heidelberg, Deutschland

Ziel. Die Bestimmung der Tumormutationslast mittels des Goldstandard der Gesamtexom-Sequenzierung (WES) ist für eine breite Routinediagnostik am FFPE Tumorgewebe nur bedingt geeignet. Mehrere größere, eigens für die TMB-Bestimmung entwickelte NGS-Genpanels sind mittlerweile kommerziell erhältlich. In silico Daten zur theoretischen Leistungsbestimmung dieser Panels haben kritische Punkte wie etwa die Größe der Zielbereiche bestimmt. Jedoch gibt es kaum Studien über die reale Performance der TMB-Panelsequenzierung unter Laborbedingungen.

Methoden. Wir haben ca. 100 verschiedene Tumore mit Fokus auf Lungenkarzinomen und kolorektalen Karzinomen mit 4 unterschiedlichen Genpanels untersucht, von denen WES-Daten vorlagen. Die Größe der Panels lag zwischen 0,39 und 1,8 Megabasen (Mb).

Ergebnisse. Die ermittelten TMB-Werte der Lungenkohorte $(n=29)$ lagen zwischen 0 und 30,28 Mutationen/Mb. Die Mehrzahl der untersuchten Proben zeigte eine Mutationslast die in der Nähe der derzeit in klinischen Studien ermittelten Cut-Off Werte für Immuntherapien liegen. Wir konnten eine starke Korrelation der TMB-Werte und den WES-Daten für Panels mit einer Größe $>1 \mathrm{Mb}$ feststellen. Während für die kleineren Panels mit einer Größe von ca. 0,5 Mb die Sensitivität ausgehend von einem CutOff Wert von 243 somatischen Mutationen bei ca. 75 \% lag, erhöhte sich die Sensitivität für die größeren Genpanels auf $>90 \%$. Bei den kolorektalen Karzinomen $(n=20)$, die als Modell einer bimodalen TMB-Verteilung dienen (MSS vs. MSI-high) zeigt sich, dass auch kleinere Panels eine ausreichende Stratifizierung der Subgruppen erreichen. Desweiteren haben wir die Panels hinsichtlich Identifizierung therapeutisch-relevanter Mutationen untersucht, die neben der reinen TMB-Bestimmung in der Routinediagnostik eine obligate Rolle spielt. Bedingt durch die im Vergleich zum WES geringere totale Anzahl identifizierter Mutationen zeigt sich, dass für eine präzise TMB-Bestimmung die Validierung der Varianten sowie deren Klassifizierung in benigne vs. pathogene Mutationen essentiell ist. Fazit. Während die Amplikon-basierten Systeme Vorteile etwa bei kleineren Proben (z. B. Biopsaten) besitzen mit geringerem Laboraufwand, sind Hybrid Capture-Panels deutlich weniger anfällig für fixierungsbedingte Artefakte. Optimierungen prä- und postanalytischer Schritte, die Bewertung der Varianten sowie der Umgang mit den großen Datensätzen sind weitere Herausforderungen, die bei der Implementierung der Testung zu beachten sind.

\section{AG12.02}

\section{Validierung des humanen TMB-Panels (Qiagen)}

T. Herold*, K. Worm, H.-U. Schildhaus

Uniklinik Essen, Pathologie, Essen, Deutschland

Ziel. TMB (Tumor Mutational Burden) gilt inzwischen als ein prädiktiver Marker auf das Ansprechen einer zielgerichteten Immuntherapie. Das Vorliegen einer hohen Mutationslast korreliert hierbei mit dem positiven Ansprechen auf die Immuntherapie. Inzwischen finden sich verschiedene Anbieter von TMBPanels für die Hochdurchsatzsequenzierung (NGS) auf dem Markt. Alle Anbieter bieten für die TMBAnalyse Panels mit einer Größe von $>1 \mathrm{Mb}$ exonischem Bereich an. Im Rahmen des Projektes wird das Human-TMB-Panel (Fa. Qiagen) umfangreich getestet. Hierbei geht es insbesondere um die Fragestellung des minimalen Probeneinsatzes. Auf Grund des teilweise sehr limitierten Probenmaterials (bsp. Fein- 
nadelbiospsie) ist diese Frage ist für die Routinediagnostik von enormem Interesse.

Methoden. Es wurde eine Gruppe von 20 FFPE-Proben untersucht. Diese Gruppe besteht aus 8 Resektaten, 7 Biopsieproben, 2 Proben mit bekannter MSI-Low- sowie 3 Proben mit bekannter MSIHighDiagnose. Hinzu kamen eine Kontrollprobe mit diversen bekannten Mutationen sowie eine Wasserprobe als Negativkontrolle. Von den unterschiedlichen Proben wurden mehrere Duplikate an DNA aus 1, 3, 5 und 8 Schnitten von je $1 \mathrm{~cm}^{2}$ extrahiert. Für die anschließende TMB-Libraryerstellung (QIAseq Targeted DNA Panel; Human-TMB-Panel; Fa. Qiagen) wurden bis zu $40 \mathrm{ng}$ GesamtDNA (Qubit gemessen) eingesetzt. Die Sequenzierung der Proben erfolgte auf dem Illumina NextSeq, die anschließende Auswertung mittels CLC Genomics Workbench 5.0.1. Von verschiedenen Proben wurden sowohl technische wie auch biologische Replikate sequenziert.

Ergebnisse. Der molekularpathologische Workflow bestehend aus Library-Präparation, Sequenzierung sowie Auswertung konnte schnell etabliert werden. Die Ergebnisse der Sequenzierung zeigen eine klare Unterscheidung von TMB-High und TMB-Low Proben. Alle im Vorfeld als MSIHigh bestimmten Fälle konnten mit dem Assay als MSI-High bestätigt werden. Bei ausreichender DNA-Gesamtenge ( $>20 \mathrm{ng}$ ) konnte in den Replikaten eine gute Übereinstimmung der Ergebnisse erzielt werden. Bei geringerer DNA-Ausgangsmenge zeigt sich eine erhöhte Variabilität.

Fazit. Das humane TMB-Panel konnte gut in den molekularpathologischen Routineworkflow integriert werden. Ein entscheidender Faktor für eine erfolgreiche Analyse der FFPE-Proben liegt im präanalytischen Bereich. Die Qualität sowie die aus der Probe extrahierte amplifizierbare DNAGesamtmenge sind für eine erfolgreiche Analyse von extremer Wichtigkeit.

\section{AG12.03}

\section{Nachweis von MET Exon 14-Mutationen mittels MALDI-TOF}

H.-U. Schildhaus'* S. Hugo ${ }^{2}$, T. Hugo' ${ }^{2}$, L. Lukat ${ }^{2}$, K. Reuter-Jessen ${ }^{2}$ 'Universitätsklinik Essen, Institut für Pathologie, Essen, Deutschland, ${ }^{2}$ Universitätsmedizin Göttingen, Institut für Pathologie, Göttingen, Deutschland

Ziel. MET Mutationen unter Beteiligung der Intron-Exon-Übergänge von Exon 14 können durch alternatives Spleißen zu einem Verlust des gesamten Exon 14 des MET-Gens führen (Exon 14-Skipping Mutationen). Diese Veränderungen führen zu einer Stabilisierung des funktionsfähigen Proteins durch verminderte Degradation des Proteins und weisen bei verschiedenen Tumoren eine onkogene Wirksamkeit auf. TyrosinkinaseInhibitoren mit anti-MET Aktivität können bei Tumoren mit diesen Veränderungen wirksam sein. Derartige Behandlungen werden derzeit im Rahmen klinischer Therapiestudien unter anderem bei nicht-kleinzelligen Lungenkarzinomen erprobt. MET-Exon 14-skipping-Mutationen können unter anderem mittels DNA-Sequenzierung der Intron-Exon-Übergänge oder durch RNA-Sequenzierung nachgewiesen werden. Diesen Methoden ist gemeinsam, dass sie relativ aufwendig sind und längere Untersuchungszeit in Anspruch nehmen. Auch sind einige dieser Verfahren für sehr kleine Gewebeproben mit geringem Tumorzellgehalt nicht gut geeignet.

Methoden. Aus Paraffinmaterial wurde RNA isoliert (Agencourt FormaPure RNA, Beckman Coulter) und eine reverse Transkriptase-PCR durchgeführt (SuperScript ${ }^{\mathrm{Ts}}$ VILO $^{\mathrm{mt}}$ cDNA Synthesis Kit, ThermoFischer). Die cDNA wurde weiter mittels PCR und MALDI-TOF untersucht. Mischungen von Zellinien mit verschiedenen Allelfrequenzen wurden zur Etablierung eingesetzt, diese reichten von $0 \%$ (wild type) über $0,1 \%, 1 \%, 10 \%$, $20 \%, 50 \%, 80 \%$ bis $100 \%$ mutierte Zellen. 10 ng cDNA wurde zum Nachweis der MET-Exon 14-skipping Mutation mit dem MALDI-TOF basierten MassARRAY ${ }^{\circledR}$ multiplexing panel verwendet (iPLEX MET exon 14 skipping assay, Agena Bioscience). In einem weiteren Etablierungsschritt wurden klinische Gewebeproben aus FFPE-Material eingesetzt, die mittels DNA-und RNA-Sequenzierung vorcharakterisiert waren.

Ergebnisse. Bei Einsatz von 10 ng cDNA konnte die MET-Exon 14-Mutation bereits bei $0,1 \% M E T$ mutierten Zellen detektiert werden. Auch die klinischen Gewebeproben konnten korrekt klassifiziert werden.
Fazit. Der iPLEX MET exon 14 skipping Assay ist eine schnelle und sensitive Methode zum Nachweis von MET-Exon 14-Mutationen.

\section{AG12.04 \\ Entwicklung eines komplexen NGS Panels für das kolorektale Karzinom}

\section{S. Toktamis*, A. Maurer, A. Cassataro, S. von Serenyi, T. Braunschweig,} N. Ortiz-Brüchle

RWTH Uniklinik Aachen, Institut für Pathologie, Aachen, Deutschland

Ziel. Das Kolorektale Karzinom (CRC) zeigt neben den Formen hereditären Ursprungs bei den sporadischen Fällen eine multifaktorielle Ätiologie. Eine größere Subgruppe zeigt dabei Treibermutationen und/oder Ausfälle in den Mismatch-Repair-Enzymen (MMRE), die zu einer genetischen Instabilität führen, dessen Korrelat die Mikrosatelliteninstabilität (MSI) in der Diagnostik darstellt.

Das Ziel dieser Methodenetablierung besteht darin, ein spezifisches NGS Panel zur molekulargenetischen Analyse des CRC zu entwickeln. Dabei sollen in einem einzigen NGS Lauf gleichzeitig der BRAFV600 Mutationsstatus, die MLH1 Promotorhypermethylierung sowie MSI erfasst werden können.

Methoden. Aus FFPE Geweben von 104 CRC, davon 25 mit vordiagnostizierter MSI, und 71 SSA des rechten Colons sowie 56 linksseitige Läsionen wurden die MMRE (MLH1, MSH2, MSH6 und PMS2) mittels TMA immunhistochemischen Färbungen dargestellt. Von 15 Fällen mit Hinweis auf eine MSI wurde DNA isoliert und ein Teil der DNA mit dem EZ DNA Methylation-Lightning ${ }^{\text {sit }}$ Kit (Zymo Research, Irvine, USA) bisulfidkonvertiert. In fünf Multiplex-PCRs wurde BRAFV600, die MLH1 Promotorregionen $\mathrm{C}$ und $\mathrm{D}$ sowie 8 Mikrosatelliten - darunter die des Bethesda Panels - amplifiziert, mit einer Universalsequenz versehen und im Anschluss aufgereinigt. Mittels einer zweiten PCR wurden Adapter angefügt (Nextflex ${ }^{\text {Tw }}$ 16S V1-3 Amplicon Seq Kits, PerkinElmer, Waltham, USA) und die Proben äquimolar gepoolt sowie erneut aufgereinigt. Die Sequenzierung der Libraries erfolgte auf dem MiSeq-NGS-Gerät ${ }^{\mathrm{m} \mathrm{m}}$ (Illumina, San Diego, USA). Die Daten wurden mit der Software SeqPilot Modul SeqNext für Mutationen v4.4_64bit (JSI medical systems, New York, USA) und CLC Main Workbench 8.1 (Quiagen, Venlo, NLD) ausgewertet.

Ergebnisse. MLH1 war in 29 der 36 rechtskolisch detektierten CRC mit einem immunhistochemischen Profil passend zu einer MSI mit Ausfall von mindestens 2 MMRE mitbetroffen. Linkskolisch zeigten 2 von 7 CRC mit MSI eine MLH1 Beteiligung. Alle SSA ohne Atypie waren MS stabil, 7 der 13 SSA mit Atypie zeigten immunhistochemisch MSI.

In ersten Testläufen ließen sich bei ausgewählten Fällen alle PCR Produkte in der NGS Auswertung in ausreichender Menge und Qualität nachweisen. Fazit. Die Etablierung eines NGS Kolon Panels mit verschiedenen Grundansätzen konnte erreicht werden, sodass die simultane molekulargenetische Diagnostik von mehreren Patienten ermöglicht wird, insbesondere von Markern, die nicht in den konventionellen Genpanels enthalten sind. 


\section{AG Molekularpathologie II - Liquid Biopsy}

\section{AG12.05}

Somatische Mutationen in zirkulierender zell-freier DNA beim Primärstaging von Oesophaguskarzinom-Patienten sind prädiktiv für post-operative Rezidive

H. Pasternack ${ }^{*}$, J. Fassunke ${ }^{2}$, P. S. Plum ${ }^{3,4}$, S.-H. Chon ${ }^{3}$, D. A. Hescheler ${ }^{3}$ A. Gassa ${ }^{5}$, S. Merkelbach-Bruse' ${ }^{2}$ C. J. Bruns', S. Perner', M. Hallek, R. Büttner ${ }^{2}$, E. Bollschweiler ${ }^{3}$, A. H. Hölscher ${ }^{7}$, A. Quaas ${ }^{2,4}$, T. Zander, ${ }^{4,6}$, J. Weiss ${ }^{6}$, H. Alakus ${ }^{3,4}$

1 Pathologie des Universitätsklinikums Schleswig-Holstein, Campus Lübeck und des Forschungszentrums Borstel, Leibniz Lungenzentrum, Lübeck, Deutschland, 'Institut für Pathologie, Universitätsklinikum Köln, Köln, Deutschland, ${ }^{3}$ Klinik für Allgemein-, Viszeral- und Tumorchirurgie, Universitätsklinikum Köln, Köln, Deutschland, ${ }^{4}$ Gastrointestinal Cancer Group Cologne, Köln, Deutschland, ${ }^{5}$ Klinik und Poliklinik für Herz- und Thoraxchirurgie, Universitätsklinikum Köln, Köln, Deutschland, ${ }^{6}$ Klinik I für Innere Medizin, Universitätsklinikum Köln, Köln, Deutschland, ${ }^{7}$ Zentrum für Speiseröhren- und Magenchirurgie, Agaplesion Markus Krankenhaus, Frankfurt am Main, Deutschland

Ziel. Das Oesophaguskarzinom ist einer der häufigsten malignen Tumoren und weist eine hohe Mortalität auf. Ziel dieser Studie ist die Untersuchung der Durchführbarkeit sowie der klinischen Aussagekraft einer Mutationstestung an zirkulierender zell-freier DNA (ccfDNA) während des Primärstagings früher Stadien des Oesophaguskarzinoms.

Methoden. In 25 Patienten mit lokal fortgeschrittenen operablen Oesophaguskarzinomen wurden endoskopische Tumorbiopsien sowie parallele Blutproben während des Primärstagings gewonnen. An der genomischen DNA aus dem Tumorgewebe sowie der aus den Blutproben gewonnenen ccfDNA wurden vergleichende Mutationsanalysen mittels einer 12-Gen panel Parallelsequenzierung (Next Generation Sequencing, NGS) sowie digitaler PCR (ddPCR) durchgeführt. Die so gewonnenen molekularen Daten wurden mit dem post-operativen Krankheitsverlauf der Patienten korreliert.

Ergebnisse. In 21 der untersuchten Biopsien (84\%) wurde mittels Parallelsequenzierung mindestens eine somatische Mutation detektiert. Die in der Parallelsequenzierung nachgewiesenen Mutationen wurden ebenso mit vergleichbaren Allelfrequenzen mittels ddPCR detektiert. In dre der 21 Patienten mit nachgewiesenen Mutationen wurden mittels Parallelsequenzierung die gleichen Mutationen auch in der ccfDNA detektiert (14\%). Mittels ddPCR wurden zusätzlich Mutationen in der ccfDNA von fünf weiteren Patienten nachgewiesen $(8 / 21,38 \%)$.

Für alle Patienten mit kompletter Tumorresektion wurde der post-operative Krankheitsverlauf analysiert $(n=16)$. Fünf davon erlitten ein frühes Rezidiv im ersten Jahr nach der Operation, wobei in vier dieser Fälle während des Primärstagings somatische Mutationen in der ccfDNA nachweisbar waren.

Fazit. Zusammenfassend konnten wir eine höhere Sensitivität der ddPCR im Vergleich zur Parallelsequenzierung bei der Mutationsanalyse von ccfDNA zeigen. Dabei war der Nachweis somatischer Mutationen in der ccfDNA von Oesophaguskarzinom-Patienten prädiktiv für ein frühes post-operatives Rezidiv.

\section{AG12.06}

\section{Optimierung UMI-basierter Liquid Biopsy Sequenzierung: 94 getestete Fälle aus der Routine mit unterschiedlicher Fragestellung}

A. Streubel ${ }^{1 *}$, S. Stephan-Falkenau' ', J. Kollmeier², T.-G. Blum², D. Misch' ${ }^{2}$ S. Thiel', M. Schäfer ${ }^{2}$, T. Bauer' ${ }^{2}$, T. Mairinger ${ }^{1}$

'Emil von Behring Krankenhaus HELIOS Kliniken Berlin, Pathologie, Berlin, Deutschland, ${ }^{2}$ Emil von Behring Krankenhaus HELIOS Kliniken Berlin, Klinik für Pneumologie, Lungenlinik Heckeshorn, Berlin, Deutschland

Ziel. Für Patienten, bei denen aufgrund schwer zugänglicher Tumorlokalisation, Allgemeinzustand oder Compliance eine Gewebebiopsie nicht chancenreich ist, stellt die Liquid Biopsy eine mögliche Alternative dar. Derweil wurden Methoden untersucht, die zur Optimierung der Gewinnung von cfDNA beigetragen haben, dies ist vor allem bei NSCLC Patienten mit sehr geringem ctDNA Gehalt im Blut von Bedeutung. Nach Etablierung einer geeigneten Extraktionsmethode, setzen wir es uns nun zum Ziel, den UMI-basierten TaqSequencing Workflow zu optimieren Methoden. Für die Liquid Biopsy Routine Untersuchung aus dem Blut wurde von insgesamt 94 Patienten cfDNA aus Plasma mit dem ccfDNA extraction kit (Qiagen) extrahiert. Bei 59 NSCLC Fällen mit Frage nach T790M Positivität war die Primärmutation zuvor im FFPE Gewebe detektiert worden, bei weiteren 20 Fällen mit differierender Fragestellung, war eine aktivierende Mutation bekannt und zuvor mittels NGS am FFPE Material nachgewiesen. Bei weiteren 15 Fällen war eine Gewebebiopsie nicht möglich und keine Mutation bekannt und oder die Diagnose unklar. CfDNA wurde aus $4 \mathrm{ml}$ Plasma extrahiert. Die erhaltene cfDNA wurde mit dem UMI-basierten Oncomine cfDNA Assay auf dem IonTorrent S5XL sequenziert. Um die Sequenzierergebnisse zu optimieren, erhielten alle Proben einen zusätzlichen Aufreinigungsschritt in der Librarypräparation. Bei Ergebnissen mit sehr niedriger MAF oder negativem Ergebnis wurde die gesamte cfDNA aus bis zu $8 \mathrm{ml}$ Plasma für die Sequenzierung eingesetzt. Ergebnisse. Von 59 Fällen mit Verdacht auf das Vorliegen einer T790M Mutation, konnte bei 55 (92 \%) die Primärmutation im Blut nachgewiesen werden, bei 27 (46 \%) die T790M. Von 20 Fällen mit bekannter aktivierender Mutation und differenter Fragestellung, konnte diese bei 18 Patienten im Blut wiedergefunden werden ( $90 \%$ ), ein Patient zeigte eine andere aktivierende Mutation. Von den 15 mit unbekanntem Mutationsstatus oder unsicherer Diagnose, konnte bei 6 Patienten eine aktivierende Mutation gefunden werden. Optimierte Aufreinigung zeigte erhöhte MAFs. Der gesamte Einsatz extrahierter cfDNA für die Sequenzierung zeigte bei zwei von sechs zunächst negativen Fällen ein positives Ergebnis.

Fazit. In Situationen, wo eine Gewebebiopsie nicht möglich ist, stellt die Liquid Biopsy eine attraktive Möglichkeit für die Therapiestratifizierung von Krebspatienten dar. Eine Verbesserung der Sensitivitätsraten kann durch Optimierung des Library Workflows erzielt werden.

\section{AG12.07}

ctDNA als prädiktiver Marker für Ansprechen unter neoadjuvanter Radiochemotherapie (NEORECT) bei fortgeschrittenen Rektumkarzinomen

T. Grünewald ${ }^{1,2}$, S. Dintner ${ }^{1 *}$, M. Höck ${ }^{3}$, F. Sommer ${ }^{4}$, T. Kröncke ${ }^{5}$, H. Messmann ${ }^{6}$, M. Anthuber', G. Stüben ${ }^{3}$, M. Trepel', B. Märkl', R. Claus²

'Universitätsklinikum Augsburg, Institut für Pathologie, Augsburg,

Deutschland, ${ }^{2}$ Universitätsklinikum Augsburg, II. Medizinische

Klinik, Augsburg, Deutschland, ${ }^{3}$ Universitätsklinikum Augsburg, Strahlenklinik, Augsburg, Deutschland, ${ }^{4}$ Universitätsklinikum Augsburg, Allgemein-Visceral-Transplantationschirurgie, Augsburg, Deutschland, ${ }^{5}$ Universitätsklinikum Augsburg, Klinik für Diagnostische und Interventionelle Radiologie, Augsburg, Deutschland, ${ }^{6}$ Universitätsklinikum Augsburg, III. Medizinische Klinik, Augsburg, Deutschland

Ziel. Die Behandlung lokal fortgeschrittener Rektumkarzinome umfasst eine neoadjuvante Radiochemotherapie (nCRT) mit anschließender totaler mesorektaler Exzision (TME). Bei 20-30 \% der Patienten kann nach nCRT eine komplette pathologische Remission (pCR) beobachtet werden. Ein retrospektiver Vergleich von TME und „watch and wait"-Strategie zeigte nach erfolgter nCRT vergleichbare Ergebnisse. Präoperativer diagnostische Mittel wie Bildgebung, Protein-Biomarker und Histologie lassen keine Vorhersage der pCR zu. Es konnte jedoch eine MRD-Bewertung mittels ctDNA genutzt werden, um Rezidive bei Kolonkarzinomen im Stadium II vor bildmorphologischem Rezidivdetektion vorherzusagen. Somit könnte die Nachverfolgung von ctDNA bei Patienten mit Rektumkarzinom im Laufe der nCRT helfen, diejenigen mit pCR zu identifizieren und alternativ behandeln zu können.

Methoden. Die untersuchte Kohorte besteht aus Patienten mit einem Rektumkarzinom mit geplanter nCRT und TME. Eine Serie peripherer Blutproben wurde an definierten Zeitpunkten vor, während, nach nCRT und 
direkt am Tag vor TME entnommen. ccfDNA wurde aus $4 \mathrm{ml}$ Plasma isoliert. Die informativen Mutationen (Biomarker) wurden initial aus Biopsien mittels Panel-Sequenzierung zur Nachverfolgung im Blut identifiziert und anschließend für die Quantifizierung der ctDNA mittels dPCR genutzt.

Ergebnisse. Bisher wurden 25 Patienten in die Studie eingeschlossen. Bei 7 Patienten, die das Protokoll vollständig durchliefen und operiert wurden, konnte ctDNA aus Blutproben analysiert werden. Für die dPCR wurde bei Plasmaproben von Patienten mit Rektumkarzinom eine Detektionsgrenze von $0,1 \%$ etabliert. Bei fünf Patienten konnte ctDNA vor Therapiebeginn nachgewiesen, und über den Verlauf beobachtet werden. Dabei nahm die Allelfrequenz des Biomarkers über den Verlauf ab. Zwei von sieben Patienten erreichte eine pCR bzw. subtotale Remission. In einem Fall zeigte sich ein stetiger Rückgang des Biomarkers während nCRT. Bei der Blutentnahme am Tag vor TME konnte ein erneuter Anstieg beobachtet werden. Dies stand im Einklang mit der Erkenntnis neuer hepatischer Metastasen. Nach Resektion der Metastasen war der Biomarker nicht mehr nachweisbar.

Fazit. Bei Patienten mit fortgeschrittenem Rektumkarzinom ist unter nCRT ctDNA nachweisbar. Die Überwachung der ccfDNA-Dynamik und der Anteil an mutierter ctDNA während nCRT stellt einen vielversprechenden Ansatz als prädiktiven Marker für das Erreichen einer pCR nach nCRT dar.

\section{AG12.08}

\section{Nachweis von Genfusionen und Resistenzmutationen aus Plasma mittels UMI-basierter Sequenzierung von NSCLC Patienten}

A. Streubel ${ }^{*}$, V. Endris ${ }^{2}$, S. Stephan-Falkenau' ${ }^{1}$ J. Kollmeier ${ }^{3}$, T.-G. Blum ${ }^{3}$, D. Misch ${ }^{3}$, T. Bauer ${ }^{3}$, A. Stenzinger ${ }^{2}$, P. Schirmacher ${ }^{2}$, T. Mairinger ${ }^{1}$

${ }^{1}$ Emil von Behring Krankenhaus HELIOS Kliniken Berlin, Pathologie, Berlin, Deutschland, ${ }^{2}$ Universitätsklinikum Heidelberg, Institut für Pathologie, Heidelberg, Deutschland, ${ }^{3}$ Emil von Behring Krankenhaus HELIOS Kliniken Berlin, Klinik für Pneumologie, Lungenklinik Heckeshorn, Berlin, Deutschland

Ziel. Zirkulierende zell-freie Tumor DNA (ctDNA) entwickelt sich zu einem wichtigen Biomarker für Patienten mit Lungenkrebs. Insbesondere Patienten mit einer primär aktivierenden EGFR Mutation, die unter TKI Therapie Resistenzen entwickeln, ist die minimal-invasive Liquid Biopsy eine Ergänzung zur Gewebebiopsie für die Detektion von Resistenzmutationen (z.B. T790M). Liquid Biopsies haben das Potential, Tumorheterogenität darzustellen, frühzeitig das Therapieansprechen zu evaluieren, die Detektion klinisch noch schwer fassbarer Frührezidive und die Stratefizierung gezielter Therapien zu unterstützen. Aufgrund der niedrigen Konzentrationen von ctDNA im Plasma, ist die Optimierung der Methoden für die Extraktion von cfDNA ein wichtiger Erfolgsfaktor. Für die RNA basierte Fusionsdetektion stellt die Gewinnung von cfRNA aus dem Blut eine besondere Herausforderung dar, da sie sehr anfällig gegenüber enzymatischer Degradation ist und die Extraktionsmethoden entsprechend angepasst werden müssen. Unser Ziel war es, verschiedene Extraktionsmethoden zu evaluieren und technische Parameter zu untersuchen, welche wesentlich für eine RNA-basierte Fusionsdetektion aus dem Blut sein könnten.

Methoden. Wir haben Extraktionsmethoden von Qiagen, Norgen und Thermo Fisher für die Gewinnung von zellfreien Nukleinsäuren in Kombination mit UMI-basierter Sequenzierung untersucht. Hierfür wurde von 15 NSCLC Patienten mit bekannter, zuvor im FFPE Gewebe durch NGS detektierter Fusion, Plasma gewonnen. Dies schloss sowohl Fälle vor Therapiebeginn als auch Fälle, die sich im Progress unter TKI Therapie befanden, ein. Die erhaltene cfTNA wurde anschließend mit dem Lung cfTNA Assay sequenziert.

Ergebnisse. Nur bei den Verfahren mit speziellem Fokus auf die RNA Aufreinigung, konnte ausreichend RNA für eine Sequenzierung extrahiert werden. Es wurden nur Eluate mit Library Konzentrationen $>15 \mathrm{pM}$ sequenziert. Bei 10 von 15 sequenzierten Libraries konnte die bekannte Fusion nachgewiesen werden. Von diesen wiesen zwei von fünf sich im Progress befindenden Patienten, eine vorher nicht bekannte Resistenz- mutation im ALK Gen auf. Bei diesen Patienten wurde die Therapie auf alternative TKIs umgestellt.

Fazit. Fusionen aus dem Blut lassen sich anhand von RNA fokussierten Extraktionsmethoden bei $75 \%$ der von uns untersuchten Proben nachweisen. Eine totale cfTNA Extraktion verbunden mit dem Lung cfTNA Assay im Vergleich zu separater Extraktion von cfDNA/cfRNA sollte kritisch beurteilt werden.

\section{AG12.09}

\section{Entwicklung von hochsensitiven clamped Real-Time PCR Assays für die Detektion T790M der L858R und Exon 19 Deletionen im EGFR Gen}

A. Streubel, S. Stephan-Falkenau, T. Mairinger, A. Roth*

Emil von Behring Krankenhaus HELIOS Kliniken Berlin, Pathologie, Berlin, Deutschland

Ziel. Bei Patienten mit NSCLC und primärer aktivierender EGFR Mutation und Progress unter TKI Therapie, ist die T790M Mutation zu 40-55 \% Ursache für eine TKI Resistenz. Für diese Patienten kann die Liquid Biopsy eine minimal-invasive Ergänzung zur Gewebebiopsie darstellen. Für die Detektion der gesuchten Mutationen, bedarf es jedoch aufgrund des niedrigen ctDNA Gehalts im Plasma hoch sensitiver Analysemethoden. Gängige Verfahren wie Digital Droplet-PCR oder NGS- basierte Assays sind zum Teil sehr sensitiv, jedoch wenig ökonomisch und/oder zeitintensiv. Bei Verdacht auf die T790M ist es auch wichtig, die Primärmutation nachzuweisen, um so das Vorhandensein von ctDNA zu überprüfen und das Analyseergebnis zu verifizieren.

Ziel war es, eine sensitive und kostengünstige Fast Track Analyse zur Bestimmung der T790M und der häufigsten Primärmutationen im Exon 19 und $21 \mathrm{im}$ Blut zu entwickeln.

Methoden. Es wurden drei clamped Real-Time PCR Assays (SPA) mit einer Simple Probe ${ }^{\circ}$ Sonde für die T790M, die L8585R und für Deletionen im Exon 19 entwickelt. Die Wildtyp-Sequenz wurde über eine LockedNucleic Acid (LNA) unterdrückt. Es wurde eine Verdünnungsreihe aus Patienten cfDNA, positiv für T790M, L858R und E745_A750del, erstellt und die Nachweisgrenze der Methoden bestimmt. Zur Validierung des Verfahrens wurden alle Verdünnungsstufen auch mittels UMI-basierter TaqSequencing Technologie analysiert. Zusätzlich wurde Patienten cfDNA, die mittels UMI-basierter TaqSequencing Technologie in der Routine positiv für T790M, L858R und E746_A750del analysiert wurde, auch schon z. Teil mit den SPAssays untersucht: T790M $(n=28)$, L858R $(n=15)$, E746_A750del $(n=10)$. Darüber hinaus wurden jeweils $20 \mathrm{cfDNAs}$, die im NGS negativ für Mutationen im EGFR Gen waren, mit dem SPA getestet. Ergebnisse. Von denen mittels NGS positiv getesteten Patienten cfDNAs, konnten bereits folgende mittels SPA detektiert werden: T790M, $n=28$; L858R, $n=15$; E746_A750del, $n=10$. Im NGS negativ getestete cfDNAs waren in allen drei SPAs negativ. Die Korrelation zwischen der NGS Methode und den SPAs betrug $100 \%$. Alle SPAs konnten die Mutationen bis zu einer MAF von 0,4\% detektieren. Die SPAs für die T790M und die L858R Detektion wurden durch die erfolgreiche Teilnahme am QuiP Ringversuch 2018 für Blut validiert.

Fazit. Für die Detektion der T790M, der L858R und Deletionen im Exon 19 im EGFR Gen aus dem Blut, stellen die SPAs eine schnelle, kostengünstige, zuverlässige und sensitive Methoden dar. 


\section{AG Molekularpatholgie III - NGS Fusion}

\section{AG12.10 \\ Usefulness of RNA-sequencing to classify sarcomas in routine diagnostic procedures \\ F. Tirode* \\ Centre Léon Bérard, Department of Translational Research and Innovation, Lyon, France}

Sarcoma is a heterogeneous group of malignant tumours in which around 50 histological types and more than 150 molecular subtypes have been described. With the advent of new generation sequencing, the identification of new alterations has remarkably improved their diagnostic and provided hints on the underlying molecular mechanisms. However, a significant proportion of sarcomas remains uncharacterized, without pathognomonic oncogenic event and distinct biomarkers, therefore representing a major challenge in current clinical practice regarding both diagnosis and treatment. For the last three years, at the Centre Léon Bérard, we choose to use RNA-sequencing to systematically investigate sarcoma samples that remains dubious after the pathologists histological review. Herein I will present the advantages of our approach to identify oncogenic events and/ or to define molecular subtypes helping the pathologists to assign a class to otherwise unclassified sarcomas. As it will be shown, this procedure allowed us to reclassify a good number of misclassified samples, to find new alterations in known tumor types, hence enlarging their definition, but also helped us to define new sarcoma subtypes.

\section{AG12.11}

\section{Genfusionsnachweis in Karzinomen: Zwei fokussierte RNA-NGS-} Methoden im Vergleich

\section{Kirchner ${ }^{1 *}$, O. Neumann' ${ }^{1}$, A.-L. Volckmar', F. Stögbauer ${ }^{1,2}$, M. Allgäuer ${ }^{1}$,}

E. Rempel', J. Budczies ${ }^{1,3,4}$, R. Brandt', S. B. Talla ${ }^{1}$, T. Bochtler ${ }^{5,6}$, A. Krämer ${ }^{5,6}$, S. Fröhling ', C. Springfeld ${ }^{8,9}$, P. Schirmacher', V. Endris' , R. Penzel', A. Stenzinger

'Universitätsklinikum Heidelberg, Institut für Pathologie, Heidelberg Deutschland, ${ }^{2}$ Technische Universität München, Institut für Allgemeine Pathologie und Pathologische Anatomie, München, Deutschland, ${ }^{3}$ Charité Universitätsmedizin, Institut für Pathologie, Berlin, Deutschland, ${ }^{4}$ Deutsches Konsortium für Translationale Krebsforschung (Heidelberg, München, Berlin), Heidelberg, Deutschland, ${ }^{5}$ Deutsches Krebsforschungszentrum (DKFZ), Klinische Kooperationseinheit Molekulare Hämatologie/Onkologie, Heidelberg, Deutschland, ${ }^{6}$ Universitätsklinikum Heidelberg, Abteilung für Innere Medizin V, Heidelberg, Deutschland, ${ }^{7}$ Nationales Centrum für Tumorerkrankungen (NCT), Translationale Medizinische Onkologie, Heidelberg, Deutschland, ${ }^{8}$ Universitätsklinikum Heidelberg, Abteilung für Innere Medizin VI, Heidelberg, Deutschland, ${ }^{9}$ Nationales Centrum für Tumorerkrankungen (NCT), Heidelberg, Deutschland

Ziel. Genfusionen können chimärische Proteine mit veränderter Funktion erzeugen. Seit ihrer Identifikation als Tumortreiber in Sarkomen und Lymphomen gewinnen Genfusionen an diagnostischer und therapeutischer Relevanz. In Karzinomen sind Genfusionen nach bisheriger wissenschaftlicher Kenntnis insgesamt selten (0,03-0,1 \% über alle Entitäten hinweg), in einzelnen Karzinomtypen aber sehr prävalent und können teilweise mit zielgerichteten Therapien adressiert werden. Überdies kann die Detektion potentieller „Markerfusionen“ eine diagnostische Entitätszuordnung und damit eine entitätsspezifische konventionelle Therapie unterstützen. Deshalb sind sensitive und schnelle Detektionsmethoden erforderlich, die ein breites Spektrum an Genfusionen parallel in Formalin-fixierten und Paraffin-eingebetteten Proben erfassen können, die nur in begrenzter Menge und Qualität vorliegen.

Methoden. Wir beschreiben zwei Screening-Methoden für Genfusionen hinsichtlich ihrer technischen Performance. Mittels NGS-basierter Sequenzierung unter Verwendung des Oncomine Comprehensive Assay v3 (OCA) und des Archer ${ }^{\circledast}$ DX Solid-Tumorpanels (AMP) wurden 517 Pati- entenproben verschiedener Tumorentitäten aus dem gastrointestinal- und Urogenitaltrakt im Rahmen der Routinediagnostik auf Genfusionen getestet und die Ergebnisse mit orthogonalen Methoden validiert.

Ergebnisse. Insgesamt wurden 34 Fusionen detektiert und mittels SangerSequenzierung validiert. Der Anteil der verifizierbaren Genfusionen war in der AMP-Kohorte $(n=24)$ höher als in der OCA-Kohorte $(n=10)$. Beide Panels zeigen eine sehr hohe Sensitivität (100 \%) und Spezifität (99\%). Die Turnaround-Zeiten waren für beide Assays mit einem Median von 6 (OCA) respektive 9 Arbeitstagen (AMP) kurz. Die Anzahl der Probenausfälle aufgrund schlechter RNA-Qualität oder eines zu niedrigen Tumorzellgehalts waren mit 2,1 \% (OCA) bzw. 2,4 \% (AMP) in beiden Kohorten vergleichbar gering.

Fazit. Für den Nachweis bekannter Genfusionen eignet sich das fusionsspezifische OCA-Panel besser, da es viele bereits bekannte Fusionen erfasst. Das AMP-Panel erfasst hingegen gut charakterisierte und neue GenFusionspartner weniger Gene. Wir konnten zeigen, dass beide Assays für die Detektion von Genfusionen in verschiedenen Tumorentitäten in der Routinediagnostik geeignet sind und sogar bei stark degradierten Proben zu validen Ergebnissen führen.

\section{AG12.12}

\section{Vergleich von verschiedenen DNA- und RNA-basierten} Parallelsequenzierungsansätzen zum Nachweis von Fusionen

C. B. Wölwer', C. Heydt', R. Pappesch', S. Wagener', O. Velazquez Camacho', J. Rehker', M. Ball', N. Pfarr', W. Göring', J. Kumbrink', A. Hillmer', S. Merkelbach-Bruse ${ }^{1 *}$

'Universitätsklinikum Köln, Institut für Pathologie, Köln, Deutschland, 2Uniklinik Düsseldorf, Institut für Pathologie, Düsseldorf, Deutschland, ${ }^{3}$ Pathologisches Institut der LMU, München, Deutschland

Ziel. In den letzten Jahren wurden Hochdurchsatzmethoden wie die Parallelsequenzierung für die Detektion von Punktmutationen und kleinen Insertionen, Deletionen und Duplikationen, zunehmend in die tägliche Routinediagnostik integriert. Der Nachweis von chromosomalen Fusionen erfolgt zumeist weiterhin mittels Fluoreszenz-in situ Hybridisierung oder Immunhistochemie.

Diese Studie vergleicht fünf verschiedene Parallelsequenzierungsansätze für den Nachweis von Genfusionen in ALK, BRAF, FGFR1-3, MET, NTRK1-3, RET und ROS1. Hierfür wurden drei RNA-basierte MultiplexPCR Ansätze sowie ein DNA- und ein RNA-basierter Hybrid-Capture Ansatz eingesetzt.

Methoden. Ein Kollektiv aus 18 FFPE Proben und 10 fixierten Zelllinien mit bekannten Fusionen in ALK, BRAF, FGFR1-3, MET, NTRK1 und 3, RET und ROS1 wurde zusammengestellt. DNA und Gesamtnukleinsäure (tNA) wurden extrahiert. Aus der tNA wurde reine RNA hergestellt. DNA wurde mit einem kundenspezifischen SureSelect XT-Panel (Agilent) untersucht. RNA wurde mit einem kundenspezifischen QIAseq Targeted RNAscan-Panel (Qiagen) und dem Oncomine Focus Assay (Thermo Fisher Scientific) sowie dem TruSight Tumor 170 Assay (Illumina) untersucht. Die Gesamtnukleinsäure wurde mit dem FusionPlex Lung-Panel (Archer) analysiert. Alle Ansätze wurden nach Herstellangaben durchgeführt. Für die Datenanalyse wurden die Archer Analysis Software (Archer), die SureCall-Software (Agilent), die TruSight Tumor 170 App (Illumina), die Ion Reporter Software (Thermo Fisher Scientific), die Biomedical Workbench (Qiagen) sowie hausinterne Softwarepipelines verwendet.

Ergebnisse. Alle Parallelsequenzierungsansätze konnten erfolgreich durchgeführt werden. Mit dem TruSight Tumor 170 Assay konnten alle Fusionen nachgewiesen werden. Mit den anderen Assays wurden vereinzelte Fusionen nicht nachgewiesen. Zudem wurden die fünf Ansätze hinsichtlich Arbeitsaufwand, Zeit, Kosten, Ausstattung und Materialbedarf verglichen. Die Hybrid-Capture Ansätze sind teurer als die Multiplex-PCR Ansätze und haben zusätzlich den höheren Arbeitsaufwand. Zeitgleich decken sie aber neben den Fusionen auch andere Aberrationen ab. Fazit. Diese Studie hat gezeigt, dass verschiedene Parallelsequenzierungsansätze genutzt werden können um Fusionen nachzuweisen. Es gibt jedoch Unterschiede zwischen RNA- und DNA-basierten sowie Multiplex- 
PCR und Hybrid-Capture Ansätzen. Bei der Auswahl eines geeigneten Assays spielen auch die individuellen Gegebenheiten des jeweiligen Labors eine Rolle.

\section{AG12.13}

\section{Vergleich von Pyrosequenzierungs- und Next-Generation- Sequencing-Assays für die prädiktive Biomarkertestung bei Patienten mit Adenokarzinom der Lunge}

V. Tischler*, M.-C. Demes, C. Döring, K. Bankov, F. Schulze, L. Völkl, P.J. Wild Dr. Senckenberg. Institut für Pathologie, Universitätsklinikum Frankfurt, Molekularpathologie, Frankfurt, Deutschland

Ziel. Die prädiktive Markerbestimmung im Adenokarzinom der Lunge erfolgt nach der S3 Leitlinie mindestens für Mutationen in Hotspot-Regionen der Gene EGFR und $B R A F$ sowie für strukturelle Umlagerungen unter Beteiligung der Gene ALK und ROS1. Wir haben DNA- und RNAbasiertes Next Generation Sequencing (NGS) verglichen mit Pyrosequenzierung (EGFR, BRAF) und Proteinexpression (ALK, ROS1) im Rahmen unserer internen Assay-Etablierung.

Methoden. Die Performance des QIAact Lung DNA UMI Panels (Qiagen) wurde mittels quantitativem Multiplex Referenz Standard FFPE (HD200, Horizon) bestimmt, des QIAact Lung RNA UMI Panels mittels SeraSeq FFPE tumor fusion Referenz (Seracare) sowie Zelllinien mit bekannten Genfusionen (H2228, HCC78). Sechsundzwanzig Adenokarzinome der Lunge mit bekanntem EGFR und BRAF Status wurden mittels QIAact Lung DNA UMI Panel resequenziert und analysiert. 19 Fälle einer weiteren Validierungskohorte wurden zudem mit einem speziell für Adenokarzinome der Lunge designten QIAact Custom Panel untersucht und interinstitutionell im Rahmen eines Konsortiumprojekts (nationales Netzwerk genomische Medizin, nNGM) verglichen. 20 Adenokarzinome der Lunge wurden mittels QIAact Lung RNA UMI Panel auf therapeutisch relevante Genfusionen untersucht und verglichen mit den Resultaten der ALK (Klon OTI1A4, OriGene) und ROS1 (Klon EP282, Cell Marque) Immunhistochemie. Alle NGS-Assays liefen auf der GeneReader Plattform (Qiagen).

Ergebnisse. Alle genomischen Alterationen der HD200 Referenz wurden im Next NGS detektiert. Für die Gene EGFR und BRAF wurden alle Alterationen im NGS Assay richtig erkannt $(5 \times$ aktivierende EGFR Mutation, 0 BRAF Mutationen), entsprechend einer Sensitivität und Spezifität von jeweils $100 \%$ in der Resequenzierungskohorte. Zusätzlich wurde in drei EGFR- und BRAF-Wildtyp-Fällen eine aktivierende KRAS Mutation detektiert $(2 \times$ KRAS p.G12C, $1 \times$ KRAS p.G12V). Die weitere Validierungskohorte zeigte eine weitgehende Übereinstimmung. Alle 5 immunhistochemisch ALK-positiven Adenokarzinome zeigten eine Genfusion unter Beteiligung des Gens $A L K$, entsprechend einer Sensitivität und Spezifität von $100 \%$. Von den sechs immunhistochemisch ROS1 positiven Fällen wurde bei einem Fall eine ROS1 Genfusion nachgewiesen.

Fazit. Auf der von uns getesteten NGS-Plattform fand sich eine sehr gute Testperformance der DNA- und RNA-basierten Assays. Eine positive ROS1 Immunhistochemie erfordert eine Bestimmung des ROS1 Status mittels zweiter Methode.
AG12.14

Kombinierte, zielgerichtete DNA- und RNA-Sequenzierung der ersten $\mathbf{3 0 0 0}$ NSCLC Patienten in der Heidelberger Routinediagnostik

A.-L. Volckmar ${ }^{\text {* }}$, J. Leichsenring ${ }^{1}$, M. Kirchner', P. Christopoulos ${ }^{2,3}$, O. Neumann', J. Budczies',4,5, C. M. Morais de Oliveira', E. Rempel', I. Buchhalter ${ }^{1,6}$, R. Brandt', M. Allgäuer', S. B. Talla', M. von Winterfeld', E. Herpel', B. Göppert' ', A. Lier', H. Winter ${ }^{2}$, T. Brummer', S. Fröhling ${ }^{8}$, M. Faehling ${ }^{9}$, J. R. Fischer ${ }^{10}$, C. P. Heußel ${ }^{2}$, F. Herth' ${ }^{2}$, P. Schirmacher', M. Thomas ${ }^{2,3}$, V. Endris' ${ }^{1}$, R. Penzel' ${ }^{1}$, A. Stenzinger ${ }^{1,11,12}$

'Universitätsklinikum Heidelberg, Institut für Pathologie, Heidelberg, Deutschland, ${ }^{2}$ Universitätsklinikum Heidelberg, Thoraxklinik, Heidelberg, Deutschland, ${ }^{3}$ Translationales Lungenforschungscenter Heidelberg, Heidelberg, Deutschland, ${ }^{4}$ Charité Universitätsmedizin Berlin, Berlin, Deutschland, ${ }^{5}$ Deutsches Konsortium für Translationale Krebsforschung, Berlin, Deutschland, ${ }^{6}$ Deutsches Krebsforschungszentrum, Division of Applied Bioinformatics, Heidelberg, Deutschland, ${ }^{7}$ Universität Freiburg, Institut für molekulare Medizin und Zellforschung, Freiburg, Deutschland, ${ }^{8}$ Deutsches Krebsforschungszentrum, Abteilung Translationale Medizinische Onkologie, Heidelberg, Deutschland, ${ }^{9}$ Klinikum Esslingen, Klinik für Kardiologie, Angiologie und Pneumologie, Esslingen, Deutschland, ${ }^{10}$ Lungenklinik Löwenstein, Abteilung Thoraxonkologie, Löwenstein, Deutschland, "Deutsches Konsortium für Translationale Krebsforschung, Heidelberg, Deutschland, ${ }^{12}$ Nationales Centrum für Tumorerkrankungen, Heidelberg, Deutschland

Ziel. Bei Patienten mit nicht-kleinzelligen pulmonalen Karzinomen (NSCLC) und therapierbaren genetischen Alterationen sind Tyrosinkinaseinhibitoren die Behandlungsoption, welche den größten Überlebensvorteil bietet. Durch die ständig wachsende Zahl an therapierelevanten Biomarkern muss die molekularpathologische Diagnostik verlässlich, weitgefasst und schnell sein, um Patienten zu identifizieren die von den neuen Therapien profitieren. Mit dieser Arbeit zeigen wir die Umsetzbarkeit und den klinischen Nutzen von NGS-basiertem genetischen Untersuchungen anhand der Routineuntersuchung der ersten 3000 NSCLC Fälle aus unserem Institut.

Methoden. DNA und RNA aus FFPE wurde automatisch mittels Maxwell Promega extrahiert, Panel-basiert amplifiziert und parallel mittels Halbleitersequenzierung (NGS; Ion Torrent) auf Mutationen und Genfusionen untersucht.

Ergebnisse. Ingesamt zeigten 807 Patienten (27 \%) therapierelevante genetische Abberationen in EGFR, BRAF, ALK- und ROS1. Zusätzlich konnten 218 Patienten (7\%) identifiziert werden, die MET-, ERBB2- (HER2) oder RET-Veränderungen zeigten, für die potentiell wirksame off-label Therapien vorhanden sind. Außerdem wurden durch die Panelsequenzierung weitere Mutationen in Genen wie TP53 (55\%), KEAP1 (11 \%) und STK11 (11 \%) erfasst, die das Ansprechen auf Chemo- oder Immuntherapie beeinflussen. Bei Genfusionen wurden neben den Fusionspartnern auch die fusionierten Exons erfasst, welche für das Therapieansprechen und die Prognose wichtig sind und daher zur besseren Therapiesteuerung dienen könnten.

Fazit. Als diagnostisches Werkzeug bietet NGS eine hohe Verlässlichkeit, niedrige Ausfallraten $(<5 \%)$, kurze Bearbeitungszeiten (6 Tage, 4 Werktage), relativ geringe Kosten und einfachere Materialanforderungen im Vergleich zur sequentiellen Testung therapierelevanter Gene. Die gründliche molekulare Charakterisierung von Lungentumoren kann einen großen Beitrag zu individualisierten Therapieentscheidungen sowie zur klinischen und translationalen Forschung in der Thoraxonkologie leisten. 


\section{AG Herz-, Gefäß-, Nieren- und \\ Transplantationspathologie}

\section{AG13.02 \\ Glomerular diseases associated with myeloproliferative and myelodysplastic/myeloproliferative neoplasms}

\section{Büttner-Herold', C. Sticht', S. Porubsky ${ }^{3 *}$ \\ 'Pathologisches Institut, Universitätsklinikum Erlangen, Erlangen, Germany, ${ }^{2}$ Center of Medical Research, University Medical Centre Mannheim, University of Heidelberg, Mannheim, Germany, ${ }^{3}$ Pathologisches Institut, Medizinische Fakultät Mannheim, Universität Heidelberg, Mannheim, Germany}

Background/Aims. Myeloproliferative neoplasms (MPN) and myelodysplastic/myeloproliferative neoplasms (MDS/MPN) represent clonal hematopoietic diseases characterized by proliferation of myeloid cells. The spectrum of glomerular alterations associated with MPN has been addressed by only few reports. For MDS/MPN no data is available. Our aim was to systematically evaluate kidney biopsies performed in patients with known MPN or MDS/MPN.

Methods. Retrospective analysis of kidney biopsies in patients with the diagnosis of MPN or MDS/MPN was performed. The cohort $(n=27)$ encompassed patients with chronic myeloid leukemia (CML, $n=5)$, polycythemia vera (PV, $n=8$ ), primary myelofibrosis (PMF, $n=4)$, essential thrombocythemia $(\mathrm{ET}=2)$ and chronic myelomonocytic leukemia (CMML, $n=3$ ) as well as MPN or MDS/MPN without further specification $(\mathrm{MPN}=4, \mathrm{MDS} / \mathrm{MPN}=1)$. In order to control for age-related phenomena, the findings were compared to age-and sex-matched zero-time graft biopsies.

Results. The patients manifested with proteinuria ( $n=24 / 27,89 \%)$, partially in nephrotic range $(n=10 / 27,37 \%)$, hematuria $(n=15 / 24,64 \%)$ and kidney failure $(n=25 / 25,100 \%)$. In comparison to age- and sex-matched controls, MPN and MDS/MPN patients showed a significantly higher ratio of segmentally and globally sclerosed glomeruli, mesangial hypercellularity and expansion. Moreover, GBM alterations with ultrastructural signs of endothelial damage and subendothelial edema represented frequent findings ( $n=24 / 27,89 \%)$. Intracapillary thrombocytes as detected by immunohistochemistry for CD61 could be observed in 18 cases $(n=18 / 27$, $67 \%)$. Mesangiolysis $(n=5 / 27,19 \%)$ and features compatible with thrombotic microangiopathy $(n=9 / 27,33 \%)$ constituted other less frequent findings. Extramedullary hematopoiesis was present in 3 cases $(n=3 / 27,11 \%)$. Conclusions. Patients with MPN and MDS/MPN show glomerular scarring that exceeds age-related phenomena. Some of the biopsies indicate that a low-level chronic endothelial damage or thrombotic microangiopathy might represent the mechanisms resulting in mesangial and glomerular sclerosis manifesting mainly as proteinuria and renal insufficiency. In addition to the anti-neoplastic therapy, optimization of risk factors for kidney failure and early recognition of renal complication should be recommended.

\section{AG13.03 \\ Detection and characterization of atherosclerosis in coronary arteries-role of high-resolution imaging techniques in combination with histology}

\section{R. Moritz-Tugral ${ }^{*}$, F. Flockerzi', G. Martels' ${ }^{2}$, R. M. Bohle1, M. Kampschulte ${ }^{2}$} 'Institut für Pathologie - Universitätsklinikum des Saarlandes, Homburg/ Saar, Germany, ${ }^{2}$ Institut für Radiologie - Justus-Liebig-Universität Gießen, Gießen, Germany

Objectives. Micro-CT in cardiovascular tissue allows high-resolution imaging in combination with histology. Beyond the 3D-architecture of vessel trees and pathologic changes like atherosclerosis, stenosing inflammatory lesions and peripheral narrowing e.g. in allograft vasculopathy can be detected. The characterization of the $3 \mathrm{D}$-structure of the microvasculature as well as histology of the corresponding changes in the arterial wall give important insight into the pathogenesis of vascular lesions.

Methods. Coronary artery specimens (animal models as well as human specimens) were infused with a lead containing contrast media (Microfil) and then scanned using high-resolution micro-CT systems (e.g. SkyScan, Kontich, Belgium) at a minimal resolution of approximately $5 \mathrm{~mm}$. In a new approach, the specimens were treated with phosphotungstic acid (PTA) before scanning to achieve better soft tissue differentiation. After reconstructing the datasets, the $3 \mathrm{D}$-architecture of the vessel trees, the vasa vasorum density as well as plaque morphology were analyzed (Analyze ${ }^{\text {tw }}$ 9.0, Biomedical Imaging Resource, Mayo Clinic, Rochester, MN). Following the imaging analysis, the corresponding areas were examined histologically. Results. Using these imaging techniques, it was possible to identify individual vessel trees to the capillary level and to study the branching patterns. It was also possible to identify coronary atherosclerotic plaques at different stages of progression and the distribution of vasa vasorum in the different lesion types. As a result of these findings it was possible to develop clinically available imaging modalities and algorithms to identify vulnerable plaques and stenosing degenerative microvascular lesions which might cause myocardial injuries in patients.

Conclusion. In order to get more detailed 3D information of the different lesion types, new imaging techniques are required. Treatment of the specimens with phosphotungstic acid (PTA) and subsequent CT scanning at different tube settings is a promising new approach. Using this technique even small, soft tissue containing plaque components can be depicted in more detail. Therefore, it is easier to identify and quantify very early arterial lesions and pick these areas for histologic examination in order to shed some light into the early pathogenesis of atherosclerosis.

\section{AG13.04}

\section{Histology in calcified and/or stented bioprosthetic pulmonary valved conduits with endocarditis}

\section{Sigler ${ }^{1 *}$, T. Paul ${ }^{2}$}

'Universitätsmedizin Göttingen, Pädiatrische Kardiologie und Intensivmedizin, Göttingen, Germany, ${ }^{2}$ Universitätsmedizin Göttingen, Klinik für Pädiatrische Kardiologie und Intensivmedizin, Göttingen, Germany

Background. Bioprosthetic pulmonary valves have a high incidence of endocarditis. Thrombotic material is considered the nidus for these infections. We reviewed a series of explanted valved pulmonary conduits with a history of endocarditis.

Methods. Valved pulmonary conduits had been implanted in patients with congenital heart disease. All specimen were surgically excised due to endocarditis. After fixation in formalin and embedding in hard resin (methylmethacrylate), standard stainings as well as immunohistochemical stainings were applied. Macroscopic and histological analysis focused on localization and quality of endocarditic lesions.

Results. 19 valved pulmonary conduits (Melody transcatheter valve $n=12$, Hancock $n=3$, Homograft $n=2$, Contegra $n=2$ ) were analyzed. Average time between implantation and explantation had been 66 months ( 5 to 231 months). Endocarditic lesions were localized at the basis of the semilunar valves in 18 of 19 specimen, at the conduit wall in 15 of 19 , and at the valve edges in 10 of 19 patients. All identified endocarditic lesions consisted of typical thrombus material and fibrin condensations with included inflammatory cells (granulocytes and lymphocytes).

Conclusions. In a large series of explanted valved pulmonary conduits from patients with endocarditis, we demonstrate formation of typical endocarditic lesions macroscopically and histologically. Lesions at the basis of semilunar valves were an almost constant finding whereas the edges of the valves were affected much less frequent. We speculate that the high incidence of endocarditis in bioprosthetic valves may in part be explained by thrombus apposition at the valve basis as a primary nidus for development of an endocarditis. In contrast, the often supposed mechanism of endothel injury due to shear stress at the edges of the valves may play a minor role. Findings imply that intensified anticoagulation should be discussed for bioprosthetic valves in pulmonary position. 


\section{AG13.05 \\ Morphological classification of interstitial nephritis and its associated causes}

M. Noriega*, S. Akram, F. Person, T. Wiech

Universitätsklinikum Eppendorf Hamburg, Hamburg, Germany

Aim. Insterstital nephritis accounts for $12 \%$ of patients in dialysis in Germany and for $3-5 \%$ of native kidney biopsies at our institiution. Kidney biopsy is the Gold Standard for the diagnosis of interstitial nephritis. In almost $40 \%$ of the cases there is no clinical or anamnestic clue about the cause of the interstitial nephritis.

The aim of our study is to identify a histomorphological pattern of interstitial nephritis in the biopsy, which could correlate with its cause.

Methods. We analyzed 199 biopsies of native kidney with known cause of interstitial nephritis and divided them into different clinical groups (antibiotics, colitis ulcerosa-mesalazin, drug-associated, IgG4-associated disease, infection, sarcoidosis, Sjögren disease, TINU, urinary tract infection (UTI) and others).

Results. Almost all of the cases evidenced an elevated creatinin level at the time of biopsy. The extension of tubular atrophy and interstitial fibrosis was markedly higher in the IgG4-associated diesease group (90\% vs $43 \%$ in the rest of the groups). Also here was significant the presence of IgG4 positive plasmacells $(p<0.05)$. The amount of plasmacells was higher in the Sjögren and IgG4-associated diesease group $(p<0.05)$. The frequency of granulomata was highest in the sarcoidosis group followed by the drug-associated group. The amount of neutrophiles was significantly higher in the UTI group $(p<0.05)$. The presence of mast cells and the tubular basement membrane positivity for IgG were not specific for any of the groups. Conclusion. These results give us some histomorphological clues about the cause of the interstitial nephritis in the renal biopsy.

\section{AG13.06}

\section{Chylöse Komplikationen unterschiedlicher Ausprägung und} diverser Kompartimente in der rekonstruktiven Gefäßchirurgie

\section{U. Barth ${ }^{*}$, Z. Halloul', F. Meyer}

'Otto-von-Guericke-Universität mit Universitätsklinikum Magdeburg A. ö. R., Bereich Gefäßchirurgie, Klinik für Allgemein-, Viszeral-, Gefäßund Transplantationschirurgie, Magdeburg, Deutschland, ${ }^{2}$ Otto-vonGuericke-Universität mit Universitätsklinikum Magdeburg A. ö. R., Klinik für Allgemein-, Viszeral-, Gefäß-und Transplantationschirurgie, Magdeburg, Deutschland

Einleitung. Chylöse Komplikationen, die auch im gefäßchirurgischen Operationsprofil in beachtenswerter Häufigkeit vorkommen, sind hinsichtlich ihres adäquaten Managements sehr anspruchsvoll.

Zielsetzung \& Methode. Ausgewählte Präsentation, komplexe Zusammenfassung und Diskussion mittels einer aktuellen Auswahl relevanter wissenschaftlicher Referenzen incl. i) kompakte Kurzübersicht zu epidemiologischen, klassifizierenden, symptomatischen, diagnostischen und therapeutischen Aspekten chylöser Komplikationen in der Gefäßchirurgie sowie ii) repräsentative und beispielhafte Fallberichte aus der klinisch-alltäglichen Praxis. Ergebnisse (komplexe patienten- und befundassoziierte Eckpunkte).

- Die Basistherapie des Lymphödems/postrekonstruktiven Ödems ist die „Komplexe Physikalische Entstauungstherapie“ (KPE), die unter Umständen mehrere Jahre durchgeführt werden muss.

- Bei Lymphozelen ist zunächst der Spontanverlauf abzuwarten, bei Persistenz und klinischen Beschwerden können ableitende Punktionen oder die passagere Instillation von Doxycyclin oder Ethanol versucht werden.

- Zusätzlich kommt bei Lymphfisteln stufenweise der Einsatz von Vakuumverbänden, die Radiatio und selektive Lymphgefäßligatur nach Methylenblau-Injektion zum Einsatz.

- Chylascites und Chylothorax sollten - wie mittlerweile im Konsens weitgehend etabliert - zunächst konsequent konservativ, initial mit Paracentese/Thoracocentese, proteinreicher und fettarmer Diät mit MCTFetten oder totaler parenteraler Ernährung in Kombination mit dem
Einsatz eines Somatostatin-Analogons (nur als ultima ratio operativ mit dem Ziel der Lymphgefäßligatur - dann ggf. mit präoperativem Sahneverzehr) therapiert werden.

Zusammenfassung. Chylöse Komplikationen bieten einen nicht unbeträchtlichen Spielraum zunächst konservativer Maßnahmen, die im Sinne des Stufenkonzepts vor dem Stellen der Op-Indikation ausgeschöpft sein sollten.

Schlussfolgerung. Mit dem suffizienten befundgerechten Management chylöser Komplikationen sollte der versierte Gefäßchirurg vertraut sein, was den erfahrenen Kliniker und Operateur im interdisziplinären Setting mit Angiologie, interventioneller Radiologie, Viszeralchirurgie, Thoraxchirurgie und teils chirurgischer Intensivmedizin erfordert.

\section{Postersitzungen}

\section{Endokrine/Neuroendokrine Pathologie - Poster}

\section{DGP.P1.01 \\ Molekulare Charakteristika der Evolution hoch maligner Schilddrüsenkarzinome - vom PTC/FTC zum ATC}

A. Haak' , C. Wickenhauser', L. Heukamp², K. Neukirchner'3 , L. Werner', U. Siebolts ${ }^{1 *}$

'Uniklinik Halle (Saale), Institut für Pathologie, Halle, Deutschland, ${ }^{2}$ Institut für Hämatopathologie Hamburg, Hamburg, Deutschland, ${ }^{3}$ Pathologie und Zytologie Stollberg-Niederdorf, Stollberg-Niederdorf, Deutschland

Ziel. Das anaplastische Schilddrüsenkarzinom (ATC) ist die undifferenzierte Form der aus Follikelepithelzellen entstehenden Schilddrüsenmalignome mit einer der schlechtesten Prognosen aller soliden Neoplasien überhaupt. ATC können entweder direkt aus Follikelepithelzellen entstehen oder es kann eine sequentielle Genese über die differenzierten Schilddrüsenkarzinome (FTC, PTC), das schlecht differenzierte Schilddrüsenkarzinom (PDTC) bis zum ATC beschrieben werden. Die molekularen Charakteristika des ATC scheinen dabei im Vergleich mit differenzierten Schilddrüsenkarzinomen im Sinne der Entdifferenzierung vergleichsweise komplex. Die initiierte Studie hat das Ziel anhand eines Kollektivs von 10 ATC mit sequentieller Entwicklung die individuellen molekularen Signaturen verschieden differenzierter Tumoranteile, im Sinne einer histomorphologischen Heterogenität, vergleichend darzustellen.

Methoden. Jeweils 3 unterschiedlich differenzierte Regionen (FTC/PTC, PDTC und ATC) von 10 Patienten des Universitätsklinikums Halle (Saale) mit der Diagnose eines anaplastischen Schilddrüsenkarzinoms mit entsprechender Tumorheterogenität, wurden zur anschließenden DNAExtraktion mikrodissektiert. Die so gewonnenen DNA-Proben wurden mittels Hybrid-Capture basierter Parallelsequenzierung (NewOncology NEOPlus; Illumina NextSeq) von mehr als 340 krebsassoziierten Genen mit einem exonischen Territorium von $>1,1 \mathrm{Mb}$ auf das Vorliegen von Punktmutationen, InDels, Translokationen, Kopienzahlveränderungen, Mikrosatelliteninstabilität und Mutationslast (TMB) analysiert.

Ergebnisse. Aus unserem Paraffinarchiv wurden 40 Schilddrüsenresektate hinsichtlich ihrer histomorphologischen Heterogenität untersucht. Davon konnten in 10 Fällen zwei bis drei verschiedene Differenzierungsstadien sowohl histomorphologisch als auch immunhistochemisch beschrieben werden. Erste Daten zur molekularen Charakterisierung spiegeln die für die verschiedenen Entitäten getrennt veröffentlichten molekularen Charakteristika und zeigen für die verschieden differenzierten Anteile individueller Tumoren eine Zunahme der molekularen Heterogenität im Sinne einer klonalen Evolution.

Fazit. Die vorliegende Studie ermöglicht neue Einsichten in die zunehmende Komplexität molekularer Veränderungen, im Sinne einer klonalen Evolution individueller histologisch heterogener Tumoren, mit fortschreitender Entdifferenzierung von malignen Tumoren der Schilddrüsenfollikelepithelzellen vom PTC/FTC bis zum ATC. 


\section{DGP.P1.02}

\section{New insights into intranuclear inclusions in thyroid carcinoma: association with autophagy and with BRAFV600E mutation}

\section{S. Schwertheim ${ }^{1 *}$, S. Theurer', H. Jastrow ${ }^{2}$, D. Westerwick', S. Bertram ${ }^{1}$, C. M. Schaefer ${ }^{1}$, J. Kälsch ${ }^{1,3}$, K. W. Schmid ${ }^{1}$, H. A. Baba ${ }^{1}$}

'Institut für Pathologie/Universitätsklinikum Essen, Essen, Germany, ${ }^{2}$ Institut für Anatomie/Universitätsklinikum Essen, Essen, Germany, ${ }^{3}$ Institut für Gastroenterologie und Hepatologie/Universitätsklinikum Essen, Essen, Germany

Aim. Intranuclear inclusions (NI) in normal and neoplastic tissues have been known for a long time, representing one of the diagnostic criteria for papillary thyroid carcinoma (PTC). BRAFV600E-mutation analysis is an important diagnostic tool for PTC and BRAF activation is involved in many biological processes including cell proliferation and autophagy. Our aim was to characterise NI in thyroid carcinoma, clarify their biological function and a possible association to BRAFV600E mutation.

Methods. Intranuclear inclusions in 108 paraffin-embedded specimens of thyroid carcinoma were analysed. We considered an inclusion as positive if it was delimited by a Lamin AC (nuclear membrane marker) stained intact membrane and completely closed. Transmission electron microscopy (TEM), immunohistochemistry (IHC), immunofluorescence (IF) and 3D reconstruction were performed to investigate the content and the shape of the NI. BRAFV600E mutation was analysed by next generation sequencing. Results. We found that $30 \%$ of the thyroid carcinoma cases harboured at least one Lamin AC positive inclusion; most frequently (77\%) in PTCs. The maximum number of NI per case was $114 / \mathrm{mm}^{2}$. TEM analyses revealed degenerated mitochondria, endoplasmic reticulum and lamellar bodies within the NI. 3D reconstruction of IF stained nuclei demonstrated that NI were completely surrounded by nuclear membrane and closed without any contact to the cytoplasm. They were positively stained for the autophagy-associated proteins LC3B, ubiquitin, cathepsin D, p62 and cathepsin B in 14-29\% of the cases. Double IF revealed co-localization of LC3B \& ubiquitin, p62 \& ubiquitin and LC3B \& p62 in the same NI. BRAFV600E mutation was significantly associated with the occurrence of NI and with immunoreactivity for autophagy-associated proteins in the NI. BRAF-IHC revealed that some of these BRAF-positive thyrocytes contained mutant BRAF in their NI. Conclusion. We demonstrate intranuclear inclusions (NI) in thyroid carcinomas, delimited by nuclear membrane and located entirely within the nucleus. We assume that NI derive from invaginations of the cytoplasm that completely detach from the latter. The presence of autophagy-associated proteins within the NI together with degenerated organelles and lysosomal proteases suggests that NI play a role in autophagy and proteolysis. The BRAFV600E mutation appears to be involved in these biological processes.

\section{DGP.P1.03}

\section{Schilddrüse - Tissue Micro Array (TMA)}

\section{Bauer ${ }^{1 *}$, C. Geppert ${ }^{2}$, K. Lorenz ${ }^{3}$, C. Wickenhauser ${ }^{1}$, U. Siebolts ${ }^{1}$}

'Universitätsklinikum, Institut für Pathologie, Halle an der Saale, Deutschland, ${ }^{2}$ Friedrich-Alexander-Universität Erlangen, Institut für Pathologie, Erlangen, Deutschland, ${ }^{3}$ Universitätsklinik für Viszerale, Gefäßund Endokrine Chirurgie, Abteilung für Endokrine Chirurgie, Halle an der Saale, Deutschland

Ziel. Die endokrine Chirurgie der Schilddrüse ist ein traditionsreicher und überregional etablierter und bekannter Schwerpunkt der halleschen Universitätsmedizin. Daraus folgend verfügt das Institut für Pathologie über ein jahrzehntelang gesammeltes breites Spektrum an paraffinierten Schilddrüsenorganpräparaten. In Kooperation mit der Klinik für Viszerale, Gefäß- und Endokrine Chirurgie liegen zu den Patienten ferner klinische Verlaufsdaten vor. Um dieses Gewebegut der wissenschaftlichen Nutzung im Rahmen der Biomarkerforschung zuzuführen, wurde nun ein Kollektiv von 310 neoplastischen und nicht-neoplastischen Schilddrüsenerkrankungen zusammengestellt und in Tissue Micro Arrays (TMA) gebündelt Methoden. Ausgewählt wurden Proben aus dem Paraffinarchiv des Instituts für Pathologie des Universitätsklinikums Halle des Zeitraums von
2014 bis 2018. In Kooperation mit dem Institut für Pathologie des Universitätsklinikums Erlangen wurden die TMAs entworfen und mit dem TMA Grand Master (Sysmex) hergestellt.

Ergebnisse. Die TMAs umfassen 60 nicht-neoplastische Erkrankungen (Morbus Basedow, Autoimmunthyreoiditis und Struma colloides nodosa), 60 Schilddrüsenadenome (mikrofollikuläre, mikro-et makrofollikuläre und onkozytäre Schilddrüsenadenome) sowie 190 maligne Schilddrüsentumoren (ATC, PDTC, FTC, PTC und MTC) mit repräsentativem Material jeweils aus dem Tumorzentrum und der Invasionsfront. Jede Probe ist doppelt repräsentiert und zusätzlich bestehen von den neoplastischen Proben parallele Stanzen von nicht-neoplastischem Gewebe auf gesonderten Blöcken. Die insgesamt 28 in Doubletten erstellten TMA wurden jeweils mit maximal 120 Stanzen bestückt. Zu allen Proben liegen entsprechende klinische und pathologische Datensätze vor.

Fazit. Das vorgestellte umfassende TMA Kollektiv an neoplastischen und nicht-neoplastischen Schilddrüsenerkrankungen ermöglicht nun eine systematische Analyse von Biomarkern zwischen den Krankheitsentitäten sowie im direkten Vergleich mit gesundem und reaktivem Gewebe. Erste Studien mittels immunhistochemischer Charakterisierung und Multi Spectral Imaging sind, teils in Kooperation mit anderen Instituten, initiiert.

\section{DGP.P1.04}

\section{Nukleoporin Nup153 - ein Marker für neuroendokrine Tumoren?}

K. Holzer ${ }^{*}$, E. Herpel' ${ }^{2}$, F. Bergmann ${ }^{3}$, T. Muley ${ }^{4}$, M. Meister', B. Goeppert ${ }^{2}$, A. Warth ${ }^{5}$, P. Schirmacher' ${ }^{2}$ S. Singer

'Universitätsmedizin Greifswald, Pathologisches Institut, Greifswald, Deutschland, ${ }^{2}$ Universitätsklinikum Heidelberg, Pathologisches Institut, Heidelberg, Deutschland, ${ }^{3}$ Klinikum Darmstadt, Pathologie, Darmstadt, Deutschland, ${ }^{4}$ Universitätsklinikum Heidelberg, Thoraxklinik, Sektion Translationale Forschung, Heidelberg, Deutschland, ${ }^{5}$ ÜGP MVZ Institut für Pathologie, Zytologie und Molekularpathologie, Wetzlar, Deutschland

Ziel. Der in die Kernmembran eingebettete Kernporenkomplex (NPC) ist ein elementarer Bestandteil des Kerntransportsystems. Der NPC besteht aus $\sim 30$ verschiedenen Nukleoporinen (Nups), die auch transport-unabhängige Funktionen aufweisen können (z. B. über Chromatininteraktion Regulation von Genen im Rahmen der Zelldifferenzierung oder Zellzykluskontrolle). Zu diesen Nups gehören Nup153 und Nup98 über deren Gewebs- bzw. Zell-spezifische Expression bislang wenig bekannt ist und im vorliegenden Projekt untersucht wurde.

Methoden. Unter Verwendung eines Pan-Tissue Mikroarrays (TMA) wurden Gewebe verschiedener Organe (u. a. Schilddrüse, Lunge, Pankreas und Dünndarm/Appendix vermiformis) bzgl. der Nup153- und Nup98-Expression immunhistochemisch untersucht. Aufgrund der auffallenden Positivität von neuroendokrinen Zellen für Nup153 wurde anschließend die Expression von Nup153 an entsprechenden neuroendokrin und nichtneuroendokrin differenzierten Tumoren bestimmt.

Ergebnisse. Eine starke immunhistochemische Positivität für Nup98 war in allen Zellen der untersuchten Gewebe zu verzeichnen. Hingegen zeigte sich eine Positivität für Nup153 lediglich in neuroendokrinen Zellen wie bspw. den C-Zellen der Schilddrüse oder den Zellen der LangerhansInseln des Pankreas. Bemerkenswert war, dass diese immunhistologische Positivität in der großen Mehrzahl der entsprechenden neuroendokrin differenzierten Neoplasien beibehalten wurde: 93,7\% der medullären Schilddrüsenkarzinome $(n=16), 95,2 \%$ der NET der Appendix vermiformis $(n=21), 92,8 \%$ der Tumoren des Dünndarms $(n=32), 60,4 \%$ der NET des Pankreas $(n=48)$ und $80,6 \%$ der Lungenkarzinoide $(n=126)$. Im Gegensatz dazu wiesen die korrespondierenden, nicht-neuroendokrin differenzierten Tumoren keine nennenswerte Nup153-Positivität auf (z. B. NSCLC $0 \%, n=47$ ).

Fazit. Unsere bisherigen Daten deuten auf einen überraschenden Zusammenhang zwischen Nup153 und neuroendokriner Zelldifferenzierung hin. Unabhängig von den noch zu untersuchenden, molekularen Mechanismen könnte Nup153 bei neuroendokrinen Neoplasien als ergänzender immunhistochemischer Marker dienen. 


\section{DGP.P1.05}

\section{Schilddrüsengewebe-Ektopie in der Nebenniere - Ein Fallbericht in Zusammenschau mit der Literatur}

\section{J. Rawitzer ${ }^{\text {* }}$, M. K. Walz' ${ }^{2}$ A. Kapakoglou' ${ }^{2}$ K. W. Schmid' ${ }^{1}$ H. Reis ${ }^{1}$ \\ 'Institut für Pathologie, Universitätsmedizin Essen, Universität Duisburg- Essen, Essen, Deutschland, ${ }^{2}$ Klinik für Chirurgie und Zentrum für Minimal Invasive Chirurgie, Kliniken Essen-Mitte, Essen, Deutschland}

Ziel. Anhand einer Schilddrüsengewebe-Ektopie in der Nebenniere diskutieren wir den Fall und geben einen Überblick über die entsprechende Literatur.

Methoden. Wir untersuchten ein Adrenalektomiepräparat einer initial maximal 7,6 cm großen multizystischen Nebennierenläsion unter Anwendung histologischer und immunhistochemischer Verfahren. Die Ergebnisse wurden mit dem klinischen Befund korreliert. Es folgte eine Literaturrecherche zur Schilddrüsengewebe-Ektopie und deren Entstehungsmechanismen.

Ergebnisse. Histologisch zeigte sich in der fibrosierten Zystenwand unauffälliges Schilddrüsengewebe ohne Malignitätskriterien mit Positivität gegenüber Pan-Zytokeratin (CK-plus), CK7, TPO, TG, TTF-1 und PAX8 bei Negativität für CK20, Napsin A, Inhibin, MelanA und Calcitonin. Die proliferative Aktivität (Ki67) belief sich auf maximal $5 \%$. Unter klinischer Korrelation konnten wir eine Absiedelung eines Schilddrüsenmalignoms und Vorliegen eines Teratoms ausschließen und diagnostizierten eine adrenale Schilddrüsengewebe-Ektopie. Auch weitere Kontrolluntersuchungen der Patientin ergaben keinen Anhalt für ein primäres Schilddrüsenmalignom. Mittels Literaturrecherche ermittelten wir zwölf weitere vergleichbare Fälle. Unser Fall weist zahlreiche Übereinstimmungen mit diesen Fallberichten aus der Literatur auf. Dabei liegt eine weibliche Prädominanz vor, die Betroffenen sind überwiegend mittleren Alters und die Nebennierenläsionen sind typischerweise asymptomatisch und werden inzidentell mittels bildgebender Untersuchungen entdeckt.

Fazit. Ektopes Schilddrüsengewebe ist außerhalb der Kopf-Hals-Region selten und ist dort zumeist mit Bezug zur Schilddrüsenanlage lokalisiert. Zudem tritt es sehr selten mediastinal und äußerst selten extramediastinal auf (Porta hepatis, Nebenniere, Vaginalwand). In der Nebenniere ist Schilddrüsenparenchym jedoch die geläufigste Form ektopen Gewebes. Konzepte zur Entstehung subdiaphragmal lokalisierten Schilddrüsengewebes umfassen die Metaplasie und eine überschießende Migration der Schilddrüsenanlage. Zudem könnte das Vorliegen diaphragmaler Hernien begünstigend wirken. Allerdings weist jede wissenschaftliche Theorie bei subdiaphragmaler Lokalisation gewisse Limitationen auf, sodass es zur Klärung weiterer Forschung bedarf.

\section{DGP.P1.06}

\section{Immunhistochemische Charakterisierung strumaler Karzinoide}

\section{S. Theurer*, T. Herold, K. W. Schmid \\ 'Institut für Pathologie/Universitätsklinikum Essen, Essen, Deutschland}

Ziel. Strumale Karzinoide sind ausgesprochen seltene Tumoren des Ovars und bestehen aus Schilddrüsengewebe, im Sinne einer Struma ovarii, mit partieller neuroendokriner Differenzierung. In aller Regel handelt es sich um Tumoren, die kein aggressives Verhalten zeigen, es sind aber auch metastasierte Situationen beschrieben.

Aufgrund der Seltenheit der Diagnose sind überwiegend Fallberichte in der Literatur zu finden. Immunhistochemische und/oder molekularpathologische Charakterisierungen ganzer Fallserien sind bislang nicht durchgeführt worden. Ziel der Untersuchung war es daher eine Serie strumaler Karzinoide hinsichtlich ihres immunhistochemischen Verhaltens zu untersuchen. In einem zweiten Schritt werden die Tumoren auch molekulargenetisch untersucht, um ggf. therapeutisch relevante Mutationen nachzuweisen.

Methoden. Es wurde eine Fallserie von 11 strumalen Karzinoiden immunhistochemisch für Thyreoglobulin, TTF-1, Chromogranin A, Synaptophysin SP11, ki67, Islet-1, CDX-2, SSTR2 und SSTR5 untersucht.
Ergebnisse. Alle Tumoren zeigten eine positive Reaktion für die neuroendokrinen Marker Synaptophysin SP11 und Chromogranin A. Außerdem waren alle Tumoren positiv für Thyreoglobulin. $72 \%$ der Tumoren exprimierten den Transkriptionsfaktor TTF-1 $(n=8)$. Die Proliferationsaktivität (ki67) lag für alle Fälle bei maximal $2 \%$. In $64 \%$ der Fälle zeigte der Tumor eine positive nukleäre Reaktion für Islet-1 $(n=7)$, während alle Tumoren negativ für CDX-2 waren. Außerdem zeigte sich ein positives Färbeverhalten für Somatostatinrezeptoren (SSTR2 und SSTR5).

Fazit. Die vorliegende Fallserie aus 11 Fällen ist die bislang größte immunhistochemisch untersuchte Serie strumaler Karzinoide. Wir konnten zeigen, dass es sich um Tumoren mit Mischexpression thyreoidaler und neuroendokriner Marker handelt, die, entsprechend ihres klinisch überwiegend indolenten Verhaltens nur gering proliferieren. Außerdem exprimiert ein Großteil der Tumoren den Transkriptionsfaktor Islet-1. Die immunhistochemische Expression der Somatostatinrezeptoren 2 und 5 kann gegebenenfalls diagnostisch zur Metastasensuche oder aber auch therapeutisch für die Therapie mit Somatostatinrezeptoranaloga genutzt werden.

\section{DGP.P1.07 \\ Identifizierung tumorassoziierter Transkripte in follikulären Läsionen der Schilddrüse}

S. Kalbourtzis*, B. Kölsch, A. Kutritz, A. Kindler-Röhrborn, K.-W. Schmid Universitätsklinikum Essen, Institut für Pathologie, Essen, Deutschland

Ziel. Das Ziel bestand darin Transkripte von Genen zu identifizieren, deren Expression mit der Entstehung follikulärer Adenome assoziiert ist. Die entsprechenden Proteine könnten sowohl als molekulare Marker für diese Tumoren, als auch als Ansatzpunkte für zielgerichtete Tumorprävention Anwendung finden. Die Unterscheidung zwischen hyperplastischen und neoplastischen Läsionen in der menschlichen Schilddrüse ist schwierig. Hierfür bot sich das Tiermodell der Tumorentstehung in der Schilddrüse der Ratte an, welche durch jodarme Diät (JD) und N-methyl-N-nitrosourea (MNU) induziert wird.

Methoden. Expressionsanalysen wurden mit Hilfe von Illumina Expression Arrays durchgeführt. Dazu wurde RNA aus gepoolten Schilddrüsen verwendet. Zur Validierung dieser Ergebnisse wurden RealTime PCRs durchgeführt. Um die Lokalisation der identifizierten Transkripte in Gewebeschnitten erfassen zu können, wurde sowohl die Fluoreszenz in situ Hybridisierung (FISH) als auch die Chromogene in situ Hybridisierung (CISH) etabliert.

Ergebnisse. Während $43 \%$ der weiblichen LE/StmRatten nach Behandlung mit JD und MNU follikuläre Adenome entwickelten, lag die Rate bei männlichen Tieren bei $75 \%$. BNRatten entwickelten diese Tumore nur in marginalem Ausmaß. Es wurden acht Kandidatengene mittels Illumina Expression Array identifiziert (Acvrl1, Adm2, Banf2, Lamb1, Ramp3, Slc5a5, Smpd3 und Trib2). Die Transkripte dieser Gene stiegen nur in den Schilddrüsen männlicher JD/MNU behandelter LE/StmRatten aufsteigenden Alters an. FISH und CISH waren nicht sensitiv genug, um die Transkripte der Kandidatengene im Gewebeschnitt nachzuweisen. Erst mit dem ViewRNA ${ }^{\mathrm{TM}}$ ISH Tissue 1-Plex Assay, der ein bis zu 3000-fach intensiveres Leuchtsignal im Vergleich zu anderen FISHMethoden hervorruft, gelang der Nachweis der RNA von Adm2, Slc5a5 und Smpd3. Überraschenderweise waren diese Transkripte nicht in den follikulären Adenomen, sondern in der unmittelbaren Umgebung des Tumors zu finden, wobei die Expressionsstärke in der Peripherie abnahm.

Fazit. Die klare Steigerung der Expression von Adm2, Slc5a5 und Smpd3 während der Entwicklung follikulärer Adenome in Schilddrüsen von Ratten, die mit einer JD/MNU behandelt worden sind, lässt eine funktionelle Beteiligung vermuten. Die Erkenntnis, dass im Tiermodell Transkripte hochexprimiert im Normalgewebe vorliegen, das den Tumor umgibt, lenkt den Blick auf das TumorMicroenvironment, dessen Rolle bei der Entstehung von Tumoren vielfach unterschätzt wird. 
DGP.P1.08

Tumornekrosen sind ein zuverlässiges Kriterium für die Unterscheidung zwischen benigne und maligne bei Nebennierenrindentumoren

\section{S. Theurer ${ }^{1 *}$, P. Alesina ${ }^{2}$, K. A. Metz' ${ }^{1}$ M. Walz ${ }^{2}$ K. W. Schmid ${ }^{1}$}

${ }^{1}$ Universitätsklinikum Essen, Institut für Pathologie, Essen, Deutschland, ${ }^{2}$ Kliniken Essen-Mitte, Klinik für Chirurgie und Zentrum für Minimal Invasive Chirurgie, Essen, Deutschland

Ziel. Die Einordnung von Nebennierentumoren hinsichtlich ihrer Dignität ist eine Herausforderung in der histopathologischen Diagnostik, da kein zuverlässiges Scoring-System für die Unterscheidung von benigne/ maligne existiert. Die Scoring-Systeme von Weiss (1984) und van Slooten (1985) ziehen mehrere Parameter (unter anderem Mitoserate, nukleärer Grad, atypische Mitosen, invasives Verhalten, Nekrosen) für die Vorhersage des biologischen Verhaltens heran. Zwar werden beide Scores regelmäßig verwendet, der Score nach Weiss findet sogar Eingang in die aktuelle WHO-Klassifikation der endokrinen Organe, jedoch zeigen sich immer wieder falsch positive und falsch negative Fälle, die mit diesen ScoringSystemen eingeordnet wurden.

Ziel der hier dargestellten Untersuchung war ein histomorphologisches Charakteristikum zu finden, welches die Einteilung in Adenom/Karzinom sicher rechtfertigt.

Methoden. In der vorliegenden Arbeit wurden 856 Nebennierenrindentumoren begutachtet, die zwischen 1994 und 2018 in Essen operativ entfernt wurden. Phäochromozytome, Conn-Adenome, Nebennierenhyperplasien (M. Cushing) und Nebennierenmetastasen wurden von der Untersuchung ausgeschlossen. Alle Tumoren wurden histologisch begutachtet und mit ki67 hinsichtlich ihrer Proliferationsaktivität immunhistochemisch untersucht.

Ergebnisse. Von insgesamt 856 untersuchten Nebennierenrindentumoren waren 448 funktionell (FT; 425 Hyperkortisolismus, 14 Virilisierung, $1 \mathrm{Fe}$ minisierung, 8 kombinierte Sekretion) und 408 waren nicht-funktionell (NFT). Die mediane Größe der FT betrug 3,7 $\pm 1,7 \mathrm{~cm}(1,5-16 \mathrm{~cm})$, die mediane Größe der NFT lag bei 4,3 $\pm 2,4 \mathrm{~cm}$ (range 0,5-18 cm). Histomorphologisch wurden 32 Fälle als Nebennierenrindenkarzinom (ACC, $3,8 \%$ ) beschrieben. Alle diese Tumoren zeigen Tumornekrosen. In den 824 als Adenom klassifizierten Tumoren waren keine Nekrosen zu finden. Nach einem medianen follow-up von 10,3 Jahren zeigten 23 der 32 diagnostizierten ACCs Fernmetastasen (71,8 \%), während keiner der Patienten aus der Adenomgruppe Metastasen entwickelte.

Fazit. In dieser Arbeit konnten wir zeigen, dass Tumornekrosen als singuläres morphologisches Charakteristikum malignes Verhalten von Nebennierenrindentumoren vorhersagen kann und daher die Einordnung als Karzinom bei Vorhandensein von Nekrosen gerechtfertigt ist. Nekrose als alleiniges Entscheidungsmerkmal für Malignität kennt man auch von anderen Tumoren, wie dem gering differenzierten Schilddrüsenkarzinom.

\section{DGP.P1.09}

\section{Identifizierung von Genen, die die Ausbildung follikulärer Neoplasien der Schilddrüse begünstigen, im Tiermodell}

\section{B. Kölsch, S. Theurer, C. Fischer, N. Skrynecki, A. Kutritz, K. W. Schmid, A. Kindler-Röhrborn* \\ Universität Duisburg-Essen, Institut für Pathologie, Essen, Deutschland}

Ziel. Exogene Faktoren wie Jodmangel aber auch genetische Prädisposition stellen Riskofaktoren für die Ausbildung von Knoten der Schilddrüse dar. Frühere Studien haben gezeigt, dass ca. 60 \% gutartiger Schilddrüsenknoten monoklonalen Ursprungs sind und damit zu den Neoplasien gehören. Diese Veränderungen lassen sich nur mit Hilfe komplexer molekularpathologischer Verfahren von polyklonalen hyperplastischen Knoten unterscheiden. Dies erschwert die Identifizierung prädisponierender genetischer Faktoren als Ansatzpunkte für molekulare Tumorprävention beim Menschen. LE Ratten als Modelorganismen sind nach einer entsprechenden Behandlung hochsuszeptibel gegenüber der Entstehung folliku- lärer Neoplasien und erlauben durch Kreuzung mit den resistenten BN Ratten genomweite Assoziationsanalysen.

Methoden. Die Ratten einer $(\mathrm{BN} \times \mathrm{LE}) \mathrm{F}_{2}$ Kreuzung erhielten ab dem 28 . Lebenstag eine iodarme Diät (ID) und am 50. Tag eine Injektion mit NMethyl N-nitrosoharnstoff (MNU). Alle Tiere wurden im Alter von 260 Tagen getötet. Die Schilddrüsen wurden histologisch begutachtet. Von jeder Ratte war am 28. Tag eine Schwanzbiopsie genommen worden, aus der genomische DNA isoliert wurde. Diese wurde mit 112 genomweit verteilten SNP Markern genotypisiert. Die Assoziation zur Entstehung von follikulären Neoplasien wurde mit Hilfe des Armitage trend tests analysiert. Gen Expressionsanalysen wurden mit Hilfe von Biochips durchgeführt. Ergebnisse. Bei 31 von $267(\mathrm{LE} \times \mathrm{BN}) \mathrm{F}_{2}$ Ratten wurden follikuläre Neoplasien in der Schilddrüse entdeckt (11\%); davon 28 bei männlichen Tieren $(22 \% ; \mathrm{N}=130)$ und 3 bei weiblichen $(2 \% ; N=137 ; p=0,0001)$. Bei der Assoziationsanalyse, die nur an männlichen Tieren durchgeführt wurde, wurden genom-weit signifikante Loci auf den Rattenchromosomen 6, 12 und 14 entdeckt. Genom-weit variiert die Expression von 543 Genen zwischen Schilddrüsen von männlichen LE und BN Ratten, 8 davon liegen im Locus auf Chr. 6, 3 im Locus auf Chr. 12 und 5 im Locus auf Chr. 14. Fazit. Durch die Behandlung von LE/Stm $\times \mathrm{BN} \mathrm{F}_{2}$ Ratten mit MNU/ID entwickeln sich 10-fach mehr Neoplasien in männlichen als in weiblichen Tieren. Drei Haupt-Loci kontrollieren die durch MNU/ID induziert Entwicklung der Tumoren in männlichen Tieren.

In jedem dieser Loci befinden sich Gene, deren Expression zwischen suszeptiblen LE- und resistenten BN Ratten signifikant unterschiedlich ist und in menschlichen Schilddrüsen überprüft werde sollen.

\section{DGP.P1.10 \\ Expression des Somatostatinrezeptors in medullären Schilddrüsenkarzinomen}

S. Theurer ${ }^{1 *}$, I. Binse ${ }^{2}$, K. Herrmann ${ }^{2}$, M. Ingenwerth', E. Mairinger ${ }^{1}$, K.W. Schmid', F. Mairinger ${ }^{1}$

'Institut für Pathologie/Universitätsklinikum Essen, Essen, Deutschland, ${ }^{2}$ Klinik für Nuklearmedizin, Universitätsklinikum Essen, Essen, Deutschland

Ziel. Medulläre Schilddrüsenkarzinome (MTC) sind seltene maligne endokrine Tumoren, die aus den parafollikulären C-Zellen der Schilddrüse entstehen. Stromadesmoplasie gilt als prognostischer Faktor für Metastasierung. Zur Therapie stehen in der metastasierten Situation lokal chirurgische Verfahren und systemische Chemotherapie zur Auswahl.

Die Expression von Somatostatinrezeptoren (SSTR) kann in differenzierten neuroendokrinen Tumoren sowohl diagnostisch, als auch therapeutisch genutzt werden.

Ziel dieser Untersuchung war die Dokumentation der Expression von Somatostatinrezeptoren in medullären Schilddrüsenkarzinomen und die Analyse hinsichtlich einer prognostischen Bedeutung, sowie die Herausstellung einer Patientengruppe, die Somatostatinrezeptoren exprimiert und somit von nuklearmedizinischer Theranostik profitieren kann.

Methoden. Es wurde eine Serie von 26 medullären Schilddrüsenkarzinomen hinsichtlich der Expression von SSTR2 und 5 immunhistochemisch untersucht und bezüglich ihrer Assoziation zu Desmoplasie, Lymphknoteninvasion und Geschlecht analysiert.

Ergebnisse. Es wurden insgesamt 26 MTCs untersucht. $58 \%(n=15)$ der Patienten waren weiblich, $42 \%(n=11)$ männlich. 23 Fälle $(88 \%)$ zeigten eine Stromadesmoplasie, in 9 Fällen (35\%) waren bereits Lymphknotenmetastasen ausgebildet, wobei Lymphknotenmetastasen nur bei Desmoplasie-positiven Fällen auftraten. In 5 Fällen (19\%) konnte eine immunhistochemisch positive Reaktion für SSTR2 gezeigt werden, 3 Fälle (12 \%) waren positiv für SSTR5. Dabei war ein Fall positiv für SSTR2 und SSTR5. Auffällig war eine heterogene Verteilung der Anfärbung innerhalb des Tumors in allen Fällen. Eine SSTR2-Expression war nur in Fällen mit Stromadesmoplasie zu finden, während SSTR5 auch in einem desmoplasiefreien Fall zu sehen war. Alle Fälle, in denen eine Expression von SSTR nachgewiesen werden konnte, hatten keine Lymphknotenmetastasen $(p=0,05)$. SSTR2-Positivität trat ausschließlich in Fällen von weiblichen Patienten auf $(p=0,04)$. 
Fazit. SSTR2 und 5 werden in medullären Schilddrüsenkarzinomen exprimiert und können immunhistochemisch nachgewiesen werden. Diese Rezeptoren sind vielversprechende Zielstrukturen für die nuklearmedizinische Diagnostik und Therapie. Auch wenn SSTR2 bislang nur in nodal negativen und Desmoplasie-positiven Fällen nachgewiesen werden konnte, müssen größere Falluntersuchungen zeigen, ob sich SSTR als prognostischer Marker für die Vorhersage von Metastasierung eignet.

\section{DGP.P1.11}

\section{Tumorbegrenzung als prognostischer Risikofaktor für die zervikale Lymphknotenmetastasierung beim sporadischen Medullären Schilddrüsenkarzinom (MTC)}

\section{P. Kaatzsch ${ }^{1 *}$, K. Lorenz ${ }^{2}$, C. Wickenhauser' ${ }^{1}$ U. Siebolts'}

'Universitätsklinikum Halle (Saale), Institut für Pathologie, Halle (Saale), Deutschland, ${ }^{2}$ Universitätsklinikum Halle (Saale), Abteilung für Viszerale, Gefäß- und Endokrine Chirurgie, Halle (Saale), Deutschland

Ziel. Das sporadische Medulläre Schilddrüsenkarzinom (MTC) trägt ein hohes Risiko für eine zervikale Lymphknotenmetastasierung. Als Risikofaktoren für eine lymphonodale Ausbreitung werden unter anderem die Tumorgröße, ein organüberschreitendes Wachstum, die intratumorale Stromadesmoplasie sowie der serologische CEA (carcinoembryonic antigen)-Spiegel diskutiert. Während MTC im Stadium T3 bis T4 in der Regel durch eine diffuse Infiltration des umgebenden Parenchyms charakterisiert sind, findet man bei Tumoren im Stadium T1 bis T2 vermehrt Fälle mit umschriebenem bis kapselartig begrenztem Wachstum.

Unsere initiierte Studie hat das Ziel anhand einer histomorphologischen Einteilung der Tumorinvasionsfront an MTC im Stadium T1 bis T2 unter Verwendung eines größeren Patientenkollektivs im Vergleich zu bereits veröffentlichten Studien die Eignung der peritumoralen Begrenzung als prognostischer Marker für die regionale, lymphonodale Metastasierung zu überprüfen.

Methoden. Unser Kollektiv umfasst 145 sporadische Medulläre Schilddrüsenkarzinome (MTC) im Stadium T1 bis T2 $(<4 \mathrm{~cm})$ von Patienten im Alter von 24 bis 85 die zwischen 1994 und 2018 chirurgisch behandelt wurden. Die Auswertung der histomorphologischen Präparate wurde von zwei Pathologen getrennt voneinander durchgeführt und die Begrenzung bzw. die Morphologie der Randgebiete der Tumoren in die Kategorien „invasiv“ bzw. „minimal invasiv“ und „umschrieben“ eingeteilt. Es erfolgte eine anschließende Korrelation mit den klinischen Daten zur lymphonodalen Metastasierung.

Ergebnisse. 33 (23\%) von 145 MTC wurden in die Kategorien „minimal invasiv" bzw. „umschrieben“ eingeordnet. Von den betreffenden Patienten verzeichnete zum Zeitpunkt der Operation keiner eine regionale lymphonodale Metastasierung bei im Median 42 untersuchten Lymphknoten. In der Gruppe ,invasiv“ zeigten 55 (49\%) von 112 Patienten einen positiven Nodalstatus.

Fazit. Die Klassifizierung der Tumorinvasionsfront bei MTC im Stadium T1 bis T2 $(<4 \mathrm{~cm})$ ermöglicht, nach unseren Daten, eine starke prognostische Vorhersage zum Risiko einer regionären, lymphonodalen Metastasierung zum Zeitpunkt der Operation. Aus unserer Sicht kann diese Information eine zusätzliche Entscheidungshilfe zur Therapieplanung hinsichtlich einer zervikalen Lymphonodektomie darstellen.

\section{DGP.P1.12}

\section{Neuroendokriner Tumor im Analkanal - Eine Entität?}

\section{A. von Herbay ${ }^{1 *, 2}$, A. Eckhardt ${ }^{2}$, G. Quaranta ${ }^{3}$}

${ }^{1}$ Hanse-Pathologie, Hamburg, Deutschland, ${ }^{2}$ Schwarzwald-Baar-Klinikum, Institut für Pathologie, Villingen-Schwenningen, Deutschland, ${ }^{3}$ SchwarwaldBaar-Klinikum, Chirurgische Klinik, Villingen-Schwenningen, Deutschland

Neuroendokrine Tumoren (NET) des Gastro-Entero-Pankreatischen (GEP) Systems bilden eine gut etablierte Teilgruppe der NET beim Menschen. Aber selbst in größeren Fallserien von GEP-NET finden NET im Analkanal keine Erwähnung. Wir berichten einen solchen seltenen Fall.
Klinik. Bei einer asymptomatischen 77-jährigen Frau wurde im Rahmen einer Routineuntersuchung beim Hausarzt rektal-digital eine kleine Raumforderung getastet. Nach proktologischer Untersuchung erfolgte zunächst eine Zangenbiopsie der Raumforderung an der Linea dentata. Nach erster Diagnosestellung erfolgte chirurgisch eine lokale Tumorexision. Histopathologische Befunde. Im Excidat ist der Tumorherd 0,8 cm groß und umschrieben. Das Epizentrum liegt im mittleren Analkanal, im Übergangsbereich der Rektumtypmukosa des oberen Analkanals zur plattenepithelialen Mukosa des unteren Analkanals. Die mittel-großen Tumorzellen bilden vornehmlich nestformige, seltener auch trabekuläre Verbände. Die Kerne sind mittelgroß, vesikulär. Mitosen sind nicht auffällig. Immuncytochemisch sind alle Tumorzellen positiv für Synaptophysin (MAk 27 G12, Fa. Leica), ein Teil auch für Chromogranin A (MAk 5H7, Fa. Leica). Negativ reagieren die Zellen für verschiedene Cytokeratine (MAks AE1/AE3; Fa. Leica), p40 (MAk BC28; Fa. Zytomed) und CDX2 (MAk AMT28, Fa. Leica). Die Proliferationsaktivität ist mäßig hoch: 15 \% Ki67 positive Kerne (MAk Mib1; Fa. Medac). Zusammenfassend führte dies zur Diagnose eines NE-Tumors Grad 2.

Diskussion. Für die seltenen NET im Analkanal wird in der WHO-Klassifikation eine Beurteilung analog zu NET im Rektum empfohlen. Der dargestellte Fall eines NET im Analkanal weist allerdings Aspekte auf (u.a. Cytokeratine negativ), welche ihn von den meisten NET des Rektums unterscheiden.

\section{DGP.P1.13}

\section{Vagales Paragangliom - ein seltener neuroendokriner Tumor im} Kopf-Hals-Bereich

\section{B. Presztoczki ${ }^{1 *}$, C. Mozet ${ }^{2}$, A. von Herbay ${ }^{1,3}$}

'Schwarzwald-Baar Klinikum, Pathologie, Villingen-Schwenningen, Deutschland, ${ }^{2}$ Schwarzwald-Baar Klinikum, Hals-Nasen-Ohrenheilkunde, Kopf- und Halschirurgie, Villingen-Schwenningen, Deutschland, ${ }^{3}$ HansePathologie, Pathologie, Hamburg, Deutschland

Eine kleinere Teilgruppe der NET bilden die parasympathischen Paragangliome, welche exklusiv im Kopf-Hals-Bereich auftreten. Wir berichten einen solchen seltenen Fall.

Klinik. Bei einem 50-jährigen Mann erfolgten Untersuchungen zur Abklärung seines langjährigem Reizhustens. Endoskopisch wurde linkseitig eine partielle Stimmlippenparese festgestellt. CT und MRT zeigten eine Raumforderung nahe der Carotisbifurkation links. Unter der Verdachtsdiagnose eines Glomustumors erfolgte HNO-chirurgisch eine Tumorexision. Intraoperativ wurde eine Verbindung des Tumors zum N. vagus festgestellt Dies führte zur Verdachtsdiagnose eines Neurinoms.

Histopathologische Befunde. Im Excidat ist der Tumorherd 2,4 cm groß und umschrieben, er hängt einem Teilstück des N. vagus an. Zentral und perizentral sind rund $75 \%$ des Tumorvolumens sklerotisch und fast azellulär. Peripher bilden die Tumorzellen vornehmlich kleinere nestformige Verbände, keine größeren „Zellballen“, umgeben von einem schmalen fibrovaskulären Stroma mit spindeligen Sustentakularzellen. Die Kerne sind klein und kaum anisomorph. Mitosen sind nicht auffällig.

Immuncytochemisch sind alle Tumorzellen positiv für Synaptophysin (MAk 27 G12; Fa. Leica) und für N-CAM (CD56; Mak 1B6; Fa. Leica). Negativ reagieren die Zellen für verschiedene Cytokeratine (MAks AE1/ AE3; Fa. Leica), für CEA (MAk II 7; Fa. Leica) und für Calcitonin (pk; Fa. Leica). Die Proliferationsaktivität ist sehr gering: $<1 \%$ Ki67 positive Kerne (MAk Mib1; Fa. Medac). Die Sustentakularzellen sind positiv für Protein S100 (pK; Fa. Leica). Zusammenfassend führte dies zur Diagnose eines vagalen Paraganglioms.

Diskussion. Gemäß der neuen WHO-Klassifikation (4. Ausgabe, 2017) gelten alle Paragangliome im Kopf-Hals-Bereich als potentiell maligne, auch wenn nur einige metastasieren. Der dargestellte Fall eines Kopf-Hals-NET war umschrieben, subtotal sklerotisch, und hatte eine sehr geringe Proliferationsaktivität. Diese Befunde sind suggestiv für eine benigne Läsion. 
DGP.P1.14

Gering differenzierte neuroendokrine Karzinome des Kolons: Eine klinisch-pathologische Studie von 19 Fällen

I. Boeck ${ }^{*}$, E. Weihe ${ }^{2}$, A. Krieg ${ }^{3}$, H.-E. Gabbert', A. Raffel ${ }^{5}$, M. Krausch ${ }^{5}$, H.J. Krämling ${ }^{6}$, H. Neuhaus 7 , M. Anlauf ${ }^{8}$

'MVZ ÜGP Institut für Pathologie, Zytopathologie und Molekularpathologie, Wetzlar, Deutschland, ${ }^{2}$ Institut für Anatomie und Zellbiologie,

Abteilung für molekulare Neurowissenschaften, Marburg, Deutschland, ${ }^{3}$ Heinrich-Heine-Universität, Klinik für Allgemein- und Viszeralchirurgie, Düsseldorf, Deutschland, ${ }^{4}$ Universitätsklinikum Düsseldorf, Institut für Pathologie, Düsseldorf, Deutschland, ${ }^{5}$ Marienhospital Gelsenkirchen, Klinik für Allgemein- und Viszeralchirurgie, Gelsenkirchen, Deutschland, ${ }^{6}$ Evangelisches Krankenhaus Düsseldorf, Klinik für Allgemein- und Viszeralchirurgie, Düsseldorf, Deutschland, ${ }^{7}$ Evangelisches Krankenhaus Düsseldorf, Klinik für Gastroenterologie, Düsseldorf, Deutschland, ${ }^{8}$ MVZ ÜGP Institut für Pathologie, Zytopathologie und Molekularpathologie, Limburg, Deutschland

Ziel. Neuroendokrine Karzinome (NEC) von Kolon und Rektum sind aggressive und seltene Tumoren. Mit der WHO-Klassifikation von 2010 wurde erstmals die Entität der großzelligen neuroendokrinen Karzinome (LCNEC) von den kleinzelligen euroendokrinen Karzinomen (SCNEC) abgegrenzt. Ziel der vorliegenden Arbeit ist eine umfassende pathologische Charakterisierung dieser Tumoren.

Methoden. Über einen Zeitraum von vier Jahren wurden an zwei Tumorzentren 455 Patienten mit kolorektalem Karzinom (KRK) operiert. Diese wurden retrospektiv immunhistochemisch auf das Vorhandensein spezifischer neuroendokriner Marker gescreent und drei in der WHO definierten Subgruppen gering differenzierter NEN zugeordnet (LCNEC, SCNEC, gemischt adenoneuroendokrine Karzinome (MANEC)). Diese wurden mit 16 immunhistochemischen Markern charakterisiert und molekularpathologisch auf therapeutisch/prognostisch relevante Aberrationen hin untersucht. Zwei LCNEC-Zelllinien wurden etabliert und immunhistochemisch charakterisiert.

Ergebnisse. Von den 455 KRK exprimierten 6,4\% $(n=29)$ spezifische neuroendokrine Marker. Davon ließen sich 2,6 \% LCNEC ( $n=12), 0,9 \%$ SCNEC $(n=4)$ und 0,7 \% MANEC $(n=3)$ zuordnen. Zusätzlich kristallierte sich eine vierte Subgruppe der cribriformen adendoneuroendokrinen Karzinome (CCANE) heraus $(n=9,2,2 \%)$. LCNEC und MANEC traten überwiegend rechtskolisch auf ( $83 \%$ bzw. $67 \%$ ), wohingegen SCNEC und CCANE linkskolisch lokalisiert waren. Zum Zeitpunkt der Erstdiagnose lag oft ein UICC-Stadium IV vor (50 \% LCNEC, $33 \%$ MANEC, $75 \%$ SCNEC, $56 \%$ CCANE). Alle LCNEC exprimierten kräftig und homogen Synaptophysin, Pan-Zytokeratin und CK8/18. p53 wurde in $75 \%(n=9)$, CDX2 wird in $>80 \%(n=10)$ exprimiert. Keine NEN-Subgruppe zeigte eine Expression von HER2/neu, c-kit, SSTR2A oder SSTR5. Molekularpathologisch wiesen $58 \%$ der LCNEC $(n=7)$ eine V600E-BRAF-Mutation auf und $17 \%(n=2)$ eine KRAS-Mutation in Codon 12 oder 13. Ckit-Mutationen in den Exonen 9 und 11 oder EGFR-Mutationen in den Exonen 18, 19 oder 21 wurden nicht detektiert.

Fazit. LCNEC treten häufiger auf als angenommen und zeigen im Vergleich zu konventionellen Adenokarzinomen häufiger V600E-BRAF-Mutationen. Inwiefern daraus therapeutische Implikationen erwachsen, müssen weitere Studien zeigen.

\section{DGP.P1.15}

Semiquantitative Analyse immunhistochemischer PD1- und PDL1-Expression bei benignen und malignen Schilddrüsentumoren

T. Hager ${ }^{1 *}$, K. J. Schmitz ${ }^{1,2}$, S. Ting ${ }^{1}$, K. W. Schmid ', S.-Y. Sheu-Grabellus ${ }^{1,2}$

'Universitätsklinikum Essen, Institut für Pathologie, Essen, Deutschland, 2Pathologie Recklinghausen, Recklinghausen, Deutschland

Ziel. Unter dem Gesichtspunkt der schlechten Prognose gering differenzierter Formen maligner Schilddrüsentumore und des hohen Potenzials immuntherapeutischer Ansätze bei soliden Tumoren war eine mögliche Übertragbarkeit etablierter Ansätze der immunhistochemischen PD-L1-
Diagnostik solider Tumore (einschließlich Überprüfung des PD1-Status) auf Schilddrüsentumore Ziel dieser Untersuchung.

Methoden. Ein Kollektiv mit insgesamt 111 Fällen von benignen (16 Strumen und 12 follikuläre Adenomen) sowie malignen (23 papilläre, 20 follikuläre, 20 gering differenzierte und 20 anaplastische Karzinome) Schilddrüsentumoren wurde investigativ und ohne Korrelation klinischer Daten und ohne Kenntnis des Mutationsstatus immunhistochemisch auf PD1 und PD-L1 untersucht. Die Ergebnisse wurden mit einem semiquantitativen Scoring-System, einer modifizierten Variante des sog. „Histo Score“ (H Score), bewertet.

Ergebnisse. Für PD1 konnte keine signifikante Expression, für PD-L1 eine Expression in $17,9 \%$ der untersuchten benignen und $36 \%$ der malignen Läsionen, mit Subsummierung von $65 \%$ der follikulären und $70 \%$ der anaplastischen Schilddrüsenkarzinome, verifiziert werden.

Fazit. Technisch und morphologisch ist die Übertragung der immunhistochemischen PD-L1-Diagnostik nach aktuellen Kriterien solider Tumoren praktikabel. Insbesondere follikuläre und anaplastische Schilddrüsenkarzinome kommen den Ergebnissen zufolge als potenzielle Entitäten für mögliche immuntherapeutische Ansätze in Betracht. Für die definitive Validierung werden jedoch additive Studien unter Korrelation zusätzlicher Parameter (tumorassoziierte Immunreaktion, Mutationslast, klinische Daten) benötigt.

\section{DGP.P1.16}

\section{Surprising diagnosis of a sarcoidosis-associated tumor lesion beside an adenoma in histopathological investigation of the surgical specimen}

\section{Denzel', M. Petersen' ', K. Reschke' , R. Moritz-Tugral', D. Jechorek,} R. S. Croner', F. Meyer ${ }^{1 *}$

'University Hospital, Dept. of General, Abdominal, Vascular and Transplant Surgery, Magdeburg, Germany, ${ }^{2}$ University Hospital, Dept. of Nephrology and Hypertensiology, Endocrinology and Diabetology, Magdeburg, Germany, ${ }^{3}$ University Hospital, Institute of Pathology, Magdeburg, Germany

Background. There is a broad spectrum of differential diagnoses of diffuse $\&$, in particular, (multi-)nodular goiter including malignancy.

Aim. Scientific case report based on i) topic-related references from the medical literature $\&$ ii) specific experiences obtained in the successful clinical case management as example of the diagnosis-specific care of the basic disease to demonstrate a rare but representative clinical finding of a surprising diagnosis.

Case presentation. (clinical, intra-/postop., histopathological findings, therapeutic approach \& follow-up recommendations): A 62-years old male patient reported on increasing size of nodular goiter, local pain \& impaired swallowing as sudden \& new clinical signs. Medical history had been significant for a known nodular goiter for years. Clinical examination revealed this multinodular goiter confirmed by ultrasound, which showed-in addition-no hint for hilar \& mediastinal lymph node enlargement. Scintigraphy demonstrated a "cold" nodule at the right thyroideal lobe (laboratory parameters: TSH \& calcium serum levels, within normal range-renal function, normal). Taken together, indication for thyreoidectomy was derived because of increasing size of the goiter, reported complaints \& to clarify definitely histopathological diagnosis of the cold nodule. Intraoperatively, neuromonitoring for undoubtful identification of the recurrent laryngeal nerve was used as appropriate-there was a slight reduction of the signal.

Histopathological investigation revealed complete resection of the thyroideal gland after performed thyroidectomy with necrotizing granulomatous inflammatory changes interpreted as sarcoidosis. In addition, there was a microfollicular adenoma of $10 \mathrm{~mm}$ in diameter within the right thyroideal lobe-no hint for malignancy.

Postop. course showed a temporary palsy of the recurrent laryngeal nerve (no change of postop. parathyroid hormone \& calcium serum levels). The substituting medication with L-Thyroxin ${ }^{\circledast}(75 \mu \mathrm{g})$ was initiated. Patient was discharged on the $3 \mathrm{rd}$ postop. day (no disturbance of wound healing). 
Suture material should be removed on the 5 th postop. day, TSH serum level should be controlled within 3 weeks.

Conclusion. The surprising diagnosis of sarcoidosis in histopathological investigation of a specimen after thyreoidectomy due to a nodular goiter is a rare event but indicates the basic option to diagnose such finding out of the broad differential diagnosis profile.

\section{Präzisionsonkologie - Poster}

\section{DGP.P2.01}

\section{Tissue damage after re-perfusion in transplant liver organs}

\section{Z. Halloul', H. Lippert ${ }^{2}$, F. Meyer ${ }^{3 *}$}

'University Hospital, Dept. of General, Abdominal, Vascular and Transplant Surgery, Division of Vascular Surgery, Magdeburg, Germany, ${ }^{2}$ Otto-vonGuericke University, Institute of Quality Assurance in Operative Medicine, Magdeburg, Germany, ${ }^{3}$ University Hospital, Dept. of General, Abdominal, Vascular and Transplant Surgery, Magdeburg, Germany

Background. The success of standardized liver transplantation (LTx) bases on substantial advances in surgical techniques \& an optimized, patient-adapted immunosuppressive therapy. The use of cadaveric organs is influenced by

i) a (possibly short) organ transfer,

ii) a (possibly minimized) ischemia effect by a lowered organ temperature with effective solutions for tissue conservation, such as HTK/UW solutions, \&

iii) reperfusion effects (by oxidative stress).

Aim. To assess quality of transplanted liver organs by simply determined parameters, already started during surgical intervention.

Methods. In all consecutive patients, systematic blood samples were withdrawn in a perioperative setting of LTx $(-1 \mathrm{~h} ; 0 ;+1 /+6 \mathrm{~h} ;+1 /+3 /+7 \mathrm{~d}) \&$ liver rinsing blood fractions during reperfusion phase after vascular anastomosis $(-1 \mathrm{~h} / 0 /+1 \mathrm{~h})$ were obtained \& analyzed:

1) AST/ALT/GLDH

2) MDA/protein carbonyle each correlating to parenchymal damage \& cold/warm ischemia time (CIT/WIT);

3) postoperative factors V/ATIII.

Results. From 1995-2009, 75 patients were enrolled (finally 60 with a completely analyzed spectrum of parameters). The rinsing blood was suitable to characterize damage of liver parenchyma/oxidative stress. CIT/WIT were in a short time frame, which was defined by the transplantation management \& the standardized surgical technique-no strong correlations of damage parameters \& time periods of ischemia. Oxidative-stress parameters showed only slight alterations/low correlations to other parameterstherefore, a causal association of ischemia/reperfusion, oxidative stress \& cell damage can not be derived (only between CIT \& AST). Obviously, the solutions for organ conservation provide an effective antioxidative protection. With regard to the impact of ischemia onto the transplanted organ, it was found that time if ischemia \& GLDH correlated during the mid-term postoperative course (supported by the fact that GLDH is a suitable liver-specific laboratory parameter for assessment of damage).

Conclusion. Ischemia-reperfusion damage bases on oxidative stress phenomenons. The extent of parenchymal damage can be quantified by analysis of the initial rinsing blood fractions. However, the advanced standardization did not lead to indicative courses of damage. During the establishing process of novel parameters to assess quality of LTx, rinsing blood can be considered a suitable material for analysis \& the presented laboratory parameter profile appears feasible \& well-proven.
DGP.P2.02

\section{Das Management arterio-viszeraler/-lumenaler Fisteln in repräsentativen Fallkonstellationen}

\section{U. Barth ${ }^{1 *}$, M. Pech ${ }^{2}$, Z. Halloul' ${ }^{1}$ F. Meyer ${ }^{3}$}

'Otto-von-Guericke-Universität mit Universitätsklinikum Magdeburg A. ö. R., Bereich Gefäßchirurgie, Klinik für Allgemein-, Viszeral-, Gefäßund Transplantationschirurgie, Magdeburg, Deutschland, ${ }^{2} \mathrm{Otto}$-vonGuericke-Universität mit Universitätsklinikum Magdeburg A. ö. R., Klinik für Radiologie und Nuklearmedizin, Magdeburg, Deutschland, ${ }^{3}$ Otto-vonGuericke-Universität mit Universitätsklinikum Magdeburg A. ö. R., Klinik für Allgemein-, Viszeral-, Gefäß-und Transplantationschirurgie, Magdeburg, Deutschland

Einleitung. Abdominelle arterielle Fisteln zu umgebenden luminären Organen sind seltene Erkrankungen, die ein individuelles Management erfordern.

Fallkonstellationen.

1. 70-jähriger Pat. (Dx: AEG Typ II) - Gastrektomie mit Splenektomie \& Ös.-Resektion + Colonsegment-Interposition (Histologie: pT2aN1[1/18]L1V1G3), später nachfolg. Anast.-Insuff. mit Implantation eines selbstexp. Stents bei Diagn. einer „high-flow“-aortoös. Fistel.

2. 79-jähriger Pat. mit ureteroiliacaler Fistel \& Hämaturie/Bl.-Tamponade b. Ureterstrikturen bds. infolge neoadj. RadiochemoTx eines suprasphinkt. Rektum-Ca \& folg. Rektumexstirpation (ypT3ypN0M0) mit interventionell-radiol. Verschluss der A. iliaca int. re \& re-iliacales Stenting du. „cross-over"-Manöver v. li-femoral.

3. 70-jähriger Pat. Aneurysma spurium d. dist. Anastomose einer aorto-aortale Rohrproth. Proth. Explantat. + subclaviobifem. Bypass wg. anhaltender Infektsituation zeigte eine duodenale Fistel. Unbeabs. „Bridging“ durch EVAR erwies sich vor def. Versorgg. als geeignete therap. Interimslösg. z. Verhinderg. einer drohenden aortointest. Fistel

4. 72-jähriger Pat. mit ak. Reblutung aus Desc.-Stoma (b. irresektablem T4-Rektum-Ca) mit Coiling des blut. Astes d. AMI (init. Blutstillung mit Stenting d. AIE re)-i) Ca wurde „entdacht“ \& ii) die Fistel exzidiert (incl. iliac. Stententferng. \& Gefäßligatur). Dx: Primäre iliaco- \& nachfolg. mesentericoenterale Fistel mit Rezidivblutg. im unt. GI-Trakt aufgr. eines infiltrativ wachs. Rektum-Ca.

5. 46-jähriger Patient im postop. Verlauf nach Mehrf.-nekrosektomien eine ob. GI-Blutung (A. lienalis) i. R. ak. nekrotis. Pancreatitis. Tx: Min.-invasive, alternativ CT-geführte, perkut. Thrombinschauminjektion als Bridging (Zeitgewinn) wg. einer Ps.-Zystenblutg. b. ak. Pancreatitis \& simult. Aortendissektion.

6. 57-jährige Patn. mit Pseudoaneurysma der A. gastrica sinistra (AGS) incl. art.-venöse Fistel zur V. coronaria ventriculi - führte zu (supra-)selektiver Katheterisierg. \& Embolisierg. mit Mikro-Coils von Fistel, Aneurysma \& art. Zuflusses via DSA (+ Truncus-coel.-Stenose; AGS weiter offen).

Schlussfolgerung. Das befundgerechte Management art. Fisteln ist extrem anspruchsvoll \& erfordert die interdisz. Expertise eines tertiären gefäßmed. Zentrums.

\section{DGP.P2.03}

\section{Prognostic impact of different histological grading schemes in acute graft versus host disease of the colon}

A. Kreft ${ }^{1 *}$, H. Neumann ${ }^{2}$, M. Schindeldecker ${ }^{3}$, E.M. Wagner-Drouet ${ }^{4}$

'Universitätsmedizin Mainz, Pathologie, Mainz, Germany,

${ }^{2}$ Universitätsmedizin Mainz, Endoskopie, Mainz, Germany,

3Universitätsmedizin Mainz, Pathologie/Tissue Biobank, Mainz, Germany,

${ }^{4}$ Universitätsmedizin Mainz, Hämatologie, Mainz, Germany

Aim. Intestinal acute graft versus host disease (aGvHD) is associated with substantial morbidity and mortality in patients who underwent allogenic hematological stem cell transplantation (alloHSCT). Recent studies pointed to a prognostic impact of histological grading in intestinal GvHD. Here we compare three different grading systems. 


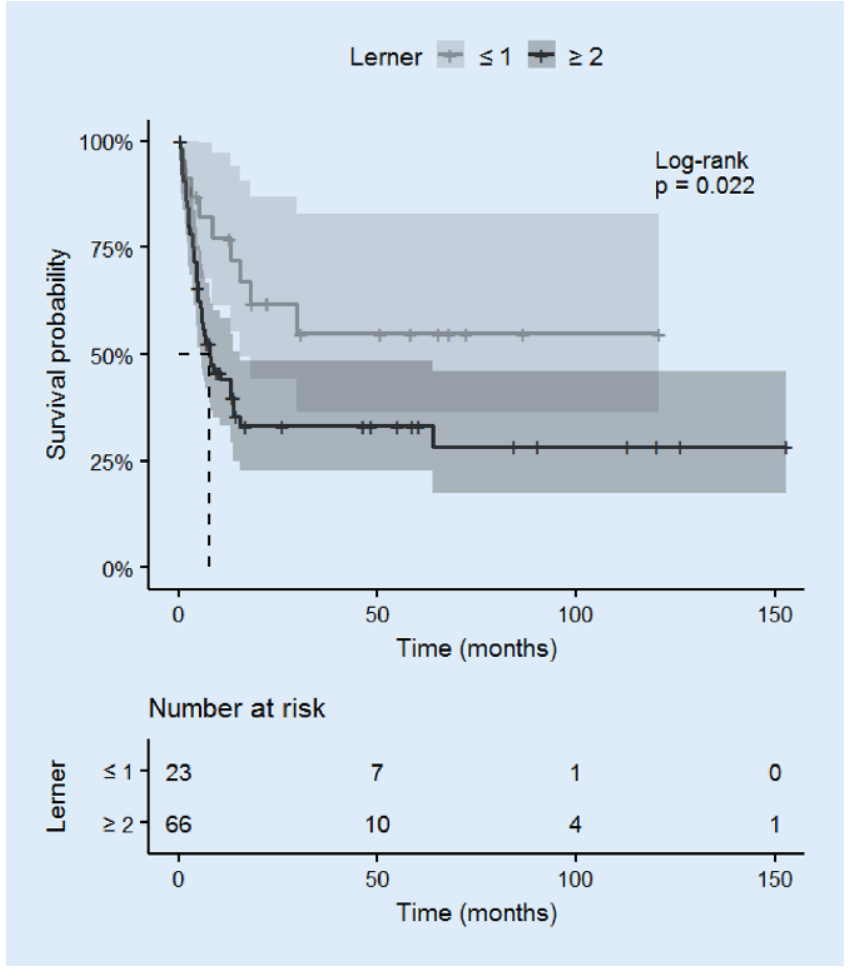

Fig. 1 | DGP.P2.03 $\Delta$ Correlation of non Relaps related Mortality and histologic Lerner Grade of GvHD in the Colon

Methods. We analyzed data from 89 patients with clinical signs of aGVHD (day +20 to +200 after HSCT) in which a series of at least 3 biopsies from different sites of the colon were taken, altogether 425 biopsies. Histological grading was performed for each biopsy according to the Lerner classification (grade 0: normal mucosa, grade 1: crypt cell apoptosis, grade 2: crypt destruction, grade 3: focal mucosa denudation, grade 4: diffuse mucosa denudation), the Sale classification (grade 0: normal, grade 1: crypt abscess with necrotic or atypical epithelial cells, grade 2: individual, non-contiguous crypt loss, grade 3: contiguous areas of two or more lost crypts, grade 4: mucosa denudation) and the Melson classification (grade 0: normal, grade 1: crypt cell apoptosis, grade 2: individual, non-contiguous crypt loss, grade 3: contiguous areas of two or more lost crypts, grade 4: mucosa denudation). For each biopsy series the maximum, the minimum, the median and the mean grade were correlated with the non relaps related mortality using the log-rank test.

Results. The survival was associated with the Lerner grade of aGvHD in the biopsy series of the colon after alloHSCT (• Fig. 1 |DGP.P2.03); with the maximum- $(p=0.02)$, as well as the mean- $(p=0.02)$ and the median grade $(p=0.04)$, but not with the minimum grade $(p=0.3)$. The other scores did not reveal a significant correlation with survival (Melson grades: maximum: $p=0.27$, minimum: $p=0.82$, mean: $p=0.33$, median: $p=0.29$; Sale grades: maximum: $p=0.36$, minimum: $p=0.55$, mean: $p=0.25$, median: $p=0.17$ ).

Conclusion. In conclusion we found that only the histological grading of aGvHD of the colon according to Lerner was associated with the prognosis in patients after alloHSCT. The maximum and the mean grade in a biopsy series was the most predictive, whereas the minimum grade yielded no significant information on prognosis. We found no significant correlation of the Sale- or the Melson grade with survival in our collective.

\section{DGP.P2.04 \\ Zur Optimierung der panelbasierten Messung der Tumormutationslast}

J. Budczies ${ }^{1 *}$, E. Rempel', M. Allgäuer', P. Christopoulos' ${ }^{2}$ D. Kazdal', V. Endris', P. Schirmacher ${ }^{1}$, A. Stenzinger ${ }^{1}$

'Universitätsklinikum Heidelberg, Pathologie, Heidelberg, Deutschland, 2Universitätsklinikum Heidelberg, Thoraxklinik, Heidelberg, Deutschland

Ziel. Methodische Grenzen bei der Messung der Tumormutationslast (tumor mutational burden, TMB) durch panelbasierte Sequenzierungsmethoden wurden mathematisch und durch Simulationen in Exomsequenzierungsdaten analysiert, um die Grundlagen für eine präzise und reproduzierbare Methodik zu legen.

Methoden. Die Eignung von fünf verschieden großen Sequenzierungspanels für die TMB-Messung wurde einerseits in einem Zufallsmutationsmodell und andererseits durch Simulationen in den Mutationsdaten der 10.000 Tumore des TCGA-Projekts untersucht.

Ergebnisse. Der Variationskoeffizient (coefficient of variation, CV) der TMB-Messung, definiert als Standartabweichung der gemessenen Mutationszahl relativ zur Höhe des TMBs, war im Zufallsmutationsmodell einer exakten mathematischen Behandlung zugänglich: Der CV nimmt sowohl proportional zur Quadratwurzel der Panelgröße als auch proportional zur Quadratwurzel des TMB ab. In Simulationen verschiedener Panels in den TCGA-Daten konnte dieses mathematsche Gesetz bestätigt werden. Für die drei größten Panels mit einem abgedeckten Bereich der kodierenden Sequenz zwischen 1,1 und 1,4 Mbp lag der CV für einen Tumor mit 10 Mutationen/Mbp bei $35 \%$. Für diese drei Panels lagen Missklassifikationsraten für eine Aufspaltung in Tumore mit hohem TMB und Tumore mit niedrigem TMB durch einen Schwellenwert von $n=199$ Mutationen bei 10-12 \% für die Lungenadenokarzimome und bei 17-19\% für die Lungenplattenepithelkarzinome der TCGA-Kohorte. Als neues Konzept ersetzten wir den TMB-Schwellenwert durch ein Intervall, innerhalb dessen keine zuverlässige Klassifikation des TMB in „hoch“ oder „niedrig“ mittels Panelsequenzierung möglich war. Zusammenfassend wuchs für Tumore mit TMB nah am Schwellenwert 10 Mutationen/Mb die Ungenauigkeit der TMB-Messung bei Unterschreitung einer Panelgröße 1 Mbp stark an. Die Panelgröße ist noch kritischer bei der Verwendung von niedrigeren TMB-Schwellenwerten, die zukünftig insbesondere für Tumorentitäten mit generisch niedriger Mutationslast klinisch wichtig werden könnten. Im hergeleiteten mathematischen Gesetz ist transparent, dass ein halb so großer Schwellenwert durch ein doppelt so großes Panel kompensiert werden kann in dem Sinn, dass der CV des TMB dann für einen Tumor am Schwellenwert dieselbe Größe besitzt.

Fazit. Die transparente Beschreibung der methodeninhärenten Ungenauigkeiten bei der TMB-Messung durch Panelsequenzierung unterstützt die Einführung valider TMB-Tests in der Routinediagnostik.

\section{DGP.P2.05}

\section{The landscape of somatic variant Interpretation in precision} oncology

J. Leichsenring ${ }^{1 *}$, P. Horak' ${ }^{2}$, S. Kreutzfeld ${ }^{2}$, C. Heining ${ }^{3,4}$, A.-L. Volckmar', O. Neumann', M. Kirchner', C. Ploeger', C. Heilig', D. Kazdal', M. Allgäuer', A. Harms' ', E. Rempel', U. Lehmann ${ }^{5}$, I. Bonzheim ${ }^{6}$, R. Marienfeld', M. Werner', F. Fend ${ }^{6}$, M. Börris' ${ }^{8}$, S. Lassmann ${ }^{8}$, T. Longerich' ${ }^{7}$, W. Weichert ${ }^{9}$, P. Schirmacher', R. Penzel', V. Endris', F. Klauschen ${ }^{10}$, H. Glimm ${ }^{3}$, S. Fröhling ${ }^{2}$, A. Stenzinger ${ }^{1}$ 'Pathologisches Institut, Universitätsklinikum Heidelberg, Heidelberg, Germany, ${ }^{2}$ Nationales Centrum für Tumorerkrankungen (NCT), Heidelberg, Germany, ${ }^{3}$ Nationales Centrum für Tumorerkrankungen (NCT), Dresden, Germany, ${ }^{4}$ Universitätskrankenhaus Carl Gustav Carus, Dresden, Germany, ${ }^{5}$ Pathologisches Institut, MHH, Hannover, Germany, ${ }^{6}$ Pathologisches Institut, Universitätskrankenhaus Tübingen, Tübingen, Germany, ${ }^{7}$ Pathologisches Institut, Universitätskrankenhaus Ulm, Ulm, Germany, ${ }^{8}$ Pathologisches Institut, Universität Freiburg, Freiburg, Germany, ${ }^{9}$ Pathologisches Institut, Technische Universität München, München, Germany, ${ }^{10}$ Pathologisches Institut, Charité Universitätsmedizin, Berlin, Germany 
Aim. With increasingly comprehensive molecular profiling of cancer types, clinical interpretation (i. e. actionability level) of genetic alterations is becoming more challenging. Recently, classifications for diagnostic variant interpretation have been introduced to guide clinical management in a cancer precision medicine framework.

Methods. We review and describe the specifics of each major classification and exemplify their recommendations. We highlight shared features and differences as well as major influencing factors and unresolved issues that need to be addressed to achieve a unified classification that can be broadly implemented and applied diagnostically.

Results. All proposed variant classifications provide a framework for the clinical assessment of the detected genetic alterations and help prioritization of the corresponding targeted therapies. These classifications are relatively easily applicable for most well-characterized alterations, which are already considered standard of care. For the remaining, newly discovered, rare or individual genetic alterations, each classification has its advantages and drawbacks and not all alterations are classified equally. Differences depend on the specific evidence levels defining every category within each scheme, which is influenced by clinical and biological rationale, but also by different socioeconomic circumstances including various regulatory approvals of targeted compounds in different health care systems.

Conclusion. Comparison of the classifications underlines the need for a clinically useful and universally applicable variant reporting, which is instrumental for efficient decision-making based on sequencing analysis in oncology.

\section{DGP.P2.06}

\section{An unbiased screen for prognostic markers identifies Annexin A9} for independent risk stratification in colon cancer

M. Elmasry ${ }^{1 * 2,}$, A. Jung ${ }^{1,3,4}$, T. Kirchner ${ }^{1,3,4}$, D. Horst ${ }^{3,4,5}$

'Ludwig-Maximilians-Universität/Institute of Pathology, München, Germany, ${ }^{2}$ Mansoura University/Faculty of Medicine, Department of Pathology, Mansoura, Egypt, ${ }^{3}$ German Cancer Consortium (DKTK), Heidelberg, Germany, ${ }^{4}$ German Cancer Research Center (DKFZ), Heidelberg, Germany, ${ }^{5}$ Charité-Universitätsmedizin Berlin/Institute of Pathology, Berlin, Germany

Background and aims. For patients with colon cancer, the risk for disease recurrence and death mainly depends on disease stage. Yet, patients with early stage colon cancer may still succumb to the disease. Here, we demonstrate an unbiased approach to identify new biomarkers that may aid in risk stratification beyond clinical staging.

Methods. We used gene expression data of 457 colon cancer cases with clinical follow-up from The Cancer Genome Atlas (TCGA) to identify candidate genes with prognostic power. Multivariate analysis including age gender, T-stage, nodal status, and microsatellite instability further selected for independent prognostic markers. Among the top candidates, we then selected Annexin A9 (ANXA9) for further validation on the protein level in two colon cancer case collections that were stratified for patient survival $(n=244)$ and tumor metastasis $(n=90)$, respectively.

Results. We identified 194 genes, the expression of which had putative prognostic power for patient survival within the TCGA colon cancer data set Thirty-five of these genes showed independent prognostic power in proportional hazards regression analyses. Annexin A9 ranked among the top genes for prediction of poor survival $(p=0.0001)$. On the protein level, Annexin A9 exhibited differential expression in colon cancer tissues, ranging from complete absence to strong expression. Interestingly, Annexin A9 expression was restricted to tumor cells located at the tumor edge in most cases. High Annexin A9 levels indicated worse cancer specific survival in patients with stage II colon cancer $(p=0.003)$, and strongly correlated with synchronous liver metastasis in a matched case control collection $(p=0.001)$.

Conclusion. Here, we present an unbiased approach to find novel prognostic biomarkers for patients with colon cancer. In this context, we identify and validate Annexin A9 that may aid in risk stratification beyond clinical staging.
DGP.P2.07

NGS-basierte Detektion behandelbarer Genfusionen beim nichtkleinzelligen Lungenkarzinom (NSCLC) - neuer Goldstandard in der Routinediagnostik?

S. Stephan-Falkenau' ${ }^{\text {, }}$ A. Streubel', R. Sauer ', U. Goldmann', J. Kollmeier², T.-G. Blum², T. Bauer', T. Mairinger'

'Institut für Gewebediagnostik/MVZ Helios Klinikum Emil von Behring, Berlin, Deutschland, ${ }^{2}$ Lungenklinik Heckeshorn/Helios Klinikum Emil von Behring, Pneumologie, Berlin, Deutschland

Ziel. Der leitliniengerechte Einsatz zielgerichteter Therapien beim NSCLC setzt eine umfassende aber gewebesparende sowie zeitnahe molekularpathologische Diagnostik voraus. Dies beinhaltet auch die Detektion der wachsenden Zahl behandelbarer Genfusionen. Um diesen Anforderungen gerecht zu werden, wurde die Routinediagnostik von der Immunhistochemie-, rtPCR- sowie FISH-basierten sequentiellen Testung auf Next Generation Sequencing (NGS) umgestellt.

Methoden. Aus FFPE-Gewebe der Routinediagnostik (19\% Resektate, $81 \%$ Biopsien/EBUS) wurde RNA extrahiert, die umgeschriebene cDNA mit dem CustomFusionPanel v2 (Ampliseq) auf dem IonTorrentS5XL sequenziert und mit der IonReporter Software 5,6/5,10 analysiert (ThermoFisher Scientific, Waltham, MA USA). Häufigkeiten wurden mittels ChiQuadrat Test verglichen.

Ergebnisse. 1684 Patienten mit NSCLC (82 \% ACA, $5 \%$ SCC, $2 \%$ AdSqu, $1 \%$ LCLC, $1 \%$ SC, $1 \%$ LNEC, $8 \%$ NSCLC) wurden von $11 / 16$ bis $01 / 19$ molekularpathologisch untersucht. Behandelbare Genumlagerungen wiesen vor allem Patienten mit Adenokarzinomen im ALK-Gen (2,8\%) und im ROS-1 Gen (0,7 \%) auf. Parallel wurden 250 Fluoreszenz-in-situ-Hybridisierungen (FISH), derzeitiger Goldstandard, durchgeführt. 19/149 auf ALK-Fusionen getestete Fälle waren FISH positiv, diese Fälle wurden zu $100 \%$ auch mittels NGS detektiert. 2/39 (5\%) mittels NGS detektierter Fusionen (EML4-ALK, V1 bzw. V3a) waren FISH negativ. Unter den 100 ROS-1 FISH-Analysen fanden sich 2 positive Tumoren, von denen aber nur in einem Fall der NGS-Befund positiv korrelierte. 2/9 (22\%) mittels NGS detektierter ROS1 Fusionen (CD74-ROS1 und TPM3-ROS1) wurden mittels FISH nicht erkannt. Weiter fand sich in 2,5\% aller ab 07/17 erfassten Patienten (32/1290) ein MET Exon 14 Skipping Event, wobei die sarkomatoiden Karzinome mit 16,7 \% (4/24; $p<0,00001)$ den höchsten Anteil aufwiesen. Auch potentiell behandelbare Fusionen, z. B. im RET-Gen $(0,7 \%$ aller ACA) sowie je eine CD74-NRG1 und eine FGFR3-TACC3 Fusion konnten detektiert werden. Die Zeit vom Materialeingang bis zum integrierten molekularpathologischen Befund betrug 6d, der Median lag bei 5d. Fazit. Durch die Umstellung der molekularpathologischen Routinediagnostik von der sequentiellen Testung auf NGS können behandelbare und potentiell behandelbare Fusionen beim NSCLC bei hoher diagnostischer Sensitivität materialsparend und mit kurzer Bearbeitungszeit detektiert werden.

\section{DGP.P2.08 \\ EMT und Angiogenese im Adenokarzinom des Pankreas - Eine TMA-gestützte Analyse möglicher prognostischer Marker}

M. Schmitz ${ }^{1 *}$, A. Fernandez ${ }^{1}$, S. Heinrich ${ }^{2}$, W. Roth' ${ }^{1}$ S. Foersch ${ }^{1}$

${ }^{1}$ Universitätsmedizin Mainz, Institut für Pathologie, Mainz, Deutschland, ${ }^{2}$ Universitätsmedizin Mainz, Klinik für Allgemein-, Viszeral- und Transplantationschirurgie, Mainz, Deutschland

Ziel. Mit einer Überlebensrate von circa 10 \%, einem aggressiven Wachstumsverhalten, sowie einer ausgeprägten Therapieresistenz, gehört das Pankreaskarzinom (PDAC) zu den Tumorentitäten mit der schlechtesten Prognose. Zu den Mechanismen, die maßgeblich an der Tumorigenese beteiligt sind, zählt die Epitheliale-Mesenchymale-Transition (EMT). Diese beschreibt einen Prozess hoher Zellplastizität, in dem es Zellen durch Verlust epithelialer Eigenschaften gelingt, den ursprünglichen Zellverband zu verlassen. Ebenfalls von hoher Tumor-biologischer Relevanz ist die Angiogenese, welche sich z.B. über die Expression von Wachstumsfaktoren wie VEGF oder die Microvesseldensity (MVD) ausdrückt. Das Projekt be- 
schäftigt sich damit, Zusammenhänge zwischen EMT und Angiogenese aufzudecken und Erkenntnisse über mögliche prognostische Marker für Patienten mit PDAC zu gewinnen.

Methoden. Das untersuchte Kollektiv besteht aus 275 Patienten mit PDAC. Zunächst wird ein TMA aus Tumorzentrum, Invasionsfront, sowie befallenen Lymphknoten oder Fernmetastasen, angefertigt. Mittels Immunhistochemie werden diverse EMT- und Angiogenese-assoziierte Moleküle hinsichtlich ihres Expressionslevels analysiert. Die untersuchten Marker beinhalten ZEB1, N-Cadherin, Snail, Slug, SOX2, D2/40, CD31, CD34 und Nestin. Die Auswertung erfolgt mittels digitaler Bildanalyse, auch hinsichtlich komplexer morphometrischer Zusammenhänge. Danach erfolgt eine Korrelation der Markerexpression zu den Überlebensdaten der Patienten. Ergebnisse. Sowohl EMT-assoziierte Moleküle, als auch AngiogeneseMarker werden in der PDAC Kohorte unterschiedlich exprimiert. Dabe zeigt z. B. ZEB1 ein teils zytoplasmatisches, teils nukleäres Färbeverhalten. Mittels digitaler Bildanalyse können Signale verschiedener Lokalisationen ausgewertet werden. Darüber hinaus erlauben Classifier basierend auf Verfahren des maschinellen Lernens eine Unterscheidung unterschiedlicher Gewebebereiche, wie z. B. Gefäßstrukturen vs. umgebendes Bindegewebe Fazit. Nach Bestimmung der Expressionslevel der EMT-assoziierten Marker und der für die Angiogenese relevanten Moleküle werden diese mit den klinisch-pathologischen Daten und den Überlebensdaten korreliert. Hieraus soll ein prognostisches Modell entwickelt werden, welches eine bessere Abschätzung des klinischen Verlaufs der Patientinnen und Patienten mit PDAC ermöglicht. Darüber hinaus ist geplant, die an der Kohorte gewonnenen Erkenntnisse durch zusätzliche in vitro Experimente zu ergänzen.

\section{DGP.P2.09}

\section{Sensitivitätsvergleich verschiedener NGS Panel mit molekularen Barcodes für den ctDNA Nachweis}

\section{Ball*, J. Fassunke, C. Heydt, J. Rehker, R. Pappesch, R. Büttner, S. Merkelbach-Bruse} Universitätsklinikum Köln, Pathologie, Köln, Deutschland

Ziel. Für den sensitiven Nachweis zirkulierender Tumor-DNA (ctDNA) der Lunge mit Mutationsfrequenzen unter $1 \%$ muss eine hohe Sequenziertiefe erreicht werden. Bei diesen Sequenziertiefen kommt es zu PCRDuplikaten, welche bei vielen auf dem Markt üblichen Amplikon basierten Paneln nicht von einzigartigen Sequenzen unterschieden werden können. Um diese Duplikate in der späteren Analyse zu erkennen, wurden in dieser Studie Panel verglichen, bei denen jedes Molekül mit einem einzigartigen molekularen Barcode (UMI) markiert wird. Der Vergleich der Methoden und Kits verschiedener Hersteller soll die Grundlage für die Etablierung einer dieser Methoden in der Routinediagnostik an ctDNA liefern.

Methoden. In dieser Studie wurden verschiedene zielgerichtete Panel mit molekularen Barcodes für den Nachweis von ctDNA der Lunge in Blutplasma verglichen. Das Kit des Herstellers Qiagen arbeitet mit dem Verfahren der Single-Primer-Extension, die Kits der Hersteller Roche, Illumina und Agilent mit dem Hybrid-Capture Verfahren.

Die ctDNA Extraktion erfolgte auf dem Promega Maxwell RSC. Die Qualitätskontrolle der Librarypräparation wurde auf der Agilent TapeStation durchgeführt. Die Libraries wurden auf dem MiSeq und NextSeq (Illumina) sequenziert. Für den Vergleich wurden neben der erzielten Sensitivität auch der Zeitaufwand und die Implementierbarkeit in der Routinediagnostik bewertet.

Ergebnisse. Der entscheidende Faktor für die Sensitivität des Panels ist die Komplexität (Anzahl einzigartiger Moleküle in der NGS-Library) und Qualität (Verhältnis von gewünschter Library zu Adapter) der erstellten DNA-Libraries. Bei geringen Einsatzmengen zeigten die HybridCapture Panel die höchste Komplexität, das Single-Primer-Extension $\mathrm{Pa}$ nel die niedrigste. Bei ausreichenden Einsatzmengen von mehr als $50 \mathrm{ng}$ DNA zeigten die Libraries keine bis geringe Adapterpeaks. Bei geringen Einsatzmengen unter 5 ng DNA, wies das Single-Primer-Extension Panel hohe Adapterkonzentrationen auf. Beim Vergleich des Zeitaufwands waren die Hybrid-Capture Panel sehr viel arbeitsintensiver und schwieriger zu automatisieren.
Fazit. Um die höchste Sensitivität zu gewährleisten, sollte ein Hybrid Capture Verfahren verwendet werden, welches arbeitsintensiver und schwerer zu automatisieren ist. Single-Primer-Extension wäre eine Alternative, wenn genug Ausgangsmaterial zur Verfügung steht, was bei Blutproben von unterschiedlicher Qualität und mit schwankenden DNA-Mengen oftmals nicht gewährleistet ist.

\section{DGP.P2.10}

\section{Age matters-epigenetic age of the major NSCLC-subtypes in comparison to tumor free lung tissues}

T. Goldmann ${ }^{1 *}$, S. Marwitz' , L. Heinbockel', S. Scheufele ${ }^{2}$, C. Kugler ${ }^{3}$, M. Reck ${ }^{4}$, K. F. Rabe ${ }^{5}$, S. Perner' ${ }^{1}$ O. Ammerpoh ${ }^{2}$

${ }^{1}$ Research Center Borstel, Pathology Department of the University Medical Center Schleswig-Holstein (UKSH), Lübeck Campus and the Research Center Borstel, Lübeck and Borstel, Borstel, Germany, ${ }^{2}$ University Medical Center Schleswig-Holstein (UKSH), Kiel Campus, Institute of Human Genetics, Kiel, Germany, ${ }^{3}$ Lung Clinic Grosshansdorf, Surgery Department, Großhansdorf, Germany, ${ }^{4}$ Lung Clinic Grosshansdorf, Oncology Department, Großhansdorf, Germany, ${ }^{5}$ Lung Clinic Grosshansdorf, Pneumology Department, Großhansdorf, Germany

We analyzed the epigenetic age of the major NSCLC-subtypes and corresponding tumor-free lung tissues by means of Methyome analyses using the epigenetic signature that has recently been described [1]. In both major NSCLC subtypes (adenocarcinoma and squamous cell carcinoma) the calculated epigenetic age of the tumors was different from the chronological age. While adenocarcinomas exhibited an age acceleration, squamous cell carcinomas showed a rejuvenation compared to the corresponding tumor-free lung tissue as well as the chronological age of the patients. The rejuvenated epigenetic pattern in squamous cell carcinomas was associated with a trend towards the expression of stem cell-like genes according to transcriptome profiles generated from the same cohort. These observations showing substantial dfferences between the main tumor sub-entities in NSCLC deserve further studies of the underlying pathways to generate a broad understanding of the complex biology behind these findings.

\section{References}

1. Marwitz et al (2018) Int J Cancer 143(12):3061-3070

\section{DGP.P2.11}

\section{Mobile Snap-Freezing Einheit für Biobankingprozesse pathologischer Proben}

T. Müller' ${ }^{1}$, T. Gemoll², T. Schmidt ${ }^{1}$, A. Krampitz², S. Müller' ${ }^{1}$ T. Sagadin ${ }^{1 *}$, V. von Walcke-Wulffen', J. Habermann ${ }^{2}$

'BioKryo GmbH, Sulzbach/Saar, Deutschland, ${ }^{2}$ Universität zu Lübeck, Klinik für Chirurgie, Sektion für Translationale Chirurgische Onkologie und Biomaterialbanken, Lübeck, Deutschland

Ziel. Mobile Snap-Freezing Einheit für Biobankingprozesse pathologischer Proben

Methoden. Mit Hilfe des neu entwickelten Snap-Freezing-Gerätes ist das Schockgefrieren von Gewebe an Orten ohne eigene Einfrierkapazitäten, wie z. B. OP-Sälen, möglich. Dadurch kann frisch entnommenes Gewebe, z. B. Tumorgewebe, direkt nachdem die Entnahme aus dem Körper stattgefunden hat, schockgefroren werden. Wichtige Parameter wie mRNA oder Phosphoproteine können nicht mehr degradieren. Dieses Verfahren wird im Rahmen der personalisierten Medizin oder genauer bei der personalisierten Therapieentscheidung an Bedeutung gewinnen, wenn anhand des erwähnten Tumorgewebes besagte Therapieentscheidungen getroffen werden müssen. Das zu gefrierende Gewebe wird über eine Fallschiene sehr schnell zwischen zwei vorgekühlte, tiefkalte Platten geführt und durch ein Aufeinanderschlagen dieser Platten schockgefroren.

Ergebnisse. Dieses Verfahren konnte sich gegen Standardschockgefrierverfahren, wie z. B. dem Eintauchen der Gewebeprobe in flüssigen Stickstoff oder Isopentan, behaupten. Hierfür wurde eine Validierung auf DNA- 
, RNA- und Proteinebene anhand von Lungengewebe von Menschen wie auch bei Darmgewebe von Mäusen durchgeführt. Dabei wurde histologisch zwar eine leichte Quetschung des Gewebes verzeichnet, jedoch führte diese zu keiner Veränderung der Gewebemorphologie bzw. zu keiner Beeinträchtigung der histologischen Beurteilung. Bzgl. der molekulardiagnostischen Auswertungen gab es keine signifikate Auswirkung auf die Qualität und Konzentration von DNA, RNA, Proteine oder deren Phosphorylierungsstatus. Im Gegenteil konnte durch den schnellen, standardisierten Einfriervorgang eine Präzisierung der Ergebnisse stattfinden. Fazit. Nach dem Schockgefrieren kann der Behälter als Transportgefäß verwendet werden, sodass eine eingefrorene Proben keine Unterbrechung der Kühlkette erfährt. Das Transportgefäß erfüllt die IATA-Norm zum Transport von Gefahrgut. Gleichzeitig verwendet das Gerät kein Isopentan oder ungebundenen flüssigen Stickstoff. Dieser Umstand ist ein wesentliches Element zur Arbeitssicherheit im Rahmen des SnapFreezings.

Diese Entwicklung wurde im Rahmen des Zentralen Innovationsprogramms Mittelstand (ZIM) unter der Kennziffer KF3340401SB4 gefördert.

\section{DGP.P2.12}

\section{Mutational profiles of primary pulmonary adenocarcinomas and their paired brain metastases}

\section{S. Berezowska ${ }^{*}$, A. Kündig' ${ }^{1}$ C. Fung ${ }^{2}$, A. Scherz 3 , E. Herrmann ${ }^{4}$, E. Ermis ${ }^{4}$, R. A. Schmid ${ }^{5}$, E. Hewer', E. Vassella \\ 'Institut für Pathologie, Universität Bern, Bern, Switzerland, ${ }^{2}$ Universitätsklinik für Neurochirurgie, Inselspital, Universitätsspital Bern, Bern, Switzerland, ${ }^{3}$ Universitätsklinik für Onkologie, Inselspital, Universitätsspital Bern, Bern, Switzerland, ${ }^{4}$ Universitätsklinik für Radio- Onkologie, Inselspital, Universitätsspital Bern, Bern, Switzerland, ${ }^{5}$ Universitätsklinik für Thoraxchirurgie, Inselspital, Universitätsspital Bern, Bern, Switzerland}

Aim. Brain metastases present a significant complication in lung cancer patients. Studies on histologically heterogeneous collectives have shown some genetic divergence between brain metastasis and primary tumor. Alas, data on paired samples is rare. Thus, we aimed to comprehensively investigate the molecular profiles of a homogeneous cohort of brain metastases from primary adenocarcinomas of the lung.

Methods. We assembled a cohort of all consecutive solid cancer brain metastases resected and diagnosed at our University hospital 2000-2015, with subsequent molecular analyses of paired tissue from pulmonary adenocarcinomas and brain metastases using the oncomine comprehensive cancer panel v3.

Results. Concordant with literature, most brain metastases originated from primary lung cancer $(212 / 431 ; 49 \%)$, comprising 145 adenocarcinomas (68\%), 22 squamous cell carcinomas (10\%), 18 NSCLC-NOS (9\%), and 27 small cell carcinomas (13\%), as assessed from pathology reports. In 76 lung cancer cases including adenocarcinomas, resection material from both sites was sufficiently abundant for molecular analyses.

We then analyzed 94 samples comprising 47 pairs of lung adenocarcinoma and brain metastases, identifying 206 missense mutations, 50 truncations, 6 inframe indels, 78 copy number variations and 5 fusions. The mutation frequencies were in the range expected from the TCGA dataset. Analyses of the primary tumors showed a significantly higher frequency of KRAS mutations $(28 / 47,60 \%)$ in comparison to our own data from routine clinical diagnostics $(41 / 116,35 \%$ on all UICC-stage IV lung cancer specimens, and 33/95, $35 \%$ on intrathoracic tumors only), and the TCGA-dataset (32\%). Only 3 tumors were resected following neoadjuvant chemotherapy, and none showed KRAS-mutation, excluding chemotherapy related alterations as an explanation for our findings.

Most genetic alterations were preserved in the metastases. Oncoprint analyses of genetic alterations present exclusively in the brain metastases $(16 / 49,33 \%)$ revealed a bias towards the EGFR signaling pathway. Notably, secondary KRAS mutations (19\%) and MYC-amplifications (44\%) were among the most frequent alterations.
Conclusion. Our results suggest a role of KRAS and MYC alterations in the pathobiology of brain metastases of pulmonary adenocarcinomas. This might have direct clinical implications with the recent reports on inhibitors selectively targeting KRAS.

\section{DGP.P2.13}

\section{Metastasis of solitary fibrous tumor is associated with the} acquisition of chromosomal imbalances

I. Petersen ${ }^{1 *}$, F. Sahm ${ }^{2}$, C. Kölsche 3 , S. Lang ${ }^{4}$, U. Will ${ }^{5}$, T. Lesser ${ }^{6}$, A. von

Deimling ${ }^{2}$

'SRH Poliklinik Gera GmbH - Waldklinikum Gera, Institut für Pathologie, Gera, Germany, ${ }^{2}$ Universitätsklinikum Heidelberg, Abteilung für Neuropathologie, Heidelberg, Germany, ${ }^{3}$ Universitätsklinikum Heidelberg, Institut für Pathologie, Heidelberg, Germany, ${ }^{4}$ SRH Wald-Klinikum Gera, Klinik für Pneumologie/Infektiologie, Hämatologie/Onkologie, Diabetologie, Gera, Germany, ${ }^{5}$ SRH Wald-Klinikum Gera, Gastroenterologie, Hepatologie und Allgemeine Innere Medizin, Gera, Germany, ${ }^{6}$ SRH Waldklinikum Gera, Thorax- und Gefässchirurgie/Angiologie, Gera, Germany

Aims. Solitary fibrous tumor (SFT) is a soft tissue tumor of intermediate dignity. In most cases, it is not metastastic and behaves as a localized benign neoplasm. However, the potential for metastasis is well documented. So far, there are no reliable biomarkers for metastatic spread.

Methods. We report the case of a 58 year old female patient with a metastatic SFT.

Results. The patient first received a fine needle biopsy of a process in the left hilar region of the lung. The cytological specimen was processed by a cytoblock protocol. It showed an unusual solid neoplasia with fibrous stroma. Immunohistochemistry revealed CD34 and nuclear STAT6 expression which led to the diagnosis of a SFT. In the staging process, a tumor mass in the axillary region became evident that was first sampled by a fine needle biopsy. A benigne fibrous spindle cell tumor was diagnosed and complete excision of the tumor was recommended. Instead, a larger tumor biopsy was done because the tumor could not be totally removed. The biopsy also led to the diagnosis of a SFT. Proliferation acitivity was low (Ki67 1-2\%). One pulmonary lesion was then removed by a wedge resection from the lung which harboured a tumor of $6 \times 5 \mathrm{~mm}$. Since the pulmonary tumor was smaller than the axillary neoplasm and revealed a heterogenous mitotic activity (single high power field with 3 mitosis) together with an increased Ki67 index (5-10\%, focally up to $15 \%)$, the pulmonary tumor was diagnosed as a lung metastasis of the axillary SFT. A global methylome analysis confirmed this interpretation. The methylation analysis (Illumina 850k) and the Sarcoma classifier algorithm (V11b4) grouped both tumors within the methylation class "solitary fibrous tumor/hemangiopericytoma". The concomitant copy number variation analysis did not show any alteration in the axillary tumor. In contrast, the lung SFT harboured gains of chromosomes 5, 7, 8, 13, 18 and 21 as well as focal losses on chromosomes 17 and 19.

Conclusions. Chromosomal imbalances were obviously associated with the acquisition of the metastatic phenotype of the SFT. Similar findings have been reported in metastatic synovial sarcoma. Methylome and concomitant copy number variation analysis not only constitute a new tool for the classification of soft tissue tumors but may also predict their biological behaviour. Given the power of this technique for classification and its potential for grading, it may become a routine procedure in tumor diagnostics.

\section{DGP.P2.14}

\section{Integrated Analysis of PD-L1 Status in Human Glioma}

T. Kraus ${ }^{*}$, G. Hutarew ${ }^{1}$, A. Wernstedt' ${ }^{1}$, B. Ladisich' ${ }^{2}$, C. Schwartz' ${ }^{2}$, P. A. Winkler', K. Sotlar

'University Hospital Salzburg, University Institute of Pathology, Salzburg, Austria, ${ }^{2}$ University Hospital Salzburg, University Clinic of Neurosurgery, Salzburg, Austria

Aim. Glioblastoma (GBM, WHO Grade IV) is the most frequent primary brain tumour of adults having a very unfavourable outcome. As highly 
malignant brain tumours, one of the key characteristics of glioblastomas is their infiltrative growth into the surrounding brain. Up to date, there is still no curative therapy available and reported median survival times remain in the range of only $12-15$ months. Recent research revealed distinct molecular alterations in Glioblastoma, such as MGMT (O6-Methylguanin-DNS-Methyltransferase) promoter methylation, IDH1/2 (isocitrate dehydrogenase) mutations and loss of heterozygosity at $1 p$ and $19 q$ (LOH1p/19q). However, no molecularly targetable therapy is available yet. In order to assess new therapeutic perspectives in GBM therapy, the aim of the current study is to clarify the significance of PD-L1 (programmed cell death ligand 1) expression in glioma and to correlate protein expression data with molecular tumour profile.

Methods. We immunohistochemically analysed the expression of PD-L1 in gliomas by applying the PD-L1 22C3 antibody. Moreover, we conducted CD3, CD8 and CD45 immunohistochemistry and correlated the data with established molecular glioma markers.

Results. We found that PD-L1 is expressed on human glioma cells. Analysis of PD-L1 levels in different glioma subtypes revealed a strong intertumoural variation of PD-L1 protein. Furthermore, we found that there is only a minor fraction of $\mathrm{CD} 3$ positive $\mathrm{T}$-lymphocytes and $\mathrm{CD} 8$ positive cytotoxic T-lymphocytes present in glioma, but there is a variable number of CD45 positive leukocytes in glioma. Additionally, we correlated PD-L1 expression with molecular glioma hallmarks such as MGMT-promoter methylation, IDH1/2 mutations and LOH1p/19q.

Conclusion. In summary, we performed an integrated analysis of PD-L1 expression in different glioma subtypes and found considerable variations in PD-L1 protein expression levels, indicating PD-L1 as a potential new marker in glioma assessment.

\section{DGP.P2.15}

Combined inactivation of Tp53 and Mir34a enhances invasion and metastasis of colorectal cancer via IL6R/STAT3 and PAI-1 activation

\section{G. Öner', M. Rokavec', M. Kaller', N. Bouznad' ' D. Horst' ${ }^{2}$, T. Kirchner'², H. Hermeking ${ }^{1 *}$ \\ 'Pathologisches Institut/Ludwig-Maximilians-Universität München, Experimentelle und Molekulare Pathologie, Munich, Germany, 2Pathologisches Institut/Ludwig-Maximilians-Universität München, Munich, Germany}

By analysis of the TCGA database we determined that combined inactivation of MIR34A and TP53 occurs in $~ 50 \%$ of primary, human colorectal carcinomas (CRCs) that progress to distant metastasis and is associated with poor prognosis of CRC patients. Here we generated Mir34a/ Tp53-deficient mice to investigate the underlying molecular mechanisms and evaluate therapeutic strategies for miR-34a and p53 deficient CRCs. Combined loss of Mir $34 a$ and Tp53 enhanced tumor incidence, size, invasion and local metastasis in a mouse model of sporadic CRC when compared to loss of Mir34a and Tp53 alone. mRNA profiles of CRCs with the 4 different genotypes were determined by RNA-Seq. Among the mRNAs up-regulated in Tp53/Mir-34a-deficient CRCs Pai-1 was characterized as a new Mir34a-target. Inhibition of the up-regulated Mir34a-targets IL-6R and PAI- 1 by an IL-6Ra neutralizing antibody (MR16-1) and a small molecule inhibitor of PAI-1 (Tiplaxtinin) inhibited proliferation, invasion and metastasis of Mir34a/Tp53-deficient CRCs in mice. Elevated Pai-1 expression was associated with MIR34A promoter methylation and TP53 mutation in primary colon cancer samples from 61 patients. Therefore, Mir34a effectors, which are up-regulated in Mir34a/Tp53-deficient tumors, may represent attractive targets for the treatment of CRC patients.
DGP.P2.16

Der Einzelnukleotidpolymorphismus rs7121 im Gen GNAS und dessen Einfluss auf Tumorprogression, Therapieansprechen und Überleben bei Tumorpatienten

B. Möhlendick ${ }^{1 *}$, F. Roghmann ${ }^{2}$, H. Jütte ${ }^{3}$, K. W. Schmid ${ }^{4}$, W. Siffert ${ }^{1}$

${ }^{1}$ Universitätsklinikum Essen, Institut für Pharmakogenetik, Essen, Deutschland, ${ }^{2}$ Marien Hospital Herne, Klinik für Urologie und NeuroUrologie, Herne, Deutschland, ${ }^{3}$ Ruhr-Universität Bochum, Institut für Pathologie, Bochum, Deutschland, ${ }^{4}$ Universitätsklinikum Essen, Institut für Pathologie, Essen, Deutschland

G-Protein-gekoppelte Rezeptoren spielen eine Schlüsselrolle in multiplen Signaltransduktionswegen. Eine abnorme Aktivität der stimulatorischen $\mathrm{G}_{\mathrm{s}} \mathrm{\alpha}$-Untereinheit, welche durch das Gen GNAS kodiert wird, konnte häufig mit Krebs assoziiert werden. $\mathrm{G}_{\mathrm{s}} \alpha$ verfügt über die katalytischen Bindungsstellen, die für die Erkennung von spezifischen extrazellulären Effektoren, sowie der Adenylylcyclase dienen. Über weitere intrazelluläre Signalkaskaden können Tumorwachstum, Angiogenese und Metastasierung gefördert werden. Alterationen in der DNA-Sequenz und Konformationsänderungen des $\mathrm{G}_{\mathrm{s}} \alpha$-Proteins können die Funktion von $\mathrm{G}_{\mathrm{s}} \alpha$ verstärken oder abschwächen. In der letzten Dekade konnte von mehreren Arbeitsgruppen bei einem breiten Spektrum von verschiedenen humanen Tumoren gezeigt werden, dass der Genotyp des synonymen Einzelnukleotidpolymorphismus rs7121 (c.393C > T) einen Einfluss auf Tumorprogession, Therapieansprechen und Überleben hat.

Bei insgesamt 13 Entitäten, wie z. B. Urothelial- und nicht-kleinzelligen Lungenkarzimomen zeigte sich hierbei, dass das Vorliegen des T-Allels oder des TT-Genotyps mit geringerem Krebsrisiko und/oder einem verlängerten Progressions-freien Intervall oder dem Gesamtüberleben korreliert.

Bei Gallengangs-, Mamma- und Ösophaguskarzinomen hingegen ist das T-Allel, bzw. der TT-Genotyp mit einem verringertem Therapieansprechen und Überleben assoziiert.

Bisher konnte noch nicht abschließend geklärt werden, wie es bei unterschiedlichen rs7121 Genotypen zu einer veränderten Genexpression und zu der protektiven oder pathogenen Funktion des Proteins kommt.

Um GNAS rs7121 als Biomarker für Tumorprogression, Überleben und Therapieansprechen in die klinische Routinediagnostik einzuführen, soll dessen Eignung mittels einer neuen Studie validiert werden. Hierbei werden an Proben von Patienten mit Gallengangs- und Urothelialkarzinomen die Unterschiede im Therapieansprechen und Überleben auf Grund von rs7121 Genotyp, somatischen GNAS-Mutationen, GNAS RNA-Expression und $\mathrm{G}_{s} \alpha$ Proteinexpression analysiert. Des Weiteren werden mittels in vitro Experimenten die funktionellen Auswirkungen der beiden Genotypen auf das $\mathrm{G}_{\mathrm{s}} \alpha$-Protein mittels Knock-In bzw. Knock-Out Versuchen analysiert. Zusammenfassend zeigte sich in zahlreichen Studien eine starke Korrelation des GNAs rs7121 Genotyps mit dem Therapieansprechen und/oder Überleben von Tumorpatienten, so dass seine Funktionsweise und Eignung als vielversprechender klinischer Biomarker nun abgeklärt werden soll.

\section{DGP.P2.17}

\section{Molekularpathologie von ZNS-Metastasen des Lungenkarzinoms}

\section{B. Hanke ${ }^{1 *}$, J. Haybaeck', C. Mawrin ${ }^{2}$}

'Otto-von-Guericke Magdeburg University, Institut für Pathologie, Magdeburg, Deutschland, ${ }^{2}$ Otto-von-Guericke Magdeburg University, Institut für Neuropathologie, Magdeburg, Deutschland

Ziel. Tumoren der Lunge gehören zu den häufigsten Todesursachen und nehmen unter den Krebstodesfällen in Deutschland Platz 1 (Männer) bzw. Platz 2 (Frauen) ein. Allerdings sind effektive Therapiestrategien zur Behandlung dieser Patientenpopulation bisher nicht hinreichend etabliert. Die Kenntnis der molekularen Alterationen dieser Metastasen ist essentiell für die Behandlung der Patienten, weil gegebenenfalls auch spezifische Therapiestrategien (Tyrosinkinase-Inhibitoren, Checkpoint-Inhibitoren u. a.) zur Verfügung stehen. Die vorliegende Arbeit soll den aktuellen 
Wissensstand zur Molekularpathologie von Lungenkarzinom-Metastasen im zentralen Nervensystem darstellen.

Methoden. Es erfolgte eine Literatur-Recherche in Pubmed, zusätzlich wurden Daten einer Kohorte von 33 Patienten mit synchronen Lungenkarzinom-Hirnmetastasen herangezogen.

Ergebnisse. K-RAS-Mutationen treten bei Primärtumoren mit einer Häufigkeit von 30-32 \% auf und sind somit die häufigsten Mutationen. BRAFMutationen werden in 2-7\% der Fälle gefunden, MET-Amplifikationen treten in 2-3\% der Fälle auf. ALK-Translokationen können in 1-5\% der Tumoren nachgewiesen werden. Seltener sind Mutationen bei ROS1 $(1,7-$ 2 \%), Her2/MEK (0,9-2 \%) bzw. RET1 (0,9-1 \%). EML4-ALK-Translokationen findet man in weniger als $5 \%$ der Primärtumoren, allerdings mit einer hohen Konkordanz von über $90 \%$ zwischen Primum und Metastase. Aktivierende EGFR-Mutationen finden sich in 10-40 \% der Lungenherde, aber in $40-61 \%$ der Metastasen. Für die Konkordanz zwischen Primum und Metastase sind Werte zwischen $68 \%$ und $100 \%$ berichtet. FGFR1Amplifikationen finden sich in $3 \%$ (Primärtumoren) bzw. $15 \%$ (Metastasen) der Fälle, was auf eine geringe Konkordanz bzw. möglicherweise auch eine Beteiligung des FGFR1-Gens an der Metastasierung schließen lässt. ROS1-Mutationen sind mit 1,8 \% (Primum) bzw. 1,3 \% (Metastasen) seltenere Genalterationen beim Lungenkarzinom. C-MET Genamplifikationen finden sich in 21,6\% der Metastasen, C-MET-Proteinexpression in 44,4 \%. Fazit. Für bestimmte Marker stehen Daten zur Frequenz von Genalterationen zur Verfügung. Diese müssen aber noch an größeren Kohorten bestätigt und überprüft werden, um den Wert als prognostische Marker zu erhöhen. Eine genauere Kenntnis der Molekularpathologie der Lungenkarzinom-Hirnmetastasen wird in Zukunft dabei helfen mögliche molekulare Zielstrukturen für eine spezifische Therapie zu identifizieren und somit die Behandlung der Patienten zu optimieren.

\section{AG Gastroenteropathologie Poster I}

\section{AG01.P1.02}

\section{Das Immunprofil des Oesophaguskarzinom}

S. Wagener-Ryczek ${ }^{*}$, M. Schoemmel', C. Bruns' ${ }^{2}$, T. Zander ${ }^{3}$, F. Gebauer ${ }^{2}$, H. Alakus' ${ }^{2}$, S. Merkelbach-Bruse', R. Buettner', M. Thelen ${ }^{3}$, H. Schloesser ${ }^{3}$, A. Quaas

${ }^{1}$ Uniklinik Köln, Institut für Pathologie, Köln, Deutschland, ${ }^{2}$ Uniklinik Köln, Allgemein-, Viszeral- und Tumorchirurgie, Köln, Deutschland, ${ }^{3}$ Uniklinik Köln, Innere Med I, Köln, Deutschland

Ziel. Das Oesophaguskarzinom (EAC) zählt zu den Tumorentitäten mit einer niedrigen Überlebensrate von unter $20 \%$. Neue Therapiemöglichkeiten, wie Immuntherapien könnten das Ansprechen und Überleben verbessern. Bisher gibt es jedoch keinerlei Charakterisierung des Immunprofils von EAC, welches therapierelevanter Checkpoints, prognostische Cancer Testis Antigene (CTA) oder Inflammationsmarker umfasst. Des Weiteren ist unbekannt, ob eine vorherige neoadjuvante Chemotherapie (NACT) den Immunstatus bezüglich einer möglichen Zweitlinientherapie mit Immuncheckpointinhibitoren negativ beeinflusst.

Methoden. RNA aus FFPE Tumor- und Normalgewebe behandlungsnaiver $(n=29)$ und post-NACT Patienten $(n=17)$ wurde mittels Genexpressionsassay (PanCancer Immuneprofile Panel, NanoString) auf 770 immunrelevante Marker untersucht.

Ergebnisse. Die signifikant veränderten Gene sind an der Regulation von Immunantworten, T- und B-Zellfunktionen sowie der Antigenpräsentation beteiligt.

Die durch CD3-Expression gemessene T-Zell-Anreicherung wurde in den naiven EAC hochreguliert und in den Proben nach NACT-Behandlung verringert. Es wurde gezeigt, dass der T-Zell-Co-Rezeptor CD8, der MHCI an Antigen-präsentierenden Zellen bindet, unabhängig von der Therapie im Tumorgewebe 3-fach erhöht ist. Wir haben außerdem die sogenannte Inflammationssignatur (TIS) bestimmt, um das Ansprechen auf eine mögliche PD-L1-Blockade vorherzusagen. Die Kohorte behandlungsnai- ver EAC zeigte eine numerisch höhere TIS- und HLA-Expression als postNACT EAC. Wir haben auch das Tumormikromillieu (TME) untersucht, welches sich aus Checkpoint-Inhibitoren, der Sekretion von immunmodulierenden Molekülen und Chemokinen zusammensetzt. Der ImmunCheckpoint-Rezeptor CTLA-4 war in der EAC signifikant hochreguliert, die PD-1-Expression zeigte eine 2-3fach erhöhte Expression, während die Expression von PD-L1 mit normalem Gewebe vergleichbar war. Wir haben außerdem die Expression anderer Checkpoints wie HAVCR3, LAG3 und CD-276 ausgewertet. Die immunmodulierenden Moleküle ARG1 und IDO1 des Tumormikromilieus zeigten eine signifikant unterschiedliche Expression in EAC gegenüber normalem Gewebe sowie gegenüber der NACT-Gruppe.

Fazit. Primäre EAC zeigen ein Immunprofil, welches sie für eine mögliche Immuntherapie prädestinieren. Desweiteren zeigte sich eine negative Beeinflussung des lokalen Immunstatus durch vorherige NACT, wodurch eine Kombination aus Immuntherapie und NACT nur eingeschränkt empfehlenswert wäre.

\section{AG01.P1.03}

\section{Hippo/YAP pathway activation in oesophageal cancer}

K. Singvogel ${ }^{1 *}$, V. Hollek', B. Riedel', M. Werner ${ }^{1,2}$, S. Lassmann ${ }^{1,2,3}$ ${ }^{1}$ Institute for Surgical Pathology, University Medical Center Freiburg, Freiburg, Germany, ${ }^{2}$ German Cancer Consortium (DKTK) and German Cancer Research Center (DKFZ), Heidelberg, Germany, ${ }^{3}$ BIOSS Centre for Biological Signaling Studies, University of Freiburg, Freiburg, Germany

Aim. The Hippo signalling pathway is a key regulator of growth control, stem cell function, proliferation and apoptosis. In human cancers, a high aberrant Hippo/YAP signalling activity can be observed. Here, we explored the relevance of YAP/Hippo signalling in esophageal cancer.

Methods. Tissue specimens of oesophageal squamous (ESCC) $(n=5)$ and adenocarcinomas (EAC) $(n=5)$ were examined for YAP by immunohistochemistry. Activation of Hippo/YAP signalling (triggered by contact inhibition) was explored in ESCC $(n=4)$ and EAC $(n=3)$ cell lines by measuring mRNA expression of the YAP target AREG. Using Kyse150 and OE33 cells, YAP was inhibited by Verteporfin (VP) and the effects on cell viability, cell migration and changes in signalling pathways were examined by MTS assy, Ibidi migration assay and protein expression profiling (ScioDiscover protein expression Arrays ${ }^{\circ}$, Sciomics, Heidelberg), respectively. Protein candidates were further analysed by specific siRNAs (Qiagen). Results. Tissue specimens of ESCC and EAC revealed-atypical-nuclear accumulation of YAP protein expression. Moreover, YAP target gene AREG remained expressed upon contact inhibition in ESCC and EAC cell lines. Nevertheless, by inhibition of YAP with VP, cell viability was strongly reduced in all cell lines and cell migration was inhibited in ESCC cell line Kyse150 upon VP treatment. Protein expression profiling identified several putative YAP target proteins (Kyse150 $n=53$; OE33 $=50$ ) involved in these cellular effects. Indeed, upon depletion of the selected candidates CD9 and TMED2 cell migration was inhibited in Kyse 150 cells.

Conclusion. Taken together, our study revealed that oncogenic Hippo/YAP signalling via the tetraspanins CD9 and TMED2 has a key role in oesophageal cancer cell migration and may be further exploited as target for potential therapeutic intervention.

\section{AG01.P1.04}

Secretome analyzes of cancer-associated fibroblasts-new drivers of cell migration in esophageal cancer?

M. Lux ${ }^{1 * 2,}$, K. Singvogel', N. Herbener', F. Beier', S. Laßmann ${ }^{1,2,3}$, M. Werner ${ }^{1,3}$ ${ }^{1}$ Institute for Surgical Pathology, University Medical Center Freiburg, Freiburg, Germany, ${ }^{2} \mathrm{BIOSS}$ Centre for Biological Signaling Studies, University of Freiburg, Freiburg, Germany, ${ }^{3}$ German Cancer Consortium (DKTK) and German Cancer Research Center (DKFZ), Freiburg, Germany

Aims. Cancer-associated fibroblasts (CAFs) within the tumor microenvironment are important for tumor development and progression. Here, we 
examined cross-talk between esophageal normal fibroblasts (NOFs) and CAFs with esophageal cancer cells for cell migration.

Methods. Primary case-matched NOFs and CAFs (Underwood et al., J Pathol. 2015;235:466-77) were used in 2D migration assays (ibidi, Martinsried) with esophageal squamous (Kyse410, OE21) and esophageal adenocarcinoma (OE33) cell lines. Targeted secretome analysis (scioCD antibody array; Sciomics, Heidelberg) of co-culture supernatants were performed.

Results. In comparison to NOFs, CAFs significantly induced migration of the tumor cell-lines (observed gap closure within $24 \mathrm{~h}$ : [Kyse410/CAF $100 \%$ vs Kyse $410 / \mathrm{NOF} 7.3 \%, p<0.0001$ ]; [OE33/CAF $99 \%$ vs OE33/NOF $6.9 \%, p<0.0001$ ]; gap closure within 12 h: [OE21/CAF 97.7\% vs OE21/ NOF $52.3 \% p<0.01])$. Targeted secretome analysis identified 54 distinct proteins (12 NOF-, 14 CAF-associated). High levels of Interleukin 6-a prominent target of cancer cell migration-but also novel targets like $\mathrm{Cy}$ tokine-like protein (CYTL) were measured in CAF co-cultures. Protein levels of Beclin and Endocan were elevated in NOF co-cultures.

Conclusion. Our data underline the cross-talk between CAFs and esophageal cancer cells for migration and reveal known (IL6) and novel candidate proteins (CYTL) mediating this exchange. Moreover, NOFs may harbor putative inhibitory factors limiting esophageal cancer cell migration.

\section{AG01.P1.05}

\section{Gendermedizinische Aspekte im Outcome beim Magenkarzinom}

P. Mahendran ${ }^{1}$, H. Ptok ${ }^{1}$, R. Steinert ${ }^{2}$, S. Wolff', R. Otto ${ }^{3}$, H. Lippert ${ }^{3}$, I. Gastinger ${ }^{3}$, F. Meyer ${ }^{1 *}$

'Klinik für Allgemein-, Viszeral-, Gefäß- und Transplantationschirurgie, Universitätsklinikum Magdeburg A. ö. R., Magdeburg, Deutschland, ${ }^{2}$ Klinik für Allgemein- und Viszeralchirurgie, St Josefs-Krankenhaus, Salzkotten, Deutschland, ${ }^{3} \mathrm{AN}$-Institut für Qualitätssicherung in der Operativen Medizin, Otto-von-Guericke-Universität, Magdeburg, Deutschland

Hintergrund. Das Magenkarzinom(Ca) gehört trotz durchaus kurativen chir.-op. Therapieoptionen zu den häufigsten malignen Erkrankungen mit nicht unbeträchtlicher Mortalität.

Ziel. Untersuchung geschlechtsspezif. Unterschiede im frühpostop./Langzeit-onkochir. Outcome.

Patienten/Methode. Von 2007-2009 wurden 2897 Patienten mit primärem Magen-Ca erfasst-Design. Prospektive multizentr. Beob.-Studie. Patienten-/Befund-/Diagnostik-/Therapie- \& Prognose-assoziierte Aspekte wurden genderspezifisch uni-/multivariat getestet.

Ergebnisse. Männer waren jünger als Frauen (Durchschnittsalter: 67,74 vs. 70,31 Jahre; $P<0,001)$, wiesen häufiger eine Dysphagie $(P<0,009)$, einen intestinalen Typ nach Laurén $(P<0,001)$ sowie eine ASA-III-Einstufung $(P<0,017)$ auf. Signifikante Risikofaktoren waren höherer Alkoholkonsum/Nikotinabusus/pulmonale Ereignisse. Der kardioösophageale Übergang wurde als Tumorlokalisation häufiger detektiert $(P<0,001)$. Sowohl OP-Dauer als auch Krankenhausverweildauer waren signifikant länger.

Frauen hingegen hatten häufiger Oberbauchschmerzen/Erbrechen sowie einen diffusen \& Mischtyp $(P<0,001)$. Sie waren adipöser \& weniger anfällig für allg. Komplikationen $(P<0,001)$.

Morbidität: Transthorakal erweiterte Gastrektomie, Tumorlokalisation (Kardia), höherer ASA-Score, M1-Status, längere OP-/Verweildauer waren signifikante Einflussfaktoren. Bezüglich Letalität hatten Männer mit Mischtyp, nicht erreichtem R0-Resektionsstatus \& Komplikation im hohen Alter ein höheres Sterberisiko.

5-Jahres-,,overall survival“(OS), -„disease-free survival“(DFS) \& -Lokalrezidivrate(LRR) lagen bei 35,5/48,1/4,3\%. Im OS/DFS zeigten Männer bzw. Frauen mit Komplikationen ein schlechteres medianes Überleben als ohne Komplikationen $(P<0,001)$. Männer hatten ein signifikant schlechteres medianes DFS als Frauen (48,6 vs. 71,2 Monate). Auf die LRR hatte das Geschlecht keinen signifikanten Einfluss.

In der multivariaten Analyse waren hinsichtlich des OS das männl. Geschlecht, Dysphagie, Erbrechen, diffuser \& Mischtyp, steigender R-Status \& hohes UICC-Stadium signifikante Einflussfaktoren. Männer mit steigendem Alter \& höheren UICC-Stadium, Dysphagie, Erbrechen, diffu- sem Typ \& Morbidität hatten ein signifikant schlechteres krankheitsfreies Überleben (DFS). Ein erhöhtes UICC-Stadium zeigte sich signifikant mit der LRR assoziiert.

Fazit. Das Magen-Ca erscheint eine gendermedizinisch relevante Tumorentität mit differenten Prognoseaspekten zugunsten des weibl. Geschlechts zu sein.

\section{AG01.P1.06}

Endoscopic necrectomy of infected „,walled-off necroses (WON)“ in acute necrotizing pancreatitis-data obtained in a unicenter observational study

K. Jäger ${ }^{1}$, F. Füldner ${ }^{1}$, F. Meyer ${ }^{2 *}$, U. Will ${ }^{1}$

'Municipal Hospital (,SRH Wald-Klinikum Gera'), Dept. of Gastroenterology, Hepatology and General Internal Medicine, Gera, Germany, ${ }^{2}$ University Hospital, Dept. of General, Abdominal, Vascular and Transplant Surgery, Magdeburg, Germany

Background. Minimally invasive endosc. \& surgical interventions have priority in the therapy of "walled-off necroses" (WON). Percutaneous \& EUS-guided internal drainages are preferred.

Aim \& Methods. A monocentric population was investigated retrospectively in prospectively collected peri-interventional data (study design). Overall, 105 patients with necrotizing pancreatitis \& infected WON undergoing translumenal endosc. necrectomy (inclusion criteria) from 2004 to 2017 were identified.

Results. In total, 68 men/37 women were enrolled in the study (median age, $59 \mathrm{yrs}$ ). Mean hospital stay was $44 \mathrm{~d}$. Fourty five $\%$ of the patients were treated at the intensive care unit; $86 \%$ of the cases presented with a bacterial infection of the WON whereas in $40 \%$, mycotic infection was found. First interventional measure was performed after a mean time period of $28 \mathrm{~d}$; in $54 \%$, this was a percutaneous drainage. Internal drainages were used in 46 patients $(43.8 \%)$ after a mean time period of $35 \mathrm{~d}$. The combination of percutaneous \& internal drainages permitted an excessive lavage, which was performed in 57 patients (54.3\%); 87 individuals (82.9\%) were treated by internal (transluminal) endosc. necrectomy $\&$ in 8 subjects $(9.2 \%)$, a percutaneous necrectomy was additionally performed. In only $20 \mathrm{pa}-$ tients (19\%), complete necrectomy was achieved. It was found that for the therapeutic success, long-term internal drainage was substantially important. Appr. 30\% of patients were discharged with an Axios ${ }^{\mathrm{TM}}$ stent (Boston Scientific) \& $60 \%$ with pigtail drainages in situ. Complications such as bleeding or perforation occurred in 8 cases (7.6\%), 11 patients underwent surgical intervention (rate, $10.5 \%)$. Mortality was $7.6 \%(n=8)$. The stents were removed after 3 months. There was a recurrence of cyst or WON in 8 patients (rate, $7.6 \%$ ), only 4 patients (3.8\%) needed endosc. re-treatment. Conclusion. Step-up approach to be used as the basic algorithm in acute necrotizing pancreatitis comprising external drainage, internal/external drainage (+ rinsing via drainage) \& endoscopic necrectomy appears feasible, efficient \& safe.

The endosc. necrectomy was performed if the clinical status had not improved despite a sufficient internal \& external drainage. The complete necrectomy is not an indispensable prerequisite for a favorable outcome but, however, the sufficient long-term drainage is essential.

\section{AG01.P1.07}

\section{MET as resistance factor for afatinib therapy in gastric cancer cells}

K. Ebert*, T. Kunzke, S. Keller, G. Zwingenberger, B. Luber

${ }^{1}$ Technische Universität München, Institut für Allgemeine Pathologie und Pathologische Anatomie, München, Germany

Objectives. The therapeutic options for advanced gastric cancer are still limited. Several drugs targeting the epidermal growth factor receptor family have been developed. So far, the HER2 antibody trastuzumab is the only drug targeting the HER-family that is available to gastric cancer patients. The pan-HER inhibitor afatinib is currently investigated in clinical trials and shows promising results in cell culture experiments and patient-de- 
rived xenograft (PDX) models. However, some cell lines do not respond to afatinib treatment. Thus, the determination of resistance factors can help to find the best treatment option for gastric cancer patients.

Methods. Four gastric cancer cell lines were screened for afatinib sensitivity by WST1 proliferation assay. MET expression in afatinib-resistant Hs746T cells was reduced by means of siRNA transfection. The effects of MET knockdown on signal transduction, cell proliferation and motility were examined. Moreover, the impact of afatinib was compared between MET knockdown cells and control cells.

Results. We identified the afatinib resistance of the gastric cancer cell line Hs746T. MET knockdown in Hs746T cells resulted in impaired signal transduction and reduced cell proliferation and motility. Moreover, the afatinib resistance of Hs746T cells was reversed after MET knockdown. Conclusions. The amplification of $M E T$ is confirmed as a resistance factor for afatinib therapy in gastric cancer cells. Whether MET is a useful resistance marker for afatinib therapy or other HER-targeting drugs in patients should be investigated in clinical trials.

\section{AG01.P1.08 \\ Differentiation and classification of gastric cancer subtypes based on MALDI TOF Imaging and spectra analysis of gastric cancer organoids}

L. Sommer ${ }^{1 *}$, C. Sperling ', A. Zürich', F. Zakrzewski', D. Stange ${ }^{2,3}$, D. Aust ${ }^{4,5}$, P. Hönscheid ${ }^{1,4}$, G. Baretton ${ }^{4,5}$

'University Hospital Carl Gustav Carus of Technische Universität Dresden, Institute of Pathology, Dresden, Germany, ${ }^{2}$ University Hospital Carl Gustav Carus of Technische Universität Dresden, Department of Visceral, Thoracic and Vascular Surgery, Dresden, Germany, ${ }^{3}$ National Center for Tumor Diseases (NCT), Partner Site Dresden, Dresden, Germany, ${ }^{4}$ National Center for Tumor Diseases (NCT) Dresden, Core Unit for Molecular Tumor Diagnostics (CMTD), Dresden, Germany, ${ }^{5}$ University Hospital Carl Gustav Carus of Technische Universität Dresden, Institute of Pathology and Tumor and Normal Tissue Bank of the University Cancer Center (UCC), Dresden, Germany

Introduction. The current clinical standard to categorise the diverse group of gastric carcinoma is set by the WHO and Laurén classifications. However, it often remains difficult to undertake a consistent, distinct classification. One promising tool to improve clinical decisions has been described by the use of matrix-assisted laser-based desorption and ionisation (MALDI) Imaging. The method can be used to measure protein and peptide masses which are projected on geometrical coordinates and matched with the microscopic image. Therefore, it is a powerful instrument to push forward rapid and high-molecular proteome diagnostics of cancer subtypes. Methods. A cohort of 35 different FFPE tissue blocks has been investigated. Each sample contained tumour and healthy tissue for classification and validation of the mass spectra. In addition, we included 3 given organoids and the tissue of their origin. Tissue sections of $4 \mu \mathrm{m}$ were cut and mounted on ITO-coated conductive slides. Paraffin was removed and heat-induced epitope retrieval was performed. Followed by an on-slide enzymatic digestion, the samples have been covered with HCCA matrix before measurement. The $50 \mu \mathrm{m} \times 50 \mu \mathrm{m}$ spot specific spectra have been acquired in the range of $\mathrm{m} / \mathrm{z} 600-3200$ by MALDI TOF instrument.

Results. 35 gastric cancer tissue samples have been morphohistological classified (WHO, Laurén). So far 18 samples have been additionally analysed by MALDI Imaging procedures. Using MALDI Imaging specific software, validation of different tissue areas showed divergent mass spectra profiles of healthy and tumour regions. The quality control of all samples showed a high comparability of the individual measurements (intensity/ mass range) and allows the summarisation of samples to mass spectrometry cohorts (PCA). The histologic morphology defining gastric cancer subtypes can be reproduced by the MALDI spectra. Further analysis to classify representing subgroups will be done next. Resulting mass spec pattern will as well be used to identify individual masses for further biomarker investigation.
Conclusion. Gastric cancer treatment is based on a multimodal therapy concept, which requires an identification of specific molecular targets to individualise therapeutic options. MALDI Imaging enables us to detect protein and peptide patterns which help to distinguish cancer subtypes and define mass spec profiles, which can be used as biomarker for targeted therapeutic decisions.

\section{AG01.P1.09 \\ Maligne intestinale Obstruktion - Sicht der chirurgischen Behandlungsführers}

F. Meyer ${ }^{1 *}$, J. Middelhoff ${ }^{2}$, H. Ptok', U. Will ${ }^{3}$, L. Meyer ${ }^{4}$

'Klinik für Allgemein-, Viszeral-, Gefäß- und Transplantationschirurgie,

Universitätsklinikum Magdeburg A.ö. R., Magdeburg, Deutschland, ${ }^{2} \mathrm{MVZ}$

Herderstraße, Magdeburg, Deutschland, ${ }^{3} \mathrm{SRH}$ Waldklinikum GmbH, Gera,

Deutschland, ${ }^{4}$ Klinik für Allgemein- und Viszeralchirurgie, Helios-Vogtland, Plauen, Deutschland

Ziel. Darstellung der Möglichkeiten moderner interventioneller Techniken der Behandlung intestinaler symptomatischer Stenosen je nach Lokalisation in der oral-aboralen Ausdehnung sowie der intra-/extraintestinalen Manifestationsursache am Gastrointestinal(GI)-Trakt(s) aus chir. Sicht.

Methoden. Kompakte Kurzübersicht, basierend auf aktueller wiss. Literatur \& eig. klin. Erfahrungen, untersetzt durch Bildbeispiele zur Veranschaulichung inhaltlicher Teilaspekte.

Ergebnisse. (Eckpunkte): - Die Obstruktion kann sowohl von intra- od. extraluminal eintreten: intraluminale Obstruktion betrifft vor allem die intestinalen Hohlorgane (Ösophagus, Magen, Dünn-, Dickdarm, Rektum); von außen treten extraintestinale Tumormanifestation zumeist der parenchymatösen Organe (Leber, Pankreas, Mesenterium, Retroperitoneum) in Erscheinung. Als Sonderfälle können die Gallenblase \& Gallenwege sowie der Pancreasgang komprimiert sein. - Je nach Lokalisation unterscheiden sich die Therapiemöglichkeiten: a) kurative Resektion, b) palliative Bypassanlage (gastroenteral, biliodigestiv, enteroenteral/interenterisch), c) explorative Laparotomie (Diagnosesicherung \&/od. Dekompression, Stomaanlage, peritoneovenöse Shuntanlage, Komplikationsbeherrschung/ -,korrektur"), d) Portimplantation.

Endoskopische Verfahren nehmen in der periop. Konditionierung \& bei der Option alleiniger Symptomkontrolle zu.

- Eine erfolgreiche Intervention ermöglicht eine schnelle \& langfristige Symptomkontrolle, Erhöhung der Lebensqualität \& erfüllt den Patientenwunsch.

- Im Vordergrund stehen Linderung der Symptome, Verlängerung der Lebenszeit, ggf. auch eine günstigere Ausgangslage für chir. Sanierung.

- Periinterventionelle Morbidität \& Letalität sind entscheidende Zielparameter der Qualitätssicherung.

Fazit. Bei lokalisationsabhängiger MIO ist zwischen kurativer/palliativer Therapieintention zu differenzieren, multimodale Therapieoptionen sollten befund- \& risikogerecht ausgewählt \& angewandt werden. Ausgiebige klin. Erfahrung \& Expertise im therapeutischen Management (endoskopisch, chir.-operativ, kombinierend) sind im interdisz. Setting zwingend erforderlich.

\section{AG01.P1.10}

Loss of caspase- 8 in mice is associated with a spontaneous phenotype of the large intestine

\section{N. Gaßler ${ }^{*}$, U. Schneider ${ }^{1}$, E. Kaemmerer ${ }^{1,2}$, M. K. Jeon ${ }^{1,3}$, C. Liedtke ${ }^{4}$}

'Institute of Pathology/RWTH Aachen University, Aachen, Germany, ${ }^{2}$ Kinder- und Jugendmedizin/RWTH Aachen University, Aachen, Germany, ${ }^{3}$ Division of Medical Oncology/Yonsei University, Seoul, Republic of Korea, ${ }^{4}$ Department of Medicine III/RWTH Aachen University, Aachen, Germany

Aims. The cysteine-aspartic acid protease Caspase-8 (Casp8) represents the apical initiator in death receptor-mediated apoptosis. Loss of Casp8 in intestinal epithelial cells results in fulminant epithelial necroptosis and Paneth cell death in the small intestine. The small intestinal mucosa phe- 
notype includes features of Crohn's disease. It has been shown that pharmacological Notch inhibition with the gamma-secretase inhibitor dibenzazepine (DBZ) is able to partially overcome the knockout-induced loss of secretory cell differentiation. At present, Casp8-related activities on the large intestinal mucosa are not well characterized.

Methods. Mice expressing a Cre-transgene under control of the murine villin promoter were crossed with genetically modified mice carrying loxP recombination sites in intron 2 and 4 of the murine Casp8 gene in a C57/ BL6 background resulting in mice lacking Casp8 specifically in intestinal epithelial cells (Casp $\left.8^{\text {deltaIEC}}\right)$. The large intestine of Casp $8^{\text {deltaIEC }}$ mice and cre-negative control littermates were histomorphologically investigated and further characterized using qRT-PCR, Western blotting, and immunohistochemistry.

Results. Intestinal Casp8 depletion was associated with epithelial cell death in the large intestine. Throughout the crypts, nuclear remnants and in creased influx of inflammatory cells resembling necroptosis were found. The proliferative zone in crypts visualized by anti-Ki67 immunostainings was injured. The number of goblet cells was diminished. Pharmacological Notch inhibition was able to partially overcome the spontaneous phenotype of Casp $8^{\text {deltaIEC }}$ mice by reconstitution of cellular proliferation in crypts and secretory differentiation of cells.

Conclusions. Casp8 activities are involved in the large intestinal mucosa physiology and tissue homeostasis. Casp8 acts in the intestinal Notch network probably assisted by stromal components.

\section{AG01.P1.11 \\ Targeting Interleukin-6 (IL-6) trans-signaling to inhibit intestinal tumorigenesis \\ C. Garber* \\ Otto-von-Guericke University Magdeburg, Institute of Pathology, Magdeburg, Germany}

Background. The pleiotropic cytokine Interleukin-6 (IL-6) is not only important for homeostatic functions like immune cell differentiation, but has rather strong pro-inflammatory properties. Increased IL-6 levels are found in all inflammatory diseases, and blocking IL- 6 is a valuable therapeutic approach that is already in clinical use. IL-6 activates its target cells either via the membrane-bound IL-6 receptor (IL-6R, termed 'classic signaling') or via soluble forms of the IL-6R (sIL-6R, termed 'trans-signaling') which is causative for the pro-inflammatory properties of IL-6. Although both modes of signaling result in homodimerization of the ubiquitously expressed signal-transducing receptor gp130, this dichotomy allows the selective inhibition of the pro-inflammatory trans-signaling pathway. Methods. We used several genetically modified mouse strains in which different components of the IL- 6 signaling cascades were knocked-out to study the role of the different IL-6 signaling modalities in tumor formation. Specifically, we used the $\mathrm{Apc}^{\mathrm{Min} /+}$ model, which develops dysplasia and carcinoma predominantly in the small intestine, and the sporadic AOM-induced tumor model, a mouse model of chemically-induced colorectal cancer. We analyzed tumor number and tumor size in the mice. Furthermore we determined gene expression via qRT-PCR and different signaling pathways within the tumor tissue via immunohistochemistry.

Results. We found that mice lacking total IL-6 signaling or mice in which only IL-6 trans-signaling was blocked showed reduced tumor numbers in the $\mathrm{Apc}^{\mathrm{Min} /+}$ model. We confirmed this dominant role of IL-6 trans-signaling in the sporadic AOM-induced tumor model. Furthermore, we found that genetic deletion of the metalloprotease ADAM17, which generates the soluble IL-6R and thus initiates the IL-6 trans-signaling pathway, is sufficient to significantly reduce tumorigenesis in the $\mathrm{Apc}^{\mathrm{Min} /+}$ model.

Conclusion. Targeting the IL- 6 trans-signaling pathway might represent a novel therapeutic strategy for the treatment of intestinal tumors.
AG01.P1.12

NGS of intraductal biopsies is feasible and potentially improves the diagnostic yield of patients with with biliary dysplasia and neoplasia

K. Bankov ${ }^{1 * 2,}$, C. Döring ', M. Schneider', S. Hartmann ${ }^{1,3}$, R. Winkelmann', J. G. Albert', , W. O. Bechstein ${ }^{5}$, S. Zeuzem ${ }^{2}$, M. L. Hansmann', J. PevelingOberhag $^{1,2,4}$, D. Walter ${ }^{1,2}$

'Dr. Senckenberg Institute of Pathology, University Hospital Frankfurt, Frankfurt, Germany, ${ }^{2}$ Department of Internal Medicine 1, University Hospital Frankfurt, Frankfurt, Germany, ${ }^{3}$ Reference and Consultant Center for Lymph Node and Lymphoma Pathology, Goethe University, Frankfurt, Germany, ${ }^{4}$ Department for Gastroenterology, Hepatology and Endocrinology, RobertBosch Hospital, Stuttgart, Germany, ${ }^{5}$ Department of General and Visceral Surgery, University Hospital Frankfurt, Frankfurt, Germany

Aims. Definite diagnosis and therapeutic management of cholangiocarcinoma (CCA) remains a challenge. The aim of the current study was to investigate feasibility and potential impact on clinical management of targeted sequencing of intraductal biopsies.

Methods. Intraductal biopsies with suspicious findings from 16 patients with CCA in later clinical course were analyzed with targeted sequencing including tumor and control benign tissue ( $n=55$ samples). A CCA-specific sequencing panel containing 41 genes was designed and a dual strand targeted enrichment was applied.

Results. Sequencing was successfully performed for all samples. In total, 79 mutations were identified and a mean of 1.7 mutations per tumor sample (range $0-4$ ) as well as 2.3 per biopsy (0-6) were detected and potentially therapeutically relevant genes were identified in 6/16 cases. In 14/18 (78\%) biopsies with dysplasia or inconclusive findings at least one mutation was detected. The majority of mutations were found in both surgical specimen and biopsy (68\%), while $28 \%$ were only present in biopsies in contrast to $4 \%$ being only present in the surgical tumor specimen.

Conclusions. Targeted re-sequencing from intraductal biopsies is feasible and potentially improves the diagnostic yield. A profound genetic heterogeneity in biliary dysplasia needs to be considered in clinical management and warrants further investigation.

\section{AG01.P1.13}

Quantitative LC-MS-basierte Proteomic-Studie von FFPE Gewebeproben zur Identifizierung von deregulierten Proteinen in Gallenblasenkarzinomen

F. Truckenmueller', B. Goeppert', S. Pusch', I. Heinze², J. Kirkpatrick², P. Schirmacher ${ }^{1}$, A. Ori' ${ }^{2}$ S. Rössler ${ }^{1 *}$

${ }^{1}$ Universitätsklinikum Heidelberg, Heidelberg, Deutschland, ${ }^{2}$ Leibniz Institute on Aging - Fritz Lipmann Institut (FLI), Jena, Deutschland

Ziel. Diese Studie beschäftigt sich mit dem bislang wenig erforschten Gallenblasenkarzinom (GBC). Zu den Risikofaktoren für GBC zählen u. a. Alter, Geschlecht, Übergewicht, Cholelithiasis und chronische Cholezystitis. Die einzige kurative Behandlung ist die radikale Resektion, jedoch kommt diese durch die späte Diagnosestellung nur für wenige Patienten infrage und ohne Operation ist die 2-Jahres-Überlebensrate unter $10 \%$. Daher ist die Entwicklung neuer Behandlungsmöglichkeiten und zielgerichteter Therapien nötig.

Methoden. In dieser Studie führten wir quantitative LC-MC-basierte Proteomanalysen von insgesamt 18 FFPE-Tumorproben, 5 gesunden Gallenblasen und 5 Stroma-Proben einer deutschen GBC-Kohorte durch. Es wurden drei vergleichende Analysen durchgeführt: Tumor vs. Normalgewebe, Tumor vs. Stroma und Tumorproben von Patienten mit kurzem vs. langem Überleben. Die unterschiedlich exprimierten Proteine wurden einer Pathway-Analyse unterzogen. Aus den signifikant unterschiedlichen Stoffwechselwegen wurden potentielle Tumorsuppressor-Kandidaten ausgewählt. Die Rolle dieser Gene hinsichtlich Proliferation, Migration und Klonogenizität wurde in GBC-Zelllinien untersucht.

Ergebnisse. Die Analyse, Tumor vs. Normalgewebe resultierte in 1766 signifikant (adj. P-val <0,05) unterschiedlichen Proteinen. Zu den herunter 
regulierten Signaltransduktionswegen gehören u. a. die Organisation des Zytoskeletts und die Zelladhäsion. Um erste Kandidatenproteinen einzuschränken wurden folgende Kriterien gewählt: 1.) mind. 4-fache Reduktion der Kandidaten im Tumorgewebe und 2.) signifikante Deregulation des assoziierten Signaltransduktionsweges. Dies führte u. a. zur Identifizierung von FHL1 und ANK3. Beide Proteine waren in den Tumorproben stark herunter reguliert: FHL1: 8,6-fach mit FDR $=0,008$ und ANK3: 4,5-fach mit $\mathrm{FDR}=0,0002$. Wegen geringer bis mittlerer endogener Expression der Kandidatenproteine wurden die GBC-Zelllinien NOZ und G-415 ausgewählt und die biologischen Funktionen von FHL1 und ANK3 untersucht. FHL1-Überexpression hemmte die Migration und die Koloniebildung und unterstützt damit eine tumor-suppressive Rolle in GBC.

Fazit. Durch Proteomanalysen einer klinisch- und pathologisch gut charakterisierten GBC Kohorte wurde eine Vielzahl an unterschiedlich regulierten Proteinen und betroffenen Krebs-relevanten Stoffwechselwegen identifiziert. Funktionelle Studien unterstützen die tumor-suppressive Rolle von FHL1 welches ein mögliches Therapie-Ziel darstellt.

\section{AG Gastroenteropathologie Poster II}

\section{AG01.P2.02 \\ Histopathologische Evaluation proliferativer hepatozellulärer Läsionen in Mausmodellen \\ K. Steiger', N. Groß², R. Rad' ${ }^{2}$ U. Ehmer', W. Weichert', C. Mogler ${ }^{1 *}$ \\ ${ }^{1}$ Technische Universität München, Institut für Allgemeine Pathologie und Pathologische Anatomie, München, Deutschland, ${ }^{2}$ Technische Universität München, Center for Translational Cancer Research (TranslaTUM), TUM School of Medicine, München, Deutschland, ${ }^{3}$ Klinikum rechts der Isar, 2. Med. Klinik, München, Deutschland}

Ziel. Zur Erforschung pathogenetischer Prinzipien und Zusammenhänge im Rahmen der Entstehung und Progression des hepatozellulären Karzinoms existieren verschiedenste Mausmodelle. Histopathologisch zeigen allerdings Mausmodelle oft auch eine Vielzahl anderer proliferativer Läsionen, welche bisher hinsichtlich der Frequenz ihres Auftretens noch nicht umfassend charakterisiert wurden.

Methoden. 439 proliferative Leberläsionen aus verschiedenen Mausmodellen wurden durch 2 Pathologen (je ein Tier- und Humanpathologe) unabhängig evaluiert und nach publizierten Kriterien diagnostiziert. Bei Nichtübereinstimmen der Diagnosen wurden diese reevaluiert und konsentiert diagnostiziert oder als nicht klassifizierbar eingeteilt.

Ergebnisse. Unter 439 proliferativen hepatozellulären Läsionen konnten 161 hepatozelluläre Karzinome identifiziert werden. Weiterhin wurde eine Vielzahl anderer Läsionen diagnostiziert, darunter die häufigsten Kategorien hepatozelluäre Foci (13 \%) und Ovalzelltumoren (14 \%). 27 Läsionen konnten trotz Reevaluation nicht abschließend klassifiziert werden (6 \%). Bei 92 Fällen wurden Fett- und Glykogeneinlagerungen als Ursache einer makroskopisch sichtbarenLäsion identifiziert, echte Neoplasien konnten in diesen Fällen nicht diagnostiziert werden (21\%).

Fazit. Proliferative hepatozelluläre Läsionen stellen ein inhomogenes Spektrum aus echten Neoplasien und reaktiven Veränderungen dar. Trotz intensiver Evaluation und komparativem Diagnostikansatz lassen sich nicht alle Läsionen rein histomorphologisch abschließend klassifizieren.

\section{AG01.P2.03}

Functional relevance of the extracellular matrix proteins Periostin and Tenascin $\mathrm{C}$ in liver damage and regeneration

M. Hrabak ${ }^{1 *}$, L. Frohn', B. Wingerath', M. Schlensog', O. Felda' , M. Reich', I. Regel', I. Esposito'

'Universitätsklinikum Düsseldorf, Institut für Pathologie, Düsseldorf, Germany, ${ }^{2}$ Universitätsklinikum Düsseldorf, Klinik für Gastroenterologie, Hepatologie und Infektiologie, Düsseldorf, Germany, ${ }^{3}$ Klinikum der LMU München, Medizinische Klinik und Poliklinik II, München, Germany
Background. Chronic hepatic injury is associated with liver fibrosis. Liver fibrosis is characterized by the abnormal accumulation of extracellular matrix proteins, including Periostin (POSTN) and Tenascin C (TNC), which are mainly produced by activated hepatic stellate cells (aHSC). This study aims at disclosing the role of Periostin and Tenascin C in liver damage and regeneration.

Material and methods. The carbon tetrachloride $\left(\mathrm{CCl}_{4}\right)$-model of toxic hepatic injury and the bile duct ligation (BDL) model of cholestatic-obstructive injury were applied in POSTN-knockout, TNC-knockout and wildtype mice. Liver tissues were analyzed after 2, 4 and 8 weeks of $\mathrm{CCL}_{4}$-treatment and 3, 7 and 21 days after BDL, respectively. HE, Movat-Trichrome and/or Picro Sirius Red staining were used to assess morphology and fibrosis. Immunohistochemistry for $\alpha$-smooth muscle actin (aSMA), CK19, Sox9 and Ki-67 were performed on BDL mice for further characterization of the regeneration process.

Results. In the $\mathrm{CCl}_{4}$-model, the POSTN-KO mice showed a higher mortality rate $(21 \%)$ compared to TNC-KO mice (13\%) and wildtype mice (7\%). In the BDL-model, mortality rates were comparable among genotypes. Histological analysis revealed a reduced fibrotic response in POSTN-KO mice compared with TNC-KO and wildtype mice. Immunohistochemistry showed early perisinusoidal activation of $\mathrm{HSC}$ ( $\alpha \mathrm{SMA}$ ) in POSTN-KO mice as well as a more developed ductular reaction (CK19), which in all genotypes was associated with HSC activation and displayed with a portal-to-perivenular gradient. The progenitor marker SOX9 was strongly expressed in hepatocytes at early time points with a portal-to-perivenular gradient. In the Ki-67 staining, a prolonged proliferation of hepatocytes was observed in the POSTN-KO mice compared to the other genotypes, where only few positive cells were encountered at $21 \mathrm{~d}$ after BDL.

Conclusion. Both Periostin and Tenascin C contribute to liver fibrosis after liver damage. Loss of Periostin results in impaired liver regeneration with increased mortality, possibly due to interaction with progenitor cells/ hepatocyte proliferation. Further characterization of the mouse models generated in this study will focus on the identification of the cell types and pathways involved in these interactions.

\section{AG01.P2.04 \\ Hypoxia-inducible lipid droplet-associated protein is upregulated and predicts prognosis in hepatocellular carcinoma}

D. A. Ridder ${ }^{1 *}$, K. Berndt ${ }^{1}$, H. R. Witzel', A. Weinmann' ${ }^{2}$, J. U. Marquardt ${ }^{2}$, M. Schindeldecker ${ }^{1,3}$, S. Heinrich ${ }^{4}$, W. Roth' ${ }^{1}$, B. K. Straub ${ }^{1}$

'University Medical Center of the Johannes Gutenberg University, Institute of Pathology, Mainz, Germany, ${ }^{2}$ University Medical Center of the Johannes Gutenberg University, Department of Internal Medicine, Mainz, Germany, ${ }^{3}$ University Medical Center of the Johannes Gutenberg University, Tissue Bank, Mainz, Germany, ${ }^{4}$ University Medical Center of the Johannes Gutenberg University, Department of General-, Visceral- and Transplant Surgery, Mainz, Germany

Aim. Liver cancer is the second most common cause of cancer-related death worldwide, with hepatocellular carcinoma (HCC) being its predominant form. There is an urgent need to identify new prognostic markers to determine prognosis and select specific therapies. Hypoxia-inducible lipid droplet-associated protein (HILPDA) is induced in different cancer types, predicts worse prognosis and inhibits fatty acid oxidation, but its role in HCC, a tumor that frequently shows increased amount of lipid droplets, has not been investigated so far.

Methods. In order to investigate the prevalence of HILPDA-expression in HCCs in a large cohort of patients by immunohistochemistry, we established a tissue microarray (TMA) of HCCs of 574 patients that were resected at the University Medical Center Mainz from 1998 to 2017. Kaplan-Meier, Wilcoxon rank-sum test, log rank and univariate Cox's regression analysis and Spearman's rank correlation were used to determine associations between HILPDA-expression, serum AFP-levels, patients' survival, etiology of underlying liver disease and other clinical parameters such as liver enzymes. 
Results. We detected specific HILPDA immunoreactivity in over 95\% of the HCCs, with strong HILPDA expression in about 5\%, intermediate expression in about $25 \%$ and low expression in about $65 \%$ of primary HCCs. HILPDA was significantly induced in HCCs compared to surrounding non-neoplastic normal and cirrhotic liver tissue. Increased HILPDA expression correlated with decreased survival (HR 1.31; 95\% CI, 1.04-1.64, $p<0.05)$ and was associated with higher tumor grade. Patients suffering from chronic hepatitis C showed increased HILPDA levels in HCC and non-neoplastic liver, whereas hemochromatosis was associated with lower HILPDA expression. There was also a trend towards lower HILPDA expression in patients with non-alcoholic steatohepatitis. We did not detect a significant association of HILPDA expression with other parameters (macrovascular invasion, presence or absence of cirrhosis, presence of HBV-infection, primary biliary cholangitis, alphal-antitrypsin deficiency, nor with liver enzymes, CA19-9, albumin and urea serum levels).

Conclusion. HILPDA expression was induced in HCC, as determined by immunohistochemistry, and higher HILPDA levels were associated with unfavorable prognosis and higher tumor grade. Further in vitro and immunohistochemical studies are currently undertaken to unravel the underlying mechanism.

\section{AG01.P2.05}

Impact of the metabolic factor such as body mass index (BMI) onto the outcome in colon cancer(Ca) surgery-interims analysis

R. Kreyer ${ }^{*}$, B. Gebauer', R. Otto ${ }^{2}$, I. Gastinger ${ }^{2}$, H. Lippert ${ }^{2}$, R. S. Croner', F. Meyer ${ }^{1}$

'Klinik für Allgemein-, Viszeral-, Gefäß- und Transplantationschirurgie, Universitätsklinikum Magdeburg A. ö. R., Magdeburg, Germany, ${ }^{2}$ AN-Institut für Qualitätssicherung in der Operativen Medizin, Otto-von-GuerickeUniversität, Magdeburg, Germany

Aim. To verify the impact of body overweight \& obesity on immediate post-operative (rather surgical) \& long-term oncological outcomes following colon Ca surgery.

Method. Patients were classified according to WHO definitions for BMI into under- $\left(<18.5 \mathrm{~kg} / \mathrm{m}^{2}\right) /$ normal $\left(18.5-24.9 \mathrm{~kg} / \mathrm{m}^{2}\right) /$ overweight $(25-$ $\left.29.9 \mathrm{~kg} / \mathrm{m}^{2}\right)$ \& obese $\left(\geq 30 \mathrm{~kg} / \mathrm{m}^{2}\right)$. Early postop. outcome comprised morbidity (i.e., specific \& general complication rates) \&

ii)

mortality (during hospital stay).

Long-term oncological outcome was specifically characterized by 5-yr-overall survival (5-yr-OS), 5-yr-disease-free survival (5-yr-DFS) \& 5 -yr-local recurrence rate (5-yr-LRR)-design, prospective multi-center observational study.

Results. In total, 8574 patients were enrolled (mean age, 71 [range, 18-98] years [yr]; sex ratio, male:female $=53.7: 46.3 \%)$. The relative portions for the BMI categories were as follows: Underweight, $2.1 \%$; normal weight, $36.5 \%$; overweight, $40.3 \%$ \& obese, $21.2 \%$. The highest progression of the tumor disease was found in the underweight patients. More advanced tumor stages (according to UICC classification) were detected in the norma weight group compared to overweight \& obese patients $(P<0.001$ each). In addition, both underweight $\&$ obese patients showed worse ASA scoring $(P<0.001)$. With a total morbidity of $35 \%$, obese patients suffered most from surgical complications $(P<0.001) v s$. underweight category was associated with the highest rate of general complications after surgical intervention $(P=0.183)$. The overall in-hospital mortality was $3.7 \%$. Obese subjects had better 5-yr-OS (63.1\%) than normal weight individuals $(54.4 \%$, $P<0.001)$. In addition, overweight cases were not different compared to obesity $(P=0.205)$. The lowest 5 -yr-OS rates were found in the underweight group of patients $(38.9 \% ; P<0.001-$ overall 5 -yr-OS, $58.8 \%)$. With the lowest proportion of local recurrences (5-yr-LRR, 1.4\%), only the obesity category had a significant influence on 5-yr-LRR $(P<0.016$; LRR in total, $2.88 \%)$. Despite the higher 5-yr-LRR in the underweight cases, it was not significantly different $(P>0.264)$
Conclusion. Most surgical complications were found in obese patients who nevertheless had the best 5-yr-OS rate \& lowest 5-yr-LRR. Results are similar to previously obtained rectal Ca data on long-term outcome emphasizing the obesity paradox. Further statistical considerations are required to determine factors with significant impact onto outcome following colon Ca surgery.

\section{AG01.P2.06}

\section{Parallele Progression primärer kolorektaler Tumoren und Metastasen}

J. Schmeller ${ }^{1 *}$, A. Bilecz' ${ }^{2}$, M. Wessolly', S. Borchert ${ }^{1}$, E. Mairinger', C. Aigner ${ }^{3}$, T. Herold', T. Hager', R. F. H. Walter', F. Mairinger', K. W. Schmid', B. Hegedüs ${ }^{3}$ 'Institut für Pathologie, Essen, Deutschland, ${ }^{2}$ 2nd Institute of Pathology, Semmelweis University, Budapest, Ungarn, ${ }^{3}$ Ruhrlandklinik, Westdeutsches Lungenzentrum am Universitätsklinikum Essen gGmbH, Essen, Deutschland

Einleitung. Derzeit werden zwei unterschiedliche Modelle zur Entstehung von Metastasen diskutiert. Das lineare Modell beschreibt die Fähigkeit der Tumore zur Metastasierung nach subklonaler Evolution einzelner Zellen des Primärtumors. Im Gegensatz dazu geht das parallele Modell von einer frühen Dissemination einer gemeinsamen malignen Ursprungszelle aus, welche jeweils eine unabhängige Progression zeigt. Beide Modelle können aufgrund unterschiedlicher molekularer Eigenschaften unterschieden werden und die Identifikation kann dabei helfen eine geeignete Therapieauswahl zu treffen. Ziel dieser Arbeit war es Mutationsprofile von primären kolorektalen Karzinomen (CRC) zu identifizieren und mit korrespondierenden metastasierter Tumoren zu vergleichen.

Methoden. Aus jeweils 30-Formalin-fixierten Paraffin-eingebetteten Geweben von kolorektalen Karzinomen und den korrespondierenden Lebermetastasen wurde DNA isoliert. Zur Identifikation der jeweiligen Genotypen wurde diese dann mittels zielgerichteter Amplicon-Sequenzierung unter Verwendung eines Tumorpanels (45 tumorassoziierte Gene), analysiert.

Ergebnisse. In den Primärtumoren wurden insgesamt 57 Mutationen identifiziert, von denen 9 ausschließlich im Primarius gefunden wurden. In den Metastasen konnten 69 Mutationen detektiert werden von denen 33 nicht im Primärtumor nachweisbar waren. Bei 9 Patienten wurde das exakt gleiche Mutationsmuster im Primärtumor und in der Metastase gefunden. Bei 21 Patienten wurden einzigartige Mutationen entweder im Primarius (4 Patienten), was für das parallele Tumorprogressionsmodell spricht, oder in der Metastase gefunden.

Fazit. In der Studie konnte gezeigt werden, dass bei 4 von 30 Patienten die Metastasierung parallel zum Primärtumor voranschreitet. Eine Analyse des molokularen Status von sowohl Primarius als auch der Metastase könnte helfen, die derzeitige Molekulardiagnostik zu verbessern und personalisierte Therapiestrategien weiterzuentwickeln.

\section{AG01.P2.07}

\section{ATF2 is a metastasis suppressor in colorectal cancer}

K. Huebner ${ }^{1 *}$, A. Roehe ${ }^{2}$, J. Prochazka ${ }^{3}$, M. Kleisnerova ${ }^{3}$, P. Kunze', J. K. Muenzner', M. Kunz', K. Erlenbach-Wuensch' ', S. Merkel'5, R. Sedlacek ${ }^{3}$, A. Hartmann ${ }^{1}$, R. Schneider-Stock

'University Hospital Erlangen, Friedrich-Alexander Universität ErlangenNürnberg, Institute of Pathology, Erlangen, Germany, ${ }^{2}$ Federal University of Health Sciences, Department of Pathology and Legal Medicine, Porto Alegre, Brazil, ${ }^{3}$ Czech Centre for Phenogenomics, Institute of Molecular Genetics of the ASCR, Prague, Czech Republic, ${ }^{4}$ Friedrich-AlexanderUniversity Erlangen-Nürnberg, Institute of Medical Informatics, Erlangen, Germany, ${ }^{5}$ University Hospiital, Friedrich-Alexander-University ErlangenNürnberg, Department of Surgery, Erlangen, Germany

Aim. Previous studies in melanoma have shown an ambivalent role of the activating transcription factor 2 (ATF2) as an oncogene or tumor suppressor. Upon cellular stress, ATF2 is phosphorylated by MAP kinases (N-terminal) or by ATM (C-terminal) leading to the formation of homo- 
or heterodimers of the AP- 1 complex that consequently results in an ATF2-dependent damage gene signature. However, the function of ATF2 in colorectal carcinoma (CRC) is only poorly investigated. Thus, we aimed to elucidate its function using in vitro, in vivo and translational approaches. Methods. ATF2 levels were determined by immunohistochemical (IHC) stainings in CRC samples. A CRISPR/Cas9-induced ATF2 deletion was introduced in the colorectal carcinoma cell line HCT-116. To identify deregulated genes upon ATF2 loss, a NanoString gene expression array was performed and validated using qRT-PCR and ATF2si treated HCT-116, HT- 29 and DLD- 1 cells. The proliferative, invasive and migratory potential of ATF2 KO cells was investigated by the 3D spheroid model, the chicken chorioallantoic membrane (CAM) assay and mouse xenografts based on Luciferase-labelled HCT-116 ATF2 KO cells.

Results. IHC of human CRC samples showed a strong nuclear and cytoplasmic expression of ATF2 in the tumor center, whereas ATF2 was lost towards the invasion front. The mouse xenograft model revealed an aggressive growth of the ATF2 KO clones by direct disruption of the abdominal wall and invasion into the abdominal cavity of the mice. To unravel the role of ATF2 in peritoneal metastazation we identified 12 deregulated genes under ATF2 KO, majorly grouped in the protein kinase pathway. We validated an upregulation of metastasis associated TACSTD2 when ATF2 was lost. ATF2 KO tumor cells had an impaired capability to form 3D spheroids, but had a higher migratory potential. They used the non-proteolytic way of invasion in Matrigel and showed loose junctions with F-actin spots resembling a more mesenchymal phenotype. Similarly, ATF2 KO in ovo grafts showed loosely packed tumor masses that massively invaded the CAM losing the typical pushing front growth pattern of the MSI HCT116 cell line. Nevertheless, dissemination into embryonic organs was not reinforced, suggesting that ATF2 KO cells did not gain ability for invading the vascular system.

Conclusion. We give new evidence that ATF2 mediated loss in CRC might be associated with peritoneal dissemination as one of the first steps in this metastatic cascade.

\section{AG01.P2.08}

Einfluss intratumoraler Heterogenität und klonaler Evolution auf das Therapieansprechen von Rektumkarzinomen

\section{J. Lieberich ${ }^{1 * 2}$, K. Heselmeyer-Haddad ${ }^{2}$, Y. Ceribas' ${ }^{1}$, T. Ried ${ }^{2}$, T. Gaiser',} D. Hirsch ${ }^{1,2}$

'Universitätsmedizin Mannheim, Pathologie, Mannheim, Deutschland, ${ }^{2}$ National Institutes of Health, National Cancer Institute, Bethesda, USA

Ziel. Das Ansprechen von Rektumkarzinomen auf eine neoadjuvante Radiochemotherapie variiert von vollständiger Tumorpersistenz bis zu kompletter Regression des Tumors. Bislang ist nur unzureichend verstanden, welche Faktoren dieses individuell unterschiedliche Therapieansprechen bedingen. Rektumkarzinome sind durch wiederkehrende, tumortypspezifische Muster chromosomaler Aneuploidien und eine erhöhte genomische Instabilität gekennzeichnet. Innerhalb eines Tumors besteht mitunter eine erhebliche genetische Heterogenität mit distinkten Subklonen. Ziel dieser Arbeit ist es den Einfluss der multimodalen neoadjuvanten Therapie des Rektumkarzinoms im Hinblick auf die intratumorale Heterogenität zu untersuchen und zu klären, wie sich die klonale Tumorzusammensetzung unter Therapie ändert.

Methoden. Anhand von gepaarten prätherapeutischen Tumorproben und neoadjuvant therapierten Rektumkarzinomresektaten ( $n=10$ Patienten) untersuchten wir mittels der von uns neu entwickelten Methode der immuno-multiplex-interphase-Fluoreszenz-In-Situ-Hybridisierung (immuno-miFISH) Kopienzahlveränderungen von 14 Genloci (APC, BRAF, CDX2, CDKN2C, COX2, DBC2, EGFR, HER2, KRAS, MYC, PIK3CA, SMAD4, TP53, ZNF217) und einem Zentromer (CEN10) als Ploidiegradkontrolle auf Einzelzellebene. Als Kontrollgruppe analysierten wir zusätzlich Gewebeproben, Biopsien und Resektate, von therapienaiven Rektumkarzinompatienten $(n=3)$.

Ergebnisse. Die immuno-miFISH zeigte divergierende Aberrationsmuster und ein unterschiedliches Ausmaß intratumoraler Heterogenität. Die
Tumorhauptklone waren vor allem gekennzeichnet durch Zugewinne von EGFR, MYC, CDX2 und ZNF217 sowie Verluste von SMAD4 und TP53. Während bei einigen Patienten die klonale Zusammensetzung prä- und posttherapeutisch relativ stabil blieb, wiesen andere Patienten eine deutliche Verschiebung der klonalen Verhältnisse auf unter Favorisierung von Klonen mit TP53-Verlust. Patienten ohne neoadjuvante Therapie zeigten in den Tumorproben von Biopsie und Resektat ein sehr beständiges klonales Muster ohne Änderung der Hauptklone.

Fazit. Unsere bisherigen Ergebnisse zeigen, dass genetisch distinkte Klone unterschiedlich auf die neoadjuvante Therapie des Rektumkarzinoms ansprechen. Der durch die Therapie ausgelöste Selektionsdruck führte bei einem Teil der Patienten zu einer deutlichen Veränderung der klonalen Zusammensetzung, wobei Klone mit TP53-Verlust einen Überlebensvorteil zu haben schienen.

\section{AG01.P2.09}

\section{Impact of PD-L1 on the pathological response after neoadjuvant} chemoradiation therapy in locally advanced rectal cancer

E. Klieser ${ }^{1 *, 2}$, L. Weiss' ${ }^{3}$, F. Huemer ${ }^{3}$, T. Jäger ${ }^{4}$, P. Schredl ${ }^{4}$, W. Iglseder ${ }^{5}$, R. Urbas ${ }^{1,2}$, D. Neureiter ${ }^{1,2}$

${ }^{1}$ Institute of Pathology, Paracelsus Medical University, Salzburg, Austria, ${ }^{2}$ Cancer Cluster Salzburg, Paracelsus Medical University, Salzburg, Austria, ${ }^{3}$ Laboratory for Immunological and Molecular Cancer Research, Illrd Medical Department, Paracelsus Medical University, Salzburg, Austria, ${ }^{4}$ Department of Surgery, Paracelsus Medical University, Salzburg, Austria, ${ }^{5}$ Department of Radiotherapy and Radio-Oncology, Paracelsus Medical University, Salzburg, Austria

Objective. The combination of chemoradiation therapy and consecutive oncological resection is considered standard for the treatment of locally advanced adenocarcinomas of the rectum (T3/4 and/or node positive) ${ }^{1}$. However, more than half of the patients do not respond to the therapy, but are still exposed to the risks of toxicity ${ }^{2}$. To date, there are no accepted predictors for the outcome of neoadjuvant chemoradiation therapy (neoCRTx) that can be determined using less than just resected samples. To find a possible alternative, we investigated the immune response in rectal cancer before and after neoCRTx, especially with regard to the PD-L1 expression.

Methods. Both the biopsy material and the surgical resectate of 72 pretreated cases, from an already well characterized, prospectively maintained colorectal cancer database of the single center Salzburg ${ }^{3^{\prime \prime}}$ were immunohistochemically examined with antibodies against CD3, CD8 and PD-L1 (tumor proportion score (TPS), mononuclear inflammatory cells (MNICs) und combined positive score (CPS) were recorded and calculated). The findings were compared with tumor regression scores (AJCC, DworakRödel, Mandard) and tumor budding in the resected specimen.

Results. The number of PD-L1 expressing tumor cells and immune cells as well as MNICs and CPS decreased significantly after neoCRTx. The expression of PD-L1 does not correlate positively with the number of CD3+ and CD8+ lymphocytes in both biopsy and resectate. The TPS, the MNICs and especially the CPS of the biopsy correlate significantly with tumor regression in all applied classification systems.

Conclusion. In this study, we could show that in rectal carcinomas (1) PDL1 expression (TPS, MNIC and CPS) is lower after neoCRTx, (2) CPS is an appropriate prognostic value for regression grading, and (3) a high CPS in the biopsy correlates with a better tumor regression in the surgical resectate. This may allow neoadjuvant therapy regimens to be modified immediately after histological verification.
References
1. Sauer R et al (2004) N Engl J Med 351(17):1731-1740
2. Rödel $C$ et al (2012) Lancet Oncol 13(7):679-687
3. Jäger T et al (2017) Dis Colon Rectum 60(8):815-826
4. Jäger T et al (2018) Strahlenther Onkol 194(11):991-1006 


\section{AG01.P2.10}

\section{Der Tumor-Regressionsgrad nach Dworak als prognostischer Indikator für das Ansprechen von Rektumkarzinomen nach neoadjuvanter Radiochemotherapie}

\section{J. Lüke' ${ }^{1 *}$, R. Bücker', T. Hansen' ${ }^{1}$, F. Hartmann ${ }^{3}$, W. Hiller', U. Schäfer ${ }^{2}$} 'Institut für Pathologie, Klinikum Lippe $\mathrm{GmbH}$, Detmold, Deutschland, ${ }^{2}$ Klinik für Strahlentherapie, Klinikum Lippe GmbH, Lemgo, Deutschland, ${ }^{3}$ Klinik für Onkologie und Hämatologie, Klinikum Lippe GmbH, Lemgo, Deutschland, ${ }^{4}$ Klinik für Allgemein-, Viszeral- und Thoraxchirurgie, Klinikum Lippe GmbH, Detmold, Deutschland

Ziel. Ziel dieser Studie war die Untersuchung des prognostischen Stellenwertes des Tumor-Regressions-Grading (TRG) nach Dworak bezogen auf das progressionsfreie Überleben (PFS) nach neoadjuvanter Radiochemotherapie (RCT) in lokal fortgeschrittenen Fällen von Rektumkarzinomen. Methoden. Wir untersuchten ein Kollektiv von 159 Patienten mit einem lokal fortgeschrittenen Rektumkarzinom, die jeweils ein standardisiertes Regime einer neoadjuvanten RCT in einem Zeitraum von Januar 2007 bis Dezember 2016 erhalten hatten. Das progressionsfreie Überleben (Endpunkt: Jeder Rückfall nach chirurgischer Resektion) wurde statistisch gegen den histopathologischen TRG-Status (Dworak Grad $1+2$ versus Dworak Grad 3+4) und gegen weitere potentielle Risikofaktoren analysiert (Alter, Geschlecht, prä- und postoperatives T-Stadium, prä- und postoperativer N-Status, R-Status, Grading, Lymphangiosis und Hämangiosis carcinomatosa, verwendetes Chemotherapie-Regime, Therapieverzögerung). Risikofaktoren mit dem Ergebnis eines hoch-signifikanten Einflusses $(p<0,01)$ auf das PFS in der univariaten Kaplan-Meier-Schätzung wurden mittels einer multivariaten Analyse auf Grundlage des Cox-Regressions-Modells weiter auf unabhängige Signifikanz getestet.

Ergebnisse. Bei einem mittleren Follow-up-Zeitraum von 42,5 Monaten ergab sich ein mittleres PFS von 91 Monaten. In der univariaten KaplanMeier-Schätzung ergab sich ein mittleres progressionsfreies Überleben von 53,6 Monaten für die TRG-Dworak-Grade $1+2(n=109)$ und 121 Monaten für die Grade $3+4(n=50)(p<0,001)(\bullet$ Abb. $1 \mid$ AG01.P2.10). Als andere hoch-signifikante Risikofaktoren konnten der postoperative $\mathrm{N}$-Status, die Lymphangiosis carcinomatosa und der R-Status identifiziert

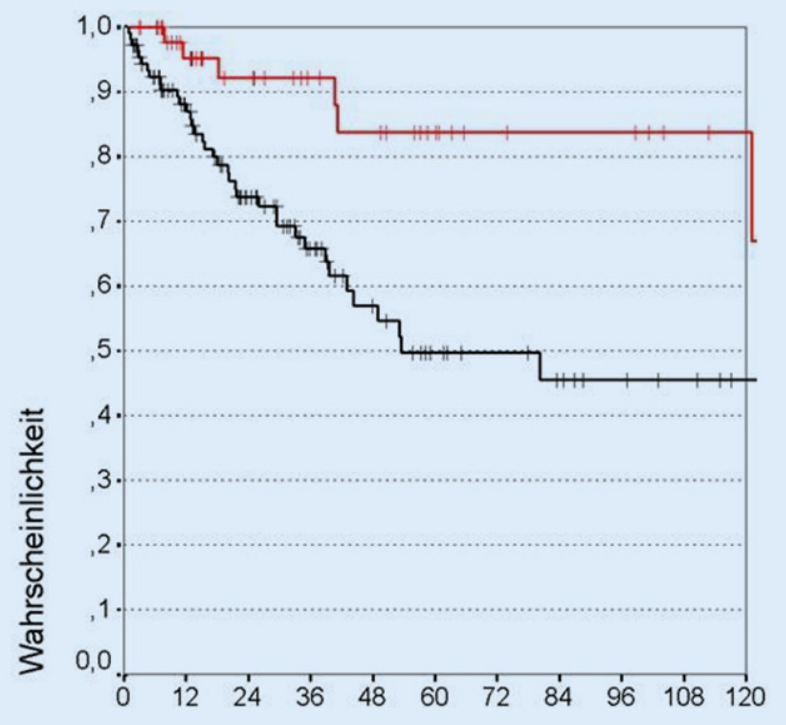

Progressfreie Zeit in Monaten werden. In der multivariaten Analyse waren nur der TRG-Grad und postoperative N-Status unabhängige Risikofaktoren.

Fazit. In dieser Studie wurde an einem Kollektiv von 159 Patienten gezeigt, dass das histopathologische Tumor-Regressions-Grading nach Dworak ein wichtiger und unabhängiger signifikanter prognostischer Indikator für das onkologische Outcome im Sinne eines PFS in lokal fortgeschrittenen Rektumkarzinomen nach neoadjuvanter RCT ist.

\section{AG01.P2.11}

Mechanisms of invasiveness and metastasis in colorectal cancerfunctional relevance of phospho-PEA-15

\section{S. Deckert ${ }^{1 *}$, S. Z. Martin', S. Foersch', W. Roth ${ }^{1}$, K. E. Tagscherer}

'Institut of Pathology, University Hospital, Mainz, Germany

Objective. PEA-15 (phosphoprotein enriched in astrocytes of $15 \mathrm{kDa}$ ) is a multifunctional protein containing a classical death effector domain (DED) and two phosphorylation sites at Ser104 and Ser116. It is associated with many fundamental cellular processes like apoptosis, proliferation and migration. Therefore, PEA- 15 has been widely investigated in different cancer entities. Although colorectal carcinoma (CRC) is one of the three most commonly diagnosed cancers worldwide and characterized by a high mortality due to metastasis, the role of PEA-15 in CRC is rarely described. Methods. Single cell clones ectopically overexpressing PEA-15 (PEA-15 ${ }^{\mathrm{wt}}$ ), a non-phosphorylatable (PEA-15 ${ }^{\mathrm{AA}}$ ) or a phosphomimetic double mutant $\left(\mathrm{PEA}-15^{\mathrm{EE}}\right.$ ) were generated in two different CRC cancer cell lines, HCT116 and DLD-1. Effects of PEA-15 overexpression on proliferation, migration, invasiveness and spheroid formation were examined. Additionally, immunohistochemical staining of patient derived CRC tissue was performed to investigate the clinical relevance of PEA-15 and both phosphorylated forms.

Results. Ectopic overexpression of PEA- $15^{\mathrm{wt}}$ resulted in a decreased migration of HCT116 cells. This decrease was even more distinct in cells ectopically overexpressing the non-phosphorylatable (PEA-15 ${ }^{\mathrm{AA}}$ ) and the phosphomimetic (PEA-15 ${ }^{\mathrm{EE}}$ ) mutant of PEA-15. Similar effects of PEA15 overexpression could be seen on cellular invasiveness in HCT116 cells. Neither overexpression of PEA- 15 nor the double mutants showed comparable differences on migratory behavior and invasiveness in DLD-1 cells. However, the process of spheroid formation appeared to be more challenging for PEA-15 overexpressing HCT116 and DLD-1 cells. Immunohistochemical staining of patient derived CRC tissue provided first indications of a differential expression of PEA-15 and its phosphorylated forms in CRC.

Conclusion. Our results demonstrate that PEA-15 has an impact on cellular migration, invasiveness and spheroid formation in CRC. Therefore, the further elucidation of underlying mechanisms as well as the evaluation of PEA-15 as a prognostic factor for patients with CRC is warranted.

AG01.P2.12

Cholangiocarcinogenesis is a developmental process driven by distinct sequential alterations of the cellular transcriptome

T. Albrecht*, M. A. Loeffler, M. Kirchner, A. Stenzinger, P. Schirmacher, B. Goeppert, S. Roessler

Heidelberg University Hospital, Institute of Pathology, Heidelberg, Germany

Aim. Carcinogenesis of bile duct tumors today is considered a multistep process, morphologically reflected in the existence of two histologically defined precursor lesions, biliary intraepithelial neoplasia (BilIN) and intraductal papillary neoplasia of the bile duct (IPNB). However, current knowledge on the molecular alterations in cholangiocarcinogenesis is scarce and no information is available regarding the chronological sequence of the changes involved. This study aimed to identify early, potentially driving genetic events.

Methods. Of 12 patients with distal cholangiocarcinoma (dCCA), non-neoplastic biliary epithelium (NB), high-grade BilIN (BilIN-3) or IPNB, and invasive tumor were isolated by laser capture microdissection of FFPE

Abb. 1 | AG01.P2.10 $\Delta$ Kaplan-Meier-Schätzung bezogen auf PFS gruppiert nach TRG (Schwarz: TRG 1+2; rot:TRG 3+4) 
tissue sections resulting in three matched sample sets for both BilIN and IPNB $(n=36)$. Total RNA was extracted and gene expression of a panel of 770 cancer-relevant genes was assessed quantitatively using the nCounter ${ }^{\circ}$ System (NanoString Technologies).

Results. We identified 180 genes with significantly altered expression from non-neoplastic tissue to invasive dCCA, of which WNT10A, COL5A1 and COL1A2 ranked highest (each $p<0.0001$ ). Of these, a subset of 126 genes demonstrated gradual up- or downregulation. Notably, the three Wnt-signaling pathway proteins WNT5B (fold change: NB vs. BilIN 2.4, BilIN vs. dCCA 2.2), WNT10A (NB vs. BilIN 3.6, BilIN vs. dCCA 7.9) and AXIN2 (NB vs. BilIN 3.1, BilIN vs. dCCA 1.9) were among the proportionally strongest, sequentially upregulated genes. The three genes with most prominent gradual downregulation were FGF19 (dCCA vs. BilIN 47.2, BiIIN vs. NB 2.5), BNIP3 (dCCA vs. BilIN 5.8, BilIN vs. NB 2.8) and PCK1 (dCCA vs. BilIN 3.8, BilIN vs. NB 2.4). Strikingly, gene expression of several collagen encoding genes was markedly augmented in the sequence from BilIN to dCCA (e.g. COL1A1 and COL1A2, $p<0.0001$, fold change $>30$ ). First in vitro experiments confirmed robust protein expression of WNT5B and WNT10A in different cholangiocarcinoma cell lines.

Conclusion. Here we show that cholangiocarcinogenesis is accompanied by distinct sequential changes in the cellular transcriptome. In particular, we identified WNT5B, WNT10A and AXIN2 to be increasingly expressed during this process, indicating dysregulation of the Wnt-signaling pathway. Secondly, late carcinogenesis seems to be associated with a significant upregulation of collagen genes, possibly creating a tumor-promoting microenvironment.

\section{AG01.P2.13 \\ Prognostic relevance of neoadjuvant radiochemotherapy in $\mathrm{N}+$ rectal Ca with limited tumor infiltration of the wall $<12 \mathrm{~cm}$ above the anocutaneous line}

\section{H. Ptok', D. Jacob ${ }^{2}$, F. Meyer ${ }^{1 *}$, H. Lippert ${ }^{3}$, I. Gastinger ${ }^{3}$}

'University Hospital, Dept. of General, Abdominal, Vascular and Transplant Surgery, Magdeburg, Germany, ${ }^{2}$ University Hospital, Dept. of Anesthesiology and Intensive Care, Magdeburg, Germany, ${ }^{3}$ Otto-vonGuericke University, Institute of Quality Assurance in Operative Medicine, Magdeburg, Germany

Background. There are no data on the prognostic improvement by neoadjuvant (neoadj.) radiochemotherapy (RCTx) in rectal cancer (Ca) with positive nodal status $\left(\mathrm{cN}^{+}\right)$.

Method. From the data obtained in the multicenter observational study on the treatment of rectal Ca (Institute of Quality Assurance in operative Medicine, Otto-von-Guericke University with University Hospital, Magdeburg-Germany), in particular, patients with the intention of a radical resection of a cT2 rectal cancer $(<12 \mathrm{~cm}$ above ACL) and no adjuvant RCTx but also no distant metastases were analyzed. Patients were subdivided into 4 groups (Gr.): Gr. 1 [ $n=1.112]$ : cT2, pN0, no neoadj. RCTx; Gr. 2 [ $n=352]$ : cT2, pN+, no neoadj. RCTx; Gr. 3 [n=231]: cT2, ypN0, neoadj. RCTx; Gr. 4 [ $n=61]$ : cT2, ypN+, neoadj. RCTx. 5-year(yr)-local recurrence rate (LRR) and 5-yr-distant metastases rate (DMR) were determined and compared among groups.

Results. Patients of Gr. $1 \& 2$ were significantly (signif.) older $(p<0.001)$, had more cardial risk factors $(p=0.011)$ and their tumor lesions were higher above ACL than in patients of Gr. $3 \& 4(p<0.001)$. There were no further differences with regard to pretherapeutic patient- or tumor-associated parameters comparing the groups. Histopathological findings revealed a signif. larger diameter of the tumor lesion in patients of Gr. 1 $\& 2(p<0.001)$ and a signif. greater number of investigated lymph nodes $(p<0.001)$. Comparing the groups, there were no signif. differences of TME quality $(p=0.444)$ and portion of $\mathrm{pCRM}(+)$ resections $(p=0.572)$. After a median follow-up of 54 months, (y)pN+ patients showed a signif. higher 5-yr-LRR (Gr. 2: 7.3\%; Gr. 4: 7.2\%) compared to (y)pN0 patients (Gr. 1:3.7\%; Gr. 3: 2.8\%). Patients of Gr. 3 had the lowest 5-yr-DMR (8.9\%)-Patients of Gr. 1: 17.2\% (Gr. 1 vs. Gr. 3: $p=0.048$ ). The highest rate was found in patients of Gr. 2 (25.8\%; Gr. 2 vs. Gr. 1: $p=0.001)$ \& Gr. 4 (24.4\%; Gr. 4 vs. Gr. 1: $p=0.069)$.

Conclusion. The data seem to indicate that neodj. RCTx may provide-in addition to the local effect-also a systemic effect by the upfront treatment such as neoadj. RCTx (in particular, with regard to limited metastatic tumor growths), which should be subject of further analyses.

\section{AG01.P2.14}

Heat shock after middle-distance run during summer time of middle Europe resulting in multi-organ failure

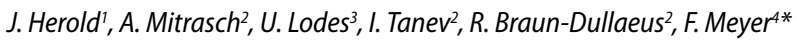
${ }^{1}$ Klinik für Gefäßmedizin, Klinikum Darmstadt, Bereich Angiologie, Darmstadt, Germany, ${ }^{2}$ Klinik für Kardiologie und Angiologie, Universitätsklinikum Magdeburg A.ö. R., Magdeburg, Germany, ${ }^{3}$ Klinik für Anästhesiologie und Intensivtherapie, Universitätsklinikum Magdeburg A.ö.R., Magdeburg, Germany, ${ }^{4}$ Klinik für Allgemein-, Viszeral-, Gefäßund Transplantationschirurgie, Universitätsklinikum Magdeburg A. ö. R., Magdeburg, Germany

Background. Hyperthermia is considered a life-threatening diagnosis (Dx), which need to be immediately \& sufficiently diagnosed \&, subsequently, the patient needs to undergo appropriate \& complex treatment measures.

Aim. By means of a scientific case report, a patient with the rare but relevant Dx of an acute heat shockis described based on i) the clinical experiences obtained in the case management $\&$ ii) related to selective references from the literature.

Case presentation. On a hot summer day $\left(28^{\circ} \mathrm{C}\right)$, a 28 -years old male patient took part in a middle-distance run of $3 \mathrm{~km}$ during that he collapsed, experienced vomiting but continued running \& reached finish where he collapsed again.

Immediately, specific \& complex intensive care measures were initiated: In detail, i) immediately, external ice packs were placed at the body surface (followed by "Arctic Sun" cooling pads), cold infusion was initiated \& the patient was transferred to ICU of the reporting clinic at a tertiary center of care: body temperature now, $40.2^{\circ} \mathrm{C}$; alternating neurological symptomatology; renal insufficiency (GFR, $41 \mathrm{~mL} / \mathrm{min}$ ), laboratory parameter profile (SI) as follows: GLDH, 468 (normal range: $<120$ ) mmol/s.L; myoglobin, $1.942(<72.0) \mu \mathrm{g} / \mathrm{L} ; \mathrm{ii})$ after $12 \mathrm{~L}$ of fluids had been given within the first $12 \mathrm{~h}$ (fluid balance, $+8.500 \mathrm{~mL}$ ) \& further $8 / 2$ units of FFP/red cell packs, resp., Shaldon catheter was implanted via internal jugular vein to initiate a high-cut-off dialysis \&, thus, to eliminate protein due to rhabdomyolysis. However, hemostasis failed due to heat-induced failure of hepatogenic protein synthesis, a "circulus vitiosus", which had been initiated \& could not be overcome despite max. therapeutic measures \& substitution.

Though the status seemed to be stabilized after the initial collapse episode, intensified monitoring \& treatment became mandatory.

LTx as ultima ratio was seriously considered because of MOF.

However, cerebral edema worsened due to massive infusions \& decreased protein levels based on liver failure prompting to craniotomy to lower intracranial pressure from the consequences of which \& unstable hemostasis the patient finally died.

Discussion. Old people can develop the classic not-stress-induced heat shock but also young athletic sportsmen can underlie the risk (of) \& generate the stress-induced heat shock with fatal outcome after relatively "normal" sport activities (3-km run!) in case of warm weather outside even in our Northern latitudes. 


\section{AG Uropathologie Poster I}

\section{AG02.P1.01 \\ Klinische Epidemiologie des Urachuskarzinoms in Deutschland und den USA - ein Vergleich \\ T. Hager ${ }^{*}$, K. Kraywinkel' , C. Niedworok ${ }^{3}$, T. Szarvas 3 , , B. Hadaschik ${ }^{3}$, K. W. Schmid', H. Reis' \\ 'Institut für Pathologie, Universitätsmedizin Essen, Universität Duisburg- Essen, Essen, Deutschland, ${ }^{2}$ Robert Koch-Institut, Berlin, Deutschland, ${ }^{3}$ Klinik für Urologie, Universitätsmedizin Essen, Universität Duisburg-Essen, Essen, Deutschland, ${ }^{4}$ Klinik für Urologie, Semmelweis Universität, Budapest, Ungarn}

Ziel. Urachusmalignome sind insgesamt Raritäten und die Datenlage zu Inzidenz, klinikopathologischen Kriterien und Überlebensraten entsprechend gering. Ziel dieser Untersuchung war die Darstellung deutschlandweiter Daten dieser seltenen Entität sowie deren Vergleich zu den USA. Methoden. Daten zu Urachusmalignomen aus den Jahren 2010 bis 2014 in Deutschland wurden über das Tumorregister des Robert Koch-Institutes nach den Parametern ICD-O-3-Code, Histologie, Inzidenz und Mortalität anonymisiert gesammelt und ausgewertet. Das Ergebnis wurde mit den ebenso nach gleichem Muster und zum gleichen Zeitraum abgerufenen Daten des „Surveillance, Epidemiolgy, and End Results Program (SEER, USA)" verglichen.

Ergebnisse. Insgesamt waren für Deutschland im Zeitraum 2010-2014 146 Urachuskarzinom-Fälle (davon 92 Adenokarzinome und 32 Urothelkarzinome) gemeldet. Das mittlere Alter bei Diagnose war mit 65,5 Jahren zu beziffern. Das relative 5-Jahres-Überleben für Urachuskarzinome (UrC) ist diesen Daten zufolge gesamt mit $46 \%$ zu bewerten. Im Vergleich ergab die Analyse der verfügbaren SEER-Daten für den gleichen Zeitraum 151 gemeldete UrC (davon 119 Adenokarzinome und 19 Urothelkarzinome) Das mittlere Alter bei Diagnose war hier 61 Jahre. Das relative 5-JahresÜberleben wurde anhand dieser Daten mit 52,7 \% kalkuliert.

Fazit. Die erhobenen Daten zeigen sowohl für Deutschland als auch für die SEER-Analyse eine sehr geringe UrC Inzidenz. Aufgrund der Seltenheit der Erkrankung sowie auch lokaler Gegebenheiten ergeben sich Schwachstellen in der Datenerhebung. Die Ergebnisse hinsichtlich der Entitäten, Altersverteilung und dem relativen 5-Jahres-Überleben sind allerdings zwischen den SEER- und für Deutschland erhobenen Daten (soweit repräsentiert) als relativ äquivalent zu bewerten, wobei jedoch zu betonen ist, dass für beide Register nur eine Abdeckung selektiver Regionen vorliegt.

\section{AG02.P1.02 \\ Das Urachuskarzinom: Ein Update aktueller molekularer Ergebnisse}

H. Reis ${ }^{1 *}$, C. Niedworok', S. Ting', T. Hager', B. Hadaschik2 , N. Nagy ${ }^{3}$, C. Oláh ${ }^{3}$, T. Szarvas ${ }^{2,3}$

'Institut für Pathologie, Universitätsmedizin Essen, Universität DuisburgEssen, Essen, Deutschland, ${ }^{2}$ Klinik für Urologie, Universitätsmedizin Essen, Universität Duisburg-Essen, Essen, Deutschland, ${ }^{3}$ Klinik für Urologie, Semmelweis Universität, Budapest, Ungarn

Ziel. Das Urachuskarzinom (UrC) ist eine seltene aber aggressive Tumorerkrankung. In der letzten Zeit hat das Wissen um molekulare Eigenschaften dieser Entität deutlich zugenommen. In diesem Zusammenhang möchten wir ein Update unserer aktuellen Ergebnisse zeigen.

Methoden. Eine Kohorte von 44 UrC-Fällen (Adenokarzinome) wurde per selbst angepasster, Panel-basierter Hochdurchsatzsequenzierung besonders zur Rolle von APC-, PTEN- und DICER1-Veränderungen untersucht, z. T. ergänzt durch immunhistochemische (IHC) Analysen (betaCatenin). Zudem wurde eine Kohorte von 31 Fällen (UrC: $n=10$, primäre Adenokarzinome der Harnblase (PBAC): $n=11$, kolorektale Adenokarzinome (CRC): $n=10$ ) mittels proteomischer Methoden (label-freie Proteomanalyse/IHC) zu (differential-)diagnostischen Markern untersucht
Zuletzt wurde eine Kohorte von UrC-Adenokarzinomen bezüglich der prognostischen Relevanz eines selbst angepassten miRNA-Sets evaluiert. Ergebnisse. In der Analyse der sequenzierten Kohorte zeigten $47 \%$ der Fälle zumindest eine Alteration in APC-, PTEN- oder DICER1 inkl. zweier bislang beim UrC nicht berichteter APC-Mutationen (p.Y1075*, p.K1199*) und einer PTEN-frameshift Mutation (p.C211 fs). Eine beta-Catenin-Positivität (IHC) fand sich bei $36 \%(8 / 22)$ mit nur geringer Überlappung zum APC-Mutationsstatus (1/8). In den proteomischen Untersuchungen wurden 5 vielversprechende Marker identifiziert (CLCA1, ACAA1, COR1A, CATD, NME2). In der miRNA-Analyse zeigte sich ein diskriminierender Effekt.

Fazit. Es wurden weitere, bislang beim UrC z. T. nicht berichtete molekulare Ergebnisse erhoben, die eine diagnostische, prognostische oder prädiktive Wertigkeit aufweisen.

\section{AG02.P1.03}

\section{PD-L1-Expression in plattenepithelialen Tumoren der Harnblase}

R. Morsch', M. Rose ${ }^{2 *}$, A. Maurer ${ }^{2}$, M.-A. Cassataro ${ }^{2}$, T.-A. Vögeli', R. Knüchel', N.T. Gaisa

'Uniklinik RWTH Aachen, Klinik für Urologie, Aachen, Deutschland, 2Uniklinik RWTH Aachen, Institut für Pathologie, Aachen, Deutschland

Ziel. Immun-Checkpoint-Inhibitoren (CPI) sind inzwischen nach positiver Tumor-Testung auch in der Erstlinientherapie des Harnblasenkarzinoms zugelassen. Unbekannt ist jedoch die Expression von programmed death-ligand 1 (PD-L1) in seltenen Tumortypen der Harnblase. Ziel dieser Studie ist es erstmalig die PD-L1-Expression bei Plattenepithelkarzinomen (SCC) der Harnblase zu bestimmen, um zu evaluieren, ob auch SCC Patienten von einer CPI-Therapie profitieren könnten.

Methoden. Gewebe-Mikroarrays von 108 formalinfixierten, paraffineingebetteten SCC Geweben (45 Urothelkarzinome mit partieller plattenepithelialer Differenzierung, 63 reine SCC) wurden mit verschiedenen Anti-PD-L1-Antikörpern immunhistochemisch gefärbt (Klone 28-8, 22C3, SP142 und SP263). Die PD-L1-Expression von Tumor- (Cologne-Score) und Immunzellen (IC-Score) sowie der CPS (Combined Positivity Score) wurde bestimmt. Die statistische Datenerfassung erfolgte mittels SPSS (23.0).

Ergebnisse. Es fand sich keine differente PD-L1-Expression zwischen gemischten und reinen SCC. Die verwendeten PD-L1-Antikörper zeigten hingegen ein deutlich unterschiedliches Färbeergebnis: Für Tumorzellen wurde eine positive Färbung (TC-Score $\geq 1$ ) in 33,0 \% (28-8; 35/106), 1,9 \% (SP142; 2/108), 49,1 \% (SP263; 52/106) und 14,3\% (22C3, 15/105) festgestellt. Immunzellen zeigten eine positive PD-L1-Expression (IC-Score $\geq 1$ ) in $43,4 \%(28-8 ; 46 / 106), 9,3 \%$ (SP142; 10/108), 60,4 \% (SP263; 64/106) und $26,7 \%(22 \mathrm{C} 3 ; 28 / 105)$ der Fälle. Unter Berücksichtigung aktueller Richtlinien für die Erstlinientherapie mit Pembrolizumab (CPS $\geq 10$ ) und Atezolizumab (IC-Score $\geq 2$ ), deuten unsere Ergebnisse auf eine Therapieoption hin, die abhängig von den verwendeten Antikörpern zwischen 0 \% und $38 \%$ variiert. Während SP142 keine klinische Bedeutung aufweist, bestünde nach Evaluation mit 28-8, SP263 oder 22C3 eine Therapiemöglichkeit in jeweils $26 \%, 38 \%$, oder $14 \%$ für Pembrolizumab und in jeweils $22 \%, 30 \%$ bzw. $3 \%$ für Atezolizumab.

Fazit. Unsere Daten zeigen eine deutliche, teils starke PD-L1-Expression in SCC der Harnblase sowohl in Tumor- als auch Immunzellen. Somit weisen unsere Daten auf einen Urothelkarzinom-äquivalenten Anteil von Patienten hin, die für eine Pembrolizumab- oder Atezolizumab-Erstlinientherapie in Frage kämen. Da alternative und wirksame adjuvante Therapieoptionen fehlen, sollte die Anwendung von CPI bei SCC-Patienten in Betracht gezogen werden. Hierfür sind zeitnahe klinische Studien dringend erforderlich. 
AG02.P1.04

\section{Detection of PD-L1 RNA expression in immunohistochemically} negative patients: Are the negatives a heterogeneous group?

U. Sommer*, M. Großer, D. Aust, K. Jöhrens, P. Hönscheid, G. Baretton Carl Gustav Carus Universitätsklinikum Dresden, Institut für Pathologie, Dresden, Germany

Aims. Immune checkpoint inhibition is an already well established therapy for advanced urothelial carcinoma. Identification of patients who are likely to respond to PD-1 or PD-L1 blockade is of paramount importance for clinical decision making. In different clinical trials a correlation between immunohistochemical PD-L1 expression and response to checkpoint inhibition has been shown. Albeit not perfect, the immunohistochemically determined PD-L1 status is currently the best validated biomarker for response prediction. Interestingly, there are patients who respond to immune checkpoint therapy despite lack of PD-L1 expression. These observations and experiences suggest that there might be differences in biology of the tumours, which are only partially revealed by the various available diagnostic antibodies/kits. We investigated PD-L1 RNA expression in metastasized urothelial bladder cancer in order to be able to detect any potential differences in the tumours one step ahead of the protein level.

Methods. A total of 21 formalin-fixed, paraffin-embedded (FFPE) resection specimens from patients with metastasized urothelial bladder cancer were immunostained for PD-L1 using the E1L3N-antibody from Cell Signaling. Consecutively RNA ISH was performed to detect PD-L1 RNA using the ViewRNA ISH Tissue 2-Plex Assay (Thermo Fisher) and the PD-L1 target specific probe set (VA1-14391-01). Slides were digitized and manually quantified by Image viewer v.3.1 (Ventana medical systems).

Results. While protein and RNA expression on tumor and immune cells show comparable results in the IHC positive patient group, we found PDL1 RNA expression on tumor cells (TCs) in the IHC negative group. IHC negative patients did not show PD-L1 RNA expression on their immune cells.

Conclusions. It appears that the immunohistochemically negative tumors are a heterogeneous group and a part of them respond to an immune checkpoint blockade. The detection of PD-L1 RNA may be an extended diagnostic step that improves the prediction of therapy response.

\section{AG02.P1.05}

TERT promoter mutation analysis is a helpful diagnostic tool to distinguish benign and malignant spindle cell lesions of the urinary bladder

\section{S. Bertz ${ }^{1 *}$, V. Weyerer', R. Stöhr', B. Wullich², A. Hartmann', A. Agaimy}

'Universitätsklinikum Erlangen, Pathologisches Institut, Erlangen, Germany, ${ }^{2}$ Universitätsklinikum Erlangen, Urologische und Kinderurologische Klinik, Erlangen, Germany

Background. Inflammatory myofibroblastic tumors (IMT) and postoperative spindle cell nodules (PSCN) of the urinary bladder are rare benign pseudosarcomatous myofibroblastic spindle cell proliferations which may be diagnostically challenging. In contrast, sarcomatoid urothelial carcinoma (sUC) is a life-threatening disease, which requires prompt aggressive treatment. Diagnosis of IMT/PSCN may on occasion cause severe diagnostic difficulties, especially in ALK-negative cases: both may display morphologic features suggestive of malignancy such as brisk mitotic activity, necrosis or atypia. Moreover, frequent expression of cytokeratins can be misleading. On the other hand, sUC may show IMT-like morphology. TERT promoter mutations have been reported as characteristic molecular events in urothelial cancers, however, little is known about these alterations in spindle cell lesions of the bladder. We performed comparative immunohistochemistry and assessment of the TERT promoter mutation status in IMT/PSCN and sUC of the urinary bladder.

Materials and methods. 25 spindle cell lesions of the bladder diagnosed as IMT $(n=6)$, PSCN $(n=2)$ and sUC $(n=17)$ were compared. Analysis included histomorphological assessment and immunohistochemistry with cytokeratins (Pancytokeratin, CK18, CK19), ALK (clone D5F3), GATA3, p63 and p53 and SNaPshot analysis of three hot spot regions of the TERT promoter gene.

Results. sUC vs IMT/PSCN showed frequent necrosis (16/17 vs $2 / 8)$, high mitotic index ( $>5 / \mathrm{HPF}$ in $16 / 17 \mathrm{vs}<1 / \mathrm{HPF}$ in $7 / 8$ ), and heterologous elements (7/17 vs $0 / 8)$. While expression of pancytokeratin was frequent in both groups (12/14 vs 5/7), ALK (D5F3) was limited to the IMT/PSCN $(0 / 14$ vs $5 / 8)$, and p63 was seen in sUC only ( $11 / 17$ vs $0 / 7)$. Wild-type p53 pattern was found in 0/14 sUC vs 8/8 IMT/PSCN. Mutations of the TERT promoter were found in 14/14 sUC vs 0/7 IMT/PSCN.

Conclusions. Detection of TERT promoter mutations or ALK rearrangement in spindle cell lesions of the bladder is confirmatory for sUC and IMT in the majority of cases. In cases without TERT or ALK alterations, clinical history and careful assessment of classical histomorphologic and immunohistochemical features (high mitotic index, necrosis, heterologous differentiation, $\mathrm{p} 53$ and p63 staining pattern) may be helpful to discriminate benign from malignant lesions.

\section{AG02.P1.06}

Molecular identification of telomerase reverse transcriptase (TERT) promotor mutations in primary and recurrent tumors of urinary bladder

J. Roggisch ${ }^{1 *}$, T. Ecke ${ }^{2}$, S. Koch ${ }^{1,3}$

${ }^{1}$ Helios Klinikum Bad Saarow, Pathology, Bad Saarow, Germany, ${ }^{2}$ Helios Klinikum Bad Saarow, Urology, Bad Saarow, Germany, ${ }^{3}$ Brandenburg Medical School, Bad Saarow, Germany

Aim. Recently, more and more tumor markers for bladder cancer were discovered. One novel tumor marker TERT (promotor mutation) occurs in majority of cancers including glioblastoma, melanoma, urothelial, bladder, hepatocellular carcinoma and thyroid cancer and is of particular importance for tumor research. In bladder cancer and other urothelial cancer the TERT promotor mutations exist in all stages and grades and are more frequent than other earlier reported genetic alterations. Furthermore we want to figure out which role does TERT promotor mutations play in urothelial bladder cancer. Additionally we want to compare the TERT promotor mutation status from primary tumor and their recurrence.

Methods. For this purpose, we detect TERT promotor mutation sequencing status in tumor tissues from 75 invasive and non-invasive urothelial bladder cancer patients. Properly 23 of these bladder cancer patients have a recurrence. Moreover we detect TERT promotor mutation sequencing status in the recurrence.

Results. Overall, 84\% (63/75) contained TERT promotor mutations. Additionally, $80 \%(20 / 25)$ of invasive and $86 \%(43 / 50)$ non-invasive tumors harbored TERT promotor mutations. The majority of these mutations were $\mathrm{C} 228 \mathrm{~T}(58.7 \%)$ and C250T (18.7\%). We also identified rare promotor mutations (C228A $(n=1)$; C259T + C228T $(n=1) ; \mathrm{C} 231 \mathrm{~T}+\mathrm{C} 228 \mathrm{~T}(n=1)$; CC228-229TT $(n=2)$ ). In our cohort, four TERT promotor mutations in the recurrence differ from the primary tumor.

Conclusion. Our findings suggest TERT promotor mutations were frequent in invasive and non-invasive urothelial bladder cancer, making them potential therapeutic targets. Furthermore we compare primary and recurrent tumors to identify how specific alterations changed in these tumors relative to clinical interventions and outcomes to guide clinical decisions.

\section{AG02.P1.07 \\ Über die Kollagen- und Keratin-Expression beim Urothelkarzinom der Harnblase}

M. Ingenwerth ${ }^{1 *}$, P. Nyirády ${ }^{2}$, B. Hadaschik ${ }^{3}$, C. Oláh ${ }^{2}$, T. Szarvas ${ }^{2,3}$, H. Reis ${ }^{1}$ Institut für Pathologie, Universitätsmedizin Essen, Universität DuisburgEssen, Essen, Deutschland, ${ }^{2}$ Klinik für Urologie, Semmelweis Universität, Budapest, Ungarn, ${ }^{3}$ Klinik für Urologie, Universitätsmedizin Essen, Universität Duisburg-Essen, Essen, Deutschland

Ziel. Das invasive Urothelkarzinom der Harnblase (UCB) geht zumeist mit einer stromalen Desmoplasie einher. Dieses Bindegewebe zeigt eine 
besondere, bei verschiedenen Tumorentitäten progressionsrelevante Kollagenzusammensetzung, die mit dem tumoralen Zytokeratin verknüpft ist und mit der epithelialen-mesenchymalen Transition (EMT) in Verbindung gebracht wurde. Da beim UCB zur extrazellulären Kollagenzusammensetzung bislang kaum Daten vorliegen, haben wir diesbezüglich eine größere Kohorte analysiert.

Methoden. An 102 kryokonservierten und 180 Formalin-fixierten und in Paraffin eingebetteten (FFPE) Proben wurde mittels RT-qPCR und Immunhistochemie die Expression von Kollagen 1A1, Kollagen 3A1 und Kollagen 5A2 sowie von den Zytokeratinen 14 und 17 gemessen. Klinische und Follow-up Daten wurden erhoben und mit den Ergebnissen korreliert.

Ergebnisse. Die col1a1-, col3a1-, col5a2- und krt14-mRNA Expression war in high-grade und muskelinvasiven Urothelkarzinomen der Harnblase (MIBC) signifikant gesteigert. Das krankheitsspezifische Überleben war bei Patienten mit hohen Expressionsraten von colla1 $(p=0,004)$, col3a1 $(p=0,004)$ und col5a2 $(p=0,028)$ signifikant kürzer. Die Proteinexpression von CK14, COL3A1 und Col5A2 war beim MIBC verglichen zum nicht-muskelinvasiven Urothelkarzinom der Harnblase (NMIBC) signifikant höher, wie es auch für die Proteinexpression von CK14 $(p=0,006)$ und COL5A2 $(p=0,002)$ in high-grade gegenüber low-grade Karzinomen galt. Das krankheitsspezifische Überleben war bei Patienten mit hohen Proteinexpressionsraten von COL5A2 $(p=0,033)$ und CK14 $(p=0,042)$ signifikant kürzer.

Fazit. Die prognostische Relevanz der Kollagen- und Zytokeratin-Expressionsmuster beim Urothelkarzinom könnte im Zusammenhang mit EMT-bedingten Veränderungen stehen. Zudem könnten Verbindungen zu molekularen Subtypen des Urothelkarzinoms, wie beispielsweise dem basalen/squamösen Typ, bestehen.

\section{AG Uropathologie Poster II}

\section{AG02.P2.01 \\ Vergleich des HPV Status peniler Karzinome mittels Chipron Technik mit dem Surrogatmarker p16}

\section{R. Winkelmann ${ }^{1 *}$, M. Demes' ${ }^{1}$, M. Schneider ${ }^{2}$, V. Tischler' ${ }^{1}$ M.-L. Hansmann', P. Wild' , S. Vallo ${ }^{3}$ \\ 'Dr. Senckenbergisches Institut für Pathologie, Frankfurt am Main, Deutschland, ${ }^{2}$ Universität Duisburg, Duisburg, Deutschland, ${ }^{3}$ Hochtaunus Kliniken, Bad Homburg, Deutschland}

Ziel. Penile Karzinome sind seltene Erkrankungen zumeist mit plattenepithelialer Morphologie. U. a. bei Kopf-Hals-Tumoren und Analkarzinomen ist bekannt, dass der Infektionsstatus durch Humane Papilloma Viren (HPV) des Tumors prognostische Signifikanz erreichen kann. Zie ist es, die Korrelation zwischen dem Surrogatmarker p16 und dem HPVStatus beim Peniskarzinom bzw. dem carcinoma in situ im tumorösen als auch im angrenzenden Normalgewebe zu evaluieren. Weiterhin soll die Prävalenz der jeweiligen Subtypen in unserem Kollektiv bestimmt werden. Methoden. Von Formalin-fixiertem Paraffin-eingebettetem (FFPE) Gewebe von 60 penilen Neoplasien und angrenzendem Normalgewebe aus dem Archiv des Dr. Senckenbergischen Institutes für Pathologie, Frankfurt am Main, wurde p16 bestimmt. Zusätzlich erfolgte eine HPV Subtypisierung mittels Polymerasekettenreaktion (PCR) basierter Technik sowoh im Tumor als auch im angrenzenden Normalgewebe des FFPE Materials (Chipron LCD Array 3.5).

Ergebnisse. Die p16 Färbung zeigte insgesamt 22 Abweichungen vom PCR basierten HPV-Status im Normal- bzw. Tumorgewebe. In 46 von $60 \mathrm{Tu}-$ morproben (invasives Karzinom und Carcinoma in situ) war die p16 Färbung positiv. Bei den Tumorproben, bei welchen mittels PCR eine HPV Infektion ausgeschlossen wurde, waren 7 Proben p16 positiv. Bei den Tumorproben, bei denen HPV bestätigt worden war $(n=33)$, waren 28 Proben 16 positiv.
Von 60 untersuchten Proben wurde in der Mehrzahl HPV 16 im Tumor (29/60) detektiert. 4 Fälle wiesen im Tumor eine Mehrfachinfektion mit den HPV Subtypen 18 und 53; 16 und 70; 16 und 44 sowie 16 und 58 auf. In 2 Fällen wurde HPV 11 und in einem Fall HPV 31 nachgewiesen. In 16 Fällen zeigte auch das peritumorale Normalgewebe eine nachweisbare HPV Infektion. Hier wurden die Subtypen 16 (15 von 60) und 11 (1 von 60) nachgewiesen. In 44 von 60 peritumoralen Proben wurde kein HPV nachgewiesen.

Fazit. In 36,67 \% der Proben besteht eine Diskordanz zwischen der p16 Färbung und dem PCR-basierten HPV-Status. Eine HPV Infektion tritt in $55 \%$ der untersuchten penilen Neoplasien unserer Kohorte auf. Mischinfektionen im Tumor wurden in 6,67 \% der Fälle ermittelt.

Es stellt sich somit die Frage, ob es eine alternative Nachweismethode gibt, die eine geringere Diskordanz zu dem PCR-basierten Ergebnis aufweist.

\section{AG02.P2.02}

\section{Mdm2-Promotorpolymorphismus rs2279744 hat keinen Einfluss} auf das Erkrankungsrisiko für das Plattenepithelkarzinom des Penis

R. Stöhr ${ }^{1 *}$, O. Wendler', J. Giedl', N. T. Gaisa3 , G. Richter', V. Campean ${ }^{5}$, M. Burger ${ }^{6}$, B. Wullich', S. Bertz' , A. Hartmann

'Universitätsklinikum, Institut für Pathologie, Erlangen, Deutschland, 2Universitätsklinikum, Hals-Nasen-Ohren-Klinik, Erlangen, Deutschland, ${ }^{3}$ Uniklinik RWTH, Institut für Pathologie, Aachen, Deutschland, ${ }^{4}$ Institut für Pathologie, Hameln, Deutschland, Institut für Pathologie, Ansbach, Deutschland, ${ }^{6}$ Universitätsklinik, Klinik für Urologie, Regensburg, Deutschland, ${ }^{7}$ Universitätsklinikum, Urologische und Kinderurologische Klinik, Erlangen, Deutschland

Ziel. Das Mdm2-Protein ist ein wichtiger negativer Regulator von TP53 und ist auf transkriptioneller Ebene stark reguliert. Ein funktioneller Polymorphismus im $M d m 2$-Promotor ( $M d m 2$ SNP309 T>G, rs2279744) führt zu einer erhöhten Affinität des Transkriptionsaktivators SP1 zum Mdm2Promotor und resultiert in einer verstärkten Transkription. Die „G“-Allelvariante von rs2279744 konnte bereits als Risikofaktor für die Entstehung verschiedener Tumorentitäten identifiziert werden. Weiterhin konnte gezeigt werden, dass für HPV-assoziierte Tumoren (z. B. Plattenepithelkarzinom der Zervix oder orale und oropharyngeale Plattenepithelkarzinome) der Polymorphismus rs2279744 ebenfalls einen Einfluss auf das Erkrankungsrisiko bei Vorliegen einer HPV-Positivität besitzt. Für das Plattenepithelkarzinom des Penis gibt es bisher noch keine Daten zur Bedeutung des Mdm2-Polymorphismus rs2279744 für das Erkrankungsrisiko generell oder im Zusammenhang mit dem HPV-Status. Daher sollte diese Frage durch Bestimmung der Verteilung des Mdm2-Promotorpolymorphismus rs2279744 in einer Fall/Kontroll-Studie näher untersucht werden.

Methoden. Nach Mikrodissektion und DNA-Isolierung aus FFPE-Gewebe wurden die Allelvarianten des rs2279744-Polymorphismus in den Tumoren und in normalem Penisgewebe von 106 Patienten mit Plattenepithelkarzinom des Penis sowie in einer Kontrollkohorte $(n=124)$ ohne maligne Erkrankung mittels Restriktionsfragmentlängenpolymorphismus (RFLP)Analyse bestimmt. Die HPV-Bestimmung in den Tumoren erfolgte mittels PCR unter der Verwendung der GP5+/6+-Primer und anschließender Subtypen-spezifischer PCR.

Ergebnisse. Die Genotypenverteilung lag sowohl für die Kontrollkohorte als auch für die Karzinomgruppe im Hardy-Weinberg-Gleichgewicht. Die Verteilung des $M d m 2$ SNP309 zeigte keine signifikanten Unterschiede zwischen der Kontrollkohorte und der Karzinomgruppe $(p=0,86)$. Auch für das dominante $(p=0,58)$ bzw. rezessive $(p=0,85)$ Modell ergaben sich keine signifikanten Unterschiede in der Allelverteilung zwischen beiden Kohorten. Es zeigte sich weiterhin keine signifikant unterschiedliche Genotypenverteilung zwischen HPV-negativen und HPV-positiven Fällen $(p=0,44)$. Fazit. Der Mdm2-Promotorpolymorphismus rs2279744 hat in unserer Fall/Kontrollstudie keinen Einfluss auf das Erkrankungsrisiko für ein Plattenepithelkarzinom des Penis. Bezogen auf den HPV-Status zeigte sich ebenfalls weder ein Einfluss noch ein additiver Effekt auf das Erkrankungsrisiko bei HPV-positiven Fällen. 
AG02.P2.03

\section{Molekulare Charakterisierung von Harnblasen-Tumoren vom Müller-Typ}

\author{
N. Ortiz Brüchle ${ }^{1 *}$, A. Maurer', E. Dahl', I. Losen', R. Golz², R. Knüchel-Clarke', \\ N.T. Gaisa' \\ 'Uniklinik RWTH Aachen, Institut für Pathologie, Aachen, Deutschland,
} ${ }^{2}$ Helios Klinikum Wuppertal, Institut für Pathologie, Wuppertal, Deutschland

Ziel. Die WHO-Klassifikation von 2016 definierte erstmals HarnblasenTumoren vom Müller-Typ. Diese seltenen Tumoren umfassen klarzellige Karzinome (früher mesonephrische Karzinome) und endometrioide Karzinome. Die molekulare Tumorentstehung dieser Tumoren ist bislang wenig verstanden. Ziel dieser Studie war es daher, das Mutationsspektrum (Punktmutationen, Genfusionen) dieser Tumoren mittels Next-Generation-Sequencing (NGS)Panel-Analytik zu untersuchen.

Methoden. Es wurden vier klarzellige Karzinome (KK) sowie ein endometrioides Karzinom (EK) der Harnblase nach manueller Mikrodissektion mittels Illumina NextSeq untersucht. Die Library-Generierung erfolgte mittels AmpliSeq Illumina Comprehensive Assay v3 (161-Gene). Die Datenanalyse wurde mit der SeqPilot-Software (SeqNext-Modul, JSI medical systems; Allelfrequenz: $\geq 10 \%$, Frequenz in der Normal-Bevölkerung: $<2 \%$ ) bzw. dem RNA-Amplicon-Modul (Illumina; Fusion-Score: $>2,0$ ) durchgeführt. Aus einschlägigen Datenbanken bekannte benigne sowie nicht-kanonische intronische und stumme Varianten wurden nicht berücksichtigt.

Ergebnisse. In allen fünf Karzinomen konnten klinisch relevante molekulare Veränderungen nachgewiesen werden. Neben trunkierenden Mutationen des ARID1A-Gens $(n=2 / 5, \mathrm{KK})$ und funktionell relevanten Mutationen des TP53-Gens $(n=1 / 5, \mathrm{KK})$ fanden sich aktivierende Mutationen des PIK3CA- $(n=2 / 5, \mathrm{KK}, \mathrm{EK})$ und CTNNB1-Gens $(n=1 / 5$, EK). Darüber hinaus wurden Missense-Mutationen von unklarer Signifikanz in 8 weiteren Genen (KK, EK) detektiert. Im endometrioiden Karzinom wurde zudem eine EIF3E; RSPO2-Fusion nachgewiesen, welche sich in keinem der klarzelligen Karzinome zeigte.

Fazit. Trotz der kleinen Kohorte von sehr seltenen Tumoren des MüllerTyps ergaben sich erstmals Hinweise, dass sich das Mutationsspektrum von klarzelligen und endometrioiden Karzinomen etwas unterscheidet Das Mutationsspektrum überlappt nur teilweise mit den Adenokarzinomen der Harnblase. Im endometrioiden Karzinom war eine parallele Aktivierung des WNT-Signalwegs durch eine RSPO-Fusion sowie eine aktivierende CTNNB1-Mutation auffällig. Um diese Tumoren zuverlässig molekular zu charakterisieren, ist perspektivisch die Sequenzierung größerer Kohorten notwendig. Über kollaborative Zusendungen von Tumoren freuen wir uns sehr.

\section{AG02.P2.04 \\ Circulating levels and tissue expression of chromogranin A in urothelial bladder cancer and renal cell carcinoma}

H. Reis ${ }^{1 *}$, T. Hager' ${ }^{1}$ B. Jardin-Watelet ${ }^{2}$, N. Bourgoin ${ }^{2}$, M. Hoffmann ${ }^{3}$, P. Nyirády ${ }^{4}$, A. Csizmarik', B. Hadaschik ${ }^{5}$, T. Szarvas ${ }^{4,5}$

'Institut für Pathologie, Universitätsmedizin Essen, Universität DuisburgEssen, Essen, Germany, ${ }^{2}$ ThermoFisher Scientific Biomarkers, Clinical Diagnostic, Nîmes, France, ${ }^{3}$ Klinik für Urologie, Universitätsklinikum Düsseldorf, Heinrich-Heine-Universität, Düsseldorf, Germany, ${ }^{4}$ Klinik für Urologie, Semmelweis Universität, Budapest, Hungary, ${ }^{5} \mathrm{Klinik}$ für Urologie, Universitätsmedizin Essen, Universität Duisburg-Essen, Essen, Germany

Aim. Neuroendocrine features are occasionally found also in non-neuroendocrine neoplasms. Recently, a neuroendocrine-like molecular subtype has been described in urothelial bladder cancer (BC). A hallmark of neuroendocrine neoplasms is the presence of Chromogranin A (CGA) which is widely used as a tissue and serum marker. Encouraged by our prior incidental observation of high soluble CGA (sCGA) levels in a small group of $\mathrm{BC}$ patients, we aimed to evaluate sCGA concentrations and their associations with clinicopathological data in large cohorts of $\mathrm{BC}$ and renal cell carcinoma (RCC) as an additional group.
Methods. Blood concentrations of CGA were evaluated in a training set of BC $(n=188)$ and RCC $(n=77)$ as well as in healthy controls $(n=97)$. The positive findings in the $\mathrm{BC}$ cohort were verified in an independent validation BC cohort $(n=125)$ and 116 healthy controls. In addition, CGA protein levels were evaluated by immunohistochemistry (IHC) and CGA mRNA expression by RT-qPCR. Data were correlated with clinicopathological parameters including comorbidities with known effect on sCGA values and impact on patients' overall (OS) and disease-specific survival (DSS) was calculated.

Results. In the training set, sCGA levels were significantly higher in BC $(63.9 \mathrm{ng} / \mathrm{mL})$ but not in RCC $(30.6 \mathrm{ng} / \mathrm{mL})$ compared to age-matched 97 healthy controls $(29.4 \mathrm{ng} / \mathrm{mL})$. Furthermore, high sCGA levels (cutoff: upper $20 \%)$ were independently associated with poor OS and DSS $(p<0.001$, $p=0.002)$. In RCC, no such correlations were observed. In the BC validation set, a high CGA level (cutoff: upper 20\%) was an independent predictor of poor OS and DSS $(p=0.009, p=0.017)$. sCGA levels were inversely correlated with glomerular filtrating rate (GFR) and linearly correlated with creatinine clearance and urea concentrations. In addition, sCGA levels were significantly higher in elderly individuals in both $\mathrm{BC}$ cohorts and in the control group. These correlations were not related to the prognostic value of CGA in BC. Tissue CGA levels were low to absent in BC independent from sCGA concentration.

Conclusion.

- sCGA is elevated in BC training set compared to healthy age-matched controls

- High sCGA is an independent marker of poor OS and DSS in BC

- The prognostic relevance of sCGA seems not to be related to the presence of impaired renal function or other comorbidities

- The source of high sCGA levels in BC remains to be elucidated

- sCGA levels are not elevated in RCC

\section{AG02.P2.05}

\section{Proteomic distinction of renal oncocytomas and chromophobe renal cell carcinomas}

V. Drendel', B. Heckelmann', C. Schell', L. Kook', M. L. Biniossek², M. Werner', C. Jilg ${ }^{3}$, O. Schilling ${ }^{*}$

'University Medical Center Freiburg, Institute of Surgical Pathology, Freiburg, Germany, ${ }^{2}$ University of Freiburg, Institute of Molecular Medicine and Cell Research, Freiburg, Germany, ${ }^{3}$ University Medical Center Freiburg, Department of Urology, Freiburg, Germany

The distinction of benign renal oncocytomas (ROs) and chromophobe renal cell carcinomas (chRCCs) is in some cases challenging. We aimed for the differential proteome profiling of ROs and early-stage chRCCs in order to better understand their distinguishing protein patterns. Using a discovery cohort of six RO cases and six chRCC cases, we employed explorative proteomics with liquid chromatography-tandem mass spectrometry. At $1 \%$ false discovery rate, we identified and quantified $>3900$ proteins. The proteomic expression profiling clearly discriminated ROs and chRCCs and highlighted established features such as accumulation of mitochondrial proteins in ROs together with emphasizing the accumulation of endo-lysosomal proteins in chRCCs. In particular, we noticed enrichment of lysosomal-associated membrane protein 1 (LAMP1) in chRCC and of integrin alpha-V (ITGAV) in RO. These results were further validated in a considerably larger validation cohort comprising $42 \mathrm{RO}$ cases and 31 chRCC cases. Here, immunohistochemistry (IHC) corroborated enrichment of LAMP1 in chRCC and of ITGAV in RO. Our results strengthen the utility of formalin-fixed, paraffin-embedded specimens for proteomic profiling. We present one of the first differential proteome profiling studies on ROs and chRCCs and highlight differential abundance of LAMP1 and ITGAV in these renal tumors. 
AG02.P2.06

\section{Ceruloplasmin expression in renal cell carcinoma correlates with} higher grade and shortened survival

\section{A. Zimpfer ${ }^{1 *}$, M. Maruschke ${ }^{2,3}$, M. Bastian ${ }^{4}$, H. Zettt $\left.\right|^{5}$, O. W. Hakenberg ${ }^{2}$, P. Schuff-Werner ${ }^{4}$, A. Erbersdobler ${ }^{1}$ \\ 'Universitätsmedizin Rostock, Institut für Pathologie, Rostock, Germany, 2Universitätsmedizin Rostock, Urologische Klinik und Poliklinik, Rostock, Germany, ${ }^{3}$ Urologische Klinik, Helios Hanseklinikum Stralsund, Stralsund, Germany, ${ }^{4}$ Universitätsmedizin Rostock, Institut für Klinische Chemie und Laboratoriumsmedizin, Rostock, Germany, ${ }^{5}$ Zentrales Klinisches Krebsregister M-V, Rostock, Germany}

Aims. Previously, ceruloplasmin (CP) was found significantly overexpressed on transcriptional level in clear cell (cc) renal cell carcinoma (RCC). The present study aimed to analyse CP protein expression in tumor tissues, as well as urine and plasma CP protein levels in RCC patients pre- and postoperatively followed by clinicopathological correlations and survival analysis.

Methods. CP was analysed in serum and urine samples of 65 patients with ccRCC divided into three groups according to histological grade. CP was assayed in Li-Heparin-plasma samples directly after blood sample collection on a Beckman Coulter Image 800 Immunochemistry System. The AssayMax Human Ceruloplasmin ELISA Kit (Fi. ASSAYPRO) was used to detect the levels of $\mathrm{CP}$ in urine samples. Using tissue-microarrays (TMA), immunohistochemical CP expression was analysed in 317 RCC tumor samples. CP expression was defined by cytoplasmatic staining in $>10 \%$ of tumor cells and graded into a two-tiered system (negative, positive). Clinical data included age at diagnosis, sex, grade, stage, therapy, overall survival (OS) and progression-free survival (PFS).

Results. Spearman correlation analysis revealed significantly higher serum and urine CP levels in G3 or G4 tumors versus G1 or G2 ccRCC ( $p=0.041$ and $p=0.006$, respectively). On TMAs, CP expression was found in 121/309 (39.2\%) ccRCC and 2/8 (25\%) unclassified RCCs. Pearson $\chi 2$ tests revealed significant correlations between $\mathrm{CP}$ expression and WHO/ISUP grade $(p=0.009)$, high grade disease $(p=0.001)$ and survival $(p=0.016)$. Log rank tests showed a significant shorter survival in CP positive cases $(p=0.019)$, which was not confirmed in multivariate Cox regression analysis. There was a clear trend to a shorter OS $(p=0.086)$ and PFS $(p=0.068)$ in CP positive high stage RCC.

Conclusions. CP protein expression profiles in ccRCC are in line with previous RNA expression analysis. $\mathrm{CP}$ expression is linked to high grade and high stage disease and reduced survival in RCC. Also, CP protein levels in bio fluid samples confirm this differential $\mathrm{CP}$ expression due to its association with nuclear grade of malignancy in ccRCC.

\section{AG02.P2.07}

\section{Funktionelle Analysen von histonmodifizierenden Enzymen im} klarzelligen Nierenzellkarzinom

P. Lazar-Karsten ${ }^{1 *}$, N. Klümper ${ }^{2}$, I. Werninghaus', J. Dittmer', H. Pasternack', A. Offermann', S. Perner', J. Kirfel

'Pathologie des Universitätsklinikums Schleswig-Holstein, Campus Lübeck und des Forschungszentrums Borstel, Leibniz Lungenzentrum, Lübeck, Deutschland, ${ }^{2}$ Klinik und Poliklinik für Urologie und Kinderurologie, Universitätsklinikum Bonn, Bonn, Deutschland, ${ }^{3}$ Pathologie des Universitätsklinikums Schleswig-Holstein, Campus Lübeck, Lübeck, Deutschland

Ziel. Die Therapieoptionen für Nierenkarzinome beschränken sich bisher meistens auf chirurgische Entfernung des Tumors. Besonders Patienten mit Metastasen haben eine kurze tumorfreie Überlebenszeit. Unsere bioinformatische Analyse der TCGA-Daten zeigten, dass histonmodifizierende Enzyme und im speziellen die Familie der Lysin-Demethylasen KDM2 (KDM2A und KDM2B) und die Histon-Deacetylasen HDAC (HDAC1, HDAC7 und HDAC10) im Vergleich zum tumorfreien Gewebe im klarzelligen Nierenkarzinom signifikant höher exprimiert werden. Eine Überexpression von KDM2A und KDM2B korreliert mit niedriger Überlebens- rate der Patienten und scheint daher das Tumorwachstum zu fördern. Das Ziel der Experimente ist es, ein besseres Verständnis für die Rolle der Lysin-Demethylasen KDM2A und KDM2B und Histon-Deacetyalsen in der Tumorigenese zu gewinnen und zu überprüfen, ob diese als neue Therapieziele in der Behandlung von Patienten mit Nierenzellkarzinom eingesetzt werden können.

Methoden. Zunächst wurden die Ergebnisse der TCGA-Datenanalyse an einer eigenen Kohorte des klarzelligen Nierenzellkarzinoms verifiziert. Anschließend wurden die Expressionslevel von KDM2A, KDM2B und HDACs in verschiedenen Zelllinien des klarzelligen Nierenzellkarzinoms bestimmt und die geeignete Zelllinie für Knockdown- bzw. Überexpressionsexperimente ausgewählt. Um zu zeigen, ob die Mitglieder der Familien der Lysin-Demethylasen und Histon-Deacetylasen eine direkte Rolle in der Tumorigenese spielen, wurde der Effekt von Inhibitoren der Enzyme und von siRNAs gegen das jeweilige Gen durch funktionelle Analysen wie Zellvitalitäts- und Migrationsassay getestet.

Ergebnisse. Transfektionsversuche zeigten für die Histondemethylase KDM2B einen Verlust von Zellvitalität und Zellproliferation, der möglicherweise durch Zellzyklusgene vermittelt wurde, welche die Transition von G1/S-Phase bzw. die DNA-Replikation in der S-Phase beeinflussen. Außerdem scheint KDM2B in der Regulierung von Genen, die für die Migration und epithelial-zu-mesenchymalen Transition (EMT) der Tumorzellen wichtig sind, involviert zu sein.

Fazit. Histonmodifizierende Enzyme scheinen das Tumorwachstum der klarzelligen Nierenzellkarzinome direkt zu beeinflussen, indem sie Zellzyklus- und EMT-assoziierte Gene induzieren oder reprimieren.

\section{AG02.P2.08 \\ Nachweis des Isochromosom i(p12) bei Keimzelltumoren mittels quantitativer PCR}

S. Filmar ${ }^{1 *}$, P. Ströbel', O. Dschun', S. Kaulfuß ${ }^{2}$, F. Bremmer ${ }^{1}$

'Institut für Pathologie, Universitätsmedizin Göttingen, Göttingen, Deutschland, ${ }^{2}$ Institut für Humangenetik, Universitätsmedizin Göttingen, Göttingen, Deutschland

Ziel. Keimzelltumoren (KZT) repräsentieren die häufigsten bösartigen Tumoren bei Männern im Alter zwischen 18 und 35 Jahren. In etwa $80 \%$ der Fälle liegt ein sogenanntes Isochromosom des $p$-Arms des Chromosoms 12 (i(p12)) vor. In seltenen Fällen kann die große morphologische Vielfalt (z.B. somatische Malignität) auch unter zu Hilfenahme immunhistochemischer Untersuchungen ein diagnostisches Problem darstellen. Auch wenn das i(p12) z. B. mittels FISH Analysen nachgewiesen werden kann, gibt es immer wieder Fälle bei denen diese Methode eine zuverlässige Aussage über ein i(p12) nicht zulässt. Die Idee im vorliegenden Projekt war es, eine alternative Möglichkeit zum Nachweis eines i(p12) in KZT zu etablieren.

Methoden. Insgesamt wurden 156 (testikuläre und mediastinale KZT sowie deren Metastasen) Formalin-fixierte und Paraffin-eingebettete (FFPE) Gewebeproben untersucht. Die Kontrollgruppe bestand aus 47 Fällen tumorfreien Hodengewebes, Metastasen anderer Malignome sowie Epidermoidzysten. Aus den Proben wurde DNA extrahiert und mittels quantitativer PCR hinsichtlich des Nachweises eines i(p12) untersucht. Für die Amplifikation bei der PCR wurden vier unterschiedlich lokalisierte Primer für den $12 p$-Arm, zwei für den 12 q-Arm sowie zwei weitere Referenzprimer auf $17 \mathrm{q}$ und $3 \mathrm{p} 2$ definiert.

Ergebnisse. Von 156 untersuchten Tumoren konnten bei 143 (91,1 \%) Proben ein Isochromosom nachgewiesen werden, während 14 Fälle $(8,9 \%)$ kein i(p12) aufwiesen. Bei der Kontrollgruppe konnte ebenfalls kein i(p12) nachgewiesen werden.

Fazit. Die etablierte quantitative PCR eignet sich als Zusatzmethode, um bei unklaren Fällen morphologische und immunhistochemische Befunde sinnvoll zu ergänzen und somit die Diagnose eines KZT zuverlässig sichern zu können. 


\section{AG02.P2.09}

\section{Seminomatöse Hodentumore sind heterogen auf dem Transkirptionslevel}

T. Nestler ${ }^{1 *}$, F. Haidl', M. Wittersheim ${ }^{2}$, P. Dalvi',3, S. Wagener ${ }^{2}$, D. Pfister ${ }^{1}$, M. Hellmich ${ }^{4}$, U. Koitzsch', ${ }^{2,3}$, R. Büttner ${ }^{2,3}$, M. Odenthal ${ }^{2,3}$, A. Heidenreich ${ }^{7}$ 'Universitätsklinik Köln, Klinik für Urologie, Köln, Deutschland, 2Universitätsklinik Köln, Institut für Pathologie, Köln, Deutschland, ${ }^{3}$ Universitätsklinik Köln, Center for Molecular Medicine, Köln, Deutschland, ${ }^{4}$ Universität zu Köln, Institut für Medizinische Statistik und Bioinformatik, Köln, Deutschland

Ziel. Bis zu 40 \% der rein seminomatösen Keimzelltumoren sind bereits zum Zeitpunkt der initialen Diagnose metastasiert. Zusätzlich haben bis zu 20 \% der Patienten eine okkulte Metastasierung, die jedoch bisher aufgrund fehlender Marker nicht diagnostiziert werden können.

Daher ist unsere Hypothese, dass sich metastasierte- und nicht metastasierte Seminome auf molekularer Ebene unterscheiden. Für wenige andere Tumorarten wurde gezeigt, dass Gene, die mit dem Prozess der Metastasierung assoziiert sind, besonders an der Tumorfront häufiger unterschiedlich exprimiert sind. Deshalb untersuchten wir verschiedene Tumorareale von Seminomen bei nicht metastasierten und metastasierten Patienten.

Methoden. Eingeschlossen wurden seminomatöse Hodentumorpatienten; nichtmetastasierte Patienten ohne adjuvante Therapie und mit einem rezidivfreien Follow-up von mindestens zwei Jahren $(n=21)$ sowie Patienten mit Metastasen bei initialer Diagnose $(n=14)$. Aus FFPE-Hodentumorgewebe wurden die Regionen der Tumorfront (TF) und des Tumorzentrums (TC) bei jedem Patienten identifiziert und mittels Laser-CaptureMikrodissektion separiert. Aus allen TF- und TC-Proben wurde die RNA extrahiert und eine Multiplex-Genexpressionsanalyse erfolgte mittels der nCounter-Technologie von Nanostring. 770 bekannte Onkogene wurden mit dem PanCancer Progression Panel analysiert. Zur Analyse der Expressionsdaten wurden verschiedene bioinformatische Methoden verwendet. Ergebnisse. Die hierarchische Clusteranalysis zeigte keine unterschiedlichen Gencluster zwischen metastasierten und nicht-metastasierten $\mathrm{Pa}$ tienten. In der metastasierten Gruppe waren in der TF verglichen mit dem TC mehr Gene (29 Gene) signifikant unterschiedlich exprimiert ( $\log 2$ fold change $>1,5$, FDR $<0,05)$ im Vergleich zu den nicht metastasierten $\mathrm{Pa}$ tienten (12 Gene).

Ein Vergleich von TF und TC für jeden einzelnen Patienten zeigte eine stark variierende Genexpression zwischen diesen beiden Bereichen. Die Lasso-Regressionsanalyse konnte für das TC keine Gensignatur zur Vorhersage von Metastasen aufzeigen. Jedoch reichte für die TF eine Signatur von nur sechs Genen aus, um Metastasen mit einer Spezifität von $100 \%$ und einer Sensitivität von 92,9\% vorherzusagen.

Fazit. Die Studie beschreibt erstmalig die Tumorheterogenität von Seminomen und eine Gensignatur, die Metastasen vorhersagen könnte und an okkult metastasierten Hodentumoren validiert werden sollte.

\section{AG Kinder- und Fetalpathologie Poster}

\section{AG03.P.01 \\ Post mortem examination of a female baby with placental TRPV6 defect \\ E. Gradhand ${ }^{1 *}$, A. Mason 1 , C. Burren ${ }^{2}$ \\ 'Severn Pathology, Histopathology, Bristol, United Kingdom, ${ }^{2 B}$ Bristol Royal Hospital for Children, University Hospitals Bristol NHS Foundation Trust, Department of Paediatric Endocrinology, Bristol, United Kingdom}

Aim. Insufficient maternal-fetal calcium transport across the placenta can cause transient neonatal hyperparathyroidism (TNHP) with associated skeletal abnormalities. Recently, six cases of TNHP have been associated with mutations in TRPV6 (transient receptor potential cation channel, subfamily V, member 6), an epithelial calcium-selective channel.
Methods. We report the findings at post mortem of an infant with antenatal-onset skeletal dysplasia and compound heterozygous TRPV6 likely pathogenic variants. At 20 weeks antenatal scan this infant had rib and chest wall deformities, pulmonary hypoplasia and polyhydramnios. She required ventilation from birth. Early antenatal skeletal survey confirmed severe osteopenia with multiple rib and metaphyseal fractures. Calcium and phosphate metabolism normalised with increased bone density, but she remained ventilator dependent. At 17 weeks of age she suffered two cardiac arrests leading to multi-organ failure and intensive care was withdrawn.

Results. Post mortem showed evidence of abnormal bone architecture on macroscopic and microscopic examination. Bendy bones with reduced bony trabeculae were noted. On microscopy, the growth plates showed increased activity of the chondrocytes but normal architecture of the growth zone reflecting the postnatal normalisation of calcium availability. Similarly, the post mortem skeletal survey showed much improved bone density but with short ribs and reduced thoracic volume. Borderline lung hypoplasia was present with microscopic features in keeping with multi-organ failure. Cardiac microscopic examination showed mild hypertrophy and disarray of the cardiomyocytes with a normal conduction system. The histological findings were non-specific and consistent with adrenaline and/ or corticosteroid administration. Placental histology shows no significant abnormalities on routine stains.

Conclusion. This is the first reported post mortem in a patient with skeletal dysplasia secondary to TRPV6 variants. Disrupted placental calcium transfer leads to abnormal in utero skeletal mineralisation which improves with normal calcium availability postnatally. Interestingly, the skeletal abnormalities were apparent earlier antenatally than in previous reported cases and the clinical course was more severe.

\section{AG03.P.02}

Hochgradige Reduktion der Cajalzellen - isolierte Ursache einer CIPO oder Befund im Rahmen eines Syndroms?

\section{A.M. Müller ${ }^{*}$, G. R. Ortner ${ }^{2}$, C. Staude ${ }^{3}$}

'Praxis für Pathologie an der Uniklinik Köln, Zentrum für Kinderpathologie, Köln, Deutschland, ${ }^{2}$ Universitätsklinik Düsseldorf, Klinik für Allgemeine Pädiatrie, Neonatologie und Kinderkardiologie, Düsseldorf, Deutschland, ${ }^{3}$ Universitätsklinik Düsseldorf, Abteilung für Kinderchirurgie, Düsseldorf, Deutschland

Ziel. Häufigste Ursache einer Darmtransportstörung ist eine Aganglionose oder eine nekrotisierende Enterokolitis (NEC), seltener intestinale Atresien, ganz selten degenerative oder entzündliche viszerale oder neuronale Schädigungsmuster. Vorgestellt wird ein subtotales Fehlen von Cajalzellen als Ursache einer Darmtransportstörung.

Falldarstellung. 4-monatiges männliches, ehemaliges Frühgeborenes der $36+0$ SSW. Vorstellung mit 2 Monaten bei ausgeprägter Gedeihstörung und Ess-Fütter-Störung trotz Sondenernährung. Aufnahmebefund: sehr agitierter Säugling. Gewicht: 3800 g (<1.P). Körperlänge: 54 cm (1.P). Im weiteren Verlauf zunehmende neurologische Auffälligkeiten mit ophistothoner Körperhaltung und - vor allem bei den Mahlzeiten - starker motorischer Unruhe bei unauffälligen EEGs. Radiologische zerebrale Bildgebung: unspezifische Veränderungen mit Balkenhypoplasie und diskreten Kleinhirnveränderungen. Gastroenterologisches Leitsymptom: rezidivierendes Erbrechen, das selbst unter Aminosäurennahrung und jejunaler Dauersondierung persistierte. Kein Durchfall. Keine Obstipation. Unter hochkalorischer total parenteraler Ernährung nahezu stagnierender Gewichtsverlauf. Endoskopisch keine Hinweise auf eine Magen-Darm-Passagestörung, intestinale Stenosierung oder Dilatation.

Bei intermittierend galligem Erbrechen und akutem Abdomen intraoperativ Ausschluss eines Volvolus und Diagnose einer Malrotation Typ 1. Entnahme von Proben aus Dünn- und Dickdarm für die immun- und enzymhistochemisch sowie elektronenmikrokopische Diagnostik.

Pathomorphologische Untersuchungsergebnisse. Morphologisch regelrechte Dünn- und Dickdarmwand mit regelrechten Ganglienzellen, insbesondere regelrechte Struktur der Muscularis propria mit ausreichen- 
der bindegewebiger Verschiebeschicht. Keine Entzündungszeichen. Keine Vernarbungen. Immunhistochemie: subtotales Fehlen von Cajalzellen. Fazit. Bei Ausschluss einer Aganglionose, autoimmunen Leiomyositis, Ganglionitis, degenerativen Veränderungen der Muscularis propria i.S. einer primären oder sporadischen viszeralen Myopathie, fokalem/segmentalen Verlust der glatten Muskulatur, alpha-Glattmuskel-Aktin-Mangel, sog. Honeycomb-Fibrose oder Desmosis coli jedoch subtotalem Fehlen von Cajal-Zellen ist der Mangel an Cajal-Zellen als Ursache der Darmtransportstörung anzusehen. Differentialdiagnostisch ist dieser Befund in Assoziation mit einer syndromalen sensorischen und autonomen Neuropathie zu diskutieren. Eine Whole-Exome-Sequenzierung steht an.

\section{AG03.P.03 \\ Bisher nicht beschriebene Leber-, Thymus- und einseitige Nebennierenaplasie sowie Lungenhypoplasie}

\section{J. Fries ${ }^{*}$, N. Sarioglu², A. M. Müller ${ }^{3}$}

'Universität zu Köln, Institut für Pathologie, Köln, Deutschland, ${ }^{2}$ Charité Universitätsmedizin Berlin, Institut für Pathologie/Sektion Paidopathologie, Berlin, Deutschland, ${ }^{3}$ Praxis für Pathologie, Zentrum für Kinderpathologie an der Uniklinik Köln, Köln, Deutschland

Ziel. Berichte über eine Leberhypoplasie sind selten. Berichte über eine Leberagenesie findet man so gut wie gar nicht. Dies mag daran liegen, dass eine Leberagenesie auch mit einem fetalen Leben nicht vereinbar ist. Wir berichten über einen intrauterin in der 25. Gestationswoche verstorbenen Feten mit Leber-, Thymus- und einseitiger Nebennierenaplasie.

Klinische Angaben und durchgeführte Untersuchungen. Männlicher Fet der 25 SSW. Lt. klinischen Angaben IUFT; konnatale Infektionen ausgeschlossen. Fetale Obduktion und anschließende histologische Untersuchung.

Obduktionsbefunde. Hochgradig autolytischer, makrokopisch eumorpher männlicher Fet von $370 \mathrm{~g}$ Gewicht, $20 \mathrm{~cm}$ SSL, Fußlänge von $32 \mathrm{~mm}$ (jeweils entsprechend 19.-20. SSW). Situs solitus mit regelrechter kardialer, system- und pulmonalveöser Konnektionen. Lungenhypoplasie beidseits. Keine Anlage eines Thymus, der Leber und der rechten Nebenniere. Nachweis einer Gallenblase. Im Bereich des rechten Oberbauchs ein verzweigtes Gefäßnetz mit zentralem Ductus venosus von der Nabelschnur bis zum rechten Vorhof verfolgbar, passend zum Lebergefäßsystem.

Fazit. Es handelt sich nach unserer Literatursuche um den 4. Bericht einer Leberagenesie, in unserem Fall assoziiert mit einer Thymus- und einseitigen Nebennierenagenesie. Diese Assoziation ist bisher nicht beschrieben. Die Leber stellt beim Feten im 2. Trimenon nicht nur ein zentrales Stoffwechselorgan dar, sondern ist auch zentraler Ort der (extramedullären) Blutbildung. Eine Leberagenesie ist mit einem Leben nicht vereinbar. Die Ausbildung der Gallenblase bei fehlender Leber ist möglich, da beide Organe sich unabhängig voneinander entwickeln. Das Lebergefäßsystem entsteht aus dem Dottersackgefäßsystem und der Nabelvene, und zwar bevor die Lebernparenchymzellen ausgebildet werden. Bei dem hier statt einer Leber nachweisbaren Gefäßnetz dürfte es sich um das ursprünglichen Dottersack-/Nabelgefäßsystem handeln, das nicht von Leberparenchymzellen umwachsen wurde.

Bzgl. der Genese der Leber- und Thymusagenesie sowie der Lungenhypoplasie ist eine Herunterregulirung des Homebox Gens Hex zu diskutieren, das eine zentrale Bedeutung für die Ausbildung von Leber, Thymus und Lunge hat und das gemeinsame Fehlen von Leber und Thymus sowie die Lungenhypoplasie erklären könnte.

\section{AG03.P.04}

\section{Letaler Epignathus - Fallbericht einer seltenen Entität}

T. Hager ${ }^{1 *}$, F. Körber ${ }^{2}$, A. M. Müller ${ }^{3}$, J. Fries ${ }^{4}$

'Universitätsklinikum Essen, Institut für Pathologie, Essen, Deutschland, 2Uniklinik Köln, Abteilung für Kinderradiologie, Köln, Deutschland, ${ }^{3}$ Uniklinik Köln, Praxis für Pathologie/Zentrum für Kinderpathologie, Köln, Deutschland, ${ }^{4}$ Uniklinik Köln, Institut für Pathologie, Köln, Deutschland
Hintergrund. Fetale Teratome sind meist in der Sakrococcygealregion lokalisiert. Nur sehr selten findet man sie cervicofacial. Noch seltener sind rhinopharyngeael Teratome. Sie werden bei Lokalisation im Bereich der Mundhöhle und/oder Pharynx als Epignathus bezeichnet. Der Tumor besteht aus allen 3 Keimblättern. Die Anlage ist mehrheitlich im Bereich des Os sphenoidale zu finden. Aufgrund ihrer intrakraniellen und/oder laryngealen Ausdehnung führen sie oft zu einer respiratorischen Insuffizienz. Die Operabilität hängt vom Ausmaß des Tumors ab.

Methoden. Wir berichten über einen männlichen, in der 31. SSW per Sectio caesarea geborenen Jungen mit einem bereits pränatal diagnostizierten, das gesamte Mittelgesicht und den Unterkiefer überformenden Tumor. Der Tumor war pränatal im Ultraschall bereits diagnostiziert worden. Bei Inoperabilität verstarb das Kind wenige Stunden postpartal. Radiologische und pathomorphologische Befunde werden demonstriert.

Ergebnisse. Im Rahmen der Obduktion wurde ein $120 \mathrm{~g}$ schwerer, das gesamte Mittelgesicht und den Unterkiefer überformender Tumor, abpräpariert. Weitere Fehlbildungen fanden sich nicht. Als Ausgangspunkt des Tumors konnte das Gaumendach identifiziert werden. Durch die Tumorausdehnung zeigte sich eine Zerstörung des Schädeldachs. Histologisch konnte ein aus allen drei Keimblättern aufgebautes Teratom bestätigt werden.

Fazit. Oropharyngeale Teratome entstammen von kraniofazialen Strukturen. Sie machen 2-9\% aller humanen Teratome aus. Die Ätiologie ist bisher unbekannt. 48 Fälle wurden, laut unserer Recherche, bisher publiziert. Der Tumor kann gemäß seiner Topographie als episphenoides, als epipalatines Teratom oder Epignathus klassifiziert werden. Histologisch sind craniofaziale Teratome aufgebaut aus Mesoderm und Ektoderm und entsprechen einem Dermoid oder als sog. echte Teratome aus Abkömmlingen aller drei Keimblätter. Im Gegensatz zum vorliegenden Fall ist der Epignathus, lt. Literatur, oft mit weiteren Fehlbildungen assoziiert.

\section{AG03.P.05 \\ Diprosopus. Vom Parapagus diprosopus zum Cephalopagus diprosopus}

K. Schoner ${ }^{1 *}$, S. G. Kircher ${ }^{2}$, H. Rehder ${ }^{1,2}$

'Philipps-Universität Marburg/UKGM GmbH Standort Marburg, Institut für Pathologie - Bereich Fetalpathologie, Marburg, Deutschland, ${ }^{2}$ Medizinische Universität Wien, Institut für Medizinische Genetik, Wien, Österreich

Ziel. Die erste erhaltene Darstellung eines Diprosopus als ,double goddess woman sharing power' stammt aus Mexiko um etwa 1000 BCE. Die ersten wissenschaftlichen Veröffentlichungen hierzu erfolgten 1664, 1779 und 1861 durch Heiland, Pestalozzi und Förster. Weitere Fallberichte folgten. Insgesamt sind weltweit 36 Diprosopusfälle dokumentiert. Wir fügen diesen Beobachtungen sechs neue Fälle hinzu unter besonderer Berücksichtigung von Form und Ausmaß der Doppelfehlbildung und der begleitenden inneren Fehlbildungen.

Methoden. Vier betroffene weibliche Feten der 19. bis 39. SSW wurden fetalpathologisch und röntgenologisch untersucht und die Befunde photographisch dokumentiert. Zwei Exponate der pathologischen Sammlung im ,Narrenturm' des kunsthistorischen Museums in Wien wurden einer 3D-Computertomographie unterzogen.

Ergebnisse. Der faciale Phänotyp ist wesentlich durch das Ausmaß der Doppelfehlbildungen geprägt. Er reicht von der Verdoppelung nur der Nase und/oder der oralen Strukturen bis hin zur Verdoppelung des gesamten Gesichts mit getrennten oder fusionierten Orbitae und Ohren in der Mittellinie. Eine Sonderform stellt der Janus-Typ eines Diprosopus dar. Entsprechend der Lokalisation der facialen Doppelstrukturen sind auch Schädelknochen, Hypophyse und Gehirn von zumeist partiellen Verdoppelungen betroffen. Die häufigsten Begleitfehlbildungen sind die bevorzugt cranialen Neuralrohrdefekte und die LKG-Spalten. Mögliche innere Fehlbildungen betreffen Zwerchfell und Herz.

Fazit. Der Diprosopus gehört mit einer Prävalenz von 2:1.000.000 zu den extrem seltenen sog. ,Orphan Diseases. Den bisher publizierten 36 Fällen stehen 6 eigene Beobachtungen gegenüber. Die Ursache der facialen Doppelfehlbildungen ist unbekannt. Die Frage, ob es sich hierbei um ei- 
nen Mittelliniendefekt oder um eine frühe (12.-15. Tag p.c.) inkomplette Zwillingsbildung handelt, wird kontrovers diskutiert. Hinsichtlich der phänotypischen Übergänge bis hin zum Dicephalus, der Prädominanz des weiblichen Geschlechts, auch in unseren Fällen, und der bisher fehlenden Hinweise für zugrundeliegende Gendefekte, ist letztere Hypothese zu befürworten. Die Möglichkeit korrektiver Maßnahmen bei partiellem Diprosopus setzt die Kenntnis der Anatomie der betroffenen Strukturen und der Begleitfehlbildungen voraus.

\section{AG03.P.06 \\ Männliches Frühgeborenes mit multiplen intrauterinen Herzinfarkten bei kongenitalem Hydrops}

\section{E. Lippe ${ }^{1 *}$, D. Ridder', S. Kunzmann' ${ }^{2}$, W. Roth' ' L. Seidmann ${ }^{1}$}

'Universitätsmedizin Mainz, Institut für Pathologie, Mainz, Deutschland, ${ }^{2}$ Bürgerhospital und Clementine Kinderhospital, Klinik für Neonatologie, Frankfurt am Main, Deutschland

Ziel. Intrauterin auftretende Herzinfarkte sind eine seltene Diagnose mit einem Sterberisiko von bis zu 80-90 \%. Die Schwierigkeit einer korrekten Diagnose ist bei überwiegend unspezifischen, in einer Vielzahl neonataler Krankheitsbilder vorkommenden Symptomen hoch. Identifikation des Wiederholungsrisikos und Planung präventiver Maßnahmen für folgende Schwangerschaften sind wichtige Ziele der pathomorphologischen Untersuchung.

Wir berichten über einen 10 Tage alt gewordenen Zwilling der 24+2 SSW mit klinisch unklarer Kardiomegalie, kongenitalem Hydrops und postnatal therapierefraktärer kardio-respiratorischer Insuffizienz mit Pneumothorax. Beim Geminipartner wurde eine Gehirnblutung und nekrotisierende Enterokolitis diagnostiziert.

Methoden. Im Rahmen einer Obduktion wurden makroskopische und radiologische, sowie an den hierbei entnommenen Gewebeproben histologische, immunhistochemische und elektronenmikroskopische Untersuchung durchgeführt.

Ergebnisse. Das untersuchte Frühgeborene wies multiple ältere Herzinfarkte mit reaktiver Kardiomegalie und Hyperplasie der Kardiomyozyten auf. Eine primäre Kardiomyopathie, ebenso wie kardiale Fehlbildungen und entzündliche Veränderungen wurden morphologisch ausgeschlossen. Zudem wurden hämorrhagische Infarkte der rechten Lunge und unilaterale pulmonale Lymphangiektasien mit intestitiellem Emphysem der linken Lunge als morphologisches Korrelat des linksseitigen Pneumothorax bei postnatalem unreifebedingtem Air-Leak-Syndrom diagnostiziert.

Im Vordergrund der postnatal infaust verlaufenden Erkrankung des Kindes standen die multiplen Herzinfarkte mit kompensatorischer Kardiomegalie und progredienter globaler Herzinsuffizienz mit Hydrops. Es handelt sich hier um eine pränatale thrombembolische Erkrankung beider Geminipartner mit unterschiedlichem klinisch-morphologischem Schädigungsmuster. Zur Ätiologie der pränatalen Gerinnungsstörung konnte auf Basis der morphologischen Befunde keine sichere Aussage getroffen werden. Zwecks Bestimmung des Wiederholungsrisikos sollten eine erbliche Thrombophilie, sowie ein latent verlaufender Gestationsdiabetes der Mutter klinischerseits ausgeschlossen werden.

Fazit. Intrauterine Herzinfarkte sind eine seltene Komplikation bei pädiatrischen Patienten mit kongenitalem Hydrops und stellen ein komplexes Problem der interdisziplinären Differentialdiagnostik und Therapie für Frühgeborene/Neugeborene dar.

\section{AG03.P.07}

Meconium periorchitis - an unconventional differential diagnosis of the acute scrotum and unclear infantile scrotal tumor mass

H. Krause', A. Biering' ', L. von Rhoden ${ }^{3}$, S. Kroker', P. Buhtz', F. Meyer ${ }^{5 *}$, S. Turial ${ }^{6}$

'Dept. of General, Abdominal, Vascular and Transplant Surgery, University Hospital, Division of Pediatric Surgery, Magdeburg, Germany, ${ }^{2}$ Municipal Hospital - Klinikum Wolfsburg, Dept. of Pediatrics, Wolfsburg, Germany, ${ }^{3}$ Dept. of Radiology and Nuclear Medicine, University Hospital, Division of Pediatric Radiology, Magdeburg, Germany, ${ }^{4}$ Institute of Pathology, University Hospital, Magdeburg, Germany, ${ }^{5}$ Dept. of General, Abdominal, Vascular and Transplant Surgery, University Hospital, Magdeburg, Germany, ${ }^{6}$ Municipal Hospital - HELIOS Dr. Horst Schmidt Kliniken, Dept. of Pediatric Surgery and Congenital Malformations, Wiesbaden, Germany

Background. Meconium periorchitis is a rare disease, which i) is characterized by an asymptomatic scrotal tumor lesion,

ii) imposes as ,acute scrotum“ and

iii) predicts a meconium-induced peritonitis including intrusion of meconium via the open "Processus vaginalis testis" from a pathogenetic point of view.

The therapeutic profile varies from clinical observation to orchidectomy, which is rarely necessary in retrospect.

Aim. Sensitisation of the junior staff in pediatric surgery to take into account meconium periorchitis for differential diagnosis and to avoid unnecessary procedures, such as orchidectomy.

Method. Compact short overview including a selective literature search and own clinical experiences in daily practice as well as a representative clinical case.

Results (corner points).

- Following the first description by Olnick et Hatcher (in 1953), there were 61 cases in the literature until 2009 according to Jeanty et al. $(n=62$ cases including the own patient).

- A precise incidence is not known-that one of meconium peritonitis is 1:35,000 live births (age of first diagnosis, 4 weeks).

- As diagnostic measures, symptomatology aspects as well as pre- and postpartal ultrasound findings were used-in addition, imaging modes such as X-ray (abdominal plain film), CT scan, MRI.

- The therapeutic spectrum ranged from „wait and see“ to orchidectomy; however, it has been established that in case of adequate knowledge on the disease, orchidectomy is actually not necessary. Due to the association of meconium peritonitis with cystic fibrosis, screening is recommended.

- Exemplary case: Premature baby (36th week of pregnancy) with pronounced disturbance of enteral feeding and inflated abdomen underwent surgical exploration due to bilateral hydroceles of atypical appearance, which confirmed the suspected diagnosis of a meconium periorchitis. Under protection of the testicles, meconium was removed. Postoperative course was uneventful.

Conclusion. In case of correct diagnosis, a "wait-and-see" approach seems to be appropriate consulting an interdisciplinary team of gynecologist, neonatologist and pediatric surgeon. In doubt of this, e. g., in case of suspected torsion, incarceration or tumor lesion, an exploration is recommended. Radiological (X-ray based) imaging needs to be limited to a minimum due to the today's great standard of "high-end" ultrasound options.

\section{AG03.P.08}

Totale Kolonaganglionose - diagnostische und therapeutische Herausforderung anhand eines Fallbeispiels

S. Kiefer ${ }^{1 *}$, U. Teufel-Schäfer ${ }^{2}$, W. Kluwe ${ }^{3}$, M. Werner', S. Huber-Schumacher' ${ }^{1}$ Institut für klinische Pathologie, Universitätsklinikum Freiburg, Freiburg, Deutschland, ${ }^{2}$ Klinik für Allg. Kinder- und Jugendmedizin, Universitätsklinikum Freiburg, Freiburg, Deutschland, ${ }^{3}$ Klinik für Allgemeinund Viszeralchirurgie, Abteilung Kinderchirurgie, Universitätsklinikum Freiburg, Freiburg, Deutschland 
Hintergrund. Die Häufigkeit der totalen Kolonaganglionse (TCA) als sehr schwere Form eines M. Hirschsprung (HD) wird mit 2-13\% aller HDs angegeben. In $75 \%$ dieser Fälle ist zusätzlich mindestens das terminale Ileum mitbetroffen (Jirásek-Zuelzer-Wilson-Syndrom). In 50 \% der Fälle liegt dabei eine Mutation in RET vor.

Die klinische Symptomatik weicht meist von der des kurzstreckigen HD ab bzw. tritt verzögert auf, wodurch sich die klinische Diagnostik erschwert Neben der Rektumsaugbiopsie sind zur Bestimmung des aganglionären und des hypoganglionären Segments unbedingt laparoskopisch gewonnene seromuskuläre Stufenbiopsien nötig. Essentiell ist dabei die Bestimmung der hypoganglionären Zone, um möglichst viel Rest-Darm zu erhalten und die Spät-Komplikationen zu mindern.

Fallbeispiel mit klinischem Verlauf. Wir berichten über ein weibliches Neugeborenes mit Anlage einer Bishop-Koop-Anastomose bei Mekoniumileus am 4. Tag postpartal. Der Verdacht auf eine TCA wurde 1 Monat postpartal durch erste Biopsien aus dem Colon descendens und einem Ileum-Teilresektat geäußert. Zwei Monate postpartal erfolgte die Diagnosesicherung und Bestimmung des aganglionären Segments anhand 16 seromuskulärer Biopsien aus Rektum, gesamten Kolon und Dünndarm bis $20 \mathrm{~cm}$ ab Treitz'schem Band (z. T. via Schnellschnittanalyse). Der Nachweis von Ganglienzellen gelang bei $70 \mathrm{~cm}$ ab Treitz. Die mehrfach notwendige Stomaanlage erfolgte im hypoganglionären Segment. Klinisch bestand zunächst ein Kurzdarmsyndrom. Aktuell erfolgt eine parenterale Ernährung mit zusätzlicher oraler Ernährung (150-200 ml Brei/Tag). Das Mädchen zeigt jetzt ein Perzentilen-paralleles Gedeihen. Eine humangenetische Analyse im Verlauf ist geplant.

Zusammenfassung. Die TCA ist ein seltenes Krankheitsbild, welches Pädiater, Kinderchirurgen und Pathologen vor große diagnostische und therapeutische Herausforderungen stellt. Unser Fallbericht verdeutlicht das Vorgehen bei der histomorphologischen Diagnostik mit Hilfe der Enzymhistochemie zur Bestimmung der Aganglionose und des hypoganglionären Segmentes. Auf Grund des Vorliegens einer kausalen Keimbahnmutation im RET-Gen (bis $50 \%$ ) und hohem Wiederholungsrisiko sollten eine genetische Beratung der Eltern und eine humangenetische Testung des betroffenen Kindes erfolgen.

\section{AG03.P.09 \\ Lipom des Retroperitoneum - seltene Ursache für eine Beeinträchtigung der kindlichen Darmpassage}

T. Hager ${ }^{1 * 2}$, P. Hechenleitner ${ }^{3}$, K. Freund-Unsinn ${ }^{4}$, J. Hager ${ }^{3}$

'Institut für Pathologie, Universitätsklinikum Essen, Essen, Deutschland, ${ }^{2}$ Institut für Pathologie, Medizinische Universität Innsbruck, Innsbruck, Österreich, ${ }^{3}$ Department Operative Medizin, Abteilung für Kinder- und Jugendchirurgie, Medizinische Universität Innsbruck, Innsbruck, Österreich, ${ }^{4}$ Universitätsklinik für Radiologie, Kinderradiologie, Medizinische Universität Innsbruck, Innsbruck, Österreich

Ziel. Fettgewebstumoren zählen mit einer Inzidenz von 16 \% zu den häufigsten vom Weichgewebe ausgehenden Tumoren. Differentialdiagnosen sind das Lipom, (insbes. im Kindesalter) das Lipoblastom und das Liposarkom. Bei Kindern kommen, im Gegensatz zu den Erwachsenen, Fettgewebstumoren (insbes. der Bauchhöhle) selten vor. Im Rahmen der präoperativen Diagnostik ist die Frage nach dem biologischen Verhalten intraabdomineller/retroperitonealer Fettgewebstumore oft nicht sicher zu klären. Diese Herausforderung wird mit dieser Kasuistik diskutiert.

Kasuistik. Ein Patient (m, 11 Jahre) wurde wegen eines seit 5 Wochen intermittierend auftretenden Druckgefühls in abdomine an einem auswärtigen Krankenhaus vorgestellt. Da der klinische Befund (Abdomen, Routinelabor) unauffällig war, wurde auf eine additive Sonographie verzichtet und eine konservative Therapie angeraten, auf die sich die Beschwerden kurzzeitig zurückbildeten. Vier Monaten später wurde der Patient wegen nunmehr bestehender Bauchschmerzen wieder vorgestellt. Bei der Untersuchung ergab sich der Verdacht auf ein Tumorgeschehen im rechten Hemiabdomen bei wieder unauffälligen Laborparametern. Bildgebend (Sonographie, MRT) wurde eine Fettgewebsgeschwulst im rechten Mittel-/ Unterbauch diagnostiziert. Der Patient wurde deshalb an die Innsbrucker
Kinderchirurgie überwiesen. Nach klinisch-pathologischer Besprechung wurde auf eine - diskutierte - Tumorpunktion verzichtet und die Indikation zur Tumorresektion gestellt. Bei der Laparotomie zeigte sich im rechten Mittelbauch ein scharf abgegrenzter lipomatöser Tumor mit Verdrängung bzw. Impression des Coecums und Colon ascendens. Die Exstirpation erfolgte in toto. Histopathologisch handelte um ein $15 \times 13 \times 5,5 \mathrm{~cm}$ großes und $160 \mathrm{~g}$ schweres reifes Lipom. Der postoperative Verlauf sowie das weitere Follow-Up (Kontrollen 6 u. 10 Monate bzw. 5 Jahre nach OP) waren unauffällig.

Fazit. Retroperitoneale Fettgewebstumore gelten bei Kindern als Seltenheit. Symptome wie abdominelles Druckgefühl, Schmerzen und/oder eine Beeinträchtigung der Darmperistaltik können bei entsprechender Tumorgröße auftreten, sind aber kaum diagnostisch wegweisend. Die Bildgebung ist allerdings i.d. R. konklusiv, das biologische Verhalten jedoch nicht immer sicher zu bewerten. Da diesbezüglich eine Tumorpunktion nicht weiterführt, sind eine radikale Tumorresektion und eine histopathologische Klärung des Tumorverhaltens indiziert.

\section{AG03.P.10 Ungewöhnlicher zystischer Befund am Auge}

H. Göbel ${ }^{*}$, A. M. Lentzsch ${ }^{2}$, L. M. Heind ${ }^{2}$

${ }^{1}$ Uniklinik Köln, Institut für Pathologie, Köln, Deutschland, ${ }^{2}$ Uniklinik Köln, Klinik für Augenheilkunde, Köln, Deutschland

Ziel. Wir präsentieren den Fall eines 5 jährigen Mädchens, das einen seit 2 Jahren bestehenden, schmerzlosen Exophthalmus aufwies. Es bestand laut Fremdanamnese der Mutter kein Visusproblem oder eine Diplopie. Jedoch lag teilweise ein Lidschlussdefekt während des Schlafens vor.

Methoden. Bei der ophthalmologischen Untersuchung ergab sich keine Visusminderung, der Lidschluss war im wachen Zustand erhalten. Es erfolgten eine Echographische und MRT-Untersuchung, die eine zystische retrobulbäre Raumforderung zeigten. Die zusätzliche serologische Abklärung und eine Vorstellung in der Pädiatrie rundeten die intiale Untersuchung ab. Hierbei ergaben sich im Differentialblutbild, in der Gerinnungsuntersuchung sowie bei Leber- und Nierenwerten keine Auffälligkeiten. CRP war negativ. Die Zyste wurde operativ vollständig entfernt und histologisch aufgearbeitet.

Ergebnisse. Hierbei zeigten sich überraschend zahlreiche Scolices passend zu einer Hydatidenzyste. Bei den weiteren Untersuchungenergaben sich keine zweiteren Absiedelungen. Bis zur letzten Untersuchung in 2018 zeigte sich nach postoperativer Behandlung mit 2 Zyklen Albendqzol für 28 Tage ein unauffälliger Verlauf.

Fazit. Bei zystischen Läsionen sollte differentialdiagnostisch eine Echinokokkose bedacht werden.

\section{AG03.P.11 \\ Clinicopathological correlation of fetal defects following medical and surgical termination of pregnancy in a large cohort: a comparison}

\section{Boecking ${ }^{1 *}$, A.M. Müller ${ }^{2}$}

'University of California, San Francisco, Pathology, San Francisco, United States, ${ }^{2}$ Praxis für Pathologie/Zentrum für Kinderpathologie, an der Uniklinik Köln, Cologne, Germany

Aim. Despite the advances in postmortem fetal imaging, pathology examinations are still recognized as the gold standard for confirming prenatally diagnosed fetal anomalies. Increasingly popular surgical abortion techniques, such as Dilation \& Evacuation [D\&E], provide fragmented and/or incomplete specimens, making clinicopathological correlation difficult and imperfect compared to medical induction terminations, generally yielding intact specimens. In this study, we correlate pathology findings with prenatal diagnoses in intact and D\&E specimens.

Methods. Clinicopathological correlation of fetal specimens from 2 institutions was performed over a 5 year period. Clinical and pathology findings in 416 intact fetuses obtained in Germany and 413 D\&E specimens 
terminated in the USA were correlated. Termination of pregnancy was based on abnormal prenatal ultrasound examination and abnormal karyotype, categorized into 1 of 7 groups (chromosomal aberrations, body cavity, central nervous system [CNS], cardiac, genitourinary, musculoskeletal and miscellaneous defects). Cases with multiple defects were also assigned to an additional category, multiple anomalies.

Results. Induction termination was based on 4 body wall, 25 cardiac, 60 CNS, 25 genitourinary, 29 musculoskeletal, 35 miscellaneous defects, 98 cases with multiple anomalies, and 141 chromosomal aberrations. D\&E was performed for 9 body wall, 17 cardiac, 89 CNS, 14 genitourinary, 13 musculoskeletal, 32 miscellaneous defects, 104 cases with multiple anomalies, and 135 chromosomal aberrations. Overall, at least one prenatally diagnosed anomaly was confirmed in $92 \%$ of the intact specimens, with complete agreement in $71 \%$ of major defects, and $56 \%$ of D\&E cases with complete agreement in $41 \%$. Autopsy of intact specimens supplemented prenatal diagnoses in $62 \%$ and altered them in $69 \%$, compared to $28 \%$ of additional findings and $37 \%$ of diagnostic alterations in fragmented specimens. Miscellaneous defects, e.g. facial clefts, had the highest correlation rate among intact specimens (74\%), whereas most consistent agreement was seen in musculoskeletal defects following D\&E (70\%).

Conclusion. In a substantial number of intact and fragmented fetal specimens, examination corrects or refines prenatal diagnoses; however, induction termination should be favored if complete cataloguing of anomalies is crucial for subsequent genetic counseling.

\section{AG03.P.12}

\section{Gastrointestinal involvement in two cases with multisystem Langerhans Cell Histiocytosis}

\section{A. Honhold' ' H. Rees' ${ }^{2}$ E. Volonaki', D. Basude', C. Spray', E. Gradhand ${ }^{3 *}$ 'Bristol Royal Hospital for Children, University Hospitals Bristol NHS Foundation Trust, Department of Paediatric Gastroenterology, Bristol, United Kingdom, ${ }^{2}$ Bristol Royal Hospital for Children, University Hospitals Bristol NHS Foundation Trust, Department of Paediatric Oncology, Bristol, United Kingdom, ${ }^{3}$ Severn Pathology, Histopathology, Bristol, United Kingdom}

Introduction. Langerhans Cell Histiocytosis (LCH) is a rare disorder in which there is dysregulation of antigen-presenting dendritic cells. Primarily LCH affects the skin or bones but can involve a variety of the bodies systems including the gastrointestinal (GI) tract. The incidence is estimated at 4.1 per million in the UK and ROI. We report the case of two children with multisystem LCH (MS-LCH) who suffered with enteral protein loss and were found to have similar duodenal changes on endoscopy.

Methods. Patient 1 (7 m, Male) presented with failure to thrive, a protein losing enteropathy and rash. LCH was subsequently diagnosed via biopsy of the rash. Due to the low Albumin an endoscopy was performed and GI-biopsies were taken.

Patient 2 (14 m, Female) presented with failure to thrive, severe cradle cap and poor dentition. Patient 2 also had a low albumin and enteropathy. $\mathrm{LCH}$ was diagnosed on histology of soft tissue surrounding an extracted tooth. GI biopsies were taken.

Both patients had macroscopic endoscopy findings of inflamed mucosa. Patient 2 had cobblestoning of the duodenum. In Patient 1, ulceration of the duodenum was seen.

Results. Histology for patient 1 confirmed the macroscopic findings of ulceration and identified a Langerhans cell infiltrate.

Histology for Patient 2 showed villous distortion including accumulation of eosinophils. A definite Langerhans cell infiltrate was not seen.

Conclusions. While GI involvement is rare in MS-LCH we saw two recent cases who presented with failure to thrive and diarrhoea leading to protein loss. These symptoms corresponded to duodenal inflammation on endoscopy, however, only patient 1 had definite histological LCH infiltrate of the duodenum. The biopsy taken from patient 2 was rather shallow, because the mucosa appeared very friable and it was important to avoid any bleeding. The macroscopic features of both patients were almost identical and despite absence of Langerhans cells in the GI-biopsy of patient 2, the presence of the an LCH involvement in the soft tissue of the gum makes a gut involvement very likely. The LCH in patient 2 was only diagnosed by chance, because the tooth was submitted for histological examination. These two cases show, that a gut LCH involvement should be considered in young patients with skin rash and intractable protein losing enteropathy.

\section{AG03.P.13}

\section{Proteomic characterization of juvenile neuroblastoma}

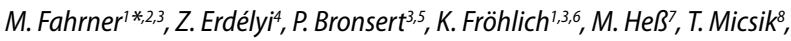
M. Garami ${ }^{4}$, O. Schilling ${ }^{3,5,6}$

'University of Freiburg, Spemann Graduate School of Biology and Medicine (SGBM), Freiburg, Germany, ${ }^{2}$ University of Freiburg, Faculty of Biology, Freiburg, Germany, ${ }^{3}$ Faculty of Medicine and Medical Center - University of Freiburg, Institute for Surgical Pathology, Freiburg, Germany, ${ }^{4}$ Faculty of Medicine, Semmelweis University, 2nd Department of Pediatrics, Budapest, Hungary, ${ }^{5}$ German Cancer Consortium (DKTK) and German Cancer Research Center (DKFZ), Heidelberg, Germany, ${ }^{6}$ Faculty of Medicine - University of Freiburg, Institute of Molecular Medicine and Cell Research, Freiburg, Germany, ${ }^{7}$ Faculty of Medicine and Medical Center - University of Freiburg, Institute of Medical Biometry and Statistics, Freiburg, Germany, ${ }^{8}$ Faculty of Medicine, Semmelweis University, First Department of Pathology and Experimental Cancer Research, Budapest, Hungary

Aim. Proteomic characterization of tumor cells and tissues is gaining increasing interest. Tumor-focused proteome investigations serve to yield novel insights into tumor biology and provide a means to molecularly segregate clinical phenotypes. We performed multiplexed quantitative proteome profiling of a cohort $(n=58)$ of juvenile neuroblastomas (NBLs). Our cohort included all INSS Stages (I-IVs), reflecting both high as well as low SIOPEN risk stratification.

Methods. The direct and system-wide protein-level analysis by tandem mass-spectrometry is the preferred approach since the limited correlation of mRNA and protein levels severely restricts the ability to predict quantitative protein biology from mRNA alone. Formalin-fixed, paraffin-embedded tumor tissue specimens were successfully used for mass spectrometry based proteomics, further highlighting their suitability for proteome-wide profiling studies. We performed several batches of TMT-11plex labelling combined with high $\mathrm{pH}$ reversed phase HPLC fractionation to allow for a comprehensive proteomic profile of the different NBL samples. For statistical analysis, the measured intensities were normalized using a combination of the Voom and the ComBat function in R.

Results. Amplification of the MYCN gene was found in 14 (of 52 tested) patients. The cohort-wide proteome coverage exceeded 2000 reliably and consistently identified and quantified proteins.

Conclusion. This data set provides novel insight into NBL biology and stratification.

The first both authors contributed equally to this work. The both last mentioned authors share the last authorship.

\section{AG Hämatopathologie Poster}

\section{AG04.P.01}

Fluoreszenzmehrfachfärbung und digitale Bildanalyse zur Untersuchung von Makrophagen-Subpopulationen im Mikromilieu von malignen Lymphomen

A. Wallner ${ }^{1 *}$, K. Koch ${ }^{1}$, W. Klapper ${ }^{1}$

'Universitätsklinikum Schleswig-Holstein, Campus Kiel, Institut für Pathologie, Sektion Hämatopathologie, Kiel, Deutschland

Ziel. Verschiedene Lymphome weisen innerhalb der Infiltrate eine große Anzahl nicht-neoplastischer Zellen (z. B. Makrophagen) auf, die als Mikromilieu bezeichnet werden. Makrophagen können eine Polarisierung in pro-inflammatorische M1- und anti-inflammatorische M2-Makropha- 


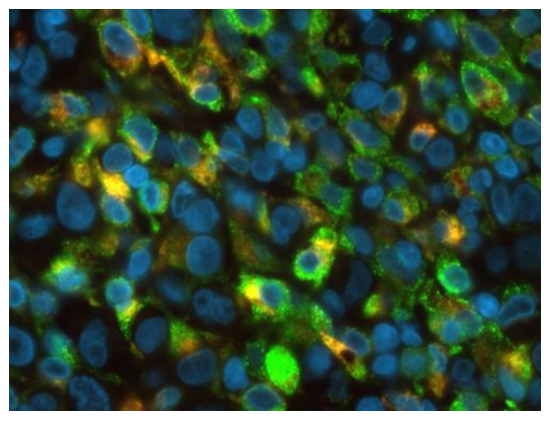

Abb. 1 | AG04.P.01 Fluoreszenzmehrfachfärbung CD68 (grün)/ CD163 (rot)

gen (sog. Subpopulationen) aufweisen. Ziel der Arbeit ist es, den Anteil der M2-Makrophagen im Mikromillieu von Lymphomen zu bestimmen. Methoden. Verwendet wurden Gewebe von follikulären Lymphomen ( $\mathrm{FL}$, $n=12$ ), diffusen großzelligen B-Zell-Lymphomen (DLBCL, $n=3$ ), klassischen Hodgkin Lymphomen (cHL, $n=3$ ), hyperplastischen Tonsillen $(n=4)$ und Lymphknoten $(n=3)$. Fluoreszenzmehrfachfärbungen mit Antikörpern gegen CD68 (als Marker für alle Makrophagen) und CD163 (als Marker für M2-Polarisierung) wurden mittels Bildanalyse (Software Tissue Studio 64, Definiens) analysiert.

Ergebnisse. Es findet sich in allen untersuchten Materialien keine vollständige Überschneidung der positiven Signale für CD163 und derer für CD68. Makrophagen zeigen auf ihrer großen Oberfläche Abschnitte mit Expression von CD163, die nicht CD68 positiv sind und umgekehrt (- Abb. 1 |AG04.P.01). Somit ist die Überschneidungsfläche von CD163 und CD68 nicht notwendigerweise ein gutes Maß für den Anteil von M2Makrophagen. Aus diesem Grund wurde der Flächenanteil von CD68 und CD163 sowie der Quotient CD163/CD68 als Maß für den relativen Anteil M2-polarisierter Makrophagen verwendet.

Der Gesamtmakrophagengehalt (CD68) ist in FL niedriger als in aktiviertem lymphatischen Gewebe. Der Gehalt M2-polarisierter Makrophagen (CD163) ist in FL, cHL und aktiviertem lymphatischen Gewebe ähnlich. Diese Gruppen zeigen auch in sich einen homogenen Anteil an Makrophagen und M2-polarisierten Makrophagen, während DLBCL hier deutliche Unterschieden zwischen einzelnen Lymphomen aufweisen und in Einzelfällen einen deutlich erhöhten Gehalt an Makrophagen und speziell auch M2-polarisierten Makrophagen zeigen.

Fazit. Die nicht exakte Kolokalisation von CD68 und CD163 in Makrophagen erschwert die Bestimmung von Makrophagenpolarisation in Gewebeschnitten mittels Bildanalyse. Der Quotient aus CD163 und CD68 gefärbten Flächen zeigt, dass der Anteil der M2 polarisierten Makrophagen im DLBCL heterogen ist und sich zum Teil deutlich von den Werten in anderen Lymphomentitäten unterscheidet.

\section{AG04.P.02 \\ Subtypisierung des diffus großzelligen B-Zell Lymphoms: Ein Vergleich zwischen Mutationsanalyse und immunhistochemischer Bestimmung der Ursprungszelle}

\section{J. Steinhilber ${ }^{1 *}$, A. Mayer ${ }^{1}$, I. Bonzheim ' ', F. Fend' ', L. Quintanilla-Martinez' 'Institut für Pathologie des Universitätsklinikums Tübingen, Tübingen, Deutschland}

Ziel. Diffus großzellige B-Zell Lymphome (DLBCL) können anhand von Genexpressionsanalysen nach ihrer Ursprungszelle in die drei Subgruppen ABC-Subtyp, GCB-Subtyp und eine unklassifizierbare Gruppe unterteilt werden, die auch unterschiedliche Mutationsprofile aufweisen. Der Subtyp hat einen Einfluss auf die Prognose und potentiell die Therapie. Ein gebräuchliches Surrogat für die molekulare Subklassifizierung ist der Hans Algorithmus mit den Färbungen für CD10, BCL6 und MUM1. Ziel der Studie war eine NGS-Panelanalyse des Mutationsspektrums von DLBCL, im Vergleich mit der Bestimmung der Ursprungszelle nach dem Hans Algorithmus.

Methoden. 35 GCB und 30 ABC DLBCL, klassifiziert nach dem Hans Algorithmus, wurden mit einem Ion AmpliSeq ${ }^{\text {Tm }}$ custom NGS Panel unter- sucht, das die 10 am häufigsten im DLBCL mutierten Gene enthält. Neben MYD88 und $C D 79 B$, typischerweise im ABC-Subtyp sowie BCL2 und $E Z H 2$ gewöhnlich im GCB-DLBCL mutiert, wurden die Gene CARD11, TNFAIP3, PRDM1, PIM1, IRF4 und BCL6 analysiert.

Ergebnisse. In der Mutationsanalyse zeigten $75 \%$ (49/65) der analysierten DLBCL mindestens eine Mutation in den untersuchten Genen. Teilweise wurden in PIM1, BCL2 und CD79B mehrere Mutationen pro Fall detektiert. MYD88 und $C D 79 B$ waren signifikant häufiger (13 vs. 4 und 11 vs. 3) im ABC als im GCB-Subtyp mutiert. 31 \% (11/35) der GCBDLBCL wiesen Mutationen von BCL2 (9 vs. 2) und/oder EZH2 (4 vs. 0) auf, die charakteristisch für den GCB-Subtyp sind und somit seltener im ABC-Subtyp vorkommen. Interessanterweise wurden in $11 \%(4 / 35)$ der immunhistochemisch als GCB-DLBCL klassifizierten Fälle Mutationen in den Genen MYD88 und CD79B gefunden. Alle vier Fälle waren triplepositiv für CD10, BCL4 und MUM1. Die übrigen untersuchten Gene sind im ABC und im GCB-Subtyp ähnlich häufig mutiert.

Fazit. Die Mutationsanalyse stellt eine verlässliche und relativ einfache Methode zur Unterstützung der Subklassifizierung des DLBCL dar. Die zahlreichen Mutationen in PIM1, BCL2 und CD79B sind typische Folgen der somatischen Hypermutation. Es zeigt sich wie erwartet ein signifikanter Zusammenhang zwischen MYD88 und CD79B Mutationen und dem ABC-Subtyp sowie zwischen BCL2 und EZH2 Mutationen und dem GCBSubtyp. Interessanterweise weisen nach dem Hans Algorithmus dreifach positive und demnach als GCB-Subtyp zu klassifizierende Fälle dem ABCSubtyp zuzuordnende MYD88 und CD79B Mutationen auf, was eine Reevaluation des Algorithmus nahelegt.

\section{AG04.P.03}

Prognostic value of indoleamine 2,3 dioxygenase in patients with higher-risk myelodysplastic syndromes treated with azacytidine

C. Müller-Thomas', K. Götze', U. Germing ${ }^{2}$, M. Rudelius ${ }^{3 *}$

${ }^{1}$ III. Med. Klinik der TUM, Munich, Germany, ${ }^{2}$ Medizinische Klinik der HHU Düsseldorf, Düsseldorf, Germany, ${ }^{3}$ Pathologisches Institut der LMU München, Munich, Germany

Hypomethylating agents (HMAs) are the current standard of care for patients with higher-risk myelodysplastic syndromes (MDS) not eligible for stem cell therapy; however, only a few patients respond to HMA treatment. Because of the incomplete understanding and the inherent biological complexity of MDS, reliable predictors of the therapeutic response are still missing, and it is a major challenge to develop new treatment strategies. One promising approach is the combination of azacytidine (AZA) with checkpoint inhibitors; however, the potential benefit of targeting the immunomodulator indoleamine 2.3 dioxygenase (IDO-1) in MDS has not yet been evaluated.

We analyzed a cohort of 95 patients with higher-risk MDS treated with at least 3 cycles of AZA. We observed moderate to strong IDO- 1 expression at $37 \%$. IDO-1 positivity was predictive of treatment failure $(p<0.0001)$ and shorter overall survival. It is well documented that the catabolic function of IDO-1 leads to cell cycle arrest in cytotoxic T cells and indeed, IDO-1 positivity was correlated inversely with the ratio of cytotoxic $\mathrm{T}$ lymphocytes to the total number of infiltrating T lymphocytes. Moreover, in contrast to IDO-1-negative patients, IDO-1-positive patients failed to show an increase in infiltrating cytotoxic T lymphocytes under AZA treatment. Although further studies are needed, it might well be that IDO-1 expression leads to an immunosuppressive microenvironment in MDS, thereby leading to treatment failure.

In conclusion, IDO-1 is expressed in more than one-third of patients with higher-risk MDS and is predictive of treatment failure and shorter survival. IDO-1 is emerging as a promising target, especially for combination therapies with HMAs. 


\section{AG04.P.04}

Impact of EZH2 mutations for DZNep-mediated apoptosis in B-cell lymphomas

\section{Akpa ${ }^{1 *}$, K. Kleo' ${ }^{1}$ E. Oker ${ }^{1}$, L. Dimitrova' ${ }^{1}$, M. Hummel ${ }^{1}$}

${ }^{1}$ Charité Universitätsmedizin Berlin/Institute of Pathology, Berlin, Germany

Aim. We aim to investigate the influence of the EZH2 mutation status of B-cell lymphomas on the sensitivity of these cells to apoptosis by 3-Deazaneplanocin A (DZNep).

Methods. To check for EZH2 gain-of-function mutations, we performed Sanger sequencing using genomic DNA and RNA (cDNA) isolated from $12 \mathrm{~B}$-cell lymphoma cell lines. This analysis was confined to 3 frequent mutation hot spots on exon 16 (Tyr646) and 18 (Ala682 and Ala692). We also checked the sensitivity of the cell lines to DZNep-mediated apoptosis by treating them with $5 \mu \mathrm{M}$ DZNep and measuring apoptosis afterwards by flow cytometry (Annexin V and Propidium Iodide staining). To show the relationship between the EZH2 mutation status and the response of cell lines to DZNep-induced apoptosis, we grouped the cell lines based on the percentage of apoptosis recorded upon DZNep treatment.

Results. Although the Tyr646 mutation occurs more frequently in B-cell lymphomas when compared to Ala682 and Ala692 mutations, DZNep causes apoptosis of these lymphoma cell lines independent of their EZH2 mutation status and type of mutation.

Conclusion. Although mutations in EZH2 are regarded as important biomarkers for lymphomas of B-cell origin, our study shows that they do not particularly influence the sensitivity of these cell lines to apoptosis by DZNep. Other molecular mechanisms appear to be more relevant for the resistance against DZNep treatment.

\section{AG04.P.05}

\section{PAX5 expression in Merkel cell carcinoma}

E. Chteinberg ${ }^{1 * 2,}$, W. Gerritsen ${ }^{1}$, E.-J. Speel', J. van den Oord ${ }^{3}$, V. Winnepenninckx' ${ }^{1}$, M. Zenke ${ }^{2,4}$, A. K. Kurz ${ }^{5}$, A. zur Hausen ${ }^{1}$

'Maastricht University Medical Centre, Department of Pathology, Maastricht, Netherlands, ${ }^{2}$ Institute for Biomedical Engineering RWTH Aachen, Department of Cell Biology, Aachen, Germany, ${ }^{3}$ University of Leuven, Laboratory of Translational Cell and Tissue Research, Leuven, Belgium, ${ }^{4}$ RWTH Aachen University, Helmholtz Institute for Biomedical Engineering, Aachen, Germany, ${ }^{5}$ University Hospital Aachen, Department of Internal Medicine IV, Aachen, Germany

Objectives. Merkel cell carcinoma (MCC) is a rare, but very aggressive skin cancer which is characterized by a typical trilinear differentiation: neuroendocrine (Chromogranin A and synaptophysin), epithelial (e.g. Cytokeratin 20) and early B cell differentiation (e.g. PAX5, TdT). PAX5 is the key transcription factor which is responsible for the B-cell lineage commitment. We investigated the expression of PAX5 on the transcriptional level in MCCs and MCC cell lines including PAX5 isoforms. In addition, we assessed PAX5 expression on the translational level by Western blotting and immunohistochemistry (IHC) using different PAX5 antibodies targeting diverse regions of PAX5.

Methods. RT-PCR was performed to test for specific N- and C-terminal PAX5 expression including splice variants in MCCs $(n=16)$ and MCC cell lines (e.g. MKL-1, MKL-2 and WaGa). In addition, IHC with anti-PAX5 antibody clones DAK-PAX5 (Dako) and the SP34 (Roche) was performed and compared. Furthermore, Western blotting was applied using the anti-PAX5 antibody D19F8 (Cell Signaling). The ALL cell line REH and REH transfected with the viral oncogene sTAg of Merkel cell polyomavirus (MCPyV) were used as controls.

Results. In all MCC cells PAX5 full length transcript could be detected using RT-PCR. In addition, the alternative splice variants $\Delta 2, \Delta 2 / 3, \Delta 2 / 4$, $\Delta 9, \Delta 8, \Delta 7 / 8, \Delta 8 / 9, \Delta 6 / 7 / 8$ were identified in MCC tissues and MCC cell lines which are known to be expressed in normal and leukemic $B$ cells. Moreover, in the B cell ALL cell line REH the $\Delta 6 / 7 / 8$ was induced by MCPyV sTAg. PAX5 IHC using DAK-PAX5 was in good agreement with PAX5 RNA expression. SP34 revealed to a far lesser extent PAX5 detection compared to DAK-PAX5 and PAX5 RNA expression in MCC and MCC cell lines. Western blotting using the anti-PAX5 antibody clone D19F8 revealed PAX5 expression in the MCC cell lines MKL-1, MKL-2, WaGa and PeTa.

Conclusion. Here, we report that PAX5 and its isoforms are consistently detected by different techniques in all tested MCC cells. The induction of Pax5 $56 / 7 / 8$ isoform in some MCPyV-positive MCC next to full length Pax5 additionally indicates that PAX5 is constitutionally expressed in MCC. Previously this isoform was only detected in leukemia cells. These findings strongly support our hypothesis that MCC originates from prepro B cells.

DAK-PAX5 antibody is superior to SP34 to detect PAX5 protein expression in MCC cells by IHC.

\section{AG04.P.06 \\ DNA methylation analysis of extranodal marginal zone B-cell Iymphoma (MZBL) of the stomach}

R. Dugge ${ }^{1 *}$, R. Wagener ${ }^{2,3}$, J. Kolarova ${ }^{2,3}$, R. Siebert ${ }^{2,3}$, P. Möller', T. F. E. Barth ${ }^{1}$

'Ulm University, Institute of Pathology, Ulm, Germany, ${ }^{2}$ Ulm University,

Institute of Human Genetics, Ulm, Germany, ${ }^{3}$ Ulm University, Medical Center, Ulm, Germany

Aim. Helicobacter pylori induced gastritis leads to small cell gastric extranodal MZBL (SC MZBL) of the mucosa-associated lymphoid tissue (MALT). It progresses to a large cell MZBL (LC MZBL). WHO regards the LC MZBL as "diffuse large B-cell lymphoma (DLBCL) in the presence of accompanying MALT lymphoma”. Previously our lab has shown that LC MZBL is distinct from the DLBCL based on morphology, immunohistochemistry, chromosomal profiling, and expression profiling. The aim here is to analyze the DNA methylation pattern of MALT lymphomas.

Methods. The cohort of 26 gastric MALT MZBL samples (taken from the Institute of Pathology, Ulm University) included 4 SC MZBL, 11 LC MZBL, 9 large cell component of composite lymphoma (ComL) and 2 composite lymphoma including both the large cell and the small cell components $(\mathrm{ComL}+\mathrm{S})$. The cohort also included follicular lymphoma (FL, $n=87)$, DLBCL $(n=78)$, nodal MZBL $(n=8)$ and Burkitt lymphoma $(n=41)$ analyzed in the ICGC MMML-Seq project. We also included benign B cells $(n=93)$. DNA isolation was done for the microdissected tissue (QIAamp DNA Mini Kit and Covaris truXTRAC FFPE DNA mictotube kit). Illumina’s Infinium MethylationEPIC Bead Chip array kit was used for DNA methylation study of the MALT MZBL samples and the HumanMethylation 450 BeadChip array for the other lymphomas. The data was analyzed using GenomeStudio and Qlucore Omics Explorer.

Results. The gastric MALT MZBL showed a higher mean DNA methylation value in comparison to the other B-cell lymphomas ( $p=0.0001)$. In an unsupervised analysis $\left(\sigma / \sigma_{\max }=00.7,2019 / 424549\right.$ loci) of the entire B-cell lymphoma cohort, the gastric MALT lymphomas clustered with the FL and DLBCL. A supervised analysis of LC MZBL and DLBCL, identified 1030 significantly differentially methylated loci (560 genes) $\left(\sigma / \sigma_{\max }=0.4\right.$, $\mathrm{q}<=0.0001$ ). A supervised analysis of the gastric MALT MZBL samples from different progression stages $\left(\sigma / \sigma_{\max }=0.4, \mathrm{q}<=0.0001,7840\right.$ loci), showed two clusters: Cluster 1 encompassed SC MZBL and ComL+S, whereas cluster 2 contained LC MZBL and ComL.

Conclusion. The DNA methylation profiling shows that during the progression to a large cell MALT lymphoma, the DNA methylation level increases at certain loci. We identified significantly differentially methylated loci between LC MZBL and DLBCL pointing to a differential regulation. Hence, differences identified by DNA methylation analysis can improve the understanding of the biological and clinical features of gastric MALT MZBL. 
AG04.P.08

Zytokinvermittelte Polarisierung von Makrophagen in Hodgkinlymphomen induziert durch die Interaktion von PDL1 und CD80

A. Brobeil ${ }^{*}$, U. Wenig ${ }^{2}$, R. Savaí ${ }^{3}$, S. Mansouri ${ }^{3}$, M. Rummel' ${ }^{2}$ D. Körholz ${ }^{2}$, C. Mauz-Körholz², A. Bräuninger², S. Gattenlöhner ${ }^{2}$

'Justus-Liebig-Universität, Institut für Pathologie, Gießen, Deutschland, ${ }^{2}$ Justus-Liebig-Universität, Gießen, Deutschland, ${ }^{3}$ Max Planck Institute for Heart and Lung Research, Bad Nauheim, Deutschland

Zahlreiche Studien bestätigen die Wirksamkeit einer neuen Immuntherapie mittels Checkpointinhibitoren (Pembrolizuman, Nivolumab) im klassischen Hodgkinlymphom. Der angenommene und teils in in vitro Versuchen bekräftigte Wirkmechanismus soll durch PD-1 positive T-Zellen vermittelt sein. Diese binden an PDL1 auf der Hodgkin-/Reed-SternbergZelle und sollen dadurch „abgeschalten“ werden. Hierbei besteht jedoch eine deutliche Diskrepanz in der geringen PD-1 Expression der zahlreichen T-Zellen im reaktiven Infiltrat. Das reaktive Infiltrat ist wesentlicher Bestandteil des Hodgkinlymphoms. Hierbei handelt es sich um einen „Umbau“ der Lymphknotenarchitektur unter Induzierung eines charakteristischen Entzündungsinfiltrates, bestehend unter anderem aus B- und T-Lymphozyten, Granulozyten und Makrophagen.

Wir konnten bereits zeigen, dass PDL1 und CD80 sowohl auf einer Hodgkin-/Reedsternbergzelle (HRS) autokrin interagiert als auch auf den umgebenden Makrophagen. Unter Überexpression von PDL1 und CD80 in HEK293 Zellen konnte eine Hodgkin-typische de novo Zytokrinexpression nachgewiesen werden. Die zusätzlich untersuchte Signaltransduktion nach Überexpression zeigte ebenfalls Charakteristika einer HRS mit Aktivierung z. B. des NFkB-Signalweges. Die Signaltransduktion mit konsekutiver Zytokinexpression führt zu einer Polarisierung der im reaktiven Infiltrat enthaltenen Makrophagen, welche sich nun pro-tumorogen verhalten (M2-Makrophagen). Die Applikation von Nivolumab kann diese Polarisation hin zu anti-tumorogenen Makrophagen (M1) beeinflussen. Somit führt Interkation von PDL1 und CD80 auf einer HRS führt zu einer zielgerichteten Signaltransduktion mit konsekutiver Zyto- und Chemokinexpression und Sekretion, welche für das entzündliche „Remoddeling“ des befallen Lymphknotens essentiell ist. Es entsteht ein gegenseitige Stimulation der Makrophagen und HRS, welche die Erkrankung weiter unterhält.

\section{AG04.P.09 \\ PTP1Bdelta6 und PTP1Bdelta2-4 - zwei PTP1B Varianten mit unterschiedlichen Effekten auf den JAK/STAT Signalweg}

\section{Zahn*, B. Kaluszniak, R. Marienfeld, P. Möller}

Universitätsklinikum Ulm, Pathologie, Ulm, Deutschland

Ziel. Das klassische Hodgkin Lymphom (kHL) ist unter anderem durch eine konstitutive JAK/STAT Signalgebung charakterisiert, die zu Überleben und Proliferation der malignen HRS Zellen beiträgt. Die molekulare Basis, die dieser konstitutiven Aktivierung zugrunde liegt, konnte bisher nicht vollständig entschlüsselt werden. Jedoch wurden bereits die Inhibition bzw reduzierte Expression negativer JAK/STAT Regulatoren, wie der Protein Tyrosin Phosphatase 1B, im kHL beschrieben. Da PTP1B eine essentielle Rolle in der Regulation des JAK/STAT Signalweges spielt, sollten die Kontrollmechanismen die zur Aktivität dieser Phosphatase beitragen näher untersucht werden. In dieser Arbeit wurde die PTP1BD2-4-Mutante funktionell charakterisiert und zudem mit der PTP1BD6-Spleißvariante verglichen. Beide Varianten wurden sowohl in kHL Zelllinien als auch in Tumorproben identifiziert.

Methoden. Die funktionelle Analyse der beiden Varianten wurde mittels Phosphatase und Immunoblot Analysen, Luziferase Reporter Experimenten und EMSA durchgeführt. Die Expression der PTP1B mRNA wurde durch semiquantitative RealTime-PCR (sqPCR) bestimmt.

Ergebnisse. Um die Funktion der PTP1BD2-4-Mutante zu bestimmen, wurde ihr Einfluss auf den JAK/STAT-Signalweg im Vergleich mit der PTP1BD6-Spleißvariante untersucht. Die Expression von PTP1BD6 verstärk- te die transkriptionale Aktivität, die nukleäre Translokation, DNA-Bindung und Zielgen-Expression des Transkriptionsfaktors STAT6. Die Expression der PTP1BD2-4-Mutante führte hingegen nur zu einer moderaten Veränderung der STAT-Aktivität. Es konnte gezeigt werden, dass auch sehr geringe Mengen von PTP1BD6 einen deutlichen inhibitorischen Effekt auf die Phosphatase-Aktivität des wildtypischen (wt) PTP1B ausüben. Zudem konnte eine Abnahme des PTP1B ${ }_{\mathrm{WT}}$-Proteinspiegels durch die Koexpression der PTP1BD6-Spleißvariante gezeigt werden. Weder die Koexpression der enzymatisch inaktiven $\mathrm{PTP}_{1 \mathrm{~B}} \mathrm{C}_{15 \mathrm{~S}}$ noch der PTP1BD2-4 Mutante hatten vergleichbare Effekte auf die Aktivität und die Proteinmenge des PTP1 $\mathrm{B}_{\mathrm{WT}}$. Fazit. Zusammenfassend lässt sich ein deutlicher Unterschied zwischen der PTP1BD2-4-Mutante und der PTP1BD6-Spleißvariante feststellen. Während die PTP1BD6-Spleißvariante ein Teil eines aktiven Regulationsmechanismus zu sein scheint, führt der Verlust der Exone 2-4 nur zu einem Aktivitätsverlust von PTP1B. Im Wesentlichen sprechen die Daten für die Notwendigkeit einer tiefergehenden Analyse, um den Einfluss von PTP1B Varianten im kHL näher zu identifizieren.

\section{AG Gynäko- und Mammapathologie Poster}

\section{AG05.P.01}

\section{Comparison of PD-L1 expression in matched cytological and} histological specimens of non-small cell lung carcinoma

O. Chijioke*, S. Eppenberger-Castori, B. Baschiera, S. Grieshaber, L. Bubendorf, S. Savic

University Hospital Basel, Institute of Pathology and Medical Genetics, Basel, Switzerland

Aim. PD-L1 testing by immunohistochemistry is standard of care in advanced non-small cell lung carcinoma (NSCLC) as a predictive marker for immunotherapy. Notably, up to $40 \%$ of advanced NSCLC are diagnosed by cytology alone with no concurrent positive biopsy. In this study, we developed protocols using three different anti-PDL1 antibodies to assess PD-L1 expression by immunocytochemistry on conventional, ethanol-fixed cytological specimens and compared performance to matched formalin-fixed and paraffin-embedded histological specimens stained with the SP263 assay.

Methods. We prospectively collected matched cytological and histological specimens from 58 NSCLC patients. Immunocytochemistry was performed on the Leica Bond platform using laboratory developed protocols for SP142, SP263 and E1L3N anti-PD-L1 antibodies, respectively. PD-L1 expression on matched histological specimens was tested using the SP263 assay on Ventana BenchMark Ultra according to the manufacturer's protocol.

Result. SP142 and SP263 immunocytochemistry gave highly concordant results (kappa value of 0.81 ) when dichotomized for the clinically relevant threshold of $50 \% \mathrm{PD}-\mathrm{L} 1$ positive tumor cells. The best correlation between SP263 assay on histological specimens using this threshold and cytological samples was found with SP142 (84\% agreement) followed by SP263 and E1L3N. Two of the discordant results with negative or lower PD-L1 results in cytology throughout all three tested antibodies and positive results for the corresponding biopsies were most probably caused by tumor heterogeneity of PD-L1 expression as subsequently shown in the respective resection specimens. The other discordant results with negative cytology results were most likely due to suboptimal fixation. Furthermore, since November 2017 we prospectively monitor PD-L1 status in NSCLC from our routine practice in a nation-wide online platform (www.biopath.ch). Here, in a 1 -year period, we found a similar frequency of PD-L1 $\geq 50 \%$ in conventional cytological $(30 \%, 39 / 130)$ and histological $(29 \%, 63 / 214)$ specimens. Conclusion. Conventional cytological specimens are suitable for PDL1 testing in NSCLC. The obtained results are in good agreement with matched histological specimens using the SP263 assay, provided that pre-analytic steps for the cytological specimens are well controlled and the specimens optimally fixed. 
AG05.P.02

\section{Rezidiv eines Sarkoms im Becken}

M. Gajda*, B. Theis

'Institut für Rechtsmedizin, Sektion Pathologie, Jena, Deutschland

Ziel. Uterine Sarkome stellen weniger als $5 \%$ aller malignen Tumore des Corpus uteri dar. Der Anteil der Stromasarkome an den Uterussarkomen beträgt $10-15 \%$, ca. $50 \%$ der Patientinnen sind prämenopausal. Das Stromasarkom des Endometriums (ESS) ist ein Tumor, der den endometrialen Stromazellen ähnelt und typischerweise das Myometrium infiltriert Derzeit gültige Unterteilung (WHO):

a) endometranes Stromasarkom, low grade mit einer besseren Prognose

b) endometranes Stromasarkom, high grade

c) undifferenziertes uterines Sarkom (kann von Endo- oder Myometrium ausgehen) mit einer schlechten Prognose bzw. aggressivem Verlauf. Die Differenzierung aller Typen erfolgt anhand des Grades der nukleären Atypien, des Vorhandenseins von Nekrosen und z.T. anhand charakteristischer zytogenetischer Aberrationen.

Methoden. Genaue histopathologische Untersuchung, Verlauf eines klinischen Falls (in der Ukraine 1992 diagnostiziertes „Fibrosarkom des Uterus") und Überprüfung der Literatur.

Ergebnisse. Zur pathologischen Untersuchungen gelangen graue Gewebsstücke, zusammengelegt $2,5 \times 2 \times 1 \mathrm{~cm}$ messend. Es zeigt sich das Bild eines Spindelzelltumors mit unterschiedlicher Zellularität. Neben weitgehend azellulären, fibrös imponierenden Abschnitten zeigen sich auch zellreiche Areale. Die Tumorzellen besitzen kleine, relativ isomorphe Kerne. Eine auffällige mitotische Aktivität besteht nicht. Keine Nekrosen. Die Tumorzellen zeigen eine kräftige positive Reaktion gegen Desmin, ER und PR. Die Gefäße zeigen eine positive Reaktion gegen ASMA und CD34, die Tumorzellen sind jedoch negativ. Keine positive Reaktion gegen CD10 und STAT6. Nur einzelne Blutgefäße zeigen eine positive Reaktion gegen Caldesmon. Etwa 2 bis $3 \%$ der Tumorzellkerne exprimieren Ki67-Antigen. Nachweis einer JAZF1-Translokation mittels FISH. Die histologische, immunhistochemische und molekularpathologische Konstellation spricht für ein endometranes Stromasarkom (low grade) (- Abb. 1|AG05.P.02 und $\bullet$ Abb. 2 | AG05.P.02).

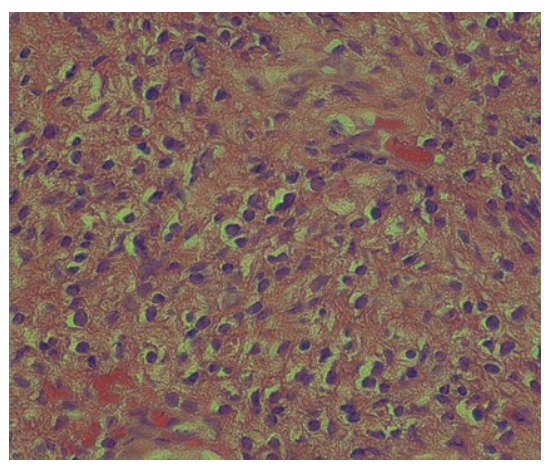

Abb. 1 | AG05.P.02 Metastase eines low grade ESS H\&E 400x

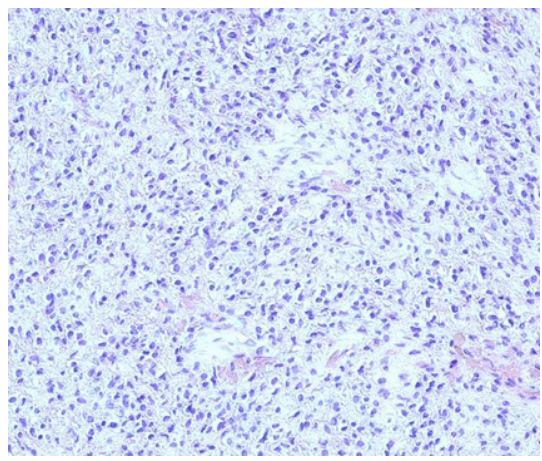

Abb. 2 | AG05.P.02 Metastase eines low grade ESS H\&E 200x
Fazit. Es handelt sich um den ungewöhnlichen Fall eines mesenchymalen Uterustumors mit Ausgang vom Endometrium. Die immunhistochemischen Reaktionen waren zuletzt nicht spezifisch für ein Uterussarkom. Das JAZF1/JJAZF1-Fusionsgen scheint für Stromatumoren des Endometriums spezifisch zu sein, da es bis dato in keinen anderen humanen Tumoren gefunden wurde. Stromasarkome sind durch die Möglichkeit von späten Rezidiven charakterisiert. Das Tumorstadium, der Typ der Operation und der Differenzierungsgrad bestimmen das Risiko eines Rezidivs im Becken.

\section{AG05.P.03}

IgG4-assoziierte sklerosierende Mastitis als seltene Ursache eines tumorartigen Befundes der Mamma

M. Kriegsmann ${ }^{1 *}$, C. Gomez ${ }^{2}$, J. Heil', B. Schäfgen², E. Gutjahr1,

K. Kriegsmann ${ }^{3}$, C. Flechtenmacher', B. Goeppert', H.-P. Sinn ${ }^{1}$

${ }^{1}$ Universität Heidelberg, Pathologie, Heidelberg, Deutschland, ${ }^{2}$ Universität Heidelberg, Abteilung für allgemeine Frauenheilkunde und Geburtshilfe, Heidelberg, Deutschland, ${ }^{3}$ Universität Heidelberg, Abteilung für Hämatologie, Onkologie und Rheumatologie, Heidelberg, Deutschland

Ziel. Wir berichten über eine 49 Jahre alte Patientin, die während einer Eigenuntersuchung der linken Brust mehrere bis max. 1,6 cm große schmerzlose Knoten festgestellt hatte. In der klinischen Bildgebung ergab sich der dringende Verdacht auf ein multifokales Mammakarzinom. Es wurden Ultraschall-gesteuerte Stanzbiopsien entnommen und mit der Verdachtsdiagnose eines Mammakarzinoms links eingesandt.

Methoden. Konventionell-histologische und immunhistologische Aufarbeitung der Stanzbiopsien.

Ergebnisse. In den Hämatoxylin-Eosin Färbungen der Biopsiezylinder zeigte sich als Hauptbefund eine zellarme Sklerose, und damit assoziiert herdförmige, unscharf begrenze, plasmazellreiche Rundzellinfiltrate, ohne Bezug zum duktalen oder lobulären System. Immunhistologisch waren die Rundzellinfiltrate durch eine dichte Population CD138/IgG4 koexprimierender Plasmazellen charakterisiert, mit bis zu 51/hochauflösendem Gesichtsfeld. Ein Karzinom war nicht nachweisbar. Die daraufhin durchgeführte serologische IgG4-Bestimmung war mit 15,94 kU/l über den Referenzbereich erhöht. Die Diagnose einer IgG4-assoziierten sklerosierenden Mastitis wurde gestellt.

Fazit. Während IgG4-assoziierte Erkrankungen in Organen wie zum Beispiel dem Pankreas, der Speicheldrüsen oder der Schilddrüse in der Literatur gut dokumentiert sind, sind tumorartige Manifestation, die die Kriterien einer IgG4-assoziierte Erkrankungen erfüllen, in der Mamma bisher nur selten beschrieben. Bei Herdbefund und dem histologischen Bild einer interstitiellen, plasmazellreichen sklerosierenden Entzündung sollte daher an die Möglichkeit einer IgG4-assoziierten sklerosierenden Mastitis gedacht werden.

\section{AG05.P.04}

Curative status (RO) due to neoadjuvant radio-chemotherapy followed by salvage-exenteration in advanced cervical cancer with vesico-vaginal fistula

P. Hass' ${ }^{1}$ F. Meyer ${ }^{2 *}$, S. D. Costa ${ }^{3}$, U.-B. Liehr', A. Perrakis', R. S. Croner', T. Brunner

'Dept. of Radiation Oncology, University Hospital, Magdeburg, Germany, ${ }^{2}$ Dept. of General, Abdominal, Vascular and Transplant Surgery; University Hospital, Magdeburg, Germany, ${ }^{3}$ Dept. of Gynecology \& Obstetrics, University Hospital, Magdeburg, Germany, ${ }^{4}$ Dept. of Urology and Pediatric Urology, University Hospital, Magdeburg, Germany

Background. For cervical cancer(Ca) with broad tumor(Tu) infiltration of the anterior rectal wall \& a manifest cervicovaginal fistula at the time of primary diagnosis, brachytherapy $(\mathrm{Tx})$ can not be initiated-thus, curative approach by RCTx alone can actually not be further pursued since the S3 guidelines do not provide any therapeutic advice since there is no study-based evidence. 
Aim. To describe 2 cases with locally advanced Tu growth of stage IVA who had - at the time of primary diagnosis - a cervicovaginal fistula \& a broad Tu infiltration of the anterior rectal wall.

Patients/Method. Scientific case reports.

Case 1: 48-years old patient with G2-differenciated squamous cell carcinoma of the uterine cervix \& a manifest vesico-vaginal fistula (cT4acN0cM0). Because of urinary congestion, nephrostoma at both sides was created. After accomplishment of a simultaneous RCTx ad 50.4 Gy \& preoperative re-staging to reliably exclude M1-situation, an anterior exenteration (due to no Tu infiltration of the rectal wall), ureteral reconstruction \& re-modelling of the urinary bladder were performed by 8 weeks post-radiation. Case 2: 45-years old patient with G3-differenciated squamous cell carcinoma of the uterine cervix, cT4acN1 (at both common iliac arteries) cM1 (suspicious paraaortic lymph node metastases [Mts]) - thus, Tu lesion was classified minimally as UICC-stage IVA (or IVB in case of manifest paraaortic lymph node Mts). In addition to the Tu-induced vesico-vaginal fistula, there was also a broad Tu infiltration of the anterior rectal wall. By 8 weeks after accomplishment of RCTx including paraaortic lymph nodes ad 50.4 Gy +2 cycles of Cisplatin-based CTx (week 1+5), hysterectomy including ovarectomy at both sides, left ureteral resection, segmental ileum resection $(10 \mathrm{~cm})$, anterior rectal resection + partial resection \& reconstruction of the urinary bladder as well as creation of a left nephrostoma were performed.

Results. The final histopathological Tu stages according to TNM classification were-in case

1: ypT0ypN1(1/9)cM0,

2: ypT0ypN0(0/10)L0V0cM0.

In both cases, $\mathrm{R} 0$ resection status was achieved. Postoperative courses were uneventful.

Conclusion. In conclusion, the 2 cases show that a curative approach (pursuing to achive R0 resection) including an effective fistula treatment appears basicly possible \& promising under interdisciplinary collaboration of all (potentially) involved disciplines (such as radiation oncology, gynecology, abdominal surgery, urology).

\section{AG05.P.05 \\ Eisenoxidnanopartikel induzierte Makrophagen Aktivierung und deren Einfluss auf die Tumormikroumgebung}

K. Römhild ${ }^{*, 2}$, K. Lindelauf', S. M. Dadfar', S. von Stillfried ${ }^{2}$, R. Knüchel${ }^{2}$, F. Kiessling ${ }^{1}$, T. Lammers ${ }^{1}$

'Universitätsklinik RWTH Aachen, Experimentelle Molekulare Bildgebung, Aachen, Deutschland, ${ }^{2}$ Universitätsklinik Aachen, Institut für Pathologie, Aachen, Deutschland

Ziel. Mammakarzinome stellen eine der am häufigsten auftretenden Krebsarten bei Frauen, mit einer Sterberate von $26 \%$, dar. Es wird zwischen molekular definierten Brustkrebssubtypen unterschieden, die den Einsatz individueller Therapien ermöglichen. Eine zielgerichtete Therapie mit Fokus auf das Immunsystem ist bei Malignen Melanomen und Lungenkarzinomen bereits Teil des therapeutischen Spektrums. Bisher haben nur wenige Studien von der erfolgreichen Anwendung von Immuntherapien gegen Brustkrebs berichtet.

Durch den gezielten Einsatz von Eisenoxidnanopartikeln wollen wir die Aktivierung von Makrophagen und eine Stimulation des Immunsystems zur Therapie von Brustkrebs bewirken

Methoden. Eine systematische Untersuchung von Eisenoxidnanopartikeln unterschiedlicher Grösse und Beschichtung hinsichtlich Toxizität, Aufnahme und Polarisierung von Makrophagen wurde durchgeführt. Hierfür wurden in vitro humane und murine Makrophagen-Zelllinien und Primärzellen mit verschiedenen Eisenoxidnanopartikeln (u. a. Ferumoxytol) anhand von XTT, ICP-MS bzw. Eisenfärbung und PCR untersucht. Weiterhin wurde in Co-Kultur-Experimenten der Einfluss von eisenbehandelten Makrophagen auf humane und murine chemosensitive sowie chemoresistente Brustkrebszelllinien betrachtet.

Ergebnisse. Die Viabilitätsstudien zeigten keine erhebliche Toxizität der untersuchten Eisenpartikel. Mittels der angestellten ICP-MS Messungen und der durchgeführten Eisenfärbung konnte eine Aufnahme der Eisenoxidnanopartikel durch die Makrophagen in Abhängigkeit von Nanopartikelkonzentration und Partikelbeschichtung gezeigt werden. Die zum jetzigen Zeitpunkt noch nicht vollständig abgeschlossenen PCR-, sowie Co-Kultur Untersuchungen werden zusätzlich Aufschluss über die Polarisierung der Makrophagen und deren Einfluss auf die Brustkrebszellen geben.

Fazit. Eisenoxidnanopartikel- aktivierte Makrophagen könnten der Stimulation des Immunsystems dienen und möglicherweise in Kombination mit bekannten Immuntherapien, wie anti-PD-L, Einsatz in der Brustkrebstherapie finden.

\section{AG05.P.06}

Is there a need of excisional biopsy after diagnosis of B3 breast lesions in core biopsies?-An interdisciplinary single center study

R.Erber ${ }^{1 *}$, S. Jud ${ }^{2}$, F. Heindl' ${ }^{2}$, M. Wunderle ${ }^{2}$, J.Emons ${ }^{2}$, C. Rauh ${ }^{2}$, C. C. Hack ${ }^{2}$, M. P. Lux ${ }^{2}$, M. W. Beckmann' ${ }^{2}$ P. A. Fasching ${ }^{2,3}$, E. Wenkel', R. SchulzWendtland ${ }^{4}$, M. Uder ${ }^{4}$, A. Hartmann ${ }^{1}$, C. Preuß ${ }^{2}$

'Universitätsklinikum, Comprehensive Cancer Center Erlangen-EMN, Pathologisches Institut, Erlangen, Germany, ${ }^{2}$ Universitätsklinikum, Comprehensive Cancer Center Erlangen-EMN, Frauenklinik, Erlangen, Germany, ${ }^{3}$ University of California at Los Angeles, David Geffen School of Medicine, Department of Medicine, Division of Hematology and Oncology, Los Angeles, United States, ${ }^{4}$ Universitätsklinikum, Comprehensive Cancer Center Erlangen-EMN, Radiologisches Institut, Erlangen, Germany

In breast core biopsies, lesions are categorized into B1 to B5 lesions. B3 category defined as benign lesions with uncertain malignant potential includes heterogeneous histopathological breast parenchyma changes. In clinical routine, handling of $\mathrm{B} 3$ lesions in vacuum-assisted biopsies (VAB) or core needle biopsies (CNB) aims at reaching an optimum management but the perfect procedure may remain unclear in some cases. In our study, we assessed the malignancy rate associated with various B3 lesions after surgical excision and final histological examination.

In a single center study, we retrospectively evaluated 201 cases of vacuumassisted (VAB) or core needle biopsies (CNB) with B3 lesions from 05/2016 to $07 / 2018$. Inclusion criteria were a successfully performed VAB or CNB of a suspicious lesion in mammography and/or breast sonography and/ or MRI resulting in histopathological diagnosis of a B3 lesion followed by excisional biopsy and available histological results.

Inclusion criteria were met in 148 of 201 cases with excisional biopsy resulting from $\mathrm{B} 3$ lesions in $\mathrm{VAB}$ or $\mathrm{CNB}$. In the surgical specimens of pretherapeutical diagnosed $\mathrm{B} 3$ lesions, that could harbor more than one $\mathrm{B} 3$ lesion, malignancy rate was $3.4 \%$ for invasive breast cancer (BC, $n=5$ ) and $9.5 \%$ for ductal carcinoma in situ (DCIS, $n=14$ ). B3 lesions that were upgraded to BC and DCIS by open biopsies were lobular neoplasia (LN, $n=7 / 12,58.3 \%$ ), intraductal papilloma (PA, $n=6 / 48,12.5 \%$ ), atypical ductal hyperplasia (ADH, $n=5 / 25,20.0 \%$ ) and flat epithelial atypia (FEA, $n=6 / 53,11.3 \%$ ), respectively. One radial scar (RS, $n=1 / 11,9.1 \%$ ) and one fibroadenoma ( $n=1 / 16,6.3 \%)$, respectively, were diagnosed each as DCIS in the final histopathological report.

Upgrading of B3 lesions to malignant lesions in surgical specimens (i. e. $\mathrm{BC}$ and DCIS) expected from literature occurs in 3-28\% for LN, $14-27 \%$ for PA, 7-58\% for ADH, $0-21 \%$ for FEA and $0-16 \%$ for RS, respectively. Expected rate of malignancy ranges between 20 and $34 \%$. In our study, upgrade rate was lower than expected from literature data with $3.4 \%$ for BC and $9.5 \%$ for DCIS (12.9\%) in excisional biopsy. Given this low upgrade rate from $\mathrm{B} 3$ to malignant lesions, it is debatable whether excisional biopsy has to follow every diagnosed B3 lesion. Alternatives like minimal invasive breast biopsy (VABB), renaissance of stereotactic excisional biopsy (e.g. $\mathrm{ABBI}$ ) or so called "wait and see" strategies should be investigated further. 


\section{AG05.P.07}

Entwicklung eines Prädiktionsmodelles der Platin-Sensisitivität im high-grade serösen Ovarialkarzinom auf Basis einer digitalen Genexpressionssignatur

F.D. Mairinger ${ }^{*}$, A. Bankfalvi', K. W. Schmid ', E. Mairinger ${ }^{1}$, P. Mach', R. F. H. Walter ${ }^{1,3}$, S. Borchert', S. Kasimir-Bauer ${ }^{2}$, R. Kimmig' ${ }^{2}$, P. Buderath ${ }^{2}$

'Universitätsklinikum Essen, Institut für Pathologie, Essen, Deutschland, 'Universitätsklinikum Essen, Klinik Frauenheilkunde und Geburtshilfe, Essen, Deutschland, ${ }^{3}$ Universitätsklinikum Essen, Ruhrlandklinik - Westdeutsches Lungenzentrum, Essen, Deutschland

Ziel. Das Ansprechen auf Platin-basierte Chemotherapieregime ist einer der prognostischen Hauptfaktoren des high-grade serösen Ovarialkarzinomes (HGSOC). Obwohl der genaue Mechanismus der Platinresistenz bislang unklar ist, legen aktuelle Entwicklungen der Forschung einen essentiellen Einfluss des Immunsystems nahe. Dennoch fehlen prädiktive Marker beinahe zu Gänze. Die vorliegende Arbeit versucht, den Einfluss des Tumor Mikromileus in HGSOC auf ein Ansprechen zu untersuchen und prädiktive Signaturen zu identifizieren.

Methoden. 11 Platin-sensitive sowie 12 Platin-resistente HGSOCs wurden mittels NanoString digitaler Genexpressionsanalyse auf 770 immunrelevante Gene hin untersucht. Als Validierungskohorte wurden öffentlich verfügbare Genexpressionsdaten (RNA-Seq) von 303 epithelialen Ovariankarzinomen der The Cancer Genome Atlas (TCGA)-Datenbank verwendet. Verschiedene Scoring-Systeme basierend auf unterschiedlichen Algorithmen wurden entwickelt und hinsichtlich ihres Prädiktionspotentiales (Risk-of-Resisctance, Disease-free Survival, Overall Survival) überprüft. Ergebnisse. Scoring Systeme basieren auf der mRNA Expression von 11 (Risk-of-Resisctance), 7 (Overall Survival) bzw. 4 (Disease-free Survival) konnten durch maschinelles Lernen erfolgreich generiert und anschließend an der Validierungskohorte validiert werden.

Fazit. Unsere Ergebnisse legen nahe, dass ein Ansprechen auf eine Platinbasierte Chemotherapie mit spezifischen Prozessen der Immunantwort gegen den Tumor vergesellschaftet ist. Basierend auf dieser Erkenntnis konnten wir prädiktive Werkzeuge erstellen, mit deren Hilfe das Patientenmanagement von HGSOC in naher Zukunft hoffentlich deutlich verbessert werden kann.

\section{AG05.P.08}

Einfluss der Metallothionein Expression auf Tumor-Immunantwort in serösen high-grade Ovarialkarzinomen

E. Mairinger ${ }^{1 *}$, P. Buderath' ${ }^{2}$, S. Borchert ${ }^{1}$, P. Mach ${ }^{2}$, M. Wessolly', D. Westerwick', R. F. H. Walter1,3, J. Schmeller', R. Kimmig', B. Jasani, K.W. Schmid', A. Bankfalvi', F. D. Mairinger ${ }^{1}$

'Universitätsklinikum Essen, Institut für Pathologie, Essen, Deutschland, ${ }^{2}$ Universitätsklinikum Essen, Klinik für Frauenheilkunde und Geburtshilfe, Essen, Deutschland, ${ }^{3}$ Universitätsklinikum Essen, Ruhrlandklinik Westdeutsches Lungenzentrum, Essen, Deutschland, ${ }^{4} T a r g o s$ Molecular Pathology GmbH, Kassel, Deutschland

Ziel. Die intrazelluläre Zink-Homöostase spielt eine entscheidende Rolle bei diversen zellulären Prozessen insbesondere der Modulation des Immunsystems. Metallothioneine (MT) sind Proteine, die in der Lage sind, freie Zinkionen innerhalb der Zelle zu binden und auf diese Weise immunologische Prozesse zu mediieren. Ziel der vorliegenden Studie war es den Einfluss von Metallothioneinen auf Prognose und Überleben von Patientinnen mit high-grade serösen Ovarialkarzinomen (HGSOC) und deren Immunantwort gegen den Tumor zu untersuchen.

Methoden. HGSOC-Tumorproben von 24 Patientinnen wurden im Hinblick auf ihre Genexpressionssignatur mittels der NanoString nCounter Plattform untersucht. Das verwendete Panel beinhaltet 770 immunassoziierte Ziele sowie 30 Referenzgene. Zusätzlich wurde die zugehörige MTExpression immunhistochemisch gefärbt und mittels eines semiquantitativen Scoring-Systems evaluiert.

Ergebnisse. Rund 43 \% der Proben wiesen eine detektierbare MT-Expression auf. Diese war in unserer Studienkohorte signifikant mit längerem progressionsfreiem sowie längerem Gesamtüberleben assoziiert. Darüber hinaus zeigten die MT positiven Tumore eine stärkere Aktivierung des TZell-Rezeptor Signalwegs, höhere Level an IFN $\gamma$, Perforinen und diversen Granzymen. Dies lässt auf eine stärkere immunologische anti-TumorAntwort schließen.

Fazit. Metallothionein Überexpression ist für HGSOC ein guter prognostischer Marker, der mit erhöhter anti-Tumor-Immunantwort und damit besserem Überleben assoziiert ist. Die von uns beobachte Immunaktivierung war dabei nicht nur auf T-Zellen beschränkt, sondern ließ sich auch auf andere Immunmechanismen ausweiten.

\section{AG05.P.09 \\ FAP und FN1 - neue organunabhängige Marker für Diagnostik und Therapie humaner Tumoren?}

E. Mairinger ${ }^{1 *}$, P. Buderath', S. Theurer', S. Borchert', P. Mach², T. Hager', D. Westerwick', R. F. H. Walter ${ }^{1,3}$, J. Schmeller', R. Kimmig ${ }^{2}$, K. Herrmann ${ }^{4}$, A. Bankfalvi', K. W. Schmid', F. D. Mairinger'

'Universitätsklinikum Essen, Institut für Pathologie, Essen, Deutschland, 2Universitätsklinikum Essen, Klinik für Frauenheilkunde und Geburtshilfe, Essen, Deutschland, ${ }^{3}$ Universitätsklinikum Essen, Ruhrlandklinik Westdeutsches Lungenzentrum, Essen, Deutschland, ${ }^{4}$ Universitätsklinikum Essen, Klinik für Nuklearmedizin, Essen, Deutschland

Ziel. Eine erhöhte Anzahl tumorassoziierter Fibroblasten und Stromadesmoplasie sind ein starker prognostischer Marker, der in diversen humanen Tumoren auf Malignität und (Lymphknoten-) Invasion hinweist. Fibroblast Activating Protein (FAP) und Fibronectin1 (FN1) sind zwei Marker, die stark mit Fibroblastenaktivierung assoziiert sind. Insbesondere FAP gerät immer mehr in den diagnostischen sowie therapeutischen Fokus, besonders in der Nuklearmedizin/Radiopharmazie.

Methoden. 149 Proben von Patienten mit verschiedenen Tumorgeweben und -entitäten (Ovar, Brust, Schilddrüse) mit verschieden starker Ausprägung einer desmoplastischen Stromareaktion wurden im Hinblick auf ihr mRNA Expressionsprofil via NanoString nCounter Platform untersucht. Das hierfür speziell designte Panel bestand aus 209 Ziel- sowie 9 Referenzgenen. Zusätzlich wurden FAP und FN1 immunhistochemisch gefärbt und mittels semiquantitativem Scoring-System ausgewertet.

Ergebnisse. FAP und FN1 waren in unserer Studienkohorte stark mit dem Auftreten einer Stromadesmoplasie assoziiert. Darüber hinaus korrelierten beide Marker mit Malignitäts- bzw. metastatischem Potential der Neoplasien. Dies konnte unabhängig vom Ursprungsgewebe des Tumors bzw. der Tumorentität gezeigt werden. $36 \%$ aller Proben zeigten eine starke Akkumulation von FAP.

Fazit. FN1 und FAP sind beides Proteine, die organunabhängig Hinweise auf die Malignität eines Tumors geben können. Vor allem im Hinblick auf „Theranostics“ ist FAP ein vielversprechender Marker für neue Ansätze der Nuklearmedizin, der eine weitere Schnittstelle zwischen Pathologie und Klinik bieten könnte.

\section{AG05.P.10}

\section{Unusual Sertoli Leydig cell tumor with high-level AFP in a 16-year young patient}

D. Mayr ${ }^{1 *}$, E. Schmoeckel ${ }^{1,2}$, K. Friedrich ${ }^{2}$, A. Forberger ${ }^{2}$, A. Jung ${ }^{1}$, T. Kirchner ${ }^{1}$

'Pathologisches Institut der LMU München, Munich, Germany, Institut für Pathologie des Universitätsklinikums Carl Gustav Carus, Dresden, Germany

Aim. A 16-year old young woman came to hospital with a large, multicystic ovarian tumor (diameter $17 \mathrm{~cm}$ ) and an AFP >7000 ng/ml. After extensive investigations a biphasic tumor with on the one hand a glandular differentiation and one the other hand a cell-rich stroma with small glands was described. The epithelium expressed CDX2 and Cadherin-17, focally CK20 and Claudin-18 and sporadically chromogranin and synaptophysin. Additionally a positive reaction was seen for AFP, Glypican 3, SALL4 and INI-1. Negative were CK7, OCT-4, ER, PAX8, WT-1, CD30, CD56, cal- 
retinin and PLAP. Based on these results the pathologist favor a yolk sac tumor with focal differentiation into gland-like structures (intestinal type) Methods. After re-evaluation of the transmitted slides, in our institute according immunostainings and molecular analysis were done. In addition, we could demonstrate a positivity in the stroma for WT-1, Inhibin, CD56, Vimentin and weakly CD99. The large glands were CK7 and dotlike CD10, the small gland-like structures weakly Inhibin and calretinin positive. Ki-67 was high in the glands and low in the stroma. In our molecular analysis, two oncogene-activating mutations in the DICER1-gene could be demonstrated.

Result. Based on morphology, immune profile and molecular result we diagnosed an unusual variant of a Sertoli Leydig cell tumor (SLCT) with heterologous elements.

Conclusion. In more than $60 \%$ of all SLCT a mutation in the DICER1 gene can be detected. However, it is important to note that DICER1 mutations are not specific for SLCT. According to the literature, SLCTs may have AFP-producing cells, which may be associated with endodermal differentiation. The heterologous intestinal-type glands in SLCTs often have a yolk sac like (endodermal sinus-like) immunophenotype with a positivity for Glypican3, SALL4, AFP. These results should not lead to misinterpretation as yolk sac tumor. For diagnosis extensive sampling, carefully histomorphological examination, immunohistochemical stainings and, in case of doubt, DICER1-mutation analysis can be recommended.

\section{AG Informatik, Digitale Pathologie und Biobanking Poster}

\section{AG07.P.01 \\ Was sieht das PSMA-PET? Korrelation von Autoradiografie, Histologie und Immunhistochemie am Adenokarzinom der Prostata mittels digitaler Pathologie}

M. Reiser ${ }^{1 *}$, K. Schwamborn' ${ }^{1}$ H. Wang ${ }^{2}$, M. Schottelius ${ }^{2}$, N. Yusufi', M. Eiber ${ }^{2}$, W. Weichert ${ }^{1}$, K. Steiger

'Institut für Allgemeine Pathologie und Pathologische Anatomie der Technischen Universität München, München, Deutschland, ${ }^{2}$ Nuklearmedizinische Klinik des Klinikums rechts der Isar, München, Deutschland

Ziel. Die spezifische Expression von PSMA im Prostatagewebe und die erhöhte Expression im Prostatakarzinom erlaubt der Nuklearmedizin die zielgerichtete $\mathrm{Lu}^{117}$-PSMA-Therapie sowie die prä-/intraoperative PSMABildgebung zur Detektion von Metastasen. Jedoch treten vereinzelt PSMAnegative Prostatakarzinome bzw. Karzinomareale auf, wobei deren biologische Eigenschaften im Vergleich zum PSMA-positiven Prostatakarzinom noch nicht untersucht sind. Um Areale mit unterschiedlicher Anreicherung des PSMA-Liganden identifizieren und molekularpathologisch analysieren zu können, soll ein Workflow zur Koregistrierung von präoperativer Bildgebung und Histologie/Immunhistochemie etabliert werden. Methoden. Die Patienten erhalten 1 Tag prä-OP einen Tc99 m-PSMALiganden mit anschließender SPECT-CT Bildgebung. Die Prostatektomiepräparate werden als Frischpräparat an uns übersandt und unverzüglich gemäß dem diagnostischen Standard zugeschnitten. Jede zweite Scheibe wird in Formalin der Autoradiografiemessung zugeführt und nach Fixierung über Nacht wieder in die Routinediagnostik eingeschleust. Eine Beeinträchtigung der Autoradiografie durch Formalinfixierung wurde im Voraus ausgeschlossen. Nach Anfertigung von Großflächenschnitten mit HE-Färbung und PSMA-Immunhistochemie werden diese manuell und landmarkenbasiert als Großflächenscan mit einem Aperio CS2 Slidescanner digitalisiert, die Karzinomareale mit der Software Aperio ImageScope annotiert und schließlich mit dem Autoradiografiebefund überlagert. Ergebnisse. Der etablierte Workflow erlaubt die Koregistrierung von Autoradiografie und (Immun-)Histologie und dadurch die Analyse von Morphologie und PSMA-Expressionsprofil der autoradiografisch positiven bzw. negativen Areale. Bisher wurden 5 Patienten von 51 bis 79 Jahren
(MW 64 Jahre) untersucht. Voraussetzung für die radioguided surgery war ein positive Nodalstatus (2-4 LK-Metastasen). Das Tumorstadium variierte von pT2c bis pT3b, der Gleason-Score von 7b bis 9. So konnten bereits autoradiografisch und immunhistochemisch negative Karzinomareale identifiziert werden, die sich der PSMA-Bildgebung entziehen und nun histomorphologisch und molekularpathologisch weiter untersucht werden sollen.

Fazit. Es ist uns gelungen, einen Workflow zu etablieren, der die Prozessierung Tc99 m-PSMA-markierter radikaler Prostatektomiepräparate mit Korrelation von Histologie/PSMA-Immunhistochemie und Autoradiografie am selben Gewebsmaterial ohne Interferenz mit der klin. Diagnostik erlaubt.

\section{AG07.P.02}

\section{Automated detection of the HER2 gene amplification status in} Fluorescence in situ hybridization images for diagnostics of cancer tissues

F. Zakrzewski ${ }^{1 *}$, W. De Back', M. Weigert ${ }^{3,4}$, T. Wenke ${ }^{5}$, S. Zeugner ${ }^{1}$, R. Mantey ${ }^{6}$, K. Friedrich', I. Roeder ${ }^{2,6}$, D. E. Aust ${ }^{1,6}$, P. Hoenscheid ${ }^{1,6}$, G. B. Baretton ${ }^{1,6}$

${ }^{1}$ Carl Gustav Carus Universitätsklinikum Dresden, Institut für Pathologie, Dresden, Germany, ${ }^{2}$ Technische Universität Dresden, Institut für medizinische Bioinformatik, Dresden, Germany, ${ }^{3}$ Max Planck Institute of Molecular Cell Biology and Genetics (MPI-CBG), Dresden, Germany, ${ }^{4}$ Center for Systems Biology Dresden (CSBD), Dresden, Germany, ${ }^{5}$ ASGEN GmbH $\&$ Co. KG, Dresden, Germany, ${ }^{6}$ National Center for Tumor Diseases (NCT), Partner Site Dresden, Dresden, Germany

Aim. The detection of the gene amplification status of human epidermal growth factor receptor 2 (HER2) is applied for evaluating a clinical strategy e.g. an anti-HER2-therapy in breast or stomach cancer. For that reason, the detection of HER2 gene amplification status is the fundamental prerequisite in histopathological diagnostics. We targeted the automation of HER2 gene amplification detection in Fluorescence in situ hybridization (FISH) images via trainable neural networks.

Methods. We applied a deep learning-based system for the detection, localization and classification of interphase nuclei depending on their HER2 gene amplification state in FISH images. Our system consist of two deep neural network architectures which are trained on (1) the detection and classification of interphase nuclei into normal, low-grade and high-grade and on (2) the detection and classification of FISH signals into HER2 and into the centromere of chromosome 17 (CEN17). In the first convolutional neural network (CNN) step interphase nuclei are localized image-wide and a first classification is applied. This classification is controlled and supplemented by HER2/CEN17 FISH signal ratios for the same nucleus by the second CNN. Consequently, an automated image-wide decision on the HER2 gene amplification stage is possible.

Results and conclusion. The accuracy of our deep learning-based system is on par with that of a pathologist. FISH images can now be analyzed at once regarding their image-wide HER2 gene amplification status. The automatic pipeline is a first step towards assisting the pathologist in evaluating the HER2 status of tumors using FISH images, for analyzing FISH images in retrospective and for optimizing the documentation of each tumor sample by automatically annotating and reporting of the HER2 gene amplification specificities. 


\section{AG07.P.03}

BiasCorrector: an online tool for correction of measurement biases in quantitative epigenetic data

\begin{abstract}
L. Kapsner ${ }^{1 *}$, M. Zavgorodnij' ${ }^{2}$, S. Majorova ${ }^{3}$, A. Hartmann ${ }^{4}$, S. Mate , H.-U. Prokosch ${ }^{5}$, F. Haller ${ }^{4}$, E. Moskalev

'Universitätsklinikum Erlangen, Das Medizinische Zentrum für Informations- und Kommunikationstechnik, Erlangen, Germany, ${ }^{2}$ Staatliche Universität Woronesh, Mathematische Fakultät, Woronesh, Russian Federation, ${ }^{3}$ Staatliche Technische Universität Woronesh, Fakultät für Informationstechnologie und Sicherheit, Woronesh, Russian Federation, ${ }^{4}$ Universitätsklinikum Erlangen, Institut für Pathologie, Erlangen, Germany, ${ }^{5}$ Friedrich-Alexander-Universität Erlangen-Nürnberg, Institut für Medizininformatik, Biometrie und Epidemiologie, Erlangen, Germany
\end{abstract}

Measurement biases in DNA methylation studies may hamper interpretation of results. PCR-amplification of bisulfite-treated DNA often results in a selective enrichment of either unmethylated or methylated alleles, known as PCR-bias. Additional measurement biases may be introduced by the very quantification methods. We have earlier developed a process for correcting measurement biases by accepting their occurrence during experimentation but adjusting the results by a comparison with to calibration data derived from the calibration DNA samples of different methylation percentages. The correction process based on cubic polynomial regression was found to be optimal and applicable irrespective of the loci that were interrogated. To facilitate the applicability of this process, we aimed at developing a software tool for automatic correction of raw methylation values and extensive validation using our experimental data obtained by different technologies.

Our earlier developed algorithm was implemented in the statistical programming language R (Team R.C., 2018) and provided as a Shiny ${ }^{\circledast}$ web application using the $\mathrm{R}$ package shiny (Chang et al., 2018). DNA methylation percentages of cancer-associated genes were quantified in calibrator DNA samples (Qiagen) by using bisulfite pyrosequencing (Qiagen), massively parallel sequencing of amplicons (Roche) and hybridisation onto in situ synthesised oligonucleotide microarrays (febit).

BiasCorrector was developed with a graphical user interface and its application requires no prior programming experience. The app operates in two alternative modes: analysis of one gene in multiple biological samples (pyrosequencing data) or multiple genes in one specimen (microarray and sequencing data). The best regression type-cubic polynomial or hyperbolic-is selected automatically by analysing the sum of squared errors. Correction of each raw methylation value in every biological sample is performed server-based. Alternatively, the program can be downloaded and run locally. The final corrected percentages are displayed in a tabular format and can be downloaded by a user. Publication-ready regression plots and further statistical parameters can be included in the final report. The correct operation of BiasCorrector was confirmed for both modes of correction and all types of experimental data.

BiasCorrector enables fast testing and accurate correction of raw methylation percentages providing a substantial support for epigenetic studies.

\section{AG07.P.04}

\section{Automatische Segmentation von Stanzbiopsiezylindern durch ein} U-net

T. Münchow ${ }^{1 *}$, J. Leichsenring ${ }^{2}$, K. Simon ${ }^{3}$, J.-P. Radtke ${ }^{4,5}$, P. Schelb ${ }^{1}$, H.-P. Schlemmer ${ }^{1}$, K. Maier-Hein ${ }^{3}$, M. Hohenfellner ${ }^{5}$, P. Schirmacher ${ }^{2}$, A. Stenzinger ${ }^{2}$, D. Bonekamp ${ }^{1}$

'Deutsches Krebsforschungszentrum (DKFZ), Radiologie, Heidelberg, Deutschland, 'Universitätsklinikum Heidelberg, Pathologisches Institut, Heidelberg, Deutschland, ${ }^{3}$ Deutsches Krebsforschungszentrum (DKFZ), Medical Image Computing, Heidelberg, Deutschland, ${ }^{4}$ Deutsches Krebsforschungszentrum (DKFZ), Heidelberg, Deutschland, ${ }^{5}$ Universitätsklinikum Heidelberg, Urologie, Heidelberg, Deutschland

Ziel. Training eines Convolutional Neural Network (CNN) zur Segmentation von Gewebeschnitten aus Prostatastanzbiopsiezylindern.
Methoden. 50 konsekutive Patienten mit klinischem Verdacht auf Prostatakarzinom wurden bei $3 \mathrm{~T}$ an einem MR System mit einem PI-RADS kompatiblen multiparametrischen Protokoll untersucht. Gezielte Ultraschall-MRT Fusionsbiopsien aller PI-RADS $\geq 3$ Läsionen wurden zusätzlich zu systematischen 24-fach Sextantenbiopsien nach dem Ginsburg Schema durchgeführt. Hämatoxylin-Eosin gefärbte Stanzzylinderschnitte wurden mit einem Hamamatsu NanoZoomer 210 Digital slide scanner mit einer Auflösung von $40 \times$ digitalisiert. Prostatisches Drüsengewebe, Immuninfiltrate und Tumorareale unterteilt nach Gleason Wachstumsmuster sowie weitere Anomalitäten wurden manuell mittels NanoViewer Software annotiert. Die digitalen Annotationen der Stanzzylinder in Vergrößerung $40 \times$ sowie $10 \times$ wurden in $256 \times 256$ Pixel große Kacheln unterteilt. In einer Subkohorte mit 20 Patienten wurden von 79 manuell annotierten Stanzzylindern 44 zum Training verwendet, damit lagen für das Training eines U-net ca. 120.700 Einzelbilder zur Verfügung. Diese wurden durch Rotation (-pi/2 bis + pi/2), Skalierung $(0,7$ bis 1,3$)$ und elastische Deformation (alpha 0 bis 175, sigma 9 bis 13) in jeder der insgesamt 20 Epochen verschieden augmentiert. Automatische Segmentationen der Zylinderkacheln im Testset wurden wieder zu vollständigen Bildern zusammengesetzt, um eine visuelle Beurteilbarkeit des Resultates zu gewährleisten.

Ergebnisse. Manuell annotierte Tumorareale wurden vom U-net sehr zuverlässig identifiziert. Die Spezifität muss noch optimiert werden. Der Dice-Koeffizient von Tumorzellen liegt im Trainings Set bei über 0,8, im Test Set bislang bei etwa 0,5. Dem offensichtlich auftretenden Overfitting wird erwartungsgemäß mit der Inklusion aller 50 Patienten in Trainings- bzw. Test Set entgegengewirkt werden können. Die genaue Spezifität und Sensitivität des finalen U-net wird bis zur Konferenz ermittelt und vorgestellt. Fazit. Ein artifizelles neurales Netzwerk erreichte erste vielversprechende Ergebnisse bei der Segmentation von Gewebsschnitten aus Prostatastanzbiopsiezylindern.

\section{AG07.P.05}

\section{Herausforderungen und Erfolge im Biobanking am Beispiel der} Gewebebank des Nationalen Centrums für Tumorerkrankungen (NCT)

N. Volk ${ }^{1 *}$, S. Schmitt ${ }^{2}$, C. Döllinger ${ }^{2}$, A. Maier ${ }^{2}$, P. Schirmacher ${ }^{3}$, E. Herpel ${ }^{1,3}$

'Universitätsklinikum Heidelberg, Gewebebank des NCT, Heidelberg, Deutschland, ${ }^{2}$ Universitätsklinikum Heidelberg, BioMaterialBank Heidelberg, Heidelberg, Deutschland, ${ }^{3}$ Universitätsklinikum Heidelberg, Pathologisches Institut, Heidelberg, Deutschland

Biobanken sammeln humane Proben und stellen diese für die Forschung zur Verfügung. In den letzten Jahren erhöhte sich die Nachfrage nach Biomaterialien stetig. Zusätzlich brachten neue Rahmenbedingungen richtungsweisende Veränderungen mit sich. Wie sich die Voraussetzungen für das Biobanking und die Arbeitsabläufe der Biobanken verändert haben, soll hier am Beispiel der Gewebebank des NCT aufgezeigt werden. Die Gewebebank wurde im Jahr 2005 gegründet, um Gewebe gemäß SOPs $\mathrm{zu}$ asservieren und für die Forschung aufzuarbeiten. Im Jahr 2006 wurden dabei 411 Proben kryo-asserviert und in einer Access Datenbank erfasst. Die zusätzlichen Dienstleistungen umfassten das Anfertigen von Schnitten aus Kryomaterial sowie aus FFPE-Gewebe, das vom Pathologischen Institut zur Verfügung gestellt wurde, des weiteren IHC und das Anfertigen von TMAs. Das Projektaufkommen lag 2006 bei 44. Bis 2008 wurde ein QM System etabliert, so dass die Gewebebank 2009 akkreditiert werden konnte. Da keine einheitliche Biobank Norm vorlag, erfolgte die Akkreditierung nach der DIN EN ISO/IEC 17.020. Im Jahr 2018 hat sich das Projektaufkommen auf 267 und die Zahl der jährlich asservierten Proben auf 1233 erhöht. Zudem wurde das Angebot erweitert, so dass nun die Extraktion von Nukleinsäuren sowie virtuelle Mikroskopie angeboten werden können. Um die Probenregistrierung zu verbessern wurden barcodierte Probenröhrchen und ein LIMS System eingeführt. Zur Erfassung der Dienstleistungen sowie der Antikörper wurden zusätzliche Datenbanken programmiert. Zudem wurde ein Businessmodell entwickelt, um die Nachhaltigkeit der Gewebebank zu verbessern. Weitere Maßnahmen um das Biobanking lokal zu fördern, war der Zusammenschluss aller Hei- 
delberger Biobanken in einem Dachverbund, der BMBH. Derzeit beteiligt sich die Gewebebank auch an (inter)nationalen Netzwerken wie GBA und BBMRI. In Zusammenarbeit mit der GBA konnte die Nutzerzufriedenheitsabfrage von einer Rückmelde E-Mail auf eine detaillierte OnlineUmfrage umgestellt werden. Eine weitere Entwicklung im Bereich Biobanking ist die Einführung einer eigenen Biobank Norm, der DIN ISO 20387. Obgleich der Fortschritte, fehlen weiterhin gesetzliche Rahmenbedingungen, so dass sich die Biobanken z.Z. nur an Stellungnahmen z. B. des Nationalen Ethikrats orientieren können. Die Arbeit der (inter)nationalen Netzwerke ist daher erforderlich, um das öffentliche Interesse zu erhöhen, gesetzliche Leitlinien zu erarbeiten und die Nachhaltigkeit sicher zu stellen.

\section{AG07.P.06}

\section{Entwicklung eines Webportals an der Gewebebank des NCT zur Beantragung von Biomaterial und Daten für die klinische Forschung}

W. S. Keunvo Nogning Yeffou ${ }^{1 *}$, C. Döllinger ${ }^{1}$, S. Schmitt ${ }^{1}$, R. Kirsten ${ }^{2}$, E. Herpel ${ }^{1}$ ${ }^{1}$ BioMaterialBank am Pathologischen Institut, Universitätsklinikum Heidelberg, Heidelberg, Deutschland, ${ }^{2}$ Nationales Centrum für Tumorerkrankungen (NCT), Heidelberg, Deutschland

Ziel. Durch die Etablierung von zentralisierten Biomaterialbanken ist auch der Dokumentationsaufwand für die Bearbeitung und Herausgabe von Biomaterial gestiegen. Um im Rahmen eines kontrollierten Projektmanagements die Prozessierung und Abgabe von Biomaterialproben dokumentieren und nachverfolgen zu können, müssen Forscher ihre benötigten Proben in Form eines Projektantrags an der Gewebebank des NCT Heidelberg anfordern. Die hierfür notwendigen Formulare werden häufig noch in Papierform an die Biobank übermittelt. Um den Prozess zu beschleunigen, abzusichern und zu verbessern, wurde ein Web-basiertes Antragsportal entwickelt.

Methoden. Zur Beantragung von Biomaterial (bzw. auch von Dienstleistungen und Daten) stellen die Forscher einen Antrag mit einem kurzem Exposée des geplanten Forschungsprojekts und ihren Anforderungen an die Biobank. Dieser wird zunächst geprüft und muss ein Genehmigungsverfahren durchlaufen, bis er schließlich von den Mitarbeitern der Biobank bearbeitet werden kann.

Bisher lief das Antragsverfahren an der Gewebebank des NCT papierbasiert, d. h. die Forscher füllten ein Formular aus, welches per Post oder Fax an die Biobank übermittelt wurde. Alle Anträge mussten dann per Hand in ein Datenbanksystem übertragen werden, was einen unnötigen Zeitaufwand bedeutete und fehleranfälliger war.

Ergebnisse. Um das Antragsverfahren zu beschleunigen, wird ein Webportal entwickelt, bei dem sich Forscher einloggen, neue Anträge stellen und Informationen über den Status ihrer bereits gestellten Anträge abrufen können. Die eingegebenen Daten werden dort zunächst auf Plausibilität geprüft und laufen anschließend über eine Schnittstelle in die Datenbank des Antragsverwaltungssystems der Gewebebank des NCT. Dort müssen die Anträge lediglich noch geprüft und freigegeben werden, bevor sie als Projekt bearbeitet werden. Biobank-Mitarbeiter sollen das Portal auch dazu nutzen können, um Informationen über ihre betreuten Projekte abzurufen (z. B. der Status der Bearbeitung).

Fazit. Durch die Einführung eines Antragsportals verringert sich der Dokumentationsaufwand und die Bearbeitungszeit für Projektanträge. Weiterhin kann das Portal auch genutzt werden, um Informationen über den Status von Anträgen zu erhalten.

\section{AG07.P.07}

\section{„Friendly“ Auditsystem zur kontinuierlichen Verbesserung von} Biobanken

C. Hartfeldt ${ }^{1 *}$, B. Meinung ${ }^{2}$, C. Specht ${ }^{1}$, P. Schirmacher ${ }^{3}$, M. Kiehntopf $^{2}$, M. Hummel', S. Schmitt'

${ }^{1}$ Charité Universitätsmedizin Berlin/Institut für Pathologie, German Biobank Node, Berlin, Deutschland, ${ }^{2}$ Institut für Klinische Chemie und Laboratoriumsdiagnostik, Integrierte Biobank Jena, Jena, Deutschland, ${ }^{3}$ Institut für Pathologie/Universitätsklinikum Heidelberg, Heidelberg, Deutschland, ${ }^{4}$ Institut für Pathologie/Universitätsklinikum Heidelberg, BioMaterialBank Heidelberg, Heidelberg, Deutschland

Ziel. Die Qualitätsmanagementsysteme der Biobanken in der German Biobank Alliance (GBA) wurden auf der Grundlage des QM-Manuals und des Regelwerks vom German Biobank Node (GBN) harmonisiert. In „friendly“ Audits werden Verbesserungspotentiale auf Proben-, Prozess- und Systemebene identifiziert, und entsprechende Rückmeldung soll dazu beitragen, die Prozesse der Biobanken weiterzuentwickeln und zu verbessern. Übergeordnet wird das Auditprogramm der GBA mit den Programmen nationaler und internationaler Netzwerke (DZGs, NAKO Gesundheitsstudie, BBMRI-ERIC) harmonisiert.

Methoden. Das Auditkonzept für die GBA-Biobanken basiert sowohl auf der Leitlinie zur Auditdurchführung DIN EN ISO 19011, auf den derzeit im Biobanking angewandten Normen DIN EN ISO 9001:2015, $17025,17020,15189$, sowie der kürzlich veröffentlichten Biobankennorm ISO 20387. Um die Audits durchführen zu können erhielten angehende Auditoren zunächst eine mehrtägige Schulung in Kooperation mit der TÜV Süd- Akademie, gefolgt von einer biobankspezifischen Schulung durch Fachexperten aus der GBA. Die finale Qualifizierung zum Auditor wurde durch einen Online-Test sowie eine Bewertung der praktischen Tätigkeit als Auditor über ihre fachliche und Normen-Kompetenz erreicht. Ergebnisse. Innerhalb der GBA wird jede Biobank einmal jährlich auditiert von einem Auditteam bestehend aus einem Lead- und einem CoAuditor. Das GBA-Auditprogramm bietet somit auch eine Plattform zur Weiterentwicklung für die Biobanken. Bereits die ersten Audits zeigten einen enormen Wissens- und Erfahrungsaustausch für alle Beteiligten. In jährlichen Meetings werden die Auditoren außerdem zu Änderungen der angewendeten Normen und weiteren aktuellen Themen geschult und sich intern zur Auditdurchführung und einer Verbesserung des Auditprogramms austauschen.

Fazit. Es wird angestrebt, das Konzept des GBA-Auditsystem auf andere nationale Netzwerke mit Biobanking-Aktivitäten auszudehnen, wie z. B. die Deutschen Zentren für Gesundheitsforschung und die NAKO Gesundheitsstudie, um einen gemeinsamen Ansatz zur Integration und Harmonisierung der Prüfungsaktivitäten auf nationaler Ebene zu initiieren. Hierfür nahmen bereits Mitarbeiter dieser Konsortien an den Auditorenschulungen teil. Zukünftig soll das GBA-Auditkonzept in Abstimmung mit BBMRI-ERIC auch in das Konzept von Audits auf europäischer Ebene einfließen.

\section{AG07.P.08}

\section{BRoTHER-a unique Bavarian-Czech cooperation to overcome} hurdles for Biobank cooperation

\section{Brochhausen ${ }^{1 *}$, J. Kinkorova ${ }^{2}$, K.-F. Becker ${ }^{3}$, O. Topolcan ${ }^{2}$, M. Evert ${ }^{1}$}

'Universität Regensburg, Institut für Pathologie, Regensburg, Germany, 2University Hospital Pilsen, Department of Immunochemistry, Pilsen, Czech Republic, ${ }^{3}$ Technische Universität München, Institut für Pathologie, Munich, Germany

Aim. Bio-banking represents a pivotal prerequisite for further developments in personalized medicine. Therefore, building networks represent a crucial element to cooperate. On the European level the "Biobanking and Biomolecular Resources Research Infrastructure-European Research Infrastructure Consortium" (BBMRI-ERIC) is an important network for biobanks in Europe. However, regional biobank-networks could significantly improve the translational and basic research within the connect- 
ed regions. To enable an optimal collaboration of regional biobanks, web based tools for data exchanges are mandatory to guarantee a long-term success of such a network.

Methods. The aim is to create a prototype of a digital pathology framework in which secondary consultations regarding biobank-specimens could be conducted remotely for accurate tissue diagnosis and the potential use in a research project (i.e. tele-pathology). Furthermore, we implemented a student exchange program to introduce students from medicine and natural sciences in the biobank idea and the different methods involved in biobanking. Finally, we set-up events to inform the public about the need and the potential of Biobanking to optimize personalized medicine and to encourage participation.

Results. We successfully set-up a pathology framework which enables whole slide Imaging even optimized for small screens. We integrated up to 10 students in our exchange program who were involved in the development of the pathology framework and in the different methods use in the partner sites. Finally, different public events informed highly successful regarding personalized Medicine and biobanking.

Conclusion. The three columns of the BRoTHER project opens innovative perspectives to overcome hurdles in biobank cooperations over different medical systems. Furthermore, the network established strategies to inform the public about biobanking and its relevance for personalized medicine.

\section{AG07.P.09 \\ A Bavarian-Czech student exchange program in BRoTHER introduces students in biobanking}

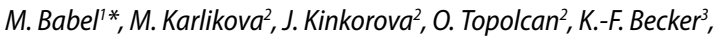
C. Brochhausen'

'Universität Regensburg, Institut für Pathologie, Regensburg, Germany, ${ }^{2}$ University Hospital Pilsen, Department of Immunochemistry, Pilsen, Czech Republic, ${ }^{3}$ Technische Universität München, Institut für Pathologie, Munich, Germany

Aim. Biobanking represents a crucial tool in personalized medicine, which combine different aspects from medicine, biology, cryotechnology and engineering. Thus, biobanking is a real interdisciplinary field. Since the techniques and the aims in biobanking underly tremendous dynamic processes it is important to be aware of the latest developments within the different fields, especially in digitalization. BRoTHER represent a Bavarian-Czech network to facilitate the cooperation of biobanks via digitalization. The aim of the student exchange program within the BRoTHER project is to introduce students of medicine but also from natural sciences into the infrastructure, the different techniques and the hardware systems used in modern biobanking.

Methods. During site visits at the partner biobanks and a summer school the students from the Bavarian and Czech project partners will learn about the handling of hard- and software systems for biobanking as well as the impact of pre-analytics for the quality of biobank specimens. Furthermore, introduction in histochemical and immunohistochemical methods will be performed. The site visits will be monitored by student evaluation and feed-back discussions within the whole consortium.

Results. At least 10 students (8 medical students, 2 students in biochemistry) take part of the exchange program. During the first site visit the students worked in the Department of Immunochemistry to get an introduction and to work with radioimmunoassays. The second event of the exchange program was the first BRoTHER Summer school, where the students discussed with leading experts in the field the questions of specimen quality, IT-systems, hard- and sorftware solutions and the question of data safety in the light of the new European Data Regulation. In the evaluation the students highlighted the experience they did not only on the scientific level but also on the social level: they appreciated the experience they could made in a scientific research laboratory abroad in a different medical system. Furthermore, they highly appreciated the experince in a mixed group of students from medicine and natural sciences.
Conclusion. The BRoTHER student exchange program provide an excellent opportunity to learn about the various parameters of biobanking in different scientific cultures and medical systems. Furthermore, it demonstrates the relevant role of pathology within the biobank scene to medical students.

\section{AG Thoraxpathologie Poster}

\section{AG10.P.01 \\ Dreidimensionale Morphologie der Neoangiogenese in Pulmonal- venöser Verschlusserkrankung und Pulmonaler Kapillärer Hämangiomatose}

\section{Neubert', P. Borchert ${ }^{1 *}$, H.-O. Shin' ${ }^{2}$, F. Linz ${ }^{3}$, W. Wagner', G. Warnecke', F. Länger', A. Haverich' ${ }^{2}$, H. Stark', M. Höper ${ }^{2}$, M. Kühnel', M. Ackermann ${ }^{5}$, D. Jonigk ${ }^{2}$}

'Medizinische Hochschule Hannover, Institut für Pathologie, Hannover, Deutschland, ${ }^{2}$ Medizinische Hochschule Hannover, Hannover, Deutschland, ${ }^{3}$ Johannes Gutenberg-Universität Mainz, Mainz, Deutschland, ${ }^{4}$ Translational Lung Research Center Heidelberg (TLRC), Heidelberg, Deutschland, ${ }^{5}$ Heinrich-Heine-Universität und Universitätsklinikum Düsseldorf, Düsseldorf, Deutschland

Ziel. Die Pulmonal-venöse Verschlusserkrankung (PVOD) ist eine seltene Lungenerkrankung die durch fibrotische Obliterationen der Pulmonalvenen gekennzeichnet ist. Diese führen durch eine Widerstandserhöhung im Lungenkreislauf zu pulmonaler Hypertonie (PH) mit einem progressiven Verlauf durch Rechtsherzversagen. Die aktuelle Nizza-Klassifikation für $\mathrm{PH}$ ordnet die PVOD gemeinsam mit der pulmonalen kapillären Hämangiomatose (PCH) in Gruppe 1' ein, da sich beide Erkrankungen häufig zusammen manifestieren und vermutlich unterschiedliche Manifestationen desselben Krankheitsprozesses darstellen. Die PCH ist dabei durch abnorme Proliferation der Lungenkapillaren mit Verbreiterung der Alveolarsepten charakterisiert. Die zugrunde liegenden Entstehungsmechanismen beider Erkrankungen sind bisher wenig verstanden. Deshalb wurde eine umfassende Analyse an Lungengewebe eines PVOD-Patienten durchgeführt.

Methoden. Die dreidimensionale Struktur vaskulärer Läsionen der PVOD und PCH wurde in einem humanen Lungenexplantat erstmals mit multiplen, sich ergänzenden Techniken wie Micro-Computer Tomographie, Elektronenmikroskopie, Microvascular Corrosion Casting, konventioneller Lichtmikroskopie und Genexpressionsanalyse untersucht.

Ergebnisse. Erstmals konnte die intussuszeptive Angiogenese und Sprouting als dreidimensionale Korrelate der vaskulären Neoformationen in der PCH nachgewiesen werden. Die intussuszeptive Angiogenese ist ein vaskulärer Prozess, bei dem existierende Blutgefäße durch die Bildung von intravaskulären Laminae geteilt werden.

Fazit. Unsere Ergebnisse legen nahe, dass venöse Verschlüsse bei der PVOD Scher- und Dehnungskräfte in den Lungenkapillaren erhöhen und diese darauf mit intussuszeptiver Neoangiogenese als - „reaction to injury pattern" - reagieren.

\section{AG10.P.02}

\section{Characterization of epithelial membrane proteins (EMP1-3) in} human lung cancer

\section{Abubrig, Y. Ma, Y. Chen*}

Uniklinikum Jena, Pathologie, Jena, Germany

Aims. The epithelial membrane proteins (EMP1-3) belonging to the peripheral myelin protein $22-\mathrm{kDa}$ (PMP22) gene family are involved in epithelial differentiation. Dysregulation of EMP1-3 has been found in various cancer types. Here we investigated the role of EMP1-3 in human lung cancer. 
Methods. Expression of EMP1-3 mRNA in 11 lung cancer cell lines together with human bronchial epithelial cells (HBEC) was examined by real-time RT-PCR. Methylation status of EMP1 and EMP2 was analyzed by demethylation test and bisulfite sequencing. EMP1-3 protein expression was evaluated in 55 samples of primary lung tumor by immunohistochemistry on tissue microarray. The functional role of EMP2 was analyzed by stable transfection with an expression vector containing the full-length cDNA of EMP2.

Results. EMP1-3 showed different expression patterns in lung cancer. EMP1 mRNA was widely downregulated in 11 lung cancer cell lines compared to HBEC; EMP2 mRNA was highly expressed in 3 out of 11 lung cancer cell lines, while in other 8 cancer cell lines EMP2 mRNA was decreased; enhanced EMP3 mRNA was detected in the majority of lung cancer cell lines (8 out of 11). Demethylation test showed increased EMP1 and EMP2 mRNA expression after demethylation reagent 5-AZA treatment. However only lung cancer cell line $\mathrm{H} 23$ exhibited methylation in the exon of EMP1 revealed by bisulfite sequencing. In primary lung tumors, EMP1 expression was significantly associated with lung tumor size $(p=0.004)$ The functional analysis of EMP2 after stable transfection in lung cancer cells is still in progress.

Conclusions. Our data suggest that EMP1 and EMP2 mRNA are widely downregulated in lung cancer cell lines and EMP1 protein expression is significantly related to lung tumor stage.

\section{AG10.P.03 \\ Eine Überexpression des 20S-Proteasomes ist Tumor-abhängig und verhindert ein Ansprechen gegen Bortezomib im malignen Pleuramesotheliom}

\section{R. F.H. Walter ${ }^{1,2}$, S. R. Sydow', J. Schmeller', E. Mairinger', C. Vollbrecht, R. Werner, ${ }^{4,5}$, E. Berg ${ }^{4}$, J. Kollmeier 6 , D. C. Christoph ${ }^{7,8}$, T. Mairinger ${ }^{5}$, J. Wohlschläger ${ }^{1,9}$, K. W. Schmid ${ }^{1}$, F.D. Mairinger ${ }^{1 *}$ \\ 'Universitätsklinikum Essen, Institut für Pathologie, Essen, Deutschland, 2Universitätsklinikum Essen, Ruhrlandklinik - Westdeutsches Lungenzentrum, Essen, Deutschland, ${ }^{3}$ Beuth Hochschule für Technik Berlin, Berlin, Deutschland, ${ }^{4}$ Charité Universitätsmedizin Berlin, Institut für Pathologie, Berlin, Deutschland, ${ }^{5}$ Helios Klinikum Emil von Behring, Institut für Gewebediagnostik, Berlin, Deutschland, ${ }^{6} \mathrm{Helios}$ Klinikum Emil von Behring, Klinik für Pneumologie, Berlin, Deutschland, ${ }^{7}$ Kliniken Essen- Mitte, Essen, Deutschland, ${ }^{8}$ Universitätsklinikum Essen, Westdeutsches Tumorzentrum, Essen, Deutschland, ${ }^{9}$ Diakonissenkrankenhaus Flensburg, Institut für Pathologie, Flensburg, Deutschland}

Ziel. Bortezomib wurde als Inhibitor des 20S Proteasomes bereits in diversen Lymphom-Entitäten zugelassen. Klinische Studien im malignen Pleuramesothelioms (MPM), als Einzeltherapie oder in Kombination mit Cisplatin, zeigten keine ausreichenden Erfolge, obwohl ein Teil der Patienten durchaus profitierte. Die vorliegende Arbeit präsentiert eine potentielle Erklärung für dieses Phänome.

Methoden. MPM von 84 Patienten sowie vier Zelllinien wurden mittels qPCR auf die Expressionslevel der proteasomalen Untereinheiten PSMA1, PSMA5, PSMB1, PSMB2, PSMB4 and PSMB5 hin untersucht. Darüber hinaus wurden die Zelllinien mit Bortezomib behandelt und über einen Zeitverlauf von $72 \mathrm{~h}$ Apoptose, Zellviabilität/Seneszenz sowie Nekrose mithilfe Enzymbasierter Fluorenzenzassays bestimmt. Die Enzymaktivität der einzelnen katalytischen Proteasomalen Untereinheiten wurde mittels funktioneller Assays quantifiziert.

Ergebnisse. Alle proteasomalen Untereinheiten mit Ausnahme von PSMB2 zeigten eine starke Überexpression im MPM verglichen mit gesundem Kontrollgewebe (alle $p<0,001$ ). Bezüglich der Inhibition mit Bortezomib zeigten die beiden Zelllinien mit vergleichbar niedriger Expression sowie niedriger Aktivität der katalytischen Untereinheiten PSMB2 und PSMB5 ein deutlich besseres Ansprechen (LD50 zwischen 50 nM und 100 $\mathrm{nM}$ ) als die beiden anderen Zelllinien, welche im Großen und Ganzen therapieresistent waren. Interessanterweise war Apoptose- Induktion der sensitiven Zelllinien deutlich besser als die Standardtherapie mit Cisplatin.
Fazit. Expression und Aktivität der katalytischen Untereinheiten des 20SProteasomes scheinen einen guten prädiktiven Marker für ein Ansprechen auf eine Bortezomib Therapie im MPM darzustellen. Die Gruppe der MPM mit niedriger Proteasom Aktivität scheint gut auf eine solche Therapie anzusprechen. Eine Biomarker-basierte Stratifizierung der Patienten könnte das Ergebnis von klinischen Studien mit Proteasom-Inhibitoren deutlich verbessern und zu einem positiven Abschluss bringen.

\section{AG10.P.04}

\section{Fibulin 2 is silenced by DNA hypermethylation and histone} acetylation in lung cancer

\section{Y. Ma* ${ }^{*}$ B. Theis, Y. Chen}

Section Pathology of the Institute of Forensic Medicine, University Hospital Jena, Friedrich Schiller University Jena, Jena, Germany

Aims. Fibulin-2 (FBLN2) is an extracellular matrix protein belonging to the five-member fibulin family. It has been shown that fibulin family plays an essential role in elastic fiber formation during development. Fibulin-2 exerts tumor suppressive function in nasopharyngeal and breast cancer; however, its role in human lung cancer has not yet been elucidated. Aims of this study were to analyze the expression of FBLN2, explore the epigenetic regulation, investigate its function in human lung cancer cells and evaluated its clinical relevance in primary lung cancer patients.

Methods. FBLN2 expression in lung cancer cell lines was analyzed by real-time RT-PCR and western blotting. Epigenetic regulation of FBLN2 was examined by demethylation, deacetylation tests, bisulfite sequencing (BS) and methylation-specific-primer (MSP). In primary lung tumors, the protein expression of FBLN2 will be evaluated by immunohistochemistry on tissue microarray. The cell-based functional assays will be performed after FBLN2 stable transfection.

Results. Compared to human bronchial epithelial cells (HBEC), FBLN2 was down-regulated in 9 out of 11 lung cancer cell lines except H1650 and H1975 at mRNA level. The protein level of FBLN2 was consistent to the mRNA expression profile except for H1975, in which FBLN2 was down-regulated. After treatment with demethylation agent 5'-Aza-2'-DC and deacetylation agent Trichostatin A, increased FBLN2 mRNA expression was found in 10 lung cancer cell lines except H23. Data from BS and MSP indicated that FBLN2 DNA was partially methylated in selected CpG islands in the promoter region. The functional analysis and the evaluation of FBLN2 in primary lung tumor tissues are in progress.

Conclusions. Based on the currently available data, we conclude that the FBLN2 gene silencing in lung cancer cell lines is associated with DNA methylation and histone acetylation.

\section{AG10.P.05}

\section{Potential role of Tenascin C (TNC) in human non-small cell lung cancer progression}

\section{Schlensog*, J. Limberg, I. Esposito}

Pathologie der Heinrich Heine Universität Düsseldorf, Düsseldorf, Germany

Aim. Tenascin C (TNC) is an extracellular matrix protein and a potential biomarker for different tumor types e.g. osteo- and chondrosarcomas, bladder and lung cancer. Since lung cancer comprises heterogeneous biological and molecular subtypes, we investigated the role of TNC in non-small cell lung cancer, the most frequent subtype (about $85 \%$ ) of all lung cancers.

Methods. TNC expression was evaluated immunohistochemically using a tissue microarray (TMA) consisting of 101 lung adenocarcinomas (LUAD) and 32 tumor-adjacent normal lung tissues. In addition, based on an independent data set from The Cancer Genome Atlas (TCGA), we examined TNC mRNA expression in LUAD and normal tissue samples, validating our immunohistochemical scoring of TNC level. Furthermore, in this data set the TNC mRNA expression was correlated to essential clinicopathologic parameters e.g. tumor size, staging, mutational status of EGFR and KRAS. Subsequently, patient survival analysis was examined based on TNC 
mRNA expression and expression subtype of LUAD patients (bronchioid, squamoid, magnoid).

Results. Immunhistochemical staining of TNC in our LUAD patient cohort revealed a significant increase $(P<0.0001)$ of TNC protein level in primary tumor samples and showed TNC protein being located in peritumoral stromal cells. Independent TCGA data revealed a significant $(P<0.0001)$ increase of TNC expression in adeno-as well as squamous cell carcinoma, validating the immunhistochemical analysis of our LUAD TMA. In addition, abundant TNC expression in LUAD was significantly associated with squamoid expression subtype, while low TNC levels were linked to magnoid-type adenocarcinoma $(\mathrm{P}<0.0001)$. Furthermore, correlation analysis demonstrated a significant correlation of TNC mRNA expression and EGFR protein level $(\mathrm{P}<0.0001 ; \mathrm{R}=0.276)$ as well as increased TNC in EGFR mutated LUAD patients. In line with this correlation, copy-number analysis of EGFR revealed increasing TNC mRNA expression in cases with higher EGFR copy number.

Conclusion. Increased TNC deposition is observed in the peritumoral stroma of lung adenocarcinoma. Additionally, this is the first study revealing a correlation between TNC expression and EGFR aberration in primary LUAD as well as an association with the more aggressive magnoid expression subtype. This study provides evidence that TNC expression might be a biological relevant factor in human lung adenocarcinoma progression in an EGFR-dependent manner.

\section{AG10.P.06 \\ Klinische Validierung hochgradiger MET-Amplifikation in nicht- kleinzelligen Lungenkarzinomen}

\section{H.-U. Schildhaus ${ }^{1 *}$, D. A. Cron ${ }^{2}$, T.R. Overbeck}

${ }^{1}$ Universitätsklinik Essen, Institut für Pathologie, Essen, Deutschland, ${ }^{2}$ Universitätsmedizin Göttingen, Institut für Pathologie, Göttingen, Deutschland, ${ }^{3}$ Universitätsmedizin Göttingen, Klinik für Hämatologie und Medizinische Onkologie, Göttingen, Deutschland

Ziel. MET-Amplifikationen kommen bei zahlreichen humanen Tumoren vor, darunter auch bei nicht-kleinzelligen Lungenkarzinomen. Für METInhibitoren (Tyrosinkinaseinhibitoren) konnte eine Wirksamkeit bei MET-amplifizierten NSCLC gezeigt werden, wobei offenbar ein Gen-Dosis-Effekt besteht. Tumoren mit besonders hohem Amplifikations-Niveau sprechen möglicherweise besser auf die Behandlung an.

Bislang ist jedoch unklar, wie eine hochgradige MET-Amplifikation zu definieren ist. Ferner besteht Unklarheit darüber, ob die MET-Amplifikation eine echte onkogene Treiber-Alteration ist, die auch mit einem eigenen spezifischen Phänotyp der Tumorerkrankung einhergeht.

Methoden. 373 NSCLC Fälle wurden unselektiert und prospektiv auf das Vorliegen von Genkopiezahl-Erhöhungen mittels FISH getestet. Die durchschnittliche Genkopiezahl, die MET/CEN7 Ratio sowie weitere FISH-Parameter wurden erfasst und mit klinischen und morphologischen sowie molekularpathologischen Charakteristika der Tumoren korreliert. Ergebnisse. Basierend auf der Variabilität der erhobenen Daten wurden eine neue Top Level-Kategorie der MET-Amplifikation definiert ( $>90$. Perzentile der durchschnittlichen Genkopiezahl; $\geq 10$ MET-Genkopien pro Tumorzelle). Dieses Kriterium wurde von $2 \%$ der untersuchten Tumoren erfüllt. Diese Tumoren waren ausnahmslos gering differenzierte Adenokarzinome vom prädominant soliden Subtyp, die jedoch auch Eigenschaften pleomorpher Karzinome aufwiesen. In seltenen Fällen konnten auch zusätzlich bestehende Mutationen in KRAS oder MET (Exon 14-skipping Mutation) nachgewiesen werden. EGFR-, ALK- oder ROS1Alterationen waren in dieser Subgruppe nicht nachweisbar. Wichtigster klinischer Parameter war eine signifikant kürzere Überlebenszeit (medianes OS: 8 Monate). Die extrem schlechte Prognose war dabei unabhängig vom primären Tumorstadium und von der Art der durchgeführten Therapie.

Fazit. Die hier neu definierte Top Level-Kategorie der MET-Amplifikation bei NSCLC definiert eine spezifische Subgruppe von pulmonalen Adenokarzinomen mit ungünstiger Prognose und charakteristischen morphologischen Eigenschaften.

\section{AG10.P.07}

Deciphering molecular mechanisms of chemoresistance in SCLC

C. Heidel' ${ }^{*}$, M. Jokic ', A. Fähnrich', C. Kümpers', W. Vogel', I. Vlasic', F.-O. Paulsen', T. Olchers', T. Goldmann', H. Bohnenberger', P. Ströbel', M. Reck', H. Bösmüller ${ }^{5}$, F. Fend ${ }^{5}$, J. Kirfel' ', H. Busch'2, S. Perner ${ }^{7}$

${ }^{1}$ Pathologie des Universitätsklinikums Schleswig-Holstein, Campus Lübeck und des Forschungszentrums Borstel, Leibniz Lungenzentrum, Lübeck, Germany, 'Institute of Experimental Dermatology, University of Lübeck, Lübeck, Germany, ${ }^{3}$ LungenClinic Grosshansdorf, Airway Research Center North (ARCN), Grosshansdorf, Germany, ${ }^{4}$ Institut für Pathologie, Universitätsmedizin Göttingen, Göttingen, Germany, ${ }^{5}$ Institut für Pathologie und Neuropathologie Universitätsklinikum Tübingen, Tübingen, Germany

Aim. SCLC is an aggressive lung cancer type with little therapeutic choice outside of the cisplatin-etoposide chemotherapy box introduced decades ago. This calls for the identification of novel targets and their rapid implementation into the clinics, especially since immunotherapy doesn't seem to deliver reliable survival benefits to the patients. We therefore sought to identify the key transcriptomic changes occurring in the chemorelapsed and untreatable SCLC that responded well to the first-line chemotherapy. We analyzed the whole transcriptomes of pre- and post-therapeutic SCLC of the same patient in order to find the key players that might be the focus of targeted therapy for SCLC in the near future.

Methods. We identified 26 SCLC patients which responded well to firstline chemotherapy with usable FFPE biopsies of pre- and chemorelapsed tumors. After isolating RNA, we performed the Array XS analysis on the FFPE tumors covering whole-transcriptome (in total of more than 20,000 genes). Findings of the transcriptomic analysis were studied on the protein level by the means of immunohistochemistry.

Results. We identified distinct transcriptomic profiles of pre-treatment SCLC and their chemorelapsed counterparts with the most striking difference being in the exclusion of immune pathways in the chemorelapsed SCLC. This finding would explain to certain extent the lack of benefit of immunotherapy in the treatment of SCLC. We also found a number of kinases being upregulated in the chemorelapsed SCLC indicating that a potential for the targeted treatment of chemorelapsed SCLC exists.

Conclusion. This study gives invaluable insight into the key differences in transcriptomic profiles of chemorelapsed and pre-treatment SCLC which due to various clinical and pathological obstacles could not be analyzed in the past. We believe that the identification of significantly upregulated targetable molecules in chemorelapsed SCLC gives hope for the design of novel targeted therapy that should significantly improve the survival of SCLC patients in the near future.

\section{AG10.P.08 \\ Identifying immune infiltration pattern of PD-L1 positive and negative lung adenocarcinoma}

C. Heidel' ${ }^{*}$, M. Jokic ${ }^{1}$, A. Fähnrich ${ }^{2}$, C. Kümpers', W. Vogel', I. Vlasic', H. Busch', J. Kirfel', S. Perner'

'Pathologie des Universitätsklinikums Schleswig-Holstein, Campus Lübeck und des Forschungszentrums Borstel, Leibniz Lungenzentrum, Lübeck, Germany, ${ }^{2}$ Institute of Experimental Dermatology, University of Lübeck, Lübeck, Germany

Aim. Immune check-point inhibition has shown promising results in the treatment of several tumors but there is an urge to closely characterize mechanisms of tumor immune infiltration based on tumor PD-L1 expression. In this study we aim to identify specific transcriptomic patterns that correspond to the immune cell infiltration in lung adenocarcinoma taking into account tumor PD-L1 positivity as well as the total tumor immune cell infiltration, defined either by "hot" or "cold". In this manner, we aim to investigate whether tumor immune cell infiltration specificity depends on the tumor PD-L1 expression.

Methods. 142 lung adenocarcinomas were assessed for the PD-L1 expression by the means of IHC and divided into "PD-L1 positive" and "PD-L1 negative" groups. When assessing tumor PD-L1 positivity, we set a high 


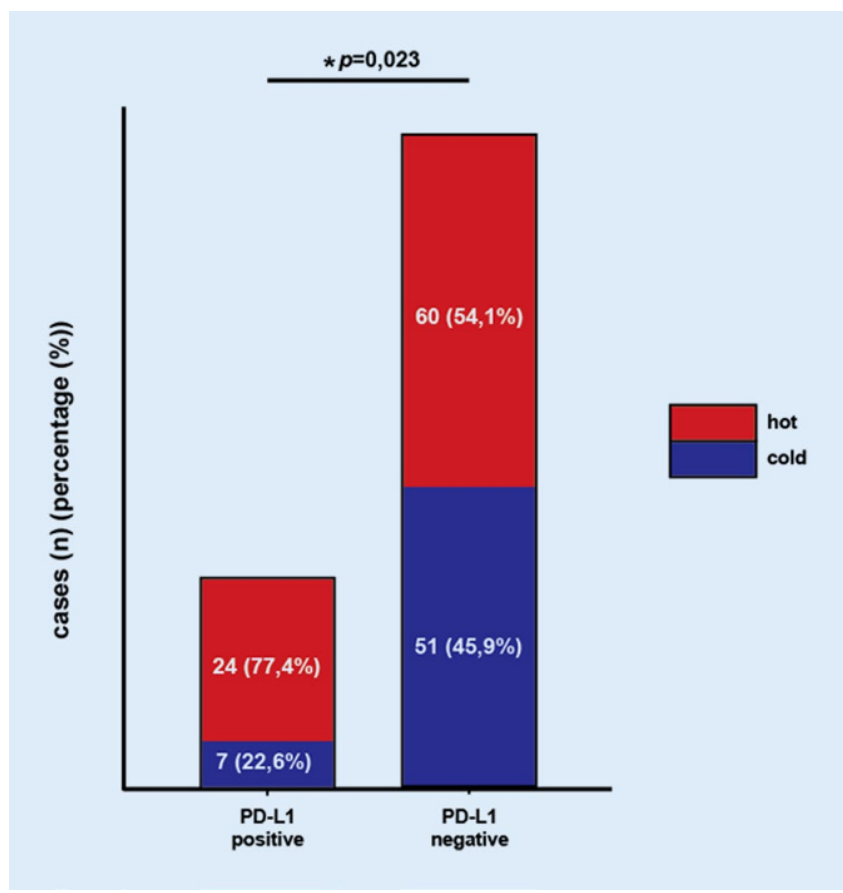

Fig. 1 | AG10.P.08 $\Delta$ Distribution of "hot" and "cold" immune phenotype depending on tumor PD-L1 expression

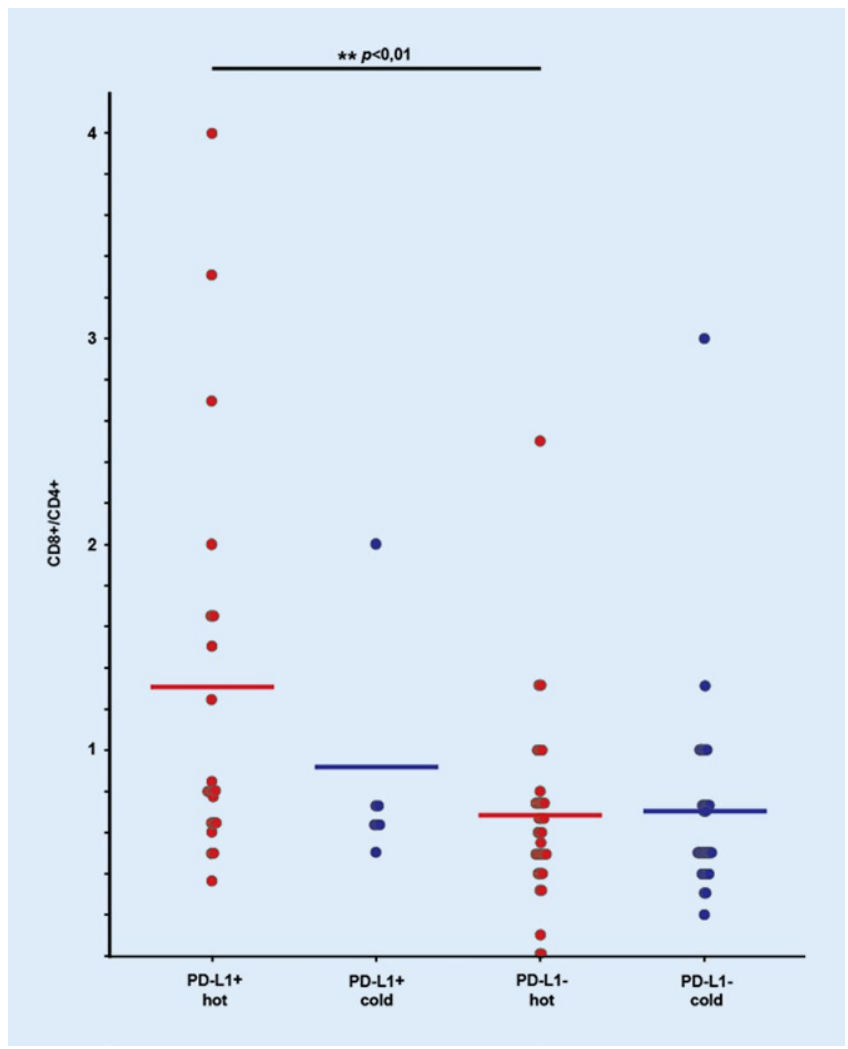

Fig. 2 | AG10.P.08 $\Delta$ Distribution of CD8+/CD4+ in "hot" and "cold" tumors depending on tumor PD-L1 expression threshold $(>50 \%)$ in order to minimize the effect of PD-L1 expression heterogeneity. Lung adenocarcinoma cases were further classified according to the total immune cell infiltration into the two groups assessed by pathological microscopy. Tumors with high total tumor immune cell infiltration were characterized as the "hot tumors" while the tumors with low or absent total tumor immune cell infiltration as the "cold tumors". In this way, we assembled four groups of cases, namely PD-L1 pos. and "hot", PD-L1 pos. and "cold", PD-L1 neg. and "hot" and PD-L1 neg. and "cold" which were analyzed for differential expression of 770 genes covering 24 different immune cells by the NanoString nCounter PanCancer Immune Profiling Panel Analysis.

Results. We first assessed the distribution of "hot" and "cold" lung adenocarcinoma in PD-L1 positive and PD-L1 negative cases. As shown in - Fig. 1 | AG10.P.08, PD-L1 positive tumors were significantly more infiltrated than PD-L1 negative counterparts. Furthermore, PD-L1 positive tumors attract more cytotoxic CD8+ immune cells than their PDL1 negative counterparts but only when heavily infiltrated ("hot" tumors) (- Fig. 2|AG10.P.08). Next steps include transcriptomic profiling of defined groups for genes identifying a panel of infiltrated immune cells.

Conclusion. The distribution of total immunological "hotness" depends on the PD-L1 status in lung adenocarcinoma. Tumors expressing PD-L1 also attract more cytotoxic CD8+ lymphocytes than their PD-L1 negative but also heavily infiltrated counterparts. Upcoming experiments will reveal whether PD-L1 expression selects for the specific tumor infiltration pattern in lung adenocarcinoma.

\section{AG10.P.09}

Prominent entrapment of native lung tissue in primary \& metastatic non-epithelial intrapulmonary neoplasms frequently mimics pulmonary adenofibroma

\section{R. Erber*, F. Haller, A. Hartmann, A. Agaimy}

Pathologisches Institut, Universitätsklinikum Erlangen, Comprehensive Cancer Center Erlangen-EMN, Friedrich-Alexander-Universität Erlangen, Erlangen, Germany

Pulmonary nodules are increasingly identified and biopsied to verify or rule out metastatic disease. Familiarity with diverse patterns of intrapulmonary non-epithelial neoplasms is mandatory for distinguishing benign from malignant and primary from metastatic, in both biopsy material and resection specimens. Entrapment of native pulmonary epithelium within metastatic neoplasms in the lung is a known pitfall in context of differential diagnoses of biphasic pulmonary lesions but has not been sufficiently illustrated in surgical pathology literature.

Archived routine and consultation files (2012-2018) were searched for non-epithelial lung lesions including both primary and metastatic and benign and malignant. After review, frequency, extent and pattern of entrapped lung epithelium were recorded.

After excluding 24/71 cases as not fulfilling requirements for further analysis, cohort (overall 47 ) comprised 38 pulmonary metastases (80.9\%; 35 various sarcoma types, 2 germ cell tumors, 1 nephroblastoma), 8 primary pulmonary non-epithelial lesions [including 6 primary intrapulmonary solitary fibrous tumors and 1 pulmonary adenofibroma (PAF)] and 1 perivascular epithelioid cell tumor (PEComa). 23/47 (48.9\%) showed entrapment of respiratory/alveolar epithelium with variable extent. In 8/47, entrapped pulmonary epithelium was seen mainly in the peripheral tumor portion, the remainder $(15 / 47,31.9 \%)$ showing prominent entrapped alveolar/respiratory epithelium throughout the lesion. Based on the cellularity of the background metastasis, the pattern closely mimicked adenomyoepithelial neoplasms (1/38), biphasic synovial sarcoma (2/38) or pulmonary blastoma (1/38). Notably, there was presence of diffuse component of papillary leaflet-like variably dilated glands throughout some lesions imparting a characteristic fibroadenoma- or phylloides-like pattern (11/47). This feature was restricted to neoplasms with low-grade histological features and paucicellular sclerosing stroma imparting a pattern indistinguishable from PAF or fibroepithelial hamartomas. 
This study highlights the many pitfalls related to prominent entrapment of native lung tissue in primary and metastatic non-epithelial intrapulmonary neoplasms. Interpretation of biphasic pulmonary nodules should comprise consideration of patient's history of extrapulmonary neoplasm and careful analysis of the epithelial component supplemented by appropriate immunohistochemistry (TTF1).

\section{AG10.P.10 \\ Wnt4 activated noncanonical pathway in malignant thymic tumors}

X. Zhang ${ }^{1 *}$, E. Schneider ${ }^{1}$, B. Schalk ${ }^{2}$, A. Marx' ${ }^{1}$ D. Belharazem ${ }^{1,3}$

'Institute of Pathology, University Medical Centre Mannheim, University of Heidelberg, Mannheim, Germany, ${ }^{2}$ Department of Neurology, University of Regensburg, Regensberg, Germany, ${ }^{3}$ Medical Research Center (ZMF), University Medical Centre Mannheim, University of Heidelberg, Mannheim, Germany

Background. Thymoma and thymic carcinoma (TC) are rare thymic epithelial tumors with poorly understood pathogenesis, classified as $\mathrm{A}, \mathrm{AB}$, B1, B2, B3 and TC. The Wnt pathway is known to be important in thymic aging and involution, and overexpression particularly of the WNT4 (Wnt, member 4) ligand is related to a variety of cancers. Endogenous Wnt inhibitors regulate wnt signaling, but the regulation in thymic tumors is unknown.

Methods. mRNA and protein of wnt ligands and their inhibitors were quantified by RT-qPCR and western blot in whole tissue extracts of normal thymuses (NT, $N=7)$, thymomas type $\mathrm{A}(n=8) ; \mathrm{AB}(n=23) ; \mathrm{B} 1(n=4)$; B2 $(n=18) ; \mathrm{B} 3(n=6)$ and TC $(n=11)$. Secreted wnt4 were measured in primary thymic epithelial cells (pTECs) by ELISA and $\beta$-catenin were also analyzed by immunohistochemistry in B3 thymoma and TC tissues. Besides, we examined c-Jun N-terminal kinase (JNK) and NFAT mRNA and protein expression in thymoma cells with downregulation of Wnt4.

Results. Significant increased WNT4 mRNA and protein expression was found in B3 and TC compared to normal thymus $(p<0.0001)$. WNT4 receptor, Frizzled receptor 6 (Fzd 6) showed higher expression in B3 and TC than NT and other thymoma subtypes. The corresponding expression of WNT4 inhibitors were measured at the cell membrane and nuclear level. On the nuclear level, inhibitor TCF3, TCF4, TLE2 and TLE4 show different expression in $\mathrm{B} 3$ and all other thymic tumors. Wnt 4 secreted highly in pTECs derived from B3 than normal thymus. Nuclear $\beta$-catenin expression was absent in B3 thymomas and thymic carcinoma compared to positive control. Subsequent to transfection, JNK and NFAT mRNA and protein expression were also significantly changed in shRNA-treated groups. Conclusions. This study suggests that targeting WNT4 is warrants testing as candidate gene which appears to be activated through a JNK mediated planar cell polarity-like pathway and wnt inhibitors agonist at $t$ nuclear level could also be a new efficient treatment option for thymic epithelial tumors.

\section{AG10.P.11}

\section{Cisplatins Einfluss auf Tyrosin-Kinasen - Eine Geschichte über Phosphorylierung und Sensitvität gegenüber Cisplatin}

\section{S. Borchert', P. Suckrau', M. Wessolly', J. Schmeller', E. Mairinger',} B. Hegedüs' ${ }^{2}$, T. Hager', T. Herold', W. E. E. Eberhardt', J. Wohlschlaeger', C. Aigner', A. Bankfalvi', K. W. Schmid' , F.D. Mairinger', R. F. H. Walter ${ }^{1 * 4}$ 'Institut für Pathologie, Universitätsklinikum Essen, Universität DuisburgEssen, Essen, Deutschland, ${ }^{2}$ Ruhrlandklinik, Westdeutsches Lungenzentrum am Universitätsklinikum Essen $\mathrm{gGmbH}$, Thoraxchirurgie und thorakale Endoskopie, Essen, Deutschland, ${ }^{3}$ Westdeutsches Tumorzentrum, Universitätsklinikum Essen, Universität Duisburg-Essen, Innere Klinik (Tumorforschung), Essen, Deutschland, ${ }^{4}$ Ruhrlandklinik, Westdeutsches Lungenzentrum am Universitätsklinikum Essen gGmbH, Essen, Deutschland

Ziel. Das maligne Pleuramesotheliom (MPM) ist ein aggressiver Tumor mit einer sehr schlechten Prognose. Die systemische Chemotherapie aus einer Kombination mit Pemetrexed und Cisplatin zeigt nur in $40 \%$ der Patienten ein Ansprechen. Um Ursachen für das Ansprechverhalten zu ermitteln, wurden die Phosphorylierung von Tyrosin-Kinasen und Serin/ Threonin-Kinasen während der Cisplatin-Therapie verglichen.

Methoden. Drei verschiedene MPM-Zelllinien (MSTO-211H, NCIH2052 und NCI-H2452) und eine Fibroblasten-Zelllinie (MRC-5) wurden analysiert. Die Kinaseaktivität wurde mittels der PamGene PamStation ${ }^{\star} 12$ evaluiert. Die Analyse umfasst insgesamt 340 Tyrosin- und Serin/Threonin-Stellen verschiedener Kinasen. Zusätzlich wurden Viabilität, Nekrose und Apoptose während der Therapie untersucht.

Ergebnisse. Die Phosphorylierung von Tyrosin-Kinasen wird signifikant von einer Cisplatin-Therapie beeinflusst. Besonders signifikante Änderungen gab es bei der Regulation von Zellzyklus, Zellmigration/-Adhäsion, Signaltransduktion und Immunmodulation. Durch die Cisplatin-Therapie nimmt die Phyosphorylierung der daran beteiligten Tyrosin-Kinasen ab. Die Sensitivität gegenüber Cisplatin unterscheidet sich deutlich zwischen den Zelllinien: NCI-H2052>NCI-H2452>MSTO-211H >>MRC-5. Serin/ Threonin-Kinasen werden von einer Cisplatin-Therapie nicht beeinflusst. Fazit. Die Aktivierung von Kinasen spielt scheinbar eine wesentliche Rolle bei der Zellantwort auf eine Cisplatin-Therapie. Die Phosphorylierung von Proteinen des/der Zellzyklus, Zellmigration/-Adhäsion, Signaltransduktion und Immunmodulation wird während der Therapie generell gesenkt. In Patienten gilt es zu überprüfen, ob diese Änderungen der Phosphorylierung eine Prädiktion des Ansprechens auf eine Cisplatin-Therapie erlauben.

\section{AG10.P.12}

Einfluss der Metallothionein-Expression auf die Sensitivität gegenüber Platin in Zelllinien des Malignen Pleuramesotheliom

S. Borchert ${ }^{1 *}$, P. Suckrau', M. Wessolly', J. Schmeller', E. Mairinger', B. Hegedüs' ${ }^{2}$, T. Hager', T. Herold' , R. F. H. Walter', W. E. E. Eberhardt ${ }^{3,4}$, J. Wohlschlaeger ${ }^{1,5}$, C. Aigner ${ }^{2}$, A. Bankfalvi', K. W. Schmid' , F. D. Mairinger ${ }^{1}$ 'Universitätsklinikum Essen, Institut für Pathologie, Essen, Deutschland, ${ }^{2}$ Ruhrlandklinik, Westdeutsches Lungenzentrum am Universitätsklinikum Essen gGmbH, Klinik für Thoraxchirurgie und thorakale Endoskopie, Essen, Deutschland, ${ }^{3}$ Ruhrlandklinik, Westdeutsches Lungenzentrum am Universitätsklinikum Essen gGmbH, Klinik für Pneumologie, Essen, Deutschland, ${ }^{4}$ Westdeutsches Tumorzentrum, Universitätsklinikum Essen, Universität Duisburg-Essen, Innere Klinik (Tumorforschung), Essen, Deutschland, ${ }^{5}$ Diakonissenkrankenhaus Flensburg, Institut für Pathologie, Flensburg, Deutschland

Ziel. Das maligne Pleuramesotheliom (MPM) ist ein seltener Tumor der sich, überwiegend Asbest-assoziiert, im Rippenfell entwickelt. Mit einem Ansprechen auf Platin-Analoga zu höchstens 6-14 \%, zeigt dieser Tumor eine sehr schlechte Prognose. Die Ursache für das schlechte Ansprechen konnte bisher nicht aufgeklärt werden. Die Funktion der Schwermetallentgiftung von Metallothioneinen (MT) könnte eine mögliche Erklärung für die Entstehung einer Resistenz gegenüber Platin führen.

Methoden. Die Gen- und Protein-Expression von MTs in den MPM-Zelllinien MSTO-211H, NCI-H2052 und NCI-H2452 und der humanen Lungenfibroblasten-Zelllinie MRC-5 sowie deren Sensitivität gegenüber Cisplatin wurde analysiert. Es wurde ein Knock-Down von MT1A, MT1B und MT2A durch RNA-Interferenz induziert. Die MT-Expression wurde mit Hilfe der quantitativen real-time PCR gemessen. Der Zustand der Zellen vor- und nach der Cisplatin Behandlung wurde in Hinsicht auf Viabilität, Nekrose und Apoptose untersucht.

Ergebnisse. Die Expressionslevel von MTs, insbesondere von MT2A, unterscheidet sich signifikant zwischen den untersuchten Zelllinien. Zudem konnte eine MT-vermittelte Apoptose-Induktion durch die Zugabe von Cisplatin beobachtet werden, die drei verschiedene MT-basierte zelluläre Phänotypen gezeigt hat.

Fazit. Drei verschiedene MT-basierte zelluläre Phänotypen konnten beobachtet werden. In der Mehrheit der analysierten Zelllinien scheinen MTs einen wesentlichen Teil zur Entwicklung der Cisplatin-Resistenz beizutragen. Die MT-Expression könnte in Kombination mit anderen Biomarkern 
für die Patienten-Stratifizierung, die auf dem molekularen Phänotypen basiert, nützlich sein, um den Patienten vor einer ineffektiven, nebenwirkungsreichen Therapie zu bewahren.

\section{AG10.P.13 \\ Metallothionein-Knockdown reduziert die CMGC- und Tyrosin- Kinase-Aktivität in platin-sensitiven MPM Zelllinien}

S. Borchert ${ }^{1 *}$, P. Suckrau' ${ }^{1}$ M. Wessolly', J. Schmeller', E. Mairinger', T. Hager', T. Herold', W. E. E. Eberhardt ${ }^{2,3}$, J. Wohlschlaeger ${ }^{1,4}$, C. Aigner ${ }^{5}$, A. Bankfalvi', K. W. Schmid', F.D. Mairinger', R. F. H. Walter ${ }^{1}$

'Universitätsklinikum Essen, Institut für Pathologie, Essen, Deutschland, ${ }^{2}$ Ruhrlandklinik, Westdeutsches Lungenzentrum am Universitätsklinikum Essen gGmbH, Klinik für Pneumologie, Essen, Deutschland, ${ }^{3}$ Westdeutsches Tumorzentrum, Universitätsklinikum Essen, Universität Duisburg-Essen, Innere Klinik (Tumorforschung), Essen, Deutschland, ${ }^{4}$ Diakonissenkrankenhaus Flensburg, Institut für Pathologie, Flensburg, Deutschland, ${ }^{5}$ Ruhrlandklinik, Westdeutsches Lungenzentrum am Universitätsklinikum Essen gGmbH, Klinik für Thoraxchirurgie und thorakale Endoskopie, Essen, Deutschland

Ziel. Das maligne Pleuramesotheliom (MPM) ist ein aggressiver Tumor mit schlechter Prognose. Die systemische Chemotherapie aus einer Kombination mit Pemetrexed und Cisplatin zeigt nur in $40 \%$ der Patienten ein Ansprechen. Die Ursache für das schlechte Ansprechen konnte bisher nicht aufgeklärt werden, aber in Verdacht steht eine Überexpression von Metallothioneinen (MTs). Der Einfluss von MTs auf Kinaseaktivitäten, die im Tumor meist verändert sind, könnte möglicherweise Aufschluss geben. Methoden. Drei verschiedene MPM-Zelllinien (MSTO-211H, NCIH2052 und NCI-H2452) und die humane Lungenfibroblasten-Zelllinie MRC-5 wurden hinsichtlich ihrer Kinase-Aktivität analysiert. Die Expression der Metallothioneine MT1A, MT1B und MT2A wurde mittels Transfektion mit siRNA vermindert. Die Kinase-Aktivität wurde mit Hilfe der PamGene PamStation 12 evaluiert. Mit dem PTK und STK Chip werden 340 der wesentlichen Tyrosin- bzw. Serin/Threonin-Kinasen untersucht. Der Zustand der Zelle vor- und nach dem siRNA- „Knockdown“ von MT wurde in Hinsicht auf Viabilität, Nekrose und Apoptose untersucht.

Ergebnisse. Es konnte eine erhöhte Tyrosin-Kinase-Aktivität nach der siRNA Inkubation in der Cisplatin-resistenten (NCI-H2452) und der MSTO-211H-Zelllinie, die ein mittelmäßiges Ansprechen auf Cisplatin aufweist, beobachtet werden. Zudem verringert sich die Aktivität der CMGC-Kinasen, zu denen u. A. die CDKs und MAPKs in Anhängigkeit eines Ansprechens auf Cisplatin. In der Cisplatin-resistenten Zelllinie zeigen die CMGC-Kinasen eine Steigerung der Aktivität.

Fazit. Die Expression von Metallothioneinen spielt offenbar eine wesentliche Rolle für die Aktivität spezifischer Kinasen. Insbesondere die Aktivität der CMGC wird selektiv in den platin-sensitiven Zelllinien nach Verminderung der MT Expression beeinflusst. Der „Knockdown“ der MT-Expression in Kombination mit Cisplatin könnte als neuer Therapieansatz dienen und ein verbessertes klinisches Management des Patienten ermöglichen.

\section{AG10.P.14 \\ Der interessante Obduktionsfall-Fall: 83 jährige Patientin mit rezidivierten Pleuraergüssen}

T. Hansen ${ }^{1 *}$, B. Schulz' ${ }^{1}$ U. Titze ${ }^{1}$, M. Weber ${ }^{2}$

'Institut für Pathologie, Klinikum Lippe GmbH, Detmold, Deutschland, ${ }^{2}$ Klinik für Pneumologie, Klinikum Lippe $\mathrm{GmbH}$, Lemgo, Deutschland

Ziel. Wir stellen einen ungewöhnlichen Obduktionsfall mit einem unerwarteten molekularpathologischen Ergebnis vor.

Methoden. Eine 83-jährige Patientin wurde stationär mit verschlechtertem Allgemeinzustand, Gewichtsverlust, Atemnot und Vigilanzminderung aufgenommen. Radiologisch zeigte sich ein ausgedehnter Pleuraerguss, eine Raumforderung war aber nicht abgrenzbar; laborchemisch lagen erhöhte Entzündungsparameter und akutes Nierenversagen vor. Es wurde unter dem klinischen Bild einer Sepsis mit unklarem Fokus eine Antibio-

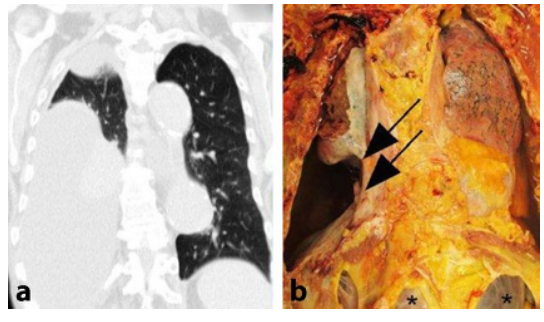

Abb. $1 \mid$ AG10.P.14 $\triangleleft$ a CT-Thorax; b tumorös ausgemauerte Pleurahöhle (Pfeile), unten Leberzysten (Stern)

tikatherapie eingeleitet. Aufgrund der Symptom-Aggravation wurde eine Pleurabiopsie entnommen, die ein Adenokarzinom der Lunge ergab. Der Zustand der Patientin verschlechterte sich trotz Intensivtherapie rasch. Die Patientin verstarb unter dem klinischen Bild einer respiratorischen Insuffizienz und akutem Nierenversagen.

Ergebnisse. Bei der Obduktion fand sich ein TTF1-positives Adenokarzinom, das die gesamte Pleura visceralis et parietalis des rechten Lungenflügels im Sinne eines pseudomesotheliomatösen Karzinoms ausgemauert hatte (- Abb. 1 | AG 10.P.14). Molekularpathologisch ergab sich eine BRAF V600E-Mutation. Neben einem rezidivierten Myokardinfarkt, einem Aneurysma dissecans der Aorta descendens und Aorta abdominalis sowie bis zu $11 \mathrm{~cm}$ großen Leberzysten und $2 \mathrm{~cm}$ großen Nierenzysten konnte im Colon ascendens ein $8,9 \mathrm{~cm}$ großes serratiertes Adenokarzinom nachgewiesen werden (immunhistochemisch cdx2+, TTF1-), wobei die Molekularpathologie hier wiederum eine BRAF V600E-Mutation aufzeigte. Fazit. Der vorliegende Fall ist zum einen bemerkenswert durch die Fülle an signifikanten Erkrankungen, die klinisch erst eine kurze Zeitspanne vor dem Exitus bzw. gar nicht evident gewesen waren. Zum anderen sind zwar Fälle von BRAF-mutierten nicht-kleinzelligen Lungenkarzinomen in Kombination mit einer weiteren BRAF-mutierten Neoplasien bekannt, jedoch bislang noch nicht in Kombination mit einem Kolonkarzinom. Wegen der therapeutischen Konsequenz empfiehlt sich insbesondere bei der Fragestellung nach multiplen Tumor-Entitäten zur exakten Diagnosestellung die histopathologische Sicherung, auch wenn bereits eine TreiberMutation nachgewiesen werden konnte.

\section{AG10.P.15}

\section{Ein Thymuskarzinom der Pleura mit Mesotheliom-imitierendem} Wuchsmuster: eine Rarität

\section{A. Mamilos ${ }^{1 *}$, M. Evert ${ }^{1}$, H. S. Hofmann ${ }^{2}$, N. Verloh ${ }^{3}$, K. Utpatel ${ }^{1}$}

'Institut für Pathologie, Universität Regensburg, Regensburg, Deutschland, ${ }^{2}$ Klinik und Poliklinik für Herz-, Thorax- und herznahe Gefäßchirurgie, Abteilung Thoraxchirurgie, Universitätsklinikum Regensburg, Regensburg, Deutschland, ${ }^{3}$ Institut für Röntgendiagnostik, Universitätsklinikum Regensburg, Regensburg, Deutschland

Ziel. Thymuskarzinome (TC), die auf dem Boden von ektopem Thymusgewebe entstehen, sind eine Rarität. Sie sind meist in der Schilddrüse zu finden und werden als CASTLE-Tumoren (Carcinoma showing thymuslike differentiation) bezeichnet. Es existieren nur vereinzelte Fallberichte für ektope primäre TC in Organen außerhalb der Schilddrüse.

Methoden. Erstbeschreibung eines TC der Pleura, das klinisch, radiologisch und umfangreich histopathologisch, immunhistochemisch und molekularpathologisch aufgearbeitet wurde.

Ergebnisse. Bei einer 33-jährigen Frau mit mantelartigem Pleuratumor links und unilateralem Pleuraerguss bestand klinischerseits der Verdacht auf ein Pleuramesotheliom. In der auswärtig beurteilbaren Biopsie wurde ein schlecht differenziertes Plattenepithelkarzinom diagnostiziert. Nach sorgfältigem Staging ist kein weiterer Tumor gefunden worden. Makroskopisch zeigte sich ein $21 \mathrm{~cm}$ großer Tumor in der Pleura links mit Ummauerung der Lunge sowie Infiltration von Lungengewebe, Diaphragma und Perikard. Histologisch sind solide Verbände eines epitheloiden malignen Tumors zu sehen. Die Tumorzellen zeigen ein schmales eosinophiles Zytoplasma und prominente Nukleolen. Immunhistochemisch sind die Tumorzellen durchgängig positiv für p40, CD117, GLUT-1, teilweise 
für CK5/6 und CK7 sowie fokal für Chromogranin A und CD5. Molekularpathologisch zeigte sich eine KIT-Deletionsmutation pV555_Q556del im Exon 11. In Anbetracht des jungen Alters, der Lokalisation und der epitheloiden Tumormorphologie haben wir ein Mesotheliom, ein NUTKarzinom, ein SMARCA4-defizientes thorakales Sarkom, ein epitheloides Sarkom, einen Keimzelltumor, ein Melanom und ein HPV- oder EBV-assoziiertes Karzinom durch weitere Untersuchungen ausgeschlossen. Auch wenn in umfangreichen Nachbettungen keine Residuen ektopen Thymusgewebes nachgewiesen werden konnten, konnte abschließend die Diagnose eines ektopen KIT-mutierten Thymuskarzinoms in der Pleura gestellt werden.

Fazit. Ektope Thymuskarzinome sind eine Rarität und dieser Fall ist die Erstbeschreibung in der Pleura. Der Nachweis der KIT-Mutation untermauert die Diagnose, da $7 \%$ der TC KIT-mutiert sind, wobei die nachgewiesene Mutation nicht für TC, sondern bislang nur für gastrointestinale Stromatumoren beschrieben ist.

\section{AG10.P.16 \\ molecular analysis of radon-induced lung carcinoma: a regional study of lung carcinoma induction by natural radon exposure in a Tyrolean village \\ C. Manzl ${ }^{1 *}$, S. Sprung', G. Gamerith², M. Kloppenburg'2 S. Merkelbach-Bruse', R. Büttner', J. Haybaeck', G. Pall \\ 'Department of Pathology, Neuropathology and Molecular Pathology, Medical University of Innsbruck, Innsbruck, Austria, ${ }^{2}$ Department of Internal Medicine, Hematology and Oncology, Medical University of Innsbruck, Innsbruck, Austria, ${ }^{3}$ Institute of Pathology, University Hospital of Cologne, Cologne, Germany}

Background and aims. Lung cancer is the leading cause of cancer-related death, and approximately $85 \%$ belong to the subclass of non-small-cell lung cancer (NSCLC). Several targetable molecular drivers, such as EGFR, ALK and ROS1, have been discovered during the past decades., and the appearance of these driver mutations might be correlated with the fundamental etiology of tumor development, for example tobacco consumption. However, next to second hand smoking or asbestos exposure, European epidemiological studies could demonstrate that a radon load/burden increases the risk of lung cancer development. So far, data on the molecular profiles of radon-induced lung carcinomas is scarce. The Tyrolean village of Umhausen, Austria, harbors 'radon prone areas' built on an alluvial fan of a giant rock slide (granitic gneiss). Compared to the control population of all Tyrol, this area has been reported to have abnormally high indoor concentrations of radon (medians of $210 \mathrm{~Bq} / \mathrm{cm}^{3}$ up to $3750 \mathrm{~Bq} / \mathrm{cm}^{3}$ in ground floor and basements, respectively), which coincides with statistically increased lung cancer diseases and mortality.

The aim of the study is the evaluation of the most relevant molecular drivers in lung cancer samples derived from radon exposure patients living in the village of Umhausen in the Tyrol.

Methodology. Analyses were performed on 18 and 23 FFPE lung cancer tumor samples from the Umhausen region and a control region in northern Tyrol, respectively. Tumor was diagnosed in accordance with the relevant WHO classification system. Rearrangements in ALK, ROS1 and RET gene and c-MET amplification were detected using FISH analysis. Mutations were monitored using a customized hotspot NGS panel, including AKT1, ALK, BRAF, CTNNB1, DDR2, EGFR, ERRB2, KRAS, MAP2K1, MET, NRAS, PIK3CA, PTEN and PT53.

Results and conclusion. Preliminary results of this study revealed a higher percentage of exon 14 skipping mutations in radon-induced lung cancer samples (21\%). Interestingly, no EGFR mutation could be detected, while an ALK or ROS1 translocation was detected in $5 \%$ of the samples analyzed. Summarizing the hitherto existing data, we believe that contrary to what is reported in the literature on KRAS or EGFR mutations there is a shift in mutation load in radon-induced lung cancers from major KRAS or EGFR mutations towards MET mutations.

\section{AG Molekularpathologie Poster}

\section{AG12.P.01 \\ Identifikation von prävalenten MET-Amplifikationsmustern bei NSCLC}

H.-U. Schildhaus ${ }^{1 *}$, J. Möcks ${ }^{2}$

'Universitätsklinik Essen, Institut für Pathologie, Essen, Deutschland, ${ }^{2}$ BioMCon GmbH, Mannheim, Deutschland

Ziel. MET-Amplifikationen bei NSCLC werden derzeit als Zielstruktur in klinischen Studien evaluiert. Bislang gibt es allerdings keine klare und klinisch relevante Definition der MET-Amplifikation. Bisherige Auswertestrategien bei FISH beruhen im Wesentlichen auf Kriterien, die im Grunde von der HER2-Amplifikation abgeleitet sind. Eine tiefergehende Analyse von MET-Aberrationsmustern bei NSCLC liegt bislang nicht vor. Diese Arbeit charakterisiert prävalente Aberrationsmuster auf Basis von klinischen FISH-Zählungen mithilfe von multivariaten Musterextraktionsverfahren.

Methoden. Ausgehend von einer pathologisch/klinisch gut charakterisierten Kohorte von 636 NSCLC-Fällen, wurden die Zählungen von je 60 Zellen (MET, CEP7) zur Ermittlung prävalenter Aberrationsmuster eingesetzt. Für die biomathematische Analyse wurden die Zählungen für jeden Fall in 13 numerische Charakteristiken überführt und mit multivariater Musterextraktion bearbeitet. Die Scores der gefundenen Muster werden mit dem bisherigen Amplifikationsklassifizierung verglichen.

Ergebnisse. Es wurden 3 prävalente Aberrationsmuster extrahiert. Die Scores für Muster 1, 2 quantifizieren jeweils andere Aspekte der Amplifikation - zusammen geben sie in guter Approximation die klinischen („klassischen“) Klassifikationen wieder, hohe Scores von beiden Mustern deuten auf eine starke Amplifikation hin. Ein drittes Muster zeigte keinerlei Relation zu den klinischen Kategorien, und zeigte eine Amplifikation von CEP7 gegenüber MET - möglicherweise eine Ko-Amplifikation eines anderen Gens.

Fazit. Zwei der drei prävalenten Aberrationsmuster bilden in guter Approximation die klinischen MET-Klassifikationen ab, d.h. mit zwei numerischen Scores lassen sich die MET-Amplifikationsgrade beschreiben. Anders als die üblichen Amplifikationskategorien, bieten die numerischen Scores der Muster kontinuierliche quantitative Messungen der MET-Amplifikation. Damit können z. B. klinische Cutoffs wie bei anderen diagnostischen Größen definiert werden oder auch in weiteren Analysen zusammen mit anderen klinischen, genetischen und therapeutischen Daten eingesetzt werden. Das dritte Anti-Amplifikationsmuster ist vorher nicht beschrieben worden, die klinische Bedeutung ist unbekannt.

\section{AG12.P.02}

\section{Tumorheterogenität im NSCLC: Kombiniertes molekulares} Profiling unter Verwendung von Gewebe und ctDNA

S. Mayer ${ }^{1 *}$, G. Schmidtke-Schrezenmeier ${ }^{2}$, F. Rücker ${ }^{3}$, B. Schmelzle ${ }^{4}$, C. Buske ${ }^{4}$, C. Kropf-Sanchem², A. Babiak', P. Kuhn', P. Möller' , R. Marienfeld

'Universitätsklinikum Ulm, Institut für Pathologie, Ulm, Deutschland, ${ }^{2}$ Universitätsklinikum Ulm, Innere Medizin II, Ulm, Deutschland, ${ }^{3}$ Universitätsklinikum Ulm, Innere Medizin III, Ulm, Deutschland, ${ }^{4}$ Universitätsklinikum Ulm, Institut für Experimentelle Tumorforschung, Ulm, Deutschland, ${ }^{5}$ Universitätsklinikum Ulm, Comprehensive Cancer Center, Ulm, Deutschland

Ziel. Die Tumor-Heterogenität stellt eine wesentliche Ursache für die Entstehung von Resistenzmechanismen gegenüber zielgerichteten und immun-onkologischen Therapieansätzen beim fortgeschrittenen nicht kleinzelligen Lungenkarzinom (NSCLC, UICC IV) dar. Dabei ist die Erhebung des Mutationsprofils sowohl zur initialen Therapieplanung als auch zur Abschätzung eventueller Resistenzmechanismen von herausragender Bedeutung. Für die molekularpathologische Analyse bilden hierbei Gewebebiopsien den Goldstandard, sie spiegeln jedoch nicht die komplette Heterogenität eines Tumors wider. Eine mögliche Alternative stellt die Analyse 
von zellfreier zirkulierender Tumor-DNA (ctDNA) dar. Ziel dieser Studie ist es, für die zukünftige Beurteilung des Krankheitsverlaufs eine umfassende Betrachtung der klinischen Daten im Kontext der molekularpathologischen Konstellation an einer NSCLC-Kohorte durchzuführen.

Methoden. Für die Erhebung der molekularen Profile wurden NGS - Targeted Resequencing, Immunhistochemie, FISH und RNA Fusionstranskript-Analysen durchgeführt. Die Ergebnisse wurden für die Ermittlung eines geschlechts- oder altersspezifischen Mutationsprofils mit pseudonymisierten Daten von Patienten mit NSCLC Adenokarzinom herangezogen [Registerstudie LuCa-BiO (NCT02613637)].

Ergebnisse. In unsere Gesamtkohorte $(n=56)$ zeigten 16 Patienten eine KRAS Mutation (29\%) und 10 Patienten eine EGFR Mutation (18\%), wobei kein signifikanter geschlechtsspezifischer Unterschied vorlag. Die mediane Überlebenszeit der Kohorte lag bei 16 Monaten, mit tendenziell längerem Überleben der Patienten mit EGFR Mutation (30,8 Monate) im Vergleich zu Patienten mit KRAS Mutation (16 Monate) oder ohne bekannter Mutation (13,3 Monate). Der Gehalt an zellfreier DNA ist bei Patienten $(n=41)$ mit diagnostiziertem NSCLC signifikant höher als im Vergleich zu gesunden Kontrollindividuen $(n=6)(P=0,0001)$. Jedoch konnte in der ctDNA nicht derselbe Mutationsstatus wie in der korrespondierenden Gewebeprobe nachgewiesen werden. Bei 11 Patienten mit onkogener Treibermutation konnte diese in beiden Ansätzen nachgewiesen werden, während in 4 Fällen eine Mutation nur in der ctDNA und in 8 Fällen nur in der Gewebebiopsie detektiert werden konnte.

Fazit. Die Ergebnisse der Mutations-Analysen von ctDNA und Gewebeproben sind nur bedingt konkordant. Somit unterstützen unsere Ergebnisse den Befund, dass die Verwendung der Liquid Biopsy nicht als vollständiger Ersatz zur Gewebebiopsie verwendet werden kann.

\section{AG12.P.03}

\section{Ein robustes Tool zur Kopienzahlanalyse für verschiedene amplikon-basierte NGS-Panel (ACopy)}

K. Guricova*, A. Maurer, N. T. Gaisa, S. Garczyk, R. Knüchel-Clarke, E. Dahl, N. Ortiz Brüchle

Uniklinik RWTH Aachen, Institut für Pathologie, Aachen, Deutschland

Ziel. Der Einsatz von amplikon-basierten NGS-Genpanels zum Nachweis von therapeutisch-relevanten Punktmutationen ist Stand der Technik in der Molekularpathologie. Kopienzahlveränderungen stellen ebenfalls wichtige therapeutische Zielstrukturen dar. Diese werden bei den o.g. Panel-Analysen nicht zuverlässig miterfasst. Die bisher publizierten Methoden zum Nachweis von Kopienzahlveränderungen anhand von $\mathrm{Mu}-$ tations-Panel-Daten erfordern mehrheitlich das im Routine-Alltag nicht praktikable Mitführen von Kontrollgewebe im NGS-Lauf. Die wenigen publizierten Methoden ohne dies sind für spezifische Entitäten oder Panels entwickelt worden und waren auf unsere Datensätze nicht übertragbar. Es sollte daher ein R-basiertes robustes und breit einsetzbares Tool zur parallelen Kopienzahlanalyse ohne die Verwendung von Normalkontrolldaten entwickelt werden.

Methoden. Mathematisch wird für ACopy ein exponentielles Wachstumsmodell für die Amplifikation der Einzelzielsequenzen angenommen und postuliert, dass Gruppen von Amplikons eine ähnliche Amplifikationseffizienz zeigen. Die drei Hauptschritte des Algorithmus sind: 1. Normalisierung der Coverage-Daten. 2. Cluster-Aufbau: Amplikons, deren Effizienz korreliert werden geclustert und hierbei Bootstrapping und robuste Methoden der Korrelationsberechnung verwendet. 3. Detektion der Kopienzahlveränderungen: Für jedes Amplikon im Cluster werden robuste lineare Modelle erstellt und mit Hilfe der Residuenanalyse die Ausreißer identifiziert.

Ergebnisse. Die Robustheit von ACopy wurde anhand von drei unterschiedlichen Panel-Datensätzen getestet (Panel 1: 886 Amplikons, $n=42$, Panel 2: 3782 Amplikons, $n=40$, Panel 3: 1563Amplikons $n=62$ ). Es wurde eine $>99$ \%ige Spezifizität erreicht.

Fazit. ACopy ermöglicht eine robuste Kopienzahlanalyse verschiedener Mutations-Panel-Datensätze ohne die Verwendung von Normalgewebskontrollen.

\section{AG12.P.04}

\section{Association of DNA mismatch repair and MGMT onto clinical outcome in glioblastoma patients}

C. Manzl ${ }^{1 *}$, K. Brawanski ${ }^{2}$, P. Moser ${ }^{3}$, J. Haybaeck ${ }^{1,4,5}$, C. Thomè ${ }^{2}$

'Medical University of Innsbruck, Department for Pathology,

Neuropathology and Molecularpathology, Innsbruck, Austria, ${ }^{2}$ University Hospital for Neurosurgery, Medical University of Innsbruck, Innsbruck, Austria, ${ }^{3}$ Hospital for Pathology, Tirol-Kliniken, Landeskrankenhaus Innsbruck, Innsbruck, Austria, ${ }^{4}$ Medical Faculty, Otto von Guericke University Magdeburg, Department of Pathology, Magdeburg, Germany, ${ }^{5}$ Medical University of Graz, Diagnostic \& Research Center for Molecular BioMedicine, Institute of Pathology, Graz, Austria

Introduction and aims. Glioblastoma mulitforme (GBM) is the most common and most malignant brain intrinsic tumor. With current standard treatment median survival amounts to 14.5 months. Whereas treatment was previously based on histopathological diagnosis, today's treatment is additionally adopted to molecular markers, general condition and age. After tumor resection, young patients receive combined radiochemotherapy followed by adjuvant chemotherapy with temozolomide (TMZ). $\mathrm{O}^{6}$-methylguanine-DNA-methyltransferase (MGMT) is the most important predictive marker for treatment success with TMZ. Thus elderly patients receive either adjuvant chemotherapy or radiotherapy, depending on MGMT promoter methylation. TMZ methylates the DNA, generating pre-apoptotic DNA lesions, while DNA mismatch repair (MMR) is responsible for the cytotoxic effect. MGMT counteracts the effect of TMZ removing the alkyl group, which was previously transferred by TMZ. In the case of non-functional or less expressed MGMT, MMR system is able to produce strand breaks with repair attempt, followed by further repair attempts, leading to apoptotic cell death. Inferential the cytotoxic effects of TMZ are based on the interaction of MGMT and MMR.

The aim of this trial is to prove a correlation between MGMT promoter methylation, MGMT protein level and MMR in human glioblastoma tissue samples.

Methods. 54 FFPE tissue samples were analyzed using immunohistochemistry for MMR and MGMT protein expression. In order to evaluate the promotor methylation status of MGMT isolated DNA is bisulfide converted and sequenced using pyro-sequencing technique.

Results and conclusion. Patient cohort was stratified into a younger $(<70 \mathrm{y}$, $n=33$ ) and elderly ( $>70 \mathrm{y}, n=21)$ group, representing $58 \%$ male, $42 \% \mathrm{fe}-$ male and $71 \%$ male, $29 \%$ female, respectively. Interestingly, while MGMT promotor methylation was found in $47 \%$ and $33 \%$ in the younger and the elderly patient group, percentage of methylation of MGMT promotor region was increased in female patients from 50 to $100 \%$ in the elderly patient group. Three patients showed a low number of cells with MSH2 expression, all patients were MGMT ${ }^{\text {neg }}$, male and have a mean age of $72.6 \mathrm{y}$ (range: 68-79y). Furthermore, one male patient (age: 44y) showed almost no expression of PMS2, further mutation analysis are remaining. In this ongoing project the impact of MGMT promoter methylation and MMR on success of temozolomide treatment, overall survival and progression free survival, should be clarified

\section{AG12.P.05}

\section{Vergleich von drei verschiedenen Gen-Paneln zur Bestimmung} der Tumormutationslast durch Parallelsequenzierung

\section{R. Pappesch*, C. Heydt, J. Rehker, S. Merckelbach-Bruse}

\section{Uniklinik Köln, Köln, Deutschland}

Ziel. Die Einführung von Immuntherapien in der Behandlung bestimmter Krebsarten hat die Überlebensraten von Patienten ansteigen lassen. Erste Studien mit Exomanalysen zeigen, dass die Akkumulation von Neoantigenen und somit die Tumormutationslast (TMB) ein potentieller prädiktiver Marker für den Einsatz von Immuntherapeutika sein kann. In dieser Studie wurden 3 große Gen-Panels unterschiedlicher Anbieter mit DNA aus 28 formalinfixierten und in Paraffin eingebetteten (FFPE) Proben getestet. 
Der Test wurde speziell unter dem Gesichtspunkt einer Implementierung in die Routinediagnostik durchgeführt.

Methoden. Die Bibliothekerstellung erfolgte mit folgenden Kits: Ein kundenspezifischer SureSelect ${ }^{\mathrm{XTHS}}$ Target Assay (Agilent Technologies, Santa Clara, CA, USA), das NEOplus v2 RUO Assay (New Oncology, Köln, Deutschland) und das TruSight Oncology 500 Kit (Illumina, San Diego, CA, USA, TSO500). Alle Bibliotheken wurden nach Herstellerangaben präpariert. Für die Sequenzierung wurde das NextSeq 500 System (Illumina) verwendet. Als Qualitätssicherung erfolgte eine Fragmentanalyse über das Tapestation 4200 System (Agilent Technologies).

Ergebnisse. Die getesteten Assays zeigten unterschiedliche Konzentrationen der finalen Bibliotheken. Die Fragmente aller Produkte lagen in den erwarteten Größen vor und waren für eine Sequenzierung geeignet. Im Hinblick auf die benötigte Zeit zur Bibliothekerstellung war das NEOplus v2 RUO das arbeitsintensivste Kit. Die resultierenden TMB-Werte waren für alle Panels vergleichbar. Für alle Panels ist der Zugang zu den sequenzierten Genen und den detektierten Varianten möglich. Jedoch sind im Hinblick auf Zugang und Verwaltung der resultierenden Daten die Anbieter verschieden restriktiv. Auf Grund der Tatsache, dass nicht alle Kits mit spezifischen molekularen Kennungen (unique molekular identifier UMI) arbeiten, ist die Filtereffizienz der Daten für die verwendeten Kits unterschiedlich.

Fazit. In dieser Studie wurden 3 verschiedene Gen-Panels für die TMBBestimmung getestet. Alle Panels konnten einen ähnlichen TMB-Wert für alle Proben bestimmen. Im Hinblick auf die Benutzung und Implementierung in die Routinediagnostik sind Zeit und Effizienz wichtige Parameter. In diesem Zusammenhang zeigen das TSO500 und der SureSelect ${ }^{\mathrm{XTHS}}$ Assay das größte Potential für den Gebrauch in der Routinediagnostik.

\section{AG12.P.06 \\ Vergleichende Analyse von zirkulierender und gewebebasierter Tumor-DNA zur molekularen Charakterisierung von Kolonkarzinomen}

\section{A. Haupts ${ }^{1 *}$, M. Möhler' ${ }^{2}$, W. Kneist ${ }^{3}$, W. Roth ${ }^{1}$, N. Hartmann ${ }^{1}$}

'Institut für Pathologie der Universitätsmedizin Mainz, Mainz, Deutschland, 2. Medizinische Klinik und Poliklinik der Universitätsmedizin Mainz, Mainz, Deutschland, ${ }^{3}$ Klinik für Allgemein-, Viszeral- und Transplantationschirurgie der Universitätsmedizin Mainz, Mainz, Deutschland

Ziel. Die routinemäßige molekulare Charakterisierung von Kolonkarzinomen erfolgt an Biopsien oder Resektaten. Eine Gewebeprobe kann die Tumorheterogenität nicht vollständig repräsentieren, denn sie stellt nur eine regionale Momentaufnahme dar. Zur Bestimmung des gesamten Mutationsprofils sowie zur Überprüfung des Mutationsstatus in regelmäßigen Abständen, kann die minimal-invasive Liquid-Biopsy-Diagnostik verwendet werden. Dabei wird die im Blut zirkulierende, zellfreie DNA von Tumorzellen (ctDNA) isoliert. In diesem Projekt wurde untersucht, ob diese Methode geeignet ist, den molekularpathologischen Standard der gewebebasierten DNA-Analyse zukünftig zu ergänzen.

Methoden. Die ctDNA von Patienten mit Kolonkarzinomen wurde aus Blutproben von verschiedenen Zeitpunkten (prä- und postoperativ, Therapie) extrahiert. Dann wurde die ctDNA mittels Next Generation Sequencing (Reveal ctDNA 28 Concordance Kit, ArcherDX) und digitaler PCR (QuantStudio 3D Digital PCR System, Thermo Fisher Scientific) charakterisiert und deren Mutationsstatus mit der Analyse der FFPE-GewebeDNA verglichen.

Ergebnisse. Mittels NGS-Analyse der präoperativen ctDNA wurde bei mehr als zwei Drittel der Patienten die konkordante Mutation der Gewebe-DNA gefunden. Die ctDNA zeigte zudem bei einigen Patienten zusätzliche Mutationen, die im Gewebe nicht detektierbar waren. Weiterhin konnten wir zeigen, dass sich die ctDNA-Analyse zur Detektion von tumorspezifischen Mutationen und deren dynamischer Entwicklung während der Chemotherapie eignet, um das Therapieansprechen zu verfolgen. Hierzu werden die Quantität der ctDNA (ng/ml Plasma) und die detektierten Mutationen betrachtet. Dabei korreliert die ctDNA-Konzentration mit der Tumorlast. Beispielsweise ergab die ctDNA-Analyse eines Patien- tens vor der Chemotherapie eine hohe Menge an ctDNA (23,9 ng/ml) mit einer TP53-Mutation (p.Ser313AlafsTer32, Allelfrequenz: 60,5\%), während unter Therapie (Zyklus 1-8) eine stetige Abnahme der ctDNA-Menge $(1,9 \mathrm{ng} / \mathrm{ml})$ erfolgte und die TP53-Mutation nicht mehr detektierbar war. Im weiteren Therapieverlauf (Zyklus 12) zeigte sich ein Anstieg der ctDNA-Menge (5,8 ng/ml) und die TP53-Mutation (Allelfrequenz: 9,9\%) wurde erneut detektiert, was klinisch mit einem Progress der Erkrankung korrelierte.

Fazit. Zusammenfassend ist die Liquid-Biopsy-Diagnostik eine hilfreiche ergänzende Methode zur Darstellung des Mutationsprofils von Kolonkarzinomen zu verschiedenen Zeitpunkten des Krankheitsverlaufes.

\section{AG12.P.07}

\section{A comprehensive analysis platform in Galaxy for reproducible MALDI imaging data analysis}

M. Föll ${ }^{* 2,2}$, L. Moritz ${ }^{1}$, T. Wollmann ${ }^{3}$, M. Stillger ${ }^{1,2}$, M. Werner ${ }^{1,4}$, K. Rohr ${ }^{3}$, P. Bronsert ${ }^{1,4}$, B. Grüning ${ }^{5}$, O. Schilling ${ }^{1,4}$

'Institute of Surgical Pathology, University Medical Center Freiburg, Freiburg, Germany, ${ }^{2}$ University of Freiburg, Faculty of Biology, Freiburg, Germany, ${ }^{3}$ Biomedical Computer Vision Group, BioQuant, IPMB, Heidelberg University, Heidelberg, Germany, ${ }^{4}$ German Cancer Consortium (DKTK) and German Cancer Research Center (DKFZ) University of Freiburg, Freiburg, Germany, ${ }^{5}$ Department of Computer Science, University of Freiburg, Freiburg, Germany

Aim. Matrix-assisted laser desorption/ionization (MALDI) mass spectrometry imaging allows to analyze tissue specimens for the spatial distribution of hundreds of biomolecules such as proteins, peptides and metabolites. It is a powerful tool for clinical pathology as it can assist in generating diagnoses and prognoses via the measurement of molecular and morphological tissue properties. Sample preparation and measurement are straightforward while the analysis of the large and complex data is the main bottleneck in a MALDI imaging experiment. Furthermore, standardization and quality controls are in its infancy and complete software solutions that are accessible for scientists without programming skills are missing.

Methods. To overcome current problems in the analysis of MALDI imaging data, we established an open source analysis platform in Galaxy, which is available via https://usegalaxy.eu. Available tools allow filtering, combining, preprocessing, visualization, quality control and statistical analysis of MALDI imaging data. Currently, we are working on an automatic co-registration pipeline of $\mathrm{H} \& \mathrm{E}$ and MALDI images of the same tissue in order to allow virtual microdissection of regions of interest. Additionally, we created interactive online training material, which enables also beginners in the field to successfully analyze their data.

Results. The established Galaxy platform for MALDI imaging data analysis is for free, easily accessible via a web browser and gives access to large computing capabilities of $\sim 2000$ cores, 20 TB RAM, 1.5 PB storage. The graphical user interface, together with the step by step explained training material allows users without programming knowledge and/or limited MALDI imaging experience to get started and analyze their data themselves. This makes the platform especially suited for medical students during their studies. Analyses performed in Galaxy are reproducible, can be standardized via workflows and shared with collaborators. Furthermore, Galaxy allows to combine tools from diverse scientific domains without the need to switch between different analysis platforms.

Conclusion. We provide a comprehensive analysis platform for reproducible MALDI imaging data analysis that is free to use for the scientific community and does not require any programming skills. The MALDI imaging tools are installed on the European Galaxy instance but can be easily integrated into any other, also local Galaxy instances. 
AG12.P.08

Etablierung des Qiagen-Panels DHS-6600Z zur Bestimmung der Tumormutationslast in Lungenkarzinomproben

\section{A. Vogel*, D. Wagner, M. Kloth, W. Roth, N. Hartmann \\ Institut für Pathologie, Universitätsmedizin Mainz, Mainz, Deutschland}

Ziel. Die Tumormutationslast (TMB) repräsentiert einen neuen Biomarker zur Identifizierung von Patienten, die von einer Immuntherapie mit Checkpoint-Inhibitoren profitieren. Aktuelle Studien haben gezeigt, dass TMB effektiv mit entsprechend umfangreichen gezielten Genpanels bestimmt werden kann. In dieser Studie soll ein geeigneter TMB Panel etabliert werden und Adenokarzinome der Lunge hinsichtlich des TMB-Status untersucht werden.

Methoden. Die Etablierung eines Next-Generation Sequencing (NGS) Genpanels zur Bestimmung der Tumormutationslast (QIAseq Targeted DNA Panel Human Tumor Mutational Burden Panel DHS-6600Z, Qiagen) wurde mit Hilfe eines kommerziellen Standards für Formalin-fixiertes Paraffin-eingebettetes (FFPE) Gewebe (Structural Multiplex FFPE Reference Standard, HD-Nr. HD789, Horizon) und bereits Whole-Exome sequenzierten (WES) Proben validiert. Weiterhin wurde der TMB von Lungenkarzinomen (Adenokarzinome, FFPE Gewebe), die entweder eine starke Immuninfiltration aufweisen oder immunologisch kalt sind, bestimmt.

Ergebnisse. Die Entscheidung für den TMB-Panel von Qiagen beruhte darauf, dass sowohl die Herstellung der Sequenzierbibliotheken als auch die Auswertung der Daten mittels Biomedical Genomics Workbench am besten in die schon bestehenden Arbeitsabläufe integriert werden kann. Für die Validierung und Etablierung des Protokolls wurde ein Standard für FFPE-Gewebe, mit unterschiedlichsten Mutationen, und drei schon WES analysierten Proben verwendet. Darüber hinaus wurden zusätzlich Lungenkarzinomproben untersucht. Erste Ergebnisse der Library-Herstellung und Sequenzierung zeigen einen Zusammenhang zwischen der Qualität und Konzentration der in den TMB Panel einzusetzenden DNA Proben und der Qualität der Bestimmung von Mutationen. Eine DNA-Konzentration von $100 \mathrm{ng} / \mu \mathrm{l}$ zeigte sich hier als überzeugend. Des Weiteren war eine Herstellung von Libraries aber sogar mit geringen DNA-Konzentrationen möglich. Das Protokoll des TMB-Panels wurde optimiert und erste Ergebnisse zur Etablierung erzielt.

Fazit. Die ausführlichen Ergebnisse der Etablierung und Validierung sollen präsentiert und diskutiert werden.

\section{AG12.P.09 \\ Microsatellite instability (MSI) in colorectal cancer determined by fragment analysis compared to automated PCR Idylla ${ }^{\mathrm{TM}}$ MSI test}

M. Demes*, E. Hartung, S. Soworka, V. Tischler, P.J. Wild

Dr. Senckenberg, Institute of Pathology, University Hospital Frankfurt, Frankfurt, Germany

Aim. Microsatellite instability (MSI) is detected in about $15 \%$ of all colorectal cancers. This genomic instability which is presented as a hypermutable phenotype arises from defects in the DNA mismatch repair systems ( $M L H 1, M S H 2, M S H 6$, and PMS2) responsible for the repair of errors during DNA synthesis. The MSI status has an prognostic impact and therefore the detection of microsatellite instability (MSI) is recommended for a subset patients with colorectal cancer (CRC). Currently, reference methods are immunohistochemistry and fragment analysis of frequently mutated repetitive regions of DNA. In this study we investigated the routine application of the controversial discussed Idylla ${ }^{\text {tix }}$ MSI test.

Materials and methods. The MSI status of 40 fixed and paraffin-embedded (FFPE) CRC samples as well as corresponding individual normal tissue were assessed by fragment analysis (ABI 3130xl) and automated PCR Idylla $^{\text {ax }}$ MSI testing.

Most of the tumors were classified as moderately or poorly differentiated (G2/G3) adenocarcinomas with lymph node involvements. The Idyl$\mathrm{la}^{\mathrm{Tm}}$ MSI test included homopolymers located in the ACVR2A, BTBD7, DIDO1, MRE11, RYR3, SEC31A and SULF2 genes. The loci of BAT25,
BAT26, D5S346, D2S123, D17S250, BAT40, D10S197, D18S69, D18S58, and MYCL1 were characterized by fragment analysis.

Results. The MSI status could be assessed for all samples by both methods. $21 / 40$ (53\%) colorectal tumors were microsatellite instable and were correctly detected by fragment analysis and Idylla ${ }^{\mathrm{ru}}$ MSI testing. 19/40 (47\%) tumors were microsatellite stable and identified by the methods carried out, too. The concordance analysis showed an overall agreement of both procedures of $100 \%$.

Conclusion. Data available show the plausibility of the Idylla ${ }^{\mathrm{am}}$ MSI test including novel MSI biomarkers for routine diagnostics. The Idylla testing as a simple workflow includes automated sample preparation, DNA amplification as well as the repeat length calling and reporting. Thus, this method is a helping tool for a fast detection of microsatellite instability within about $2 \mathrm{~h}$. Adversely, the costs per sample are higher as compared to fragment analysis. The primer set can not be changed and therefore no other loci of interest can be analyzed by the closed Idylla ${ }^{\mathrm{at}}$ MSI test system.

\section{AG12.P.10}

Isolierung und Anreicherung von Tumorzellen aus FFPE-Schnitten zur Optimierung der NGS-basierten Multiplex-Analyse

\section{Wölwer*, C. Heydt, J. Rehker, R. Büttner, A. Hillmer, S. Merkelbach-Bruse} Universitätsklinikum Köln, Pathologie, Köln, Deutschland

Ziel. Die molekulare, NGS-basierte Multiplex-Analyse von Tumorgewebe ermöglicht personalisierte Therapieansätze und wird zunehmend in die Routinediagnostik integriert. Einen limitierenden Faktor einer qualitätsgesicherten molekularen Testung stellt ein geringer Tumorzellgehalt dar. Je geringer der Anteil von Tumorzellen gegenüber Wildtyp-Zellen, desto höher ist die Wahrscheinlichkeit eines falsch-negativen Ergebnisses. Mutationen werden meist erst ab einer Allelfrequenz von $5 \%$ benannt, daher wird Tumorgewebe, das einen Tumorzellgehalt von unter $10 \%$ aufweist, nicht mittels NGS untersucht. Hier testen wir ein neues Verfahren, in dem Tumorzellen gezielt aus FFPE-Schnitten isoliert und angereichert werden, um anschließend mittels NGS analysiert zu werden.

Methoden. Ein Kollektiv aus FFPE Resektaten von Patienten mit einem nichtkleinzelligen Lungenkarzinom wurde zusammengestellt. Der Tumorzellgehalt wurde von einem Pathologen geschätzt und eingezeichnet. Aus den FFPE-Schnitten wurden jeweils Zellsuspensionen (Gentle Macs, Miltenyi Biotec) hergestellt. Tumorzellen wurden anschließend mithilfe von, mit magnetischen Beads gekoppelten, anti-Cytokeratin Antikörpern über einen AutoMacs Pro Separator (Miltenyi Biotec) angereichert. DNA wurde aus den angereicherten Tumorzellen extrahiert und mit dem TruSight Tumor 170 Assay (Illumina) untersucht.

Ergebnisse. Die Analyse von DNA, die aus angereicherten Tumorzellen aus FFPE Resektaten mit niedrigem geschätzten Tumorzellgehalt (unter $10 \%)$ extrahiert wurde, war effektiver im Vergleich zur in der Routinediagnostik eingesetzten Makrodissektion: die Allelfrequenz der identifizierten Treibermutation erhöhte sich im Durchschnitt um das 4,5fache. Bei höherem geschätzten Tumorzellgehalt (70 \%) brachte die Anreicherung der Tumorzellen keine erheblichen Vorteile.

Fazit. Die hier beschriebene Methodik hat Potential zur NGS-basierten Multiplex-Analyse von Tumorproben mit niedrigem Tumorzellgehalt in den Routine-Workflow eingeführt zu werden. Dies würde den behandelnden Ärzten ermöglichen, trotz eines niedrigen Tumorzellgehaltes, eine verlässliche und rationale Therapie-Entscheidung für die betroffenen $\mathrm{Pa}$ tienten zu treffen. In Zukunft wird getestet, ob dieser Ansatz auch zur Translokationsdetektion aus extrahierter RNA möglich ist. Ebenso wird untersucht, ob die hier beschriebene Methodik auch bei Biopsien angewandt werden kann. 
AG12.P.11

\section{Qualitative Kriterien für die NGS-Rohdatenanalyse:} Schlussfolgerungen aus 143 Thermo Fisher Oncomine ${ }^{\mathrm{Tm}}$ Solid Tumor Panel Analysen

\author{
M. Bihl*, J. Hench, L. Terracciano, S. Höller \\ 'Institut für Medizinische Genetik und Pathologie, Basel, Schweiz
}

Ziel. Es soll ein Referenzprotokoll für die Analyse und diagnostische Interpretation von NGS-Daten im Rahmen des Tumor-Biomarker-Screenings in primär Formalin-fixierten histologischen und auch zytologischen Proben definiert werden.

Methode. Die Einführung des diagnostischen NGS hat die Möglichkeiten der Biomarker-Detektion in Krebsbiopsien erweitert. Dennoch gibt es kein allgemein akzeptiertes automatisiertes Verfahren zur Übersetzung von Rohdaten in Diagnoseberichte. Wir analysierten die qualitativen experimentellen Kriterien von 143 Oncomine $^{\mathrm{nt}}$ Solid Analysen mit diagnostischen Biopsien, um vulnerable Stellen, die eine manuelle Überprüfung erfordern zu identifizieren.

Ergebnisse. Alle Analysen wurden auf der Ion Torrent Platform (Thermo Fisher) mit einem einzigen Filter durchgeführt, um alle möglichen $\mathrm{Mu}-$ tationen zu definieren. Diese wurden durch die regelmäßige Teilnahme an Ringstudien zur Qualitätskontrolle extern validiert. Die Konzentration und Menge der extrahierten DNA sowie die Konzentration der „Library“ erwiesen sich als robuste Qualitätsindikatoren, wenn sie mit der Anzah der Varianten, die den Filter passierten korreliert wurden. Zusätzlich können wir die Anzahl der mutierten DNA-Moleküle basierend auf der Locusspezifischen Abdeckung schätzen, was ein wichtiges Interpretationskriterium ist. Die häufigsten unentdeckten und falsch detektierten Mutationen unter den 1850 verschiedenen Mutationen, die wir bislang identifiziert haben werden diskutiert.

Fazit. Die Daten aus unserer Studie führen zu einem Vorschlag für die diagnostische Interpretation von NGS-Rohdaten aus Tumorbiopsien.

\section{AG12.P.12}

\section{Detektion von humanen Papillomaviren (HPV) in zytologischen Präparaten mittels Anyplex ${ }^{\mathrm{TM}}$ II HPV28 Detection Kit der Firma Seegene Inc.}

M. A. Ihle*, R. Büttner, M. Engels, S. Merkelbach-Bruse

Universitätsklinikum Köln, Köln, Deutschland

Ziel. Mehr als 150 verschiedene Typen der humanen Papillomaviren (HPV) sind heutzutage bekannt, die je nach Karzinogenität in Hochrisikound Niedrigrisikotypen eingeteilt werden. Die Hochrisikotypen HPV 16 und 18 beispielsweise verursachen $70 \%$ der Zervixkarzinome, des vierthäufigsten bösartigen Tumors bei Frauen weltweit. Daher ist es von essentieller Bedeutung, nicht nur HPV zu diagnostizieren, sondern auch zu differenzieren. Ziel dieser Studie ist die Etablierung des Anyplex ${ }^{\text {nt }}$ II HPV28 Detection Kit zur Detektion und Differenzierung 28 verschiedener HPV Typen an zytologischen Proben.

Methoden. Das Anyplex ${ }^{\text {tit }}$ II HPV28 Detection Kit (Seegene) deckt 19 HPV Hochrisikotypen (HPV 16, 18, 26, 31, 33, 35, 39, 45, 51, 52, 53, 56, 58, 59, 66, 68, 69, 73 und 82) und 9 HPV Niedrigrisikotypen (HPV 6, 11, 40, 42, 43, 44, 54, 61 und 70) ab. Ein Kollektiv aus 10 Proben Abstrichmaterial der Zervix in SurePath ${ }^{\mathrm{TM}}$ Medium (BD) von Patienten mit Befunden der Gruppen I bis IVa-p der Münchener Nomenklatur III wurden analysiert. Die DNA-Isolation erfolgte aus $2 \mathrm{ml}$ Transportmedium mit dem Maxwell ${ }^{\circ}$ RSC Blood DNA Kit (Promega) nach Herstellerangaben auf dem Maxwell ${ }^{\circ}$ RSC (Promega). Die DNA wurde in $60 \mu$ l Elutionspuffer eluiert. Die Konzentration wurde mit dem NanoDrop ND-2000c gemessen. Je 5 und $10 \mu \mathrm{DNA}$, unabhängig von der Konzentration, wurden in den Anyplex ${ }^{\mathrm{m}}$ II HPV28 Detection Kit eingesetzt. Die Amplifikation erfolgte auf dem CFX96 Thermocycler (Biorad) und die Auswertung automatisiert mit der Seegene Viewer Software.

Ergebnisse. Es konnte DNA aus allen 10 Proben gewonnen werden. Die durchschnittliche DNA-Konzentration lag bei $11,82 \mathrm{ng} / \mu \mathrm{l}$. Der HPV Nachweis mit $5 \mu \mathrm{DNA}$, wie vom Hersteller empfohlen, führte bei keiner der 10 Proben zu einem Ergebnis. Jedoch konnte mit $10 \mu \mathrm{l}$ DNA Einsatzmenge in allen 10 Proben ein auswertbares Ergebnis erzielt werden. In 6 Proben konnte ein übereinstimmendes Ergebnis mit der im Haus validierten Methode (PCR + ELISA) detektiert werden. In vier Proben konnten mittels Anyplex ${ }^{\text {ma }}$ II HPV28 Detection Kit zusätzliche HPV-Typen detektiert werden (sowohl Hochrisiko- als auch Niedrigrisikotypen).

Fazit. Diese Studie zeigt, dass DNA sogar aus Abstrichmaterial der Zervix in SurePath ${ }^{\mathrm{TM}}$ Medium (BD) effektiv mit dem Maxwell ${ }^{\circ}$ RSC Blood DNA Kit (Promega) semiautomatisiert isoliert werden kann. Desweiteren ist der Anyplex ${ }^{\text {tx }}$ II HPV28 Detection Kit eine schnelle und effektive Methode, um 28 verschiedene HPV-Typen auch aus zytologischen Proben nachzuweisen.

\section{AG12.P.13}

Evaluation des MET-Amplifikationsstatus im nicht-kleinzelligen Lungenkarzinom mittels Next-Generation Sequenzierung

R. Erber' ${ }^{1 *}$, R. Stöhr', E. Moskalev' ', L. Tögel', F. Fuchs'², A. Hartmann' ', F. Haller'

${ }^{1}$ Universitätsklinikum Erlangen, CCC Erlangen-EMN, Friedrich-AlexanderUniversität Erlangen, Pathologisches Institut, Erlangen, Deutschland, ${ }^{2}$ Universitätsklinikum Erlangen, CCC Erlangen-EMN, Friedrich-AlexanderUniversität Erlangen, Medizinische Klinik 1, Gastroenterologie, Pneumonologie und Endokrinologie, Erlangen, Deutschland

Hintergrund. Im nicht-kleinzelligen Lungenkarzinom (NSCLC) findet man in ca. 3-5 \% der Fälle eine Amplifikation bzw. erhöhte Genkopienzahl (GCN) des MET-Proto-Onkogens - eine Genaberration, die zur weiteren Therapiestratifizierung herangezogen werden kann. Für die Bestimmung des MET-Amplifikationsstatus ist die Fluoreszenz-in-situ-Hybridisierung (FISH) eine gut etablierte Methode, bei der Auswertung werden high- und low-level-Amplifikationen sowie Polysomie mit erhöhter GCN voneinander unterschieden. Da beim NSCLC zur Therapieoptimierung jedoch eine umfassende Multigendiagnostik erfolgen sollte, stellt das Next-Generation Sequencing (NGS) potentiell eine Gewebe-schonende Alternative zur Detektion des MET-Genstatus dar.

Methoden. An einer Kohorte von insgesamt 333 NSCLC wurde eine NGSGenpanelanalyse, mit der unter anderem MET-Genamplifikationen nachgewiesen werden können, durchgeführt. Der MET-Amplifikationsstatus aus den NGS-Daten wurde sowohl mit Hilfe eines selbstentwickelten Screening-Verfahrens mittels Excel-Makro als auch mittels einer kommerziell erhältlichen Software bestimmt. Alle im NGS als amplifiziert erkannten Fälle wurden mittels FISH (MET-Amplifikationssonde) analysiert und die NGS- und FISH-Ergebnisse miteinander verglichen. Zusätzlich wurden weitere 40 Fälle der Kohorte, die mittels NGS als nicht MET-amplifiziert eingeordnet wurden, mittels FISH evaluiert.

Ergebnisse. Mittels NGS in Kombination mit zwei verschiedenen Auswertungsverfahren als Screening-Methode wurden sieben von 333 NSCLC als MET-amplifiziert identifiziert (2,1 \%). Davon wiesen drei Fälle in der FISH eine high-level MET-Amplifikation mit GCN $>10$ auf, drei weitere eine low-level MET-Amplifikation mit GCN 4-6 und MET-CEN7 Ratio >1,3, der siebte Fall war in der FISH nicht auswertbar. Von den 40 mit METFISH als Kontrollkohorte untersuchten Fällen wiesen zwei Fälle eine erhöhte GCN von 8 bzw. 3-4 bei Polysomie auf, bei beiden Fällen wurde im NGS keine MET-Amplifikation detektiert.

Schlussfolgerung. In unserer Analyse zeigten NGS und FISH eine gute Korrelation hinsichtlich der Bestimmung einer MET-Amplifikation, insbesondere alle high-level amplifizierten Fälle wurden im NGS korrekt identifiziert. NGS eignet sich als Screening-Verfahren zur Detektion einer MET-Amplifikation, zur Unterscheidung zwischen high- und low-level-Amplifikationen bzw. einer Polysomie sollte sich jedoch eine FISHAnalyse anschließen. 
AG01.P1.01

EGFR- und BRAF-Mutationen in invertierten sinonasalen Papillomen - Heterogenität intratumoral und über die Zeit hinweg nicht selten

\section{S. Zonnur*, A. Erbersdobler, B. Schneider}

Institut für Pathologie, Universitätsmedizin Rostock, Rostock, Deutschland

Ziel. Invertierte sinonasale Papillome (ISP) sind benigne epitheliale Neoplasien, die häufig rezidivieren und lokal destruktiv wachsen können. Mutationen im Epithelial growth factor receptor (EGFR)-Gen sind häufig und in verschiedensten Tumorentitäten zu finden. Kürzlich wurden EGFR-Mutationen in den Exons 19 und 20 bei ISP und ISP-assoziierten sinonasalen Karzinomen beschrieben. Ziel dieser Arbeit war eine Analyse hinsichtlich EGFR-Mutationen in einem ISP-Kollektiv, in dem es von einigen Patienten Proben von mehreren Zeitpunkten bzw. unterschiedlichen Lokalisationen gab, so dass zusätzlich Aussagen bezüglich zeitlicher bzw. lokaler genetischer Heterogenität möglich waren. Zusätzlich wurde BRAF mit analysiert, ebenfalls ein Onkogen, das in zahlreichen Tumorentitäten mutiert ist.

Methoden. Untersucht wurden insgesamt 58 Gewebeproben von $39 \mathrm{~Pa}$ tienten, 23 Männern und 16 Frauen. Von 25 Patienten gab es eine Gewebeprobe, von 14 Patienten mehrere. Aus dem Formalin-fixierten, Paraffineingebetteten Material wurde DNA extrahiert und die Exons 19 und 20 des EGFR-Gens, sowie Exon 15 des BRAF-Gens mittels Sanger-Sequenzierung untersucht.

Ergebnisse. Von 39 Patienten zeigten 17 in keiner der untersuchten Proben eine Mutation. In 22 Patienten wurde in zumindest einer Probe eine Mutation nachgewiesen. Von 14 Patienten, von denen mehrere Proben zur Verfügung standen, wiesen 8 Mutationen auf, davon 3 Patienten dieselbe und 5 Patienten unterschiedliche. Somit konnten sowohl zeitliche als auch lokale genetische Heterogenitäten gezeigt werden.

Fazit. ISP weisen nicht selten eine Heterogenität in Bezug auf EGFR- und BRAF-Mutationen auf.

\section{DGP-Pre-Meeting}

\section{Chinese-German Cooperative Pathology Research Workshop, June 12-13, 2019, Frankfurt am Main}

\section{Chinese Poster Session (CHIN.P), June 14, 2019 Frankfurt Main}

\section{CHIN.P.01 \\ HIF-2a signaling plays a role in extracellular ATP induced breast cancer invasion and EMT}

W. Fang* ${ }^{*}$ X. Tian, H. Yang

Peking University Health Science Center, Department of Pathology, School of Basic Medical Sciences, Beijing, China

Aims. Our previous studies have shown that extracellular Adenosine 5 'triphosphate (ATP) playsan important role in invasion and epithelial-mesenchymal transition (EMT) process in breast cancer. This study is aimed to definethe mechanismunderlying ATP action.
Methods. MDA-MB-231 or MCF-7 cells were transfected withdistinct siRNAs targeting HIF-2 $\alpha$, PGK1, AKT, P2Y2, respectively. Expression of targeted genes were assayed. In vitro invasion and nude mice assay were done. Results. Here, we demonstrated that extracellular ATP could stimulate hypoxia-inducible factor (HIF) signaling and upregulate hypoxia-inducible factor-2 $\alpha$ (HIF-2 $\alpha$ ) expression. Knockdown HIF-2 $\alpha$ significantly attenuated ATP-driven invasion and EMT capacities of breast cancer cells both in vitroand in vivo. Furthermore, we revealed that the biological function of extracellular ATP in invasion and EMT process depended on HIF-2a target genes, among which lysyl oxidase-like 2 (LOXL2) and matrix metalloproteinase-9 (MMP-9) mediated ATP-driven invasion, and E-cadherin and Snail mediated ATP-driven EMT, respectively. In addition, we found that expressions of HIF- $2 \alpha$ and its target genes could be regulated via ATP-driven P2Y2-AKT-PGK1 pathway. Moreover, molecules involved in ATP-HIF-2 $a$ signaling were highly expressed in human breast carcinoma tissues and were associated with poor prognosis.

Conclusion. Taken together, these findings suggest that extracellular ATP could promote breast carcinoma invasion and EMT via HIF-2 $\alpha$ signaling, which may be potential targets for future anti-metastasis therapy.

\section{CHIN.P.02}

Prediction model of the response of breast cancer patients to neoadjuvant chemotherapy based on machine learning techniques

L. Yang, F. Ye*, Y. Li, B. Fu, H. Bu

Sichuan University, Laboratory of Pathology, West China Hospital, Chengdu, China

Aims. Although most breast cancer patients have some clinical response to treatment, many patients do not respond sufficiently. Differentiating patients who will achieve a pathologic complete response (pCR) before neoadjuvant chemotherapy (NAC) would undoubtedly improve clinical effects and promote the benefits of individualized medicine.

Methods. A total of 243 patients with primary II-III breast cancers were retrospectively included in this study. A total of 219 patients who received four cycles of NAC treatment were randomly divided into a training set $(N=133)$ and a test set $(N=86) .24$ patients who received six cycles of NAC treatment were included as the extended external test set. Clinical features were analyzed for their association with pCR by univariate and multivariate analyses. Candidate genes were selected from public microarray data sets among 829 breast cancer patients. 14 candidate genes with 3 reference genes were screened out and validated by RT-qPCR based on FFPE samples. A prediction model was built by integrating gene expression and specific clinical features of the training set and was validated by the test set. Results. The baseline pCR rate in this study was $18.9 \%$ in this study. The naive Bayes algorithmshowed a higher prediction value than random forest, support vector machine (SVM) and k-nearest neighbor (knn) algorithms $(P<0.05)$. The 17 gene-only model was positively correlated with pCR (OR, 10,569, 95\% CI, 4488-24,889, $P<0.001)$ in the multivariate analysis when all available clinical factors were included. Then, we integrated specific clinical features (HER2 status and tumor size) with the 17 gene-only model, forming an optimized "17-gene plus model". This 17 gene plus prediction model showed a high positive correlation with $\mathrm{pCR}$ (OR, 17,041, 95\% CI, 6427-45,182, $P<0.001$ ), with $87.0 \%$ sensitivity in the internal group and $100.0 \%$ sensitivity in the external group. Using this model, all the enrolled patients could be classified into sensitive (SE) and insensitive (INS) groups.

Conclusion. Instead of whole transcriptome-based technologies, panel gene expression with tens of essential genes combined with specific clinical features implemented in a machine learning model can predict chemosensitivity of breast cancer. This convenient, repeatable strategy based on FFPE samples with further melioration by enlarged clinical cohort could show promising applications for predicting the therapeutic response of breast cancer patients to NAC. 


\section{CHIN.P.03}

\section{p38-regulated FOXC1 stability is required for colorectal cancer metastasis}

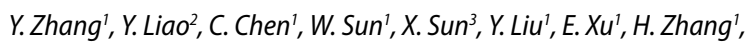
M. Lai ${ }^{*, 2}$

'Zhejiang University School of Medicine, Department of Pathology, Key Laboratory of Disease Proteomics of Zhejiang Province, Hangzhou, China, ${ }^{2}$ China Pharmaceutical University, State Key Laboratory of Natural Medicines, Jiangsu Key Laboratory of Carcinogenesis and Intervention, Nanjing, China, ${ }^{3}$ Zhejiang University School of Public Health, Department of Epidemiology \& Biostatistics, Hangzhou, China

Aims. Aberrant expression of Forkhead box C1 (FOXC1) promotes tumor metastasis in multiple human malignant tumors. Here, we aim to demonstrate the upstream modulating mode and downstream molecular mechanism of FOXC1 in CRC metastasis.

Methods. A systematic analysis of FOXC1 expression and prognosis in CRC was performed based on our clinical data and public databases. The biological function in vitrowas investigated by migration and invasion assay, while a spleen-liver metastasis model was applied to determine metastasis potential in vivo. An RNA-seq was performed to screen for FOXC1-specific target genes that were validated by real-time PCR, immunoblotting, luciferase reporter assay and ChIP assay. The interaction between $\mathrm{p} 38$ and FOXC1 was investigated by Co-IP assay, and the specific serine sites of FOXC1 for $\mathrm{p} 38$ phosphorylation were identified through constructing mutant vectors. Then, a ubiquitination assay was performed to prove that $\mathrm{p} 38$ phosphorylated FOXC1 to block its degradation.

Results. FOXC1 upregulation in CRC samples was significantly associated with poor prognosis. FOXC1 knockdown inhibited migration and invasion, while FOXC1 overexpression caused the opposite phenotype in vitro and in vivo. Furthermore, MMP10, SOX4 and SOX13 were verified as the direct target genes of FOXC1 for promoting CRC metastasis. Interestingly, Ser241 and Ser272 of FOXC1 were identified as the key sites to interact with $\mathrm{p} 38$ and phosphorylation, which were also critically required for maintaining the stability of FOXC1 protein. Moreover, FOXC1 was dephosphorylated by PP2A, and phosphorylated by $\mathrm{p} 38$, which maintained FOXC1 protein stability through inhibiting ubiquitination to regulate FOXC1 related target genes.

Conclusion. FOXC1 is strongly suggested as a pro-metastatic gene in CRC by transcriptionally activating MMP10, SOX4 and SOX13; p38 interacts with and phosphorylates the Ser241 and ser272 sites of FOXC1 to maintain its stability by inhibiting ubiquitination and degradation.

\section{CHIN.P.04}

\section{miR-192-5p silencing by genetic aberrations is a key event in} hepatocellular carcinomas with cancer stem cell features

Y. Gu, X. Wei, Y. Sun, H. Gao, X. Zheng, L. Wong, N. Liu, S. Hu, J. Ji*

Zhejiang University, Life Sciences Institute, Hangzhou, China

Aims. Cancer stem cells (CSC) in hepatocellular carcinoma (HCC) are biologically heterogeneous and contribute to therapeutic resistance. Till now, many cell surface biomarkers have been used to isolate hepatic CSCs, such as EpCAM, CD133, CD90, CD45 and CD24 etc. However, little is known about the implication of CSC heterogeneity and presence of shared molecular networks. Thus we aimed to identify potential shared regulatory pathways in various groups of $\mathrm{CSC}^{+} \mathrm{HCCs}$.

Methods. We performed class comparison of miRNA profiles between $\mathrm{CSC}^{+} \mathrm{HCCs}$ and CSC-HCCs for five different CSC biomarkers in a cohort of $241 \mathrm{HCC}$ patients. The expression of the top candidate in CSC ${ }^{+} \mathrm{HCCs}$ vs. CSC-HCCs and in HCCs vs. non-HCCs was explored in three independent HCC cohorts $(n=666)$. We performed the biological assays to investigate roles of the top miRNA candidate as well as its upstream and down-stream regulatory mechanisms in HCC development.

Results. We revealed a 14-miRNA signature to be commonly altered among five different subtypes of CSC ${ }^{+} \mathrm{HCC}$ and associate with HCC prognosis. miR-192-5p, the top ranked CSC-miRNA, is abundantly expressed in the liver but significantly downregulated in HCC. Silencing of miR-192$5 \mathrm{p}$ can induce CSC activities, in part, by targeting PABPC4, a novel potential oncogenic gene in HCC. Furthermore, both TP53 mutations and mir192 promoter hyper-methylation impede p53-mediated transcriptional activation of miR-192-5p, especially in $\mathrm{CSC}^{+} \mathrm{HCCs}$.

Conclusion. This study revealed the TP53 mutation/mir-192 promoter hyper-methylation/miR-192-5p/PABPC4 circuit as a shared genetic regulatory pathway in various groups of $\mathrm{CSC}^{+} \mathrm{HCC}$. This molecular signaling may be the driver that steers liver cells toward hepatic CSC cells, leading to hepatic carcinogenesis.

\section{CHIN.P.06}

Immunohistochemical pattern of mismatch repair proteins is related to clinicopathological features in colorectal adenocarcinomas

\section{J. Xu*, Q. Yang, K. Song, Y. Yan, S. Tao, J. Tang}

Zhejiang University School of Medicine, Department of Pathology, The Second Affiliated Hospital, Hangzhou, China

Aims. Detection of deficient mismatch repair proteins (dMMR) is clinically important in colorectal cancer (CRC) patients for Lynch syndrome screening, 5-FU based adjuvant chemotherapy and immunotherapy. As known, MLH1/PMS2 (MutL $\alpha$ )and MSH2/MSH6 (MutS $\beta$ ) perform different functions in DNA mismatch repair. So far, it is revealed that dMMR CRC patients have distinct clinicopathologic and molecular features from pMMR ones. While the difference and impact in varied patterns of MMR protein deficiency (dMutLa or d MutS $\beta$ ) is rarely reported. Our study was aimed to identify the clinicopathological features in different MMR proteins pattern of CRC.

Methods. We collected continuous 1352 Chinese patients diagnosed as CRC adenocarcinoma in SAHZU between 2013 and 2017 with immunohistochemical staining for MMR proteins (MLH1, MSH2, PMS2, and MSH6). The IHC results and histopathologic parameters were reviewed by 2 senior pathologists. Correlation between patterns of MMR protein deficiency and clinicopathological variables were statistically analyzed. Ratios were compared using chi-squire or Fisher exact test, and results with two-sided P-value $<0.05$ was considered statistically significant.

Results. 7.45\% (101/1352) of the patients showed loss of IHC staining in MMR markers. Combined loss of MMR markers expression is dominant (82.2\%), while isolated loss also existed. Loss of expression for MLH1/ PMS2 (MutLa) was observed in $68.3 \%$ of the dMMR cases, and loss of MSH2/MSH6 (MutS $\beta$ ) 31.7\%. Tumors with dMMR status were significantly associated with right-sided location $(p<0.001)$, mucinous histology type $(p=0.002)$, poorer differentiation $(p=0.006)$, perinural invasion $(p=0.004)$ and lymph node metastasis $(p=0.043)$. While MutLa and MutS $\beta$ deficient tumors show disparities in gender $(p=0.006)$, histology type $(p=0.003)$, differentiation $(p=0.003)$, lymphovascular invasion $(p=0.009)$, regional lymph node metastasis $(p=0.013)$ and tumor budding score $(p=0.002)$.

Conclusion. The frequency of MMR protein deficiency in CRC in Chinese population may be lower compared with the reported data from Western populations and can have different patterns of deficiency. Compared to MutLa deficiency CRC, MutS $\beta$ deficiency CRC was more common in male, and in papillary or mucinous adenocarcinoma, and less likely to have lymphovascular invasion, lymph node metastasis and tumor budding.

\section{CHIN.P.07}

\section{A miR-567-PIK3AP1-PI3K/AKT-c-Myc feedback loop regulates} tumor growth and chemoresistance in gastric cancer

\section{F. Zhang ${ }^{1,2}$, K. Li ${ }^{1,2}$, H. Wang ${ }^{3}$, L. Zhao ${ }^{1 *, 2}$}

'Southern Medical University, Department of Pathology, Nanfang Hospital, Guangzhou, China, ${ }^{2}$ Southern Medical University, Department of Pathology, School of Basic Medical Sciences, Guangzhou, China, ${ }^{3}$ Guangzhou Medical University, Department of Medical Oncology, Affiliated Tumor Hospital, Guangzhou, China 
Aims. Gastric cancer (GC) ranks the fifth most common cancer and third for cancer death, chemotherapy is one of the most common treatments for GC. However, chemoresistance limits the effectiveness of chemotherapy and leads to treatment failure. Studies have shown that microRNAs have significant regulatory functions in GC, while the role of miR-567 in GC tumorigenesis and chemoresistance has not been established. This study aims to investigate the biological effect of miR-567 on gastric cancer and to reveal the possible mechanism.

Methods. We measured the expression of miR-567 in 37 paired normal and stomach tumor specimens, as well as GC cell lines by Real-time PCR. The functional effects of miR-567 were validated using in vitroand in vivoassays. Dual-luciferase report assays and Chromatin immunoprecipitation (ChIP) assay were conducted for target evaluation, western blot assay was used to confirm the relationships.

Results. miR-567 was downregulated in gastric tissues and gastric cancer cells compared with normal tissues and gastric epithelial cells. In vitro, Gain- and lose-of-function assays showed miR-567 not only weakened cells proliferative ability, but also sensitized GC cells to 5-FU and oxaliplatin. In vivo, miR-567 overexpression significantly repressed the tumorigenesis of GC cells compared with the vector control. Mechanistic analyses showed that PIK3AP1 activated AKT phosphorylation in GC, miR-567 directly targeted PIK3AP1 to inactivate PI3K/AKT/c-Myc and regulated its own expression. This feedback loop further inhibited cells proliferation via PI3K/AKT pathway.

Conclusion. Our studies revealed that as a tumor suppressor, miR-567 repressed tumor growth, cells proliferation and increased drug sensitivity via a miR-567-PIK3AP1-PI3K/AKT-c-Myc feedback loop. These results suggest that miR-567 may serve as a target for chemoresistance and a potential prognostic biomarker for gastric cancer.

\section{CHIN.P.08}

\section{Using deep learning to assist in the diagnosis of thyroid nodules} on intraoperative frozen section slides

\section{Y. Li', P. Chen' ${ }^{2}$, Z. Li' ${ }^{1}$, H. Su ${ }^{2}$, L. Yang ${ }^{2}$, D. Zhong ${ }^{3 *}$}

${ }^{1}$ Chinese Academy of Medical Science, Department of Pathology, Molecular Pathology Research Center, Peking Union Medical College Hospital, Beijing, China, ${ }^{2}$ University of Florida, J. Crayton Pruitt Family Department of Biomedical Engineering, Gainesville, United States, ${ }^{3} \mathrm{China}$-Japan Friendship Hospital, Department of Pathology, Beijing, China

Aims. Frozen section provides a rapid intraoperative diagnosis that has direct impact on surgical decisions. But current situation is not satisfactory. The difficulty of interpretation and time constraints prompted us to propose a deep learning-based system to help pathologists accomplish this challenging task. We propose a patch-based method on digitalized whole slide images (WSI) through deep learning techniques study on thyroid lesions, which consists of 3 steps:

1. locating tissue region in WSI;

2. dividing tissue into image patches and using convolutional neural network to classify each patch into predefined categories;

3. integrating classification results of all patches to form final diagnosis. Methods. According to requirements of surgery, thyroid lesions were classified as benign, uncertain, or malignant. We fine-tuned InceptonV3 model on cropped thyroid patches by transfer learning, and trained patch classification model as the base model. The last fully connected layer of InceptionV3 was replaced with three outputs, standing for probability of benign, uncertain, and malignant. 349 thyroid frozen section were included for model training and validation, anadditional 259 consecutive thyroid frozen section for testing.

Results. The prediction precision of benign and malignant were $95.3 \%$ (61/64)and 96.7\% (148/153). There were 5 false positive and 3 false negative diagnoses. The percentage of predicted uncertain cases was $16.2 \%$ (42/259), including 19 benign and 16 malignant. These can be reexamined by pathologists or deferred to permanent section, thus won't cause direct consequence. Considering only benign and malignant cases, the overall accuracy was $96.4 \%$. Suspicious area was localized along with the automated diagnosis. The time cost of diagnosing a slide of size $80,000 \times 60,000$ pixels was less than $1 \mathrm{~min}$.

Conclusion. As far as we known, this is the first study of automatic frozen section diagnosis on thyroid lesions. This automatic diagnostic system can localize suspicious areas, especially those focalized or atypical areas which may be overlooked, to reduce the rate of missed diagnosis. In addition, this system can serves as an auxiliary or advisory role to assist pathologists during frozen section diagnosis.

\section{CHIN.P.09}

Practice of the new integrated molecular diagnostics in glioma: Experiences and new findings in a single center

W. $H u^{*}$

Sun Yat-sen University Cancer Center, Department of Pathology, Guangzhou, China

Aims. The new WHO classification of CNS tumors using the integrated phenotypic and molecular parameters has reestablished the CNS tumors classification in addition to traditional histology. The establishment of glioma molecular typing can more accurately predict prognosis, better guide individualized treatment to improve patient survival. This is of great significance for future exploration of new therapeutic strategies for gliomas. Methods. The expression of IDH1R132H, ATRX, H3K27M, PHH3, P53, Ki67 was detected by IHC. Molecular status of IDH1/2, TERTp and H3F3A in gliomas was analyzed using sanger sequencing. MGMTp was explored using methylation-specific PCR. $1 \mathrm{p} / 19 \mathrm{q}$ co-deletion status was firstly detected by FISH, then further confirmed by multiplex PCR-based next generation sequencing.

Results. The mutation frequency of IDH1, the most important marker of glioma in the new guideline, was $68.70 \%(79 / 115)$ in WHO grade II astrocytoma, and a total of $23.8 \%(82 / 344)$ gliomas weretriple-negative (IDH, $1 \mathrm{p} / 19 \mathrm{q}$ and TERT) in our cohort. Multivariate COX analysis revealed that only IDH, TERT and MGMT were significantly biomarkers for glioma prognosis. Noteworthily, we found 7 cases of the new molecular phenotypepresented as "IDH wildtype and 1p/19q co-deletion", not mentioned in the new WHO blue book.

Conclusion. We screened recommended markers in a large cohort of Chinese glioma patients. Our data also demonstrated the most powerful prognostic value of IDH mutation and we found a relatively low frequency of IDH mutations and a higher prevalence of triple-negative glioma in Chinese compared with American and European. In addition, the new molecular phenotype "IDH wild type and $1 \mathrm{p} / 19 \mathrm{q}$ co-deletion" glioma deserves special attention and may present as a further mechanism for the pathogenesis of glioma. These findings suggest that subgroups of diffuse gliomas defined by the newly recommended markers possess distinctive prognostic characteristics and different treatment strategy for the precision medicine.

\section{CHIN.P.10}

\section{IL13RA2: Overexpressed in human gliomas and a significant poor prognostic marker}

W. $\mathrm{Hu}^{*}$

Sun Yatsen University Cancer Center, Department of Pathology, Guangzhou, China

Aims. To study the expression of IL13RA2 in gliomas and its correlation with molecular subtypingand prognostic significance.

Methods. mRNA expression of IL13RA2 were downloaded and analyzed in two types of open access datasets (TCGA \& CGGA). Detection of IL13RA2 protein expression was adopted by immunohistochemistry in TAM. The association between IL13RA2 and molecular status (IDH, 1p19q, ATRX, MGMT and TERT) were examined using $\mathrm{c}^{2}$ and Spearman correlation test. Kaplan-Meier test and multivariate COX analyses were applied to evaluate the prognostic factors of IL13RA2.

Results. Out of all the 309 glioma cases and 20 normal brain tissues in our cohort, IL13RA2 protein totally highly expressed in 116 glioma cas- 
es $(116 / 309,37.5 \%)$ but no expression in normal brain tissues $(0 / 20,0 \%)$. 68/132(51.5\%) GBM were IL13RA2 protein high expression, especially in GBM patients with IDH1/2 wildtype and TERT promoter mutated $(76.9 \%$, 60/78). Notably, all the 13 cases of diffuse midline gliomas in our cohorts were IL13RA2 high expression. The results of spearman correlation analysis show that the expression of IL13RA2 was correlated with patients' age, WHO grade, Ki67 index, IDH1/2 status and TERT promoter status. The expression of IL13RA2 was also significant $(P<0.001)$ between normal brain tissues and GBM and between LGG and GBM. Additionally, we found IL13RA2 was strongly associated with OS and it served as a negative prognostic marker in glioma both in TCGA/CGGA datasets and our cohorts.

Conclusion. IL13RA2 is expressed in a significant proportion of gliomas and plays an oncogenic role in glioma progression, and it significantly correlates with poor prognosis. Based on its role on CAR-T therapy, it may act as an extremely important and specific therapeutic target for human gliomas,especially in GBM with IDH1/2 wildtype and TERT promoter mutated and diffuse midline glioma.

\section{CHIN.P.11}

\section{Classification of intrahepatic cholangiocarcinoma based on gross examination, pathology and characteristic gene variation}

J. Chen*

Medical School of Nanjing University, Department of Pathology, The Affiliated Drum Tower Hospital, Nanjing, China

Aims. Intrahepatic cholangiocarcinoma (ICC) is a highly lethal disease with significantly racial and regional differences, and lacking effective comprehensive therapy. For a long time, ICC has been considered as a single entity. However recently, a wide range of differences in ICC has been found.

Methods. By gross examination, ICCs can be divided into the mass forming type (MF), periductal infiltrating type (PI), and intraductal growth type (IG). Microscopically, the histologic subtypes of ICC includes cholangiolocellular carcinoma (CLC) and intraductal papillary mucinous neoplasms (IPN-B).

Results. Importantly, the biological behaviors of local infiltration in ICC are diverse, according to different types of the tumor. At the genetic level, there are some characteristic gene variations in ICC, including IDH gene mutation and FGFR2 gene fusion, which are lesser so in other carcinoma of digestive system. The risk factors of ICC range from chronic biliary bacterial inflammation, to bile stones to hepatitis virus, parasites, to primary sclerosing cholangitis, and many others. At present, relationship among these various differences in ICC have not been systematically evaluated. Conclusion. By reviewing the literatures and based on our data on Chinese patients with ICC, we improved classification system of ICC. This new classification is synthetically characterized by gross subtype, pathological feature and genetic variation (• Fig. $1 \mid$ CHIN.P.11). We hope our research results could provide useful evidence for the future studies to illustrate pathogenesis mechanisms of ICC and effective clinical manegement of patients with ICC.

\section{CHIN.P.12}

TUSC3 promotes cell proliferation and EMT via EGFR glycosylation and WNT/ $\boldsymbol{\beta}$-catenin signaling in NSCLC

X. Pei ${ }^{1,2}$, Y. Ren ${ }^{1}$, X.Xue ${ }^{3}$, Q. Wang ${ }^{1}$, Y. Ding ${ }^{1}$, J. Lin ${ }^{1 *}$

'Southern Medical University, Department of Pathology, School of Basic Medical Sciences, Guangzhou, China, ${ }^{2}$ Southern Medical University, Department of Pathology, Shenzhen Hospital, Shenzhen, China, ${ }^{3}$ Huizhou Municipal Central People's Hospital, Department of Pathology, Huizhou, China

Aims. Non-small cell lung cancer (NSCLC) is the most lethal respiratory malignancy all over the world. Tumour suppressor candidate 3 (TUSC3) is a cancer-associated gene, but its role in NSCLC is not fully understood. Our study is aimed to explore the function and underlying mechanisms of TUSC3 in NSCLC.

Methods. The expression of TUSC3 was detected by qRT-PCR, Western blot and immunohistochemistry method in 383 cases of NSCLC patients. Amplification refractory mutation system (ARMS) method was performed to detect the mutation status of epidermal growth factor receptor (EGFR) gene in NSCLC. We used peroxidase labelled Concanavalin A (ConA-HRP) combined with chemiluminescence assay to detect the glycosylation levels of both whole proteins and EGFR protein in pulmonary adenocarcinoma tissues and paired normal lung tissues. Gain-offunction and loss-of-function assays were carried on to explore the function of TUSC3 in NSCLC cell lines.

\begin{tabular}{|c|c|c|c|c|c|c|c|c|}
\hline Subtype & Proportion & Site of Liver & Clinic Features & Gross & Pathology & Biological Behavior & Gene Variation & Prognosis \\
\hline I & $15 \%$ & $\begin{array}{l}\text { Periphery of } \\
\text { liver }\end{array}$ & $\begin{array}{l}\text { with well-defined borders and } \\
\text { larger volume, but difficulty to } \\
\text { distinguish from HCC by } \\
\text { radiology }\end{array}$ & MF & CLC & Low aggressivity & $\begin{array}{l}\text { More IDH1/2 } \\
\text { mutation }\end{array}$ & Better \\
\hline II & $5 \%$ & $\begin{array}{l}\text { Centre of liver, } \\
\text { intraductal } \\
\text { growth }\end{array}$ & $\begin{array}{l}\text { With bile duct dilatation and } \\
\text { mucus secretion }\end{array}$ & IG & $\begin{array}{c}\text { IPN-B } \\
\text { associated } \\
\text { carcinoma }\end{array}$ & Low aggressivity & $\begin{array}{l}\text { More GNAS } \\
\text { mutation }\end{array}$ & Better \\
\hline III & $60 \%$ & $\begin{array}{l}\text { Periphery of } \\
\text { liver }\end{array}$ & $\begin{array}{l}\text { with well-defined borders, typical } \\
\text { feature of ICC on the enhanced } \\
\text { CT or MRI }\end{array}$ & MF & cICC & $\begin{array}{l}\text { Invade the } \\
\text { surrounding liver } \\
\text { tissue }\end{array}$ & $\begin{array}{l}\text { FGFR2 gene } \\
\text { variation }\end{array}$ & Moderate \\
\hline IV & $20 \%$ & $\begin{array}{l}\text { Centre of liver, } \\
\text { along the large } \\
\text { bile duct }\end{array}$ & $\begin{array}{l}\text { More clinical symptoms, such as } \\
\text { abdominal pain and jaundice, } \\
\text { more history of biliary opration, } \\
\text { increased serum bilirubin, ALP, } \\
{ }_{\gamma \mathrm{GT}} \text {, CA19-9 }\end{array}$ & $\begin{array}{c}\text { PI or } \\
\text { PI+MF }\end{array}$ & cICC & $\begin{array}{l}\text { High aggresivity, } \\
\text { more spread along } \\
\text { Glisson's sheath, }\end{array}$ & $\begin{array}{l}\text { Without } \\
\text { IDH1/2 or } \\
\text { FGFR2 gene } \\
\text { variation }\end{array}$ & Poor \\
\hline
\end{tabular}

Abbreviations (alphabetical order): ALP, alkaline phosphatase; cICC, conventional intrahepatic cholangiocarcinoma; CLC, cholangiolocellular carcinoma; FGFR2, fibroblast growth factor receptor 2; HCC, hepatocellular carcinoma; ICC, intrahepatic cholangiocarcinoma; $\mathrm{DH}$, isocitrate dehydrogenase ; IPN-B, intraductal papillary neoplasm of bile duct; MF, mass forming; PI, periductal infiltrating; $\gamma \mathrm{GT}$, gamma-glutamyl transpeptidase.

Fig. 1 | CHIN.P.11 $\Delta$ Classification of intrahepatic cholangiocarcinoma based on Gross examination, pathology, and characteristic gene variation 
Results. In this study, we find that high expression of TUSC3 is significantly associated with no-smoking, lymph node metastasis, distant metastasis, lower differentiation, and poor survival of NSCLC patients in a large cohort. Overexpression of TUSC 3 positively correlates with EGFR mutation, increased EGFR activity and glycosylation of EGFR protein in NSCLC tissues. The results of gain-of-function and loss-of-function analyses indicate that TUSC 3 enhance the aggressive behavior of NSCLC cells in vitro Furthermore, overexpression of TUSC 3 increases EGFR glycosylation accompanied by inhibition of autophagy and activation of $\mathrm{WNT} / \beta$-catenin signaling pathway in NSCLC cell lines.

Conclusion. Our results suggest that increased expression of TUSC 3 is associated with the malignant behavior of NSCLC cells in vivo and in vitro, which may be via aberrant glycosylation and activity of EGFR protein, and $\mathrm{WNT} / \beta$-catenin signaling pathway.

\section{CHIN.P.13}

Myeloid-restricted ablation of Shp2 restrains melanoma growth via CXCL9 and IFN-gamma production in tumor microenvironment

\section{Y. Ke}

Zhejiang University School of Medicine, Department of Pathology, Key Laboratory of Disease Proteomics of Zhejiang Province, Hangzhou, China

Aims. The Src homology 2 domain-containing protein tyrosine phosphatase 2 (Shp2) is generally considered to be an oncogene owing to its ability in enhancing the malignancy of multiple types of tumor cells; however, its role in modulating tumor immunity remains largely elusive.

Methods. LysMCre/+ Shp2flox/flox (Shp2M KO) mice and Shp2flox/flox (Shp2M WT) littermates were generated. Mice with 6-8 week age were used for experiments. B16 melanoma cell line (mycoplasma negative) was obtained from American Type Culture Collection (ATCC, Manassas, VA, USA) and tested for mycoplasma contamination (negative).

Results. Here, we reported that myeloid-restricted ablation of Shp2 suppressed melanoma growth. Mechanistically, loss of Shp2 potentiates macrophage production of CXCL9 in response to IFN-gamma and tumor cell-derived cytokines, thereby facilitating the tumor infiltration of IFN-gamma-producing $\mathrm{T}$ cells that could in turn support CXCL9 production within tumor microenvironment.

Conclusion. Collectively, our findings highlight a causative role of myeloid Shp2 in dampening $\mathrm{T}$ cell-mediated antitumor immunity by restraining the macrophage/CXCL9-T cell/IFN-gamma feedback loop. Thus, targeting macrophage Shp2 may help to create a Th1-dominant tumor immune microenvironment.

\section{CHIN.P.14}

Vulvar solitary fibrous tumor with malignant potential

\section{X. $\mathrm{Lu}^{1 *}$, Y. Wang ${ }^{2}$, X. Wang ${ }^{2}$, J. Wang ${ }^{2}$, Y.Xue ${ }^{2}$}

'Shanxi Medical University, Department of Pathology, The First Hospital, Taiyuan, China, ${ }^{2}$ Municipal Womem and Children Hospital of Taiyuan, Department of Pathology, Taiyuan, China

Aims. Primary vulvar SFT is extremely rare. Awareness of SFT in the vulva helps its recognition in pathology practice.

Methods. We report a case of solitary fibrous tumor (SFT) with malignant potential in the right labia majus. This was from a 60 -year-old woman who noticed a $0.4 \mathrm{~cm}$ nodule in the labia majus about 10 years ago. It was stable until recently when it grew rapidly into a $6 \mathrm{~cm}$ painless mass. By ultrasound, it was a solid, well-circumscribed, heterogeneous, and hypoechoic mass. Color Doppler Flow Image displayed prominent blood flow signals. The mass was excised. Gross examination of the specimen revealed an encapsulated oval mass $(5 \mathrm{~cm} \times 4 \mathrm{~cm} \times 3 \mathrm{~cm})$. The cut surfaces were solid and grey yellow-white. Routine hematoxylin-eosin stains showed sheets of spindle tumor cells focally admixed with multinucleated giant cells. No necrosis was identified. Mitotic index ranged from 1 to 3 per 10 high power fields. The tumor cells were strongly positive for CD34, Bcl-2, AACT, and estrogen receptor, focally positive for progesterone receptor, and negative for SMA, CD31, desmin, S-100, CD68, and AE1/AE3. Ki-67 immunostain showed a low proliferation rate $(<1 \%)$.

Results. The combined hisotologic and immunohistochemical features were consistent with a SFT with malignant potential.

Conclusion. Primary vulvar SFT is extremely rare. Awareness of SFT in the vulva helps its recognition in pathology practice. It should be distinguished from other spindle cell tumors such as dermatofibroma, and undifferentiated pleomorphic sarcoma. Careful histologic examination with immunostains is essential for the correct classification of tumor.

\section{CHIN.P.15}

\section{Automatic metastasis detection from H\&E stained esophagus} lymph node slides using deep semantic segmentation

W. Wang ', Z. Sun ', X. Feng ', Q. Fang ', J. Li', Y. Wang' , Z. Yang ', H. Dai', Y. Pan', J. Jia', S. Zou ${ }^{1 *}$

${ }^{1}$ Chinese Academy of Medical Science, Departments of Pathology, National Cancer Center/National Clinical Research Center for Cancer/Cancer Hospital, Peking Union Medical College Hospital, Beijing, China, ${ }^{2}$ Thorough Images, Beijing, China

Aims. Metastasis in the lymph node is a key factor for TNM staging system and the treatment of each patient after surgery can be various according to his/her TNM stage. However, it is tedious and time-consuming for pathologist to scan through tens of lymph nodes in the microscope for a single patient. Our study was aimed to combine the experience of pathologists and the computational power of deep learning to obtain a deep neural network, which can automatically detect the metastasis in H\&E esophagus lymph nodes slide.

Methods. We first collected 100 esophagus H\&E lymph node slides with diagnosed metastasis and 132 metastasis free H\&E lymph node slides. All these slides are scanned with Roche digital pathology scanner at 40X resolution. Then we used an ipad-based annotation system to draw the contour of cancer regions for slides with metastasis, and there was no need to annotate the metastasis free slide. After the collection, scanning and annotation, the digitalized slides were cut into small patches and each image patch was accompanied with its corresponding annotation patch. Overall, there was 324,264 patch pairs used in the training set. Based on these patch pairs, we trained an Deeplab_v3 model that can optimally fit the training data. After training, the learned Deeplab_v3 model can be used directly to segment the metastasis region out. Finally, depending on the segmented metastasis region, the system can automatically make suggestion of whether the given slide has metastasis or not.

Results. To evaluate the learned metastasis detection model, we collect a large coherent of clinical H\&E esophagus lymph node dataset, containing 309 with metastasis slides and 978 metastasis free slides, from Roche and Hamamatsu digital pathology scanners. The ground truth label of each slide was obtained from its pathology diagnosis. After filtering out isolated noise in the prediction, we obtained an accuracy of $88.12 \%$, which is promising.

Conclusion. Deep learning has shown the state-of-the-art performance in many fields and its ability to deal with complicated problems. In this work, we organized an annotated H\&E esophagus lymph node slide dataset and trained a deep neural network to automatically detect the metastasis in esophagus lymph node slide in a short time. 


\section{CHIN.P.16}

\section{Somatic mutations of homologous recombination repair genes in} Chinese ovarian cancers

Q. Bai ${ }^{1,2,3}$, Y. Ding ${ }^{4}$, L. Dong ${ }^{5}$, X. Wei, ${ }^{6}$ Q. Cui ${ }^{6}$, L. Bao ${ }^{1,2,3}$, M. Wang ${ }^{7}$, L. Zhang ${ }^{7}$, Y. Liu $^{6}$, Z. Zhang ${ }^{4}$, J. Ying ${ }^{5}$, X. Zhou ${ }^{1 * 2,3}$

'Fudan University Shanghai Cancer Center, Department of Pathology, Shanghai, China, ${ }^{2}$ Shanghai Medical College, Department of Oncology, Shanghai, China, ${ }^{3}$ Fudan University, Institute of Pathology, Shanghai, China, ${ }^{4}$ Nanjing Medical University, The First Affiliated Hospital, Nanjing, China, ${ }^{5}$ Chinese Academy of Medical Sciences, Cancer Hospital, Beijing, China, ${ }^{6}$ GuangDong Academy Affiliated of Medical Sciences, Guangzhou, China, ${ }^{7}$ Southeast University, ZhongDa Hospital, Nanjing, China

Aims. The prevalence rates of BRCA1/2 and other HRR gene mutations have been well elucidated in Caucasians and other populations but remain elusive in Chinese ovarian cancers.

Methods. We conducted a prospective nationwide multicenter study to survey the prevalence rate of somatic BRCAand other HRR mutations in 275 Chinese epithelial ovarian cancers from 2015 to 2018. Capture-base targeted sequencing was performed on genomic DNA from FFPE tissue samples using a panel consisting of 24 homologous recombination repair related genes, spanning $229 \mathrm{~kb}$ of human genome.

Results. We identified 125 pathogenic mutations spanning 14 genes from 104 patients, resulting in a positive detection rate of $37.8 \%$ (104/275). In our cohort, $27 \%(74 / 275)$ patients harbored pathogenic BRCA mutation, with $19.6 \%(54 / 275)$ and $6.0 \%(19 / 275)$ harboring BRCA1 and BRCA2 pathogenic mutation, respectively. The mutation types for pathogenic BRCA1/2 mutations primarily consisted of frameshift (57\%), nonsense (30.4\%) and splice-site (8.3\%). Furthermore, $10.9 \%$ patients $(30 / 275)$ had pathogenic mutations in HRR genes other than $B R C A 1 / 2$, suggesting the necessity in testing other HRR genes. In addition, 10.2\% (28/275) and $30.5 \%(84 / 275)$ of patients had variant of unknown significance (VUS) mutations in BRCA1/2or other HRR genes, respectively.

Our study revealed 26 patients with a known family history and 66 patients with no family history had pathogenic mutation in other HRR genes. Our study demonstrated that patients with a family history are more likely to have pathogenic BRCAmutation $(p=0.01)$ and other HRR gene mutation $(p=0.02)$. We also revealed that the onset age of patients with pathogenic mutation in BRCA1 ( $p=0.007)$ or other HRR genes $(p=0.004)$ is significantly younger than patients with WT genes. The follow up about the impact of the BRCA or other HRR gene mutation on the chemosensitivity, disease free survival or overall survival are ongoing.

Conclusion. We derived prevalence rates for somatic pathogenic BRCA and other HRR genes mutations in Chinese epithelial ovarian cancer patients. Our study suggested testing other HRR genes in addition to BRCAis necessary to provide more accurate assessment in ovarian cancer for accurate treatment and potential Cancer Risk prediction.

\section{CHIN.P.17}

The new idea of cancer immunotherapy: the expression of PD-L1 may reveal the immunological mechanism of resistance of EGFRTKI

Y. Liu*, Y. Jia, S. Li

The Fourth Hospital of Hebei Medical University, Department of Pathology, Shijiazhuang, China

Aims. Molecular detections guiding the treatment of non-small-cell lung cancer (NSCLC) have collected in major guidelines and widely recognized and followed by clinical practice. Besides, immuno-correlation detection and immune checkpoint inhibitors, notably antibodies targeting PD-1 and $\mathrm{PD}-\mathrm{L} 1$, have modified the management environment of patients with locally advanced or metastatic NSCLC, significantly prolonging the poor prognosis caused by EGFR resistance.

Methods. 2258 cases of NSCLC patients collected for EGFR, PD-L1(Ventana SP263), MET and HER2 detections simultaneously from the medical records of Fourth Hospital of Hebei Medical University between January 2016 and January 2019, 1195 cases with EGFR mutations (1196/2258, 52.9\%), 335 cases had a high expression of PD-L1 (>50\%). Real-time quantitative polymerase chain reaction (RT-qPCR) was used for EGFR detection. MET and HER2 results were verified in Fluorescence in situ hybridization (FISH) while immunohistochemical staining were decided to be $2+$. All statistical analyses were performed using IBM SPSS software.

Results. There were 24 cases $(24 / 335,7.16 \%)$ with high expression of PDL1 as well as T790M mutation, which was significantly higher than that of 44 cases $(44 / 1923,2.29 \%)$ with low expression of PD-L1 and T790M mutation $(\mathrm{X} 2=23.224, \mathrm{P}=0.000)$. The patients with high expression of PD-L1 and MET mutation or high expression of PD-L1 and HER2 amplification was $14(14 / 335,4.18 \%)$ and $9(9 / 335,2.69 \%)$ respectively, which had no statistical difference with low expression group (60/1923, 3.12\%; $53 / 1923,2.76 \%)(p=0.318, p=0.943)$. Among 68 EGFR-TKI resistance cases, the positive rate of PD-L1 in 16 cases of primary resistance to EGFR was higher than that of acquired resistance to EGFR-TKI ( $56.25 \%$ vs $25 \%$, $\mathrm{X} 2=5.459, \mathrm{P}=0.031$ ). In EGFR positive cases, the number of patients with high expression of PD-L1 was different in adenocarcinoma, squamous cell carcinoma, adenosquamous cell carcinoma and mucinous adenocarcinoma (X2 $=157.241, \mathrm{P}=0.000)$. The high expression rate of PD-L1 was $10.9 \%(97 / 890,10.9 \%)$ in adenocarcinoma and $34.4 \%(69 / 200,34.4 \%)$ in squamous cell carcinoma.

Conclusions. It can be inferred that the high expression of PD-L1 is related to the resistance of EGFR. The high expression of PD-L1 may speculate the existence of T790M mutation, and the resistance mechanism of T790M mutation may be related to immunity.

\section{CHIN.P.18}

\section{Clinical pathological analysis of hepatocellular adenoma in China}

L. Chen*, Y. Ji, Y. Hou, H. Zeng

Fudan University Affiliated Zhongshan Hospital, Department of Pathology, Shanghai, China

Aims. To summarize the clinical and pathological features of hepatocellular adenoma (HCA).

Methods. Retrospective analysis of clinical data, imaging and pathology was made on the patients who were diagnosed as HCAs from 2000 to 2012. Immunohistochemical stainings (Evnsion ${ }^{\mathrm{TM}}$ method) for CD34, LFABP, SAA, CRP, $\beta$-catenin, Ki-67, Glypican3, GS, HSP70 were applied to the routine paraffin section of some cases. The cases were subclassified as four groups according to WHO classification of Tumors of HCAs. The patients who were diagnosed as HCAs before 2010.12.31 were followed up. Results. 54 cases were diagnosed as HCAs among liver tumor patients from 2000 to 2012. 20 were men, 34 were women, aged 16 to 75 years (mean 31 years). Of 52 patients who had complete clinical and imaging data, 8 (15.4\%) presented with abdominal pain or discomfort, 41(78.8\%) with no related symptoms and diagnosed by physical examination or other diseases. 3 patients had history of glycogen storage disease, 2 patients had used oral contraceptives, and no patients had chronic hepatitis. Image showed that 24 cases (46.2\%) were probably malignant while 28 (53.8\%) were benign. All the patients underwent surgical resection, 3 patients with glycogen storage disease received liver transplantation. More than 86 tumors were removed ( 43 were solitary, 9 were multiple), size varied from 0.5 to $21 \mathrm{~cm}$, and the mean diameter was $7.2 \mathrm{~cm}$. Background liver was normal. With immunohistochemical results, 35 cases were subclassified as inflammatory HCAs $(13,37.1 \%)$, HNF1a-inactivated HCAs $(9,25.5 \%)$, b-catenin-activated HCAs (5, 14.3\%), unclassified HCAs (8, 22.9\%). 22 patients who had been followed up showed no evidence of tumor metastasis or recurrence.

Conclusions. Hepatocellular adenomas prefer occur in young people with no history of chronic hepatitis or cirrhosis. The incidence ratio of male and female is 1:1.7. the risk factor of oral contraceptive exposure is not verified in China. Image would misdiagnose about half of HCAs as malignant tumors. Histopathology accompany with immunohistochemistry is useful to HCA's diagnosis and subclassification. Partial hepatectomy is associated with good prognosis. 


\section{Autorenindex}

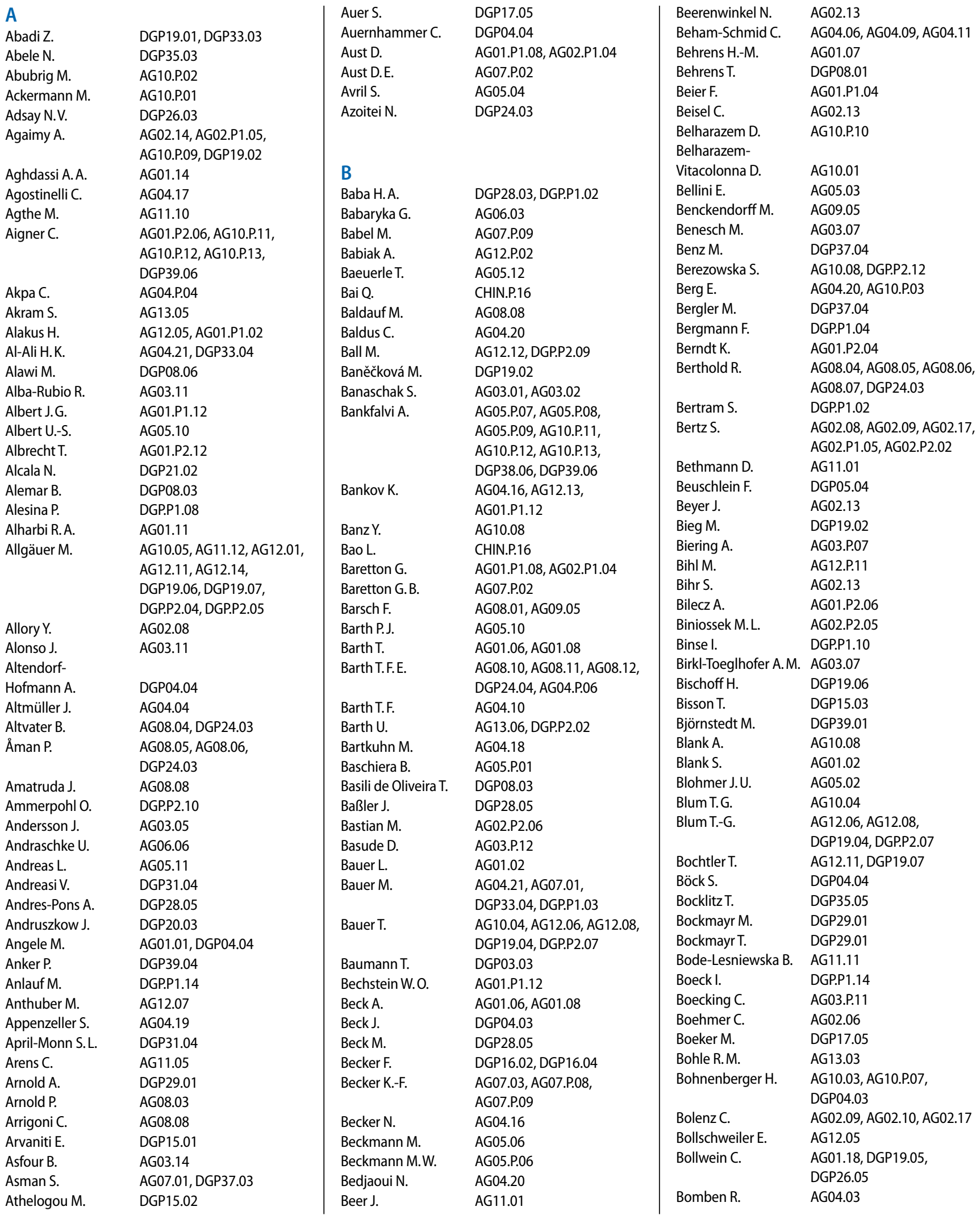




\begin{tabular}{|c|c|c|c|c|c|}
\hline Bonekamp D. & AG07.P.04 & & DGP19.01, DGP19.06, & Compérat $\mathrm{E}$. & AG02.08 \\
\hline Bonella F. & DGP39.06 & & DGP.P2.04 & Connors J. & AG04.01 \\
\hline Bonrouhi M. & DGP09.02 & Buderath P. & AG05.P.07, AG05.P.08, & Cooke A. & DGP28.05 \\
\hline \multirow[t]{2}{*}{ Bonzheim I. } & AG04.07, AG04.22, & & AG05.P.09 & Corrò C. & AG02.13 \\
\hline & AG04.P.02, DGP.P2.05 & Buettner R. & AG01.P1.02 & Costa S.D. & AG05.P.04 \\
\hline Boor P. & H04.05 & Buhtz P. & AG03.P.07 & Cron D.A. & AG10.P.06 \\
\hline Boos L. & DGP07.04 & Bukur J. & AG11.01 & Croner R. & AG01.16 \\
\hline Borchert $\mathrm{P}$. & AG10.P.01 & Burchardi N. & AG05.02 & Croner R.S. & AG01.P2.05, AG05.P.04, \\
\hline \multirow[t]{4}{*}{ Borchert S. } & AG10.04, AG01.P2.06, & Burdak-Rothkamm S. & DGP08.06 & & DGP.P1.16 \\
\hline & AG05.P.07, AG05.P.08, & BurgdorfS. & DGP09.02 & Csizmarik A. & AG02.P2.04 \\
\hline & AG05.P.09, AG10.P.11, & Burger I. A. & DGP16.03 & Cui Q. & CHIN.P.16 \\
\hline & AG10.P.12, AG10.P.13 & Burger M. & AG02.09, AG02.17, & CuiW. & AG05.11 \\
\hline Börris M. & DGP.P2.05 & & AG02.P2.02 & Curioni A.C. & AG03.06 \\
\hline Bösch F. & AG01.01, DGP04.04 & Burkert C. & AG02.12 & Curioni- & \\
\hline Bösherz M.-S. & DGP19.03 & Burren C. & AG03.P.01 & Fontecedro A. & AG10.07 \\
\hline Boskamp T. & DGP19.05 & Bürrig K.-F. & DGP03.06 & Cyra M. & AG08.04, AG08.05, AG08.06, \\
\hline Bösmüller $\mathrm{H}$. & AG10.P.07 & Busch H. & AG10.P.07, AG10.P.08 & & AG08.07, DGP24.03 \\
\hline Bourgoin N. & AG02.P2.04 & Buschhüter N. & AG07.01, DGP37.03 & Cyran A. & AG11.05 \\
\hline Bouznad N. & DGP.P2.15 & Buske C. & AG12.P.02 & Czapiewski P. & AG03.07 \\
\hline Boxberg $\mathrm{M}$. & AG01.17, AG05.14 & Büttner R. & AG02.02, AG12.05, AG02. & & \\
\hline Brägelmann J. & AG11.04, DGP16.04 & & P2.09, AG10.P.16, AG12.P.10, & & \\
\hline Brambilla E. & DGP21.02 & & AG12.P.12, DGP.P2.09 & D & \\
\hline Brandes D. & AG08.06 & Büttner-Herold M. & AG13.02 & Da Silveira W. & AG03.11 \\
\hline Brandl L. & AG07.04 & & & Dadfar S.M. & AG05.P.05 \\
\hline Brandt R. & $\begin{array}{l}\text { AG10.05, AG12.11, AG12.14, } \\
\text { DGP19.06 }\end{array}$ & C & & Dahl E. & $\begin{array}{l}\text { AG02.18, AG07.01, AG02. } \\
\text { P2.03, AG12.P.03, DGP37.03 }\end{array}$ \\
\hline Braren R. & AG01.12 & Calvisi D.F. & AG01.10, DGP26.02 & Dai H. & CHIN.P.15 \\
\hline Bräsen J.H. & DGP20.04 & Campean V. & AG02.P2.02 & Dai W. & DGP20.04 \\
\hline Braun M. & AG01.04 & CampoE. & AG04.07 & Dallmayer M. & AG08.08 \\
\hline Braun-Dullaeus R. & AG01.P2.14 & Capper D. & DGP29.01 & Dalvi P. & AG02.P2.09 \\
\hline \multirow[t]{2}{*}{ Bräuninger $A$. } & AG04.15, AG04.18, & Carlson J. & AG03.12, AG03.13 & Datta K. & AG01.15, DGP16.05 \\
\hline & AG04.P.08 & Casadonte R. & AG09.03, DGP19.05, & Dauch D. & DGP28.05 \\
\hline \multirow[t]{2}{*}{ Braunschweig $\mathrm{T}$. } & AG11.06, AG12.04, & & DGP26.05 & De Back W. & AG07.P.02 \\
\hline & DGP03.07 & Casanova R. & DGP35.01 & De la Torre C. & DGP33.03 \\
\hline Brawanski K. & AG12.P.04 & Casjens S. & DGP08.01 & De Nully Brown P. & AG04.05 \\
\hline Brcic L. & DGP04.03 & Cassataro A. & AG12.04 & Deckert S. & AG01.P2.11 \\
\hline Bremmer $\mathrm{F}$. & AG02.18, AG02.P2.08 & Cassataro M.-A. & AG11.06, AG02.P1.03 & Dedes K. & AG05.03 \\
\hline Bressem K. & DGP29.01 & Cathomas G. & AG04.02 & Deininger $S$. & DGP19.05 \\
\hline Breuhahn K. & DGP28.02, DGP28.05 & Caux C. & DGP21.02 & Delis A. & AG03.03 \\
\hline Breyer J. & AG02.06, AG02.09, AG02.17 & Ceribas Y. & AG01.P2.08 & Demes M. & AG02.P2.01, AG12.P.09 \\
\hline Brieu N. & DGP15.02 & Chang K. & AG05.13 & Demes M.-C. & AG12.13 \\
\hline Brobeil A. & AG04.P.08 & ChavezE. & AG04.01 & Demircioglu A. & DGP36.01 \\
\hline \multirow[t]{3}{*}{ Brochhausen C. } & AG01.22, AG06.05, AG08.01, & Che L. & AG01.10, DGP26.02 & Denkert C. & AG05.02 \\
\hline & AG09.05, AG07.P.08, & Chen C. & CHIN.P.03 & Denzel D. & DGP.P1.16 \\
\hline & AG07.P.09, DGP18.05 & Chen J. & CHIN.P.11 & Deplazes P. & AG01.06, AG01.08 \\
\hline Bronger $\mathrm{H}$. & AG05.14 & Chen L. & CHIN.P.18 & Derks J. & DGP21.02 \\
\hline \multirow[t]{2}{*}{ Bronsert $\mathrm{P}$. } & AG03.P.13, AG12.P.07, & Chen P. & CHIN.P.08 & Desch A.-K. & AG04.15 \\
\hline & DGP17.05 & Chen $\mathrm{X}$. & AG01.10, DGP26.02 & Dettmer M. & DGP07.02, DGP07.04 \\
\hline Brucker S. & AG05.16 & Chen Y. & AG10.P.02, AG10.P.04 & Deutsch A. & AG04.06, AG04.09, AG04.11 \\
\hline Brüggemann M. & AG04.04 & Cheng Y.-Y. & DGP24.03 & Dezső K. & DGP39.03 \\
\hline Brummer T. & AG12.14 & Chessa F. & DGP09.02 & Di Domenico A. & DGP31.04 \\
\hline Brüning T. & DGP08.01 & Chiappinelli K. & AG02.09 & Dieckmann J. & DGP17.04 \\
\hline Brunner I. & DGP24.03 & Chijioke 0. & AG05.P.01 & Dietmaier W. & AG08.09 \\
\hline Brunner T. & AG05.P.04 & Chon S.-H. & AG12.05 & DiGuilio A.L. & DGP28.05 \\
\hline Bruns $\mathrm{C}$. & AG01.P1.02 & Chong L. & AG04.01 & Dimitrova L. & AG04.20, AG04.P.04 \\
\hline Bruns C.J. & AG12.05 & Choschzick M. & AG05.03 & Ding Y. & CHIN.P.12, CHIN.P.16 \\
\hline Bruns V. & DGP37.04 & Christoph D.C. & AG10.P.03 & Dinter $\mathrm{H}$. & DGP04.03 \\
\hline Brüwer K. & DGP04.04 & Christoph S. & DGP31.03 & Dintner S. & AG12.07 \\
\hline BuH. & CHIN.P.02 & Christopoulos P. & AG12.14, DGP19.06, & Dirksen U. & AG03.11, DGP24.01 \\
\hline Bubendorf $\mathrm{L}$. & AG05.P.01 & & DGP.P2.04 & Dirnhofer S. & AG04.02, AG04.05 \\
\hline Buchhalter I. & AG12.14 & Chteinberg E. & AG01.11, AG04.P.05 & Dittmer J. & AG02.P2.07 \\
\hline Buchner A. & AG02.05, DGP15.02 & Chute D. & DGP08.03 & Dogan S. & DGP08.03 \\
\hline Bücker R. & AG01.P2.10 & Cidre-Aranaz F. & AG03.11, AG08.08 & Doglioni D. & DGP31.04 \\
\hline Budai A. & DGP38.04, DGP39.04 & Cieslak A. & $\mathrm{AG} 04.20$ & Döllinger C. & AG07.P.05, AG07.P.06 \\
\hline \multirow[t]{3}{*}{ Budczies J. } & AG10.05, AG12.01, AG12.11, & Claassen M. & DGP15.01 & Dombrowski F. & AG01.03, AG01.09, AG01.14, \\
\hline & AG12.14, DGP08.04, & Claus R. & AG12.07 & & AG02.12, DGP05.03, \\
\hline & & Clevers H. & KN02 & & DGP28.05 \\
\hline
\end{tabular}




\begin{tabular}{|c|c|c|c|c|c|}
\hline Döme B. & DGP39.06 & Esposito I. & AG02.18, AG06.03, & Fuchs F. & AG12.P.13 \\
\hline Dong L. & CHIN.P.16 & & AG01.P2.03, AG10.P.05, & Führer D. & DGP31.03 \\
\hline \multirow[t]{2}{*}{ Döring $C$. } & AG04.16, AG12.13, & & DGP26.03, DGP26.04 & Fuhrich N. & AG02.09 \\
\hline & AG01.P1.12, DGP17.04 & Esser M. & AG09.03 & Füldner $\mathrm{F}$. & AG01.P1.06 \\
\hline Döring $P$. & AG01.03, AG01.14 & Evert K. & AG01.10 & Fullár A. & DGP38.03 \\
\hline Dottermusch M. & AG01.07 & Evert M. & AG01.10, AG08.09, & Fülöp A. & DGP39.04 \\
\hline Drendel V. & AG02.P2.05 & & AG07.P.08, AG10.P.15, & Fung $C$. & DGP.P2.12 \\
\hline Drewes L. & AG05.08 & & DGP18.05, DGP23.03, & Furrer $\mathrm{E}$. & AG01.08 \\
\hline Dröge A. & AG04.20 & & DGP26.02 & & \\
\hline Droste C. & DGP08.06 & Evgeny $\mathrm{M}$. & DGP08.07 & & \\
\hline Drucker $\mathrm{E}$. & DGP28.05 & & & $\mathbf{G}$ & \\
\hline Dschun 0. & AG02.P2.08 & & & Gabbert H.-E. & DGP.P1.14 \\
\hline Duensing $S$. & DGP08.04, DGP29.03 & $\mathbf{F}$ & & Gabriel A. & DGP21.02 \\
\hline Dugge R. & AG04.P.06 & Faehling M. & AG12.14 & Gach F. & DGP35.02 \\
\hline Dummer R. & AG11.08 & Fähnrich A. & AG10.P.07, AG10.P.08 & Gaida M. & AG01.02 \\
\hline Dürr 0. & DGP35.01 & Fahrner M. & AG03.P.13 & Gaisa N.T. & AG02.04, AG02.05, AG02.18, \\
\hline \multirow[t]{3}{*}{ Dutta S. } & AG01.15, DGP16.05 & Falconi M. & DGP31.04 & & AG02.P1.03, AG02.P2.02, \\
\hline & & Fang Q. & CHIN.P.15 & & AG02.P2.03, AG12.P.03 \\
\hline & & Fang W. & CHIN.P.01 & Gaiser T. & AG01.P2.08, DGP36.05 \\
\hline $\mathbf{E}$ & & Fankhauser $C$. & DGP15.01 & Gajda M. & AG05.P.02 \\
\hline \multirow[t]{2}{*}{ Eberhardt W.E.E. } & AG10.04, AG10.P.11, & Fasching $\mathrm{P}$. & AG05.06 & Gamerith G. & AG10.P.16 \\
\hline & AG10.P.12, AG10.P.13 & Fasching P.A. & AG05.02, AG05.P.06 & Gao H. & CHIN.P.04 \\
\hline Eberli D. & DGP16.03 & Fassunke J. & AG12.05, DGP.P2.09 & Garami M. & AG03.P.13 \\
\hline Ebert K. & AG01.P1.07 & Fayad M. & DGP08.03 & Garbers C. & AG08.03, AG11.10, \\
\hline Ebrahimsade S. & AG05.10 & Fechter K. & AG04.09, AG04.11 & & AG01.P1.11 \\
\hline EckeT. & AG02.P1.06 & Federle L. & AG01.16 & Garczyk S. & AG02.04, AG02.05, \\
\hline Eckert A. & AG11.01 & Federmann B. & AG04.22 & & AG12.P.03 \\
\hline Eckhardt A. & DGP.P1.12 & Felda 0. & AG01.P2.03 & Gascoyne R. & AG04.01 \\
\hline \multirow[t]{3}{*}{ Eckstein M. } & AG02.06, AG02.08, AG02.09, & Felder B. & AG05.02 & Gassa A. & AG12.05 \\
\hline & AG02.10, AG02.17, AG05.12, & Fend $\mathrm{F}$. & AG04.07, AG04.22, & Gaßler N. & AG01.P1.10 \\
\hline & DGP08.07, DGP37.04 & & AG04.P.02, AG10.P.07, & Gastinger I. & AG01.P1.05, AG01.P2.05, \\
\hline Ehmer U. & AG01.P2.02 & & DGP.P2.05 & & AG01.P2.13 \\
\hline Eiber M. & AG07.P.01 & Feng $\mathrm{X}$. & CHIN.P.15 & Gattei V. & AG04.03 \\
\hline Eichhorn P. & AG06.06 & Ferguson J. & AG03.06 & Gattenlöhner S. & AG04.15, AG04.18, \\
\hline Eilts $\mathrm{R}$. & DGP19.02 & Fernandez A. & DGP35.02, DGP.P2.08 & & AG04.P.08 \\
\hline Elezkurtaj S. & AG04.20 & Fernandez-Cuesta L. & DGP21.02 & Gebauer B. & AG01.P2.05 \\
\hline Elges S. & DGP23.05 & Ferraro D. A. & DGP16.03 & Gebauer F. & AG01.P1.02 \\
\hline Ellinger J. & AG02.03 & Filmar S. & AG02.P2.08 & Geiger J. & DGP35.02 \\
\hline Elmasry M. & AG07.04, DGP.P2.06 & Fink L. & AG07.02 & Geissinger $\mathrm{E}$. & AG04.19 \\
\hline Embgenbroich $\mathrm{M}$. & DGP09.02 & Fischer A.K. & AG05.16 & Geißler S. & AG08.12 \\
\hline Emons J. & AG05.P.06 & Fischer $\mathrm{C}$. & DGP.P1.09 & Gemoll T. & DGP.P2.11 \\
\hline \multirow[t]{6}{*}{ Endris V. } & AG10.05, AG12.01, & Fischer $\mathrm{H}$. & DGP17.05 & Gentles A.J. & AG01.04, AG03.04 \\
\hline & AG12.08, AG12.11, AG12.14, & Fischer J.R. & AG12.14 & Geppert C. & AG01.16, AG02.09, AG02.17, \\
\hline & DGP08.04, DGP19.01, & Flechtenmacher $\mathrm{C}$. & AG05.P.03 & & AG06.06, DGP37.04, \\
\hline & DGP19.06, DGP19.07, & Flockerzi F. & AG13.03 & & DGP.P1.03 \\
\hline & DGP29.03, DGP.P2.04, & Foersch S. & AG01.P2.11, DGP35.02, & Geppert C.I. & AG05.12 \\
\hline & DGP.P2.05 & & DGP.P2.08 & Gerke J. & AG03.11, AG08.08 \\
\hline Engel J. & AG07.04 & Foll $\mathrm{M}$. & DGP21.02 & Gerlach M. M. & AG04.02 \\
\hline Engels $\mathrm{M}$. & AG12.P.12 & Föll M. & AG12.P.07 & Germing U. & AG04.P.03 \\
\hline Engleitner T. & DGP26.03 & Forberger $\mathrm{A}$. & AG05.P.10 & Gerritsen W. & AG04.P.05 \\
\hline Eppenberger- & & Fox B.A. & AG11.01 & Gessler M. & AG05.13 \\
\hline Castori S. & AG05.P.01 & Franke N.M. & DGP03.06 & Ghantous A. & DGP21.02 \\
\hline \multirow[t]{2}{*}{ Erben $\mathrm{P}$. } & AG02.06, AG02.09, AG02.10, & Franke S. & DGP08.05 & Ghossein R. & DGP08.03 \\
\hline & AG02.17 & Frauenfeld L. & AG04.07 & Giedl J. & AG02.P2.02 \\
\hline \multirow[t]{3}{*}{ Erber R. } & AG05.12, AG05.P.06, & Freiberger S.N. & AG11.08 & Giefing $M$. & AG04.16 \\
\hline & AG10.P.09, AG12.P.13, & Freund-Unsinn K. & AG03.P.09 & Giesche J.P. & AG08.12 \\
\hline & DGP19.02 & Fricker K.S. & DGP15.01 & Girard N. & DGP21.02 \\
\hline Erbersdobler $\mathrm{A}$. & AG01.P1.01, AG02.P2.06 & Friebe $\mathrm{M}$. & DGP35.03 & Glavy J.S. & DGP28.05 \\
\hline Erdélyi Z. & AG03.P.13 & Friedrich $\mathrm{K}$. & AG05.P.10, AG07.P.02 & Glimm H. & DGP.P2.05 \\
\hline Erlenbach- & & Fries J. & AG03.P.03, AG03.P.04 & Göbel H. & AG03.P.10 \\
\hline Wuensch K. & AG01.P2.07 & Fröhlich K. & AG03.P.13 & Goebeler M. & AG04.19 \\
\hline \multirow[t]{2}{*}{ Erlmeier F. } & AG02.09, AG02.14, AG02.15, & Fröhling S. & AG12.11, AG12.14, & Goebell P. & AG02.15 \\
\hline & AG02.17, DGP09.01 & & DGP19.01, DGP24.03, & Goeppert B. & AG11.12, AG01.P1.13, \\
\hline Ermis E. & DGP.P2.12 & & DGP.P2.05 & & AG01.P2.12, AG05.P.03, \\
\hline \multirow[t]{3}{*}{ Ernst G. } & DGP35.05 & Frohn L. & AG01.P2.03 & & DGP.P1.04 \\
\hline & & Frosina D. & DGP04.05, DGP08.03 & Goldmann T. & AG10.P.07, DGP.P2.10 \\
\hline & & Fu B. & CHIN.P.02 & Goldmann U. & DGP.P2.07 \\
\hline
\end{tabular}




$\begin{array}{ll}\text { Golz R. } & \text { AG02.P2.03 } \\ \text { Gomez C. } & \text { AG05.P.03 } \\ \text { Goncharova O. } & \text { AG04.17 } \\ \text { Göppert B. } & \text { AG12.14 } \\ \text { Gordon J. } & \text { DGP26.02 } \\ \text { Göring W. } & \text { AG12.12 } \\ \text { Götze K. } & \text { AG04.P.03 } \\ \text { Graber A. } & \text { AG04.02 } \\ \text { Gradhand E. } & \text { AG03.06, AG03.P.01, } \\ & \text { AG03.P.12 } \\ \text { GräfC. } & \text { AG06.02 } \\ \text { GräterT. } & \text { AG01.06 } \\ \text { Greten F. } & \text { AG01.21 } \\ \text { Gretz N. } & \text { DGP33.03 } \\ \text { Grevenstein D. } & \text { AG08.01 } \\ \text { Grieshaber S. } & \text { AG05.P.01 } \\ \text { Griff S. } & \text { AG10.04 } \\ \text { Grimm F. } & \text { AG01.08 } \\ \text { Grimm J. } & \text { AG01.06, AG01.08 } \\ \text { Gröne H.-J. } & \text { DGP09.02 } \\ \text { GroßC. } & \text { DGP26.03 } \\ \text { Groß D. } & \text { AG06.01, AG06.02, } \\ & \text { DGP03.01 } \\ \text { Groß N. } & \text { AG01.P2.02 } \\ \text { Grosser B. } & \text { AG01.02 } \\ \text { Großer M. } & \text { AG02.P1.04 } \\ \text { Grötzinger J. } & \text { AG08.03 } \\ \text { Gruber M. } & \text { AG05.16 } \\ \text { Grüner B. } & \text { AG01.06 } \\ \text { Grünewald I. } & \text { AG08.06 } \\ \text { Grünewald T. } & \text { AG03.11, AG05.13, } \\ & \text { AG08.08, AG12.07 } \\ \text { Grüning B. } & \text { AG12.P.07 } \\ \text { GuY. } & \text { CHIN.P.04 } \\ \text { Guenther M. } & \text { AG01.19 } \\ \text { Guillet C. } & \text { AG05.03 } \\ \text { Guntinas-Lichius O. } & \text { DGP35.05 } \\ \text { Guricova K. } & \text { AG12.P.03 } \\ \text { Gürtl-Lackner B. } & \text { AG03.12, AG03.13 } \\ \text { Gütgemann I. } & \text { AG01.04, AG03.04 } \\ \text { Gutjahr E. } & \text { AG05.P.03 } \\ \text { Gwinner W. } & \text { DGP20.04 } \\ & \end{array}$

\section{$\mathrm{H}$}

\begin{tabular}{ll} 
Haak A. & DGP.P1.01 \\
Häberle L. & DGP26.04 \\
Habermann J. & DGP.P2.11 \\
Hack C.C. & AG05.P.06 \\
Hadaschik B. & AG02.11, AG02.P1.01, \\
& AG02.P1.02, AG02.P1.07, \\
& AG02.P2.04 \\
Hafner S. & AG08.05, DGP24.03 \\
Hagberg H. & AG04.05 \\
Hager J. & AG03.P.09 \\
Hager T. & AG01.P2.06, AG02.P1.01, \\
& AG02.P1.02, AG02.P2.04, \\
& AG03.P.04, AG03.P.09, \\
& AG05.P.09, AG10.P.11, \\
Haidl F. & AG10.P.12, AG10.P.13, \\
Hakenberg O.W. & DGP.P1.15 \\
Hakroush S. & AG02.P2.09 2.06 \\
Hallek M. & DGP19.03 \\
Haller B. & AG12.05 \\
\hline
\end{tabular}

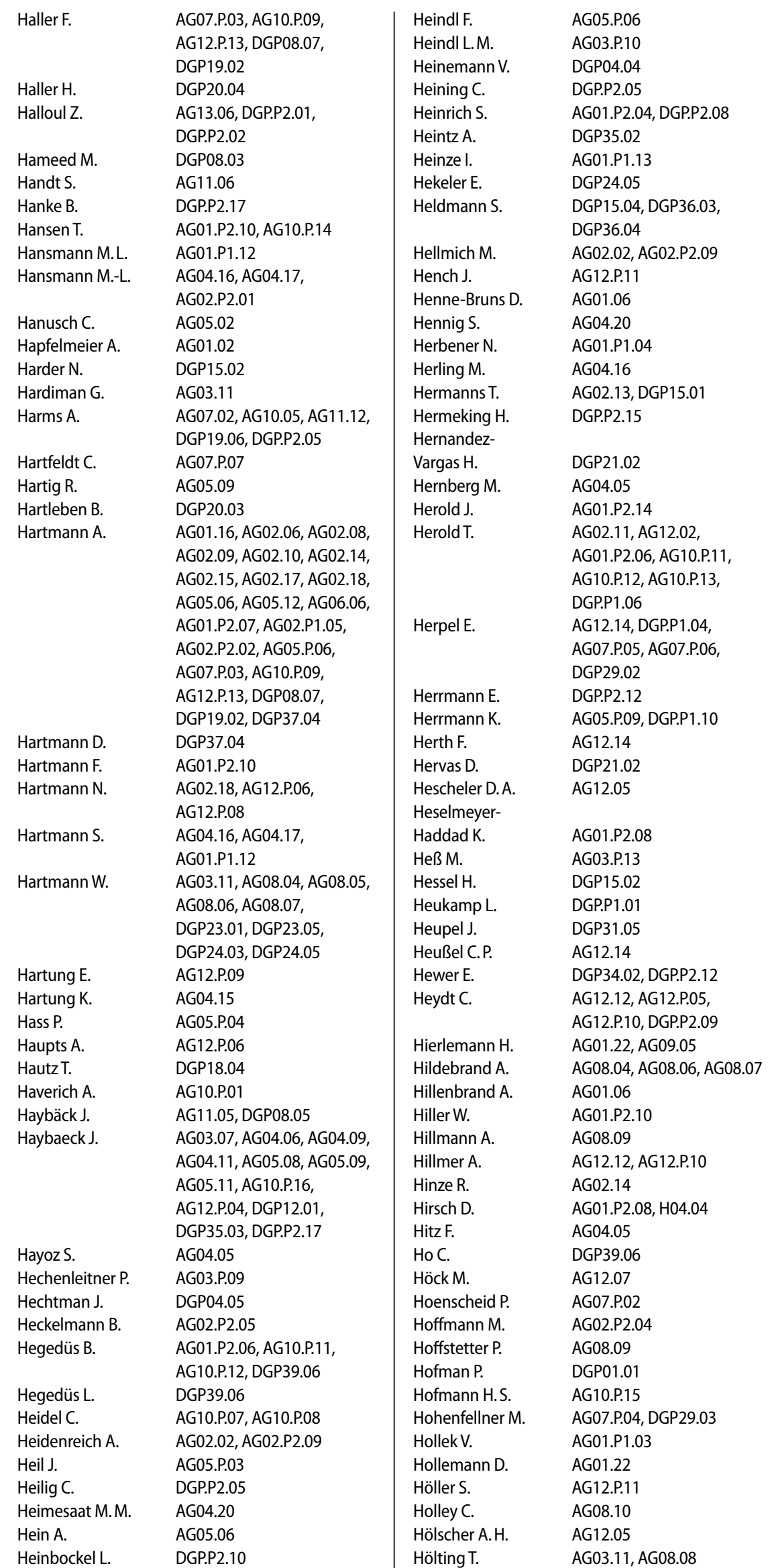




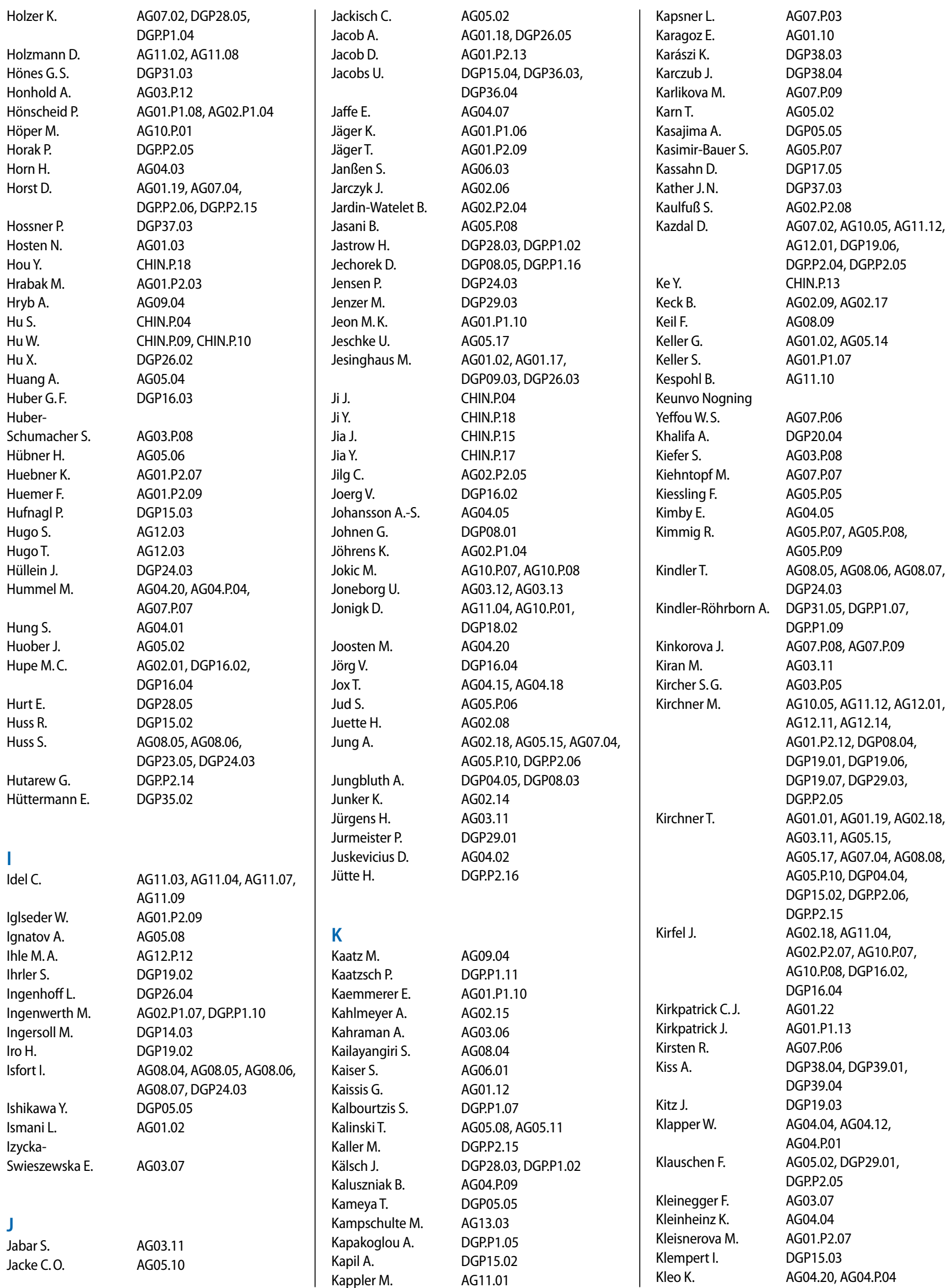




\begin{tabular}{|c|c|c|c|c|c|}
\hline Klieser E. & AG01.P2.09 & Kreutzfeld S. & DGP.P2.05 & Leichsenring J. & AG02.18, AG07.02, AG10.05, \\
\hline Klimstra D. & DGP04.05 & Kreyer R. & AG01.P2.05 & & AG11.12, AG12.01, AG12.14, \\
\hline Klöppel G. & DGP05.05, DGP26.03, KN01 & Krieg A. & DGP.P1.14 & & AG07.P.04, DGP19.06, \\
\hline Kloppenburg M. & AG10.P.16 & Kriegmair M. & AG02.06 & & DGP19.07, DGP29.03, \\
\hline Kloth M. & AG12.P.08 & Kriegmair M.C. & AG02.17 & & DGP.P2.05 \\
\hline Klotz S. & DGP33.03 & Kriegsmann J. & AG07.02, AG09.03, & Leichsenring $\mathrm{M}$. & AG07.02 \\
\hline Klufah F. & AG01.11 & & DGP19.05 & Leich-Zbat E. & AG04.03 \\
\hline Klümper N. & AG02.P2.07 & Kriegsmann K. & AG07.02, AG09.03, & Lendvai G. & DGP39.01 \\
\hline Kluwe W. & AG03.P.08 & & AG05.P.03, DGP19.05, & Lenggenhager $\mathrm{D}$. & DGP16.03 \\
\hline Kneist W. & AG12.P.06 & & DGP19.06 & Lentzsch A.M. & AG03.P.10 \\
\hline Knösel T. & DGP04.04 & Kriegsmann M. & AG07.02, AG09.03, AG10.05, & Lenze D. & AG04.20 \\
\hline Knott M. & AG03.11, AG08.08 & & AG11.12, AG05.P.03, & Lesser T. & DGP.P2.13 \\
\hline Knüchel R. & AG02.04, AG02.05, AG02.18, & & DGP19.01, DGP19.05, & Leuschner (†) I. & AG03.05 \\
\hline & AG02.P1.03, AG05.P.05, & & DGP19.06, DGP26.05 & Levesque M.P. & AG11.08 \\
\hline & DGP20.03 & Kristiansen G. & AG01.04, AG02.03, AG03.04 & Li J. & AG03.11, AG08.08, CHIN.P.15 \\
\hline Knüchel-Clarke R. & AG02.P2.03, AG12.P.03 & Kroker S. & AG03.P.07 & LiK. & CHIN.P.07 \\
\hline Knuechel-Clarke R. & AG11.06 & Kröncke T. & AG12.07 & LiS. & CHIN.P.17 \\
\hline Knuth E. & DGP05.03 & Kronenberg P.A. & AG01.08 & LiY. & CHIN.P.02, CHIN.P.08 \\
\hline Kobarg J.H. & DGP19.05 & Kropf-Sanchem C. & AG12.P.02 & LiZ. & CHIN.P.08 \\
\hline Koch A. & DGP31.05 & Krüger S. & AG01.07 & Liao Y. & CHIN.P.03 \\
\hline Koch K. & AG04.12, AG04.P.01 & Krupar R. & AG11.03, AG11.04, AG11.07, & Lichtenthaler S. & AG01.17 \\
\hline Koch R. & AG10.02 & & AG11.09 & Lieberich J. & AG01.P2.08 \\
\hline Koch S. & AG02.P1.06 & Küffer S. & AG10.02, AG10.03, & Lieberz R. & DGP17.04 \\
\hline Koellermann J. & AG02.18 & & DGP04.03, DGP19.03 & Liedtke C. & AG01.P1.10 \\
\hline Koelsch B. & DGP31.05 & Kugler C. & DGP.P2.10 & Liehr U.-B. & AG05.P.04 \\
\hline Kohl M. & AG02.P1.02 & Kuhn P. & AG12.P.02 & Lier A. & AG12.14 \\
\hline Kohlruss M. & AG01.02 & Kuhn P.-H. & AG01.17 & Limberg J. & AG10.P.05 \\
\hline Kohlwes E. & AG07.02 & Kühnel M. & AG10.P.01, DGP27.03 & Lin J. & CHIN.P.12 \\
\hline Köhrle J. & DGP31.02 & Kühnel M.P. & AG11.04 & Lindelauf $\mathrm{K}$. & AG05.P.05 \\
\hline Koitzsch U. & AG02.P2.09 & Kumbrink J. & AG12.12 & Lindemann- & \\
\hline Kolarova J. & AG04.P.06 & Kümpers $C$. & AG10.P.07, AG10.P.08, & Docter K. & AG02.04 \\
\hline Kollmeier J. & AG10.04, AG12.06, AG12.08, & & DGP08.02, DGP16.02 & Lingohr $\mathrm{P}$. & AG01.04 \\
\hline & DGP19.04, DGP.P2.07, & Kündig A. & DGP.P2.12 & Linz F. & AG10.P.01 \\
\hline & AG10.P.03 & Kunz M. & AG01.P2.07 & Liou I. & AG01.19 \\
\hline Kölsch B. & DGP.P1.07, DGP.P1.09 & Kunze C. & AG05.02 & Lippe E. & AG03.P.06 \\
\hline Kölsche C. & AG05.13, AG08.13, & Kunze P. & AG05.12, AG01.P2.07 & Lippert H. & AG01.P1.05, AG01.P2.05, \\
\hline & DGP.P2.13 & KunzkeT. & AG01.P1.07 & & AG01.P2.13, DGP.P2.01 \\
\hline Komminoth $\mathrm{P}$. & DGP04.01, DGP07.02, & Kunzmann S. & AG03.P.06 & Liu N. & CHIN.P.04 \\
\hline & DGP07.04 & Küppers R. & AG04.17 & Liu Y. & CHIN.P.03, CHIN.P.16, \\
\hline Kommoss $\mathrm{F}$. & AG05.13, AG05.13 & Kuppler P. & AG11.07, AG11.09 & & CHIN.P.17 \\
\hline Kommoss S. & AG05.16 & Kürten $\mathrm{P}$. & AG04.13 & Lodes U. & AG01.P2.14 \\
\hline König L. & AG08.02 & Kurz A.K. & AG01.11, AG04.P.05 & Loeffler M. A. & AG01.P2.12 \\
\hline Kontsek E. & DGP38.04, DGP39.01 & KusakE. & DGP37.03 & Lohmann S. & DGP15.03 \\
\hline Konukiewitz B. & AG01.12, DGP05.05, & Kutritz A. & DGP31.05, DGP.P1.07, & Loibl S. & AG05.02 \\
\hline & DGP26.03 & & DGP.P1.09 & Lokau J. & AG08.03, AG11.10 \\
\hline Kook L. & AG02.P2.05 & & & Longerich $\mathrm{T}$. & DGP19.01, DGP33.03, \\
\hline Körber F. & AG03.P.04 & & & & DGP.P2.05 \\
\hline Körholz D. & AG04.15, AG04.18, & L & & Lorenz K. & DGP.P1.03, DGP.P1.11 \\
\hline & AG04.P.08 & Ladisich B. & DGP.P2.14 & Losen I. & AG02.P2.03 \\
\hline Kötter M. & DGP37.04 & Lai M. & CHIN.P.03 & Lotz G. & AG02.03, DGP39.06 \\
\hline Kovacs I. & DGP39.06 & Lammers T. & AG05.P.05 & Lotz J. & DGP15.04, DGP36.03, \\
\hline Kovalszky I. & DGP38.03 & Lang S. & AG06.02, DGP.P2.13 & & DGP36.04 \\
\hline Krämer A. & AG12.11, DGP19.07 & Lange U. & DGP24.03 & LuX. & CHIN.P.14 \\
\hline Krämling H.J. & DGP.P1.14 & Langer $R$. & AG01.05, AG10.08 & Luber B. & AG01.P1.07 \\
\hline Krampitz A. & DGP.P2.11 & Länger $F$. & AG10.P.01 & Lück S. & AG03.14 \\
\hline Krassnig S. & AG03.07 & Lantuejoul S. & DGP21.02 & Lugli A. & AG10.08 \\
\hline Kratzer W. & AG01.06 & Lassmann S. & AG01.P1.03, DGP.P2.05 & Lukat L. & AG12.03 \\
\hline Kraus T. & DGP.P2.14 & Laßmann S. & AG01.P1.04 & Lüke J. & AG01.P2.10 \\
\hline Krausch M. & DGP.P1.14 & Latteyer S. & DGP31.03 & Lurje I. & AG02.04, AG02.05 \\
\hline Krause $\mathrm{H}$. & AG03.P.07 & Lazar-Karsten P. & AG02.P2.07 & Lux M. & AG01.P1.04 \\
\hline Kraywinkel K. & AG02.P1.01 & Lebeau A. & DGP15.04, DGP36.03, & Lux M.P. & AG05.P.06 \\
\hline Kreft A. & DGP18.03, DGP.P2.03 & & DGP36.04 & Luxenhofer T. & DGP24.04 \\
\hline Kreipe H.H. & DGP20.04 & Leblay N. & DGP21.02 & & \\
\hline Kremer A. & AG02.03 & Lechermeier A. & AG06.05 & & \\
\hline Krenauer M. & AG01.02 & Lehmann U. & DGP.P2.05 & $M$ & \\
\hline Krenn V. & AG08.02, AG08.02 & Lehr H.-A. & AG05.13 & Möller P. & AG04.P.06 \\
\hline Kreutzer S. & DGP05.04 & & & MaY. & AG10.P.02, AG10.P.04 \\
\hline
\end{tabular}




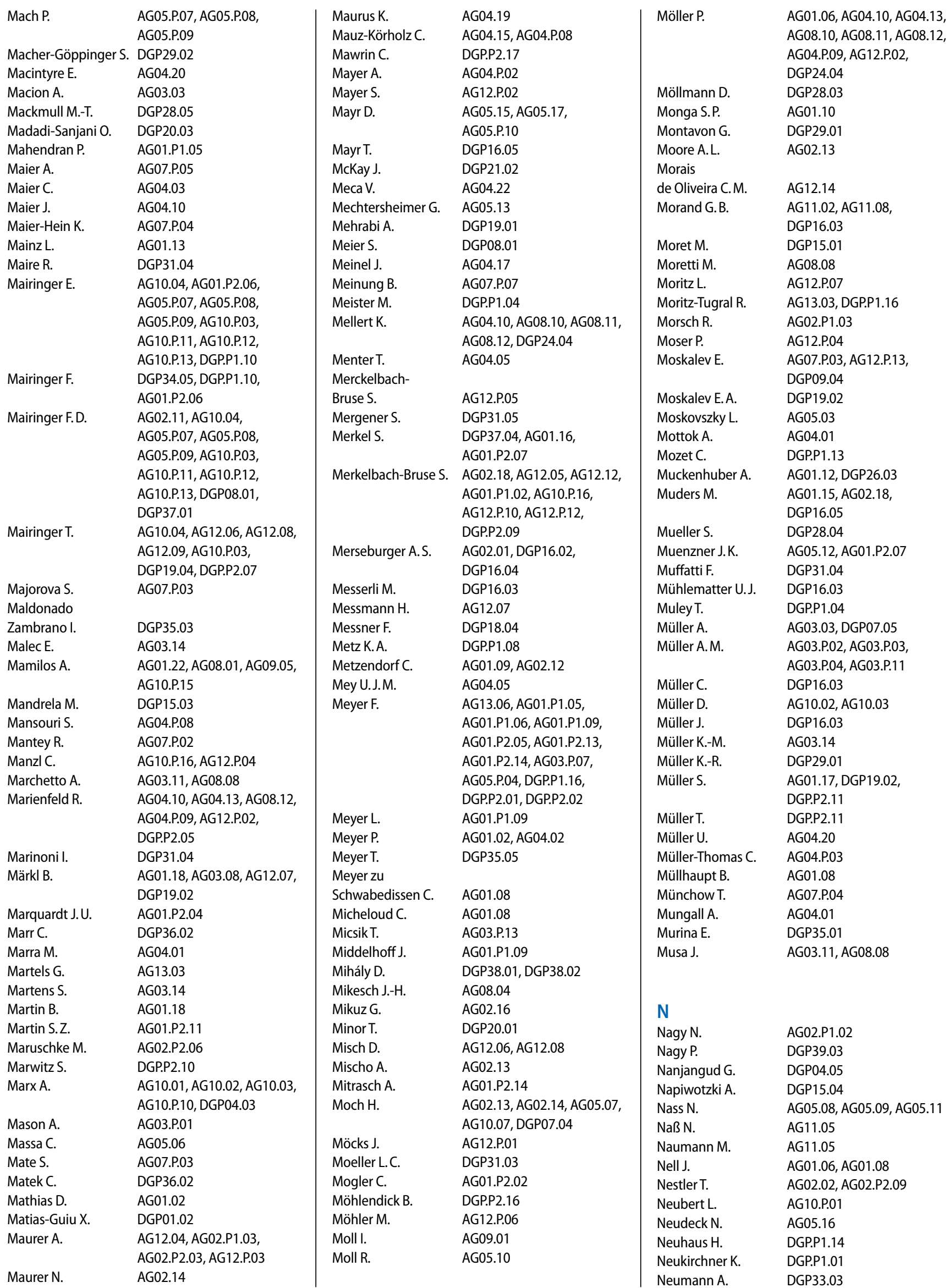




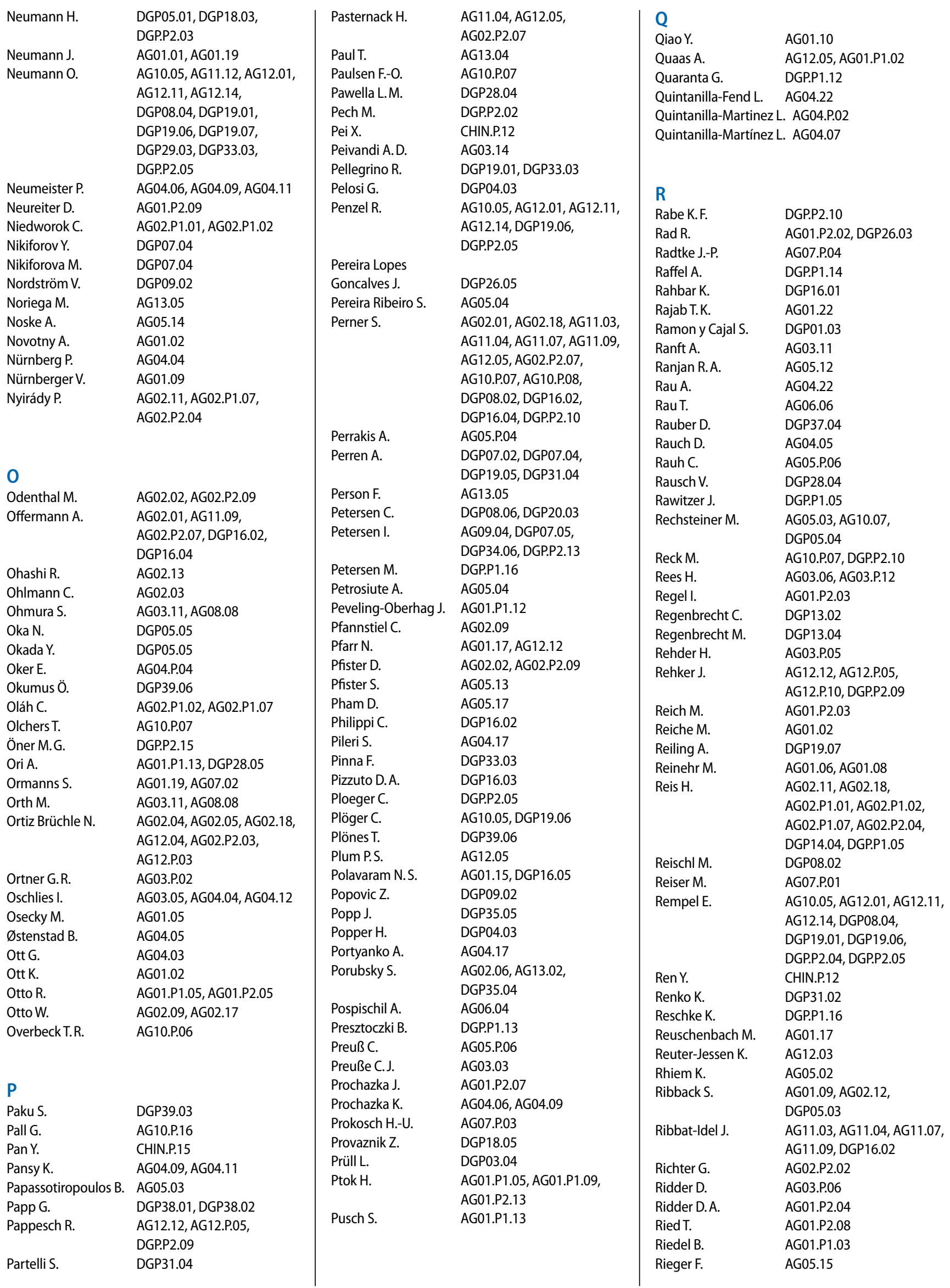


D. DGP28.05

RindiG. AG10.10

Rittler D. DGP39.06

Ritz T. DGP20.03

Röcken C. AG01.07, AG10.09

Rodriguez R. AG11.02

Roeder I. AG07.P.02

Roehe A. AG01.P2.07

Roehrl M.H.A. DGP01.04

Roessler S. AG01.P2.12, DGP28.05

Roessner A. DGP08.05

Roggisch J. AG02.P1.06

Roghmann F. DGP.P2.16

Rohr K. AG12.P.07

Rokavec M. DGP.P2.15

Romero-Pérez L. AG03.11, AG08.08

Römhild K. AG05.P.05

Roose L.M. DGP05.04

Röösli C.

Rose M.

AG11.11, DGP05.04

AG02.P1.03

Rosenblum M. DGP08.03

Rosenfeldt M. AG01.13

Rosenwald A. AG01.13, AG04.03, AG04.19,

DGP19.01

Rossig C. DGP24.03, AG08.04

Rössler S. AG01.P1.13

Roth A. AG12.09

Roth D. DGP16.02

Roth S. $\quad$ AG04.19

Roth W. AG02.18, DGP.P2.08,

AG01.P2.04, AG01.P2.11,

AG03.P.06, AG12.P.06,

AG12.P.08, DGP28.04,

DGP29.02, DGP35.02

Rothkamm K.

Roupret M.

Rozynek P.

DGP08.06

AG02.08

DGP08.01

Rücker F. AG12.P.02

Rudelius M. AG04.P.03

Ruebner M. AG05.06, AG05.12

Rueschoff J.H. DGP15.01

Rummel M. AG04.P.08

Rupp N. DGP05.04

Rupp N.J. AG11.02, AG11.08, AG11.11,

Rüschoff J.H.

Rushing E.J. $\quad$ AG11.02, AG11.11

Rustamov R. DGP34.06

\section{$S$}

Sabattini E. $\quad$ AG04.17

Sadeghi M. DGP35.03

Safi S. A. DGP26.04

Sagadin T. $\quad$ DGP.P2.11

Sahm F. DGP.P2.13

Sailer V. AG02.01, DGP16.02,

DGP16.04

Sailer V.-W. $\quad$ DGP27.01

Sakurada A. DGP05.05

Salaverria I. $\quad$ AG04.07

Sandoval J. $\quad$ DGP21.02

Sannino G. $\quad$ AG03.11, AG08.08

Sápi Z. DGP38.01, DGP38.02

Sarioglu N. AG03.P.03

Sasano H. DGP05.05

Sastre

Saucier D.

Sauer C.

Sauer R.

Savage K.

Savai R.

Savic S.

Schad A.

Schaefer C.M.

Schäfer M.

Schäfer R.

Schäfer $S$.

Schäfer U.

Schaff Z.

Schaffrath J.

Schäfgen B.

Schalk B.

Schaper S.

Schattenberg J.

Schecher $S$.

Scheffner I.

Schelb P.

Schell C.

Scherfele C.

Scherz A.

Scheufele $S$.

Schiavo Lena M.

Schibli R.

Schierle K.

Schildhaus H.-U.

AG03.11

AG08.08

AG10.03

DGP.P2.07

AG04.01

AG04.P.08

AG05.P.01

DGP06.03

DGP28.03, DGP.P1.02

AG12.06

DGP13.01

AG02.02

AG01.P2.10

DGP38.04, DGP39.01

AG04.21

AG05.P.03

AG10.P.10

AG04.20

DGP28.04

DGP29.02

DGP20.04

AG07.P.04

AG02.P2.05

AG05.11

DGP.P2.12

DGP.P2.10

DGP31.04

DGP16.03

DGP03.07

Schilling 0.

AG12.02, AG12.03,

AG10.P.06, AG12.P.01

AG02.P2.05, AG03.P.13, AG12.P.07

Schindeldecker M. AG01.P2.04, DGP18.03, DGP29.02, DGP.P2.03

Schirmacher P.

AG05.13, AG07.02, AG10.05,

AG11.12, AG12.01, AG12.08,

AG12.11, AG12.14,

AG01.P1.13, AG01.P2.12,

AG07.P.04, AG07.P.05,

AG07.P.07, DGP19.01,

DGP19.06, DGP19.07,

DGP28.02, DGP28.04,

DGP28.05, DGP29.03,

DGP33.03, DGP.P1.04,

DGP.P2.04, DGP.P2.05

Schlattjan M. DGP28.03

Schlemmer H.-P. $\quad$ AG07.P.04

Schlensog $\mathrm{M}$.

AG01.P2.03, AG10.P.05,

DGP26.04

Schlesner M. $\quad$ AG04.04

Schlitter A.M. DGP26.03

Schloesser H. AG01.P1.02

Schmeller J.

Schmelzle B.

Schmid A.

Schmid K.W.
AG10.04, AG01.P2.06, AG05.P.08, AG05.P.09, AG10.P.03, AG10.P.11, AG10.P.12, AG10.P.13 AG12.P.02

AG10.08

AG02.11, AG10.04, AG01.P2.06, AG02.P1.01, AG05.P.07, AG05.P.08, AG05.P.09, AG10.P.03, AG10.P.11, AG10.P.12, AG10.P.13, DGP08.01, DGP28.03, DGP31.02, DGP31.03, DGP31.05,
DGP34.03, DGP.P1.02, DGP.P1.05, DGP.P1.06, DGP.P1.08, DGP.P1.09, DGP.P1.10, DGP.P1.15, DGP.P2.16

Schmid K.-W. $\quad$ DGP.P1.07

Schmid R.A. DGP.P2.12

Schmid S. DGP17.05

Schmidberger J. AG01.06

Schmidt C. AG06.06

Schmidt D. $\quad$ AG05.13

Schmidt G. DGP15.02

Schmidt K.W. DGP39.06

Schmidt M. DGP03.01

Schmidt T. $\quad$ AG01.02, DGP.P2.11

Schmidtke-

Schrezenmeier G. AG12.P.02

Schmitt A.

Schmitt J.

Schmitt M.

DGP07.02, DGP07.04

DGP28.02

DGP35.05

AG07.P.05, AG07.P.06,

AG07.P.07

Schmitt V.

AG09.05

Schmitt V.H. AG01.22

Schmitz J. DGP20.04

Schmitz K.J. DGP.P1.15

Schmitz M. DGP.P2.08

Schmitz R. AG04.15

SchmitzT. DGP23.05

Schmoeckel E. AG05.15, AG05.17,

Schneeberger S. DGP18.04

Schneeweiss A. AG05.02

Schneider B. AG01.P1.01

Schneider E. AG10.P.10

Schneider M. $\quad$ AG01.P1.12, AG02.P2.01

Schneider U. AG02.04, AG02.05,

AG01.P1.10

Schneider-Stock R. AG05.12, AG01.P2.07,

DGP37.04

Schnitzler T. $\quad$ AG02.05

Schoeder V. DGP08.05

Schoemmel M. AG01.P1.02

Schöffski P. $\quad$ AG08.04

Scholl C. DGP24.03

Scholl U. DGP04.02

Schönberger S. AG03.04

Schoner K. AG03.P.05

Schottelius M. AG07.P.01

Schraml P. AG02.13

Schramm A. DGP39.06

Schredl P. AG01.P2.09

Schrimpf D. $\quad$ AG05.13

Schröck E. DGP21.04

Schubert-Fritschle G. DGP04.04

Schuff-Werner P. AG02.P2.06

Schuler M. DGP39.06

Schüller U. $\quad$ DGP29.01

Schulte M. AG08.05

Schulz B. AG10.P.14

Schulze A. AG01.13

Schulze F. $\quad$ AG12.13, DGP19.01

Schulz-Wendtland R. AG05.P.06

Schürmann J. $\quad$ AG10.09

Schütz E. DGP04.03 


\begin{tabular}{|c|c|c|c|c|c|}
\hline Schwamborn K. & $\begin{array}{l}\text { AG01.18, AG02.18, } \\
\text { AG07.P.01, DGP19.05, } \\
\text { DGP26.05, DGP27.05 }\end{array}$ & $\begin{array}{l}\text { Spranger J. } \\
\text { Spray C. } \\
\text { Springfeld C. }\end{array}$ & $\begin{array}{l}\text { DGP31.02 } \\
\text { AG03.P.12 } \\
\text { AG12.11 }\end{array}$ & $\begin{array}{l}\text { Sun Y. } \\
\text { Sun Z. } \\
\text { Suzuki H. }\end{array}$ & $\begin{array}{l}\text { CHIN.P.04 } \\
\text { CHIN.P.15 } \\
\text { DGP05.05 }\end{array}$ \\
\hline Schwartz C. & DGP.P2.14 & Sprung S. & AG05.11, AG11.05, & Sydow S.R. & AG10.P.03 \\
\hline Schweizer U. & DGP31.02 & & AG10.P.16 & Szakos A. & DGP39.01 \\
\hline Schwertheim S. & DGP28.03, DGP.P1.02 & Staebler A. & AG05.16 & Szarvas T. & AG02.11, AG02.P1.01, \\
\hline Schwittai I. & DGP28.04 & Stahl D. & AG01.04, AG03.04 & & AG02.P1.02, AG02.P1.07, \\
\hline Scott D. & AG04.01 & Ståhlberg A. & DGP24.03 & & AG02.P2.04 \\
\hline Sedlacek R. & AG01.P2.07 & Stange D. & AG01.P1.08 & Szekerczés T. & DGP39.01 \\
\hline Seegerer $\mathrm{P}$. & DGP29.01 & Staniszewska M. & DGP31.05 & Szijártó A. & DGP39.04 \\
\hline Seeling C. & AG08.11 & Stark H. & AG10.P.01 & Sziranyi J. & AG06.01 \\
\hline Seidmann L. & AG03.P.06 & Staude C. & AG03.P.02 & & \\
\hline Seiler M. & AG03.14 & Steffens S. & AG02.14 & & \\
\hline Seitz V. & AG04.20 & Steib F. & AG11.06 & $\mathrm{T}$ & \\
\hline Seliger B. & AG04.21, AG05.06, AG11.01, & Steidl C. & AG04.01 & Tagscherer K. & DGP29.02 \\
\hline & DGP33.04 & Steiger K. & AG01.12, AG05.14, AG01. & Tagscherer K.E. & AG01.P2.11 \\
\hline Shang $\mathrm{R}$. & DGP26.02 & & P2.02, AG07.P.01, DGP26.03 & Talla S.B. & AG10.05, AG12.11, AG12.14, \\
\hline Sheu-Grabellus S.-Y. & DGP.P1.15 & Stein S. & AG03.11, AG08.08 & & DGP08.04 \\
\hline Shia J. & DGP04.05 & Steinert R. & AG01.P1.05 & Tanev I. & AG01.P2.14 \\
\hline Shin H.-O. & AG10.P.01 & Steinhilber J. & AG04.07, AG04.22, & Tang J. & CHIN.P.06 \\
\hline Sick B. & DGP35.01 & & AG04.P.02 & Tang L. & DGP08.03 \\
\hline Siebert R. & AG04.01, AG04.04, AG08.10, & Steinke L. & AG01.19 & Tank C. & DGP17.04 \\
\hline & AG08.12, AG04.P.06 & Stenzel P. & DGP29.02 & Tannapfel A. & AG01.03 \\
\hline Siebolts U. & DGP.P1.01, DGP.P1.03, & Stenzinger A. & AG01.17, AG02.18, AG07.02, & Tao J. & AG01.10 \\
\hline & DGP.P1.11 & & AG10.05, AG11.12, AG12.01, & Tao S. & CHIN.P.06 \\
\hline Siffert W. & DGP.P2.16 & & AG12.08, AG12.11, AG12.14, & Tappe D. & DGP25.03 \\
\hline Sigler M. & AG13.04 & & AG01.P2.12, AG07.P.04, & Taran A. & AG05.16 \\
\hline Sikic D. & AG02.09, AG02.17 & & DGP08.04, DGP19.01, & Taubert $\mathrm{H}$. & AG02.09, AG02.15, AG02.17 \\
\hline Simillion C. & DGP07.04 & & DGP19.06, DGP19.07, & Taverna L. & AG01.17 \\
\hline Simmet $\mathrm{T}$. & AG08.05, DGP24.03 & & DGP29.03, DGP.P2.04, & Tavernar L. & AG07.02 \\
\hline Simon K. & AG07.P.04 & & DGP.P2.05 & Tebroke J. & AG10.03 \\
\hline Simon-Keller K. & AG10.01 & Stephan-Falkenau S. & AG10.04, AG12.06, AG12.08, & Teichmann D. & DGP29.01 \\
\hline Singer G. & AG03.07 & & AG12.09, DGP19.04, & Telenius A. & AG04.01 \\
\hline Singer $\mathrm{S}$. & DGP28.05, DGP.P1.04 & & DGP.P2.07 & Terracciano L. & AG12.P.11 \\
\hline Singvogel K. & AG01.P1.03, AG01.P1.04 & Steubel A. & AG10.04 & Teufel M. & DGP06.01 \\
\hline Sinn B.V. & AG05.02 & Steveling A. & AG01.14 & Teufel-Schäfer U. & AG03.P.08 \\
\hline Sinn H.P. & AG05.02 & Steven A. & AG11.01 & Theegarten D. & DGP08.01, DGP25.04 \\
\hline Sinn H.-P. & AG05.P.03 & Sticht C. & AG13.02 & Theis B. & AG05.P.02, AG10.P.04 \\
\hline Sinn $P$. & AG05.13 & Stief $C$. & DGP15.02 & Thelen M. & AG01.P1.02 \\
\hline Sitek B. & AG02.P1.02 & Stillger M. & AG12.P.07 & Theurer S. & AG05.P.09, DGP06.02, \\
\hline Skálová A. & DGP19.02 & Stockhammer P. & DGP39.06 & & DGP28.03, DGP31.03, \\
\hline Skowronska M. & DGP31.04 & Stocking $C$. & AG04.20 & & DGP31.05, DGP.P1.02, \\
\hline Skrobar K. & AG04.06 & Stoehr R. & AG02.08, AG02.09, AG02.10, & & DGP.P1.06, DGP.P1.08, \\
\hline Skrynecki N. & DGP.P1.09 & & AG02.17 & & DGP.P1.09 \\
\hline Slabicki M. & DGP24.03 & Stögbauer F. & AG07.02, AG12.11, & Thiel S. & AG12.06 \\
\hline Slotta-Huspenina J. & AG01.02, AG07.03 & & DGP08.04 & Thiele $\mathrm{H}$. & AG04.04 \\
\hline Smith K. & DGP15.01 & Stöhr C. & AG02.15 & Thiele R. & AG03.04 \\
\hline Sobottka B. & AG05.07 & Stöhr C.G. & AG02.14 & Tholey A. & AG10.09 \\
\hline Sohini R. & AG01.15 & Stöhr R. & AG02.18, AG02.P1.05, AG02. & Thomalla J. & AG05.02 \\
\hline Sojka N. & AG10.03 & & P2.02, AG12.P.13, DGP08.07 & Thomas C.F. & AG07.01 \\
\hline Soltermann A. & AG10.07, DGP34.05, & Stracke S. & AG01.03 & Thomas M. & AG12.14, DGP19.06 \\
\hline & DGP35.01 & Straub B.K. & AG01.P2.04, DGP19.01, & Thomè C. & AG12.P.04 \\
\hline Sommer F. & AG12.07 & & DGP28.04 & Tian X. & CHIN.P.01 \\
\hline Sommer L. & AG01.P1.08 & Streubel A. & AG12.06, AG12.08, AG12.09, & Tikkanen R. & DGP12.04 \\
\hline Sommer U. & AG02.P1.04 & & DGP19.04, DGP.P2.07 & Till H. & AG03.07 \\
\hline Sommerfeld A. & AG04.20 & Strick R. & AG02.09 & Ting $\mathrm{S}$. & AG02.P1.02, DGP.P1.15 \\
\hline Song K. & CHIN.P.06 & Strissel P. & AG02.09 & Tirode F. & AG12.10 \\
\hline Song $X$. & AG01.10, DGP26.02 & Ströbel P. & AG10.01, AG10.02, AG10.03, & Tischler V. & AG12.13, AG02.P2.01, \\
\hline Sotlar K. & DGP.P2.14 & & AG02.P2.08, AG10.P.07, & & AG12.P.09 \\
\hline Soworka S. & AG12.P.09 & & DGP04.03, DGP19.03 & Titze U. & AG10.P.14 \\
\hline Specht $C$. & AG07.P.07 & Stroucken B. & AG01.17 & Todorova R. & AG01.01 \\
\hline Speel E.J.M. & DGP08.01, DGP21.02 & Stüben G. & AG12.07 & Tögel L. & AG12.P.13, DGP08.07 \\
\hline Speel E.-J. & AG01.11, AG04.P.05 & SuH. & CHIN.P.08 & Toktamis S. & AG12.04 \\
\hline Sperling C. & AG01.P1.08 & Suckrau P. & AG10.P.11, AG10.P.12, & Tolkach Y. & AG02.03 \\
\hline Sperveslage J. & DGP23.05, DGP24.05 & & AG10.P.13 & Toma M. & AG02.18 \\
\hline Spiekermann K. & DGP36.02 & Sun W. & CHIN.P.03 & Töpfer A. & DGP16.03 \\
\hline Spitzweg C. & DGP04.04 & Sun $X$. & CHIN.P.03 & Topolcan 0. & AG07.P.08, AG07.P.09 \\
\hline
\end{tabular}




$\begin{array}{ll}\text { Törzsök P. } & \text { DGP38.04 } \\ \text { Tóth M. } & \text { DGP28.02 } \\ \text { Tötsch M. } & \text { DGP34.03 } \\ \text { Trautmann M. } & \text { AG08.04, AG08.05, AG08.06, } \\ & \text { AG08.07, DGP23.05, } \\ & \text { DGP24.03, DGP24.05 } \\ \text { Trede D. } & \text { DGP19.05 } \\ \text { Trepel M. } & \text { AG12.07 } \\ \text { Treue D. } & \text { AG05.02, DGP29.01 } \\ \text { Trippel M. } & \text { AG10.08 } \\ \text { Truckenmueller F. } & \text { AG01.P1.13 } \\ \text { Tschopp O. } & \text { DGP05.04 } \\ \text { Tserea K. } & \text { DGP35.02 } \\ \text { Tunc M. } & \text { AG05.04 } \\ \text { Turial S. } & \text { AG03.P.07 } \\ \text { Turko P. } & \text { AG11.08 } \\ \text { Turzynski A. } & \text { DGP15.04, DGP36.03, } \\ & \text { DGP36.04 } \\ \text { Tzankov A. } & \text { AG04.02, AG04.05 }\end{array}$

U

$\begin{array}{ll}\text { Uder M. } & \text { AG05.P.06 } \\ \text { Uhlendahl H. } & \text { DGP03.01 } \\ \text { Uhrig S. } & \text { DGP19.01 } \\ \text { Umbricht C. A. } & \text { DGP16.03 } \\ \text { Untch M. } & \text { AG05.02 } \\ \text { Unterluggauer J. } & \text { AG04.06, AG04.11 } \\ \text { Urbas R. } & \text { AG01.P2.09 } \\ \text { Ustaszewski A. } & \text { AG04.16 } \\ \text { Utpatel K. } & \text { AG10.P.15, DGP18.05, } \\ & \text { DGP26.02 }\end{array}$

V

\begin{tabular}{|c|c|c|c|}
\hline Vallo S. & AG02.P2.01 & Walk F. & DGP31.05 \\
\hline Valtcheva N. & DGP05.04 & Wallner $A$. & AG04.P.01 \\
\hline Van den Oord J. & AG04.P.05 & Wallwiener D. & AG05.16 \\
\hline Van der Linde L. & DGP08.02 & Walter A. & AG01.04 \\
\hline Van & & Walter D. & AG01.P1.12 \\
\hline Mackelenbergh M. & AG05.02 & Walter R.F.H. & AG10.04, AG01.P2.06, \\
\hline Vanazzi A. & AG04.05 & & AG05.P.07, AG05.P.08, \\
\hline Varga Z. & AG05.03, AG05.07 & & AG05.P.09, AG10.P.03, \\
\hline Vassella E. & DGP.P2.12 & & AG10.P.11, AG10.P.12, \\
\hline Vaxevanis $\mathrm{C}$. & AG04.21, DGP33.04 & & AG10.P.13, DGP08.01 \\
\hline Vela V. & AG04.02 & Walz M. & DGP.P1.08 \\
\hline \multicolumn{2}{|c|}{ Velazquez Camacho 0.AG12.12 } & Walz M.K. & DGP.P1.05 \\
\hline Venkataramani V. & AG10.02, DGP27.02 & WalzS. & AG01.13 \\
\hline Verloh N. & AG10.P.15 & Wan S. & DGP28.02 \\
\hline Vieth M. & DGP35.05 & Wand $\mathrm{M}$. & DGP35.02 \\
\hline Vit F. & AG04.03 & Wang B. & AG01.10 \\
\hline Vlajnic T. & DGP34.04 & Wang $\mathrm{H}$. & AG07.P.01, CHIN.P.07 \\
\hline Vlasic l. & AG10.P.07, AG10.P.08 & Wang J. & AG01.10, CHIN.P.14 \\
\hline Vo D.K. & AG05.08 & Wang M. & CHIN.P.16 \\
\hline Vo K. & AG05.09 & Wang P. & DGP26.02 \\
\hline Vogel A. & AG12.P.08 & Wang Q. & CHIN.P.12 \\
\hline \multirow[t]{3}{*}{ Vogel W. } & AG04.22, AG11.07, AG11.09, & Wang W. & CHIN.P.15 \\
\hline & AG10.P.07, AG10.P.08, & Wang X. & CHIN.P.14 \\
\hline & DGP08.02 & Wang Y. & CHIN.P.14, CHIN.P.15 \\
\hline Vögeli T.-A. & AG02.P1.03 & Wardelmann E. & AG08.04, AG08.05, AG08.06, \\
\hline Vogelmann S. & AG04.04 & & AG08.07, DGP23.05, \\
\hline Vogt J. & AG08.10 & & DGP24.03, DGP24.05 \\
\hline Voigt J. & DGP35.04 & Warnecke G. & AG10.P.01 \\
\hline Vokuhl C. & AG03.05 & Warth A. & AG07.02, DGP.P1.04 \\
\hline \multirow[t]{2}{*}{ Volckmar A.-L. } & AG07.02, AG10.05, AG11.12, & Watermann C. & AG11.03, AG11.04, AG11.09 \\
\hline & AG12.01, AG12.11, AG12.14, & Weber A. & $\begin{array}{l}\text { AG01.06, AG01.08, AG10.07, } \\
\text { DGP05.04 }\end{array}$ \\
\hline
\end{tabular}

DGP08.04, DGP19.06, DGP.P2.05

Volk N. AG07.P.05

VölkI L. AG12.13

Vollbrecht C. $\quad$ AG10.P.03, DGP29.01

Volonaki E. AG03.P.12

Von Deimling A. $\quad$ AG05.13, DGP.P2.13

Von der Wall E. AG04.20

Von Eggeling $F . \quad$ DGP35.05

Von Hahn X. AG10.03

Von Herbay A. $\quad$ DGP.P1.12, DGP.P1.13

Von Minckwitz G. AG05.02

Von Serenyi S. AG12.04

Von Stillfried S. AG05.P.05

Von Vietinghoff S. DGP20.04

Von Walcke-

Wulffen V. $\quad$ DGP.P2.11

Vrugt B. $\quad$ AG03.06

W

Wach S.

Wagener R.

Wagener S.

Wagner D. AG12.P.08

Wagner K. AG05.02

Wagner W. $\quad$ AG09.05, AG10.P.01

Wagner-Drouet E.M. DGP18.03, DGP.P2.03

Waldhart J. AG04.06

AG10.P.11, AG10.P.12,

DGP.P1.08

DGP05.04 DGP19.07, DGP29.03,

Von Rhoden L. AG03.P.07

Von Winterfeld M. AG12.14, DGP19.06

Wahlin B.E. AG04.05

\begin{tabular}{|c|c|}
\hline Weber J. & DGP26.03 \\
\hline Weber K. & AG05.02 \\
\hline Weber M. & AG10.P.14 \\
\hline Weber T.F. & DGP19.01 \\
\hline Wedemeyer $\mathrm{H}$. & DGP28.03 \\
\hline Wehweck F. & AG03.11, AG08.08 \\
\hline Wei X. & CHIN.P.04, CHIN.P.16 \\
\hline Weichert W. & $\begin{array}{l}\text { AG01.02, AG01.12, AG01.17, } \\
\text { AG01.18, AG02.17, AG05.14, } \\
\text { AG07.02, AG01.P2.02, } \\
\text { AG07.P.01, DGP05.05, } \\
\text { DGP19.05, DGP22.04, } \\
\text { DGP26.03, DGP26.05, } \\
\text { DGP.P2.05 }\end{array}$ \\
\hline Weigelt $\mathrm{B}$. & DGP08.03 \\
\hline Weigert M. & AG07.P.02 \\
\hline Weihe $\mathrm{E}$. & DGP.P1.14 \\
\hline Weiler S. & DGP28.02 \\
\hline Weinmann A. & AG01.P2.04 \\
\hline Weis C.A. & AG02.06 \\
\hline Weis C.-A. & $\begin{array}{l}\text { DGP04.03, DGP35.04, } \\
\text { DGP36.05 }\end{array}$ \\
\hline Weiß C.-A. & AG02.17 \\
\hline Weiss J. & AG12.05 \\
\hline Weiss K.H. & DGP19.01 \\
\hline Weiss L. & AG01.P2.09 \\
\hline Weiss $\mathrm{N}$. & DGP15.04 \\
\hline Weissenbacher A. & DGP18.04 \\
\hline Weissenborn C. & AG05.08 \\
\hline Weissinger S.E. & AG04.13 \\
\hline Welker L. & DGP08.02 \\
\hline Wendler 0. & AG02.P2.02 \\
\hline Wenig U. & AG04.P.08 \\
\hline Wenke T. & AG07.P.02 \\
\hline Wenkel E. & AG05.P.06 \\
\hline Wenzl K. & AG04.09 \\
\hline Werner J. & DGP04.04 \\
\hline Werner L. & DGP.P1.01 \\
\hline Werner M. & $\begin{array}{l}\text { AG01.P1.03, AG01.P1.04, } \\
\text { AG02.P2.05, AG03.P.08, } \\
\text { AG12.P.07, DGP17.05, } \\
\text { DGP.P2.05 }\end{array}$ \\
\hline Werner R. & AG10.04, AG10.P.03 \\
\hline Werninghaus I. & AG02.P2.07 \\
\hline Wernstedt A. & DGP.P2.14 \\
\hline Wessman S. & AG03.12, AG03.13 \\
\hline Wessolly M. & $\begin{array}{l}\text { AG02.11, AG10.04, AG01. } \\
\text { P2.06, AG05.P.08, AG10.P.11, } \\
\text { AG10.P.12, AG10.P.13 }\end{array}$ \\
\hline Westerhoff M. & AG01.05 \\
\hline Westerwick D. & $\begin{array}{l}\text { AG05.P.08, AG05.P.09, } \\
\text { DGP28.03, DGP.P1.02 }\end{array}$ \\
\hline Westhoff C.C. & AG05.10 \\
\hline Westphalen B. & DGP04.04 \\
\hline Wey N. & DGP15.01 \\
\hline Weyerer V. & $\begin{array}{l}\text { AG02.08, AG02.09, AG02.10, } \\
\text { AG02.17, AG02.P1.05 }\end{array}$ \\
\hline Wickenhauser C. & $\begin{array}{l}\text { AG04.21, AG05.06, AG11.01, } \\
\text { DGP33.04, DGP.P1.01, } \\
\text { DGP.P1.03, DGP.P1.11 }\end{array}$ \\
\hline Wiech T. & AG13.05 \\
\hline Wiedmer T. & DGP31.04 \\
\hline Wiemann S. & DGP19.02 \\
\hline Wiesweg M. & DGP37.02 \\
\hline Wild P. & $\begin{array}{l}\text { AG02.18, AG04.16, } \\
\text { AG02.P2.01 }\end{array}$ \\
\hline
\end{tabular}




\begin{tabular}{|c|c|c|c|}
\hline \multirow[t]{2}{*}{ Wild P.J. } & AG12.13, AG12.P.09, & $\mathbf{Z}$ & \\
\hline & DGP15.01, DGP17.04 & Zacherl C. & AG03.11 \\
\hline \multirow[t]{2}{*}{ Will U. } & AG01.P1.06, AG01.P1.09, & Zahm M. & AG05.02 \\
\hline & DGP.P2.13 & Zahn M. & AG04.13, AG04.P.09 \\
\hline Willvonseder B. & AG05.14 & Zakrzewski F. & AG01.P1.08, AG07.P.02 \\
\hline Winand E. & AG06.03 & Zamo A. & AG04.03 \\
\hline Wingerath $B$. & AG01.P2.03 & Zander T. & AG12.05, AG01.P1.02 \\
\hline Winkelmann R. & AG01.P1.12, AG02.P2.01 & Zavgorodnij M. & AG07.P.03 \\
\hline Winkler P.A. & DGP.P2.14 & Zelger B. & DGP18.04 \\
\hline Winnepenninckx V. & AG01.11, AG04.P.05 & Zelger B.G. & DGP18.04 \\
\hline \multirow[t]{2}{*}{ Winter $\mathrm{H}$. } & AG10.05, AG12.14, & Zender $\mathrm{L}$. & DGP28.05, DGP33.03 \\
\hline & DGP19.06 & Zeng $\mathrm{H}$. & CHIN.P.18 \\
\hline Wirth E.K. & DGP31.02 & Zenk J. & DGP19.02 \\
\hline Wirtz R.M. & AG02.06, AG02.09, AG02.17 & Zenke M. & AG04.P.05 \\
\hline Wittenberg T. & DGP37.04 & Zenz T. & DGP24.03 \\
\hline Wittersheim M. & AG02.02, AG02.P2.09 & Zettl H. & AG02.P2.06 \\
\hline Witzel H.R. & AG01.P2.04, DGP28.04 & Zeugner S. & AG07.P.02 \\
\hline Witzke K. & AG02.P1.02 & Zeuzem S. & AG04.16, AG01.P1.12 \\
\hline Wobser M. & AG04.19 & Zhang F. & CHIN.P.07 \\
\hline Wodlej C. & AG03.07 & Zhang $\mathrm{H}$. & CHIN.P.03 \\
\hline \multirow[t]{2}{*}{ Wohlschlaeger J. } & AG10.P.11, AG10.P.12, & Zhang L. & CHIN.P.16 \\
\hline & AG10.P.13, DGP08.01 & Zhang X. & AG10.P.10 \\
\hline Wohlschläger J. & AG10.P.03 & ZhangY. & CHIN.P.03 \\
\hline Wolf E. & AG01.13 & Zhang Z. & CHIN.P.16 \\
\hline WolffS. & AG01.P1.05 & Zhao L. & CHIN.P.07 \\
\hline Wollenberg B. & AG11.04, AG11.07, AG11.09 & Zheng X. & CHIN.P.04 \\
\hline Wollmann T. & AG12.P.07 & Zhong D. & CHIN.P.08 \\
\hline Wölwer C. & AG12.P.10 & Zhou X. & CHIN.P.16 \\
\hline Wölwer C.B. & AG12.12 & Ziegler $\mathrm{P}$. & AG01.21 \\
\hline Wong $\mathrm{L}$. & CHIN.P.04 & Zimmermann T. & AG04.18 \\
\hline Woolcock B. & AG04.01 & Zimpfer A. & AG02.P2.06 \\
\hline Worm K. & AG02.11, AG12.02 & Zinser C. & AG04.20 \\
\hline Worst T. & AG02.06 & Zoche M. & AG03.06, AG10.07 \\
\hline Worst T.S. & AG02.09, AG02.17 & Zonnur S. & AG01.P1.01 \\
\hline Wozniak A. & AG08.04 & Zou S. & CHIN.P.15 \\
\hline Wu C. & DGP34.05 & Zucca E. & AG04.05 \\
\hline \multirow[t]{2}{*}{ Wullich B. } & $\begin{array}{l}\text { AG02.08, AG02.09, AG02.15, } \\
\text { AG02.17, AG02.P1.05, }\end{array}$ & Zur Hausen A. & $\begin{array}{l}\text { AG01.11, AG04.P.05, } \\
\text { DGP08.01 }\end{array}$ \\
\hline & AG02.P2.02 & Zurek-Leffers F. & DGP24.05 \\
\hline Wullweber A. & AG02.09 & Zürich A. & AG01.P1.08 \\
\hline Wunderle $\mathrm{M}$. & AG05.06, AG05.P.06 & Zwingenberger $\mathrm{G}$. & AG01.P1.07 \\
\hline Wüseke T. & AG04.12 & Zwönitzer R. & DGP17.02 \\
\hline \multicolumn{4}{|l|}{$X$} \\
\hline Xu B. & DGP08.03 & & \\
\hline XuE. & CHIN.P.03 & & \\
\hline Xu J. & CHIN.P.06 & & \\
\hline Xu M. & AG01.10, DGP26.02 & & \\
\hline XuX. & AG05.04 & & \\
\hline Xue X. & CHIN.P.12 & & \\
\hline XueY. & CHIN.P.14 & & \\
\hline \multicolumn{4}{|l|}{ Y } \\
\hline Yamada Y. & AG10.01 & & \\
\hline Yan Y. & CHIN.P.06 & & \\
\hline Yang $\mathrm{H}$. & CHIN.P.01 & & \\
\hline Yang L. & CHIN.P.02, CHIN.P.08 & & \\
\hline Yang Q. & CHIN.P.06 & & \\
\hline Yang X. & AG05.04 & & \\
\hline Yang Z. & CHIN.P.15 & & \\
\hline Yao D. & AG05.04 & & \\
\hline YeF. & CHIN.P.02 & & \\
\hline Ying J. & CHIN.P.16 & & \\
\hline Yusufi N. & AG07.P.01 & & \\
\hline
\end{tabular}

